UNIVERSIDADE DE SĀO PAULO

INSTITUTO DE GEOCIENCIAS

DEDALUS - Acervo - IGC

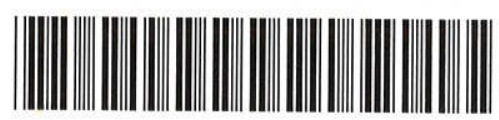

30900005756

\title{
O MAPA GEOCRONOLÓGICO DO CRÁTON AMAZÔNICO NO BRASIL: REVISĀO DOS DADOS ISOTÓPICOS
}

COLOMBO CELSO GAETA TASSINARI

CONCURSO PARA OBTENÇÃO DO TITULO DE LIVRE-DOCENTE DEPARTAMENTO DE GEOLOGIA GERAL AREA DE CONHECIMENTO: GEOLOGIA ISOTÓPICA

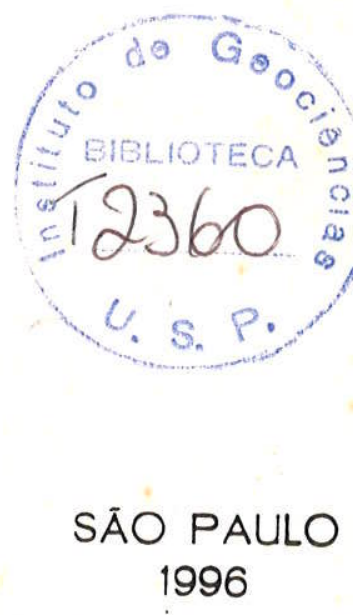




\section{SUMÁRIO}

pág.

1 - INTRODUÇÃO 1

2 - METODOLOGIA DE TRABALHO 4

3 - SIGNIFICAÇÃO GEOLÓGICA DOS MÉTODOS GEOCRONOLÓGICOS ...11

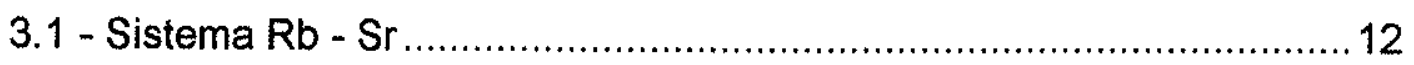

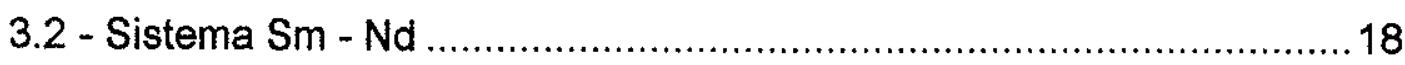

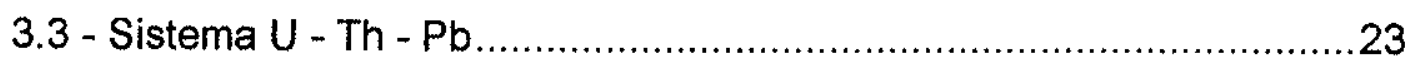

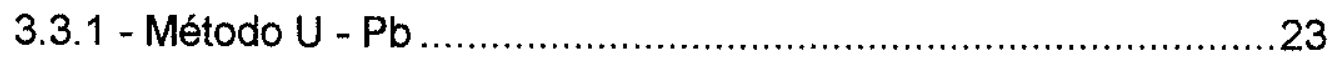

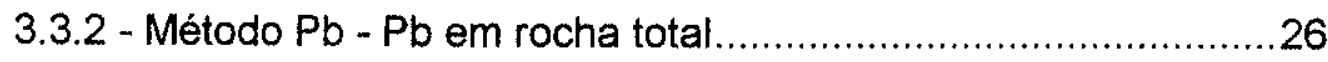

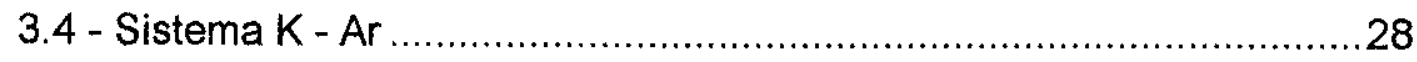

4 - DOMÍNIOS GEOCRONOLÓGICOS E ELEMENTOS TECTÓNICOS ..........31

4.1 - Domínio Amazônia Central ................................................................33

4.2- Domínio Maroni - Itacaiúnas .............................................................34

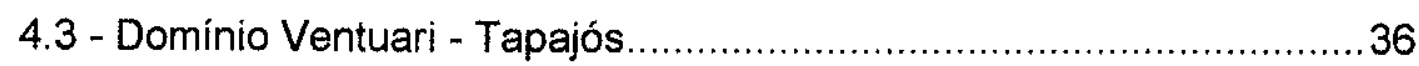

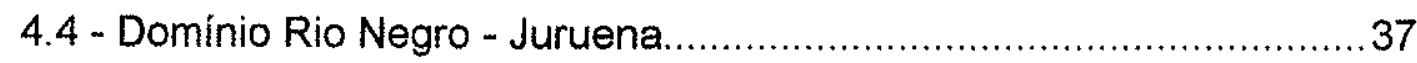

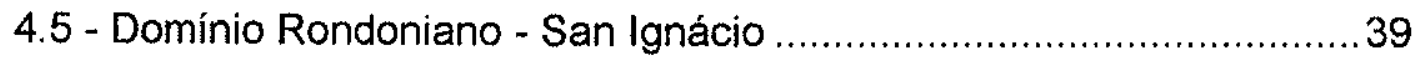

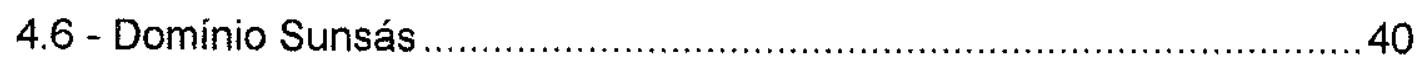

5 - CONTEXTO GEOLÓGICO E DISCUSSÕES GEOCRONOLÓGICAS .........42

5.1 - Domínio Amazônia Central ...........................................................42

5.1.1 - Sub-domínio Carajás - Iricoumé ............................................ 43

5.1.1.1 - Considerações Geológicas .........................................43

5.1.1.2 - Discussões Geocronológicas .......................................46 


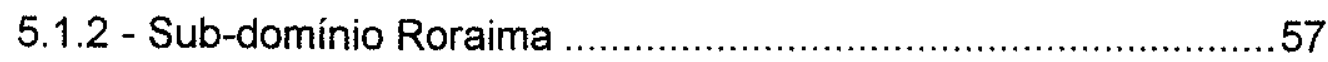

5.1.2.1 - Considerações Geológicas ...........................................57

5.1.2.2 - Discussões Geocronológicas .........................................59

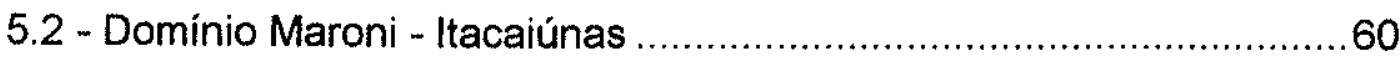

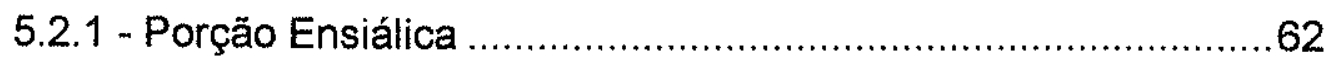

5.2.1.1 - Considerações Geológicas .........................................62

5.2.1.2 - Discussões Geocronológicas ......................................64

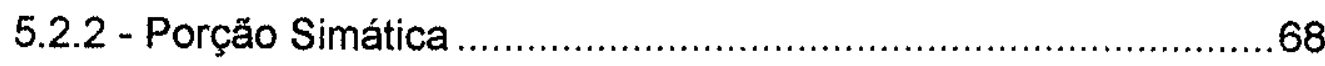

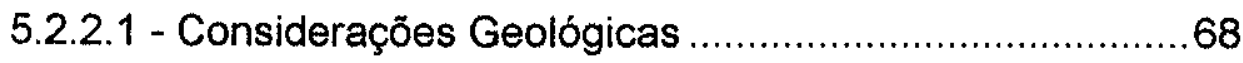

5.2.2.2 - Discussões Geocronológicas ......................................70

5.3 - Domínio Ventuari - Tapajós............................................................74

5.3.1 - Considerações Geológicas ..............................................74

5.3.2 - Discussões Geocronológicas............................................78

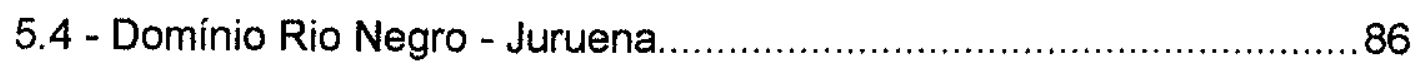

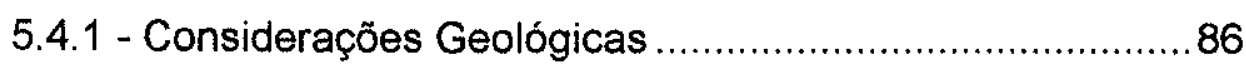

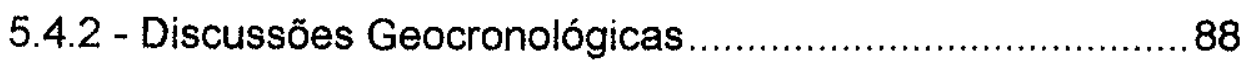

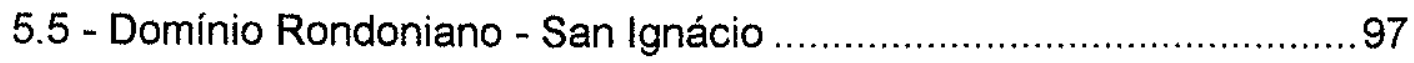

5.5.1 - Considerações Geológicas .............................................99

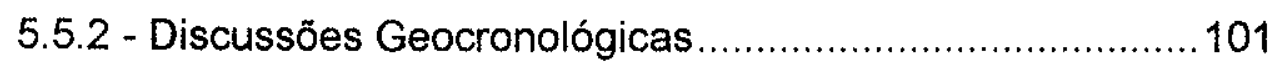

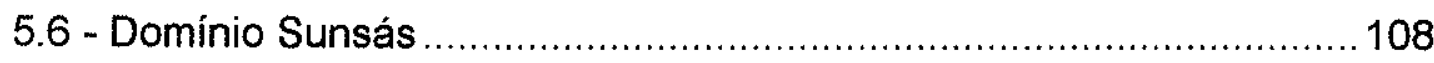

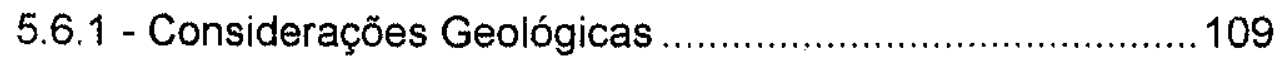

5.6 .2 - Discussões Geocronológicas .......................................... 110

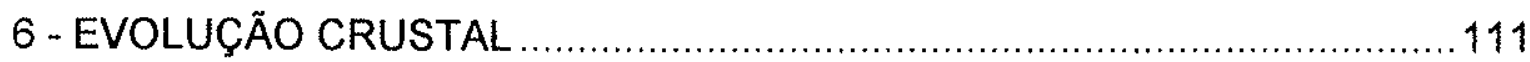

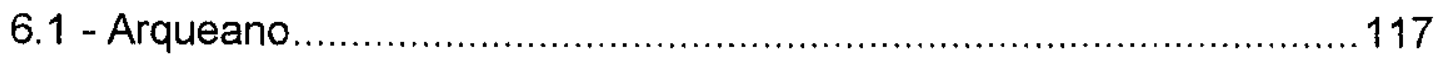

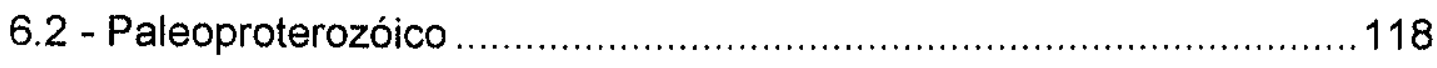

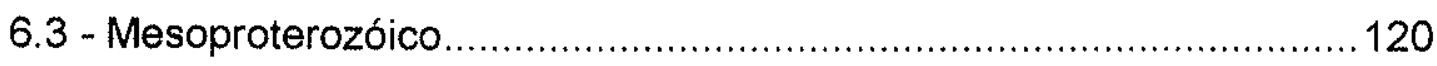

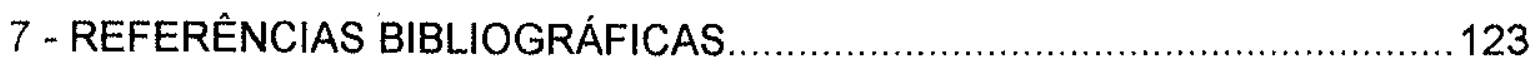




\section{INDICE DE FIGURAS}

Figura 1 - Diagrama $87 \mathrm{Sr} / 86 \mathrm{Sr}$ versus tempo geológico, onde são mostrados os campos de variação estabelecidos para o manto superior e crosta continental

Figura 2 - Representação gráfica da idade modêlo Sm - Nd em função das curvas de evolução isotópica para o CHUR e para o manto empobrecido (depleted mantle).

Figura 3 - Discordâncias das idades aparentes e a indicação da idade real de um sistema qualquer analisado.

Figura 4 - Províncias Tectônicas do Cráton Amazônico

Figura 5 - Diagrama de variação do $\varepsilon_{\mathrm{Nd}} \mathrm{em}$ função do tempo geológico, mostrando os intervalos de tempo da diferenciação manto - crosta dos protólitos crustais do Domínio Amazônia Centrai

Figura 6 - Diagrama da variação do $\varepsilon_{N d}$ em função do tempo geológico, mostrando os intervalos de tempo da diferenciação manto - crosta para os protólitos crustais das porções ensiálicas e simáticas do Dominio Maroni - Itacaiúnas.

Figura 7 - Diagrama Isocrônico $\mathrm{Rb}$ - Sr em rocha total para os granodioritos da região de Vila Creporizão - Itaituba.

Figura 8 - Diagrama isocrônico $\mathrm{Rb}$ - $\mathrm{Sr}$ em rocha total para os granitóides parcialmente alterados hidrotermalmente da região de Vila Creporizão - Itaituba.

Figura 9 - Diagrama de variação do $\varepsilon_{\mathrm{Nd}}$ em função do tempo geológico, mostrando os intervalos de tempo da diferenciação manto crosta para os protólitos crustais dos Domínios Ventuari - Tapajós e Rio Negro - Juruena.

Figura 10 - Diagrama de variação do $\mathrm{ENd}$ em função do tempo geológico, mostrando os intervalos de tempo da diferenciação manto - crosta para os protólitos crustais dos Dominios Rondoniano - San Ignácio.

Figura 11 - Seção esquemática do modêlo tectônico para o desenvolvimento dos arcos magmáticos Ventuari - Tapajós e Rio Negro - Juruena.

Figura 12 - Histograma da frequência da variação das idades modelo Sm - Nd manto empobrecido para o Cráton Amazônico, mostrando as variações dentro de cada um dos domínios definidos. 
Tabela 1 - Subdivisão do Tempo Geológico. 6

Tabeia 2 - Dados analíticos $\mathrm{Rb}$ - $\mathrm{Sr}$ para os granitóides da região de Vila Creporizão - Itaituba.

Tabela 3 - Dados analíticos $\mathrm{Sm}$ - Nd para os granitóides da região de Vila Creporizão - Itaituba.

INDICE DE QUADROS

Quadro 1 - Sumário dos dados geocronológicos do Domínio Amazônia Central.

Quadro 2 - Sumário dos dados geocronológicos do Domínio Maroni Itacaiúnas.

Quadro 3 - Sumário dos dados geocronológicos do Domínio Ventuari Tapajós.

Quadro 4 - Sumário dos dados geocronológicos do Dominio Rio Negro Juruena.

Quadro 5 - Sumário dos dados geocronológicos do Domínio Rondoniano San Ignácio.

\section{APENNDICE}

Apêndice 1 - Dados gerais das amostras analisadas geocronológicamente

Apêndice 2-Dados analíticos isotópicos das amostras analisadas geocronológicamente.

\section{ANEXO}

Mapa geocronológico do Cráton Amazônico. Partes Norte e Sul 


\section{AGRADECIMENTOS}

O autor, ao término deste trabalho, deseja agradecer aos colegas do Instituto de Geociências da USP, em especial aos Prof. Drs. Umberto G. Cordani, Koji Kawashita, Wilson Teixeira, Benjamim Bley de Brito Neves, Jorge da Silva Bettencourt e Marcos Egidio da Silva, e ao técnico Key Sato, pelo incentivo prestado para a finalização do trabalho e pelas discussões e sugestőes científicas mantidas sobre a geologia da região amazônica.

Em adição, gostaria ainda de externar a sua gratidão aos funcionários, técnicos e pesquisadores do Centro de Pesquisas Geocronológicas do IGcUSP, que desde o início da década de 70 , auxiliaram muito na obtenção de análises geocronológicas em amostras do Cráton Amazônico, que muito auxiliaram na compreensão dos eventos tectônicos que atuaram nesta área cratônica.

Para a elaboração deste trabalho e do banco de dados geocronológicos aqui apresentado, o autor contou com a colaboraçäo incansável da Matemática Ivone K. Sonoki, da aluna de pós - graduação Kátia M. Mellito e da aluna de graduação Luciana V. Rodrigues. A estas três pessoas o autor manifesta a sua profunda gratidão.

Aos funcionários Valéria dos Santos e Reynaldo Penã Castellon são também devidos agradecimentos pelos mais diversos auxílios prestados durante o desenvolvimento deste trabalho, sendo que para este último, o seu apoio na fase de digitalização do mapa geocronológico foi fundamental para o sucesso do empreendimento.

O autor desejaria ainda manifestar a sua gratidão às diversas empresas $e$ instituições, que auxiliaram de várias formas, na elaboração desta síntese, em especial a Broken Hill Property Minerals (BHP), Serviços para Mineração Crepory, Instituto Brasileiro de Geografia e Estatísitica (IBGE), Fundação de Amparo a Pesquisa do Estado de São Paulo (FAPESP) $\Theta$ ao Conselho Nacional de Desenvolvimento Científico e Tecnológico (CNPq).

Finalmente, os agradecimentos são também extensivos para a minha esposa Manuela e para a minha filha Fernanda, pelo fundamental apoio durante o desenvolvimento do trabalho e pelo auxilio prestado na fase de finalização desta tese. 


\section{1 - INTRODUÇÃO}

Nos últimos dez anos, vários trabalhos geocronológicos têm sido realizados no Cráton Amazônico, muitos deles por metodologias novas ou de maior poder interpretativo, como $\mathrm{Sm}-\mathrm{Nd}$, U-Pb e $\mathrm{Pb}-\mathrm{Pb}$, que, somados aos dados $\mathrm{Rb}-\mathrm{Sr}$ e $\mathrm{K}-\mathrm{Ar}$ obtidos neste período e às análises geocronológicas pré-existentes, têm fornecido um considerável acervo de informações, que interpretado de forma integrada com os trabalhos geológicos mais recentes, desenvolvidos em algumas regiões do cráton, fornecem uma visão atual dos processos geológico-geotectônicos que atuaram durante o pré-Cambriano na região amazônica.

Este progresso no volume de informações geológicas e geocronológicas foi proporcionado, de forma sistemática, pelas pesquisas acadêmicas efetuadas principalmente pelo Centro de Pesquisas Geocronológicas do IGc-USP e pesquisadores associados, especialmente para o PROJETO RADAM, pelo Laboratório de Geologia Isotópica da Universidade Federal do Pará e pesquisadores associados, pela Companhia de Pesquisas de Recursos Minerais (CPRM), através de seus programas de mapeamento geológico regional, pela Companhia Vale do Rio Doce através da DOCEGEO, por pesquisadores estrangeiros de diversas instituições e também nas zonas mineralizadas, pelas companhias de mineração privadas, que desenvolveram trabalhos geológicos de detalhe em áreas localizadas. Deve ser mencionado que muitas das pesquisas realizadas na região amazônica também contaram com apoio financeiro de várias agências nacionais e internacionais de apoio a pesquisa, como por exemplo, CNPq, FAPESP, FADESP, NSF e IGCP (UNESCO-IUGS).

Os primeiros trabalhos de síntese de dados geocronológicos para grandes áreas do Cráton Amazônico visando modelagens geotectônicas foram realizados na década de 70 por Amaral (1974), Basei (1977), enfocando o vulcanismo ácido a intermediário, Teixeira (1978), para o magmatismo máfico e alcalino e Tassinari (1981) para a porção ocidental do cráton. Além disso, vários trabalhos sobre evolução tectônica do cráton foram publicados nos anos 70 e 80 . Dentre os quais 
pode-se citar aqueles que admitiam uma evolução essencialmente fixista, considerando o cráton como uma massa continental estável antiga, formada no arqueano e afetada por diversos episódios de retrabalhamento crustal e rejuvenescimento termal, como Amaral (1974), Issler (1977), Almeida (1978), Gibbs e Barron (1983) e Hasui et. al. (1984), e aqueles que em contraste, suportados pelos dados radiométricos disponíveis na época, consideravam uma evolução tectônica mobilista, com o cráton evoluindo a partir de um núcleo antigo circundado por sucessivos cinturões móveis, ocorrendo uma acresção continental ao longo do tempo geológico, como Cordani et. al (1979), Cordani e Brito Neves (1982), Tassinari et. al. (1987) e Teixeira et. al. (1989).

Atualmente, com o crescente aumento de interesse sobre a geologia $e$ tectónica da Amazônia, em virtude da retomada dos trabalhos de prospecção mineral na região por parte de empresas nacionais e estrangeiras, faz-se necessária uma base de dados geocronológicos acompanhada de uma revisão e reinterpretação destes à luz dos conhecimentos geológicos atuais, para servir de embasamento para novas modelagens tectônicas e metalogenéticas da região.

Neste sentido, este trabalho apresenta uma síntese sobre o estágio atual do conhecimento geocronológico do Cráton Amazônico, obtida através da compilação de todos os dados geocronológicos disponiveis na literatura para a região amazônica brasileira até junho de 1996, e da elaboração de um mapa geocronológico desta região, que em conjunto com as informacões geológicas e geofísicas atuais do Brasil e de países limítrofes que compõem o Cráton Amazônico, permitirão o estabelecimento da evolução crustal deste importante segmento de crosta continental da plataforma Sul-Americana.

O autor dedicou praticamente toda a sua carreira científica, de 20 anos, ao estudo geocronológico do Cráton Amazônico, inicialmente participando dos trabalhos de mapeamento geológico regional acompanhado de estudos geocronológicos do então denominado Projeto RADAM e, posteriormente, Projeto RADAMBRASIL, desde 1976 até 1984, e como professor e pesquisador do Centro 
de Pesquisas Geocronológicas do Instituto de Geociências da Universidade de São Paulo, desenvolveu várias pesquisas em diversas regiões da Amazônia, publicando trabalhos de sinteses sobre a evolução tectônica do Cráton e trabalhos específicos de geocronologia. Esta experiência prévia do autor sobre a geologia e geocronologia deste Cráton o credencia plenamente para o desenvolvimento deste trabalho.

Para a realização deste trabalho foi elaborado um banco de dados com todos os dados geocronológicos recuperáveis da região amazônica, que inclui cerca de 3000 análises radiométricas, que possuíam uma localização geográfica aceitável, dentro da escala adotada para o mapa. Estes dados foram analisados criticamente, tratados de uma forma integrada e quando necessário, foram reagrupados em novos conjuntos conforme o conhecimento geológico atual, para permitir um posicionamento temporal mais preciso para as unidades estratigráficas estudadas. Posteriormente, estas análises foram lançadas em um mapa de fundo geológico, com simbologias apropriadas, de acordo com o material e método analisado, além da idade obtida, propiciando a elaboração do denominado Mapa Geocronológico. Portanto, este mapa geocronológico, juntamente com o banco de dados, que ficará disponível para a comunidade científica no CPGeo-USP, constituirão, em conjunto com a evolução crustal do Cráton Amazônico, os produtos principais deste trabalho. 


\section{2 - METODOLOGIA DE TRABALHO}

Um mapa geocronológico apresenta, em uma base geológica relativamente simples, todos os pontos relativos às localizações das amostras datadas, lançados de acordo com uma legenda que diferencia cada ponto conforme o método radiométrico utilizado, o material analisado e a idade obtida. A partir de interpretações geocronológicas pode-se atribuir cores às unidades geológicas datadas, em função das idades de formação de rochas. A adoção de simbologias características para as datações efetuadas pelo método $\mathrm{K}-\mathrm{Ar}$, que geralmente indicam idades de resfriamento, também mostram os principais periodos de estabilização tectônica regional.

A observação de mapas geocronológicos permite aos usuários uma visão das unidades geológicas datadas, do padrão de idades obtido, das épocas dos principais eventos metamórficos que atuaram no cráton e a caracterização de zonas carentes de estudos geocronológicos, que podem ser utilizadas para planejamento de trabalhos futuros. Mapas deste tipo já foi realizado anteriormente por Mascarenhas et. al. (1987) para o Estado da Bahia.

Neste mapa, as rochas pré-Cambrianas do Cráton Amazônico (parte brasileira) serão classificadas, além das suas litologias básicas, pelas suas respectivas idades, bem como pelos eventos metamórficos eventualmente superpostos, através de cores e simbologias apropriadas, respectivamente. As idades consideradas, com exceção daquelas obtidas pelo método K-Ar, serão aquelas atribuídas aos episódios de formação de rochas. O período de formação de uma rocha será aqui considerado como sendo a época de desenvolvimento da paragênese mineral principal da rocha estudada, independentemente do protólito da rocha, se mantélico ou se uma rocha crustal pré-existente. Por exemplo, no caso de um paragnaisse, a idade de formação será a época de geração do paragnaisse, não sendo considerada a idade dos sedimentos fontes, ou, no caso de um granulito, será considerada a época de granulitização, independente se o material 
granulitizado diferenciou-se do manto pouco ou muito tempo antes do evento. Já as idades de resfriamento de eventos metamórficos de diversas naturezas serão detectadas através de idades K-Ar. Para as unidades estratigráficas que não contêm datações radiométricas será atribuída uma idade com base nas relações estratigráficas disponiveis na literatura.

A listagem completa dos dados analíticos compilados encontra-se anexada no final do trabalho. Nesta relação são apresentados, em adição, o tipo de rocha e material analisado, número de laboratório, unidade geológica, localidade mais próxima e coordenadas geográficas. Para informações complementares, o leitor deverá recorrer às publicações originais, indicadas na coluna relativa às referências bibliográficas.

A base geológica adotada no mapa geocronológico é o Mapa Geológico do Brasil, na escala 1:2 500 000, de Schobbenhaus et. al. (1981) ligeiramente modificado. Como o mapa geocronológico envolve uma série de parâmetros, como simbologias e numerações variadas, preferiu-se adotar uma base geológica simples, sem muitos detalhes, para que as informações geocronológicas não se confundam com outras simbologias geológicas.

Os termos relativos ao tempo geológico citados neste trabalho são aqueles adotados na subdivisão do tempo geológico recomendada pela Subcomissão de Estratigrafia do Pré-Cambriano, vinculada à Comissão Internacional de Estratigrafia da International Union of Geological Sciences (IUGS), publicada por Plumb (1991) e Fuck (1991a,b), que constam da Tabela 1. 
TABELA 1

SUBDIVISÃO DO TEMPO GEOLÓGICO DURANTE O PRÉ-CAMBRIANO

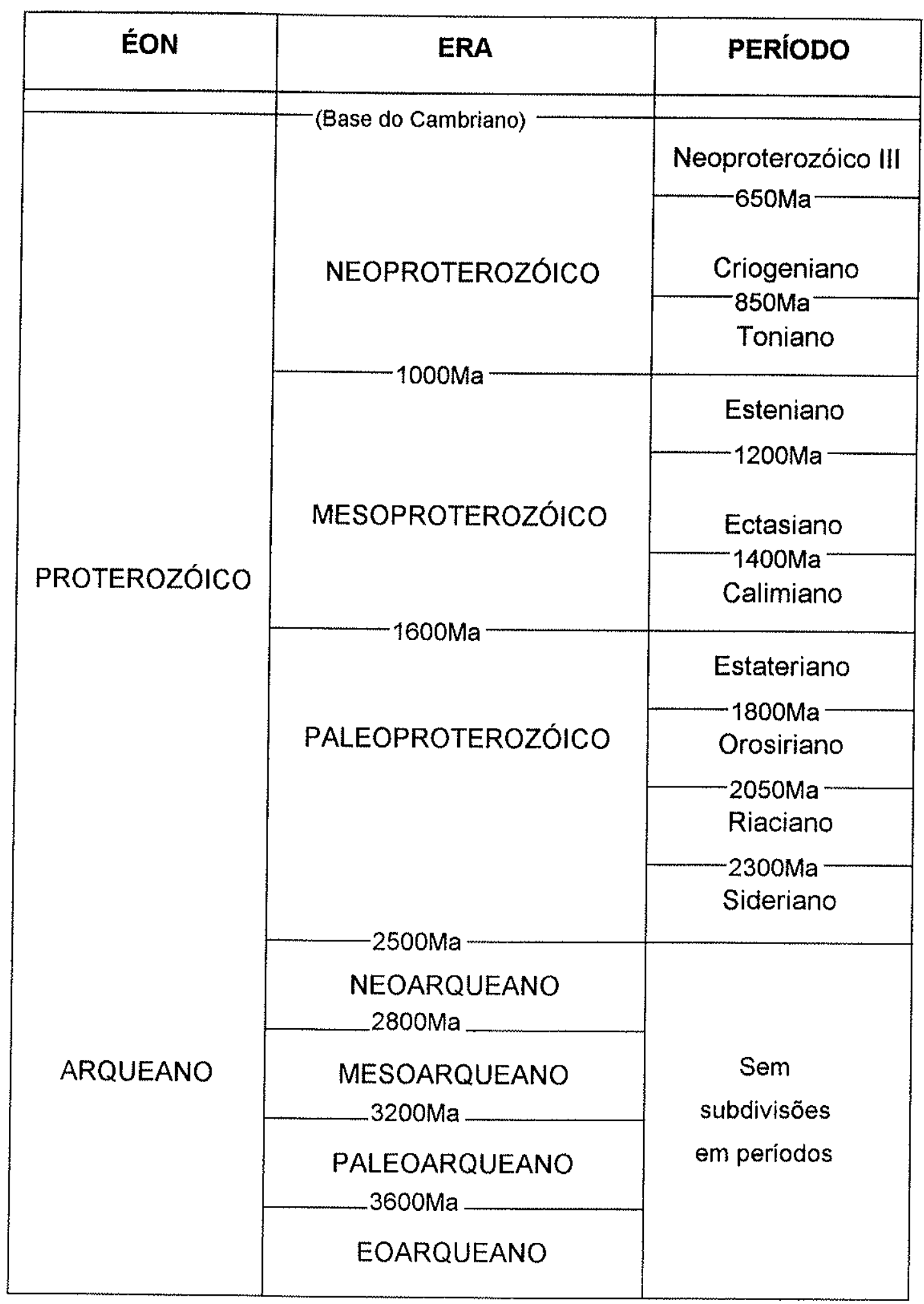


Esta subdivisão internacional do tempo geológico será aqui adotada, apesar de Brito Neves et. al. (1992) ter demonstrado que algumas das orogêneses que ocorreram no Cráton Amazônico não coincidem exatamente com os limites da subdivisão do tempo geológico considerada acima, principalmente durante o Mesoproterozóico, onde as orogenias Rio Negro - Juruena (1.80 - 1.55 Ga), que podem ser ainda subdivididas em duas $(1.8-1.7 \mathrm{Ga}$ e $1.65-1.55 \mathrm{Ga})$, e as orogenias Rondonianan - San Ignácio e Sunsás, com idades respectivas de 1.55 $1.4 \mathrm{Ga}$ e 1.3 - $1.0 \mathrm{Ga}$, possuem limites temporais diferentes dos Períodos Estateriano (1.8 - 1.6 Ga), Calimiano (1.6 - $1.4 \mathrm{Ga})$, Ectasiano $(1.4-1.2 \mathrm{Ga}) \mathrm{e}$ Esteniano (1.2 - 1.0 Ga). Para as orogenias mais antigas que $1.8 \mathrm{Ga}$, os intervalos de tempo são coincidentes. Por assim ser, no mapa geocronológico apresentado neste trabalho, foi considerada a divisão de tempo mais adequada para representar os eventos tectônicos que atuaram no Cráton.

Neste sentido as simbologias adotadas para as idades representadas no mapa seguiram a seguinte divisão:

- >3,2 Ga;

- 3,2 Ga-2,8 Ga;

- $2,8 \mathrm{Ga}-2,5 \mathrm{Ga}$;

- $2,5 \mathrm{Ga}-2,3 \mathrm{Ga}$;

- 2,3 Ga-2,05 Ga;

- $2,05 \mathrm{Ga}-1,8 \mathrm{Ga}$;

- $1,8 \mathrm{Ga}-1,55 \mathrm{Ga}$;

- 1,55 Ga-1,3 Ga;

- 1,3 Ga-1,0 Ga;

- 1,0 Ga-0,57 Ga;

- $<0,57 \mathrm{Ga}$. 
A legenda geocronológica do mapa está estruturada segundo os seguintes parâmetros:

- 1- Metodologia radiométrica (simbolos distintos e letras);

- 2- Idade (cores segundo os intervalos de idades citados acima);

- 3 - Número de Ordem (com iniciais das folhas ao milionésimo).

Informações adicionais sobre os dados geocronológicos serão fornecidas nas tabelas anexas, onde os dados analíticos e informaçöes complementares estão ordenados pelo número de ordem em duas tabelas: a primeira com as informações gerais das amostras datadas e a segunda com os dados analíticos de cada amostra, separados pela metodologia geocronológica utilizada.

O desenvolvimento do trabalho para a elaboração do mapa geocronológico e da base de dados radiométricos constou das seguintes fases:

a - Compilação dos dados geocronológicos disponíveis na literatura

Para o desenvolvimento desta fase partiu-se dos levantamentos e trabalhos efetuados pelo Projeto RADAM e posteriormente RADAMBRASIL, nas diversas folhas ao milionésimo do Cráton Amazônico, complementados com os trabalhos publicados posteriormente.

b- Elaboração da Base de Dados

Todos os dados isotópicos levantados foram lançados em uma base dados, utilizando-se o programa para PC, "MICROSOFT ACCES". Esta base de dados é composta de cinco arquivos, a saber: $\mathrm{Rb}-\mathrm{Sr} ; \mathrm{K}-\mathrm{Ar} ; \mathrm{Pb}-\mathrm{Pb} ; \mathrm{Sm}-\mathrm{Nd}$ e U-Pb, que são as metodologias radiométricas utilizadas nas determinações geocronológicas. 
As informações contidas na base dados são as seguintes:

- $\mathrm{n}^{\circ}$ de campo;

- tipo litológico;

- $n^{\circ}$ de ordem (para localização no mapa);

- $\mathrm{n}^{\circ}$ de laboratório;

- coordenadas geográficas;

- precisão das coordenadas;

- referência da folha cartográfica ao milionésimo;

- material analisado;

- unidade geológica;

- referencias bibliográficas (Tabela com os Dados Gerais);

- os dados analíticos correspondentes a cada metodologia radiométrica (Tabelas de Dados Analíticos).

\section{c - Elaboração do Mapa Geocronológico}

A partir do levantamento dos dados geocronológicos da literatura disponível, os pontos amostrados foram lançados em um mapa, na escala 1:2500 000, com fundo geológico simplificado, localizados segundo um número de ordem que inclui letras correspondentes às iniciais da folha cartográfica ao milionésimo onde o ponto está localizado. Além disto, estes pontos foram lançados com simbologias relacionadas às metodologias geocronológicas pelas quais foram analisados, e as idades obtidas, diferenciadas por cor. As coordenadas geográficas de cada ponto foram tiradas a partir da utilização do programa para microcomputador "PC". Após o mapa estar concluído, o mesmo foi digitalizado através do Programa para PC "AUTOCAD". 
d - Interpretação Geocronológica

Com base no levantamento dos dados geocronológicos existentes e nas informações geológicas e geofísicas atualmente disponiveis, os dados isotópicos foram reinterpretados $e$, quando necessário, reagrupados em diagramas adequados, de forma a possibilitar uma visão integrada dos dados, permitindo identificar os principais eventos geológicos que atuaram no cráton, posicionando-os no tempo geológico. A interpretação dos dados geocronológicos permitiu as discussões sobre evolução crustal do Cráton Amazônico que consta neste texto. 


\section{3 - SIGNIFICAÇÃO GEOLÓGICA DOS MÉTODOS GEOCRONOLÓGICOS}

A grande maioria dos dados geocronológicos atualmente disponiveis para as rochas do Cráton Amazônico são aqueles obtidos pelas metodologias $\mathrm{Rb}-\mathrm{Sr}$ e K-Ar, embora hoje já existam também um número significativo de datações pelo método $U$ $\mathrm{Pb}$ em zircões em algumas áreas do cráton e, de uma forma subordinada, idades $\mathrm{Pb}-\mathrm{Pb}$ e Sm-Nd em rocha total.

Visando a homogeneidade no tratamento interpretativo dos dados isotópicos, os mesmos foram recalculados segundo as seguintes constantes:

\section{- Sistema Rb-Sr}

$\lambda_{R b}=1,42 \times 10^{-11}$ anos $^{-1}$ *

$\left({ }^{85} \mathrm{Rb} /{ }^{87} \mathrm{Rb}\right) \mathrm{n}=2,593 \pm 0,002$ **

- Sistema K-Ar

$\lambda^{40} K_{\beta=}=4,962 \times 10^{-10}$ anos $^{-1}$ *

$\lambda^{40} \mathrm{~K}_{\varepsilon}+\lambda^{40} \mathrm{~K}_{\varepsilon}=0,581 \times 10^{-10}$ anos $^{-1}$ *

${ }^{40} \mathrm{~K}=0,001167 \% \mathrm{~K}_{\text {tot }}$ *

$\left({ }^{40} \mathrm{Ar}{ }^{36} \mathrm{Ar}\right)_{\mathrm{atm}}=295,5^{*}$ 


\section{- Sistema Sm - Nd}

$$
\begin{aligned}
& \lambda_{\mathrm{Sm}}=6,54 \times 10^{-12} \text { anos }^{-1} \\
& \left({ }^{143} \mathrm{Nd} /{ }^{144} \mathrm{Nd}\right)_{\mathrm{DM}}=0,513114^{\star \star *} \quad\left({ }^{147} \mathrm{Sm} /{ }^{144} \mathrm{Nd}\right)_{\mathrm{DM}}=0,222 \text { ***}
\end{aligned}
$$

- Sistema U - Pb e Pb - Pb

$\lambda^{238} \mathrm{U}=1,55125 \times 10^{-10} \operatorname{anos}^{-1}$ *

$\lambda^{235} U=9,8485 \times 10^{-10}$ anos $^{-1}$ *

${ }^{238} U /{ }^{235} U=137,88$ *

As referências das constantes utilizadas são as seguintes:

* Steiger and Jäger (1977); ** CPGeo-USP ; ${ }^{\star \star \star * M i c h a r d ~ e t . ~ a l . ~(1985) ~}$

\section{1 - Sistema $\mathrm{Rb}-\mathrm{Sr}$}

O sistema Rb-Sr é a metodologia radiométrica mais utilizada no Brasil, em razão de poder ser empregada numa grande variedade de rochas, da sua simplicidade analítica, do seu poder interpretativo e também por existir no Brasil desde 1972, no CPGeo - USP.

A desintegração radioativa do ${ }^{87} \mathrm{Rb}$ em ${ }^{87} \mathrm{Sr}$ permite desenvolver dois importantes parâmetros para as pesquisas no campo da geologia: 
- um método de datação de eventos geológicos, que normalmente data processos formadores de rochas;

- um traçador isotópico, $\left({ }^{87} \mathrm{Sr} /{ }^{86} \mathrm{Sr}\right)$ inicial, utilizado em geoquímica isotópica, que permite estabelecer a natureza das fontes magmáticas de rochas.

As idades $\mathrm{Rb}-\mathrm{Sr}$ podem ser calculadas de duas formas distintas, as chamadas idades convencionais e as idades isocrônicas (Faure, 1986).

O cálculo de idade $\mathrm{Rb}-\mathrm{Sr}$ convencional é efetuado através da equação 1 (exposta abaixo), que consiste em atribuir, por convenção, um valor a razão ${ }^{87} \mathrm{Sr} /{ }^{86} \mathrm{Sr}$ inicial da amostra, normalmente igual a 0,705 , o qual corresponde à relação isotópica inicial média das rochas ígneas.

Equação 1

$$
\mathrm{T}=1 / \lambda \log \left[1+\frac{\left.\left({ }^{87} \mathrm{Sr} /{ }^{86} \mathrm{Sr}\right) \mathrm{m}-\left({ }^{87} \mathrm{Sr} /^{86} \mathrm{Sr}\right) i\right]}{\left({ }^{87} \mathrm{Rb} /{ }^{86} \mathrm{Sr}\right) \mathrm{m}}\right.
$$

onde:

$m=$ razão isotópica medida;

I = razão isotópica inicial

Esta prática tem como vantagem o fato de permitir o cálculo de uma idade a partir de somente uma amostra, apresentando como principal desvantagem a imprecisão do cálculo da idade, uma vez que o valor atribuído à razão inicial pode não corresponder ao real. Entretanto, a equação 1 mostra que quando $\circ$ valor ${ }^{87} \mathrm{Sr}{ }^{86} \mathrm{Sr}$ medido é muito maior que 0,705 , a escolha de um valor para a razão inicial não é crítica para o cálculo da idade. A razão ${ }^{87} \mathrm{Sr} /{ }^{86} \mathrm{Sr}$ medida é muito grande, principalmente quando a rocha ou mineral datado possui alta razão $\mathrm{Rb} / \mathrm{Sr}$ ou então, em alguns casos, quando o material é muito antigo.

A outra forma de se calcular idades $\mathrm{Rb}$-Sr, mais utilizada atualmente, é através de diagramas isocrônicos, onde pode-se evitar o inconveniente de se 
atribuir arbitrariamente um valor para a razão inicial. A equação 1 pode ser transformada na equação 2.

Equação 2:

$$
\left({ }^{87} \mathrm{Sr}{ }^{86} \mathrm{Sr}\right) \mathrm{m}=\left({ }^{87} \mathrm{Sr}{ }^{86} \mathrm{Sr}\right) \mathrm{i}+\left({ }^{87} \mathrm{Rb} /{ }^{86} \mathrm{Sr}\right) \mathrm{m} .\left(\mathrm{e}^{\lambda t}-1\right)
$$

- que corresponde a uma equação de uma reta do tipo $y=b+x a$, na condição de que t seja uma constante. (Nicolaysen, 1961).

Esta equação, portanto, permite calcular o valor correto da razão inicial ${ }^{87} \mathrm{Sr}{ }^{36} \mathrm{Sr}$, e não mais imaginá-lo, quando se trabalha com um conjunto de amostras. Neste sentido se a razão inicial (b) é comum para todas amostras analisadas, elas definem uma reta em um diagrama $\left({ }^{87} \mathrm{Sr}{ }^{86} \mathrm{Sr}\right) \mathrm{m}$ versus $\left({ }^{87} \mathrm{Rb} /{ }^{86} \mathrm{Sr}\right) \mathrm{m}$, cujo coeficiente angular é proporcional a idade do sistema, e a origem da reta, ponto $b$, que é a intersecção desta reta com o eixo das ordenadas, corresponderá ao valor da razão inicial ${ }^{87} \mathrm{Sr} /{ }^{86} \mathrm{Sr}$ do conjunto de amostras analisado. Portanto, a condição básica para que se obtenha uma isócrona é que as amostras sejam cogenéticas, ou seja, formadas ao mesmo tempo e a partir de uma mesma fonte, de forma que tenham a mesma idade e a mesma razão inicial.

Quanto às interpretações de idades $\mathrm{Rb} / \mathrm{Sr}$, elas podem ser distintas se as idades forem obtidas em minerais separados ou em rocha total. No caso de idades em concentrados minerais de rochas ígneas e metamórficas, estas geralmente não correspondem à idade de formação das rochas, mas sim a época de resfriamento ou do último aquecimento sofrido pela rocha. Isto ocorre porque os átomos do elemento radiogênico ${ }^{87} \mathrm{Sr}$ são bastante móveis, uma vez que ocupam lugares no retículo cristalino onde são incompatíveis geoquimicamente. Por exemplo o ${ }^{87} \mathrm{Sr}$ radiogênico substitui ${ }^{87} \mathrm{Rb}$, que tem raio iônico maior, favorecendo, portanto, a mobilidade do Sr. Cada mineral se comporta como um sistema fechado, com uma temperatura de bloqueio característica, e quando o mineral se resfria a partir ba. temperatura de bloqueio, ele começa a reter ${ }^{87} \mathrm{Sr}$, fazendo com que o cronômetro $\mathrm{Rb}-\mathrm{Sr}$ comece a funcionar. Portanto, neste caso, a idade obtida será a deste resfriamento. No caso da rocha ser reaquecida até uma temperatura superior a de 
bloqueio, os átomos de ${ }^{87} \mathrm{Sr}$ sairão dos minerais enriquecidos em $\mathrm{Rb}$, como a biotita e entrarão nos minerais pobres em $\mathrm{Rb}$ como os plagioclásios, provocando a chamada re-homogeneização isotópica dos minerais, e neste caso, a idade obtida seria a deste último reaquecimento.

O sistema $\mathrm{Rb}-\mathrm{Sr}$ em rocha total se comporta como um sistema fechado, em relação a eventos de reaquecimentos, como o citado acima, onde $0{ }^{87} \mathrm{Sr}$ se redistribui entre os diversos minerais, mas não sai da rocha, tornando o sistema rocha total fechado. No caso de formação de uma rocha, a temperatura em que o sistema Rb-Sr se fecha, quando se utiliza rocha total, é superior à temperatura de resfriamento dos minerais, portanto, em geral, as idades $\mathrm{Rb}-\mathrm{Sr}$ em rocha total tendem a fornecer idades de formação de rochas. O cronômetro $\mathrm{Rb}-\mathrm{Sr}$ é zerado cada vez que o Sr, dentro de uma formação geológica, apresenta a mesma composição isotópica, o que acontece quando ocorre o fenômeno da homogeneização isotópica de $\mathrm{Sr}$ a nível de rocha total. Esta homogeneização isotópica se produz em meio líquido, por mistura de $\mathrm{Sr}$ de composição isotópica distinta, e também em meio sólido, quando a homogeneização isotópica ocorre por processos de difusão isotópica. Para o caso de rochas metamórficas, se o metamorfismo atingir intensidade suficiente para provocar homogeneizações isotópicas, a idade isocrônica $\mathrm{Rb}-\mathrm{Sr}$ em rocha total será representativa deste evento metamórfico. A granulometria, mineralogia e composição química da rocha original são fatores que condicionam a homogeneização isotópica do $\mathrm{Sr}$, podendo esta ser completa ou incompleta; neste último caso os pontos analíticos não se alinharão no diagrama isocrônico, e a idade obtida não deverá ter significação geológica.

Portanto, isócronas $\mathrm{Rb}-\mathrm{Sr}$ em rocha total datam eventos de homogeneização isotópica de $\mathrm{Sr}$, que, em geral, correspondem a época de formação das mesmas. Entretanto, quando um granitóide é afetado por fluidos tardimagmáticos, como albitizações e graisenizações por exemplo, sofrem uma perda de $\mathrm{Sr}$ nas partes afetadas, abrindo o sistema Rb-Sr e fazendo também com que as idades obtidas não representem nenhum evento geológico. 
A razão $\left({ }^{87} \mathrm{Sr} r^{86} \mathrm{Sr}\right)$ inicial de um conjunto de rochas igneas ou metamórficas pode ser utilizada como um parâmetro indicador da natureza das fontes destas rochas. Os isótopos de $\mathrm{Sr}$ conseguem diferenciar claramente um magma que foi produzido por fusão parcial de rochas da crosta continental superior, daquele produzido por diferenciação do manto superior ou por fusão parcial de crosta inferior granulítica empobrecida, não podendo, entretanto, se diferenciar entre estes dois últimos processos, porque estes dois ambientes possuem razões $\mathrm{Rb} / \mathrm{Sr}$ similares, geralmente menores que 0,04 (Moorbath e Taylor, 1981). Neste trabalho a composição isotópica de $\mathrm{Sr}$ inicial será denominada por $r i$.

O manto superior é empobrecido em $\mathrm{Rb}$, em relação a crosta continental superior, o que implica em uma evolução da razão ${ }^{87} \mathrm{Sr} /{ }^{86} \mathrm{Sr}$ mais retardada no manto do que na crosta superior. Portanto, magmas provenientes do manto superior possuem normalmente valores de $r i$. baixos, entre 0,700 e 0,705, sendo esta variação função do maior ou menor empobrecimento de $\mathrm{Rb}$ do manto, ou da época da diferenciação mantélica. Por outro lado, magmas produzidos por processos de fusão parcial da crosta continental superior, que possuem razões $\mathrm{Rb} / \mathrm{Sr}$ mais elevadas, tendem a apresentar valores de $r i$. mais altos, em geral, acima de 0,706.

O diagrama razão ${ }^{87} \mathrm{Sr} /{ }^{86} \mathrm{Sr}$ versus tempo geológico, de Faure (1985), apresentado na Figura 1, mostra a variação das razões isotópicas do $\mathrm{Sr}$ para o manto, o campo da crosta continental e a reta de evolução isotópica da Terra Global em função do tempo, permitindo que, a partir da determinação da idade e da $r$ i. de um conjunto de rochas, seja possível estabelecer algumas características geoquímicas da fonte destas rochas. Atualmente, o manto superior apresenta razões ${ }^{87} \mathrm{Sr} /{ }^{86} \mathrm{Sr}$ heterogêneas, geralmente variando entre 0,702 e 0,706 principalmente. Entretanto, para alguns tipos de manto mais enriquecidos, são encontrados valores de até 0,708 . Esta variação da composição isotópica do manto é devida a heterogeneidades mantélicas produzidas pelos sucessivos episódios de diferenciação mantélica e pela reciclagem de material continental para o manto através das zonas de subducção. 


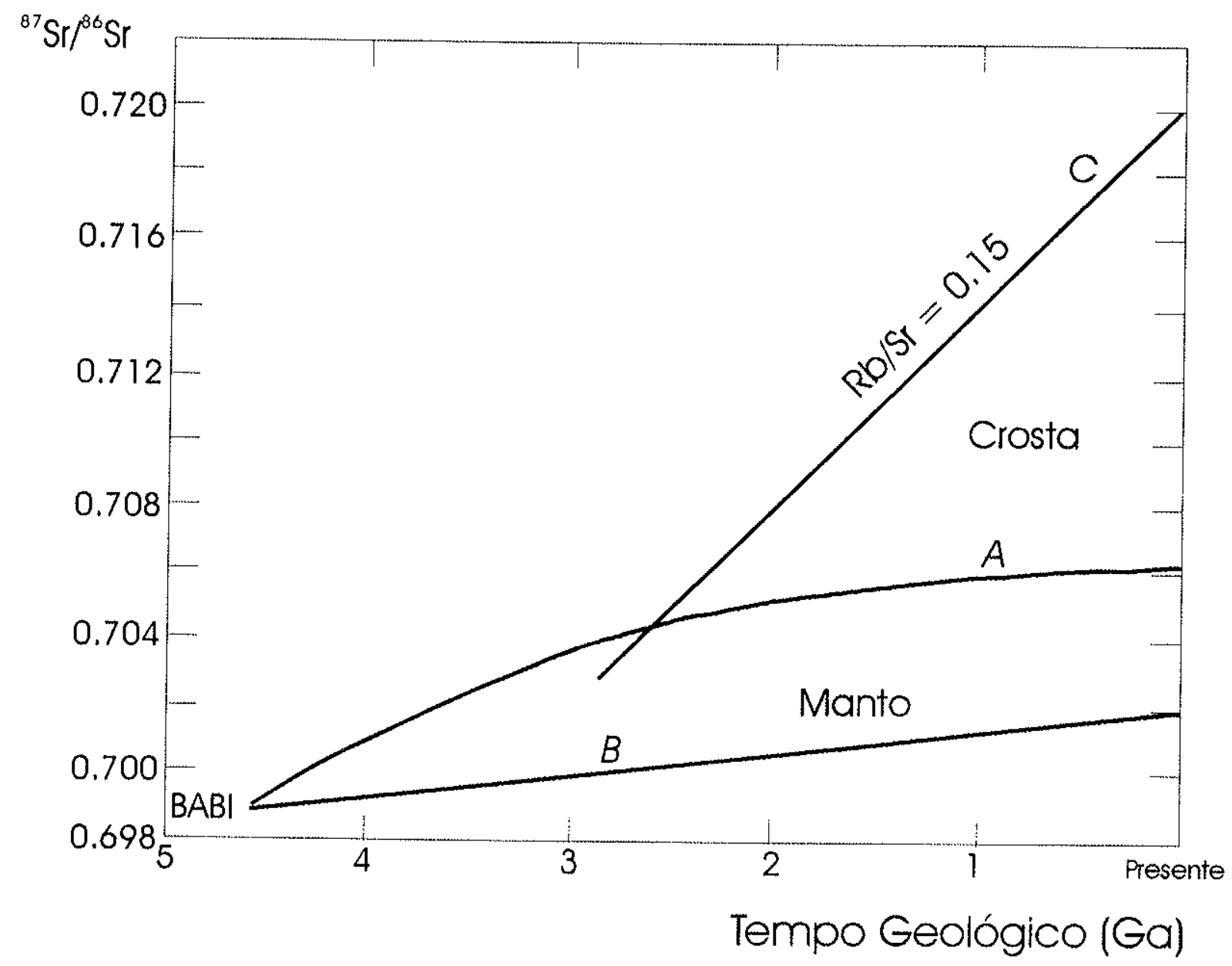

FIG. 1 - Diagrama ${ }^{87} \mathrm{Sr} /{ }^{86} \mathrm{Sr} \times$ Tempo geológico onde são mostrados os campos de variação estabelecidos para o manto superior e crosta continental (Faure, 1986) 


\section{2 - Sistema Sm - Nd}

Como o desenvolvimento do método $\mathrm{Sm}-\mathrm{Nd}$ praticamente iniciou-se no meio da década de 70, com os trabalhos de Lugmair et. al. (1975) e Nakamura et.al. (1976), e no Brasil, apenas a partir de 1994, nos laboratórios do CPGeo-USP, ainda é pequeno o número de dados por esta metodologia distribuídos pelo Cráton Amazônico.

O Sm e o Nd são dois elementos do Grupo das Terras Raras, com raios iônicos bastante próximos, e com a mesma valência, o que os tornam praticamente isoquímicos, e faz com que as rochas em geral possuam razões $\mathrm{Sm} / \mathrm{Nd}$ pouco diferenciadas, variando em geral entre 0,1 e 0,37 entre os diversos tipos de rochas e minerais. Como os Elementos Terras Raras possuem uma forte densidade de carga $\left(3^{+}\right)$e um número atômico elevado, estes elementos praticamente não se difundem no estado sólido, o que os torna pouco móveis na escala rocha total. Por outro lado, em escala de mineral, durante um processo metamórfico, ocorre uma redistribuição do Sm e do Nd entre os minerais neoformados.

A exemplo do método Rb-Sr, a sistemática Sm-Nd também fornece, além de idades de eventos geológicos, um parâmetro bastante utilizado em petrogênese, que permite caracterizar a natureza da fonte das rochas estudadas.

O cálculo de idades $\mathrm{Sm}-\mathrm{Nd}$ pode ser feito através de isócronas em rocha total e em concentrados de minerais separados, e também através de idades modelos em rocha total.

O princípio das isócronas $\mathrm{Sm}-\mathrm{Nd}$ é o mesmo daquele empregado para o método $\mathrm{Rb}-\mathrm{Sr}$, onde a equação de cálculo de idades é similar à equação de uma reta, cujo coeficiente angular é proporcional a idade do conjunto de rochas analisado, em um diagrama ${ }^{143} \mathrm{Nd} /{ }^{144} \mathrm{Nd}$ versus ${ }^{147} \mathrm{Sm} /{ }^{144} \mathrm{Nd}$. Como no instante de formação da rocha todos os seus minerais possuem a mesma composição isotópica de $\mathrm{Nd}\left({ }^{143} \mathrm{Nd} /{ }^{144} \mathrm{Nd}\right)$, estando portanto homogeneizados isotopicamente, o método 
$\mathrm{Sm}$-Nd data eventos de homogeneização isotópica, que em geral estão relacionados a eventos formadores de rochas ígneas ou metamórficas. Devido ao comportamento isoquímico do $\mathrm{Sm}$ e do $\mathrm{Nd}$, é difícil obter variações significativas nas razões $\mathrm{Sm} / \mathrm{Nd}$ em rochas cogenéticas, o que dificulta a obtenção de isócronas em rocha total.

Concentrados de minerais de uma mesma rocha normalmente permitem a obtenção de isócronas porque possuem razões $\mathrm{Sm} / \mathrm{Nd}$ com alguma variação, com valores dentro do intervalo 0,14 a 0,54 , fornecidos respectivamente pelo feldspato potássico e pela granada. Além destes minerais, são utilizados concentrados de clinopiroxênios, plagioclásios, biotitas e anfibólios. A idade obtida geralmente é interpretada como a época de formação da paragênese mineral datada, portanto, é importante que os minerais datados sejam formados durante o mesmo evento geológico. Para o caso de rochas metamórficas, Mezger et. al. (1992), demonstraram que isócronas $\mathrm{Sm}-\mathrm{Nd}$ em minerais podem indicar idades de resfriamento do sistema, logo após as condições de máximo metamorfismo, indicando que a temperatura de fechamento do sistema Sm-Nd para o par rocha total-granada seria da ordem de $600^{\circ} \mathrm{C}$.

A outra forma de cálculo de idades do sistema Sm-Nd é a denominada idade modelo. Este tipo de cálculo baseia-se no fato de que a razão $\mathrm{Sm} / \mathrm{Nd}$ na escala rocha total não varia significativamente durante processos geológicos crustais, como anatexias, metamorfismos, diagênese e alterações intempéricas. Esta razão será modificada de forma importante apenas durante o processo de diferenciação manto-crosta. Portanto, quando um magma é extraído do manto, ocorre uma modificação na razão $\mathrm{Sm} / \mathrm{Nd}$, e, a partir da incorporação do magma à crosta continental, nenhum evento geológico que possa ocorrer irá modificar de forma importante a razão $\mathrm{Sm} / \mathrm{Nd}$. Neste sentido, este princípio permite datar para qualquer rocha a época em que seu protólito crustal se diferenciou do manto superior. Como exemplo, pode-se considerar uma rocha tonalítica que se diferenciou do manto há 3,0 Ga, e que em 1,0 Ga sofreu um processo de fusão parcial originando um granitóide, datando-se este granitóide através de isócronas $\mathrm{Sm}-\mathrm{Nd}$ em rocha total 
ter-se-ía uma idade próxima a 1,0 Ga,, mas calculando-se a idade modelo $\mathrm{Sm}-\mathrm{Nd}$, encontrar-se-ía um valor muito próximo a 3,0 Ga.

O cálculo de idades modelos é feito a partir da regressão da razão ${ }^{143} \mathrm{Nd} /{ }^{144} \mathrm{Nd}$ em função da razão ${ }^{147} \mathrm{Sm} /{ }^{144} \mathrm{Nd}$, até o intercepto desta regressão com a curva de evolução isotópica de $\mathrm{Nd}$ do manto superior em função do tempo geológico, como mostrado na Figura 2. O problema se coloca justamente na elaboração desta curva de evolução isotópica do manto, uma vez que, devido às heterogeneidades mantélicas, esta ainda não é bem estabelecida. Desta forma, são criados modelos de evolução isotópica de $\mathrm{Nd}$, e em função do modelo adotado, terse-ão idades distintas.

Apesar de existirem vários tipos de manto, sob o ponto de vista geoquímico, existem dois modelos de evolução isotópica de $\mathrm{Nd}$ para o manto superior. $\mathrm{O}$ primeiro, baseado na evolução do condritos (CHUR - Chondritic Uniform Reservoir), adotado inicialmente, e o outro adotado atualmente, que é o denominado manto empobrecido (DM - Depleted Mantle), admite que o manto superior sofreria sucessivos episódios de diferenciação e fracionamento, envolvendo a extração de magmas basálticos, permanecendo um manto residual cada vez mais empobrecido geoquimicamente, e ,portanto, com a razão $\mathrm{Sm} / \mathrm{Nd}$ cada vez maior. Neste trabalho as idades Sm-Nd modelo utilizadas foram calculadas através do modelo manto empobrecido $\left(T_{D M}\right)$, através da seguinte equação:

$$
T_{D M}=1 / \lambda \log \left[1+\frac{0,513114-\left({ }^{143} \mathrm{Nd} /{ }^{144} \mathrm{Nd}\right)_{\mathrm{am}}}{0,222-\left({ }^{147} \mathrm{Sm} / /^{144} \mathrm{Nd}\right)_{\mathrm{am}}}\right.
$$

onde o símbolo am indica que as composições isotópicas são aquelas medidas atuaimente nas amostras estudadas. 


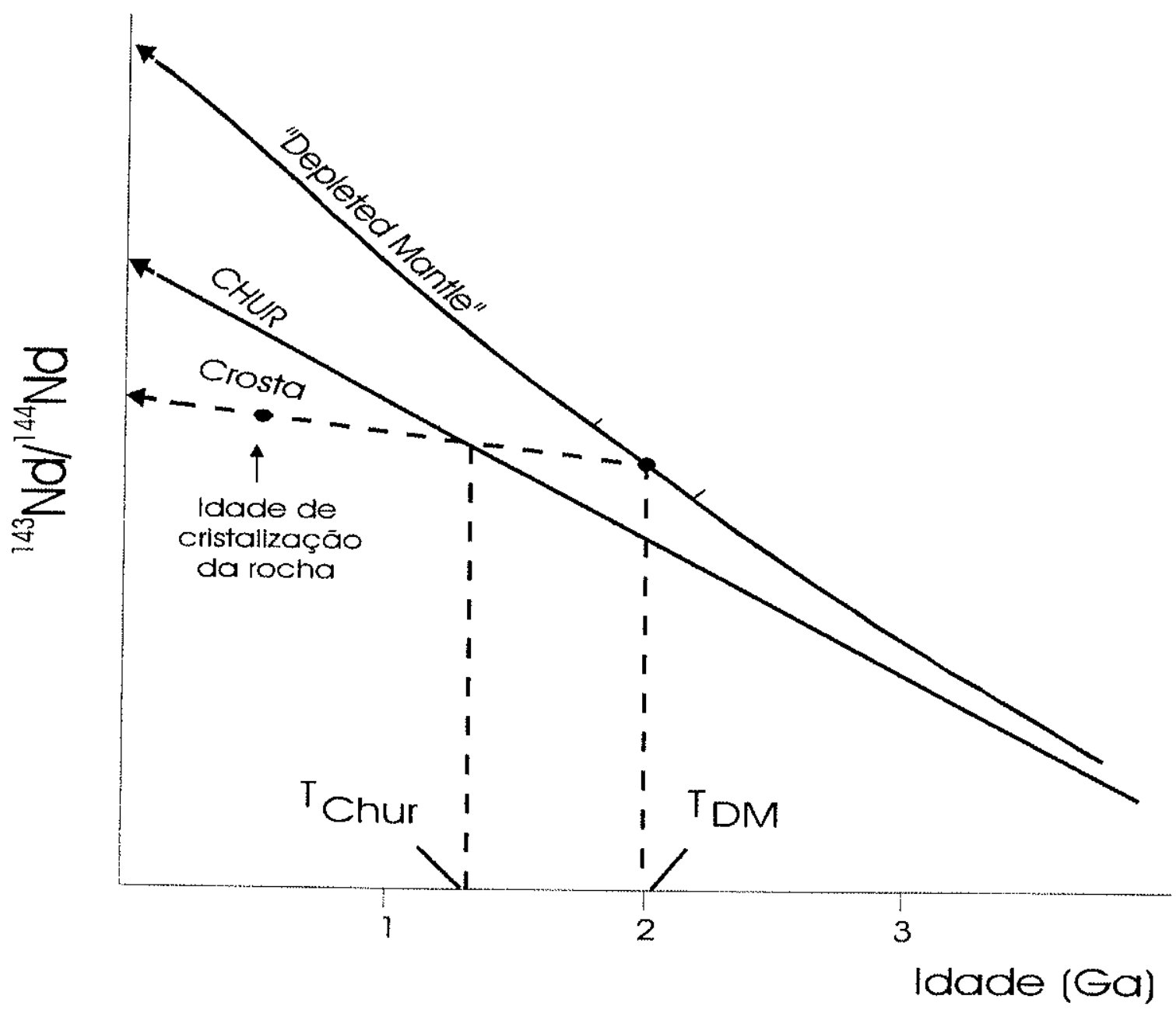

FIG. 2 - Representação gráfica da idade modelo Sm-Nd em função das curvas de evolução isotópica para o CHUR e para o manto empobrecido ("depleted mantle") 
Em alguns casos, as idades modelos calculadas podem não possuir significação geológica; isto ocorre quando:

- uma rocha é produzida por meio de fusão parcial de materiais diferenciados do manto em épocas distintas;

- quando a rocha datada é enriquecida em minerais que concentram seletivamente os elementos Terras Raras, como as monazitas e alanitas;

- quando o material é diferenciado de um manto enriquecido do tipo EMORB ou HIMU.

Da mesma maneira que o método $\mathrm{Rb}-\mathrm{Sr}$ fornece um indicador petrogenético, a $r$ $i$, o método $\mathrm{Sm}-\mathrm{Nd}$ fornece também um parâmetro muito utilizado em petrogênese denominado de $\varepsilon_{\mathrm{Nd}}$. Este parâmetro consiste basicamente na comparação da razão ${ }^{143} \mathrm{Nd} /{ }^{144} \mathrm{Nd}$ da amostra estudada com a composição isotópica do reservatório condrítico (CHUR), em uma mesma época. Este parâmetro é calculado através da seguinte equação:

$$
\varepsilon_{\mathrm{Nd}}=\left[\left({ }^{143} \mathrm{Nd} / /^{144} \mathrm{Nd}\right)_{\mathrm{am}} /\left({ }^{143} \mathrm{Nd} /{ }^{144} \mathrm{Nd}\right)_{\mathrm{CHUR}}-1\right] \times 10^{4}
$$

Portanto, se na época de formação da rocha, por exemplo, o magma parental tiver uma razão ${ }^{143} \mathrm{Nd} / /^{144} \mathrm{Nd}$ mais elevada que o condrito, como um magma diferenciado do manto superior, o valor de $\varepsilon_{N d}$ será positivo, e se a amostra tiver composição isotópica de $\mathrm{Nd}$ menos radiogênica que os condritos, o valor de $\varepsilon_{\mathrm{Nd}}$ será negativo, e indicaria uma fonte claramente crustal para este magma. Conforme De Paolo (1988), os valores médios de $\varepsilon_{\mathrm{Nd}}$ atuais para os diversos ambientes geoquímicos e tectônicos, são os seguintes:

- manto inferior $=0$;

- manto superior $=+10$;

- ilhas oceânicas $=+8$;

- ithas intra-placas (hot spots) $=0 a+8$;

- dorsais meso-oceânicas $=+10$; 
- áreas cratônicas $=-5$;

- rifts continentais $=-5 a+8$; arcos em margens continentais $=-20 a+8$.

\section{3 - Sistema U - Th - Pb}

Comparado com o número de idades $\mathrm{Rb}-\mathrm{Sr}$ e $\mathrm{K}-\mathrm{Ar}$ existentes no Cráton Amazônico, a quantidade de datações pelas metodologias U-Pb e $\mathrm{Pb}-\mathrm{Pb}$, ainda é muito pequena, embora várias análises tenham já sido realizadas, especialmente nas regiões da Serra dos Carajás e na porção ocidental da área cratônica.

O sistema U-Th- $\mathrm{Pb}$ propicia vários métodos radiométricos, dentre os quais, as técnicas $\mathrm{U}-\mathrm{Pb}$ e $\mathrm{Pb}-\mathrm{Pb}$.

\subsection{1 - Método $\mathrm{U}-\mathrm{Pb}$}

Algumas unidades estratigráficas do Cráton Amazônico, em especial na região da Serra dos Carajás, na região do Alto Rio Negro e em Rondônia, encontram-se datadas através do método $\mathrm{U}-\mathrm{Pb}$ em zircões. Dentro de um cristal de zircão, o $U^{4+}$ entra em solução sólida com $\circ \mathrm{Zr}^{4+}$ de uma maneira muito estável. Quando o urânio se desintegra em $\mathrm{Pb}^{2+}$, este último elemento com raio iônico bem menor que $\circ U$, não se liga fortemente à estrutura cristalina do zircão. Portanto, quando o zircão é afetado por eventos geológicos posteriores, o $U$ é praticamente imóvel, mas $\mathrm{O} \mathrm{Pb}$ possui alta mobilidade, e tenderá a migrar para fora do retículo cristalino do zircão com certa facilidade. Neste sentido, o sistema U - Pb se comporta como um sistema aberto.

Entretanto, quando se trabalha com dois geocronômetros, no caso ${ }^{235} \mathrm{U}$ ${ }^{207} \mathrm{~Pb}$ e ${ }^{238} \mathrm{U}-{ }^{206} \mathrm{~Pb}$, pode-se obter duas equações que definem em um diagrama ${ }^{206} \mathrm{~Pb} /{ }^{238} \mathrm{U}$ versus ${ }^{207} \mathrm{~Pb} /{ }^{235} \mathrm{U}$ uma curva que representa o lugar geométrico dos pontos 
de mesma idade inicial dos dois sistemas. Esta curva é denominada "Concórdia" (Wetherill, 1956).

Na prática, poucas amostras indicam idades concordantes, com os pontos relativos às composições isotópicas $\mathrm{U}$ - $\mathrm{Pb}$ situando-se sobre a concórdia, com exceção das monazitas. Em geral, todos os zircões apresentam alguma perda de $\mathrm{Pb}$, eo, quando isso ocorre, os pontos analíticos tenderão a se distanciar da curva Cncórdia segundo uma reta, porque a quantidade de $\mathrm{Pb}$ diminui igualmente nos dois eixos do diagrama. Quanto mais $\mathrm{Pb}$ o cristal de zircão tiver perdido, mais distante da Concórdia estará o seu respectivo ponto analítico. A reta que une os pontos que tiveram perdas de $\mathrm{Pb}$, e que portanto não indicam idades concordantes pelos dois geocronômetros, recebe o nome de "Discórdia".

Em conseqüência, o intercepto superior da Discórdia com a Concórdia forneceria a posição de um ponto analítico relativo aos zircões estudados, que, teoricamente, não teria perdido $\mathrm{Pb}$, e a posição deste ponto indicaria a idade de cristalização dos zircões datados, o que seria o ponto onde as idades apresentariam valores concordantes calculados pelos dois geocronômetros (Figura 3). Como a granulação e as propriedades magnéticas dos zircões são condicionantes da quantidade de perda de $\mathrm{Pb}$ radiogênico sofrida por eles, para se obter uma boa idade $\mathrm{U}-\mathrm{Pb}$, deve-se concentrar zircões de uma mesma amostra e selecioná-los conforme estes critérios em diversas frações para serem posteriormente datadas.

Como a perda de $\mathrm{Pb}$ normalmente ocorre nas bordas dos cristais de zircão, pode-se submeter estes cristais a uma abrasão (Processo do "air abrasion"), preservando o núcleo, no qual a perda de $\mathrm{Pb}$ é sensivelmente menor que nas bordas, e, neste caso, o ponto analítico tenderá a se situar muito próximo do intercepto superior na Concórdia, fornecendo idades muito mais precisas.

Além disso, quando os zircões apresentam núcleos herdados ou bordas recristalizadas, que em geral afetam as idades $\mathrm{U}$ - $\mathrm{Pb}$ efetuadas em populações de zircões, pode ser utilizada a datação $U$ - $\mathrm{Pb}$, realizada através do SHRIMP (Sensitive High Resolution Ion MicroProbe), que é um equipamento constituído por 


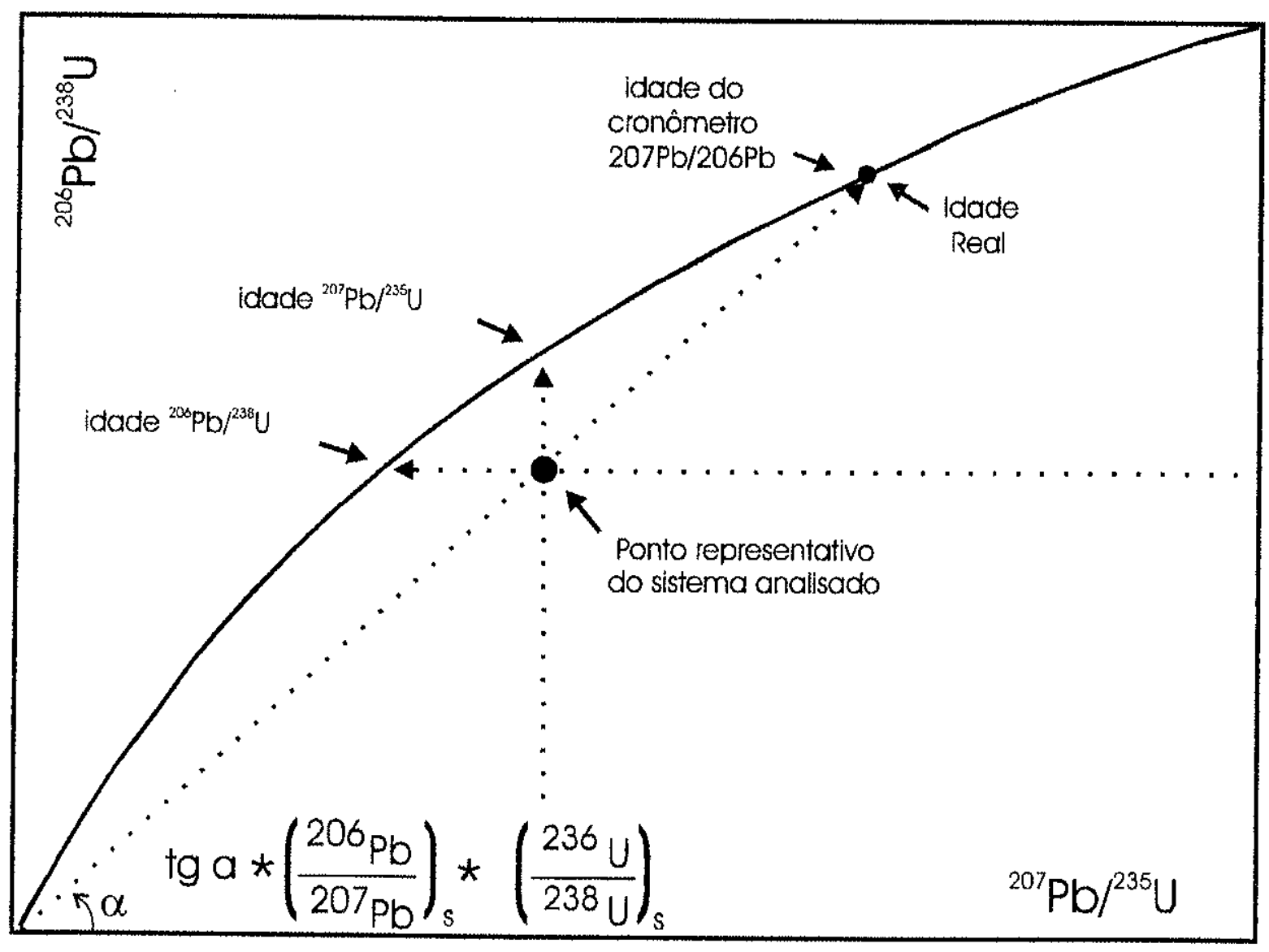

FIG. 3 - Discordâncias das idades aparentes e a indicação da idade real de um sistema qualquer anallsado. 
um sonda iônica acoplada a um espectrômetro de massa, o que permite a execução de medidas pontuais da composição isotópica através de raio laser, obtendo-se idades nas diversas zonas de um cristal de zircão, fornecendo valores de grande precisão, além de possibilitar a investigação sobre as variações de idades dentro dos cristais.

Portanto, as dataçöes U-Pb em zircōes obtidas através de Concórdias, em geral, permitem determinar a idade de cristalização da população de zircões analisada, que normalmente são um pouco mais antigas do que a idade de formação do sistema rocha total, uma vez que os zircões são os primeiros minerais a se formarem.

\subsection{2 - Método $\mathrm{Pb}$ - $\mathrm{Pb}$ em rocha total}

A combinação das equações de desintegração radioativa dos'sistemas ${ }^{235} \mathrm{U}-{ }^{207} \mathrm{~Pb}$ e ${ }^{238} \mathrm{U}-{ }^{206} \mathrm{~Pb}$ permite obter a seguinte equação:

$$
\frac{\left.\left({ }^{207} \mathrm{~Pb} / /^{204} \mathrm{~Pb}\right)_{h}-{ }^{207} \mathrm{~Pb} /^{204} \mathrm{~Pb}\right)_{i}}{\left({ }^{206} \mathrm{~Pb} /{ }^{204} \mathrm{~Pb}\right)^{h}-\left({ }^{206} \mathrm{~Pb} /{ }^{204} \mathrm{~Pb}\right)_{i}}=1 / 137,88 \frac{e^{\lambda^{\top \%}}-e^{\lambda^{\top \top T}}}{e^{\lambda T^{\circ}}-e^{\lambda \top 1}}
$$

que, para uma série de amostras cogenéticas, é uma equação de reta no sistema de coordenadas ${ }^{207} \mathrm{~Pb} /{ }^{204} \mathrm{~Pb}$ versus ${ }^{206} \mathrm{~Pb} /{ }^{204} \mathrm{~Pb}$, no qual a inclinação desta reta permite calcular a idade de homogeneização isotópica ou de formação de um dado conjunto de amostras da mesma maneira que o método $\mathrm{Rb}$ - Sr em rocha total.

A principal vantagem das isócronas obtidas pelo método $\mathrm{Pb}-\mathrm{Pb}$ em relação àquelas obtidas pelo método $\mathrm{Rb}$ - $\mathrm{Sr}$ é que, como este sistema baseia-se em um só elemento, o $\mathrm{Pb}$, a perda deste elemento por processos geológicos posteriores não influencia a idade da isócrona, pois a composição isotópica do $\mathrm{Pb}$, independemente da quantidade absoluta presente na rocha se mantem. 
$O$ método $\mathrm{Pb}$ - $\mathrm{Pb}$ possibilita também a obtenção de um parâmetro petrogenético, denominado de $\mu_{1}$, que é um valor fictício calculável, o qual representa a razão ${ }^{238} \mathrm{U} /{ }^{204} \mathrm{~Pb}$ atual da fonte do conjunto de rochas estudado. Este parâmetro é medido através da equação:

$$
\mu=\frac{{ }^{206} \mathrm{~Pb}{ }^{204} \mathrm{~Pb}-\mathrm{a}_{0}}{\mathrm{e}^{\lambda}{ }_{1}{ }^{{ }^{0}}-\mathrm{e}^{\lambda}{ }_{1}{ }^{\mathrm{t}}}
$$

onde:

$$
\begin{aligned}
& { }^{206} \mathrm{~Pb}{ }^{204} \mathrm{~Pb}=\text { intersecção da isócrona } \mathrm{Pb}-\mathrm{Pb} \text { com a Geócrona para } 4,5 \mathrm{Ga} ; \\
& \mathrm{a}_{0}=9,307 \\
& \mathrm{~T}^{\circ}=4,5 \mathrm{Ga} ; \\
& \mathrm{t}=\text { idade da isócrona } \mathrm{Pb}-\mathrm{Pb} .
\end{aligned}
$$

A razão $\mathrm{U} / \mathrm{Pb}$ na crosta continental superior é alta, o que torna as composições isotópicas de $\mathrm{Pb}$ uranogênico fortemente radiogênicas, ao passo que esta razão na crosta continental inferior, é normalmente bastante baixa, cerca de 10 vezes menor que no manto superior, provocando uma composição isotópica de ${ }^{206} \mathrm{~Pb}$ e ${ }^{207} \mathrm{~Pb}$ pouco radiogênica nas rochas granulíticas da crosta inferior, e, conseqüentemente, a evolução isotópica de $\mathrm{Pb}$ uranogênico na crosta inferior é severamente retardada em relação à crosta superior e, até mesmo ao manto superior. Portanto, devido a este comportamento diferencial, é possivel, utilizandose os isótopos de $\mathrm{Pb}$, diferenciar-se magmas gerados por processos de fusão da crosta inferior daqueles gerados a partir da diferenciação do manto superior, o que não era possivel utilizando-se apenas isótopos de Sr. Esta distinção pode ser feita através da utilização do parâmetro $\mu_{1}$.

Magmas diferenciados diretamente do manto superior apresentam valores atuais de $\mu$ dentro do intervalo 7,5 e 8,1, e magmas gerados através de processos de fusão parcial da crosta continental apresentam valores de $\mu$ acima ou abaixo 
deste intervalo (Moorbath e Taylor, 1981). Quando os valores calculados de $\mu$ forem menores que 7,5 , significa que o magma parental do conjunto de rochas estudado foi gerado em um ambiente que possui razão $\mathrm{U} / \mathrm{Pb}$ menor que o manto, ou seja, da crosta continental inferior. Por outro lado se os valores calculados forem maiores que 8,1 , pode indicar que o magma envolvido derivou-se a partir de processos de fusão parcial da crosta continental superior, onde a razão U/Pb é mais elevada que no manto superior.

\section{4 - Sistema K - Ar}

O princípio básico do método $K$ - Ar é muito simples, baseando-se na desintegração de ${ }^{40} \mathrm{~K}$ em ${ }^{40} \mathrm{Ar}$. O sistema $\mathrm{K}$ - Ar é um relógio de acumulação, desde que um átomo de ${ }^{40} \mathrm{~K}$ se desintegre em ${ }^{40} \mathrm{Ar}$, este último é retido dentro de retículo cristalino do mineral considerado através de forças mecânicas. Em consequêencia, quando este mineral é aquecido a uma determinada temperatura, o $\mathrm{Ar}$ escapa e o cronômetro é zerado novamente.

A temperatura de retentividade de $\mathrm{Ar}$ varia de acordo com os minerais datados, por exemplo, as hornblendas liberam o $\mathrm{Ar}$ à temperatura de $530 \pm 40^{\circ} \mathrm{C}$, conforme Harrison e Mac Dougall (1981), as biotitas, a uma temperatura de $300 \pm$ $50^{\circ} \mathrm{C}$ (Wagner et. al. 1977), as muscovitas, a $350 \pm 50^{\circ} \mathrm{C}$ (Purdy e Jaeger, 1976), os feldspatos potássicos de baixa temperatura a $150 \pm 30^{\circ} \mathrm{C}$. Para os plagioclásios, devido a sua estrutura cristalina complexa, não é possivel determinar com precisão a sua temperatura de retentividade, admitindo-se para esses minerais uma temperatura próxima a dos feldspatos potássicos, conforme Berger e York (1981).

Portanto, em linhas gerais, as idades $\mathrm{K}$ - Ar indicam idades de resfriamento, ou do último evento térmico que afetou a rocha estudada. Neste sentido, no caso de rochas vulcânicas que se resfriam rapidamente, as idades seriam relativas à época 
do vulcanismo. Para o caso de rochas plutônicas, as idades $\mathrm{K}$ - Ar indicariam a época de resfriamento, e, para as rochas metamórficas monocíclicas, forneceriam a época de resfriamento regional. Em terrenos policíclicos, estas idades poderiam indicar ou idades de resfriamento regional do último evento metamórfico ou de algum evento anterior em função das temperaturas atingidas pelos episódios metamórficos e das diversas temperaturas de retentividade dos minerais datados.

É importante ressaltar que, às vezes, as idades $K$ - Ar não possuem significação geológica, fornecendo idades mais antigas ou mais recentes do que as reais. Uma das premissas fundamentais deste método é que quando o material datado se formou, ele não continha qualquer quantidade de ${ }^{40} \mathrm{Ar}$ radiogênico, e que qualquer átomo de ${ }^{40} \mathrm{Ar}$ presente no retículo cristalino dos minerais seria produzido por decaimento radioativo "in situ" do ${ }^{40} \mathrm{~K}$.

Muitas vezes, durante o processo de formação de um mineral, ocorre a incorporação de ${ }^{40} \mathrm{Ar}$ que estava no magma e que foi aprisionado durante a cristalização do mineral, constituindo o denominado Ar hereditário. Como, em geral, os minerais datados possuem uma quantidade de ${ }^{40} \mathrm{Ar}$ radiogênico muito maior que a quantidade de $\operatorname{Ar}$ hereditário, esta quantidade inicial de Ar não modifica significativamente a idade calculada. Entretanto, quando o mineral datado é pobre em $\mathrm{K}$, e conseqüentemente possui baixo conteúdo de ${ }^{40} \mathrm{Ar}$, a quantia inicial de ${ }^{40} \mathrm{Ar}$ hereditário, se presente, pode ser significativa, e o excesso de ${ }^{40} \mathrm{Ar}$ medido pode fornecer idades mais antigas do que a real.

Por outro lado, podem ocorrer também perdas de $\mathrm{Ar}$ pelas fases minerais. Esta perda de Ar pode ser parcial ou total. Se a perda for total, o geocronômetro K - Ar será zerado, e os valores calculados de idades irão refletir a época de resfriamento do evento que provocou a perda total de $\mathrm{Ar}$ da rocha. Mas se a perda for parcial, as idades $\mathrm{K}$ - Ar calculadas indicarão idades intermediárias entre o evento que causou a perda parcial e a idade do evento que havia zerado anteriormente o cronômetro, fornecendo então, idades sem significação geológica. 
Os principais eventos geológicos que causam perdas de $\operatorname{Ar}$ são:

- Fusão Parcial;

- Metamorfismos de todas as naturezas;

- Alterações Hidrotermal e Intempérica;

- Efeitos Tectônicos

- Reaquecimentos provocados por qualquer tipo de evento. 


\section{4 - DOMÍNIOS GEOCRONOLÓGICOS E ELEMENTOS TECTÔNICOS}

O Cráton Amazônico é uma das maiores áreas cratônicas da América do Sul, tendo se estabilizado tectonicamente no final do Mesoproterozóico. Dados isotópicos provenientes de amostras do embasamento e de granitóides póstectônicos, têm demonstrado que a evolução crustal da Amazônia pode ser descrita como alguns núcleos arqueanos que foram amalgamados através de cinturões móveis de idades relativas ao ciclo orogênico Transamazônico, e que, por sua vez, estes grandes fragmentos neoformados foram acrescidos por uma sucessão de arcos magmáticos com idades variáveis desde $1.8 \mathrm{Ga}$ até $1.55 \mathrm{Ga}$. Finalmente, esta imensa área continental sofreu a atuação em sua borda sudoeste de dois eventos orogênicos de natureza predominantemente ensiálica, denominados de Rondoniano - San Ignácio e Sunsás ( Cordani et. al., 1979 ; Teixeira et. al. 1989). A partir deste trabalho e de Sato e Tassinari (1996), foi confirmada, em linhas gerais, a evolução acima, mas identificando uma diminuição das áreas arqueanas do cráton, e um conseqüente aumento das áreas paleoproterozóicas, conforme mostrado na Figura 4, caracterizando o período de tempo 2.2 - $1.8 \mathrm{Ga}$ como o mais importante período de acresção continental na Amazônia.

Neste sentido, o cráton foi dividido em domínios geocronológicos que seguem em linhas gerais a definição que consta em Mascarenhas et. al. (1989), no Mapa Geocronológico do Estado da Bahia, onde estes domínios foram definidos como áreas onde predominam certos padrões de idades radiométricas e de assinaturas isotópicas, aliados a padrões espaço-temporais de evoluções geotectônicas particulares. Cumpre ressaltar que, para maior facilidade de discussão, estes grandes domínios podem ser divididos em subdomínios, por conterem algumas diferenças geológicas e isotópicas, mas pertencendo ao mesmo sistema geotectônico. 


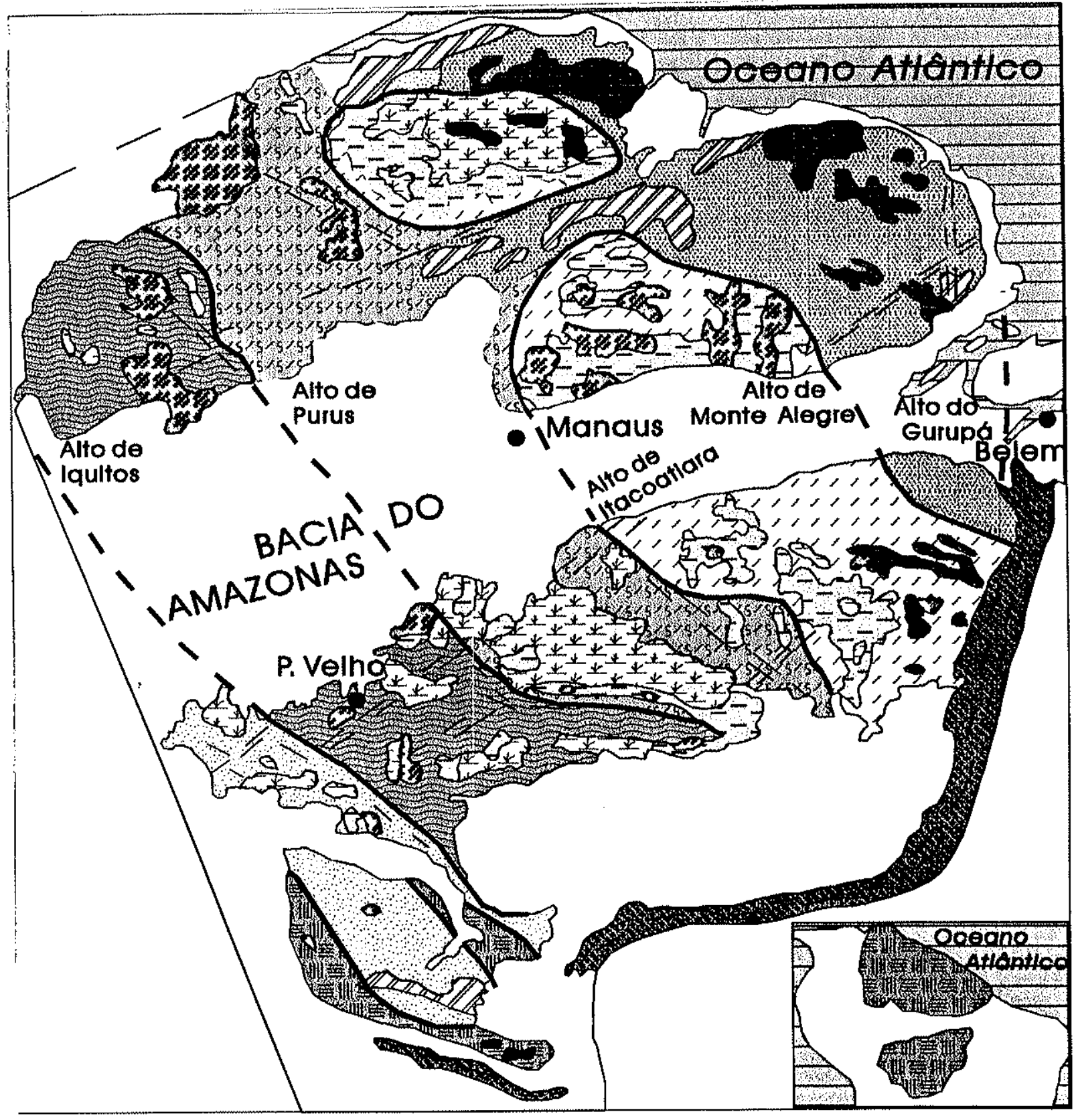

PROVÍNCIAS GEOCRONOLÓGICAS

E] Amazonla Central $>2.3 \mathrm{Ga}$

Maronl - Itacalunas

$2.2-1.9 \mathrm{Ga}$

5entuarl-Tapajós

$1,9-1,8 \mathrm{Ga}$

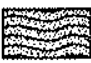

Rlo Negro - Juruena $1.8-1.55 \mathrm{Ga}$

Rondonlana - San Ignáclo $1.5-1.3 \mathrm{Ga}$

Sunsás

1.25-1.0 Ga

\section{UNIDADES GEOLOGICAS}

Coberturas Fanerozólcas

6ranltóldes

- Coberturas Sedimentares

Pré-cambrlanas

E-Z Coberturas Vulcánlcas

Ácidas-Intermedlárlas

Vulcanismo básico

Greenstone Belts

DID Complexos Granulíticos

Falxa de Dobramentos Neoproterozólca

Figura 4 - Províncias Tectônicas do Craton Amazônico 
Dessa forma, tem-se a seguinte divisão para o Cráton Amazônico:

- Domínio Amazônia Central, subdividido nos subdomínios Carajás Iricoumé e Roraima;

- Domínio Maroni - Itacaiúnas;

- Domínio Ventuari - Tapajós;

- Domínio Rio Negro - Juruena;

- Domínio Rondoniano - San Ignácio

- Domínio Sunsás.

\section{1 - Dominio Amazônia Central}

O Domínio Amazônia Central constitui uma importante provincia tectônica do Cráton Amazônico, que inclui fragmentos continentais com idades radiométricas arqueanas ou com idades antigas inferidas a partir de relações geológicas, que foram preservados pela orogenia Transamazônica, mantendo-se tectonicamente estáveis desde o arqueano, servindo de palco apenas para atividades ígneas cratogênicas durante este período orogênico.

Este domínio foi submetido a condições plataformais desde os tempos arqueanos. Seu embasamento é constituído por terrenos granito - gnáissico migmatíticos e também por terrenos granito-greenstones e complexos granulíticos, além de ocorrências menores de rochas máfica-ultramáficas e metassedimentares. Os terrenos granito-greenstones, de idades claramente arqueanas, são compostos por tonalitos, trondhjemitos e granodioritos, e pelas seqüências supracrustais que incluem unidades de rochas metavulcânicas ácidas e máfica-ultramáficas, formações ferriferas e rochas sedimentares clásticas.

O domínio em questão possui extensas coberturas de rochas vulcânicas ácidas a intermediárias, que são recobertas por seqüencias sedimentares não deformadas, com características típicas de plataforma estável, e idades desde 1,95 
$\mathrm{Ga}$ até 1,70 Ga. As rochas vulcânicas ácidas-intermediárias (Vulcanismos Xingu, Iricoumé e Surumu), incluídas no Supergrupo Uatumã (Leal et. al. 1978), são relacionadas a eventos de distensão associados com as orogenias que ocorreram na borda dos blocos cratônicos. Muitas vezes, estes episódios vulcânicos estão geneticamente relacionados com granitóides pórfiros de natureza sub-vulcânica, que em geral, possuem um contato gradacional com as seqüências vulcânicas. Repousando em inconformidade sobre os conjuntos vulcano-plutônicos ocorrem extensos depósitos sedimentares de idades pré-cambrianas, que são relacionados aos Grupos Roraima, Gorotire e Cubencranquém. Estas rochas sedimentares são afetadas por magmatismo básico de natureza fissural, com idades variáveis desde $1,88 \mathrm{Ga}$ até $1,75 \mathrm{Ga}$.

A parte norte do sub-domínio Carajás-Iricoumé e o sub-domínio Roraima, que encontram-se recobertos por rochas vulcano - sedimentares não metamorfisadas de idades de pelo menos $1,95 \mathrm{Ga}$, não possuem dados radiométricos com idades relativas ao arqueano, sendo esta idade atribuída a estes fragmentos continentais a partir da existência de condições tectonicamente estáveis, desde pelo menos 1,95 $\mathrm{Ga}$, que seria a época de formação dos terrenos granulíticos da faixa orogênica que separa estes dois sub-domínios.

Finalmente, o sub-domínio Carajás-Iricoumé foi afetado por uma grande tectônica distensional que originou magmatismo granítico anorogênico de idades entre 1,80 e 1,70 Ga. (Tassinari et. al. 1984 e Macambira et. al. 1992).

\section{2 - Domínio Maroni - Itacaiúnas}

O Domínio Maroni - Itacaiúnas teve a sua evolução metamórfica entre aproximadamente 2.15 - $1.95 \mathrm{Ga}$. Este domínio possui uma grande extensão, ocorrendo no Suriname, Guiana, Guiana Francesa e partes do Brasil (Pará e Amapá) e da Venezuela. Em grandes traços, esta província geocronológica pode ser dividida em terrenos gnáissico-granulíticos com protólitos arqueanos, os quais 
seriam partes retrabalhadas do Domínio Amazônia Central pela orogenia Maroni Itacaiúnas, e em terrenos granito-greenstone e granulíticos, diferenciados do manto durante a orogenia Transamazônica.

Muitos destes embasamentos antigos ocorrem como núcleos ao longo do domínio, encaixados em terrenos granito-gnáissico-migmatíticos, e são constituídos por rochas granulíticas de diversas naturezas, remobilizadas $\theta$ metamorfizadas no ciclo Transamazônico, como, por exemplo, o Complexo de Imataca na Venezuela, que é formado por seqüências metavulcano-sedimentares, paragnaisses, migmatitos e formações ferriferas de alto grau, que apresentam idades da ordem $3250 \mathrm{Ma}$ (Montgomery e Hurley et. al. 1978) e sofreu metamorfismo granulítico ao redor de $2,0 \mathrm{Ga}$, e os Granulitos Cobra e Coatá, no Amapá, compostos por piriclasitos, granulitos enderbíticos e charnoenderbitos de idades relativas ao final do arqueano.

A principal característica da Província Geocronológica Maroni-Itacaiúnas é a presença de grande quantidade de seqüências metavulcano-sedimentares, metamorfisadas nos fácies xisto-verde e anfibolito e intensamente deformadas, cujo intervalo de tempo em que ocorreram as deformaçöes coincide com o período de formação das rochas vulcano-sedimentares não deformadas, que ocorrem no domínio Amazônia Central. As seqüências metavulcano-sedimentares estão incluídas nos Grupos Carichapo-Pastora na Venezuela; Barama-Mazaruni na Guiana; Armina-Rosabel no Suriname; Orapu-Bonidoro, na Guiana Francesa e Vila Nova no Amapá. De uma forma geral, estas unidades geológicas foram estudadas por diversos autores, podedo-se destacar Gibbs (1980), Gibbs e Barron (1983), Bosma et. al. (1983), Gruau et. al. (1985), Egal et. al. (1994), Jorge João et. al. (1979) e Ledru e Milesí (1995), que devido a natureza, composição e evolução destas seqüências as caracterizaram como seqüências do tipo Greenstone belts de idade Paleoproterozóica. Estas unidades são constituídas por vulcanismos ácidos, intermediários e máficos, de composição toleítica, aproximadamente contemporâneos a formação de suítes tonalíticas e trondhjemíticas que ocorrem no 
domínio. Muitos destes vulcanismos são de natureza komatítica e estão relacionados à rochas sedimentares com características fluvio-deltáicas.

\section{3 - Domínio Ventuari - Tapajós}

O Domínio Ventuari - Tapajós definido neste trabalho trunca o segmento NE-SW do domínio Maroni-Itacaiúnas, que é denominado de Cinturão Granulítico da Guiana Central, sendo que os limites geográficos com o Cinturão Granulítico não são claramente definidos, pois o contato entre estas duas províncias seria transicional com as idades das rochas se tornando mais jovens a medida que se passa do cinturão granulítico da Guiana Central para este domínio, e limita-se também com a parte ocidental do Domínio Amazônia Central, estendendo-se desde o sul da Venezuela até a região do rio Tapajós, no sudoeste do Estado do Pará.

Geologicamente, compreende rochas granito-gnáissicas de composição quartzo-diorítica a granodiorítica, formadas entre 1,95 Ga e 1,8 Ga, a partir de processos de diferenciação mantélica ocorridos pouco tempo antes da formação das rochas, caracterizando a atuação de um arco magmático. Estas rochas apresentam trends estruturais NW-SE e N-S predominantemente e, em geral, estão afetadas por metamorfismos do fácies anfibolito. Associadas a estas rochas que constituem o embasamento deste domínio, ocorrem granitóides de composição diorítica a granodiorítica de caráter sin a pós-tectônicos ( Barrios, 1983; Iwanuch, 1981 e Silva et. al. 1980).

Rochas supracrustais metamorfisadas no fácies xisto - verde a anfibolito, possuem ocorrências subordinadas ao longo deste domínio, sendo incluídas na Formação Cinaruco na Venezuela e na parte sul, na região de Jacareacanga, são consideradas como Suíte Jacareacanga. Vucanismos ácidos a intermediários subseqüentes à fase sin-tectônica da orogenia, ocorrem tanto na parte norte como sul do dominio, estando relacionados a vulcanismos com idades entre $1,8 \mathrm{Ga}$ e 1,7 Ga. 
Atividades cratogênicas no âmbito do domínio Ventuari - Tapajós, que, em geral, são manifestações reflexas da orogenia Rio Negro - Juruena que desenvolveu-se na área adjacente, são representadas por magmatismos vulcanoplutônicos de natureza calci-alcalina e toleítica, e também por vários corpos de granitos circulares do tipo $A$, de natureza intra-placa, comumente apresentando textura do tipo rapakivi. $\mathrm{Na}$ região norte do domínio destacam-se dois grandes corpos graníticos que exibem textura do tipo rapakivi, que são os batólitos de $\mathrm{El}$ Parguaza, na Venezuela, e o de Surucucu, em Roraima, com idades próximas a $1550 \mathrm{Ma}$.

Além disso aparecem também coberturas de rochas sedimentares sem metamorfismo regional, depositadas em rifts em ambiente epinerítico, marinho de águas rasas, em uma seqüência transgressiva, principalmente incluídas no Grupo Beneficente a sul do domínio, recobrindo as unidades vulcânicas ácidas (Silva et. al. 1980 e Almeida 1974).

\section{4 - Domínio Rio Negro - Juruena}

O Domínio Rio Negro - Juruena ocorre na porção ocidental do Cráton Amazônico, sendo também constituído predominantemente por uma zona de intensa granitização e migmatização, desenvolvido através de uma sucessão de arcos magmáticos entre 1,8 e 1,55 Ga.

Este domínio é composto basicamente por rochas de composição granítica a granodiorítica, muitas das quais exibindo texturas gnáissicas. Normalmente, o metamorfismo que atingiu estas rochas é do fácies anfibolito, embora metamorfismos do fácies granulito tenham ocorrido em alguns locais. O padrão estrutural dominante do embasamento deste domínio é NW-SE, mas, em algumas áreas, são observadas estruturação superimposta NE-SW, possivelmente relacionada ao evento tectono-termal Nickeriano (1100 Ma). 
No interior da Província Rio Negro-Juruena, ocorrem pequenas exposições de rochas supracrustais, compostas por metavulcânicas $\theta$ metassedimentos de baixo grau metamórfico, que, na região norte, são incluídas no Grupo Tunuí e a sul são constituídas por metapelitos intercalados com formações ferriferas e metavulcânicas ácidas a intermediárias que são denominadas de Seqüência Metavulcano-sedimentar Roosevelt por Silva et. al. (1995).

Associados à evolução dos arcos magmáticos relacionados à Província Rio Negro - Juruena, ocorrem vulcanismos ácidos a intermediários, associados a granitos de natureza sub-vuicânica, com tendência alaskítica, de idades entre 1,65 e $1,55 \mathrm{Ga}$. Litologicamente este vulcanismo é muito similar aos que ocorrem no Domínio Ventuari - Tapajós. Já os granitos sub-vulcânicos, considerados como granitos Teles Pires, por Silva et. al. (1980), são corpos circulares, de natureza calcialcalina, alcalina e peralcalina, distribuídos preferenciaimente na parte sul do Domínio Ventuari - Tapajós, mas ocorrendo também na parte sudeste do domínio em questão. No interior do domínio Rio Negro - Juruena, ocorrem coberturas sedimentares não metamorfisadas, depositadas em ambiente continental em uma bacia controlada por um sistema de graben, incluídas por Silva et. al. (1980) na Formação Dardanelos. Intercalados no pacote de arenitos ocorrem dois derrames de basaltos com idades de 1,4 e 1,2 Ga.

Ainda no âmbito deste domínio, ocorrem vários complexos circulares, geralmente compostos por sienitos alcalinos gradando para granitos peralcalinos, e também alguns corpos kimberlíticos. Várias gerações de granitos anorogênicos ocorrem no domínio, incluindo corpos com textura rapakivi, de natureza subalcalina, exibindo características de granitos do Tipo A, intra-placa. Este magmatismo granítico compreende termos que variam de granitos alcalinos a biotita sienogranitos leucocráticos a hololeucocráticos (Dall'Agnol et. ai. 1987). 


\section{5 - Dominio Rondoniano - San Ignácio}

O domínio Rondoniano - San Ignácio encontra-se situado na parte sudoeste do Cráton Amazônico, limitando-se em parte com o domínio Rio Negro - Juruena, , através da zona de falha Marechal Rondon, que possui direção NW - SE. Inclui rochas polimetamórficas formadas principalmente dentro do intervalo de tempo 1,45 a 1,30 Ga, mas também contém núcleos preservados de rochas mais antigas, como - Complexo Granulítico de Lomas Manéches, na Bolívia, o bloco do Cabaçal, na região de Jauru no Mato Grosso e alguns núcleos menores de rochas granulíticas bandadas na zona de Jaru em Rondônia. A presença destes núcleos antigos, com idades relativas ao ciclo orogênico Transamazônico, aliada aos parâmetros de geoquímica isotópica de $\mathrm{Sr}$ e Nd confere ao domínio Rondoniano - San Ignácio um caráter evolutivo principalmente ensiálico, com o evento datado em 1,50-1,30 Ga retrabalhando rochas mais antigas formadas próximas a 1,9 Ga.

As rochas que constituem o embasamento deste domínio incluem diversos tipos de migmatitos e um grande volume de rochas gnáissicas de composição granítica a granodiorítica e anfibolitos, metamorfisadas principalmente no fácies anfibolito, embora em quantidades subordinadas ocorram granulitos bandados, charnoquitos e rochas metassedimentares de baixo grau. Estas rochas encontram se intensamente dobradas e falhadas por diversos eventos deformacionais superimpostos, apresentando lineamentos orientados preferencialmente segundo as direções WNW-ESE, NNE-SSW, NW-SE e NE-SW (Leal et. al. 1978; Litherland et. al. 1986 e Teixeira e Tassinari 1984).

Neste domínio, ocorrem em alguns locais metamorfitos de baixo e médio grau metamórfico, que constituem uma associação metavulcano-sedimentar submarina, agrupada estratigraficamente sob a denominação de Epimetamorfitos do Comemoração por Leal et.al. (1978).

Relacionado a evolução da orogenia Rondoniana - San Ignácio, ocorreram atividades magmáticas no período entre $1,45 \mathrm{Ga}$ a $1,30 \mathrm{Ga}$, tanto sobre o domínio 
homônimo, como no domínio Rio Negro - Juruena. Estas atividades são representadas essencialmente por rochas graníticas subalcalinas e alcalinas, sendo - Maciço granítico Santo Antonio (Payolla, 1994) e a Suíte Intrusiva Teotônio (Bettencourt et. al. 1995) os corpos mais importantes. Posteriormente ocorreram magmatismos graníticos de natureza anorogênica, constituídas por granitos do tipo rapakivi, cujas épocas de fomação estão dentro do intervalo de tempo 1,30 a 1,25 $\mathrm{Ga}$, e foram incluídas em um grupo denominado de "Younger Rapakivi Granites of Rondonia" e uma atividade granítica cratogênica entre 1,1 0 0,99 Ga, considerada como "Younger Granites of Rondonia" por Bettencourt et. al. (1995).

No âmbito do domínio Rondoniano - San Ignácio ocorrem coberturas sedimentares não metamorfisadas, incluidas por Leal et. al. (1978) no Grupo Guajará Mirim. Estas coberturas estão relacionadas aos "grabens" dos Pacaás Novos e Uopione, orientados geralmente E-W, e apresentam intercalações de rochas vulcânicas básicas, datadas em cerca de 1,0 Ga. Tais sedimentos, devido a sua má seleção e a sua imaturidade, foram depositados de uma forma rápida e durante o próprio desenvolvimento das atividades tectônicas relacionadas ao "graben".

\section{6 - Dominio Sunsás}

O domínio Sunsás ocorre no extremo sudoeste do Cráton Amazônico e inclui as rochas pré-cambrianas mais novas deste cráton. Este dominio comporta as rochas geradas durante a orogenia Sunsás, definida por Litherland et. al. (1986) como compreendendo a erosão de rochas geradas nos ciclos orogênicos anteriores, a deposição destes sedimentos clásticos, e subseqüente deformação e metamorfismos, acompanhados de atividades ígneas graníticas e básicaultrabásicas. A fase tectono-metamórfica do cicio orogênico Sunsás está relacionada a uma faixa móvel de direção WNW, que possui uma conecção NNW ao longo da Faixa Aguapeí no Brasil. Normalmente, esta frente está marcada por zonas miloníticas de paragnaisses intensamente retrabalhados. As deformações, em 
geral, produziram dobras isoclinais que foram redobradas mediante estruturas principais de direção WNW, embora em algumas regiões, como entre San Diablo e Concepción, na Bolívia, estruturas $\mathrm{N}$ a NNE foram reportadas (Litherland et. al. 1986).

Este domínio ocorre principalmente na Bolívia, mas aparece também no Brasil, no Estado de Mato Grosso. Inclui as rochas do Grupo Sunsás e Vibosi, chamados também de Grupo Aguapei no Brasil. Estes metamorfitos encontram - se metamorfisados no fácies xisto verde baixa até o fácies anfibolito alto.

A atividade granítica relacionada a orogenia Sunsás compreende vários tipos de plutons de forma circular ou elíptica, formando batólitos ou "stocks". Embora ocorram granitóides de caráter sincinemático, especialmente na Bolívia, onde aparecem granitos anatéticos normalmente associados à zonas de gnaisses porfiroblásticos com feldspatos potássicos, a grande maioria dos granitóides são tipicamente cratogênicos, de natureza subvulcânica e composição sub-alcalina, alcalina e peralcalina. Os contatos destes corpos são irregulares e abruptos, algumas vezes mostrando auréolas de contato com andaluzita e cordierita, outras exibindo brechas e enclaves. Estes granitóides são englobados em dois grupos cronológicos, o mais antigo com idades próximas a $1,1 \mathrm{Ga}$ e o mais novo com idades ao redor de $990 \mathrm{Ma}$ (Bettencourt et. al. 1995, e Priem et al. 1989).

Relacionadas à evolução tectónica da Faixa móvel Sunsás, ocorrem rochas básicas e ultrabásicas compondo uma intrusão diferenciada denominada de Complexo Ígneo Rincon del Tigre, datado em $992 \mathrm{Ma}$. (Litherland et. al. 1995). Associadas a estas rochas aparecem também, em quantidades subordinadas, lavas félsicas.

Avaliando - se os dados isotópicos e geoquímicos disponíveis para o Domínio Sunsás, pode-se considerar que este domínio apresenta características de uma evolução claramente ensiálica, onde os processos de retrabalhamento crustal entre 1,3 $\mathrm{Ga}$ e 1,0 $\mathrm{Ga}$ predominaram largamente sobre os processos de acresção de material juvenil. 


\section{5 -CONTEXTO GEOLÓGICO E DISCUSSÕES GEOCRONOLÓGICAS}

Os dados radiométricos existentes para as rochas pré-cambrianas da região Amazônica serão discutidos segundo a divisão do cráton em domínios geocronológicos, conforme descrito no item anterior, uma vez que tais domínios possuem evoluçóes geológicas distintas e desenvoiveram-se em diferentes ambientes geotectônicos. Os dados isotópicos obtidos pelos diversos autores serão reinterpretados de uma forma integrada, levando-se em consideração o atual conhecimento geológico do Cráton Amazônico, de tal forma que eventualmente alguns dos resultados aqui considerados poderão não corresponder exatamente às idades publicadas nos trabalhos originais, e quando isto acontecer as idades originais serão devidamente citadas.

\section{1 - Domínio Amazônia Central}

O Domínio Amazônia Central, considerado de idade arqueana, é definido como uma área de crosta continental arqueana, bordejada por cinturões móveis do Paleoproterozóico, sendo que este segmento crustal foi afetado por eventos geológicos de natureza anorogênica mais jovens. Para uma melhor descrição dos dados geocronológicos, este domínio foi subdividido, em dois sub-domínios denominados de Carajás - Iricoumé e Roraima, que corresponderiam ao que Cordani e Brito Neves (1982) denominaram de blocos Xingu e Pakaraima. Os dois sub-domínios estão separados por um cinturão móvel de idade paleoproterozóica pertencente ao domínio Maroni - Itacaiúnas. A parte meridional do domínio Carajás Iricoumé, situada a sul da Bacia Sedimentar do Amazonas, possui claramente um padrão radiométrico arqueano completo, ao passo que a parte situada a norte da Bacia Sedimentar Amazônica (Região de Iricoumé), e o sub-domínio Roraima tiveram as idades arqueanas inferidas a partir de evidências geológicas, tais como, o fato de conterem coberturas vulcano-sedimentares não metamorfisadas com 
idades de até $1,95 \mathrm{Ga}$, que correspondem às idades das rochas granuliticas do cinturão móvel que bordeja estas áreas cratônicas. Em outras palavras teriam servido de área estável tectonicamente para o desenvolvimento de uma orogenia próxima a $2,0 \mathrm{Ga}$.

\subsection{1 - Sub-domínio Carajás - Iricoumé}

\subsubsection{1 - Considerações Geológicas}

A região que engloba a Serra dos Carajás tem sido uma das áreas mais bem estudadas do Cráton Amazônico, sob todos os aspectos geológicos, uma vez que contém a importante Província Mineral dos Carajás, que possui significativas mineralizações de ouro, ferro, manganês e cobre.

Esta região, situada a sul da Sinéclise do Amazonas, possui uma geologia bastante complexa, descrita em detalhe em DOCEGEO (1988), que considera de uma forma sintética a litoestratigrafia da área como sendo constituída por seqüências do tipo "greenstone belts" da região de Rio Maria, que são denominadas de Supergrupo Andorinhas, que é subdividido em Grupo Babaçu na base e Grupo Lagoa Seca no topo. Litologicamente estes grupos são compostos, da base para o topo, por lavas ultramáficas de caráter komatítico (dunitos, peridotitos e piroxenitos), com intercalações de formaçōes ferriferas bandadas, derrames de basaltos intercalados com sedimentos químicos, metatufos, talco-xistos e clorita e quartzo sericita xistos. Acima destas unidades ocorrem as rochas incluidas no Grupo Lagoa Seca, compostas por metassedimentos clástico-químicos (grauvacas, siltitos e formações ferriferas), intercalados com lavas básicas e ultrabásicas, com alguma contribuição de lavas mais félsicas e um conjunto de rochas vuicânicas ácidas a intermediárias compostas por dacitos, riodacitos e andesitos intercalados com grauvacas e siltitos e subordinadamente lavas máficas e ultramáficas. 
Crono-correlato ao Supergrupo Serra das Andorinhas ocorre o Supergrupo Serra do Inajá, situado um pouco mais a sul, mas constituindo também seqüências do tipo "greenstone belts". Esta unidade, que é subdividida em Grupo Santa Lucia e Grupo Rio Preto, é constituída por importantes derrames de metabasaltos, intercalados por rochas metaultramáficas, formações ferríferas bandadas, cherts e metadacitos. DOCEGEO (1988) consideraram o Complexo Xingu, que inclui migmatitos, granodioritos, trondhjemitos, gnaisses e tonalitos, como posterior aos "greenstone belts".

As seqüências do tipo "greenstone belts" descritas acima são intrudidas por corpos básico-ultrabásicos, denominados de Complexos Intrusivos Luanga e Serra Azul, compostos principalmente por dunitos, peridotitos, piroxenitos e gabros anortosíticos, e também por granitóides que constituem os terrenos granitogreenstone da região, e apresentam composições tonalíticas, granodioríticas e trondhjemíticas, sendo os corpos principais denominados de Granodiorito Rio Maria, Trondhjemito Mogno e Tonalito Parazônia.

Posteriormente a estas atividades magmáticas desenvolveram-se as seqüências vulcano-sedimentares incluídas no Supergrupo Itacaiúnas, que foi criado para englobar as rochas do Grupo Grão Pará e as unidades crono-correlatas. Estas unidades litológicas ocorrem na região da Serra dos Carajás, e estão incluídas nos Grupos Grão Pará, Igarapé Salobo, Igarapé Pojuca, Igarapé Bahia e Buritirama. De uma forma geral estas unidades estão orientadas segundo a direção NW, com mergulhos acentuados para NE, e estão metamorfisadas desde o fácies xisto verde baixo até o fácies anfibolito. Litologicamente incluem gnaisses, lavas básicas com intercalações de rochas vulcânicas félsicas, formações ferríferas bandadas, quartzitos, metarcóseos, diversos tipos de xistos, arenitos, argilitos, siltitos e rochas piroclásticas e calcissilicatadas.

Recobrindo estas seqüencias vulcano-sedimentares ocorrem os sedimentos do Grupo Rio Fresco, depositados conforme uma seqüência transgressiva, dentro 
do intervalo de tempo entre 2,6 e 1,9 Ga (DOCEGEO,1988). Litologicamente é constituído por arenitos na base gradando para siltitos e sedimentos químicos no topo.

Na região da Serra dos Carajás ocorrem diversas intrusões de granitóides anorogénicos e pós-tectônicos, com idades dentro do intervalo de tempo 1,9 - 1,6 $\mathrm{Ga}$, que incluem os corpos de Serra dos Carajás, Serra da Seringa, Jamom, Cigano, Musa, Cachoeirinha, Serra dos Gradaús, Banach, Borrachudo, Marajoara entre outros. Estes granitos, estudados em maior detalhe por Dall'Agnol et. al. (1986 e 1987) e Macambira et. al. (1990), apresentam em sua maioria composições alcalinas, sendo enquadrados em granitóides do Tipo A, mas ocorrendo também granitóides com composições similares aos granitos do Tipo I caledonianos.

Ainda a sul da Bacia Sedimentar do Amazonas, a oeste da região da Serra dos Carajás, ocorrem extensas coberturas de rochas vulcânicas ácidas a intermediárias, não metamorfisadas, com granitos sub-vulcânicos associados. Estas rochas foram consideradas por Cunha et. al. (1981) como Supergrupo Uatumã. denominando as rochas vulcânicas de Grupo Iriri e as rochas granitóides de Suites Intrusivas Rio Dourado. As rochas vulcânicas da Formação Iriri assentam-se diretamente sobre as rochas polimetamórficas do embasamento e são recobertas pelas seqüências sedimentares da Formação Gorotire. Litologicamente a seqüência vulcânica é composta por dacitos, andesitos, riodacitos, riolitos, tufos de diversas naturezas e rochas piroclásticas. Do ponto de vista geoquímico a maioria das rochas possuem características calci-alcalinas.

Os granitóides da Suíte Intrusiva Rio Dourado, que geralmente mostram feições circulares, possuem contatos gradacionais com as rochas vulcânicas, o que confere a estes granitóides, segundo Cunha et. al. (1981), um tempo de colocação concomitante ou logo posterior às atividades efusivas. Petrograficamente estas rochas são constituídas por granitos pórfiros e granulares granofíricos e não granofíricos e granitos equigranulares cataclásticos. Geoquimicamente estas rochas possuem, em sua maioria, características de rochas alcalinas e calci-alcalinas. 
Recobrindo discordantemente as rochas vulcânicas descritas acima, ocorrem, ainda no sub-domínio Carajás - Iricoumé, coberturas sedimentares não deformadas, incluídas na Formação Gorotire. Esta unidade é composta por um pacote de sedimentos psamíticos, com intercalações de conglomerados, sendo que os tipos petrográficos mais comuns são: conglomerados, arenitos, arcóseos, grauvacas e siltitos.

A norte da Sinéclise do Amazonas, na região denominada de Iricoumé, ocorrem basicamente algumas exposições de terrenos gnáissico-migmatíticos, recobertos discordantemente por extensas coberturas de rochas vulcânicas ácidas a intermediárias, consideradas como Formação Iricoumé (Oliveiral et. al. 1975), cuja constituição litológica é similar aos litotipos da Formação Iriri, incluindo andesitos, dacitos, riodacitos, riolitos, tufos e ignimbritos. Quanto ao caráter geoquímico, tais rochas foram consideradas por Araújo et. al. (1976), como calci-alcalinas. Intimamente relacionados a este vulcanismo ocorrem vários corpos de granitóides de natureza sub-vulcânica, alcalinos e calci-alcalinos, denominados de Granitos Mapuera (Oliveira et. al. 1975). Os litotipos mais freqüentes incluídos como Granito Mapuera são: granitos, microgranitos, granófiros, adamelitos, granodioritos, e monzonitos. Estes granitóides são intrudidos por sienitos e rochas básicas (Araújo et. al. 1976).

\subsubsection{2 - Discussőes Geocronológicas}

No âmbito do Sub-Domínio Carajás-Iricoumé a região da Serra dos Carajás, devido a sua notável importância econômica, é uma das regiões do Cráton Amazônico melhor estudadas sob o ponto de vista geocronológico. Os estudos deste tipo iniciaram-se com Silva et. al. (1974) e Gomes et. al. (1975), passando por Tassinari et. al. (1982), Montalvão et.al. (1984), Wirth et. al. (1986), Gibbs et. al. (1986), Gastal et. al. (1987) e depois, a partir de 1988 foram realizados estudos geocronológicos de maior detalhe, que geraram importantes resultados para a 
elucidação da evolução geológica da região. Dentre estes trabalhos deve-se citar os de Montalvão et. al. (1988), Renne et. al. (1988), Olszewski et. al. (1989), Lafon et.al. (1990), Machado et. al. (1991), Macambira e Lancelot (1991 a, b e 1992), Macambira (1992), Rodrigues et. al. (1992), Lafon e Scheller (1994), Pimentel e Machado (1994), Sato e Tassinari (1996), Souza et. al. (1996).

O padrão geocronológico da região da Serra dos Carajás inclui análises radiométricas pelos métodos $\mathrm{K}-\mathrm{Ar}, \mathrm{Rb}-\mathrm{Sr}, \mathrm{U}-\mathrm{Pb}, \mathrm{Pb}-\mathrm{Pb}$ e $\mathrm{Sm}-\mathrm{Nd}$, compondo um quadro bastante completo, para definir os principais eventos geológicos que ocorreram na área. Fora da área da Serra dos Carajás, o Sub-Domínio CarajásIricoumé conta com análises geocronológicas na região das Serras do Inajá e Tapirapé, dos rios Xingu e Iriri e a norte da sinéclise do Amazonas, na área entre os rios Paru do Oeste e Uatumã, que foram abordadas pelos trabalhos de Montalvão et. al. (1975), Araújo et. al. (1976), Tassinari e Basei (1980), Cunha et. al. (1981), Barbosa et. al. (1994) e Dall'Agnol et. al. (1984).

As rochas mais antigas da Província Amazônia Central e também do Cráton Amazônico encontram-se na área da Serra dos Carajás, e são representadas por rochas tonalíticas na região de Rio Maria (Tonalito Arco Verde), datadas por U-Pb em zircões por Macambira $\theta$ Lancelot (1991a) em $2957+16$ ou -19 Ma e pelas rochas granulíticas do Complexo Pium, que indicaram uma idade isocrônica $\mathrm{Pb}-\mathrm{Pb}$ em rocha total de $3050 \pm 114 \mathrm{Ma}$, com valor de MSWD de 72 e de $\mu_{1}=9,2$ (Rodrigues et. al. 1992). Apesar deste dado ter sido interpretado pelos autores acima como a idade do protólito ígneo dos granulitos, neste trabaiho, devido ao elevado valor obtido para $0 \mu_{1}$, que indicaria que estes protólitos seriam originados a partir de fontes com alta razão U/Pb, o que é muito improvável para rochas com baixas razões $\mathrm{Rb} / \mathrm{Sr}$ da crosta continental inferior, é preferivel considerar esta idade como suspeita, já que eventos metamórficos do fácies granulíticos podem causar um empobrecimento de $\mathrm{U}$ e $\mathrm{Rb}$ nas rochas afetadas, fazendo com que idades obtidas pelo método $\mathrm{Pb}-\mathrm{Pb}$, a exemplo do método $\mathrm{Rb}-\mathrm{Sr}$ em rochas granulíticas, indiquem valores mais antigos do que os reais, como mostrado por Morbath e Taylor (1980). 
Evidências indiretas de rochas com idades entre $3,2 \mathrm{Ga}$ e 3,1 $\mathrm{Ga}$ foram obtidas pelo método U-Pb por Macambira e Lancelot (1991b) em zircões detríticos contidos nas rochas sedimentares do Grupo Rio Fresco e por Machado et. al. (1991) em componentes herdados de zircões do Granito Musa. Além disto Montalvão et. al. (1988) apresentaram alguns dados $\mathrm{Rb}-\mathrm{Sr}$ em rocha total, para rochas incluídas como Granodiorito Rio Maria, que apontavam para idades próximas a 3,1 Ga.

As seqüências do tipo greenstone belts incluídas no Super Grupo Serra das Andorinhas, encontram-se datadas diretamente através de dados U-Pb em zircões das rochas metavulcânicas e indiretamente através de idades $\mathrm{U}-\mathrm{Pb}$ em zircões detríticos das metagrauvacas intercaladas na seqüência metavulcano-sedimentar, como também em rochas intrusivas. Neste sentido as rochas metavulcânicas do Grupo Lagoa Seca indicaram idades de $2904 \pm 22 \mathrm{Ma}$ (Macambira e Lancelot, 1992) e $2979 \pm 5 \mathrm{Ma}$ (Pimentel e Machado, 1994). Zircões separados das metagrauvacas indicaram idade U-Pb de $2971 \pm 18 \mathrm{Ma}$, interpretada por Macambira e Lancelot (1991b) como a idade do embasamento das seqüências dos greenstone beits do Grupo Lagoa Seca. Em adição, Pimentel e Machado (1994), forneceram uma idade U-Pb em zircões para o Complexo Serra Azul, intrusivo nos Greenstone belts da região da Serra dos Gradaús de $2970 \pm 7$ Ma, o que implica em uma idade mínima para a seqüência.

Os dados geocronológicos apresentados sugerem que as rochas metavulcano-sedimentares dos greenstone belts da região da Serra dos Carajás evoluíram entre $3,0 \mathrm{Ga}$ e 2,9 Ga. As diferenças entre os padrões geocronológicos obtidos pelos autores acima podem ser devidas a amostras provenientes de derrames distintos, embora pertencentes às mesmas unidades estratigráficas e/ou a imprecisões analíticas.

Vários estudos geocronológicos foram realizados nos granitóides relacionados às Suítes Tonalíticas-Trondhjemíticas da região da Serra dos Carajás. Inicialmente Montalvão et. al. (1984) e (1988), Gastal et. al. (1987) e Macambira et. al. (1988), com base em estudos pelo método $\mathrm{Rb}-\mathrm{Sr}$ em rocha total, para os 
granodioritos e trondhjemitos da região de Rio Maria, estabeleceram um padrão arqueano para estes granitóides, obtendo-se idades isocrônicas entre 2,7 Ga e 2,5 $\mathrm{Ga}$, com valores de razões ${ }^{87} \mathrm{Sr} /{ }^{36} \mathrm{Sr}$ iniciais entre 0,7001 e 0,7028 , sendo os valores mais altos para as idades mais jovens. Estes dados indicavam que os protólitos crustais destas rochas não possuiam uma vida crustal significativa.

Posteriormente, através de estudos geocronológicos mais detalhados, utilizando-se o método U-Pb em zircões, Macambira e Lancelot (1991a) e Pimentel e Machado (1994) apresentaram respectivamente idades de 2874 +9/-10 Ma e 2872 $\pm 5 \mathrm{Ma}$ para os zircões do granitóide de Rio Maria. Estes últimos autores encontraram ainda, idades $\mathrm{U}-\mathrm{Pb}$ aproximadas de $2871 \mathrm{Ma}$ para o trondhjemito Mogno, e 2858 Ma para o tonalito Parazônia. Além disto, idades desta ordem foram obtidas para o Granito Mata do Surrão, de composição monzogranítica, pelo método $\mathrm{Pb}-\mathrm{Pb}$ em rocha total, indicando um valor de $2872 \pm 10 \mathrm{Ma}$ e valor de $\mu_{1}=8,2$ (Rodrigues et. al. 1992). A partir deste conjunto de dados radiométricos pode-se definir uma importante atividade granítica próxima a 2,87 Ga. As idades mais jovens obtidas para estas rochas pelo método $\mathrm{Rb}-\mathrm{Sr}$ devem se referir a eventos posteriores de remobilização, ou no caso específico das idades próximas a $2,7 \mathrm{Ga}$, indicar apenas diferenças de temperatura de fechamento de sistema relacionadas aos dois métodos isotópicos utilizados.

Na região da Serra dos Gradaús encontra-se datado o Granodiorito Cumarú, que é cortado por zonas de ciźlhamento importantes, que apresentou a idade de $2543 \pm 53 \mathrm{Ma}(r i .=0,7031 \pm 0,0003)$, obtida através de isócrona $\mathrm{Rb}-\mathrm{Sr}$ em rocha total (Lafon e Macambira, 1990).

Cerca de $300 \mathrm{~km}$ a sul da Serra dos Carajás, os terrenos granito-gnáissicos relacionados ao greenstone belt da Serra do Inajá foram datados por Tassinari et. al. (1982), através de uma isócrona $\mathrm{Rb}-\mathrm{Sr}$ de referência com idade de $2700 \mathrm{Ma}$ e razão inicial de 0,7001 , mostrando uma continuidade dos terrenos arqueanos até esta área. 
Idades $\mathrm{K}$-Ar em anfibólios e biotitas separados de rochas gnáissicas da região da Serra dos Carajás indicaram respectivamente os valores de $2638 \pm 91 \mathrm{Ma}$ e $1958 \pm 54 \mathrm{Ma}$ (Macambira et. al. 1988), evidenciando que a área foi afetado por um evento térmico durante a orogenia transamazônica, que atingiu a temperatura de $250^{\circ} \mathrm{C}$, mas não alcançou a temperatura de $500^{\circ} \mathrm{C}$. Tal fato é também corroborado pela isócrona $\mathrm{Rb}-\mathrm{Sr}$ mineral, obtida pelos mesmos autores acima citados, que forneceu uma idade de $1798 \pm 54 \mathrm{Ma}$.

As seqüências supracrustais incluídas no Supergrupo Itacaiúnas foram datadas através das metodologias $\mathrm{Rb}-\mathrm{Sr}$ e $\mathrm{Sm}-\mathrm{Nd}$ em rocha total, $\mathrm{U}-\mathrm{Pb}$ em zircões e K-Ar em minerais separados. Tassinari et. al. (1982) apresentaram uma isócrona $\mathrm{Rb}-\mathrm{Sr}$ em rocha total para xistos do Grupo Salobo, que indicou uma idade de 2700 $\mathrm{Ma}$, com razão ${ }^{87} \mathrm{Sr} /{ }^{86} \mathrm{Sr}$ inicial de 0,717 , que foi interpretada como a época do principal evento metamórfico, que afetou estas rochas.

Olszewski et.al.(1989), incluindo dados apresentados por Wirth et. al. (1986) e Gibbs et. al. (1986), apresentaram idades $U$ - $\mathrm{Pb}$ em zircões provenientes de metariolitos da seqüência metavulcânica inferior do Grupo Grão Pará, que indicou uma idade no intercepto superior do diagrama concórdia, de $2758 \pm 39 \mathrm{Ma}$, que foi considerada pelos autores op.cit. como a época de cristalização e conseqüente extrusão das lavas riolíticas do Grupo Grão Pará. Idade similar foi obtida por Machado et. al. (1991), pelo mesmo método U-Pb em zircões. Em adição, Gibbs et.al. (1986) apresentaram para as lavas máficas deste mesmo Grupo uma idade isocrônica $\mathrm{Rb}-\mathrm{Sr}$ em rocha total de $2687 \pm 54 \mathrm{Ma}$, com razão inicial ${ }^{87} \mathrm{Sr} /{ }^{86} \mathrm{Sr}$ de $0,7057 \pm 0,0010$, com o valor obtido para a razão inicial sugerindo uma certa contaminação de $\mathrm{Sr}$ crustal em meio às lavas máficas. Para as lavas ácidas os pontos analíticos apresentaram-se dispersos no diagrama isocrônico, indicando uma idade $2479 \pm 62 \mathrm{Ma}$, com razão inicial de $\mathrm{Sr}$ de $0,7152 \pm 0,0052$, que refletiria a abertura do sistema $\mathrm{Rb}-\mathrm{Sr}$ por eventos posteriores. 
Ainda Gibbs et.al. (1986) reportaram, para as rochas metavulcânicas do Grupo Grão Pará, valores de $\varepsilon_{\mathrm{Nd}}$, calculados para $2758 \mathrm{Ma}$, entre $-7,0$ e $+4,6$, o que confirma a afirmação baseada na razão incial de $\mathrm{Sr}$, de que o magma original destas rochas assimilaram consideráveis quantidades de materiais crustais durante a sua ascensão para a superfície, fato este que implica em considerar um ambiente continental para o desenvolvimento deste vulcanismo e conseqüentemente para a deposição do Grupo Grão Pará.

A sul da Serra dos Carajás, na região que inclui a Serra do Tapirapé, Tassinari e Basei (1980) apresentaram uma isócrona de referéncia $\mathrm{Rb}-\mathrm{Sr}$ em rocha total, para rochas granito-gnáissicas, consideradas do embasamento da área, que indicou uma idade de $2696 \pm 79 \mathrm{Ma}$, com razão inicial ${ }^{87} \mathrm{Sr} /{ }^{86} \mathrm{Sr}$ de $0,701 \pm 0,002$, sendo que alguns pontos analíticos, situados abaixo desta isócrona, definiram uma reta com inclinação relativa a idade de $2000 \mathrm{Ma}$, considerando-se uma razão inicial de $\mathrm{Sr}$ de 0,705. Estes dados demonstram a continuidade dos terrenos arqueanos da Serra dos Carajás para sul.

Corpos de rochas máficas-ultramáficas estratificadas, constituídos por gabros-noritos, piroxenitos e dunitos, não metamorfisados, como o da Serra do Onça (Macambira et.al. 1992), datados através de isócrona Sm-Nd em rocha total, que indicou a idade de $2375 \pm 56 \mathrm{Ma}$, com razão inicial de $\mathrm{Nd}$ de 0,50959 e valor de MSWD de 2,74 (CPRM-dado inédito). Esta idade, interpretada como a época de formação deste complexo máfico-ultramáfico, marca a ação de um evento distensivo na região de Carajás próximo a 2,4 Ga.

Durante o final do Paleoproterozóico, principalmente dentro do intervalo de tempo 1,95 Ga - 1,85 Ga, o sub-domínio Carajás - Iricoumé foi afetado por um importante magmatismo de natureza ácida a intermediária, que envolveu a intrusão de vários corpos graníticos anorogênicos, na região da Serra dos Carajás, e de um intenso vulcano-plutonismo nas áreas dos rios Xingu e Iricoumé. 
O magmatismo anorogênico envolveu granitóides de diversas composições, que apresentaram um padrão geocronológico, envolvendo os métodos $\mathrm{Rb}-\mathrm{Sr}$ e $\mathrm{Pb}-\mathrm{Pb}$ em rocha total, U-Pb em zircões e K-Ar em concentrados minerais, situado entre 1,9 Ga e 1,6 Ga. O granito Serra dos Carajás indicou idade $\mathrm{Rb}-\mathrm{Sr}$ em rocha total, obtida através de uma isócrona de referência, que incluia pontos do granito da Serra da Seringa, de $1700 \pm 45 \mathrm{Ma}$ e razão ${ }^{87} \mathrm{Sr}{ }^{86} \mathrm{Sr}$ inicial de $0,701 \pm 0,003$ (Tassinari et. al. 1982), e uma idade U-Pb em zircões de $1820 \pm 49$ Ma, obtida no intercepto superior da concórdia por Wirth et. al. (1986). Para o granito Serra da Seringa isoladamente foi obtida uma idade isocrônica $\mathrm{Rb}-\mathrm{Sr}$ em rocha total de $1730 \pm 58 \mathrm{Ma}$ e razão inicial de 0,708 \pm 0,002 (Lafon et. al. 1988, apud Macambira et. al. 1990). Além disto este granito foi também datado pelo método $\mathrm{Pb}-\mathrm{Pb}$ por evaporação de zircões em $1892 \pm 30$ Ma por Avelar et. al. (1994).

Amostras de monzogranitos do Granito Cigano revelaram idade $\mathrm{Rb}-\mathrm{Sr}$ isocrônica em rocha total de $1731 \pm 28 \mathrm{Ma}$, com $r$ i. de 0,7070 $\pm 0,0008$ (Gonçalez et. al. 1988), e idade U-Pb em zircões de $1885 \mathrm{Ma}$. (Machado et. al. 1988). O Granito Musa, por sua vez, foi datado por Gastal et. al. (1987), através de isócrona $\mathrm{Rb}-\mathrm{Sr}$, obtendo a idade de $1692 \pm 11 \mathrm{Ma}$, com $r$ i. de $0,7077 \pm 0,0005$, e por Machado et. al. (1988) pelo método U-Pb em zircões, que obteve a idade $1883 \pm 5$ Ma. Estes mesmos autores também apresentaram idades U-Pb em zircões para o Granito Pojuca de $1874 \pm 2 \mathrm{Ma}$.

Os corpos graníticos de Redenção e Velho Guilherme foram datados pelo método $\mathrm{Pb}-\mathrm{Pb}$ em rocha total por Barbosa et. al. (1994) e Rodrigues et. al. (1992) respectivamente sendo obtidas as idades de $1893 \pm 178 \mathrm{Ma}$ e $1874 \pm 30 \mathrm{Ma}$. Amostras relativas ao Granito Jamon foram analisadas por Dall'Agnol et. al. (1984), através de isócrona $\mathrm{Rb}-\mathrm{Sr}$, obtendo a idade de $1601 \pm 41 \mathrm{Ma}$, com razão inicial de $0,711 \pm 0,003$.

Os dados geocronológicos apresentados acima mostram claramente que uma importante atividade granítica de natureża anorogênica ocorreu na região da Serra 
dos Carajás, principalmente entre 1,9 Ga e 1,8 Ga. As idades Rb-Sr obtidas para os granitóides mostraram-se sistematicamente mais jovens do que as idades $\mathrm{U}-\mathrm{Pb}, 0$ que poderia sugerir que o resfriamento destes corpos foi bastante lento, tendo em vista que o fechamento do sistema $\mathrm{Rb}$-Sr ocorreu cerca de 50 a $100 \mathrm{Ma}$ depois da época de cristalização dos zircōes. Os valores normalmente elevados para as razões ${ }^{87} \mathrm{Sr} r^{36} \mathrm{Sr}$ iniciais dos granitóides indicam que durante os episódios de formação destes plutons, predominaram os processos de fusão parcial de crosta continental pré-existente.

Idades K-Ar, obtidas em concentrados de biotitas, muscovitas e anfibólios, provenientes de sete amostras dos xistos do Grupo Salobo, forneceram resultados dentro do intervalo de tempo $2.0 \mathrm{Ga}$ e $1.9 \mathrm{Ga}$ (Tassinari et. al. 1982). Além disto, idades $\mathrm{K}-\mathrm{Ar},{ }^{39} \mathrm{Ar}{ }^{40} \mathrm{Ar}$ em biotitas e $\mathrm{Rb}-\mathrm{Sr}$ em minerais apresentadas respectivamente por Gomes et. al. (1975), Renne et. al. (1988) e Macambira et.al. (1988), também indicaram idades entre 2,0 e 1,8 Ga. Estes resultados demonstram claramente que a região sofreu um aquecimento importante durante o ciclo Transamazônico, cujas causas podem ser tanto devido às atividades magmáticas cratogênicas que afetaram a área, como a eventos de natureza metamórfica, que atuaram um pouco mais a norte, relacionados a atuação da Orogenia MaroniItacaiúnas que afetou termicamente a região da Serra dos Carajás, já estabilizada tectonicamente neste periodo.

O extenso vulcanismo ácido a intermediário não deformado, que ocorre a sudoeste da Serra dos Carajás, na região do rio Xingu, encontra-se datado em 1856 $\pm 29 \mathrm{Ma}$, através de isócrona $\mathrm{Rb}-\mathrm{Sr}$ em rocha total, com razão inicial ${ }^{87} \mathrm{Sr} /{ }^{36} \mathrm{Sr}$ de $0,704 \pm 0,002$ (Cunha et. al., 1981). Os granitóides intrusivos nestas seqüências vulcânicas, quando datados pelo método $\mathrm{Rb}-\mathrm{Sr}$ em rocha total forneceram em diagrama isocrônico duas isócronas distintas, a mais velha com idade de $1737 \pm 50$ $\mathrm{Ma}(r i=0,719 \pm 0,008)$ e a mais jovem com a idade de $1641 \pm 22 \mathrm{Ma}(r i=0,703 \pm$ $0,003)$. Estes dois conjuntos de granitóides foram denominados pelos autores supracitados por Suítes Intrusivas Rio Dourado e Tarumã respectivamente. A 
primeira suíte, que indicou um valor de razão inical bastante elevado, foi derivada de magmas gerados por processos de fusão parcial de rochas crustais com alta razão $\mathrm{Rb} / \mathrm{Sr}$; já a suíte mais jovem, que apresentou uma razão inicial mais baixa, da ordem de 0,703, deve ter se originado a partir de magmas gerados por diferenciação do manto superior ou a partir de fusão de rochas da crosta continental inferior.

Apesar da ausência de dados radiométricos para as rochas do embasamento da região do rio Xingu, a idade arqueana desta área é inferida a partir da idade antiga da cobertura vulcânica não deformada (1850 Ma), e na ausência de seqüências vulcânicas e sedimentares deformadas de idades paleoproterozóicas, como aqueias que ocorrem no domínio Maroni-ltacaiúnas. Portanto, o autor não considera como definitiva a continuidade dos terrenos arqueanos da Serra dos Carajás para esta parte do sub-domínio Carajás-Iricoumé.

A norte da Sinéclise do Amazonas, nas regiões banhadas pelas bacias hidrográficas dos rios Uatumã, Trombetas e Parú do Oeste (Região de Iricoumé), ocorrem as rochas vulcânicas ácidas a intermediárias não deformadas da Formação Iricoumé, que foram datadas através de isócrona de referência $\mathrm{Rb}-\mathrm{Sr}$ em rocha total por Basei (1977) em $1790 \pm 20 \mathrm{Ma}$, com razão ${ }^{87} \mathrm{Sr} /{ }^{36} \mathrm{Sr}$ inicial de $0,7044 \pm 0,0001$. Em adição, Schobbenhaus et.al. (1994) apresentaram uma idade U-Pb em zircões provenientes de um riodacito desta seqüência com valor no intercepto superior de $1962 \pm 43 \mathrm{Ma}$. A diferença de idades conseguidas pelos dois métodos pode ser explicada pelo fato dos pontos analisados pelo método $\mathrm{Rb}-\mathrm{Sr}$ serem relativos a amostras provenientes de distintos afloramentos e não necessariamente cogenéticas, e também pela possibilidade deste vulcanismo incluir vários derrames distintos em idades. Mas, de toda a forma, estes dados demonstram a existência de coberturas vulcânicas antigas nesta região.

Associadas a estes episódios vulcânicos ocorrem importantes atividades graníticas, que constituem os denominados Granitos Mapuera e o Adamelito Água Branca. Os primeiros foram analisados geocronologicamente pelo método $\mathrm{Rb}-\mathrm{Sr}$ por 
Basei (1977), cujos pontos analíticos situaram-se entre duas retas com inclinações relativas às idades de $1790 \mathrm{Ma}$ e $1410 \mathrm{Ma}$. Santos e Reis Neto (1982) retrabalharam dados anteriores e definiram uma idade $\mathrm{Rb}-\mathrm{Sr}$ de $1807 \mathrm{Ma}$, com razão inicial de 0,7061. Neste trabalho foram retrabalhados os dados geocronológicos disponiveis para os granitos do tipo Mapuera, que definiram uma idade isocrônica $\mathrm{Rb}-\mathrm{Sr}$ de $1860 \pm 28 \mathrm{Ma}$, com razão inicial ${ }^{86} \mathrm{Sr} /{ }^{87} \mathrm{Sr}$ de $0,7056 \pm$ 0,0012 . Na região dos granitos deste tipo, Jorge João et. al. (1985a) analisaram geocronologicamente, de forma separada, o Granito Serra do Acari, através de uma isócrona $\mathrm{Rb}-\mathrm{Sr}$ em rocha total, que forneceu a idade de $1750 \pm 30 \mathrm{Ma}$ e razão ${ }^{87} \mathrm{Sr} r^{86} \mathrm{Sr}$ inicial de $0,7150 \pm 0,0001$, caracterizando a presença de atividades graníticas mais tardias neste sub-dominio.

Santos e Reis Neto (1982) apresentaram para o Adamelito Água Branca a idade isocrónica $\mathrm{Rb}-\mathrm{Sr}$ de referéncia de $1951 \mathrm{Ma}$ com $r i$. de 0,703. Em adição, Jorge João et. al. (1985b) apresentaram para amostras deste mesmo corpo, uma idade isocrônica $\mathrm{Rb}-\mathrm{Sr}$ em rocha total de $1910 \pm 47 \mathrm{Ma}$, com razão inical de 0,7023 $\pm 0,0006$ e valor de MSWD $=1,26$. Esta idade, interpretada como a época de colocação do corpo adamelítico, indica que esta rocha poderia estar ligada ao mesmo episódio gerador do vulcanismo Iricoumé.

Ainda nesta região ocorrem os granitos estaniferos Madeira e Água Boa, intrusivos nas vulcânicas Iricoumé, que foram datados por Macambira et. al. (1987) através de isócronas $\mathrm{Rb}-\mathrm{Sr}$ em rocha total, obtendo-se respectivamente as idades de $1691 \pm 60 \mathrm{Ma}(r i=0,7062 \pm 0,013)$ e de $1679 \pm 60 \mathrm{Ma}(r i=0,7113 \pm 0,002)$, caracterizando uma atividade granítica mais jovem na área. Ainda dentro deste episódio magmático está incluida a Suíte Intrusiva Abonari, que ocorre na porção nordeste do Estado do Amazonas. Recalculando-se os dados analíticos Rb-Sr que constam dos trabalhos de Veiga Jr. et. al. (1979) e Santos e Reis Neto (1982), obtêm-se a idade isocrônica de $1670 \pm 50 \mathrm{Ma}$ com uma relação incial de 0,7052 \pm 0,0034 , o que posiciona temporalmente a formação desta suite no mesmo episódio magmático gerador dos granitos Madeira e Água Boa. 
A exemplo da região do Rio Xingu, a idade arqueana deste fragmento cratônico é inferida a partir da idade antiga das coberturas vulcânicas não deformadas, que possuem a mesma idade, por exemplo, das rochas metamórficas granulíticas do Cinturão Granulítico da Guiana Central, que ocorre imediatamente a norte da região do Iricoumé, mostrando que esta região estava estabilizada tectonicamente, enquanto que na área adjacente desenvolvia-se uma importante orogênese em torno de $1950 \mathrm{Ma}$.

As atividades magmáticas básicas sob as formas de sills, diques, derrames e pequenos "stocks" atingiram praticamente todo o Cráton Amazônico, estando íntimamente relacionados a fenômenos de tração da crosta continental, já estabilizada tectonicamente (Teixeira, 1978). No sub-domínio Carajás-iricoumé o magmatismo básico ocorreu principalmente em quatro épocas distintas, que seriam:

- entre 2,5 Ga e 2,4 Ga;

- 2,0 Ga e 1,9 Ga;

-1,5 Ga e 1,4 Ga e

-entre 1,2 Ga e 1,1 Ga,

períodos estes onde a crosta continental arqueana teria sofrido processos de fraturamentos, provocados, no caso dos três últimos intervalos de tempo, pelas orogenias que ocorreram na região durante o Proterozóico; já o período situado entre 2,5 Ga e 2,3 Ga foi caracterizado por eventos distensivos marcantes neste bloco cratônico, que possibilitaram não somente o surgimento de corpos máficosultramáficos estratificados, como também condicionaram o início da deposição do Grupo Rio Fresco. Atividades ígneas de carácter alcalino ocorreram na região dos rio Trombetas e Parú do Oeste, onde amostras de quartzo sienitos e nordmarkitos provenientes dos Maciços de Erepecuru e Mapari, indicaram respectivamente as idades $\mathrm{Rb}-\mathrm{Sr}$ convencionais de $1804 \pm 69$ Ma e próximo a $1480 \mathrm{Ma}$. (Teixeira, 1978).

Durante o Neoproterozóico atividades distensivas provocaram o desenvolvimento de magmatismos básicos ao longo de fraturas, que afetaram 
termicamente algumas áreas da região da Serra dos Carajás. Estes fatos são evidenciados a partir das idades K-Ar entre 530 e $500 \mathrm{Ma}$ obtidas por Amaral (1974) para diques de diabásio que ocorrem nas regiōes dos rios Itacaiúnas e Paraopebas, e através de dados U-Pb e $\mathrm{Pb}-\mathrm{Pb}$ em calcopiritas provenientes das mineralizações de Pojuca e Serra Verde (Mougeot et. al. 1996). Esta atividade geológica mais nova provavelmente está relacionada a atuação da orogenia responsável pela Faixa de Dobramentos Araguaia - Tocantins, que desenvolveu-se a leste da área em estudo, tendo o sub-domínio Carajás-Iricoumé funcionado como ante-país deste cinturão.

Os dados isotópicos Sm-Nd obtidos nos terrenos do Sub-Domínio CarajásIricoumé apresentaram idades modelos $\mathrm{Sm}-\mathrm{Nd}$ manto empobrecido dentro do intervalo de tempo $3,0 \mathrm{Ga}$ a 2,6 Ga (Figura 5), sendo que as idades mais antigas encontram-se distribuídas na região da Serra dos Carajás. Os valores calculados de $\varepsilon_{\mathrm{Nd}}$ para as respectivas idades de formação das rochas arqueanas, situaram-se entre $+2,5$ e $-2,5$, sugerindo que estes terrenos diferenciaram-se do manto superior pouco tempo antes de sua cristalização (Sato e Tassinari, 1996).

\subsection{2 - Sub-Domínio Roraima}

\subsubsection{1 - Considerações Geológicas}

O sub-domínio Roraima ocorre na parte norte do Cráton Amazônico e está separado do sub-domínio Carajás-Iricoumé por uma faixa móvel, desenvolvida durante a orogenia Maroni-ltacaiúnas $(2,2 \mathrm{Ga}-1,95 \mathrm{Ga}$.), que amalgamou estes dois subdomínios. Esta região inclui principalmente rochas vulcano-plutônicas ácidas a intermediárias recobertas por rochas sedimentares, intercaladas por vários derrames e sills de lavas básicas. Todas estas unidades não são metamorfizadas, e se destacam no relevo, em meio ao embasamento completamente arrasado, aflorando em forma de "mesas". As rochas vulcânicas, incluídas na Formação 
Surumu por Montalvão et. al. (1975), apresentam somente deformações locais, devido a ações de falhamentos. De uma forma geral esta unidade é constituída principalmente por tufos e lavas de composição riodacítica ou andesítica, caracterizando uma associação calcialcalina. Os mesmos autores incluíram as rochas intrusivas graníticas sub-vulcânicas, que ocorrem associadas ao vulcanismo Surumu, sob a denominação de "Granodiorito Serra do Mel", que litologicamente incluem, além de granodioritos, granitos e adamelitos.

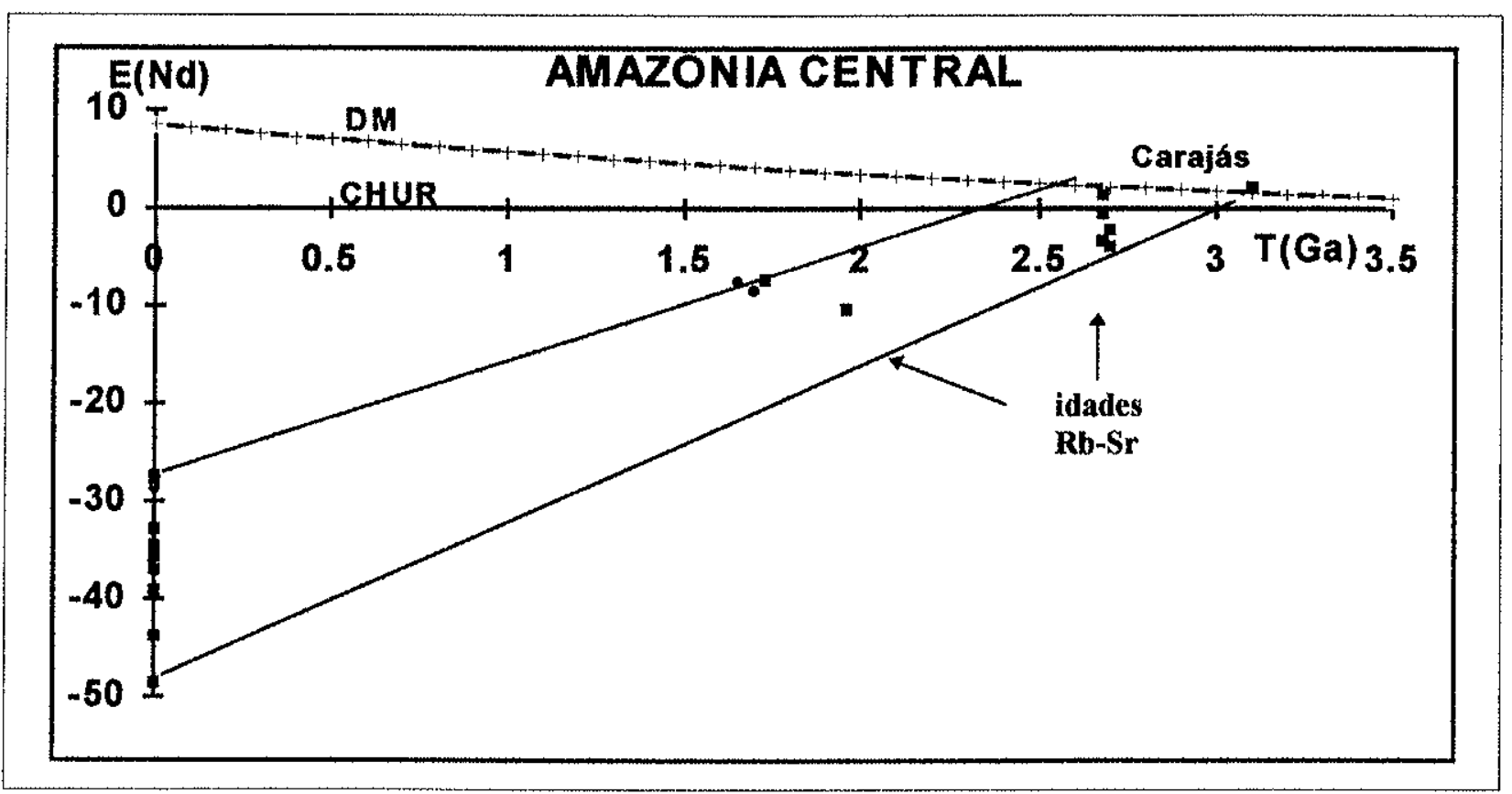

Figura 5 - Diagrama de variação do $\varepsilon_{\mathrm{Nd}}$ em função do tempo geológico, mostrando os intervalos de tempo da diferenciação manto - crosta dos protólitos crustais do Dominio Amazônia Central

O Grupo Roraima é constituído por conglomerados basais polimíticos, arcóseos, arenitos, arenitos arcoseanos, argilitos, siltitos, folhelhos e jaspes. A formação deste conjunto é produto de uma sedimentação do tipo molassóide, fluvial, deltáica e também, possivelmente marinha (Keats, 1976).

O Sub-domínio Roraima é coberto quase que totalmente pelas rochas vulcânicas ácidas a intermediárias da Formação Surumu, e pelos sedimentos do Grupo Roraima, intercalados por sills e derrames de rochas básicas. Portanto as análises geocronológicas disponíveis estão restritas às unidades vulcânicas. 


\subsubsection{2 - Discussões Geocronológicas}

Neste sentido o vulcanismo Surumu encontra-se datado através de uma isócrona $\mathrm{Rb}-\mathrm{Sr}$ de referência em rocha total, que indicou uma idade de $1860 \pm 28$ $\mathrm{Ma}$, com uma razão ${ }^{87} \mathrm{Sr}{ }^{86} \mathrm{Sr}$ inical de 0,7056 e valor de $\mathrm{MSWD}=1,70$ (dados de Basei, 1977, recalculados). Posteriormente Schobbenhaus et. al. (1994) apresentaram uma idade U-Pb em zircões provenientes de um riodacito do vulcanismo Surumu, cujo valor no intercepto superior foi de $1966 \pm 9$ Ma. Esta idade, considerada como a época de cristalização das rochas vulcânicas analisadas, é bastante concordante com a idade do vulcanismo Iricoumé, demonstrando a contemporaneidade destes dois episódio vulcânicos. Associado a este magmatismo ocorre o plutonismo Serra do Mel, cujos dados analíticos $\mathrm{Rb}-\mathrm{Sr}$ obtidos em rocha total por Basei e Teixeira (1975) e Santos e Reis Neto (1982) foram retrabalhados nesta pesquisa, e indicaram a idade isocrônica de $1769 \pm 36$ $\mathrm{Ma}$, e razão inicial de 0,7044 $\pm 0,0031$, com valor de $M S W D=1,99$.

Como pode ser observado a idade $\mathrm{Rb}-\mathrm{Sr}$ para os granitóides comagmáticos ao vuicanismo Iricoumé, é bastante mais jovem do que as idade obtida pelo método U-Pb em zircões das rochas vulcânicas, fato este que pode deixar em aberto a questão da idade de cristalização dos granitóides, que poderiam eventuaimente serem mais antigos.

Em território brasileiro o Grupo Roraima encontra-se cortado por rochas básicas, incluídas sob a denominação de "Diabásio Pedra Preta", que foram datados por Basei e Teixeira (1975), através do método $\mathrm{Rb}-\mathrm{Sr}$ em rocha total em amostras de hornfels produzidos por este vulcanismo nas rochas sedimentares do Grupo Roraima, indicando idades convencionais entre 1830 Ma e $1800 \mathrm{Ma}$. Estes dados, quando lançados em diagrama isocrônico definem uma reta com inclinação relativa a idade de $1800 \pm 70 \mathrm{Ma}$, com um valor de $r i$. em torno de 0,702 , que pode ser interpretada como a época de formação deste magmatismo. Além disto, outras manifestações básicas intrusivas em rochas do embasamento do sub-Domínio 
Roraima apresentam idades de formação próximas a 1,9 Ga, a 1,8 $\mathrm{Ga}$ e entre 1,6 Ga e 1,57 Ga (Teixeira, 1978).

Os dados geocronológicos apresentados para o vulcanismo Surumu e para o Diabásio Pedra Preta limitam no tempo geológico, pelo menos parte da sedimentação do Grupo Roraima entre 1,97 Ga. e 1,8 Ga, uma vez que os sedimentos repousam sobre as vulcánicas ácidas datadas e são cortados pelo diabásio. Como ocorrem sedimentos não cortados pelo Diabásio Pedra Preta, mas intrudidos por rochas básicas com idades de até $1,67 \mathrm{Ga}$, como o Diabásio Avanavero no Suriname, pode-se admitir que a sedimentação do Grupo Roraima prosseguiu, pelo menos até $1,6 \mathrm{Ga}$.

As idades disponiveis para as rochas do Domínio Amazónia Central encontram-se sumarizadas no Quadro 1, onde pode-se constatar que os principais episódios de formação de rochas ocorreram entre 3,0 $\mathrm{Ga}$ e 2,6 $\mathrm{Ga}$ e 2,0 $\mathrm{Ga}$ e 1,6 $\mathrm{Ga}$, sendo que o primeiro intervalo de tempo encontra-se principalmente na região entre as Serras dos Carajás e do Inajá. Durante o intervalo de tempo mais jovem predominaram as atividades magmáticas anorogênicas de carácter intraplaca em área cratônica. Pode ser notado ainda no Quadro 1, que durante o intervalo de tempo entre $2,5 \mathrm{Ga}$ e 2,0 Ga, praticamente não houve processos orogênicos formadores de rochas, apenas o desenvolvimento de complexos máficosultramáficos estratificados, indicando que neste período de calmaria tectônica, ocorreram apenas episódios distensivos e de sedimentações em bacias continentais.

\section{2 - Dominio Maroni - Itacaiúnas}

O Domínio Maroni - Itacaiúnas inclui rochas formadas durante o periodo de tempo entre 2,2 Ga e 1,95 Ga, que ocorrem na porção nordeste do Cráton Amazônico. Este domínio é dividido claramente em uma porção simática juvenil e 


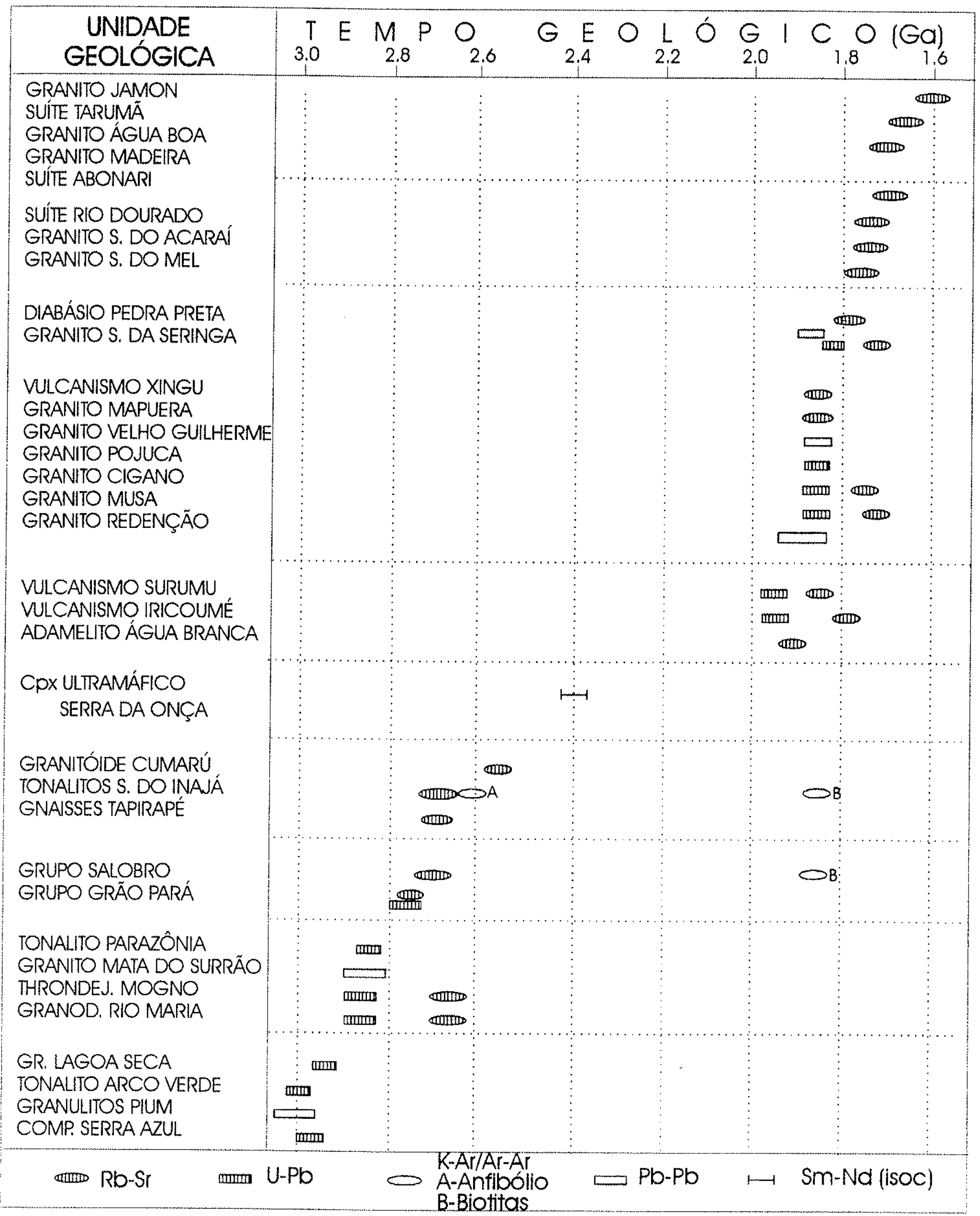

QUADRO 1 - SUMÁRIO DOS DADOS GEOCRONOLÓGICOS DOMÍNIO AMAZÓNA CENTRAL 
em uma parte ensiálica, onde as rochas existentes foram formadas a partir de processos de retrabalhamento de rochas crustais pré-existentes, e como conseqüência são encontrados núcleos preservados de rochas de idades arqueanas. O domínio Amazônia Central neste período apresentava condições cratônicas e serviu de ante-país para o desenvolvimento da orogenia Maroni Itacaiúnas, que provocou intensos episódios deformacionais durante o ciclo Transamazônico e episódios de reaquecimentos nas áreas vizinhas. A discussão dos dados geológicos e geocronológicos será efetuada separadamente para as porções ensiálica e simática respectivamente.

\subsection{1 - Porção Ensiálica}

A região ensiálica do Domínio Maroni - Itacaiúnas se estende desde o norte da região da Serra dos Carajás, circundando o Domínio Amazônia Central até o falhamento Oiapoque, que ocorre ao longo do rio homônimo, na divisa entre o estado do Amapá e a Guiana Francesa.

\subsubsection{1 - Considerações Geológicas}

A norte da região da Serra dos Carajás as rochas que constituem os terrenos granito-gnáissico-migmatíticos do Complexo Xingu foram individualizadas por Santos et. al. (1988), separando-as em cinco unidades, assim designadas informalmente:

- Unidade I, constituída predominantemente por rochas gnáissicas de composição granodiorítica e tonalítica, granulitos e anfibolitos;

- Unidade II, com rochas gnáissico-migmatíticas que incluem seqüências de rochas vulcânicas metabásicas e metassedimentares; 
- Unidade III, que inclui rochas migmatíticas de diversas estruturas e composições, com predomínio de estruturas acamadas, brechóides, dobradas, do tipo scholen, schilieren e nebulíticas, com gnaisses e granitóides subordinados;

- Unidade IV, apresentando predomínio de granitóides sintectônicos e

- Unidade $V$, que é composta por granitóides pouco deformados.

Em geral estas unidades atingem principalmente o fácies metamórfico xisto verde alto a anfibolito alto, sendo que subordinadamente algumas rochas alcançam o fácies granulito e outras o fácies xisto verde baixo.

Na região situada a norte da Bacia Sedimentar do Amazonas, no Estado do Amapá, os terrenos pré-cambrianos são compostos por rochas de natureza granulítica, consideradas como Suíte Metamórfica Ananaí e Suite Metamórfica Tartarugal Grande (Jorge João e Marinho, 1982), por rochas tonalíticas e granodioríticas, que, por vezes, englobam seqüências de rochas supracrustais e por seqüências metavulcano-sedimentares do Grupo Vila Nova. Principalmente na região do rio Cupixi e do Ipitinga ocorre um intenso magmatismo granítico, rico em feldspato potássico (alcali-granito), que constituem a Suíte Intrusiva Cupixi (Montalvão e Tassinari, 1984) e que intrudem e afetam os terrenos gnáissicomigmatíticos que são incluídos no denominado embasamento cristalino da região. Já na região do rio Falsino ocorrem os granitóides de caráter pós-tectônico da suíte Intrusiva Falsino.

A Suíte Metamórfica Ananaí compreende duas unidades litológicas, a primeira composta por granulitos básicos, onde destaca-se a variedade hiperstêniopiroclásio-granulito, e a segunda por rochas metamórficas bastante silicificadas (Jorge João e Marinho, 1982). A Suíte Metamórfica Tartarugal Grande é constituída por rochas granulíticas charnoenderbíticas divididas em Charnoquito Cuatá e Enderbitos Cobra (Jorge João et. al. , 1978). 
Ainda no âmbito do denominado embasamento do Domínio Maroni-ltacaiúnas são encontrados restos de seqüências metavulcano-sedimentares, constituídas por biotita-xistos, ortoanfibolitos e cherts, que foram fortemente afetados por um magmatismo de composição tonalítica, formando o Grupo Serra da Lombarda (De Ferran, 1988). Nesta área ocorrem ainda granitos e granodioritos intrusivos, de caráter pós-tectônico, com veios de pegmatitos associados.

Completando o quadro geológico da região do Amapá, ocorrem os metamorfitos do Grupo Vila Nova (Nagel, 1962), que compreendem anfibolitos, rochas metaultramáficas, metacherts, rochas calcissilicatadas, formações ferriferas bandadas, xistos de diversas naturezas e formações magnesíferas. Estas seqüências encontram-se metamorfisadas no fácies xisto verde, alcançando em alguns locais o fácies anfibolito.

Complementando a porção ensiálica do domínio Maroni-Itacaiúnas, mas fora do território brasileiro, encontra-se o Complexo do Imataca, na Venezuela, com idade arqueana e afetado fortemente pela orogenia Maroni - Itacaiúnas. Este núcleo é constituído por rochas granulíticas de diversas naturezas, afetadas por uma granitogênese durante o Paleoproterozóico.

\subsubsection{2 - Discussões Geocronológicas}

No segmento crustal do domínio Maroni - Itacaiúnas, a sul da sinéclise do Amazonas, os trabalhos geocronológicos estão restritos à região do médio Rio Xingu, onde Santos et. al. (1988) estudaram uma seqüência metavulcanosedimentar, reportando idades isocrônicas $\mathrm{Rb}-\mathrm{Sr}$ em rocha total para as unidades compostas por rochas calcissilicatadas, paragnaisses e rochas metabásicas. As idades obtidas foram respectivamente $1930 \pm 40 \mathrm{Ma}$ com $r$ i. de 0,7116 $\pm 0,0007$ (MSWD $=0,08) ; 1820 \pm 200$ Ma com ri. de 0,7197 $\pm 0,001$ (MSWD $=0,15)$ e $1990 \pm$ 
$80 \mathrm{Ma}$ com ri. de 0,7032 $\pm 0,0002$ (MSWD=3,04). Estes dados mostram a atuação da orogenia Maroni -ftacaiúnas retrabalhando rochas pré-existentes, provavelmente associadas ao embasamento do Domínio Amazônia Central. Pode ser notado que a idade obtida para os paragnaisses, interpretada como uma idade mínima para o metamorfismo que afetou os metassedimentos, apresenta um erro alto, e conseqüentemente é preferivel, portanto, adotar um intervalo de tempo entre 2,0 $\mathrm{Ga}$ e 1,93 Ga para o metamorfismo principal que atuou na porção sul do domínio Maroni - Itacaiúnas.

A norte da bacia sedimentar do Amazonas, onde a porção ensiálica deste domínio possui continuidade para o Estado do Amapá, os trabalhos de caráter geocronológico foram desenvolvidos principalmente nas rochas do chamado embasamento, que incluem terrenos gnáissico-migmatíticos, granulitos e diversos tipos de granitóides, e também nas seqüenncias metavulcano-sedimentares que constituem o grupo Vila Nova.

Montalvão e Tassinari (1984) apresentaram uma isócrona $\mathrm{Rb}-\mathrm{Sr}$ em rocha total para os terrenos granodioríticos e trondhjemíticos situados próximos à região do rio Cupixi, com idade de $2860 \pm 60 \mathrm{Ma}$, com ri. de $0,7025 \pm 0,0009$. 0 baixo valor obtido para a razão ${ }^{87} \mathrm{Sr}{ }^{\beta 6} \mathrm{Sr}$ inicial mostra que estas rochas diferenciaram-se do manto superior pouco tempo antes de sua cristalização, provavelmente em torno de $3,0 \mathrm{Ga}$, caracterizando um núcleo arqueano preservado em meio às rochas do Dominio Maroni - Itacaiúnas. A atuação da orogenia transamazônica nesta área é indicada pelas idades $\mathrm{K}$-Ar realizadas em minerais separados, provenientes de rochas pertencentes a estes terrenos, que forneceram idades dentro do intervalo de tempo $2100 \mathrm{Ma}-1760 \mathrm{Ma}$.

Para os terrenos granulíticos da região a leste do Rio Falsino, que incluem os denominados Charnoquitos Coatá e os Enderbitos Cobra, Lima et.al. (1982) reportaram uma isócrona $\mathrm{Rb}$-Sr em rocha total com a idade de $2450 \pm 74 \mathrm{Ma}$, com uma relação ${ }^{87} \mathrm{Sr} /{ }^{36} \mathrm{Sr}$ inicial um pouco elevada, de $0,706 \pm 0,002$, o que indica que a 
fonte destes granulitos possuía uma razão $\mathrm{Rb} / \mathrm{Sr}$ pouco mais elevada do que a média da crosta continental inferior. Alguns pontos analíticos situados próximos da origem deste diagrama isocrônico sugeriram uma idade mais antiga, da ordem de $3,0 \mathrm{Ga}$, o que em conjunto com o valor da razão inicial de 0,706 pode sugerir que a idade de $2450 \mathrm{Ma}$ obtida, reflita algum evento posterior de re-homogenização isotópica de $\mathrm{Sr}$ e que, portanto, estes granulitos teriam originalmente se formado durante o arqueano.

Os metamorfitos de fácies xisto-verde do Grupo Vila Nova encontram-se datados por algumas poucas idades $\mathrm{K}-\mathrm{Ar}$, e por uma isócrona $\mathrm{Rb}-\mathrm{Sr}$ de referência efetuada por Hurley et. al. (1968) em amostras de xistos, provenientes da Serra do Navio, sem contudo precisar a localização das amostras datadas. Esta isócrona indicou uma idade da ordem de 2100 Ma e uma ri. de 0,706, que por analogia com seqüências correlatas que ocorrem na Guiana Francesa (Formação Paramacá), pode ser interpretada como a idade de metamorfismo que afetou esta seqüência metavulcano-sedimentar. O padrão das idades K-Ar é concordante com esta interpretação, indicando valores aparentes dentro do período de tempo entre 2100 Ma e 1970 Ma para anfibólios e entre 1920 Ma e 1760 Ma para as micas, sugerindo respectivamente os períodos de resfriamento a $500^{\circ} \mathrm{C}$ e a $250^{\circ} \mathrm{C}$ (Montalvão e Tassinari,1984).

Montalvão e Tassinari (1984) estudaram geocronologicamente, através do método $\mathrm{Rb}-\mathrm{Sr}$ em rocha total os granitóides intrusivos nos terrenos tonalíticos e trondhjemítcos da região do Cupixi, incluídos na Suíte Intrusiva Cupixi, sendo analisadas amostras de granitos avermelhados ricos em microclínio neoformado. Estas rochas indicaram uma idade isocrônica de $2250 \mathrm{Ma}$ com um valor extremamente alto de razão inicial da ordem de 0,747. Estes dados provavelmente indicam a idade do evento de metassomatose de $K$ que afetou o granitóide, considerando-se que estas rochas encontram-se afetadas por uma forte zona de cizalhamento. Na região do Rio Falsino ocorre a Suíte Intrusiva homônima, que encontra-se datada através do método isocrônico $\mathrm{Rb}-\mathrm{Sr}$ em rocha total; onde uma 
isócrona de referência forneceu a idade de $1760 \pm 37$ Ma com razão ${ }^{87} \mathrm{Sr}{ }^{86} \mathrm{Sr}$ inicial de 0,716 \pm 0,002 (Lima et. al. 1974, valor recalculado).

As rochas básicas associadas aos lineamentos que ocorrem próximos ao limite deste domínio com o Domínio Amazônia Central indicam idades K-Ar em torno de $1900 \mathrm{Ma}, 1500 \mathrm{Ma}$ e $980 \mathrm{Ma}$ (Teixeira, 1978).

Idades modelo Sm-Nd manto empobrecido ( $\left.T_{D M}\right)$ calculadas para seqüências de rochas metavulcânicas da região do rio Itacaiúnas, datadas em $1820 \mathrm{Ma}$, indicaram valores próximos a 2,65 Ga (Sato e Tassinari, 1996), e os números calculados para $\varepsilon_{\mathrm{Nd}}$ em $1,82 \mathrm{Ga}$ situam-se entre $-7,9$ e -7,5, sugerindo um protólito crustal arqueano para estas rochas. Da mesma forma, os terrenos metamórficos do núcleo antigo do Cupixi, de idade próxima a $2,9 \mathrm{Ga}$, indicaram idades modelos $\mathrm{Sm}-\mathrm{Nd}\left(\mathrm{T}_{D M}\right)$ em torno de $3,1 \mathrm{Ga}$ e valores de $\varepsilon_{\mathrm{Nd}}$ entre $-0,7$ e $-1,1$, sugerindo que a época de diferenciação mantélica do protólito destas rochas ocorreu pouco tempo antes, conforme sugerido no diagrama da Figura 6.

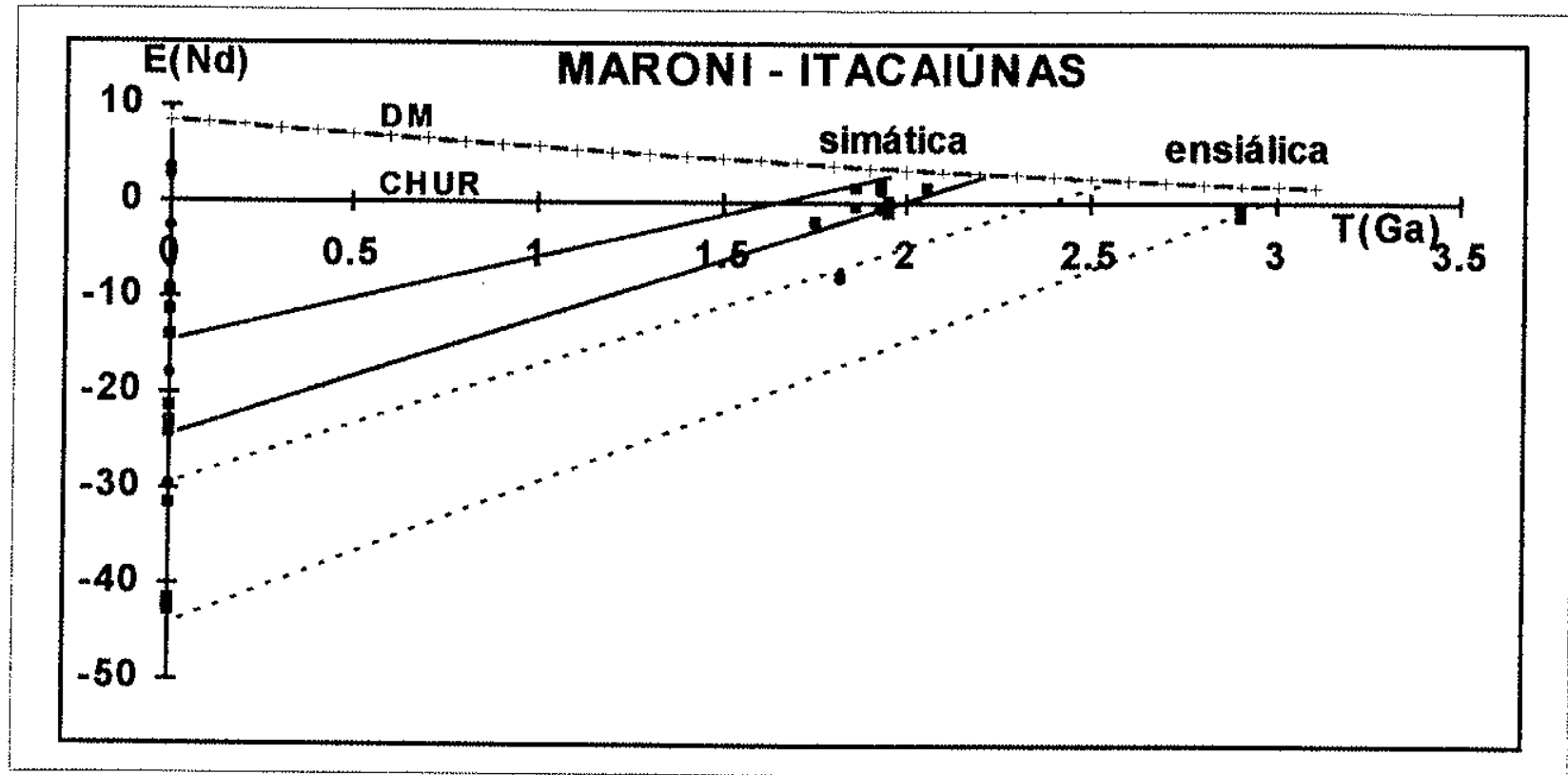

Figura 6 - Diagrama da variação do $\mathcal{E}_{N d}$ em função do tempo geológico, mostrando os intervalos de tempo da diferenciação manto - crosta para os protólitos crustais das porções ensiálicas e simáticas do Domínio Maroni - Itacaiúnas. 
Portanto, pelos dados geocronológicos expostos pode-se considerar a parte ensiálica do domínio Maroni-Itacaiúnas, que ocorre tanto a norte como a sul da Bacia Sedimentar do Amazonas, como sendo constituída por protólitos arqueanos, que poderiam representar a continuidade do domínio Amazônia Central, e que sofreram episódios de intensa deformação e de fusão parcial, durante a orogenia Maroni- Itacaiúnas $(2,2-1,95 \mathrm{Ga})$, produzindo novas rochas, e em alguns locais, onde a orogênese não foi tão acentuada, ocorreriam os núcleos antigos, como o de Cupixi no Amapá, que foram preservados como "inliers" em meio a esta orogenia.

\subsection{2 - Porção Simática}

A parte simática do Domínio Maroni - Itacaiúnas, que se diferenciou do manto superior durante os próprios episódios de formação de rochas, entre 2,2 Ga e 1,95 $\mathrm{Ga}$, ou pouco tempo antes, ocorre a noroeste da falha do Oiapoque, na Guiana Francesa, estendendo-se para o Suriname, Guiana, Venezuela e para uma ramificação, que segue o Cinturão Granulítico da Guiana Central, e penetra no Brasil em Roraima. Em território brasileiro os estudos geocronológicos para esta parte do domínio Maroni - Itacaiúnas encontram-se localizados no Estado de Roraima.

\subsubsection{1 - Considerações Geológicas}

Em geral a porção juvenil do Domínio Maroni - Itacaiúnas é constituída por seqüencias de rochas supracrustais, terrenos graníticos e migmatíticos e terrenos granulíticos. As rochas supracrustais compreendem uma série vulcano-sedimentar metamorfisadas desde 0 fácies xisto-verde baixo até $\circ$ fácies anfibolito, que constituem um cinturão de rochas verdes. Normalmente estas seqüências são compostas por metabasaltos com intercalações de lavas ultrabásicas komatíticas, 
rochas piroclásticas de composição predominantemente dacítica, e rochas detríticas como metaconglomerados, quartzitos e siltitos. Os cinturöes de rochas verdes são denominados de Formação Paramacá, na Guiana Francesa, Grupo BaramaMazaruni na Guiana, Formações Armina e Rosebel no Suriname e Grupo Pastora na Venezuela, possuindo características químicas, petrológicas e texturais de "greenstone belts" (Gibbs, 1980).

Os terrenos graníticos e migmatíticos compreendem rochas fortemente metamorfisadas e migmatizadas, que incluem gnaisses leptníticos, gnaisses com anfibólios, anfibolitos, trondhjemitos e tonalitos, constituindo o que na Guiana Francesa se denominou de Série lle de Cayenne.

Os terrenos granulíticos estão incluídos no denominado Cinturão Granulítico da Guiana Central (Kroonemberg, 1976), que é constituído pelas rochas metamórficas de alto grau do Grupos Coeroeni e Falawatra no Suriname, Complexo Kanuku na Guiana e pelo Complexo Granulítico Mucajaí em Roraima. Estes complexos são compostos, em geral, por charnoquitos bandados, silimanita e piroxênio gnaisses metamorfisados nos fácies anfibolito alto e granulito, com intercalações de anfibolitos, quartzitos e rochas calcissilicatadas. O metamorfismo de alto grau que afetou estas rochas produziu eventos de fusão parcial que propiciou uma certa migmatização das rochas granulíticas.

Os terrenos metamórficos de alto grau que ocorrem no Estado de Roraima são constituídos por gnaisses granulíticos de composição ácida, intermediária e básica, gnaisses kinzigíticos, anfibolitos, augen-gnaisses, e migmatitos de alto grau (Lima et. al. 1982). 


\subsubsection{2 - Discussões Geocronológicas}

Os estudos radiométricos na porção simática do Domínio Maroni - Itacaiúnas são bastante completos, principalmente fora do Brasil, onde mostram que os terrenos granulíticos e as seqüências supracrustais deste domínio formaram-se no Paleoproterozóico, a partir de materiais derivados do manto superior na própria época de formação das rochas, ou pouco tempo antes. Estes estudos incluem análises $\mathrm{U}-\mathrm{Pb}$ em zircões, $\mathrm{Sm}-\mathrm{Nd}$ em rocha total, $\mathrm{Rb}-\mathrm{Sr}$ e $\mathrm{Pb}-\mathrm{Pb}$ em rocha total $\mathrm{e}$ por evaporação de zircões e K-Ar em concentrados de minerais, sendo realizados principalmente em rochas da Guiana Francesa (Teixeira et. al., 1985; Gruau et. al., 1985; Ledru et.al.,1990; Egal et.al.,1994), Suriname (Othman et.al.,1994; Bosma et.al.,1984; Priem et.al.,1978) e Guiana (Gibbs, 1980).

$\mathrm{Na}$ Guiana Francesa o padrão geocronológico dos terrenos metamórficos e dos granitóides sintectônicos mostra claramente o intervalo de tempo entre 2,1 Ga e 2,0 Ga como o principal período formador de rochas, com valores de razões iniciais ${ }^{87} \mathrm{Sr}{ }^{36} \mathrm{Sr}$ baixos, próximos a 0,702 , e de $\mu_{1}$ em torno de 8,09 , indicando que tais terrenos derivaram-se de magmas juvenis. As seqüências supracrustais da Formação Paramacá foram datadas através de isócrona $\mathrm{Sm}-\mathrm{Nd}$ em rocha total, nas rochas vulcânicas, com idade de 2,11 $\pm 0,09 \mathrm{Ga}$, obtendo-se um valor de $\varepsilon_{\mathrm{Nd}}$ de $+2,1$, também indicando uma derivação mantélica para estas rochas. Zircőes detríticos das unidades sedimentares destas seqüências forneceram idades $\mathrm{Pb}-\mathrm{Pb}$ em monozircões de 2,14 Ga a 2,12 Ga, e granitóides pós-tectônicos, intrusivos na seqüência Paramacá, forneceram idades $\mathrm{Pb}-\mathrm{Pb}$ em monozircões entre $2,09 \mathrm{Ga}$ e 2,08 Ga (Egal et. al., 1994 e Ledru et.al. ,1990).

$\mathrm{Na}$ Guiana, os trabalhos geocronológicos efetuados na seqüência metavulcano-sedimentar Barama - Mazaruni mostraram idades U.Pb em zircões detríticos provenientes de metagrauvacas e de vulcânicas félsicas ente $2,25 \mathrm{Ga}$ e 2,15 Ga. Já as rochas metavulcano-sedimentares das Formações Armina e 
Rosebel, no Suriname, forneceram idade isocrônica $\mathrm{Rb}-\mathrm{Sr}$ em rocha total de 1950 $\pm 150 \mathrm{Ma}$.

O Cinturão Granulítico da Guiana Central, que no Suriname está incluído nos Grupos Falawatra e Coeroeni, apresenta idades U-Pb em zircões de 2,02 $\pm 0,03$ $\mathrm{Ma}$, isocrônicas $\mathrm{Rb}-\mathrm{Sr}$ em rocha total de $2001 \pm 97 \mathrm{Ma}$ (Priem et.al., 1978) e idades Sm-Nd modelo $T_{D M}$ de 2,3 Ga (Ben Othman, 1984), mostrando claramente um padrão geocronológico do Paleoproterozóico.

A continuidade deste cinturão granulítico para o Brasil está representada pelos granulitos que ocorrem na área dos rios Mucajai e Apiaú em Roraima. Amostras dos gnaisses associados aos maciços granulíticos apresentaram idades U-Pb em zircões de $1943 \pm 7 \mathrm{Ma}, 1921 \pm 15 \mathrm{Ma}$ e $1911 \pm 13 \mathrm{Ma}$ e idades isocrônicas $\mathrm{Rb}-\mathrm{Sr}$ em rocha total de $2019 \pm 71 \mathrm{Ma}$ com razão inicial ${ }^{87} \mathrm{Sr} /{ }^{86} \mathrm{Sr}$ de $0,7059 \pm 0,0016$ (Santos e Olszewski, 1988) e de $1908 \pm 48 \mathrm{Ma}$ com ri. de 0,7005 $\pm 0,0001$ (Lima et. al. 1986). Idades modelo Sm-Nd T $T_{D M}$ obtidas para os granulitos de Roraima indicaram idades dentro do intervalo de tempo 2,1 Ga-1,9 Ga (Vignol, 1987 e Olsewski et. al. 1989) (Figura 6), sendo que estes últimos autores reportaram idades modelos variáveis até $1200 \mathrm{Ma}$. Estes dados posicionam o evento de granulitização entre $2,0 \mathrm{Ga}$ e $1,9 \mathrm{Ga}$, a partir de material juvenil derivado do manto pouco tempo antes.

Portanto, conforme pode ser visto no diagrama de evolução isotópica do Nd da Figura 6, o comportamento dos isótopos de Nd na porção simática do domínio Maroni - Itacaiúnas é claramente contrastante com a assinatura isotópica de $\mathrm{Nd}$ obtida para as rochas da porção ensiálica, onde na parte simática as idades $T_{D M}$ indicaram valores relativos ao Paleoproterozóico e na parte ensiálica permitiram a obtenção de idades arqueanas.

Em adição, para os terrenos gnáissicos da região de Roraima, Olsewski et. al. (1989) apresentaram ainda idades U-Pb em zircões provenientes do Gnaisse Apiau no intercepto superior da Concórdia de $1883 \pm 46$ Ma e do paragnaisse Taiano portador de granadas, de $2235 \pm 19 \mathrm{Ma}$, sendo que esta última idade reflete 
a idade de uma das fontes dos sedimentos dos paragnaisses. Retrabaihando-se os dados isotópicos Rb-Sr de Basei e Teixeira (1975) obtém-se uma isócrona de referência para rochas granito-gnáissicas do embasamento em Roraima, com a idade de $1890 \pm 25 \mathrm{Ma}$ e uma ri. de 0,7040 $\pm 0,0001$.

Para os metassedimentos do Grupo Cauarane encontra-se disponivel apenas uma datação pelo método K-Ar em concentrado de anfibólios provenientes de um anfibolito intercalado na seqüência, que indicou a idade de $1920 \pm 40 \mathrm{Ma}$, sugerindo a época de resfriamento regional a $500^{\circ} \mathrm{C}$ destas rochas. Tal resultado é coerente com o padrão geocronológico obtido para os metamorfitos do Grupo Vila Nova no Amapá.

Zircões detríticos da Formação Araí do Grupo Roraima indicaram idades $\mathrm{U}-\mathrm{Pb}$ de $2171 \pm 16 \mathrm{Ma}$ (Olsewski et.al.1989), sugerindo que a fonte dos sedimentos do grupo Roraima poderia ser a cadeia de montanhas gerada na orogenia Maroni Itacaiúnas, que circunda a área cratônica coberta por estes sedimentos.

No âmbito do domínio Maroni - Itacaiúnas ocorre ainda o Granito Rapakivi Mucajaí, que foi datado através do método U-Pb em zircões, fornecendo a idade no intercepto superior da concórdia de $1544 \pm 22 \mathrm{Ma}$ (Olsewski et. al. 1989). Segundo estes autores inexistem rochas arqueanas na região de Roraima, reforçando a hipótese das rochas metamórficas estudadas representarem um episódio de acresção continental no Paleoproterozóico, mais precisamente durante o período Orosiriano.

No Quadro 2 encontra-se sumarizada a distribuição das idades de eventos formadores de rochas, que ocorreram ao longo do domínio Maroni - Itacaiúnas. Neste quadro pode ser observado que os eventos metamórficos da parte simática do domínio ocorreram principalmente entre 2,1 $\mathrm{Ga}$ e 1,9 $\mathrm{Ga}$, e as idades mais antigas estão restritas ao núcleo antigo do Cupixi, onde as idades aparentes $\mathrm{K}-\mathrm{Ar}$ sugerem a atuação da orogenia transamazônica na área. 


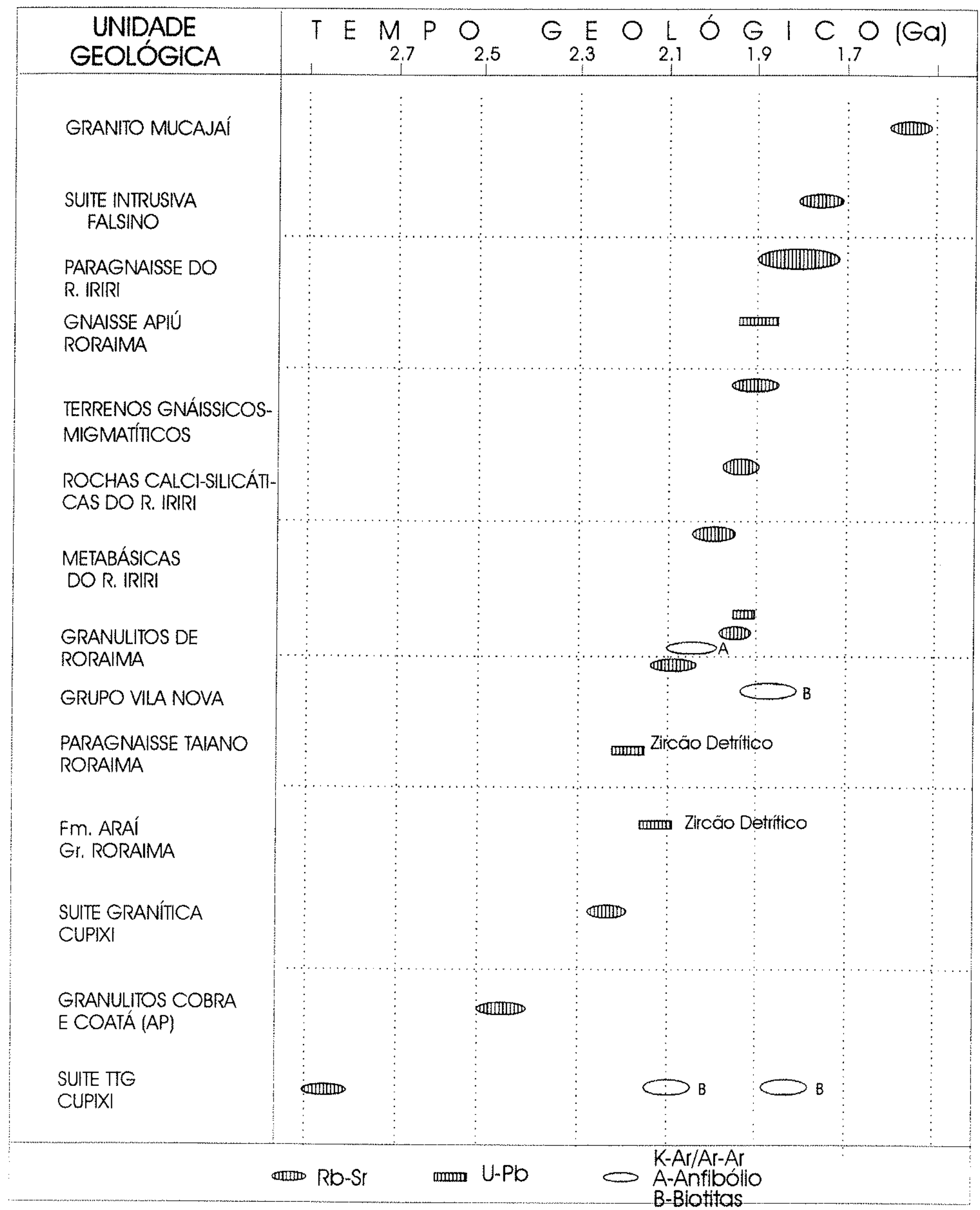




\section{3 - Dominio Ventuari - Tapajós}

O Domínio Ventuari - Tapajós é caracterizado por rochas formadas entre 1,95 Ga e 1,80 Ga, que ocorrem a oeste do Domínio Amazônia Central, estendendo-se desde a região do rio Tapajós no Estado do Pará até a parte sul da Venezuela, na área das bacias dos rios Ventuari e Orinoco. O padrão geocronológico deste domínio parece ser um pouco mais jovem que o encontrado para o domínio Maroni Itacaiúnas e difere deste, sob o ponto de vista geológico, pela grande quantidade de granitóides, a ocorrência restrita de rochas granulíticas e de seqüências supracrustais e pelas direções estruturas preferenciais. $O$ limite entre estes dois domínios, devido a inexistência de um intervalo significativo de idades entre eles, é caracterizado por uma zona de transição.

\subsection{1 - Considerações Geológicas}

$\mathrm{Na}$ parte sul deste Domínio ocorrem os terrenos granitongnáissicomigmatíticos considerados por Silva et. al. (1974) como Complexo Xingu. Estes terrenos incluem gnaisses de composições variadas, granodioritos, quartzo-dioritos, tonalitos, migmatitos e granitóides sintectônicos. As rochas deste embasamento, principalmente na parte oeste do domínio, apresentam metamorfismos que atingiram o fácies anfibolito e em alguns locais até mesmo o fácies granulito (Silva et. al. 1980). Associado a este contexto, ocorre o denominado Granodiorito Parauari (Bizinela et. al., 1980), que inclui diversos tipos litológicos como granitos, tonalitos, granodioritos, adamelitos, monzonitos, quartzo-monzodioritos, quartzo-dioritos e quartzo-sienitos, sendo os tipos predominantes os adamelitos e granodioritos.

Muitas das litologias incluídas como "Granodiorito Parauari são temporalmente distintas, ocorrendo rochas com caráter sintectônico e pertencentes 
ao denominado embasamento, como também granitóides claramente intrusivos neste embasamento, que possuem características de corpos pós-tectônicos. Como exemplo destes últimos, ocorrem os litotipos mais potássicos desta suíte magmática, que são claramente posteriores e mais evoluídos (Santos, 1982). Redenção e Silva (1995) caracterizam para alguns litotipos incluídos como Granodiorito Parauari uma composição alcalina, do tipo I, formados a partir de um protólito anfibolítico.

Mega-enclaves de anfibolitos foliados e não foliados também estão presentes em meio às rochas deste embasamento. O padrão estrutural destes terrenos é NWSE, NNE-SSW e E-W, sendo o primeiro, que marca a direção do domínio, o mais expressivo e que foi relacionado pelos trabalhos da CPRM na região, ao evento tectônico gerador das descontinuidades gravimétricas e magnéticas observadas na região do Tapajós.

A norte da sinéclise do Amazonas ocorrem rochas granito-gnáissicas de composição quartzo-diorítica a granodiorítica consideradas por Barrios (1983) como Domínio Petrotectônico Ventuari, que incluíria as Províncias Ayacucho, Manapiare e Alto Orinoco de Mendoza et.al. (1977).

Associadas a este terreno granito-gnáissico ocorrem rochas metabásicas que incluem anfibolitos e metagabros, como também rochas plutônicas de composição predominantemente quartzo-diorítica a granodiorítica, levemente foliadas e recristalizadas. Geralmente o metamorfismo que afetou estas rochas encontra-se no fácies anfibolito. As direções estruturais das rochas gnáissicas são preferencialmente segundo NW-SE e N-S, e subordinadamente NE-SW (Barrios, 1983), em concordância com as direções estruturais, que ocorrem na parte sul do domínio.

Em meio às rochas do embasamento do Domínio Ventuari - Tapajós as seqüências supracrustais aparecem de forma esparsa. Na parte sul do domínio as rochas metavulcano-sedimentares constituem a Suite Metamórfica Jacareacanga (Melo et. al. 1980), que compreende quartzitos, actinolita xistos, formações ferriferas e rochas vulcânicas de composição ácida, intermediária e até ultramáficas 
(Redenção e Silva, 1995). O metamorfismo que atingiu estas rochas foi no fácies xisto-verde, e as direções estruturais são basicamente N15W/ 40-70 NE, sendo concordantes com as direções preferenciais das rochas gnáissicas do embasamento. Na parte norte do domínio, as exposiçōes de rochas supracrustais são mais restritas, sendo constituidas por pacotes de metaconglomerados, quartzitos ortoquartzíticos e subgrauváquicos e filitos localmente associados com rochas metavulcânicas de composição ácida a intermediária (Barrios, 1983).

No interior do Domínio Ventuari - Tapajós, tanto em sua parte norte como sul, ocorrem associações vulcano-plutônicas de tendências calci-alcalinas e toleíticas isentas de metamorfismos, sendo na parte sul consideradas como Suíte Intrusiva Maloquinha e Vulcânicas Iriri e, mais a oeste como vulcano-plutonismo Teles Pires e na parte norte consideradas como vulcano-plutonismo Cuchivero.

Os granitos do tipo Maloquinha, compostos por granitos grosseiros e pórfiros, incluem principalmente álcali-granitos, monzogranitos e sienogranitos de composição alcalina metaluminosa, possuindo características anorogênicas $\theta$ natureza intraplaca. Relacionados a esta manifestação granítica ocorrem derrames de rochas vulcânicas ácidas e intermediárias, designados de Formação Iriri (Silva et. al., 1974), que é constituída por rochas com variação composicional predominante desde riolitos até dacitos, embora termos andesíticos e basálticos sejam também reportados (Silva et. al. 1980).

Os granitos Teles Pires apresentam em geral feições circulares, e possuem características de rochas subvulcânicas, tendências alasquíticas e natureza anorogênica. Geneticamente estes corpos graníticos estão relacionados às vulcânicas Teles Pires, que embora mais jovens, são consideradas como pertencentes a Formação Iriri por Silva et. al. (1974). Os litotipos mais comuns dos Granitos Teles Pires são granitos pórfiros, microgranitos, granitos gráficos, granófiros, riebeckita-granitos, granitos tipo rapakivi geralmente piterlitos e granitos. Silva et. al. (1980) caracterizaram quimicamente os granitos Teles Pires como de composição principalmente calci-alcalina e subordinadamente como alcalina. 
$\mathrm{Na}$ região norte do domínio Ventuari - Tapajós a ocorrência de séries vulcano-plutônicas são expressivas, sendo as rochas vulcânicas compostas por termos riolíticos, dacíticos e riodacíticos principalmente, ocorrendo subordinadamente andesitos e rochas piroclásticas. As rochas graníticas associadas são porfiríticas de granulação grosseira, ricas em quartzo e feldspatos alcalinos, e são consangüineas com as efusivas (Mendoza, 1975).

Ainda na parte norte do Domínio Ventuari - Tapajós, na região oeste do Estado de Roraima e na Venezuela, ocorre um plutonismo claramente cratogênico, de tendências toleíticas, representado pelos corpos graníticos de El Parguaza, na Venezuela e do Surucucus em Roraima. São rochas de composição granodiorítica a granítica, que apresentam texturas do tipo rapakivi. Litologicamente estes corpos são constituídos por granitos, granodioritos, adamelitos e quartzo-sienitos com viborgitos e piterlitos associados.

Coberturas sedimentares pré-cambrianas ocorrem principalmente na parte sul do domínio, onde aparecem as rochas relacionadas aos Grupos Gorotire e Beneficente, este último mais jovem, com idades de sedimentação entre $1550 \mathrm{M} \mathrm{e}$ $1330 \mathrm{Ma}$ (Tassinari et. at., 1978), ao passo que os sedimentos relacionados ao Grupo Gorotire devem ter uma idade mínima de 1600 Ma (Pessoa et. al. 1977). Estas coberturas sedimentares não deformadas recobrem as seqüências de rochas vulcânicas, e são constituídas por ortoquartzitos, arenitos, metarenitos, metarcóseos, siltitos, argilitos e calcários, depositados provavelmente em rifts continentais. Na região norte do domínio as rochas sedimentares são raras, e as pequenas ocorrências são compostas por conglomerados basais, quartzo-arenitos, arcóseos e argilitos e siltitos.

O magmatismo básico no domínio Ventuari - Tapajós restringe-se a diques e sills de diabásios de composição tipo olivinas-gabros, que seccionam tanto as rochas do embasamento como também as coberturas vulcânicas e sedimentares. 


\subsection{2 - Discussões Geocronológicas}

Os dados geocronológicos disponíveis para o Domínio Ventuari - Tapajós em território brasileiro situam-se em sua grande maioria na porção sul do domínio. $\mathrm{Na}$ região norte as principais informações geocronológicas encontram-se na Venezuela e em menor quantidade no Brasil .

Os terrenos granito-gnáissicos do embasamento, na parte sul do domínio, encontram-se datados na região do Domo do Sucunduri, próximo do limite com o domínio Rio Negro - Juruena, por Iwanuch (1988), onde foi obtida a idade isocrônica $\mathrm{Rb} / \mathrm{Sr}$ em rocha total de $1977 \pm 67 \mathrm{Ma}$ e razäo inicial ${ }^{87} \mathrm{Sr} /{ }^{86} \mathrm{Sr}$ de $0,702 \pm 0,001$ (MSWD $=0,32$ ). Este autor também admitiu a possibilidade desta idade ser pouco mais jovem, uma vez que ao incluir um ponto adicional pertencente a mesma unidade geológica, não colinear na isócrona, a nova idade calculada foi de 1914 $\pm 90 \mathrm{Ma}$, com uma relação ${ }^{87} \mathrm{Sr} /{ }^{86} \mathrm{Sr}$ inicial de $0,703 \pm 0,001$ (MSWD=0,7038). Retrabalhando estes dados, em conjunto com aqueles obtidos para os granitognaisses que ocorrem na mesma região por Tassinari et. al. (1978), foi obtida uma idade isocrônica $\mathrm{Rb}-\mathrm{Sr}$ em rocha total de $1910 \pm 30 \mathrm{Ma}$ com razão inicial ${ }^{87} \mathrm{Sr}{ }^{86} \mathrm{Sr}$ de $0,7027 \pm 0,0005$. Estas dados sugerem que tais rochas formaram-se em uma época próxima a $1,9 \mathrm{Ga}$ a partir de processos de diferenciação mantélica e/ou retrabalhando rochas com pouco tempo de residência crustal.

Na região do Tapajós as idades mais antigas encontradas até o momento são aquelas relativas ao denominado "Granodiorito Parauari". Essas rochas graníticas, cujas datações originais são reportadas em Bizinella et. al. (1980), foram publicadas em Santos (1982), através de idades Rb-Sr convencionais e por Santos e Reis Neto (1982) através de idade $\mathrm{Rb}-\mathrm{Sr}$ isocrônica. Estes últimos autores incluíram em um diagrama isocrônico amostras provenientes dos granodioritos Parauari, Jamanxim e Juruena, o que possibilitou a definição de uma isócrona de referência com 
inclinação relativa a idade de $1947 \mathrm{Ma}$, definindo um valor para a razão inicial de 0,7028 . Conforme Silva et. al. (1980) os granitóides do tipo Juruena são massas graníticas do embasamento, e não possuem características de corpos intrusivos; neste sentido deve-se consider a idade acima como uma idade aproximada da época de formação destes terrenos, concordando com as idades obtidas por Iwanuch (1981) para as rochas gnáissicas da região do domo do Sucunduri.

Como a região do Tapajós é uma das áreas de maior carência de dados geocronológicos do Cráton Amazônico, para a elaboração deste trabalho, o autor realizou trabalhos de campo na região do Rio Crepori, contando com o apoio da Empresa Serviços para Mineração Crepory Ltda., onde, próximo à Vila do Creporizão, amostrou através de furos de sondagem, granitóides de composições granodioríticas e graníticas. Estas amostras foram analisadas pelos métodos $\mathrm{Rb}-\mathrm{Sr}$ e Sm-Nd em rocha total, cujos dados analíticos constam das Tabelas 2 e 3.

Tabela 2 - Dados analíticos Rb - Sr para os granitóides da região de Vila Creporizão - Itaituba.

\begin{tabular}{|c|r|r|r|r|r|c|}
\hline $\begin{array}{c}\text { SPR/No. } \\
\text { CAMPO }\end{array}$ & $\operatorname{Rb}(\mathrm{ppm})$ & $\mathrm{Sr}(\mathrm{ppm})$ & ${ }^{87} \mathrm{Rb} /{ }^{86} \mathrm{Sr}$ & Erro & ${ }^{87} \mathrm{Sr}{ }^{86} \mathrm{Sr}$ & Erro \\
\hline $12282 /$ CR-01 & 281.7 & 200.6 & 4.107 & 0.115 & 0.82560 & 0.00007 \\
\hline $12284 /$ CR-09 & 267.2 & 216.8 & 3.601 & 0.101 & 0.80377 & 0.00009 \\
\hline $12285 /$ CR-10 & 291.3 & 158.2 & 5.405 & 0.151 & 0.85301 & 0.00022 \\
\hline $12286 /$ CR-11 & 317.2 & 71.4 & 13.309 & 0.364 & 1.06418 & 0.00012 \\
\hline $12287 /$ CR-12 & 374.2 & 34.1 & 34.8579 & 0.4875 & 1.696070 & 0.000120 \\
\hline $12288 /$ CR-14 & 384.6 & 33.3 & 36.8576 & 0.5128 & 1.745300 & 0.000110 \\
\hline $12289 /$ CR-15 & 409.5 & 32.8 & 40.2107 & 0.5606 & 1.848720 & 0.000120 \\
\hline $12290 /$ CR-16 & 362.8 & 51.3 & 21.7014 & 0.3007 & 1.314880 & 0.000110 \\
\hline & & & & & & \\
\hline $13088 / \mathrm{MA}-1$ & 136.1 & 181.5 & 2.182 & 0.061 & 0.76226 & 0.00008 \\
\hline $13089 / \mathrm{MA}-5$ & 170.1 & 159.2 & 3.116 & 0.087 & 0.78512 & 0.00015 \\
\hline $13090 / \mathrm{MA}-6$ & 125.8 & 188.6 & 1.940 & 0.055 & 0.75671 & 0.00010 \\
\hline $13091 / \mathrm{MA}-7$ & 152.7 & 154.9 & 2.873 & 0.081 & 0.77956 & 0.00012 \\
\hline $13092 / \mathrm{MA}-10$ & 166.5 & 156.8 & 3.097 & 0.087 & 0.78573 & 0.00017 \\
\hline $13093 / \mathrm{MA}-11$ & 113.4 & 167.0 & 1.975 & 0.056 & 0.75815 & 0.00016 \\
\hline $13094 / \mathrm{MA}-13$ & 206.8 & 166.5 & 3.627 & 0.102 & 0.79975 & 0.00011 \\
\hline
\end{tabular}


Tabela 3 - Dados analíticos Sm - Nd para os granitóides da região de Vila Creporizão - Itaituba.

\begin{tabular}{|l|l|c|c|c|c|c|c|}
\hline $\begin{array}{c}\text { No. } \\
\text { Lab }\end{array}$ & $\begin{array}{c}\text { No. } \\
\text { Campo }\end{array}$ & ${ }^{147} \mathrm{Sm} /{ }^{144} \mathrm{Nd}$ & ${ }^{143} \mathrm{Nd} /{ }^{144} \mathrm{Nd}$ & $\begin{array}{c}\mathrm{Sm} \\
(\mathrm{ppm})\end{array}$ & $\begin{array}{c}\mathrm{Nd} \\
(\mathrm{ppm})\end{array}$ & $\begin{array}{c}\mathrm{T}_{\mathrm{DM}} \\
(\mathrm{Ga})\end{array}$ & $\varepsilon_{\mathrm{Nd}}$ \\
\hline 373 & CR-09 & 0.08968 & 0.510801 & 8.366 & 56.761 & 2.60 & -12.38 (T=1.73Ga) \\
\hline 374 & CR-16 & 0.09404 & 0.511281 & 10.411 & 67.359 & 2.25 & -3.95 (T=1.73Ga) \\
\hline 386 & MA-5 & 0.12164 & 0.511773 & 9.020 & 45.121 & 2.10 & +1.71 (T=1.96Ga) \\
\hline 386 & MA-13 & 0.12293 & 0.511749 & 9.365 & 46.355 & 2.17 & +0.91 (T=1.96Ga) \\
\hline
\end{tabular}

As amostras de composição granítica indicaram idade $\mathrm{Rb}-\mathrm{Sr}$ isocrônica de $1964 \pm 16 \mathrm{Ma}$, com um valor de razão ${ }^{87} \mathrm{Sr}{ }^{86} \mathrm{Sr}$ inicial de $0,7037 \pm 0,0024$, com um valor de MSWD de 1,19 (Figura 7). Já as amostras de composição granodiorítica, que fazem contato por falha com o granito acima, indicaram uma idade isocrônica $\mathrm{Rb}-\mathrm{Sr}$ mais jovem, com valor de $1732 \pm 82 \mathrm{Ma}$ e uma relação ${ }^{87} \mathrm{Sr} r^{36} \mathrm{Sr}$ inicial de $0,7084 \pm 0,0029$, com valor de MSWD de 0,12 (Figura 8). Estas amostras apresentavam evidências de alteração hidrotermal produzidas por veios de quartzo mineralizados a ouro, o que poderia ter rejuvenescido parcialmente as amostras datadas e elevando o valor da razão inicial obtida.

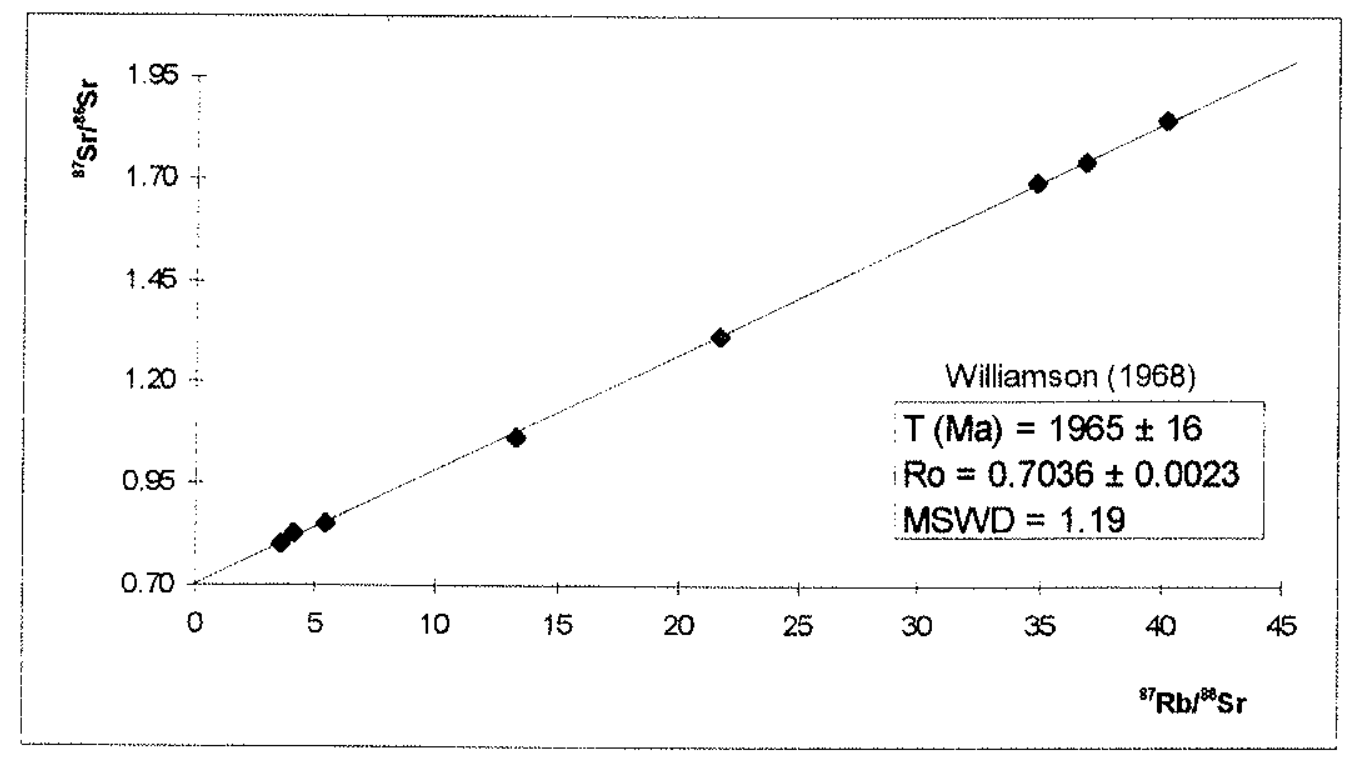

Figura 7 - Diagrama Isocrônico $\mathrm{Rb}$ - $\mathrm{Sr}$ em rocha total para os granodioritos da região de Vila Creporizão - Itaituba. 


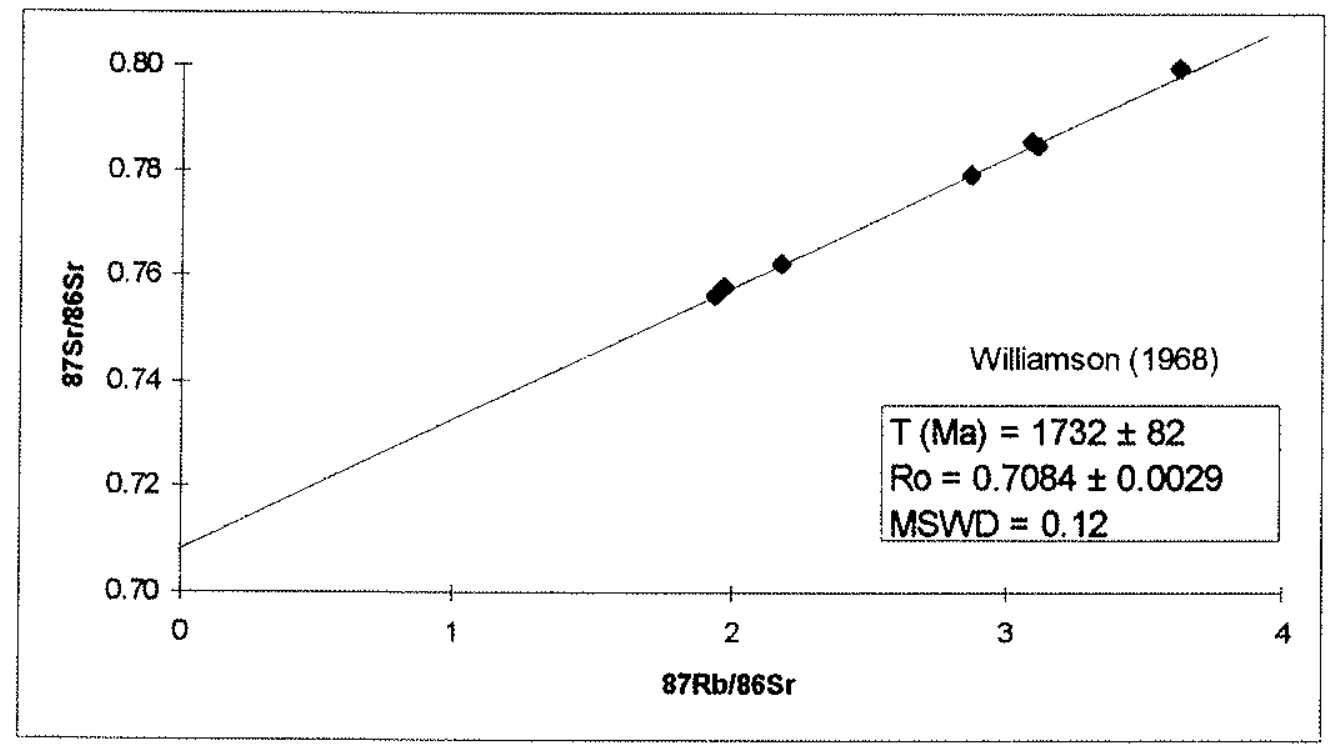

Figura 8 - Diagrama Isocrônico $\mathrm{Rb}$ - Sr em rocha total para os granitóides parcialmente aiterados hidrotermalmente da região de Vila Creporizão - Itaituba.

As idades modelos $\mathrm{Sm}-\mathrm{Nd} \mathrm{T}_{\mathrm{DM}}$, calculadas para estas rochas forneceram resultados entre 2,1 Ga e 2,0 Ga. Em adição, Sato e Tassinari (1996) calcularam os valores de $\varepsilon_{N d}$ para 2,0 Ga, que situaram-se entre $+2,1$ e -1,6 (Figura 9). Tais valores sugerem que a época de diferenciação mantélica do magma parental destas rochas ocorreu um pouco antes do período de sua formação.

Retrabalhando-se em diagrama isocrônico $\mathrm{Rb}-\mathrm{Sr}$ os dados da DOCEGEO, que constam em Basei (1977), em conjunto com os da CPRM (1973), disponiveis no Banco de Dados do CPGeo-USP, relativos a rochas gnáissicas que ocorrem nas regiões dos rios Jamanxin e Tapajós e a leste da cidade de Itaituba, obteve-se uma isócrona de referência com idade de $1800 \pm 43 \mathrm{Ma}$, com razão inicial de 0,7078 \pm 0,0033 , sugerindo a atuação de um evento mais novo de formação de rochas a partir de retrabalhamento de rochas mais antigas. 


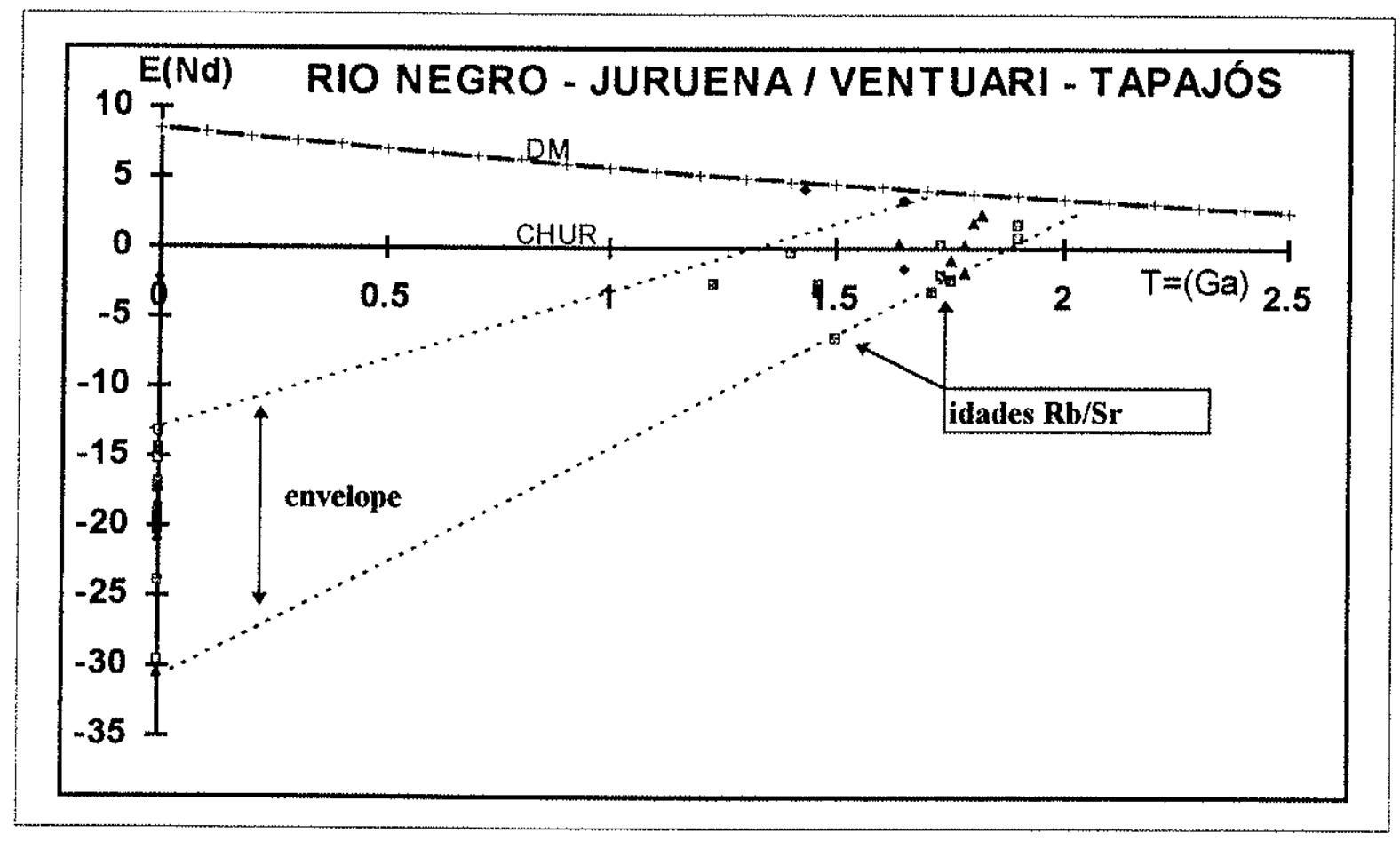

Figura 9 - Diagrama de variação do $\varepsilon_{\mathrm{Nd}}$ em função do tempo geológico, mostrando os intervalos de tempo da diferenciação manto crosta para os protólitos crustais dos Domínios Ventuari - Tapajós e Rio Negro - Juruena.

Na parte norte do Domínio Ventuari - Tapajós os estudos geocronológicos mais detalhados foram realizados na Venezuela, na área do domínio petrotectônico Ventuari definido por Barrios (1983). Gaudette e Olszewski (1981) apresentaram uma idade $\mathrm{Rb}-\mathrm{Sr}$ isocrônica em rocha total para os gnaisses do embasamento deste domínio, incluídos nos denominados gnaisses Minícia e Macabana, que indicou um valor de $1826 \pm 34 \mathrm{Ma}$ e uma composição isotópica inicial de $\mathrm{Sr}$ de $0,7027 \pm 0,0008$. $\mathrm{Em}$ adição, estes autores apresentaram idades U-Pb em zircões destas mesmas rochas, obtidas no intercepto superior da Concórdia, com valores de 1859 Ma para os gnaisses Minícia e de 1823 Ma para os gnaisses Macabana, dados estes bastante concordantes com as idades obtidas pelo método $\mathrm{Rb}-\mathrm{Sr}$.

Tassinari et. al. (1996) dataram através do método U-Pb em monocristais de zircões, através do SHRIMP, granitóides de composição quartzo-diorítica, que ocorrem no limite deste domínio com o Domínio Rio Negro - Juruena, obtendo a idade de $1835 \pm 17 \mathrm{Ma}$. 
Após a formação dos terrenos granito-gnáissicos, o domínio Ventuari Tapajós foi palco de um intenso plutonismo, muitas vezes associado com vulcanismos ácidos a intermediários. Na região do Tapajós ocorrem os maciços graníticos da Suíte Intrusiva Maloquinha, para a qual Santos e Reis Neto (1982) reportaram uma idade isocrônica $\mathrm{Rb}-\mathrm{Sr}$, calculada manualmente em torno de 1770 $\mathrm{Ma}$, com uma razão inicial de 0,706. Estes dados recalculados através dos programas específicos para cálculos de idades em computador, por Tassinari et. al. (1984), indicaram um valor de $1650 \pm 20 \mathrm{Ma}$, e um valor para relação ${ }^{87} \mathrm{Sr} /{ }^{86} \mathrm{Sr}$ inicial de 0,7065 $\pm 0,0011$, com MSWD de 1,15. Nesta mesma área, o conjunto vulcânico Tapajós - Iriri, constituído de rochas vulcânicas ácidas a intermediárias não deformadas, foi datado por Basei (1977) através de uma isócrona $\mathrm{Rb}-\mathrm{Sr}$ em rocha total em $1765 \pm 16 \mathrm{Ma}$, com uma ri. de 0,7050 $\pm 0,0071$.

Ainda na porção sul do Domínio, mais em sua parte ocidental, ocorre o conjunto vulcano-plutônico Teles Pires. As rochas vulcânicas félsicas estão na região da borda sul da Chapada do Cachimbo. Para este conjunto Basei (1977) apresentou uma idade $\mathrm{Rb}-\mathrm{Sr}$ isocrônica em rocha total de $1680 \pm 13 \mathrm{Ma}$ com $r$ i. de 0,7046, interpretada como a época principal deste episódio vulcânico.

Associado aos episódios vulcânicos ocorreram as atividades plutônicas, representadas pelos granitos do tipo Teles Pires. Estes granitóides foram inicialmente datados por Basei (1974), que apresentou uma isócrona $\mathrm{Rb}-\mathrm{Sr}$ em rocha total com idade de $1590 \pm 32 \mathrm{Ma}$. Posteriormente Silva et. al. (1980) adicionando alguns pontos analíticos à isócrona acima definiram uma idade de 1548 $\pm 28 \mathrm{Ma} \mathrm{com} r i$. de $0,707 \pm 0,001$. Retrabalhando estes dados em conjunto com àqueles obtidos por Iwanuch (1981) para os granitóides desta mesma suite, os pontos analíticos situaram-se próximos a isócrona de referência com idade de 1585 $\pm 18 \mathrm{Ma}$, e uma ri. de $0,7070 \pm 0,0006$ e com MSWD de 1,23, sugerindo uma época próxima a 1600 Ma para os episódios de formação desta suite plutônica. 
Entre 1550 Ma e 1450 Ma aproximadamente, a parte norte do Dominio Ventuari - Tapajós foi afetada por um episódio plutônico, de caráter claramente cratogênico, onde predominam os granitóides subvulcânicos, com textura rapakivi. No Brasil este plutonismo é representado pela Suíte Intrusiva Surucucu, que aflora na fronteira do Estado de Roraima com a Venezuela, ao longo da Serra Parima. Tassinari (1981) apresentou uma isócrona $\mathrm{Rb}-\mathrm{Sr}$ de referência em rocha total para os granitóides desta Suite, utilizando amostras datadas por Basei e Teixeira (1975), que definiu uma idade $1431 \pm 35 \mathrm{Ma}$ com ri. de 0,713 $\pm 0,004$ e valor de MSWD de 0,99 . Uma amostra situou-se acima da isócrona traçada, o que levou aquele autor a admitir também a presença de pulsos magmáticos precoces próximos a $1550 \mathrm{Ma}$, relacionados aos episódios plutônicos da Suíte Intrusiva Surucucu.

$\mathrm{Na}$ Venezuela este episódio plutônico está bem representado, através da colocação do batólito granítico de El Parguaza, um dos maiores plutons graníticos com textura rapakivi do mundo. Estudos geocronológicos pelo método $\mathrm{Rb}-\mathrm{Sr}$ em rocha total para este magmatismo indicaram idade isocrônica de $1531 \pm 39 \mathrm{Ma}$, utilizando-se a constante de desintegração do $\mathrm{Rb}$ de $1,39 \times 10^{-11}$ anos $^{-1}$, e $r$ i. de $0,700 \pm 0,001$ (Gaudette et. al. 1978). Recalculando-se esta idade para uma constante de $1,42 \times 10^{-11}$ anos $^{-1}$, esta isócrona indicaria uma idade próxima a 1500 Ma. Estes mesmos autores reportaram uma idade $\mathrm{U}-\mathrm{Pb}$ em zircões, obtida através do intercepto superior de $1540 \pm 20 \mathrm{Ma}$, que foi interpretada como a época de cristalização dos zircões analisados.

A parte sul do domínio Ventuari - Tapajós, após a sua estabilização tectônica, foi afetada por diversos episódios magmáticos de natureza básica, que ocorreram principalmente dentro dos intervalos de tempo situados entre 1,55 Ga e 1,4 Ga; 1,35 $\mathrm{Ga}$ e 1,25 $\mathrm{Ga}$ e entre 1,1 $\mathrm{Ga}$ e 1,0 Ga, associados aos lineamentos que cortam o domínio, como os do Tapajós e Abacaxis, e seccionando os sedimentos Grupo Beneficente, que ocorrem na borda sul da Chapada do Cachimbo, cuja deposição também foi condicionada por falhamentos em um sistema de "rifts" continentais. 


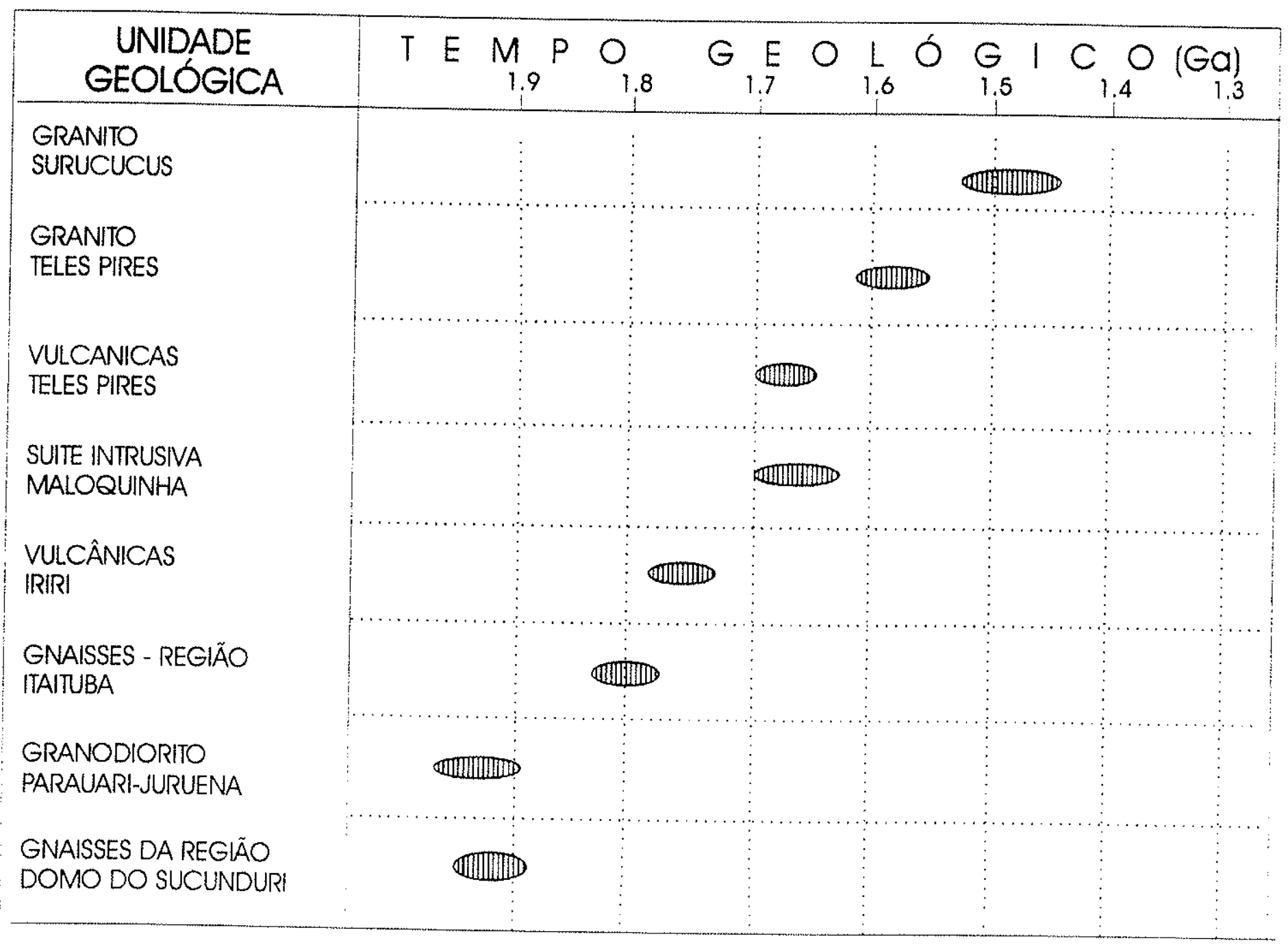

Dados Rb-Sr em Rocha Total

QUADRO 3 - SUMÁRIO DOS DADOS GEOCRONOLÓGICOS DOMINIO VENTUARI-TAPAJÓS 
A observação do Quadro 3, que sintetiza as épocas principais dos eventos formadores de rochas no Domínio Ventuari - Tapajós, indica que os terrenos sintectônicos formaram-se preferencialmente entre $1,95 \mathrm{Ga}$ e 1,8 Ga, e que entre $1750 \mathrm{Ma}$ e $1450 \mathrm{Ma}$, este domínio foi palco de atividades ígneas pós-tectônicas a anorogênicas.

\section{4 - Domínio Rio Negro - Juruena}

O domínio Rio Negro - Juruena ocupa grandes porções da parte ocidental do Cráton Amazônico, ocorrendo a oeste do Domínio Ventuari - Tapajós e estendendose desde o estado de Mato Grosso até as regiões sudeste da Colômbia e sul da Venezuela. Engloba os terrenos granito-gnáissicos formados entre 1,8 Ga e 1,55 Ga.

\subsection{1 - Considerações Geológicas}

O embasamento do domínio Rio Negro - Juruena é composto principalmente por gnaisses, granodioritos, tonalitos, migmatitos, granitos e anfibolitos. Estudos realizados por Dall'Agnol e Macambira (1992) têm mostrado que na parte norte do domínio predominam biotita-titanita monzogranitos. Toda a área abrangida pela orogenia Rio Negro - Juruena é afetada por episódios de granitizações e migmatizações, onde o metamorfismo geralmente atinge o fácies anfibolito alto, embora rochas granulíticas sejam encontradas em algumas áreas. Este embasamento se estende para a Colômbia, onde é denominado de Complexo Mitú (Galvis et. al. 1979) e para Venezuela, onde está incluído na Associação Petrotectônica Casiquiare de Barrios (1983). As direções estruturais predominantes são NW - SE, cortadas em algumas áreas por estruturas NE - SW, relacionadas a zonas de cizalhamentos posteriores, que seccionaram grandes áreas do cráton 
(Lima et. al. 1986). Afetando as rochas do embasamento ocorrem também granitóides a duas micas, descritos em Dall'Agnol e Abreu (1976), produzidos por eventos posteriores de anatexia.

No âmbito deste domínio as ocorrências de rochas supracrustais de baixo grau metamórfico são restritas. Na parte sul, rochas metavuicânicas félsicas, de composição riolíticas a riodacíticas ocorrem na área entre os Rios Roosevelt e Aripuanã, constituindo o que Scandolara et. al. (1995) incluíram no Domínio III (Roosevelt), que consiste de uma unidade inferior metavulcano-sedimentar, formada por metapelitos intercalados com ardósias, filitos, metarenitos, quartzitos, sericitaxistos, cloritas-xistos, formaçōes ferríferas bandadas, metavulcânicas ácidas a intermediárias e metatufos, e a unidade superior que é composta por siltitos, arenitos arcosianos e ortoquartzíticos e ardósias. Já na parte norte do dominio aparecem remanescentes de unidades metassedimentares, constituídas quase que exclusivamente por quartzitos, que foram denominadas por Pinheiro et. al. (1976) de Grupo Tunuí. Estas rochas ocorrem no nordeste do Estado do Amazonas e se estendem para o interior da Venezuela. Na fronteira do Brasil com a Colômbia ocorrem também seqüências arenosas e pelíticas metamorfisadas no fácies xisto verde baixo, denominados de Formação La Pedrera (Galvis et. al. 1979).

Seqüências vulcano-sedimentares cratônicas, não metamórficas, ocorrem no interior do Domínio Rio Negro - Juruena. Em geral são vulcanismos ácidos a intermediários intercalados nos pacotes inferiores de espessas coberturas sedimentares, que incluem arenitos com estratificações cruzadas, conglomerados, folhelhos, arcóseos, calcários e dolomitos. Os componentes vulcânicos são compostos basicamente por tufos e ignimbritos. Em geral estes episódios vulcano sedimentares estão associados a "rifts" continentais e na parte sul do domínio constituem o Grupo Caiabis, que ocorre nas Chapadas dos Caiabis e dos Dardanelos. Os pacotes sedimentares também apresentam intercalações de basaltos alcalinos, toleíticos e calci-alcalinos, principalmente na Serra dos Caiabís (Silva et. al. 1980). Na parte norte as ocorrências destas litologias é mais rara, 
ocorrendo vulcanismos apenas ao longo do Rio Traíra, no limite entre Brasil e Colômbia.

No interior do Domínio Rio Negro - Juruena, principalmente em sua região sul, são comuns atividades magmáticas graníticas de natureza anorogênica, como corpos de granitos peraluminosos ou metaluminosos (granitos com feldspatos alcalinos, sieno-monzogranitos e monzo- granitos), alguns deles com textura tipo rapakivi (Dall'Agnol et. al. 1987), ou ainda, como as intrusões sieníticas do Canamä, que ocorrem muito próximo do limte deste domínio com a província Ventuari - Tapajós. As intrusões de granitos do tipo rapakivi que ocorrem no embasamento da província são de diferentes idades e com características geoquímicas e petrológicas distintas. Em geral são acompanhadas por mangeritos, charnoquitos, rochas alcalinas e algumas vezes por anortositos, como os que ocorrem na região do rio Ciriquiqui e por magmatismos básicos. Estes plutons são epizonais e exibem características de granitos do tipo A intraplacas. Tosdal e Bettencourt (1996), Bettencourt et. al. (1995) e Payolla (1994) dividiram estas atividades ígneas em quatro Suítes, a saber:

- Suíte Intrusiva Serra da Providência;

- Maciço Santo Antonio e Suíte Intrusiva Teotônio,

- Granitos Rapakivi Jovens de Rondônia e

- Granitos Jovens de Rondônia.

\subsection{2 - Discussões Geocronológicas}

Para facilidade das discussões geocronológicas a região situada a norte da Bacia Sedimentar do Amazonas será denominada de Alto Rio Negro, e a área localizada na parte sul de Porto Velho - Juruena. 
Os dados geocronológicos disponiveis para os terrenos granito-gnáissicos da Domínio Rio Negro - Juruena incluem algumas centenas de determinações $\mathrm{Rb}-\mathrm{Sr}$ em rocha total em afloramentos isolados, algumas dezenas de determinações $\mathrm{K}$ - $\mathrm{Ar}$ em minerais, algumas análises $\mathrm{Pb}-\mathrm{Pb}$ e $\mathrm{Sm}$ - $\mathrm{Nd}$ em rocha total e algumas datações U - $\mathrm{Pb}$ em zircões pelo método tradicional e pelo SHIRIMP ( Sensitive High Resolution Ion Microprobe). Este quadro de datações constituído por várias metodologias geocronológicas, embora pontual ao longo de todo o domínio, permitiu caracterizar que praticamente toda a área foi formada predominantemente por material juvenil, durante o intervalo de tempo situado entre $1,8 \mathrm{Ga}$ e $1,55 \mathrm{Ga}$, com a diferenciação mantélica de seus protólitos crustais ocorrendo pouco tempo antes (Tassinari, 1981; 1984); Barrios (1983); Sato e Tassinari (1996) e Tassinari et. al. (1996).

Tassinari (1981) lançou todas as amostras relativas aos terrenos granito gnáissicos do embasamenrto do domínio em um diagrama isocrônico $\mathrm{Rb}-\mathrm{Sr}$, onde os pontos analíticos mostraram uma dispersão, distribuindo-se em forma de leque envolto por duas isócronas de referência, a superior indicando uma idade em torno de $1750 \mathrm{Ma}$ e a inferior com inclinação relativa a idade de $1550 \mathrm{Ma}$. Este comportamento é típico para um conjunto de amostras formadas dentro de um mesmo evento geodinâmico, com início em $1750 \mathrm{Ma}$ ou pouco antes, e término em torno de $1550 \mathrm{Ma}$. Visando uma melhor definição da época sintectônica principal deste evento, o mesmo autor apresentou uma isócrona $\mathrm{Rb}-\mathrm{Sr}$ em rocha total para amostras coletadas na região do alto curso do rio Aripuanã, que indicou a idade de $1700 \pm 21$ Ma e $r i$. de $0,7048 \pm 0,0006$, e para os granitóides a biotita - titanitas coletados na região banhada pelos rios Papuri e Uaupés, no Alto Rio Negro, norte do domínio, foi reportada a idade de $1698 \pm 27 \mathrm{Ma}$ com valor de $r i$. de 0,703 \pm 0,001 .

Em adição a estes resultados, Tassinari (1984) apresentou um estudo geocronológico pelo método $\mathrm{Pb}-\mathrm{Pb}$ em rocha total nas mesmas amostras datadas pelo método $\mathrm{Rb}$ - $\mathrm{Sr}$ acima reportadas, que indicou para as amostras provenientes da região do alto curso do rio Aripuanã uma idade isocrônica $\mathrm{Pb}-\mathrm{Pb}$ de $1674 \pm 85$ 
$\mathrm{Ma}$, com um valor calculado para $\mu_{1}$ de 8,24 e para as amostras provenientes da região do alto rio Negro a idade de $1630 \pm 275 \mathrm{Ma}$, com um valor de $\mu_{1}$ igual a 8,16 e de MSWD de 8,2. Em adição, Tassinari et. al. (1996) apresentaram para as rochas granito-gnáissicas que ocorrem na região de Pontes e Lacerda, no extremo sudeste do domínio, uma idade isocrônica $\mathrm{Pb}-\mathrm{Pb}$ em rocha total de $1717 \pm 120 \mathrm{Ma}$ com um valor de $\mu_{1}$ de 8,09 e de MSWD igual a 8,09.

Além disto, Tassinari et. al. (op.cit.), a fim de confirmarem o quadro geocronológico disponivel sobre estas rochas, apresentaram idades $\mathrm{U}-\mathrm{Pb} \mathrm{em}$ zircões provenientes dos biotita - titanita granitóides da região do Alto Rio Negro, cujos valores no intercepto superior foram de $1703 \pm 7$ Ma e $1521 \pm 13 \mathrm{Ma}$. Para a região Porto Velho - Juruena estes autores reportaram idades $\mathrm{U}-\mathrm{Pb}$, realizadas através do SHRIMP , em monocristais de zircões provenientes de rochas gnáissicas do embasamento, nas regiões dos rios Jamari e Machado. Para a primeira região foram datados zircões de um metadiorito, que indicaram uma idade média de 1750 $\pm 24 \mathrm{Ma}$, e para a segunda região foram datados zircões oriundos de um blastomilonito gnaisse, que forneceram uma idade média de $1570 \pm 17 \mathrm{Ma}$. Ambas as idades foram interpretadas por aqueles autores como as respectivas épocas de cristalização dos zircões analisados, e conseqüentemente dos episódios de formação das rochas datadas.

Para os terrenos granito - gnáissicos que afloram na Venezuela, como continuidade natural destes terrenos do Brasil, constituindo parte integrante do Domínio Petrotectônico Casiquiare, Barrios (1983) apresentou um diagrama isocrônico $\mathrm{Rb}$ - $\mathrm{Sr}$, onde os pontos analíticos relativos a estes terrenos definiram um leque limitado por duas isócronas de referência com inclinações relativas às idades de $1800 \mathrm{Ma}$ e $1500 \mathrm{Ma}$, com razões iniciais de 0,703 e 0,706 respectivamente, bastante similar com o padrão geocronológico obtido para estes terreno gnáissicos no Brasil. Trabalhando com amostras cogenéticas, coletadas em afloramentos próximos, este mesmo autor definiu uma idade isocrônica $\mathrm{Rb}-\mathrm{Sr}$ em rocha total para os tonalitos sintectônicos de $1782 \pm 72 \mathrm{Ma}$ com $r$ i. de $0,7041 \pm 0,0050$, coincidindo, 
dentro do erro analítico, com a idade conseguida por Gaudette e Olszewski (1981) de $1624 \pm 101$ Ma para as rochas do mesmo afloramento. Idades similares foram reportadas por Barrios (1983) para os terrenos granito - gnáissicos incluídos no denominado Domínio Petrotectônico Siapa, com idade de $1693 \pm 33$ Ma e $r i$. de $0,7059 \pm 0,0007$. Este padrão geocronológico é bastante parecido com aquele observado para os terrenos do domínio Rio Negro - Juruena no Brasil, atestando a continuidade destas rochas para o território venezuelano.

Para complementar estes estudos, Sato e Tassinari (1996) realizaram datações pela metodologia $\mathrm{Sm}$ - Nd em rocha total nas rochas do embasamento do Domínio Rio Negro - Juruena, que indicaram idades modelos manto empobrecido variáveis dentro do intervalo de tempo 2,1 $\mathrm{Ga}$ e 1,7 Ga, sugerindo a época de diferenciação manto - crosta dos protólitos das rochas estudadas, conforme mostrado na Figura 9 . Além disto, apresentaram valores para $\varepsilon_{\mathbb{N} d}$, calculados para 1,7 Ga variáveis entre $+3,6$ e $-3,0$, confirmando uma fonte predominantemente mantélica para os terrenos granito-gnáissicos regionais do domínio em questão.

A interpretação combinada dos resultados obtidos pelos mais diversos métodos geocronológicos e pelos parâmetros petrogenéticos dos isótopos de $\mathrm{Pb}, \mathrm{Sr}$ e Nd, sugere fortemente que as rochas do embasamento da Província Rio Negro Juruena formaram-se entre $1,8 \mathrm{Ga}$ e 1,55 Ga, predominantemente a partir de processos de diferenciação mantélica ocorridos pouco tempo antes da cristalização das rochas, e portanto, formando uma crosta juvenil acrescida ao então Cráton Amazônico no final do Paleproterozóico e início do Mesoproterozóico.

As idades obtidas pelo método $\mathrm{K}$ - Ar em rochas do embasamento do Domínio Rio Negro - Juruena, principalmente em biotitas, situaram-se dentro de dois intervalos de tempo, o mais antigo entre $1,4 \mathrm{Ga}$ e 1,3 $\mathrm{Ga}$ e o mais jovem entre $1.2 \mathrm{Ga}$ e $1.1 \mathrm{Ga}$. O primeiro grupo de idades foi interpretado por Tassinari et. al. (1996) como relativo aos episódios de resfriamento e estabilização tectônica do domínio, já os valores mais novos foram interpretados como reflexos de eventos de 
re-aquecimentos e de reativações tectônicas associadas aos eventos anorogênicos que atuaram na área.

As seqüencias de rochas supracrustais, que ocorrem na regiäo dos rios Roosevelt e Aripuanã (região Porto Velho - Juruena)) encontram-se datadas através de isócrona $\mathrm{Rb}$ - Sr em rocha total, que indica a idade de $1560 \pm 80 \mathrm{Ma}$ e uma $\mathrm{r} i$. de $0,701 \pm 0,003$ (Tassinari, 1981); esta pode ser interpretada como a idade do metamorfismo que afetou estas rochas. 0 baixo valor conseguido para a composição isotópica inicial de $\mathrm{Sr}$ é compativel com o caráter vulcânico destas seqüências. $A$ idade aparente $K$ - Ar disponivel para esta unidade de $1418 \pm 44 \mathrm{Ma}$ é coerente com o padrão de idades de resfriamento regional do domínio.

Na região do Alto Rio Negro ocorrem os metassedimentos quartzíticos do Grupo Tunuí, que a rigor apresentam apenas uma datação pelo método $\mathrm{K}$ - $\mathrm{Ar}$ obtida em muscovita de um filonito que indicou a idade de $1045 \mathrm{Ma}$ (Pinheiro et. al. 1976). Esta idade é interpretada como idade mínima, possivelmente relacionada ao evento dínamo - termal Nickeriano, que reativou grande parte dos falhamentos que seccionam o cráton.

Como são encontrados fragmentos de quartzitos atribuídos ao Grupo Tunuí no interior de rochas vulcânicas, que ocorrem ao longo do rio Traíra datadas em $1496 \pm 30$ Ma (Fernandes et.al. 1977) pode-se admitir a época acima como uma idade mínima para estes epimetamorfitos.

No interior do domínio Rio Negro - Juruena ocorrem diversas exposições de rochas vulcânicas ácidas a intermediárias, que possuem idades por vezes distintas, que poderiam representar diferentes pulsos vulcânicos, que ocorreriam como atividades reflexas dos processos orogênicos posteriores.

Neste sentido as amostras relativas às rochas que ocorrem na região entre os rios Sucunduri e Aripuanã, estudadas isotopicamente por Basei (1977), Silva et. 
al. (1980) e Iwanuch (1981), quando lançadas em um diagrama isocrônico $\mathrm{Rb}-\mathrm{Sr}$ situam-se próximas a uma isócrona de referência com inclinação relativa a idade de $1623 \pm 36 \mathrm{Ma}$, para uma relação ${ }^{87} \mathrm{Sr} /{ }^{36} \mathrm{Sr}$ inicial de $0,7027 \pm 0,0027$. Comportamento diferente foi observado para as rochas vulcânicas que afloram na área do médio - baixo Aripuanã, cujos pontos analíticos alinharam-se em um diagrama isocrônico $\mathrm{Rb}-\mathrm{Sr}$ segundo uma isócrona com idade de $1440 \pm 40 \mathrm{Ma}$ e uma ri. de $0,7050 \pm 0,002$.

As coberturas sedimentares pré-cambrianas que ocorrem no domínio Rio Negro - Juruena encontram-se datadas indiretamente, através de relações estratigráficas e também por idades de rochas intrusivas. As seqüências aflorantes na Serra dos Caiabís possuem dois derrames de basaltos intercalados, que foram datados pelo método $\mathrm{K}$ - Ar, tendo o inferior uma idade de $1416 \pm 14 \mathrm{Ma}$ e o superior a idade de $1225 \pm 20 \mathrm{Ma}$ (Tassinari et. al. 1978). Estes derrames limitam, portanto, a deposição destes sedimentos, como iniciando-se antes de $1500 \mathrm{Ma} \mathrm{e}$ prosseguindo até pelo menos $1200 \mathrm{Ma}$ aproximadamente.

O Domínio Rio Negro - Juruena foi afetado por intenso plutonismo, ocorrendo granitóides de diversos tipos e idades. Esta recorrência de eventos plutônicos devese a atuação de orogenias na borda oeste do domínio, que teriam provocado uma atividade magmática reflexa nesta área.

O magmatismo anorogênico relacionado a evolução da orogenia Rio Negro Juruena, na parte sul do domínio, é representado pela Suíte Granítica Teles Pires, que ocorre principalmente no Domínio Ventuari - Tapajós, que é pouco mais antigo, e em menor proporção na região sudeste do domínio em estudo, próximo do limite entre estas duas províncias. Conforme comentado nas discussões inerentes ao domínio Ventuari - Tapajós a idade deste magmatismo é $1602 \pm 30$ Ma (Silva et. al. 1980). 
A suíte Intrusiva Serra da Providência, que aflora na parte sudoeste do domínio, é constituída por piterlitos com quantidades subordinadas de wiborgitos, granitos porfiríticos, granitos pórfiros e sienogranitos (Rizzotto et. al. 1995). Estes granitos com textura rapakivi, quando datados pelo método $\mathrm{Rb}-\mathrm{Sr}$ em rocha total, produziram idades isocrônicas variáveis entre 1,5 Ga e 1,2 Ga (Leal et. al., 1978; Tassinari, 1981). Esta variação das idades pode ser devida ao fato de que as amostras utilizadas eram provenientes de corpos não comagmáticos.

Em adição Tosdal et. al. (1996) apresentaram idades $U$ - $\mathrm{Pb}$ em zircões provenientes de duas amostras do granito Serra da Providência, obtendo, no intercepto superior da curva Concórdia, as idades de $1606 \pm 24 \mathrm{Ma}$ e $1554 \pm 47 \mathrm{Ma}$, que foram interpretadas como as idades de cristalização dos zircões datados. Tassinari et. al. (1996) complementaram este quadro geocronológico, apresentando idade $\mathrm{U}$ - $\mathrm{Pb}$ em monocristais de zircões obtidas através do SHRIMP, com valor de $1588 \pm 16 \mathrm{Ma}$, concordando dentro do erro analítico com as idades obtidas pelo método $\mathrm{U}$ - $\mathrm{Pb}$ convencional. Estes dados posicionam este granitóide em um período pós-tectônico em relação a orogenia mais antiga do dominio Rio Negro Juruena, que ocorreu entre 1,8 e 1, $7 \mathrm{Ga}$.

As Suítes Intrusivas de Santo Antônio e Teotônio ocorrem na região de Porto Velho e são compostas, segundo Payolla (1994), por granitos do tipo A intraplacas, sendo a Suíte Santo Antônio constituída por monzogranitos, sienogranitos $e$ quartzo-monzonitos, de características químicas subalcalinas a peraluminosas. Já a Suíte Intrusiva Teotônio é composta por granitóides com feldspatos alcalinos, sienitos e sienogranitos metaluminosos. Bettencourt et. al. (1995) consideraram estas duas Suites como Suíte Intrusiva Teotonio e a dividiram em Complexo Alto Candeias e Maciço Santo Antônio. Para o Complexo Alto Candeias Priem et. al. (1989) apresentaram uma idade isocrônica $\mathrm{Rb}$ - $\mathrm{Sr}$ em rocha total de $1384 \pm 74 \mathrm{Ma}$ com $r i$. de 0,703 $\pm 0,009$. O Maciço Santo Antônio foi datado por Tosdal et. al. (1996) através de idades $U-\mathrm{Pb}$ em zircões, obtidas no intercepto superior, de 1406 $\pm 32 \mathrm{Ma}$ e $1387 \pm 16 \mathrm{Ma}$. Os charnoquitos da região de Jaru (Rondônia) foram 
associados ao Maciço Santo Antônio por Bettencourt et. al. (1995) e apresentaram a idade $1351 \pm 8 \mathrm{Ma}$ ( Olszewski et.al. 1989).

Dentre os granitos agrupados sob a denominação de "Granitos Rapakivi Jovens", encontram-se os corpos do Complexo São Lourenço - Caripunas e o do Igarapé Preto. Litologicamente são compostos por granitóides do tipo rapakivi de composições quartzo-sienítica e sienogranítica principalmente (Bettencourt et. al. 1995). Os granitóides São Lourenço apresentaram uma idade isocrônica Rb-Sr em rocha total de1268 $\pm 15 \mathrm{Ma}$ (Priem et. al. 1989), e idades $\mathrm{U}-\mathrm{Pb}$ em zircões oriundos deste maciço e do Maciço Caripunas, que forneceram valores no intercepto superior da curva Concórdia de respectivamente $1312 \pm 3 \mathrm{Ma}$ e $1309 \pm 24 \mathrm{Ma}$ (Tosdal et. al. 1996). Já o batólito granítico do Igarapé Preto possui idade $\mathrm{Rb}-\mathrm{Sr}$ isocrônica em rocha total de $1195 \pm 50 \mathrm{Ma}$, com razão inicial ${ }^{87} \mathrm{Sr}{ }^{36} \mathrm{Sr}$ de $0,7090 \pm 0,0026$ (Tassinari et. al. 1984).

Dentro do mesmo intervalo de tempo destes episódios graníticos ocorreram na região Porto Velho - Juruena as intrusões dos complexos alcalinos de Guariba, do Canamã e Teotônio. Estes complexos alcalinos apresentaram respectivamente idades isocrônicas $\mathrm{Rb}-\mathrm{Sr}$ em rocha total de $1260 \pm 56 \mathrm{Ma}(r \mathrm{l}=0,708) ; 1216 \pm 32$ Ma $(r i .=0,704)$ e por volta de $1250 \mathrm{Ma}$. Além destas atividades alcalinas ocorreu também a intrusão de corpos gabro - anortosíticos da Suíte Ciriquiqui - Curuquetê em torno de $1230 \mathrm{Ma}$ (Teixeira et. al. 1990).

Durante este período, na região do Alto Rio Negro, ocorreu a formação de granitóides a duas micas, que foram gerados a partir de processos de fusões parciais de níveis elevados da crosta continental em dois episódios magmáticos distintos, datados através de isócronas $\mathrm{Rb}$ - $\mathrm{Sr}$ em rocha total, que indicaram as idades de $1318 \pm 22 \mathrm{Ma}$ e $1225 \pm 23 \mathrm{Ma}$. Os valores obtidos para as relações ${ }^{87} \mathrm{Sr}{ }^{86} \mathrm{Sr}$ iniciais foram respectivamente $0,722 \pm 0,002$ e 0,714 $\pm 0,002$ (Fernandes et. al. 1977). 
A manifestação magmática de natureza granítica mais jovem, que ocorreu na parte sul do Domínio Rio Negro - Juruena, encontra-se incluída como Granitos Jovens de Rondônia. Conforme Bettencourt et. al. (1995) estes corpos graníticos possuem formas elípticas e são de natureza claramente cratogênica. Litologicamente são compostos principalmente por monzogranitos, sienogranitos, granitos com feldspatos alcalinos e leucogranitos. Em geral podem ser incluídos em duas Suítes do ponto de vista químico, a primeira como subsolvus e carácter subalcalino e a outra mais restrita, como hipersolvus e caracter alcalino a peralcalino.

Vários maciços graníticos deste grupo apresentam determinações geocronológicas; aquelas obtidas pelo método U-Pb em zircões foram calculadas em diagrama Concórdia através do intercepto superior e constam de Tosdal et. al. (1996), e as idades obtidas pelo método Rb-Sr foram calculadas a partir de diagramas isocrônicos em rocha total por diversos autores, conforme descrito a seguir:

- O Maciço Oriente Novo apresenta idades U - Pb em zircões de $1080 \pm 27$ $\mathrm{Ma}$;

- O Maciço de Santa Clara possui idade Rb-Sr de $1052 \pm 21 \mathrm{Ma}$ com ri. de $0,710 \pm 0,0008$ (Priem et. al. 1989) e U - Pb em zircões de $1081 \pm 50 \mathrm{Ma}$;

- Para o pluton de São Carlos - Caritianas, Bettencourt et. al. (1995) citaram uma idade isocrônica de $960 \pm 6 \mathrm{Ma}$, com ri. de 0,707 $\pm 0,0004$;

- O Maciço da Pedra Branca apresentou idade $\mathrm{Rb}-\mathrm{Sr}$ de $954 \pm 20 \mathrm{Ma}$ $i=0,709 \pm 0,016$; Bettencourt et. al. 1995) e U-Pb em zircões de $998 \pm 5 \mathrm{Ma}$;

- O Complexo Granítico de Massangana apresenta idade Rb-Sr de $960 \pm 27$ Ma com ri. de 0,714 $\pm 0,014$ (Priem et. al. 1989) e U - Pb em zircões de 991 $\pm 14 \mathrm{Ma}$.

No âmbito do Domínio Rio Negro - Juruena ocorreram manifestações magmáticas básicas em três intervalos de tempo distintos, sendo o mais antigo entre $1,4 \mathrm{Ga}$ e 1,35 Ga, o segundo entre 1,25 Ga e 1,15 Ga e o mais jovem entre $980 \mathrm{Ma}$ 
e $950 \mathrm{Ma}$. Estes eventos igneos, típicos de atividades distensivas, seriam conseqüência das atividades tectônicas relacionadas às orogenias Rondoniana San Ignácio e Sunsás, que ocorreram também nas áreas adjacentes, mais a oeste deste domínio.

No sumário dos dados geocronológicos disponíveis para o Domínio em questão, representado no Quadro 4, pode ser notado que os terrenos granitognáissicos do embasamento do domínio, formaram-se entre 1,75 Ga e 1,65 Ga e entre 1,6 Ga e 1,55 Ga. Pode ser ainda observado que atividades pós-tectônicas e anorogênicos ocorreram ao longo do domínio desde $1,65 \mathrm{Ga}$ até $1,0 \mathrm{Ga}$, sugerindo que a partir do término do primeiro evento formador de rochas a região sofreu episódios magmáticos relacionados às orogenias subseqüentes que se sucederam nas bordas do Domínio Rio Negro - Juruena.

\section{5 - Domínio Rondoniano - San Ignácio}

O Domínio Rondoniano - San Ignácio ocorre na porção sudoeste do Cráton Amazônico, abrangendo partes do Brasil e Bolivia, englobando rochas formadas dentro do intervalo de tempo $1,5 \mathrm{Ga}-1,3 \mathrm{Ga}$, possuindo uma correspondência temporal com o Evento Madeirense ( $1300 \mathrm{Ma} \pm 100 \mathrm{Ma}$ ), de Amaral (1974), embora a conotação tectônica entre estes eventos seja bastante distinta. Grande parte das rochas deste domínio possuem características ensiálicas, sendo produzidas principalmente através de processos de retrabalhamento de rochas mais antigas, fato este corroborado pela presença de núcleos mais antigos preservados, como "inliers" no interior do domínio. 


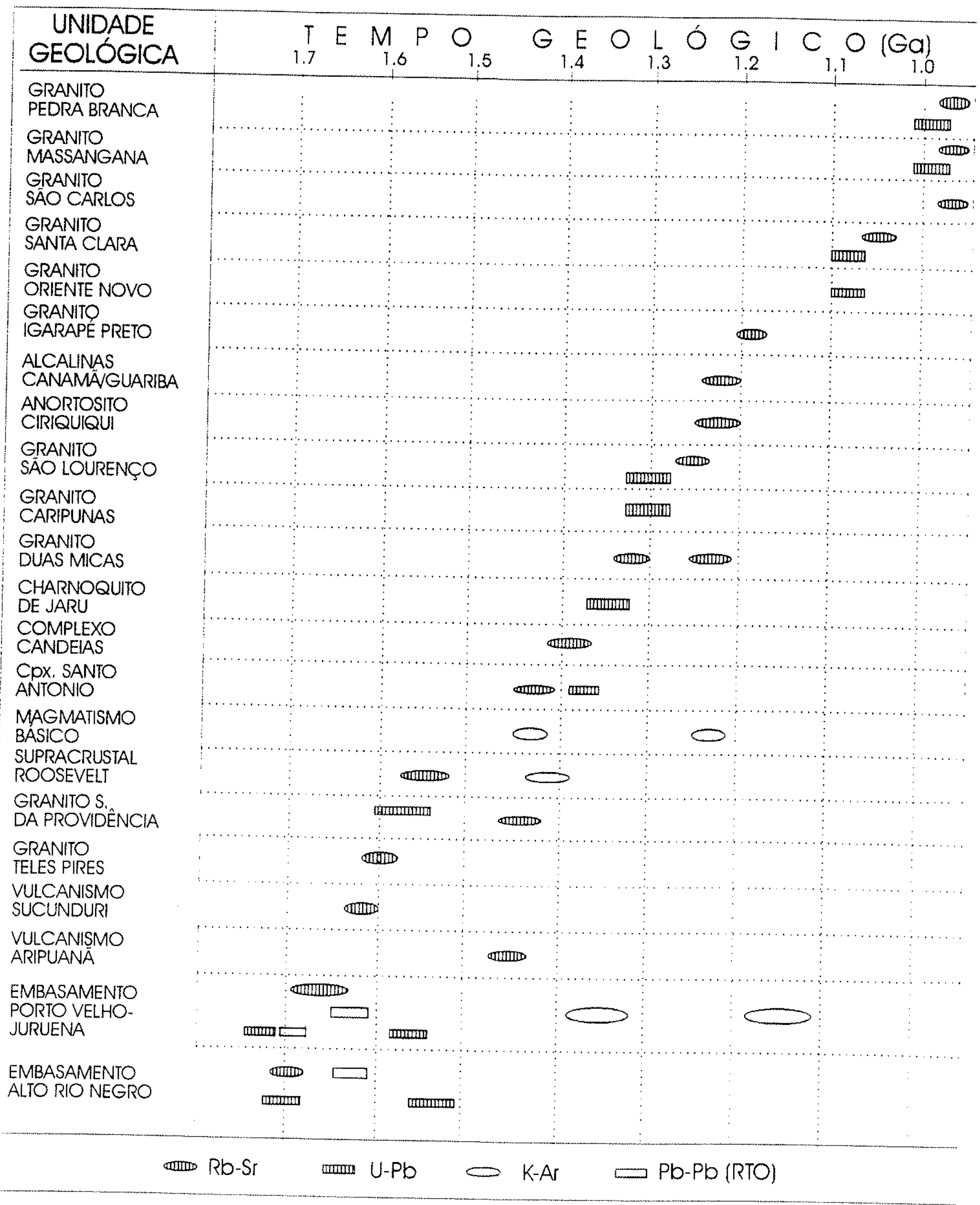

QUADRO 4 - SUMÁRIO DOS DADOS GEOCRONOLÓGICOS DOMINIO RIO NEGRO JURUENA 


\subsection{1 - Considerações Geológicas}

Rochas metamórficas de médio e alto grau, compostas basicamente por terrenos granito-gnáissico-migmatíticos e granulíticos, constituem o embasamento regional do domínio Rondoniano - San Ignácio. Litologicamente estes terrenos incluem gnaisses de diversas composições, granitos, tonalitos, granodioritos, quartzo-dioritos, adamelitos, migmatitos, anfibolitos, granulitos bandados e maciços e charnoquitos.

O padrão estrutural nesta área mostra direções preferenciais NW - SE e NE -SW, sendo que este último padrão é mais jovem e transposto sobre o anterior. Estes terrenos encontram-se individualizados em diversas unidades, como por exemplo o Complexo Jauru (Carneiro et. al.,1992), os granulitos de Ituxi - Abunã (Teixeira e Tassinari, 1984), o terreno granulítico de Lomas Manéches e o complexo gnáissico de Chiquitania na Bolívia (Litherland and Bloomfield, 1981).

Os terrenos considerados como Complexo Jauru, que consiste em um dos núcleos antigos existentes no interior do Domínio, incluem o Greenstone Belt do Alto Jauru (Monteiro et. al. 1986), que compreende três faixas de seqüências metavulcano-sedimentares separadas por terrenos granito-gnáissico-migmatíticos.

Estas seqüências metavulcano-sedimentares são constituidas por uma unidade basal de metabasaltos toleíticos com intercalaçōes de rochas vulcânicas intermediárias e ácidas e sedimentos terrígenos, por rochas ultramáficas e por um pacote de clorita-sericita-xistos. Sobreposto a esta unidade ocorre um conjunto de rochas vulcânicas ácidas a intermediárias de composição predominantemente dacítica a riodacitica e sedimentos químicos e terrigenos metamorfisados no fácies xisto - verde a anfibolito. A unidade de topo desta seqüência metavulcanosedimentar é formada essencialmente por rochas sedimentares de caráter detriticoquímico, com algumas intercalações locais de lavas basálticas. 
Seqüências supracrustais ocorrem ao longo do domínio Rondoniano - San Ignácio na região de Guajará Mirim, constituindo o que Scandolara et. al. (1995) consideraram como Domínio IV (Comemoração), incluindo os denominados Epimetamorfitos Comemoração de Leal et. al. (1978). Litologicamente estas seqüências são constituídas por uma unidade de sedimentos químico-exalativos que incluem rochas calci-silicatadas e formações ferríferas bandadas, por uma unidade vulcanogênica composta por anfibolitos, biotita-gnaisses, metabasaltos, metatufos máficos e intermediários e por um pacote formado por metarenitos, metacherts, quartzitos, biotita-gnaisses, e silimanita-biotita-quartzo-xistos. Todo este conjunto encontra-se metamorfisado no fácies anfibolito.

Rochas vulcânicas ácidas a intermediárias têm uma distribuição restrita no interior deste domínio, quando comparado com os domínios adjacentes a leste. Nesta região estas rochas constituem o Grupo Costa Marques (Santos et. al. 1979), que incluem as denominadas "Efusivas Ácidas Caripunas" de Leal et. al. (1978) e também granitos subvulcânicos de composição basicamente alcalina. Os litotipos relativos ao Grupo Costa Marques são bastante diferenciados, incluindo riolitos, riodacitos, andesitos, traquitos, alcali-riolitos, granófiros, granitos subvulcânicos e tufos riodacíticos. (Santos et. al. op.cit.). Alguns granitóides, caracterizados por Bettencourt et. al. (1995) como "Younger Rapakivi Granitoids" e "Younger Granites of Rondonia", como os Maciços de São Lourenço e Alto Candeias, são também incluídos na denominação geral de Grupo Costa Marques.

Coberturas sedimentares pré-cambrianas não metamorfisadas ocorrem no interior do Domínio Rondoniano - San Ignácio associadas a um sistema de grabens que estão presentes na Serra dos Pacaás Novos com orientação WSW - ENE. Estas unidades estão incluídas no Grupo Guajará Mirim de Leal et. al. (1978), que consiste de um pacote de rochas sedimentares, intercaladas por derrames de basaltos na parte basal do Grupo, e constituem respectivamente as Formaçőes Pacaás Novos e Nova Floresta. Basicamente a unidade sedimentar compreende arcóseos, sub-arcóseos, conglomerados arenitos e quartzitos. Já a unidade vulcânica é composta essencialmente por basaltos, embora ocorram também gabros 
e noritos. Quimicamente estas rochas caracterizam uma série alcalina, conforme Leal et. al. (op.cit.).

\subsection{2 - Discussões Geocronológicas}

Mais de uma centena de amostras dos terrenos granito-gnáissicomigmatítcos do embasamento do Domínio Rondoniano - San Ignácio encontram-se datadas principalmente pelos métodos $\mathrm{Rb}-\mathrm{Sr}$ e $\mathrm{K}-\mathrm{Ar}$, embora dados obtidos pelos métodos $\mathrm{Sm}-\mathrm{Nd}$ e U-Pb estejam também disponiveis.

Teixeira e Tassinari (1984) retrabalharam os dados geocronológicos $\mathrm{Rb}-\mathrm{Sr}$, de outros autores disponiveis na literatura até então, interpretando estes resultados através de isócronas em rocha total de referência. Neste sentido estes autores definiram para os terrenos que ocorrem na região de Ituxi - Abunã uma idade de $1490 \mathrm{Ma}$ com $\mathrm{ri}$. de 0,708 , para as rochas que ocorrem na região de Ariquemes Vila Rondônia a idade de 1450 Ma e valor de ri. de 0,704 e para o embasamento da região do Jauru, uma idade de $1400 \mathrm{Ma}$ com $r i$. de 0,703 . Estudos geocronológicos adicionais foram realizados por Payolla (dados inéditos) em granulitos migmatizados da região de Ji-Paraná, obtendo-se idade isocrônica $\mathrm{Rb}-\mathrm{Sr}$ em rocha total de $1423 \pm$ $39 \mathrm{Ma}$ com $r$ i. de 0,7106 $\pm 0,0010$, que pode ser interpretada como a idade da migmatização que afetou os granulitos mais antigos.

Para o território boliviano Litherland et. al. (1986) apresentaram idades isocrônicas $\mathrm{Rb}-\mathrm{Sr}$ em rocha total para o granitóide sin-tectônico La Junta de 1375 $\pm 80 \mathrm{Ma}(2 \sigma) \mathrm{com} r i$. de $0,7052 \pm 0,0031$, para os granitóides tardi-tectônicos do Complexo Piso Firme e do Maciço de San Javier, de respectivamente $1325 \pm 45 \mathrm{Ma}$ $(2 \sigma)$ com ri. de $0,7044 \pm 0,0026$ e $1291 \pm 41 \mathrm{Ma}(2 \sigma)$ com ri. de 0,7033 $\pm 0,0007$. 
Estes dados mostram claramente a atuação da orogenia Rondoniana - San Ignácio principalmente no intervalo de tempo entre $1500 \mathrm{Ma}$ e $1300 \mathrm{Ma}$, retrabalhando rochas pré-existentes, mas também ocorrendo, de uma forma subordinada, alguma acresção de magmas juvenis, conforme sugerido pelos baixos valores das razões ${ }^{87} \mathrm{Sr} /{ }^{86} \mathrm{Sr}$ iniciais, obtidos para os granitóides tardi-tectônicos da Bolívia e para os terreno granito-gnáissicos da região do Jauru, representada em Teixeira e Tassinari (1984).

A nivel de idades $\mathrm{K}-\mathrm{Ar}$, que indicam idades de resfriamento, as amostras provenientes da região ltuxi - Abunã forneceram um padrão de idades aparentes homogêneo entre $1350 \mathrm{Ma}$ e $1250 \mathrm{Ma}$, sendo que as amostras relativas a região de Ariquemes - Vila Rondônia indicaram resultados concentrados em dois intervalos de tempo, o primeiro entre $1350 \mathrm{Ma}$ e $1300 \mathrm{Ma}$ e o segundo próximo a $1100 \mathrm{Ma}$, e as idades aparentes obtidas para os terrenos da região do Jauru apresentaram comportamento similar, indicando idades entre $1300 \mathrm{Ma}$ e $1100 \mathrm{Ma}$ e também entre $1000 \mathrm{Ma}$ e $900 \mathrm{Ma}$. As idades $\mathrm{K}$-Ar mais antigas refletem o período de resfriamento regional da orogenia Rondoniana - San Ignácio, e as idades mais jovens relacionam-se aos períodos de resfriamento da orogenia Sunsás, que atuou na área adjascente a sudoeste.

No âmbito do dominio Rondoniano - San Ignácio ocorrem núcleos de rochas mais antigas preservados, constituídos principalmente por rochas granulíticas retrometamorfisadas ou por terrenos do tipo granito-greenstone. Vários estudos geocronológicos foram realizados nestes terrenos, que indicaram idades relacionadas ao Paleoproterozóico, mais especificamente ao período Orosiriano.

Dentro deste contexto, Carneiro et. al. (1992) apresentaram uma isócrona $\mathrm{Rb}-\mathrm{Sr}$ em rocha total para os gnaisses cinzentos que ocorrem na região de São José dos Quatro Marcos, incluída no núcleo antigo do Jauru, que forneceu a idade de $1971 \pm 70 \mathrm{Ma}$ e valor de $r i$. de 0,7017 $\pm 0,0005$ e MSWD de 0,19. Ainda dentro deste núcleo, Tassinari e Leite (inédito) dataram metatonalitos que ocorrem na região do Rio Jauru, através de uma isócrona $\mathrm{Rb}-\mathrm{Sr}$ em rocha total que indicou a 
idade de $1852 \pm 75 \mathrm{Ma}$ e um valor de razão ${ }^{87} \mathrm{Sr} /{ }^{86} \mathrm{Sr}$ inicial de 0,7028 . Estes dados indicam que o núcleo antigo do Jauru formou-se durante o Paleoproterozóico, e os baixos valores obtidos para as composições isotópicas iniciais de $\mathrm{Sr}$, sugerem que tais rochas formaram-se a partir de magmas juvenis diferenciados diretamente do manto superior, ou pouco tempo antes, descartando-se, portanto a possibilidade deste núcleo ser arqueano. Idades K - Ar obtidas em anfibólios e biotitas provenientes destes gnaisses pelos autores acima referidos, forneceram resultados entre $1580 \mathrm{Ma}$ e $1500 \mathrm{Ma}$, mostrando a época de resfriamento deste núcleo antigo.

As idades $\mathrm{Rb}$-Sr obtidas para os terrenos metamórficos do núcleo de Jauru são similares àquelas apresentadas por Litherland et. al. (1986), para o Complexo granulítico de Lomas Manéches na Bolívia, que reportaram uma isócrona Rb-Sr de referência com inclinação relativa a idade de $1961 \mathrm{Ma}$. Outro núcleo antigo no interior do domínio Rondoniano - San Ignácio foi encontrado na região de Jaru e JiParaná, onde granulitos charno-enderbíticos forneceram idade isocrônica $\mathrm{Rb}-\mathrm{Sr}$ em rocha total de $1859 \pm 46 \mathrm{Ma}$ e ri. de 0,7037 $\pm 0,0001$ (Payolla, dados inéditos).

Para as seqüências de rochas supracrustais do tipo Comemoração não existem datações radiométricas disponiveis até o momento, entretanto os metassedimentos da Formação Ascensión, do Grupo San Ignácio, que ocorre na Bolívia, e que são correlacionados aos metamorfitos Comemoração, no Brasil, apresentaram uma idade isocrônica $\mathrm{Rb}$ - Sr em rocha total, de $1344 \pm 18 \mathrm{Ma}(2 \sigma)$ com $r$ i. de 0,7056 $\pm 0,0006$ e valor de MSWD de 1,9, obtidas em amostras de gnaisses e metarcóseos (Litherland et. al. 1986). Esta idade poderia estar relacionada ao metamorfismo que afetou estas rochas, durante a orogenia Rondoniana - San Ignácio.

Os granitóides pós-tectônicos relacionados à evolução desta orogenia ocorrem em grande parte no interior do Domínio Rio Negro - Juruena. No âmbito do Domínio em estudo, esta atividade magmática está representada pelos granitos rapakivi do Complexo São Lourenço - Caripunas e pelo Granito Santa Elena, sendo o primeiro datado pelo método U - Pb em zircões em $1312 \pm 3 \mathrm{Ma}$ e $1309 \pm 24 \mathrm{Ma}$ 
(Tosdal et. al. 1996) e também por isócrona $\mathrm{Rb}-\mathrm{Sr}$ em rocha total em $1268 \pm 15$ Ma, com ri. de 0,7071 $\pm 0,0024$ (Priem et. al. 1989), e o segundo datado em 1308 $\pm 13 \mathrm{Ma}$, com $r$ i. de $0,7144 \pm 0,0051$, através de diagrama isocrônico $\mathrm{Rb}$-Sr em rocha total por Menezes et. al. (1993). Além disto ocorre também o Granito Maraboa, que apresentou idade isocrônica $\mathrm{Rb}-\mathrm{Sr}$ de $1257 \pm 125 \mathrm{Ma}$, com r i. em torno de 0,711 (Geraldes, 1996).

Em território boliviano ocorrem os granitóides Diamantina, Orobayaya e o Complexo Alcalino $\mathrm{El}$ Tigre, datados pelo método $\mathrm{Rb}$ - $\mathrm{Sr}$ em rocha total respectivamente em $1391 \pm 70 \mathrm{Ma}$, com ri. de 0,7004 $\pm 0,0033 ; 1288 \pm 33 \mathrm{Ma}$, com $r$ i. de 0,7058 $\pm 0,0031$ e $1286 \pm 46 \mathrm{Ma}$ com ri. de 0,7042 $\pm 0,0002$. (Litherland et. al. 1986). Estes dados permitem posicionar a atividade granítica pós-tectônica relativa a orogenia Rondoniana - San Ignácio entre aproximadamente $1400 \mathrm{Ma}$ e $1300 \mathrm{Ma}$.

No interior deste domínio ocorrem ainda, vários corpos graníticos de natureza cratogênica, cuja formação está associada a evolução da Orogenia Sunsás, que se desenvolveu sobre parte do domínio em estudo, durante o intervalo de tempo 1,3 Ga - 1,0 Ga. Estas atividades magmáticas estão incluídas no Grupo Costa Marques de Santos et. al. (1979) e foram agrupadas por Bettencourt et. al. (1995) sob a denominação de "Younger Granites of Rondonia".

Estes últimos autores dividiram estes granitóides em dois grupos, o mais antigo com idades em torno de $1080 \mathrm{Ma}$ e o mais jovem com idade próxima a 990 Ma. No âmbito do Domínio Rondoniano - San Ignácio predominam os granitóides relacionados ao grupo mais jovem, que estão datados através de isócrona $\mathrm{Rb}-\mathrm{Sr}$ de referência com a idade de $1018 \pm 76 \mathrm{Ma}(2 \sigma)$, e $r i$. de $0,704 \pm 0,003$, que é interpretada como próxima da época de formação deste corpos.

Esta idade é bastante próxima daquela obtida por Leal et. al. (1978) para as rochas vulcânicas ácidas, que ocorrem na porção noroeste do domínio, denominadas como "Efusivas Ácidas do Caripunas". Estas rochas vulcânicas apresentaram uma idade isocrônica $\mathrm{Rb}-\mathrm{Sr}$ em rocha total de $1140 \pm 44 \mathrm{Ma}(2 \sigma) \mathrm{com}$ 
$r i$. de $0,7193 \pm 0,0036$. O vulcanismo ácido Rio Branco, que ocorre na Serra homônima, foi datado por Barros et. al. (1982), através de uma isócrona Rb-Sr em rocha total, obtendo também uma idade similar aos granitóides, de $1130 \pm 72 \mathrm{Ma}$, com $r$ i. de 0,708 $\pm 0,002$, mostrando uma contemporaneidade entre atividades vulcânicas e graníticas nesta região.

A suíte granítica mais jovem deste domínio é a Suíte Intrusiva Guapé, definida por Barros et. al. (1982). Menezes et. al. (1993) incluindo algumas análises geocronológicas de Barros et. al.(1982) e outras próprias, definiram uma idade isocrônica $\mathrm{Rb}-\mathrm{Sr}$ em rocha total para esta Suíte de $950 \pm 41 \mathrm{Ma}$ com uma $r i$. de $0,7029 \pm 0,0013$, posicionando esta atividade magmática no início do Neoproterozóico.

As manifestações de magmatismo básico no Dominio Rondoniano - San Ignácio ocorreram em torno de $1250 \mathrm{Ma}$, entre 1,20 Ga e 1,15 Ga e entre 1,0 Ga e $0,97 \mathrm{Ga}$. Estes episódios ígneos intrudiram tanto rochas dos terrenos granitognáissicos, como também as seqüências sedimentares da Serra dos Pacaás Novos, cuja deposição, a exemplo do Grupo Beneficente, também foi condicionada por um sistema de "rifts"continentais. Cabe ressaltar que as atividades magmáticas básicas que ocorreram generalizadamente em todo o Cráton Amazônico, vão se tornando mais jovens em direção aos domínios mais novos, evidenciando a atuação dos sucessivos episódios de acresção continental, que se desenvolveram na região Amazônica.

As análises isotópicas pelo método $\mathrm{Sm}-\mathrm{Nd}$ efetuadas por Sato e Tassinari (1996) e Vignol (1987) indicaram idades modelo manto-empobrecido para as rochas granulíticas da região oeste de Porto Velho, variando entre 2,08 Ga e 1,7 Ga, para os terrenos granito-gnáissicos da porção sudeste do Domínio Rondoniano - San Ignácio entre $1,95 \mathrm{Ga}$ e 1,8 Ga. 
Os valores calculados de $\varepsilon_{N d}$ para as respectivas épocas de formação destas rochas foram respectivamente entre $-1,9$ e $-2,1$ e $-1,1$ e $-2,7$. Estes dados indicam claramente que os protólitos crustais das rochas do Domínio Rondoniano - San Ignácio formaram-se a partir de retrabalhamento de rochas diferenciadas do manto durante o paleoproterozóico, principalmente dentro do intervalo de tempo 2,0 Ga $1,8 \mathrm{Ga}$, descartando a possibilidade das rochas estudadas derivarem-se de protólitos arqueanos (Figura 10).

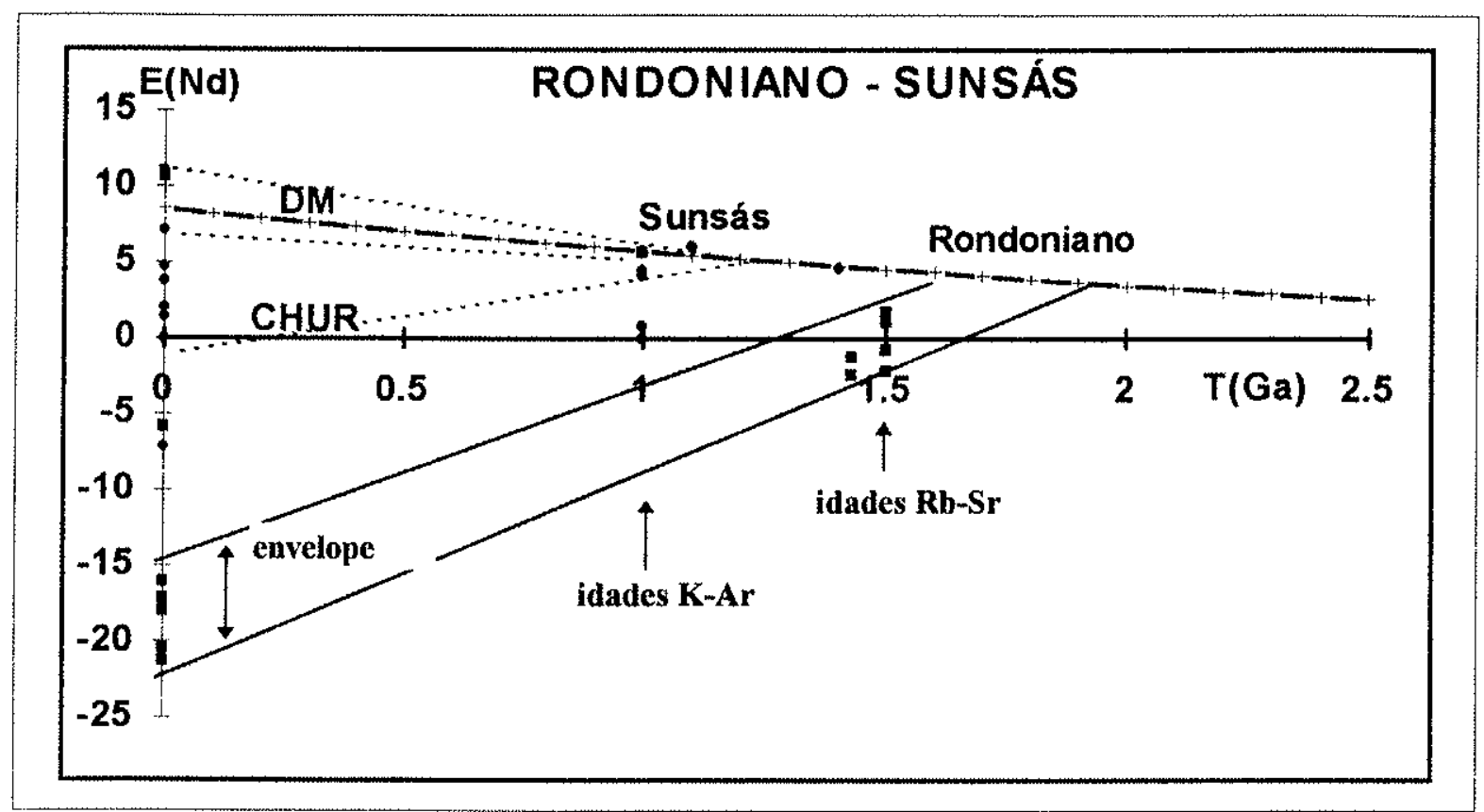

Figura 10 - Diagrama de variação do $\varepsilon_{\mathrm{Nd}}$ em função do tempo geológico, mostrando os intervalos de tempo da diferenciação manto - crosta para os protólitos crustais dos Domínios Rondoniano - San Ignácio.

As rochas anfiboliticas que ocorrem na região do Alto Guaporé apresentaram idades modelo $\mathrm{Sm}-\mathrm{Nd}$ variáveis entre $1,5 \mathrm{Ga}$ e $1,1 \mathrm{Ga}$, com valores de $\varepsilon_{\mathrm{Nd}}$ calculados para as idades de formação destas rochas situados entre +0,9 e +6,2, mostrando a adição de material mantélico durante a orogenia Rondoniana - San Ignácio à crosta continental. 


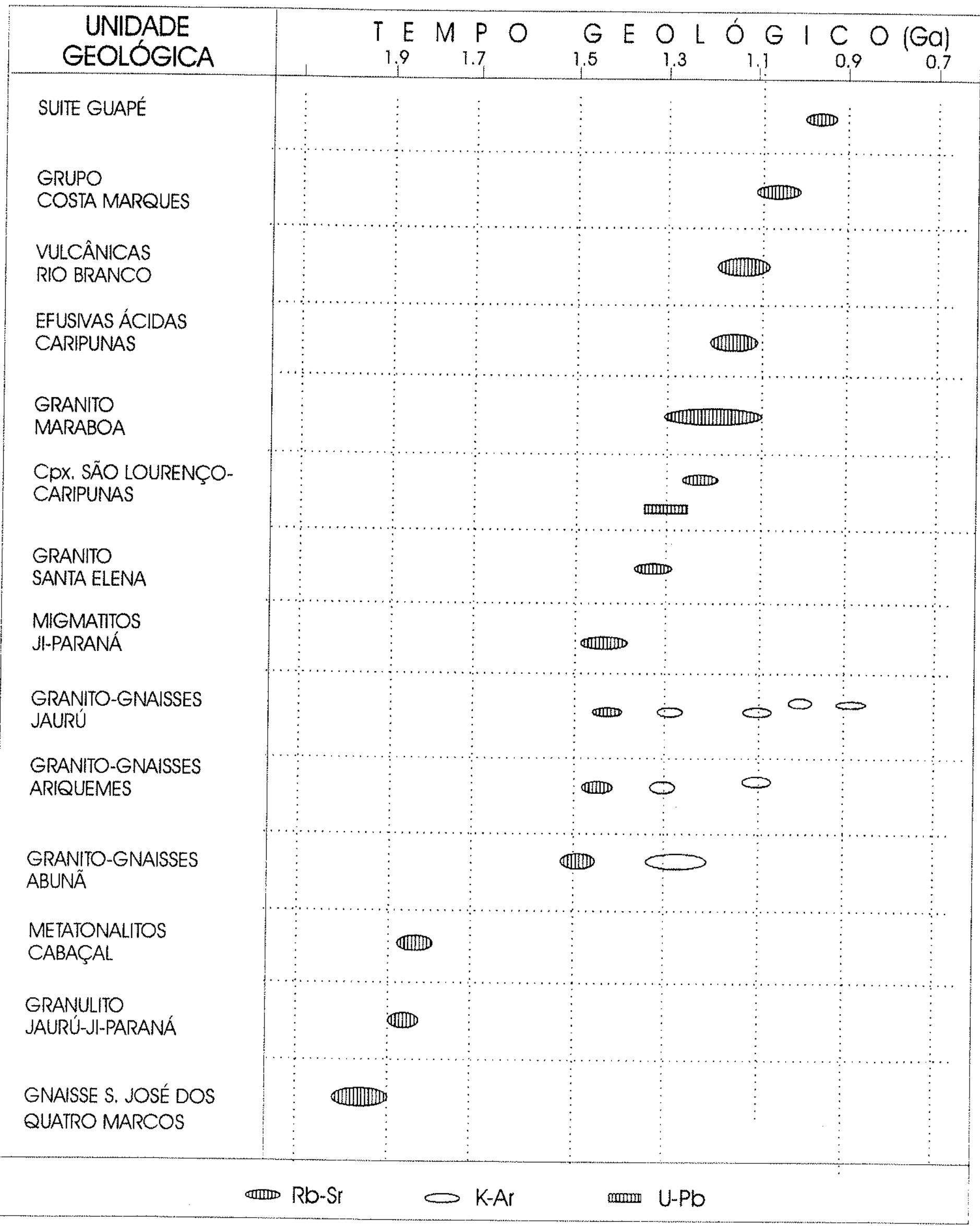

QUADRO 5 - SUMÁRIO DOS DADOS GEOCRONOLÓGICOS DOMÍNIO RONDONIANO-SAN IGNÁCIO 
No Quadro 5 , que mostra a distribuição comparativa das idades dos eventos formadores de rochas, é possivel observar que as idades relativas aos terrenos metamórficos situam-se entre $1,95 \mathrm{Ga}$ e $1,8 \mathrm{Ga}$ e entre $1,5 \mathrm{Ga}$ e 1,4 Ga, caracterizando os núcleos antigos preservados no interior do domínio, e a época sintectônica da orogenia Rondoniana - San Ignácio. Com relação às atividades graníticas pós-tectônicas e anorogênicas, pode-se notar que ocorreram de uma forma contínua desde 1,35 $\mathrm{Ga}$ até $900 \mathrm{Ma}$, refletindo também as atividades relacionadas a orogenia Sunsás.

\section{6 - Domínio Sunsás}

O Domínio Sunsás constitui a província geocronológica mais jovem do Cráton Amazônico, situada no extremo sudoeste da área cratônica, e ocorrendo principalmente na Bolívia. Neste domínio, os eventos tectônicos e magmáticos ocorreram principalmente no intervalo de tempo entre 1,25 Ga e 1,0 Ga. Apesar deste domínio não ter uma continuidade normal para a parte norte do Cráton Amazónico, as rochas granulíticas do Maciço de Garzon, que afloram no sudeste da Colômbia já nos domínios dos Andes, datadas em 1180 Ma (Alvarez e Cordani, 1981), poderiam ser a possível extensão do Domínio Sunsás para norte da Bacia Sedimentar do Amazonas.

A orogenia Sunsás foi definida por Litherland et. al. (1986) como compreendendo a erosão de rochas continentais, a deposição de seqüências clásticas e a subseqüente deformação e metamorfismo, acompanhada por atividades magmáticas graníticas e básicas. Portanto a orogenia Sunsás teve uma evolução claramente ensiálica.

Muitas das atividades magmáticas relacionadas a sua evolução ocorreram sobre os domínios Rio Negro - Juruena e Rondoniano - San Ignácio, que constituíriam o Cráton Paraguá, de Litherland et. al. (1986), que teria permanecido 
estável durante o evento Sunsás. As rochas deformadas desta orogenia estariam restritas aos Grupos Aguapei no Brasil e Sunsás na Bolívia.

\subsection{1- Considerações Geológicas}

No Brasil, o Domínio Sunsás é representado quase que exclusivamente pela sequêencia metassedimentar do Grupo Aguapeí, que encontra-se definido por Souza e Hildred (1980). Estes autores dividiram este Grupo em três formações denominadas de Fortuna, Vale da Promissão e Morro Cristalino, sendo a primeira constituída essencialmente por metarenitos ortoquartzíticos com intercalações de metaconglomerados, a intermediária composta por metassiltitos, filitos e ardósias e a formação mais jovem inclui metarenitos com intercalações de metaconglomerados e metassiltitos. De uma forma geral, as rochas metassedimentares encontram-se alinhadas segundo a direção preferencial NW-SE, com mergulhos para SW, atingindo até a verticalidade.

Menezes et. al. (1993) definiram a Seqüência Metavulcano-sedimentar Pontes e Lacerda, que situa-se estratigraficamente por baixo do Grupo Aguapeí, sendo composta por rochas vulcânicas de diversas naturezas, predominando os metabasaltos, associadas com rochas sedimentares clásticas e químicas, principalmente metapelitos. Estas rochas foram afetadas por metamorfismos do fácies xisto-verde e em alguns locais atingindo o fácies anfibolito.

As atividades graníticas sin e pós-tectônicas do Domínio Sunsás ocorrem na Bolívia, sendo representadas por sienogranitos com feldspatos potássicos bem desenvolvidos, granodioritos, monzonitos e tonalitos, este último litotipo de uma forma subordinada. 


\subsection{2 - Discussões Geocronológicas}

As rochas vulcânicas básicas da Seqüência Metavulcano-Sedimentar de Pontes e Lacerda foram datadas através do método Sm-Nd em rocha total por Geraldes (1996), que apresentou idades modelo manto-empobrecido variáveis dentro do intervalo de tempo 1,3 Ga e 1,0 Ga, que poderia ser interpretado como a idade do vulcanismo. Estas idades são concordantes com aquelas obtidas por Sato e Tassinari (1996) para os diversos corpos anfibolíticos, que ocorrem associados aos domínios Sunsás e Rondoniano - San Ignácio, o que caracteriza a atuação de um evento vulcânico em escala regional na área.

Os metassedimentos do Grupo Aguapei encontram-se datados através de relações geológicas, uma vez que não existem datações diretamente aplicadas às rochas deste Grupo. Neste sentido, considerando-se que estes metassedimentos repousam sobre um embasamento com idades variáveis entre $1400 \mathrm{Ma}$ e $1500 \mathrm{Ma}$, e estão cortados pelas rochas vulcânicas do Grupo Rio Branco, datadas em 1130 $\mathrm{Ma}$, e pelo Complexo Ígneo Rincon del Tigre na Bolívia, com idades próximas a 990 $\mathrm{Ma}$, é sensato admitir uma época entre $1400 \mathrm{Ma}$ e $1130 \mathrm{Ma}$ para a deposição e metamorfismo das rochas do Grupo Aguapeí.

O único granitóide pertencente ao Domínio Sunsás datado pelo método $\mathrm{Rb}$ - Sr é o corpo pós-tectônico denominado de Granito Casa de Piedra, que indicou a idade isocrônica de $1005 \pm 12 \mathrm{Ma}$, com ri. de 0,7156 $\pm 0,002$ e MSWD de 1,1 (Litherland et. al.,1986). Estes dados sugerem que tal granitóide formou-se no final do Mesoproterozóico a partir de processos de refusão de rochas da crosta continental pré-existente. Outros granitóides de natureza pós e sin-tectônica encontram-se datados através de idades $K$ - Ar, que forneceram valores principalmente entre $1100 \mathrm{Ma}$ e $950 \mathrm{Ma}$, caracterizando uma atividade granítica importante nesta época, que ocorreu no extremo sudoeste do Cráton Amazônico, em território boliviano. 
Análises adicionais $\mathrm{Sm}$ - Nd em rocha total foram realizadas no âmbito do Domínio Sunsás, por Sato e Tassinari (1996) em rochas anfibolíticas, indicando idades entre 1,2 Ga e 1,0 Ga, e uma amostra com idade de 1,48 Ga. Estas idades, que indicariam a época de diferenciação mantélica do magma parental destas rochas, mostram que o metamorfismo ocorreu pouco tempo após o vulcanismo, uma vez que este padrão de idades é bastante similar às idades $\mathrm{K}$ - Ar apresentadas por Santos et.al. (1979) para estas mesmas rochas. Os valores de $\varepsilon_{\mathrm{Nd}}$ calculados para 1,0 Ga variaram entre $+6,3$ e $+4,0$, sugerindo que estas rochas derivaram-se de um manto empobrecido geoquimicamente (Figura 10).

\section{6 - EVOLUÇÃO CRUSTAL}

O conhecimento geocronológico do Cráton Amazônico é baseado principalmente em idades isocrônicas $\mathrm{Rb}-\mathrm{Sr}$ em rocha total e em idades K-Ar em concentrados de minerais, além de um controle através de idades U-Pb em zircões, isocrônicas $\mathrm{Pb}-\mathrm{Pb}$ em rocha total e também por idades modelos $\mathrm{Sm}-\mathrm{Nd}$. Em algumas áreas chaves do cráton, como a região da Serra dos Carajás, a de Rondônia e a do Alto Rio Negro no Brasil, e na Guiana Francesa, estas técnicas isotópicas estão aplicadas em maior detalhe.

Apesar disto, é necessário enfatizar que o quadro geocronológico disponível para o cráton, embora suficiente para se estabelecerem modelos de evolução crustal, ainda é carente em muitas áreas e portanto, a medida que novos dados sejam gerados, existirá sempre a possibilidade da evolução crustal aqui apresentada sofrer modificações e aperfeiçoamentos.

Neste sentido, considera-se que o conhecimento da história crustal précambriana a partir dos dados isotópicos disponíveis é o pré-requisito para uma boa compreensão de como se originou e evoluiu o Cráton Amazônico. 
Segundo Hoffman (1989), o registro geológico da evolução crustal é governado pela repetida agregação e fragmentação de continentes, modulado por resfriamento secular do manto e pela acresção de crosta continental. $A$ análise e a interpretação dos dados isotópicos disponíveis para o Cráton Amazônico realizada para este trabalho, em especial daqueles dados obtidos através de idades $\mathrm{Sm}-\mathrm{Nd}$ modelo Manto Empobrecido ( $T_{D M}$ ), que indicam os períodos de diferenciação mantélica dos protólitos das rochas estudadas, permitiram determinar que cerca de $30 \%$ da área do Cráton Amazônico foi separada do manto superior durante o arqueano e os outros $70 \%$ no Proterozóico, principalmente durante o intervalo de tempo 2,2 Ga e 1,55 Ga, sendo o período em torno de 2,0 Ga o mais importante.

As tendências passadas de considerar que o cráton era basicamente constituído por rochas arqueanas retrabalhadas por eventos de reativações durante - Proterozóico, e que neste período praticamente não teriam ocorrido acresções continentais, o que implicava em admitir que o regime da tectônica de placas atuou no arqueano mas não no Proterozóico, não são suportadas pelos dados isotópicos hoje disponiveis para todo o Cráton Amazônico.

Como consequeencia da interpretação integrada dos dados geocronológicos disponiveis, pode-se considerar que o protocráton arqueano na região amazônica é um agregado de microcontinentes, representados hoje pelos sub-Domínios Carajás Iricoumé e Roraima e pelo fragmento que constitui o Complexo de Imataca, na Venezuela. Estes blocos arqueanos foram soldados através de orogenias colisionais, como a Maroni - Itacaiúnas (2,2 Ga - 1,95 Ga), que durante o seu desenvolvimento também retrabalhou parcialmente algumas porções dos segmentos crustais arqueanos, inclusive preservando alguns núcleos como "inliers" no interior de seus domínios.

A porção simática do Domínio Maroni - Itacaiúnas preservou uma considerável quantidade de material juvenil gerado principalmente entre $2,2 \mathrm{Ga}$ e $1,95 \mathrm{Ga}$. As rochas granuliticas do Cinturão da Guiana Central sugerem que os eventos que soldaram os blocos relativos aos sub-Domínios Roraima e Carajás - 
Iricoumé ocorreram entre 2,0 Ga e 1,95 Ga. Os dados geocronológicos dos terrenos que constituem o embasamento das seqüências metavulcano-sedimentares do tipo Paramacá, na Guiana Francesa, e Barama - Mazaruni na Guiana, indicam que a amalgamação entre o sub-Domínio Carajás - Iricoumé e os blocos arqueanos, que hoje situam-se no noroeste da África, ocorreu pouco tempo antes, entre 2,2 Ga e 2,1 $\mathrm{Ga}$, aproximadamente no mesmo período de tempo em que o terreno alóctone do Complexo de Imataca foi colado ao sub-Domínio Roraima.

Através destes processos de colagens, os atuais Domínios Amazônia Central e Maroni - Itacaiúnas constituiam no final do período Orosiriano, uma massa continental cratônica que iniciou um processo colisional com outro bloco cratônico, de idade paieoproterozóica, que seria o embasamento que posteriormente seria retrabalhado pelas orogenias Rondoniana - San Ignácio $(1,5 \mathrm{Ga}-1,3 \mathrm{Ga})$ e Sunsás $(1,25-1,0 \mathrm{Ga})$.

Este processo colisional, que está ilustrado na Figura 11, iniciou-se através de subducções de crosta oceânica, que geraram entre 1,9 Ga e 1,55 Ga sucessivos arcos magmáticos, e conseqüentemente a produção de uma grande quantidade de crosta continental juvenil. Por outro lado estes processos colisionais também geraram quantidades subordinadas de magmas produzidos por fenômenos de fusão parcial decorrentes da continuidade dos processos de subducção, que provocavam a fusão da base da crosta dos arcos magmáticos gerados pouco tempo antes, propiciando inclusive a formação de alguns corpos graníticos de natureza continental. Estes arcos magmáticos, que hoje constituem os Domínios Ventuari Tapajós e Rio Negro - Juruena, serviram como agentes amalgamadores destes dois protocrátons paleoproterozóicos. Após este processo colisional, próximo a 1,55 Ga, praticamente $90 \%$ da área do Cráton Amazônico já estava diferenciada do manto.

O fato da distribuição das idades das rochas, nas zonas abrangidas pelos domínios Rio Negro - Juruena e Ventuari - Tapajós, possuir uma grande coerência ao longo dos cinturões e variar lateralmente decrescendo em valores para oeste, é 


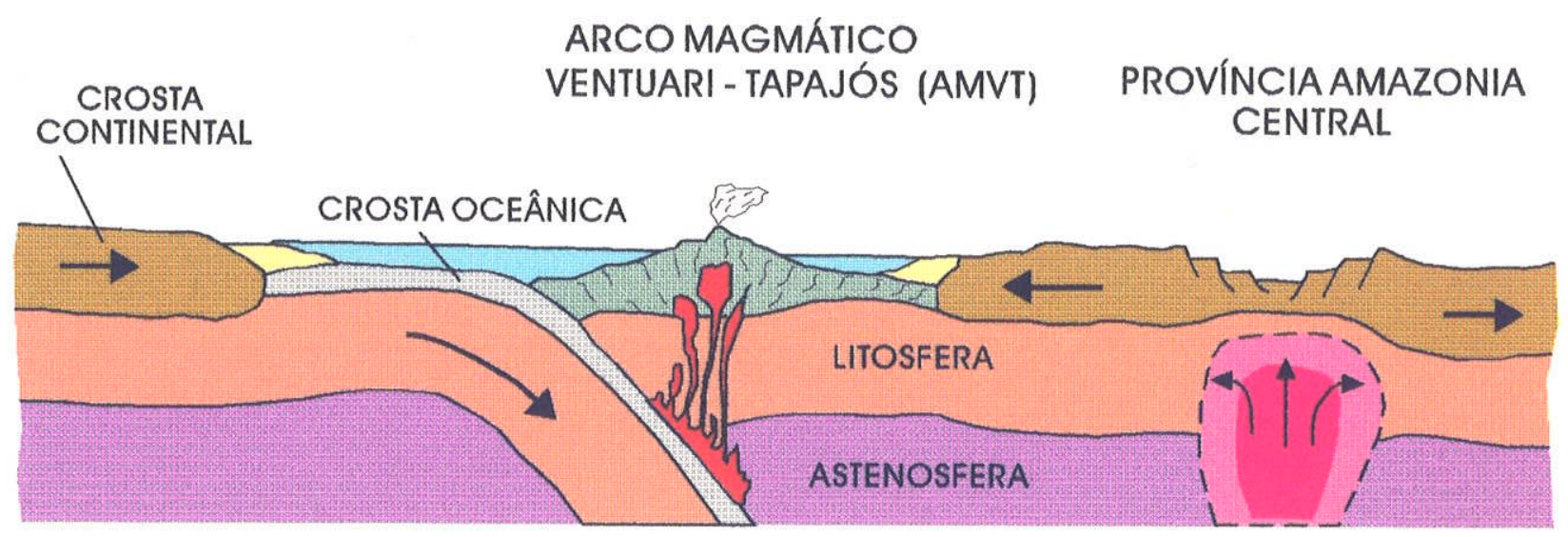

$1.95 \mathrm{Ga}-1.8 \mathrm{Ga}$

ARCOS MAGMÁTICOS

RIO NEGRO - JURUENA

PROVIINCIA AMAZONIA CENTRAL

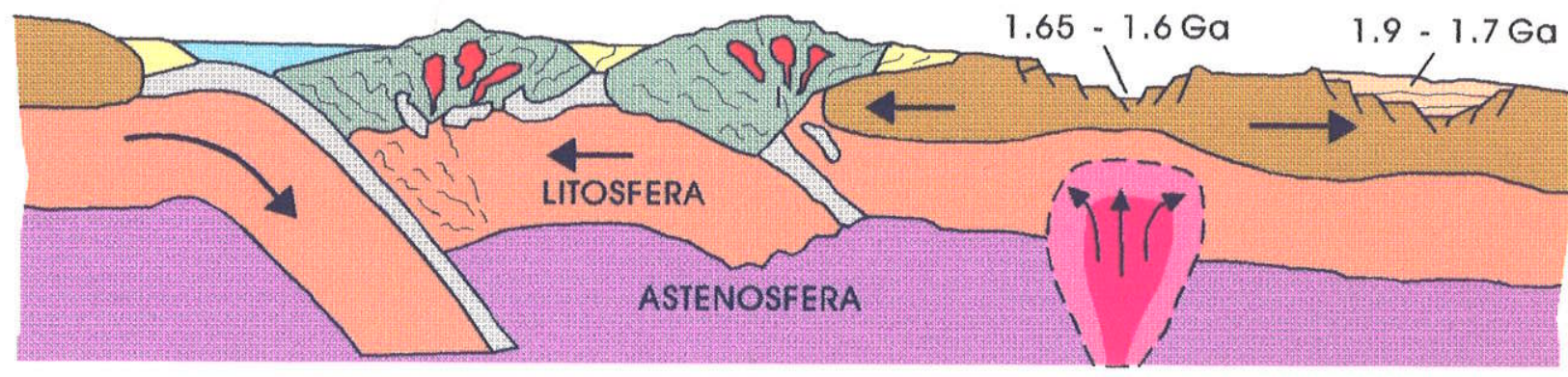

$1.8 \mathrm{Ga}-1.6 \mathrm{Ga}$

FIG. 11 - SEÇÃO ESQUEMÁTICA DO MODELO TECTÔNICO PARA O DESENVOLVIMENTO DOS ARCOS MAGMÁTICOS VENTUARI-TAPAJÓS E RIO NEGRO-JURUENA. 
um argumento favorável para a hipótese de acresção lateral através de arcos magmáticos.

Posteriormente, processos colisionais envolvendo predominantemente materiais continentais ocorreram entre $1,5 \mathrm{Ga}$ e 1,0 $\mathrm{Ga}$ na porção sudoeste do Cráton Amazônico, retrabalhando as rochas continentais pré-existentes, através das orogenias Rondoniana - San Ignácio e Sunsás, conforme indicado em Sadowski e Bettencout (1996). Somente após o término do evento colisional Sunsás, o Cráton Amazônico atingiu a sua estabilidade tectônica, configurando as suas feições atuais.

Diversas atividades magmáticas de natureza pós-tectônica e anorogênica, como também processos associados a formação e evolução de bacias, principalmente associadas a "rifts" continentais, que ocorreram entre 1,9 Ga e 1,0 $\mathrm{Ga}$, constituem as manifestações geológicas sobre as áreas cratônicas, provocadas pelas atuações das diversas orogenias posteriores.

O desenvolvimento e evolução do Cráton Amazônico através de sucessivos episódios de acresção continental é demonstrado pelas idades modelo $\mathrm{Sm}-\mathrm{Nd}$, obtidas em amostras provenientes dos diversos domínios do cráton, que estão representadas no diagrama de freqüencia das idades $T_{D M}$ da Figura 12. Neste diagrama nota-se uma distribuição das idades, que indicam épocas de diferenciação manto - crosta dos protólitos crustais, entre 3,1 Ga e 1,5 Ga, com maior freqüência nos períodos relacionados às fases orogênicas de cada domínio aqui descrito.

Como exemplo tem-se as coberturas vulcânicas ácidas e intermediárias e as sedimentares que repousam sobre o sub-Domínio Roraima e sobre a região de Iricoumé, com idades entre 1,95 Ga e 1,8 Ga formaram-se sobre o protocráton arqueano, enquanto que nas margens destes desenvolviam-se eventos tectônicos acrescionais, que incluiram a formação de rochas granulíticas relacionadas a orogenia Maroni - Itacaiúnas e de granitóides relacionados a orogenia Ventuari - 


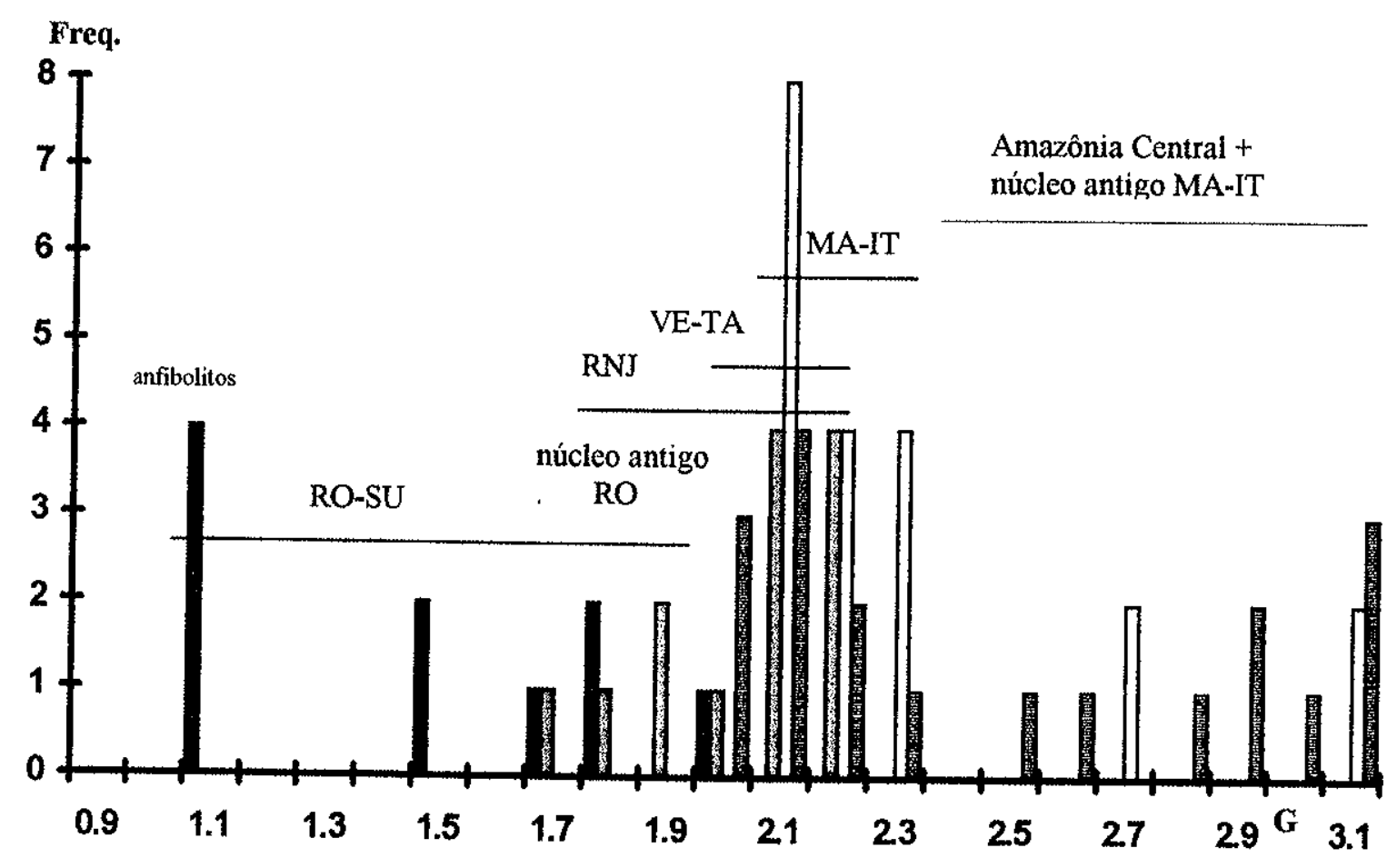

Figura 12 - Histograma da frequência da variação das idades modelo $\mathrm{Sm}-\mathrm{Nd}$ manto empobrecido para o Cráton Amazônico, mostrando as variações dentro de cada um dos domínios definidos.

Tapajós. Estas atividades cratogênicas incluem ainda granitóides do tipo A, denatureza intraplaca, corpos graniticos com textura do tipo rapakivi, corpos circulares de rochas alcalinas e magmatismos básicos, que se formaram sempre após a estabilização tectônica das áreas que os contêm.

Durante o Neoproterozóico, como atividades reflexas da orogenia brasiliana que ocorreu na borda oriental e meridional do Cráton Amazônico, vulcanismos fissurais e episódios de reaquecimentos atuaram principalmente no sub-domínio Carajás - Iricoumé. 


\section{1 - Arqueano}

No âmbito do Domínio Amazônia Central a evolução arqueana encontra-se bem representada no sub-domínio Carajás - Iricoumé, onde as exposições de rochas arqueanas estão bem preservadas. Nesta região a crosta continental mais antiga é constituída por metonalitos e granulitos com idades próximas a $3,0 \mathrm{Ga}$. Sobre esta crosta desenvolveram-se as bacias onde depositaram e evoluíriam em torno de $2,9 \mathrm{Ga}$, as seqüências do tipo "greenstone belts", que estão incluídas no Supergrupo Andorinhas. Após a formação dos cinturōes de "greenstone belts", ao redor de $2,87 \mathrm{Ga}$, a região foi afetada por um forte magmatismo granítico de composição tonalítica, trondhjemitica e granodiorítica, que completou a evolução destes terrenos.

Posteriormente, estes terrenos granito-greenstone colidiram com uma crosta continental, composta por rochas granito-gnáissicas, conforme o modelo estabelecido por Teixeira e Eggler (1994), onde próximo da sutura entre estes dois terrenos, como consequiência dos processos de subducção, em $2,75 \mathrm{Ga}$ aproximadamente, ocorreram vulcanismos basálticos calci-alcalinos de médio $\mathrm{K}$, e com a continuidade destes processos, em um ambiente continental, evoluiu a Bacia de Carajás, ocorrendo os vulcanismos básicos calci-alcalinos de alto $K$, e a deposição $\theta$ metamorfismo dos sedimentos relacionados aos Supergrupos Itacaiúnas e Inajá, já entre 2,7 Ga e 2,6 Ga.

No final do Arqueano e início do Paleoproterozóico, a região foi atingida por eventos de natureza distensionais, que propiciaram a formação de complexos máficos-ultramáficos estratificados, e a formação de bacias onde depositaram-se possivelmente as rochas relacionadas o Grupo Rio Fresco. 


\section{2 - Paleoproterozóico}

No Cráton Amazônico o período inicial do Paleoproterozóico não foi caracterizado por processos de formação de crosta continental, praticamente inexistindo terrenos diferenciados do manto entre 2,5 $\mathrm{Ga}$ e 2,3 $\mathrm{Ga}$. De uma forma geral, durante este período ocorreram fenômenos distensivos originando corpos máficos-ultramáficos e formação de rifts continentais, conforme comentado acima.

Os primeiros eventos orogênicos do Paleoproterozóico estão relacionados ao desenvolvimento da orogênese Maroni - Itacaiúnas. Esta orogenia envolveu tanto uma evolução ensiálica como simática e representa zonas de colisão entre províncias arqueanas.

As porções ensiálicas do Domínio Maroni - Itacaiúnas possuem assinaturas isotópicas de $\mathrm{Nd}$ que indicam uma origem arqueana para seus protólitos, apresentando idades de diferenciação mantélica destes similares àquelas obtidas para o Domínio Amazônia Central, sugerindo que a orogenia transamazônica retrabalhou rochas que poderiam ser a continuidade da crosta siálica da região da Serra dos Carajás. Esta evolução ensiálica desenvolveu-se principalmente entre 2,1 Ga e 1,9 Ga.

As zonas do Domínio Maroni - Itacaiúnas, que evoluíram a partir de diferenciação de material juvenil, constituem dois segmentos com idades um pouco diferentes. $O$ mais antigo, que constitui $O$ embasamento das seqüências metavulcano-sedimentares do tipo Paramacá, Barama - Mazaruni e Pastora, possui uma idade entre $2,25 \mathrm{Ga}$ e 2, $1 \mathrm{Ga}$, enquanto que o segmento mais novo é composto pelo Cinturão Granulítico Guiana Central, que apresenta idades entre 2,0 $\mathrm{Ga}$ e 1,95 Ga.

A zona orogênica mais antiga parece ter amalgamado tanto o sub-domínio Carajás - Iricoumé como o Roraima a um bloco arqueano que hoje estaria na África 
ocidental, como por exemplo o denominado Domínio Kanema Man, e ao bloco que inclui o Complexo de Imataca na Venezuela, através de um processo colisional que envolveria tanto crosta continental, produzindo uma reciclagem de material crustal, como crosta oceânica, gerando uma crosta continental juvenil entre 2,25 e 2,1 Ga. Dentro deste processo colisional teriam se originado as bacias onde evoluíram as seqüências metavulcano-sedimentares e um magmatismo granítico de natureza póstectônica.

Por outro lado, a zona orogênica mais jovem, teria soldado os terrenos arqueanos dos sub-domínios Carajás - Iricoumé com o Roraima. Este processo colisional teria produzido uma crosta continental juvenil, com formação de granulitos na base da crosta e sua posterior ascenção através de lascas, devido aos processos compressionais. Esta atividade orogênica teria se desenvolvido entre 2,0 $\mathrm{Ga}$ e 1,95 Ga, conforme sugerido pelas idades das rochas granulíticas.

Em torno de 1,9 Ga o bloco contendo os Dominios Amazônia Central e Maroni - Itacaiúnas inicia um processo colisional com um outro bloco de idade paleoproterozóica, que, como dito anteriormente, constituíria o embasamento que seria retrabalhado pelas Orogenias Rondoniana - San Ignácio e Sunsás. Este processo colisional inicialmente envolveria o choque de crostas oceânicas, conforme mostrado na Figura 11, que produziriam sucessivos arcos magmáticos, que iriam originar os domínios Ventuari - Tapajós e Rio Negro - Juruena, conforme modelo sugerido em Tassinari et. al. (1996).

Os dados isotópicos disponiveis atualmente reforçam as evidências de que os Domínios Ventuari - Tapajós e Rio Negro - Juruena tenham uma história relacionada a uma evolução de um sistema de arcos magmáticos entre 1,9 Ga e $1,55 \mathrm{Ga}$. A evolução tectônica do Cráton Amazônico durante este intervalo de tempo parece incluir pelo menos três sistemas de arcos magmáticos, o primeiro entre 1,9 $\mathrm{Ga}$ e 1,8 Ga, o segundo entre $1,8 \mathrm{Ga}$ e 1,65 Ga e o mais jovem entre $1,65 \mathrm{Ga}$ e 1,55 Ga. 
As atividades tectônicas compressionais produziriam sobre as áreas estáveis movimentos distensionais, que gerariam vulcano-plutonismo ácidos a intermediários do tipo Iriri e Teles Pires, datados em 1,75 Ga - 1,7 Ga e 1,65 Ga - 1,55 Ga. Nos sistemas de "rifts" criados ocorreriam deposição de sedimentos em ambientes epineríticos a continentais, como o Grupo Beneficente por exemplo. Portanto as coberturas vulcânicas não metamorfisadas dos vulcanismos Iriri e Teles Pires são interpretadas como associadas a sistemas de "rifts" produzidos pela subducção para leste de uma crosta oceânica, que causaria uma colisão arco - continente.

Após a estabilização tectônica de cada arco magmático, já no Mesoproterozóico, ocorreram, desde 1,60 Ga até 1,55 Ga, intrusões de corpos graníticos com textura do tipo rapakivi, como os corpos da Serra da Providência, EI Parguaza e Surucucus.

A estabilidade tectônica do Domínio Rio Negro - Juruena é atestada pelas intrusões graníticas anorogênicas dos Complexos Teotônio e Santo Antônio, ao redor de 1,4 Ga e pelas atividades básicas e alcalinas entre 1,5 Ga e 1,4 Ga.

\section{3 - Mesoproterozóico}

O período relativo ao Mesoproterozóico no Cráton Amazônico é caracterizado por atividades magmáticas de caráter pós-tectônico e anorogênico e por processos metamórficos gerados principalmente por processos colisionais envolvendo materiais crustais.

Ao redor de 1,5 Ga, após a amalgamação das duas massas continentais pelos arcos magmáticos Ventuari - Tapajós e Rio Negro - Juruena, este supercontinente, conforme modelagem elaborada por Sadowski e Bettencourt, (1996), sofreria um movimento distensivo, que provocaria uma delaminação e posterior desagregação da crosta continental, originando um oceano entre os 
blocos continentais, permanecendo um continente de um lado, que seria a Laurencia (América do Norte) e do outro lado o Cráton Amazônico.

Após a desagregação do supercontinente, movimentos convergentes produziriam a orogenia Rondoniana - San Ignácio, envolvendo uma colisão crosta oceânica versus crosta continental, produzindo uma reciclagem de rochas crustais pré-existentes e subordinadamente a acresção de material juvenil.

Com a continuidade deste processo, ainda seguindo o modelo de Sadowski e Bettencourt (1996), seriam gerados sistemas de "rifts" continentais, onde depositariam-se os sedimentos que iriam formar os Grupos Aguapeí e Sunsás, e posteriormente estes sedimentos sofreriam deformações e metamorfismos, acompanhados por atividades magmáticas graníticas e básicas, gerando as orogenias Sunsás na Amazônia e "Greenville" na América do Norte.

Portanto, a história da evolução crustal do Cráton Amazônico envolveu inicialmente processos de acresção continental durante o arqueano, através de choques de micro-continentes, formando os sub-Domínios Carajás - iricoumé e talvez o Roraima, além do bloco do Imataca. Durante o período transamazônico a orogenia Maroni - Itacaiúnas teria amaigamado este blocos arqueanos produzindo uma massa continental considerável. Durante o final do Paleoproterozóico e início do Mesoproterozóico um sistema de arcos magmáticos, incluídos nos Domínios Ventuari - Tapajós e Rio Negro - Juruena, teria soldado esta massa continental com um outro continente, que poderia ser aquele que incluía a província Superior do Escudo Canadense, formando um supercontinente.

Por volta de 1,5 $\mathrm{Ga}$ este supercontinente sofreria processos distensivos, que provocariam a desagregação da massa continental, e posteriormente através de eventos colisionais, entre $1,4 \mathrm{Ga}$ e $1,0 \mathrm{Ga}$, seriam gerados os Domínios Rondoniano - San Ignácio e Sunsás do lado do Cráton Amazônico e a Província Greenville na América do Norte. 
Esta evolução confirma a afirmação de Hoffman (1989) de que o registro geológico ao longo do tempo é governado pela agregação e fragmentação de continentes, e os dados isotópicos disponiveis para o Cráton Amazônico sugerem um processo evolutivo similar.

Para o Cráton Amazônico, os principais períodos orogênicos estabelecidos a partir do padrão geocronológico disponivel são os que se seguem:

- 3,0 Ga-2,7 Ga;

- 2,25 Ga-1,9 Ga;

- 1,9 Ga-1,8 Ga;

- 1,75 Ga-1,55 Ga;

- 1,45 Ga-1,3 Ga;

- 1,25 Ga-1,0 Ga.

Estes períodos orogênicos são muito similares àqueles estabelecidos para a América do Norte, onde Hoffman (1989) define várias províncias de terrenos granitogreenstone arqueanos, orogêneses entre $2,3 \mathrm{Ga}$ e 2,1 $\mathrm{Ga}$ e entre $2,0 \mathrm{Ga}$ e 1,8 Ga, formação de crostas juvenis entre $1,9 \mathrm{Ga}$ e 1,8 Ga e entre 1,8 Ga e 1,6 Ga. e processos tectônicos envolvendo materiais crustais entre 1,3 $\mathrm{Ga}$ e 1,0 Ga. Estes dados mostram que o Cráton Amazônico e o escudo Canadense possuem uma história geológica parecida, e poderiam ter tido uma evolução tectônica comum durante o pré-Cambriano. 


\section{7 - REFERÊNCIAS BIBLIOGRÁFICAS}

ALMEIDA, F.F.M. de; (1978) A evolução dos crátons Amazônico e do São Francisco comparada com a de seus homólogos do Hemisfério Norte. Anais XXX Cong. Bras. De Geol., 6, p. $2293-2407$, Recife

AMARAL, G. (1974) Geologia pré-cambriana da região Amazônica. São Paulo, 212p. (Tese de Livre-Docência) Instituto de Geociências, Universidade de São Paulo.

ARAÚJO, J.F.V.; MONTALVÃO, R.M.G. de; LIMA, M.I.C. de; FERNANDES, P.E.C.A.; CUNHA, F.M.B. da; FERNANDES, C.A.C.; BASEI, M.A.S. (1976) Geologia. In: Departamento Nacional da Produção Mineral. Projeto RADAM. Folha SA.21 Santarém. Rio de Janeiro, 130p. (Levantamento de Recursos Naturais, 10)

AVELAR, V.G; LAFON, J.M.; SCHELLER, T.; ARAÚJO, O.J.B.; MACAMBIRA, E.M.B; (1994) Geocronologia Pb/Pb por evaporação de zircão e Rb-Sr em rocha total do Granito Seringa, Província Mineral de Carajás. Anais do XXXVIII Cong. Bras. De Geol., Resumos, v.2 p. 387-388, Camboriú

BARBOSA, A.A; LAFON, J.M.; NEVES, A.; VALE, A.G.; (1994) O Granito de Redenção (Sul do Pará) Novos dados geocronológicos Rb-Sr e Pb-Pb. $4^{\circ}$ Simpósio de Geologia da Amazônia, Resumos, p.302-306, Belem.

BARRIOS, F. J; (1983) Caracterização geocronológica da região amazônica da Venezuela. Dissertação de Mestrada apresentada ao IGc-USP. p.123

BARROS, A.M.; SILVA, R.H.; CARDOSO, O.R.F.A.; FREIRE, F.A.; SOUZA JR., J.J.; RIVETTI, M.; LUZ, D.S.; PALMEIRAS, R.C.B.; TASSINARI, C.C.G. (1982) Levantamento de Recursos Naturais, vol. 26. Folha SD.21. Cuiabá. Geologia I, 192p. MME/SG. 
BASEl, M.A.S. (1977) Idade do Vulcanismo Ácido-Intermediário na Região Amazônica. São Paulo, 133p. (Dissertação - Mestrado) - Instituto de Geociências, Universidade de São Paulo.

BASEI, M.A.S.; TEIXEIRA, W. (1975) Geocronologia do Território de Roraima. In: Conferência Geológica Interguianas, 10a. Departamento Nacional da Produção Mineral, p. 253-73. Belém.

BEN OTHMAN, D.; POLVÉ, M.; ALLÈGRE, C.J.; (1984) Nd-Sr isotopic composition of granulites and constraints on the evolution of the lower continental crust. Nature, v.307, p. 510-515.

BERGER, G.W.; YORK, D.; (1981), Geothermometry from ${ }^{40} \mathrm{Ar} /{ }^{39} \mathrm{Ar}$ dating experiments. Geochim. Cosmochim. Acta, v.45, p. $795-811$

BETTENCOURT, J.S.; DALL'AGNOL, R; (1987) The rondonian tin-bearing anorogenic granites and associated mineralizations. In; Intern. Symp. On Granites and Associated Mineralizations. Superintendência de Geologia e Recursos Minerais, Bahia (eds.) Excurs. Guides, Salvador p.49-87.

BETTENCOURT, J.S.; TOSDAL, R.; LEITE JR, W.B.; PAYOLLA, B.L. (1995) Overview of the rapakivi granites of Rondônia Tin Province (RTP). Excursion Guide, Symposium on Rapakivi Granites and Related Rocks, Belém, p. 5-48.

BIZINELLA , G.A.; ANDRADE, A.F.; YAMAGUTI, H.S.; OLIVEIRA, J.R.; CARMONA, J.R.M.; DANTONA, R.; LOPES, R.C.; MELO, A.F.F.; (1980) Projeto Tapajós - Sucunduri. Relat. Final. CPRM / DNPM. Rel. Inéd. 6 v.

BLOOMFIELD, K; LITHERLAND, M. (1979) Summary of the geology and mineral potential of the Project area, Southern Zone. Eastern Bolivia Min.Expl. Project "Proyecto Precambriano". Phase I: 1976-1979. Rept. $n^{\circ} 1$, $53 \mathrm{p}$.

BOSMA, W.; KROONEMBERG, S.B; VAN LISSA, R.V; MAAS, K; DE ROEVER W.F (1983)An explanation of the geological map of Suriname. Contributions to the Geology of Suriname. V.27 p. 31-82. 
BRITO NEVES, B.B.; TEIXEIRA, W.; TASSINARI,C.C.G; KAWASHITA, K. (1992), A contribution to the subdivision of the precambrian in South America. Rev. Bras. de Geoc., v. 20 (1-4), p. 267 - 276.

CARNEIRO, M.A.; ULBRICH, H.H.G.J.; KAWASHITA, K.; (1992) Proterozoic crustal evolution at the southern margin of the Amazonian craton in the State of Mato Grosso, Brazil: evidence from $\mathrm{Rb}-\mathrm{Sr}$ and K-ar data. Precambrian Res. V.59, p. $263-282$.

CORDANI, U.G.; BRITO NEVES, B.B. (1982) The geologic evolution of South America during the Archean and Early Proterozoic. Revista Brasileira de Geociências, São Paulo, v.12, n.1-3, p.78-88.

CORDANI, U.G.; TASSINARI, C.C.G.; TEIXEIRA, W.; BASEI, M.A.S.; KAWASHITA, K. (1979) Evolução Tectônica da Amazônia com base nos dados geocronológicos. II Congresso Geológico Chileno. Arica, Chile, Actas, p.137-48.

CUNHA, B.C.C.; POTIGUAR, L.A.T.; IANHEZ, A.C.; BEZERRA, P.E.L.; PITTHAN, J.H.L.; SOUZA JR., J.J.; MONTALVÃO, R.M.G. de; SOUZA, A.M.S.; HILDRED, P.R.; TASSINARI, C.C.G. (1981) Levantamento de Recursos Naturais, v. 22, Folha SC22 Tocantins, Geologia I, 196p. NME/SG.

DALL'AGNOL, R.; ABREU, A.S. (1976) Características petrográficas e petrológicas do Complexo Guianense na folha NA. 19 Pico da Neblina. Anais do XXIX Cong. Bras. De Geol., v.2, p.321 - 350. Belo Horizonte.

DALL'AGNOL, R; VIEIRA, E.A.P.; SÁ, C.A.S; MEDEIROS, H; GASTAL, M.C.P; TEIXEIRA, N.P; (1986) Estado atual do conhecimento sobre as rochas granitóides da porção sul da amazônia Oriental. Rev. Bras. De Geoc., v.16, p. 11-23.

DALL'AGNOL, R.; BETTENCOURT, J.S.; JORGE-JOÃO, X.S.; MEDEIROS, H.; COSTI, H.; MACAMBIRA, M.J.B. (1987) Granitogenesis in the Northern Brazilian Region: a Review. Revista Brasileira de Geociências, v.17, n.4, p. 382-403. 
DALL'AGNOL, R.; MACAMBIRA, M.J.B. (1992) Titanita-Biotita Granitos do Baixo Rio Uaupés, Província Rio Negro, Amazonas. Parte I: Geologia, Petrografia e Geocronologia. Revista Brasileira de Geociências, v. 22, n.1, p. 3-14.

DALL'AGNOL, R.; SCHUCKMANN, W.K.; BASEI, M.A.S.; SCHELLER, T. (1984) Novos dados geocronológicos e estudo de elementos traços de maciços graníticos anorogênicos da Amazônia oriental. Estado do Pará Brasil. Anais do Il Symposium Amazônico, Manaus, p.59-74.

DE PAOLO, D. J.; (1988) Neodymium isotope geochemistry. - An introduction. Sringer-Verlag. Minerals and Rocks. 187p., Berlim

DOCEGEO (1988) Revisão litoestratigráfica da Província Mineral de Carajás. In: CVRD e SBG (eds.) Anais XXXV Cong. Bras. de Geol. Belém, Pub. Esp., p. $11-54$.

EGAL, E.; MILÉSI, J.P.; LEDRU, P.; CAUTRU, J.P.; FREYSSINET, P.; THIĖBLEMONT, D.; VERNHET, Y.; (1994) Ressources minèrales et évolution lithostructurale de la Guyane. Carte thématique minière à $1 / 100$ 000. Feuille Cayenne. Rapport BRGM, R 38019, 59p.

FAURE, G; (1986) Principles of isotope geology. ( $2^{\text {nd }}$ Ed.) New York, John Wiley \& Sons, 589p.

FERNANDES, P.E.C.A.; PINHEIRO, S.S.; MONTALVÄO, R.G.M. de; ISSLER, R.S.; ABREU, A.S.; TASSINARI, C.C.G.; (1977) Geologia. In: Levantamento de Recursos Naturais, PROJETO RADAM, Folha SA. 19 Içá. V. 14, p. 21 123.

FERRAN, A.de; (1988) Depósito de ouro de Salamangone e Mutum, Calçoene, Amapá. In; Principais Depósitos minerais do Brasil. DNPM. MME. V.3 p. 581-587. Brasília.

FUCK R.A.; (1991a) Aprovada nova escala de tempo para o pré-Cambriano. Rev. Bras. De Geoc. V.21 (2), p. 182-183

FUCK, R.A.; (1991b) Subdivisão cronométrica do arqueano: Proposta da subcomissão de estratigrafia do pré-Cambriano. 
GALVIS, V.J.; HUGUETTI, G.A.; RUGE, T.P.; (1979) geologia de la amazonia Colombiana. Bol. Geol. Ingeominas, v. XXII, (3) p.1-153. Bogotá.

GASTAL, M.C.P.; MACAMBIRA, M.J.B.; MEDEIROS, M.; DALL'AGNOL, R.; (1987) Idades e geoquímica isotópica Rb-Sr do Granito Musa e Granodiorito Rio Maria, Amazônia Oriental. Geoch. Brasiliensis, v.1 (2), p. 247-259.

GAUDETTE, H.E.; OLSZEWSKI Jr., W.J. (1981) Geochronology of the basement rocks, Amazonas Territory, Venezuela. I Symposium Amazonico. Puerto Ayacucho, p. 24 - 25, Venezuela.

GAUDETTE, H.E.; MENDOZA, V.; HURLEY, P.M.; FAIRBAIRN, H.W. (1978) Geology and age of the Parguaza rapakivi granite, Venezuela. Bull. Geol. Soc. Amer. V. 89, p. 1335-1340.

GERALDES, M.C.; (1996), Estudos geoquímicos e isotópicos das mineralizações auríferas e rochas associadas da região de Pontes e Lacerda, (MT). Dissertação de Mestrado apresentada oa Instituto de Geociências da Universidade de Campinas. 104p.

GIBBS, A.K. (1980) Geology of Barama-Ma-Zaruni Supergroup of Guyana. PhD Dissertation, Harvard Univ. Microfilms Intern. Ann. Arbor Ml, $n$. 8102054, 387p.

GIBBS, A.K.; BARRON, C.K. (1983) The Guiyana shield reviwed, Episodes 2, p. $7-14$.

GIBBS, A.K.; WIRTH, K.R.; HIRATA, W.K.; OLSEWSKI, W.J. (1986) Age and composition of the Grão Pará Group volcanics, Serra dos Carajás. Revista Brasileira de Geociências, v.16, n.2, p.201-11.

GOMES, C.B.; CORDANI, U.G.; BASEI, M.A.S. (1975) Radiometric Ages fron the serra dos Carajás area northern Brazil. Geological of America Bull., Colorado $86,939-42$.

GONÇALEZ, M.C.B; DALL'AGNOL, R.; ANGELIM, E.P.V.; MACAMBIRA, M.J.B.; DELLA SENTA, N.; (1988) Geologia do Maciço anorogênico Cigano, vale do rio Paraupebas - Pa. Anias do XXXV Cong. Bras. De Geol., v.3 p. 1132-1146. Belém. 
GRUAU, G.; MARTIN, H.; LEVEQUE, B.; CAPDEVILA, R. (1985) Rb/Sr and $\mathrm{Sm}-\mathrm{Nd}$ Geochronology of lower Proterozoic granite greenstone terrains in French Guiana, South America (inédito), Precambrian Research, v.30, p. 6380.

HARRISON, T.M.; MAC DOUGAL, I.; (1981), Excess ${ }^{40} \mathrm{Ar}$ in metamorphic rocks from Broken Hill, New South Wales: Implications for ${ }^{40} \mathrm{Ar} /{ }^{39} \mathrm{Ar}$ age spectra and the thermal history of the region. E.P.S.L., v.55, p. $123-149$

HASUI, Y; HARALY, N.L.E.; SCHOBBENHAUS, C. (1984) Elementos geofísicos e geológicos da região amazônica: Subsídios para o modêlo geotectônico. Anais do Il Symposium Amazônico, p. 129-148

HOFFMAN, P.F.; (1989) Precambrian geology and tectonic history of North America. In: The geology of North America - An overview. The Geological Society of America. V. A, p. 447 - 511.

ISSLER, R.S. (1977) Esboço Geológico Geotectônico do Craton do Guaporé. Revista Brasileira de Geociências, v.7, n. 3, p. 177-211.

IWANUCH, W. (1981) Geologia da região do Domo do Sucunduri. São Paulo, 149p. (Dissertação de Mestrado) - Instituto de Geociências, Universidade de São Paulo.

JORGE JOÃO, X.S.; et. al. (1978), Projeto Sudoeste do Amapá, Relatório Final, CPRM - DNPM, $2 v$.

JORGE JOÃO X.S; MARINHO P.A.C.; (1982) Catametamorfitos arqueanos da região Centro-Leste do Território Federal do Amapá. Anais do $1^{\circ}$ Simpósio de Geologia Amazônica,v.2, p. 207-228.

JORGE JOÃO, X.S; et.al. (1979), Geologia da região do sudoeste do Amapá e norte do Pará. Projeto Sudoeste do Amapá. DNPM - CPRM, Sér. Geol., nº 10. Sec. Geol. Bás., n 7, 125p.

JORGE JOÃO, X.S.; SANTOS, C.A.; PROVOST, A.; (1985a) Magmatismo adamelítico Agua Branca (Folha Rio Mapuera, NW do Estado do Pará). Anais do $2^{\circ}$ Simpósio de Geologias Amazônica, v.2 p. 93-109. Belém. 
JORGE JOÃO, X.S.; SANTOS, C.A.; PROVOST, A.; (1985b) Granito Serra do Acari - geologia e implicação metalogenética ( Folha rio Mapuera, NW do Estado do Pará ). Anais do $2^{\circ}$ Simpósio de Geologia Amazônica, v..2 p. 7392. Belém.

KEATS, W.; (1976), The Roraima Formation in Guayana: a revised stratigraphy and a proposed environment of deposition. Memorias do II Congresso Latino Americano de Geologia, Caracas.v.2 p. 901-940.

KROONEMBERG, S.E.; (1976) Amphibolitic-facies and granulite-facies metamorphism in the Coeroeni - Lucie area, southwestern Suriname. Thesis, Amsterdam. Geol. Mijnb. Dienst. Sur. Med. 25, p. $109-289$.

LAFON, J.M.; MACAMBIRA, M.J.B.; PEREIRA, E.D.; SCHELLER, T.; (1990) Geocronologia $\mathrm{Rb}-\mathrm{Sr}$ em rochas totais e minerais do granodiorito Cumarú, Serra dos Gradaús, PA. Anais do XXXVI Cong. Bras. de Geol. , v.6 p.29292940. Natal.

LAFON, J.M.; SCHELLER, T.; (1994) Geocronologia Pb/Pb em zircões do Granodiorito Cumarú, Serra dos Gradaús, Pa. Anais do $4^{\circ}$ Simpósio de Geologia da Amazônia, Resumos, p. 312-324. Belém.

LEAL, J.W.L.; SILVA, G.H.; SANTOS, D.B.; TEIXEIRA, W.; LIMA, M.I.C.; FERNANDES, C.A.C.; PINTO, A.C. (1978) Levantamento de Recursos Naturais, vol. 16, Folha SC.20, Porto Velho. Geologia I, 184p. MME/DNPM.

MILÉSI, J.P.; EGAL, E.; LEDRU, P.; VERNHET, Y.; THIÈBLEMONT, D.; COCHERIE, A.; TEGYEY, M.; MARTEL - JANTIN, B.; LAGNY, P.; (1995), Les mineralisations du Nord de la Guyane Française, dans leur cadre geologique. Chronique de la recherche minière, $n^{\circ} 518$, p. 5 - 58

LIMA, M.I.C.; MONTALVÄO, R.G.M. de; ISSLER, R.S.; OLIVEIRA, A.S.; BASEI, M.A.S.; ARAÚJO, J.F.V. de; SILVA, G.G.; (1974), Geologia, In: Levantamento de Recursos Naturais, PROJETORADAM - DNPM, Folha NA/NB 22, Macapá. Rio de Janeiro 
LIMA, M.I.C. de; OLIVEIRA, E.P.; TASSINARI, C.C.G. (1982) Cinturöes granulíticos da porção setentrional do Craton Amazônico. Anais do I Simpósio de Geologia da Amazônia, Belém, v.1, p.147-62.

LIMA, M.I.C.; SANTOS, J.O.S.; SIGA JR.; O. (1986) Os terrenos de alto grau do Craton Amazónico. In: XXXIV Congresso Brasileiro de Geologia, Goiânia. v.2, p. $751-65$.

LITHERLAND, M. (Co-ordinator) (1986) The geology and mineral resources of the Bolivian Precambrian Shreld. Overseas Mem. Br. Geol. Survey, v. 9, $153 p$.

LUGMAIR G.W.; SCHEIRIM, N.B. MARTI, K; (1975) Sm-Nd age of Apollo 17 basalt 75075: evidence for early differentiation of lunar exterior. Proc. Lunar Plant. Sci. Conf., $6^{\text {th }}$, p. 1419-1429.

MACAMBIRA, M.J.B.; TEIXEIRA, J.T.; DAOUD, W.K.; COSTI, H.T.; (1987) Geochemistry, mineralizations and age of tin-bearing granites from Pitinga, NW Brazil. Rev. Bras. de Geoc. V.17 (4) p. 562-570.

MACAMBIRA, M.J.B; (1992) Chronologie U-Pb, Rb-Sr, K-Ar et croissance de la croûte continentale dans IÁmazonie du Sud-Est; exemple de la région de Rio Maria, Province de Carajás, Brésil. Univ. De Montpellier II, 212p. Tese de doutorado.

MACAMBIRA, M.J.B.; LAFON, J.M.; DALL.AGNOL, R.; COSTI, H.T.; JORGE JOÃO, X.S. (1992) Geocronologia da granitogênese da província Amazônia Central Brasileira: uma revisão. Revista Brasileira de Geociências, v.20, n. $1-4$, p. $258-266$.

MACAMBIRA, M.J.B.; LANCELOT, J. (1991a) Em busca do embasamento arqueano da região de Rio Maria, sudeste do Estado do Pará. III Simpósio de Geologia da Amazônia, Belém. Anais, p. 49-69.

MACAMBIRA, M.J.B.; LANCELOT, J; (1991b) História arqueana da região do Rio Maria, SE do Estado do Pará, registrada em zircões detríticos de greenstone belt e de cobertura plaraformal. Anais do $3^{\circ}$ Simposio de Geologia da Amazônia, p.59-69. Belem 
MACAMBIRA, M.J.B.; LANCELOT, J.; (1992) Idade U.Pb em zircões de metavulcânicas do greenstone do Supergrupo Andorinhas; delimitante da estratigrafia arqueana de Carajás, Estado do Pará. Anais do XXXVII Cong. Bras. De Geol., Res. V.2 p. 188-189. São Paulo

MACHADO, N.; LINDEMAYER, Z;; LINDEMAYER, D.; (1988) Geocronologia U$\mathrm{Pb}$ da Província Mineral de Carajás, Pará: resultados preliminares. Anais do VII Congresso Latino americano de Geologia, p.339-347, Belém.

MACHADO, N.; LINDEMAYER, Z.; KROGH, T.E.; LINDEMAYER, D.; (1991) U$\mathrm{Pb}$ geochronology of archean magmatism and basement reactivation in the Carajás area. Amazon shield, Brazil. Precambrian Res. V. 49, p.329-354.

MASCARENHAS, J.F; GARCIA, T.W; (1989) Mapa Geocronológico do Estado da Bahia, 1/1000000, Texto explicativo, S.G.M. - SME, Salvador, Bahia.

MELO, A.F.F. de; et. al.; (1980). Projeto Tapajós - Sucunduri. Relatório Final, DNPM - CPRM. 8v., AT. DNPM n 2633.

MENDOZA,S.A; (1975) Estudios geoquímicos del no tectonizado granito rapakivi del Parguaza, noroeste Guayana Venezolana. X Conf. Geol. InterGuianas, Belém, p.628-656.

MENDOZA, S.V. (1977), Petrogenesis de rocas volcanicas (piroclásticas) precambricas del noroeste del Escudo de Guayana, Venezuela. Atas do V Congr. Geol. Venez., v.1, p. 363-404. Caracas.

MENEZES, R.G.; LOPES, I.; BEZERRA, J.R.L. (1993), Folha Pontes e Lacerda $1: 100$ 000. Carta Geológica e Texto explicativo. Prog. de Lev. Geol. Bas. CPRM - DNPM. $101 \mathrm{p}$.

MEZGER, K.; ESSENE, E.J.; HALLIDAY, A.N.; (1992), Closure temperature of the $\mathrm{Sm} / \mathrm{Nd}$ system in metamorphic garnets. Earth Plan. Sci. Let. v.113, p. $397-410$.

MICHARD, A; GURRIET, P.; SOUNDANT, M; ALBARÉDE, F; (1985) Nd isotopes in French Phanerozoic shales: external vs. Internal aspects of crustal evolution. Geochim. Cosmochim. Acta. V. 49 p. 601-610 
MONTALVÃO, B.M.G.; TASSINARI, C.C.G.; TEIXEIRA, W.; VASCONI, A.V. (1988) Caracterização Geocronológica $\mathrm{Rb} / \mathrm{Sr}$ dos terrenos granodioríticos e trondjemiticos da região de Rio Maria, Sul da Serra dos Carajás. In: Congresso Brasileiro de Geologia. Belém. Anais, v.3, p. 1478-87.

MONTALVÃO, R.M.G. de; MUNIZ, M.B.; ISSLER, R.S.; DALL'AGNOL, R.; LIMA, M.IC. de; FERNANDES, P.E.C.A.; SILVA, G.G. (1975) FOLHA NA-20 Boa Vista e parte das Folhas NA.21 Tumucumaque, NB.20. Roraima e NB.21. I Geologia. Levantamento de Recursos Naturais, v.8, 135p.

MONTALVÃO, R.M.G. de; TASSINARI, C.C.G. - 1984 - Geocronologia précambriana do Território Federal do Amapá (Brasil). II Simpósio Amazônico, Manaus. Anais, p. 53-8. MME/DNPM.

MONTALVÃO, R.M.G. de; TASSINARI, C.C.G.; BEZERRA, P.E.L.; PRADO, P. (1984) Geocronologia dos granitóides e gnaisses das regiões do Rio Maria, fazenda Mata Geral e Rio Itacaiunas, Sul do Pará (Distrito Carajás-Cumaru). Anais do XXXIII Congresso Brasileiro de Geologia, Rio de Janeiro, p. 275766.

MONTEIRO, H.; MACEDO, P.M.; SILVA, M.D.; MORAES, A.A.; MARCHETO, C.M.L. (1986), O greenstone belt do alto Jaurú. Anais do XXXIV Cong. Bras. de Geol., v. 2 p. 630 - 646. Goiânia.

MONTGOMERY, C.; HURLEY, P.M; (1978) Total rock U-Pb and Rb-Sr systematics in the Imataca Series. Guyana Shield, Venezuela. Earth Planetary Science letters, v.39, p.281-290.

MOORBATH, S.; TAYLOR, P.N. (1981) Isotopic evidence for continental growth in the Precambrian. In: Kroner, A. (ed) Precambrian Plate Tectonics. Elsevier Amsterdã. p. 491-525.

MOUGEOT, R.; RESPAUT,J.P.; BRIQUEU, L.; LEDRU, P.; MILESI, J.P.; LEROUGE, C.; MARCOUX, E.; (1996) Isotope Geochemistry constraints for $\mathrm{Cu}, \mathrm{Au}$ mineralizations and evolution of the Carajás Province (Para - Brazil). Anais XXXIX Cong. Bras. de Geol. v. 7, p. 321 - 324. Salvador. 
NAKAMURA, N; TATSUMOTO,M; NUNES,P.D; UNRUSH,D.M.; SCHW,A.P.; WILDEMAN, T.R; (1976) 4 by old clast in boulder 7, Apollo 17: a comprehensive chronological study by U-Pb, $\mathrm{Rb}-\mathrm{Sr}$ and $\mathrm{Sm}-\mathrm{Nd}$ methods. Proc. Lunar Planet. Sci. Conf. $7^{\text {th }}$, v.2, p. 2309-2333.

OLIVEIRA, A.S.; FERNANDES, C.A.C.; ISSLER, R.S.; ABREU, A.S.; MONTALVÃO, R.M.G. de; TEIXEIRA, W. (1975) Folha NA.21 Tumucumaque e parte da Folha NB.21. I Geologia. Levantamento de Recursos Naturais, v.9, 97p.

OLSEWSKI, W.J.; GAUDETTE, H.E.; SANTOS, J.O. (1989) Isotopic age results from the shield areas of western Brazil. GSA. Abstracts with programs. v. 20, p. 76 .

PAYOLLA, B.L. (1994) As rochas graníticas e sieníticas da Cachoeira Teotônio e Santo Antonio, Rio Madeira, Porto Velho, Rondónia: Geologia, petrografia e geoquímica. Unpublished Msc Thesis. Universidade de Brasilia, 170p.

PESSOA, M.R.; SANTIAGO, A.F.; ANDRADE, A.F. NASCIMENTO, J.O.; SANTOS, J.O; OLIVEIRA, J.R.; LOPES, R.C.; PRAZERES, W.V. (1977) Projeto Jamanxim; Relatório final. CPRM / DNPM. Relat. Inédito. 9 v. , Manaus.

PIMENTEL, M.M.; MACHADO, N.; (1994), Geocronologia U-Pb dos terrenos granito-greenstone de Rio Maria, Pará. Anais do XXXVIII Cong. Bras. De Geol. Resumos. V.2, p. 390-391. Camboriú, Santa Cararina.

PINHEIRO, S.S.; FERNANDES, P.E.C.A.; PEREIRA, E.R.; VASCONCELOS, E.G.; PINTO, A. C.; MONTALVÃO, R.M.G.; ISSLER, R.S.; DALL'AGNOL, R.; TEIXEIRA, W.; FERNANDES, C.A.C. (1976) Geologia. In: Departamento Nacional da Produção Mineral. Projeto RADAM. Folha NA.19 Pico da Neblina. Rio de Janeiro, Levantamento de Recursos Naturais, 11, p.19-137.

PLUMB, K.A. (1991) New Precambrian time-scale. Episodes, v. 14, n.2 p. 139140.

PRIEM, H.N.A.; BOELRIJK, N.A.I.M.; HEBEDA, E.H.; VERDUMEN, E.A.Th.; BON, E.H. - 1971 - Granitic Complexes and Associated tin mineralization of 
"greeeenville" Age in Rondônia, Western Brazil. Geol. Soc. Am. Bull. v.82, p. 1095-102.

PRIEM, H.N.A (1973) Provisional isotopegeochronological framework for some major events in the geologic column of Suriname. Geol. Mijnb. Dienst. Sur., Med. 22, p. 9-16.

PRIEM, H.N.A.; KROONEMBERG, S.B.; VERDURMEN, E.A.Th.; VERSHURE, R.H. (1977) Isotopic ages in the high-grade metamorphic Coeroeni Group, SW, Suriname. Geol. \& Mijnb. V.56, p. 155-160.

PRIEM, H.N.A; BON, E.H.; VERDURMEN, E.A.TH; BETTENCOURT, J.S; (1989) Rb-Sr chronology of precambrian crustal evolution in Rondonia (western margin of the Amazonian craton), Brazil. J. South Am. Earth Sci., v. 2 p. $163-170$

PURDY, J.W.; JAEGER, E.; (1976), K - Ar ages on rock forming minerals from the central Alps. Memorie di Padova, XXX.

REDENÇÃO E SILVA; et. al.; (1985), Integração Mineral no Município de Itaituba, PRIMAZ, Programa de Integração Mineral em Municípios da amazônia. CPRM. 53p. Belem.

RENNE, P.R.; ONSTOTT, T.C.; JORGE JOÃO, X.S. (1988) 40Ar-39Ar and paleomagnétic results from the Guaporé shield: further implications for the nature of the middle-late proterozoic mobile belts of Gondwanaland. Anais do VII congresso Latino americano de Geologia, p. 348-362. Belém.

RIZZOTTO, G.L.; QUADROS, M.L.E.S.; SACANDOLARA, J.E.; SILVA, C.R.; BAHIA, R.B.C.; (1995), Posicionamento tectono - estratigráfico da Sequência Metavulcano-sedimentar Roosevelt, na região limítrofe dos Estados de RO / MT. Atas do V Simp. Nac. de Est. Tect., p. $310-313$. Gramado.

RODRIGUES, E.; LAFON, J.M.; SCHELLER, T.; (1992) Geocronologia Pb-Pb da Província Mineral de Carajás. Primeiros resultados. Anais do XXXVII Cong. Bras. de Geol. Resumos. V.1, p. 183-184, São Paulo. 
SADOWSKI, G.R.; BETTENCOURT, J.S; (1996) Mesoproterozoic tectonic correlations between eastern Laurentia and the western border of the Amazonian Craton. Precambrian Res. V.76, p. 213 - 227.

SANTOS, J.O.S. (1982) Granitos proterozóicos da plataforma Amazônica. Atas do V Congresso Latino Americano de Geologia, v. 2 p. 97 - 112 Buenos Aires, Argentina.

SANTOS, J.O.; OLSZEWSKI, W. (1988) Idade dos granulitos tipo Kanuku em Roraima, In: Anais do VII Congresso Latino Americano de Geologia, v.1, p.112 - 223. Belém.

SANTOS, J.O.S.; REIS NETO, J.M. (1982) Algumas idades de rochas graníticas do Craton Amazônico. Anais do XXXII Congresso Brasileiro de Geologia, Salvador. v.1, p. 339-47.

SANTOS, R.O.B. et al (1979) Geologia. Departamento Nacional da Produção Mineral, Projeto RADAMBRASIL. Folha SD.20 Guaporé, Rio de Janeiro (Levantamento de Recursos Naturais, 19).

SANTOS, M.V.; TASSINARI, C.C.G.; SOUZA FILHO, E.E.; TEIXEIRA, W.; RIBEIRO, A.C.O.; PAYOLLA, B.C.; VASCONI, A.V.; (1988) Litoestratigrafia das rochas pré-cambrianas na Bacia do médio Rio Xingú, Altamira, Pará. Anais do VII Cong. Latin. Americ. de Geol., v1, p. 363 -377. Belém.

SATO, K; TASSINARI, C.C.G. (1996), Idades dos principais eventos de diferenciação manto - crosta do cráton Amazônico, com base em idades modelo Sm - Nd. V Simp. de Geol. da Amazônia. Bol. de Res. Exp. p. 388 390. Belém.

SCANDOLARA, J.E; SILVA,C.R; RIZZOTTO, G.J.; QUADROS, L.E.S, BAHIA, R.B.C (1995) Compartimentação litoestrutural da porção ocidental do cráton Amazônico, Estado de Rondônia. Atas do V Simp. Nac. De Estud. Tect. (SNET), p. 84 - 86 Gramado.

SCHOBBENHAUS, C.; CAMPOS, A. de; DERZE, G.R.; ASMUS, H.E. (Coordinators) (1984) Geologic Map of Brazil and adjoining Ocean Floor Including Mineral Deposits Scale 1:2.500.000 DNPM-MME. 
SCHOBBENHAUS, C.; HOPPE, A.; LORK, A.; BAUMANN, A. (1994) Idade U$\mathrm{Pb}$ do magmatismo Uatumã no Norte do Craton Amazônico Escudos das Guianas (Brasil) - Primeiros Resultados. In: XXXVIII Congresso Brasileiro de Geologia. Camboriú. Boletim Resumos Expandidos, p. 395-7.

SILVA, G.G; LIMA, M.I.C; ANDRADE, A.R.F; ISSLER, R.S.; GUIMARÃES, G; (1974) Geologia in: PROJETO RADAM , Folhas SB 22 Araguaia e SC 22 Tocantins. Levantamento de Recursos Naturais. Rio de Janeiro v.4. p. 3 45.

SILVA, G.H.; LEAL, J.W.L.; MONTALVÃO, R.M.G.; BEZERRA, P.E.L.; PIMENTA, O.N.S.; TASSINARI, C.C.G.; FERNANDES, C.A.C.; (1980) Geologia in: MME/DNPM - Projeto RADAMBRASIL, Juruena. Rio de Janeiro. Levantamento de Recursos Naturais, 20, p. 21-116.

SILVA, C.R; SCANDOLARA, J.E; RIZZOTTO, M.L; QUADROS E.S; BAHIA, R.B.C; (1995) Contribuição a evolução tectono-estrutural das rochas mesoproterozóicas do Estado de Rondônia. Atas do V Simp. Nac. de Est. Tect. (SNET), p. 87 - 89 Gramado.

SOUZA, S.R.B.; (1996) Estudo Geocronológico e de geoquímica isotópica da área de Pojuca (Província Mineral de Carajás-PA), Dissertação de mestrado apresentada ao CPGG/UFPA, 106p.

STEIGER, R.H.; JÄEGER, E. (1977) Sub comission on Geochronology: convention on the use of secay constants in Geo and Cosmochronology. Earth and Planetary Science Letters, v. 36, p. 359-62.

TASSINARI, C.C.G. (1981) Evolução tectônica da Província Rio NegroJuruena na região Amazônica. São Paulo, 2 v., 99p. (Dissertação de Mestrado) - Instituto de Geociências, Universidade de São Paulo.

TASSINARI, C.C.G. (1984) A porção ocidental do Craton Amazônico: Evidências isotópicas de acreção continental no Proterozóico Médio. Anais do Il Symposium Amazônico. Manaus. DNPM, p. 439-46. 
TASSINARI, C.C.G.; BASEI, M.A.S.B. (1980) Primeiros resultados arqueanos em migmatitos da região da serra do Tapirapé, Mato Grosso. Anais do XXXI Congresso Brasileiro de Geologia, 5, 2744-2751. Camboriú, Santa Catarina.

TASSINARI, C.C.G.; HIRATA, W.K.; KAWASHITA, K. (1982) Geologic Evolution of the Serra dos Carajás, Pará-Brazil. International Symposium on Archaean and Early Proterozoic, Geology Evolution and Metallogenesis. Salvador, Bahia. Revista Brasileira de Geologia, v.12, n. 1, 2 e 3, p.263-7).

TASSINARI, C.C.G.; SIGA JR.; O.; TEIXEIRA, W. (1984) Épocas Metalogenéticas Relacionadas a Granitogênese do Craton Amazônico. Anais do XXXII Congresso Brasileiro de Geologia, Rio de Janeiro, p. 296377.

TASSINARI, C.C.G.; TEIXEIRA, W. SIGA JR., O. (1978) Considerações cronoestratigráficas da região das Chapadas do Cahimbo e Dardanelos. In: XXX Congresso Brasileiro de Geologia, Recife. Anais, v.1, p. 477-90.

TASSINARI, C.C.G.; TEIXEIRA, W.; SIGA Jr.; KAWASHITA, K.; CORDANI, U.G; (1987) Geological evolution and evaluation of recent geochronological data in amazonian craton. Ext. Abst. Final Meeting of Working Group of IGCP Project 204. p. 20-31 - Carajás, Brasil.

TASSINARI, C.C.G; CORDANI, U.G; NUTMAN, A.P.; VAN SCHMUSS,W.R; BETTENCOURT, J.S; TAYLOR, P.N. (1996) Geochronological systematics on basement rocks from the Rio Negro - Juruena Province (Amazonian (raton), and tectonic implications. International Geology Review, V. 38, $n^{\circ}$ 2, p. 161 - 175. USA.

TEIXEIRA, J.B.G.; EGGLER, D.H.; (1994) Petrology, Geochemistry, and Tectonic setting of Archean basaltic and dioritic rocks from the $\mathrm{N}-4$ Iron Deposit, Serra dos Carajás, Pará, Brazil. Acta Geol. Leopoldensia, v.40, p. $71-114$.

TEIXEIRA, W. (1978) Significação tectônica do magmatismo anorogênico précambriano básico e alcalino na região Amazônica. XXX Congresso Brasileiro de Geologia. Recife, PE. Anais (1):477-90. 
TEIXEIRA, W.; (1990) The Proterozoic mafic dyke swarms and alkaline intrusions in the Amazonian craton, South America, and their tectonic implication, based on $\mathrm{Rb}-\mathrm{Sr}, \mathrm{K}-\mathrm{Ar}$ an ${ }^{40} \mathrm{Ar}-{ }^{39} \mathrm{Ar}$ geochronology. In: A.J. Parker, P.C. Rockwwod and D.H. Tucker (Eds), Mafic dykes and emplacement mechanisms. A.A. Balkema, Roterdam, Brookfield, p. 285-293.

TEIXEIRA,W.; BASEI, M.A.S.; TASSINARI, C.C.G. (1976) Geocronologia das Folhas Tumucumaque e Santarém. XXIX Congresso Brasileiro Geologia. Resumos, p.193.

TEIXEIRA, W.; TASSINARI, C.C.G. (1984) Caracterização geocronológica da província Rondoniana e suas implicações geoctectônicas. Anais do ॥ Symposium Amazônico, Manaus, MME/DNPM, p. 87-102.

TEIXEIRA, W.; OJIMA, S.K.; KAWASHITA, K.; (1985) Reconhecimento Geológico da Guiana Francesa: Novos dados, Integração e Implicações Tectônicas. Anais II Simpósio de Geologia da amazônia. V.1, p. 194-207. Belém.

TEIXEIRA, W.; TASSINARI, C.C.G.; CORDANI, U.G. KAWASHITA, K. (1989) A Review of the geochronology of the Amazonian Craton: Tectonic Implications. Precambrian Research, v. 42, p. 213-27.

TOSDAL, R.M.; bETTENCOURT, J.S.; LEITE Jr., W.B.; PAYOLLA, B.L.; (1996), U - Pb geochronologic framework of the Mesoproterozoic rapakivi granites of Rondônia tin province, Brazil. Anais do XXXIX Cong. Bras. de Geol., v.7 p. 337 - 339. Salvador.

VEIGA JR., J.P.; NUNES, A.C.B.; SOUZA, E.C.; SANTOS, J.O.S.; AMARAL, J.G. do; PESSOA, M.R.; SOUZA, S.A. de (1979) Projeto sulfetos de Uatumã. Relat. Final. In: Brasil, Ministério das Minas e Energia, Departamento Nacional da Produção Mineral. Manaus. Convênio DNPM/CPRM. Relat. Inédito, $6 \mathrm{~V}$.

VIGNOL, L.M.; (1987) Etudes geocemiques des granulites du Brèsil et de la zone d'Ivrea: Les elements ( $k, \mathrm{Rb}, \mathrm{Sr}, \mathrm{Sm}, \mathrm{Nd})$ et les isotopes radiogeniques 
(Sr, Nd). Diplome d'etudes approfondies de geochemie. Université Paris VII, Inst. De Physique du Globe de Paris. p.23.

WAGNER, G.A.; REIMER, G.M.; JAEGER, E.; (1977) Cooling ages derived by apatite fission track, mica $\mathrm{Rb}-\mathrm{Sr}$ and $\mathrm{K}-\mathrm{Ar}$ dating: the uplift and cooling history of the central Alps. Mem. Inst. Geol. Mineral. Univ. di Padova, XXX $28 p$.

WETHERIL, G.W.; (1956), Discordant uranium - lead ages. Trans. Amer. Geophys. Union, 37, p. 320 - 326.

WIRTH, K.R.; GIBBS, A.K.; OLSZEWSKI, W.J. (1986) U-Pb ages of zircons from the Grão Pará Group and Serra dos Carajás Granite, Pará, Brazil, Rev. Bras. De Geoc., v.16, p. 195-200 
APÊNDICE 1

TABELAS DOS DADOS GEOCRONOLÓGICOS (INFORMAÇÕES GERAIS SOBRE AS AMOSTRAS DATADAS) 
As tabelas apresentadas neste Apêndice contém as informações gerais sobre as amostras datadas, como por exemplo, as localizações, unidades geológicas a que pertencem, litologias, referências geográficas, referências bibliográficas e métodos pelos quais foram datadas.

Cabe ressaltar que, neste banco de dados não estão incluidas amostras que não dispunham de dados analíticos completos e nem aquelas cujas localizações não puderam ser resgatadas com uma confiabilidade de até $30 \mathrm{~km}$. Além disso, muitas das amostras aqui reportadas não estão incluidas em unidades geológicas definidas e portanto, nesse caso, esse ítem permaneceu em branco.

Os números de ordem das amostras datadas estão precedidos pelas iniciais das folhas ao milionésimo onde estão localizadas.

Para a consulta dos dados analíticos completos das amostras que constam deste Apêndice, o leitor deverá consultar o Apêndice 2, onde as amostras estão agrupadas conforme a metodologia geocronológica utilisada. Cumpre assinalar que este Banco de Dados poderá também ser acessado através de computador pelo programa para PC ACCES 2. 


\begin{tabular}{|c|c|c|c|c|c|c|c|c|c|c|c|c|}
\hline Ordem & Método & $\mathbf{N}^{0}$. Campo & Folha & Litologia & Material Anallsado & Unidade Geológica & Latifude & & Longitude & $\begin{array}{l}\text { Prec } \\
(\mathbf{K m})\end{array}$ & Ref & Referêncla Geográfica \\
\hline $\mathrm{BE} 1$ & K-Ar & RP 1 PA & SA 22 & Basalto & Rocha total & & $-1,0298$ & - & 54.0075 & 10 & 14 & E Rio Maecuru \\
\hline $\mathrm{BE} 10$ & $\mathrm{~K}-\mathrm{Ar}$ & AS 297 & $5 A 22$ & Basalto & Rocha total & & $-3,9167$ & - & 49.6457 & 10 & 14 & Rio Tocantins \\
\hline BE 11 & K-Ar & JD-1-PA & SA 22 & Gnaisse & Biotita & Embasamento & $-1,9333$ & - & 50.3667 & 10 & 46 & Rio Pará \\
\hline$\overline{B E} 12$ & K-Ar & CO-1-PA & SA 22 & Anfibolito & Hornblenda & Embasamento & $-0,2500$ & - & 49 & 10 & 46 & NE liha Marajó \\
\hline $\mathrm{BE} 13$ & K-Ar & $M 143$ & $\operatorname{SA2}$ & Diabásio & Plagiockásio & & $-1,8876$ & $\because$ & 53.7753 & 10 & 69 & Rio Amazonas \\
\hline $\mathrm{BE} 2$ & K-Ar & IBST 1 PA & SA 22 & Diabásio & Rocha total & & $-1,2870$ & $\because$ & 51.2843 & 10 & 14 & NW Breves \\
\hline BE 3 & K-Ar & $\overline{A B} 4$ & SA 22 & Diabásio & Plagiociásio & & $-3,6301$ & $\because$ & 53.5055 & 10 & 14 & N Rio Irin \\
\hline BE 4 & K-Ar & $\overline{A B 9}$ & SA 22 & Diabásio & Plagioclásio & & $-3,7557$ & - & 53.615 & 10 & 14 & N Rio Irini \\
\hline BE 5 & K-Ar & $A B 7$ & SA 22 & Diabásio & Plagioclásio & & 3,7135 & - & 53.5327 & 10 & 14 & N Rio Iriri \\
\hline$\overline{\mathrm{BE}} 6$ & K-Ar & PA 264 & SA 22 & Basalto & Rocha total & & $-3,6961$ & 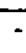 & 51.605 & 10 & 14 & Xingu river \\
\hline $\mathrm{BE} 7$ & K-Ar & 66466 & SA 22 & Diabásio & Rocha total & & $-3,9596$ & $=$ & 50.656 & 10 & 14 & E Rio Bacajáa \\
\hline $\mathrm{BE} 8$ & K-Ar & AS 296 & $\overline{S A} 22$ & Basalto & Rocha total & & - 3,9833 & - & 49.6124 & 10 & 14 & Rio Tocantins \\
\hline $\mathrm{BE} 9$ & $\mathrm{~K}-\mathrm{Ar}$ & AP 106 & SA22 & Basalto & Rocha total & & - 3,9833 & $\because$ & 49.7124 & 10 & 14 & Rio Tocantins \\
\hline C1.i & $\mathrm{U}-\mathrm{Pb}$ & $x A-1$ & SB $2215 C 22$ & Anfibolito & Zircăo & Embasamento & $-6,0333$ & - & 49.5 & 10 & 1 & SW Marabá \\
\hline $\mathrm{C1.2}$ & $\mathrm{U}-\mathrm{Pb}$ & XA-2 & $S 822 / 5 C 22$ & Anfibolito & Titanita & Embasamento & $-6,0033$ & - & 49.5 & 10 & 1 & SW Marabá \\
\hline C 1.3 & $\mathrm{U}-\mathrm{Pb}$ & $\overline{X B-1}$ & $\mathrm{SB} 22 \sqrt{S C} 22$ & Granito & Zircaro & Embasamento & $-6,0333$ & - & 49.5 & 10 & 1 & SW Marabá \\
\hline C $1 . \overline{4}$ & $\mathrm{U}-\mathrm{Pb}$ & $\mathrm{XB}-2$ & SB 22/SC 22 & Granito & Zircáo & Embasamento & $-6,00333$ & $=$ & 49.5 & 10 & 1 & SW Marabá \\
\hline C 1.5 & U-Pb & $x c-1$ & $\mathrm{SB} 22 / \mathrm{SC} 22$ & Gnaisse & Zircăo & Embasamento & $-6,0333$ & - & 49.5 & 10 & 1 & SW Marabá \\
\hline C1.6 & UPb & $x c-2$ & $\mathrm{SB} 22 / \mathrm{SC} 22$ & Gnaisse & Zircaso & Embasamento & $-6,0333$ & 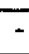 & 49.5 & 10 & 1 & SW Marabá \\
\hline C 1.7 & U-PB & $x c-3$ & SB 221SC 22 & Gnaisse & Zirca & Embasamento & $-6,0333$ & - & 49.5 & 10 & 1 & SW Marabá \\
\hline C1.8 & U-Pb & $X D-1$ & SB 22/SC 22 & Gnaisse & Zircăo & Embasamento & $-6,0033$ & - & 49.5 & 10 & 1 & S Rio ltacaiunas \\
\hline C 10 & $\mathrm{U}-\mathrm{Pb}$ & SA-1 & SB 22/SC 22 & BIF & Monazita & Grupo Salobo & $-5,8167$ & - & 50.5333 & 10 & 1 & S Rio Itacaiunnas \\
\hline C 100.1 & $\mathrm{Rb}-\mathrm{Sr}$ & AVR- $-\infty C$ & $\mathrm{SB} 22 / \mathrm{SC} 22$ & Tonalito & Rocha total & Granodionito Rio Maria & $-6,7333$ & - & 51.067 & 20 & 27 & Serra Seringa \\
\hline C 101.1 & $\mathrm{Rb}-\mathrm{Sr}$ & AVR-GD & SB $22 / S C 22$ & Tonalito & Rocha total & Granodiorito Rio Maria & $-6,7333$ & - & 51.067 & 20 & 27 & Serra Seringa \\
\hline$C_{1021}$ & $R \mathrm{~b}-\mathrm{Sr}$ & AVR-@OH & SB 22/SC 22 & Tonalito & Rocha total & Granodionito Rio Maria & $-6,7333$ & - & 51.067 & 20 & 27 & Serra Seringa \\
\hline c 1031 & $R b-S r$ & AVR- $\infty B$ & SB 22/SC 22 & Tonalito & Rocha total & Granodiorito Rio Maria & $-6,7333$ & $=$ & 51.067 & 20 & 27 & Serra Seringa \\
\hline$\overline{C 104.1}$ & $\mathrm{Rb}-\mathrm{Sr}$ & AVR-EOE & SB $2215 \mathrm{SC} 22$ & Tonalito & Rocha total & Granodionto Rio Maria & $-6,7333$ & - & 51.067 & 20 & 27 & Serra Seringa \\
\hline C 104.2 & $\mathrm{Rb}-\mathrm{Sr}$ & AVR- $-9 E^{*}$ & SB 22/SC 22 & Tonalito & Rocha total & Granodiorito Rio Maria & $-6,7333$ & $=$ & 51.067 & 20 & 27 & Serra Seringa \\
\hline C 105.1 & $\mathrm{Rb}-\mathrm{Sr}$ & EMR-17 & $5 B 2215 C 22$ & Tonalito & Rocha total & Granodiorito Rio Maria & $-6,7333$ & - & 51.067 & 20 & 27 & Serra Seringa \\
\hline C 106.1 & $\mathrm{Rb}-\mathrm{Sr}$ & AVR-256C & SB 221SC 22 & MonzoGranito & Rocha total & Granodiorito Rio Maria & $-6,7333$ & - & 51.2167 & 20 & 27 & Serra Seringa \\
\hline C 107.1 & $\mathrm{Rb}-\mathrm{Sr}$ & AVR-253 & $\mathrm{SB} 221 \mathrm{SC} 22$ & MonzoGranito & Rocha total & Granodiorito Rio Maria & $-6,7333$ & $=$ & 51.2167 & 20 & 27 & Serra Seringa \\
\hline C 108.1 & $\overline{R b}-\mathrm{Sr}$ & AVR-184B & SB $22 / \mathrm{SC} 22$ & MonzoGranito & Rocha total & Granodionito Rio Maria & -6.7333 & - & 51.2167 & 20 & 27 & Serra Seringa \\
\hline C 100.1 & $\mathrm{Rb}-\mathrm{Sr}$ & AVR-184G & $\mathrm{SB} 221 \mathrm{SC} 22$ & MonzoGranito & Rocha total & Granodiorito Rio Maria & $-6,7333$ & - & 51.2167 & 20 & 27 & Serra Seringa \\
\hline
\end{tabular}




\begin{tabular}{|c|c|c|c|c|c|c|c|c|c|c|c|c|}
\hline Ordem & Método & No. Campo & Folha & Lttologia & Material Analisado & Unldade Geológlca & Latitude & & ngltude & $\begin{array}{l}\text { Prec } \\
(\mathrm{Km})\end{array}$ & Ref & Referencla Geográflca \\
\hline C11.1 & $\mathrm{UPb}$ & $\mathrm{KA}-10-88 \mathrm{~B}(1)$ & $\mathrm{SB} 221 \mathrm{SC} 22$ & Granodionito & Zirca & Granito Carajás & $-6,1833$ & - & 50.2667 & 10 & 1 & S Rio Itacaiúnas \\
\hline C11.2 & $\overline{\mathrm{PBb}}$ & KA-10-88B (2) & $582215 C 22$ & Granodionto & Zirca & Granito Carajás & $-6,1833$ & - & 50.2667 & 10 & 1 & S Rio ltacaiúnas \\
\hline C 110.1 & $\mathrm{Rb}-\mathrm{St}$ & ÁVR-184A & $58221 \mathrm{SC} 22$ & MorzoGranito & Rocha total & Granodiorito Rio Maria & $-6,7333$ & - & 51.2167 & 20 & 27 & Serra Seringa \\
\hline C 111.1 & $\mathrm{Rb}-\mathrm{Sr}$ & AVR-184F & SB 22/SC 22 & MonzoGranito & Rocha tokal & Granodiorito Rio Maria & $-6,7333$ & - & 51.2167 & 20 & 27 & Serra Seringa \\
\hline C 112.1 & $R b-s r$ & AVR-184D & SB 22/SC 22 & Monzogranito & Rocha total & Granodiorito Rio Maria & $-6,7333$ & - & 51.2167 & 20 & 27 & Serra Seringa \\
\hline C 113.1 & $\mathrm{Rb}-\mathrm{Sr}$ & ĀVR-184E & $S B 2215 C 22$ & Monzo Granito & Rocha total & \begin{tabular}{|c|} 
Granodionto Rio Maria \\
\end{tabular} & $-6,7333$ & - & 51.2167 & 20 & 27 & Serra Seringa \\
\hline C 114.1 & $\mathrm{Rb}-\mathrm{Sr}$ & AVR-3168 & SB 22/SC 22 & MonzoGranito & Rocha total & Granodiorito Rio Maria & $-6,7333$ & $\cdot$ & 51.2167 & 20 & 27 & Serra Seringa \\
\hline C 115.1 & $\mathrm{Rb}-\mathrm{Sr}$ & AVR-315A & SB 22/SC 22 & MonzoGranito & Rocha total & Granodiorito Rio Maria & $-6,7333$ & - & 51.2167 & 20 & 27 & Serra Seringa \\
\hline C 116.1 & $\mathrm{Rb}-\mathrm{Sr}$ & $E M-R-85 C$ & SB 22/SC 22 & Granito & Rocha total & Metanic Veto G i lerme & $-6,7833$ & - & 51.15 & 20 & 27 & Serra Seringa \\
\hline C 117.1 & $\mathrm{Rb}-\mathrm{Sr}$ & 44F-FEL & SB 221SC 22 & Granito & Feidspato & Metanic Velo Gi herme & $-6,7833$ & - & 51.15 & 20 & 27 & Serra Seringa \\
\hline C 118.1 & $R b-S r$ & 44-D-FEL & SB 22 5 SC 22 & Granito & Feldspato & Metenic Veho Gi herme & $-6,7833$ & - & 51.15 & 20 & 27 & Serra Seringa \\
\hline$\overline{C 118.2}$ & $\mathrm{Rb}-\mathrm{Sr}$ & 44D-BIO & SB 22/SC 22 & Granito & Biotita & Metanic Veto Guherme & $-\overline{6,7833}$ & - & 51.15 & 20 & 27 & Serra Seringa \\
\hline C119.1 & $R b-S r$ & $E M-R-44 B$ & SB 22/SC 22 & Granito & Rocha total & Metande Veho Guinerme & $-6,7833$ & - & 51.15 & 20 & 27 & Serra Seringa \\
\hline $\mathrm{C} 12.1$ & $\mathrm{U}-\mathrm{Pb}$ & KA-9(1) & SB $22 / S C 22$ & Granito & Zircăo & Ganto Cigano & $-5,8667$ & - & 49.9333 & 10 & 1 & S Rio ltacaiúnas \\
\hline C 12.2 & $\mathrm{U}-\mathrm{Pb}$ & $\mathrm{KA-9}(2)$ & SB 221SC 22 & Granito & Zircaso & Granto Cigano & $-5,8667$ & - & 49.9333 & 10 & 1 & S Rio ltacaiúnas \\
\hline C 120.1 & $\mathrm{Rb}-\mathrm{Sr}$ & EM-R-440 & SB 22/SC 22 & Granito & Rocha total & Metalc Veho Qulline & $-6,7833$ & - & 51.15 & 20 & 27 & Serra Seringa \\
\hline C121.1 & $R b-S r$ & EM-R-44F & $582215 C 22$ & Granito & Rocha total & Metanic Veho Guineme & $-6,7833$ & $\because$ & 51.15 & 20 & 27 & Serra Seringa \\
\hline C 122.1 & Rb-Sr & EM-R-4AA & $\mathrm{SB} 22 / \mathrm{SC} 22$ & Granito & Rocha total & Metendic Velo Guilerme & $-6,7833$ & - & 51.15 & 20 & 27 & Serra Seringa \\
\hline C 123.1 & $\mathrm{Rb}-\mathrm{Sr}$ & EM-R-A4E & SB 22/SC 22 & Granito & Rocha total & Metanic Veho GiTerme & $-6,7833$ & - & 51.15 & 20 & 27 & Serra Seringa \\
\hline C 124.1 & $\mathrm{Rb}-\mathrm{Sr}$ & $E M-R-44 G$ & $582215 C 22$ & Granito & Rocha total & Metanic Veho G inerme & $-6,7833$ & - & 51.15 & 20 & 27 & Serra Seringa \\
\hline C 125.1 & $R b-S r$ & EM-R-A4C & SB $221 \mathrm{SC} 22$ & Granito & Rocha total & Metanic Veho Glineme & $-6,7833$ & - & 51.15 & 20 & 27 & Serra Seringa \\
\hline C 126.1 .1 & $\mathrm{Rb}-\mathrm{Sr}$ & $F 17-323$ & SB 22/SC 22 & Xisto & Rocha total & Grupo Salobo & $-5,7833$ & - & 50.4833 & 20 & 28 & Serra Carajás \\
\hline c 126101 & $\mathrm{Rb}-\mathrm{Sr}$ & F19-222 & $582215 C 22$ & Xisto & Rocha total & Grupo Salobo & $-5,7833$ & - & 50.4833 & 20 & 28 & Serra Carajás \\
\hline$C 126102$ & $\overline{R b}-\mathrm{Sr}$ & F19-222 & $5822 / 5 C 22$ & Xisto & Biotita & Grupo Salobo & $-5,7833$ & - & 50.4833 & 20 & 28 & Serra Carajás \\
\hline $\mathrm{C} 126.10 .3$ & K-Ar & F19-222 & SB 22/SC 22 & Xisto & Feldspato & Grupo Salobo & $--5,7833$ & - & 50.4833 & 20 & 28 & Serra Carajás \\
\hline $\mathrm{C} 12611$ & $\mathrm{Rb}-\mathrm{Sr}$ & F19-228 & $582215 C 22$ & Xisto & Rocha fotal & Grupo Salobo & $-5,7833$ & - & 50.4833 & 20 & 28 & Serra Carajás \\
\hline$C 126121$ & $\mathrm{Rb}-\mathrm{Sr}$ & $F 19-176(1)$ & $582215 C 22$ & Xisto & Rocha total & Grupo Salobo & $-5,7833$ & $\because$ & 50.4833 & 20 & 28 & Serra Carajás \\
\hline $\mathrm{C} 126.122$ & K-Ar & $519-176(2)$ & SB 22/SC 22 & Xisto & Biotita & Grupo Salobo & $-\quad 5,7833$ & $\therefore$ & 50.4833 & 20 & 28 & Serra Carajás \\
\hline C126123 & K-Ar & $F 19-176(3)$ & SB $22 / 5 \mathrm{C} 22$ & Xisto & Feldspato & Grupo Salobo & $-5,7833$ & - & 50.4833 & 20 & 28 & Sema Carajás \\
\hline $\mathrm{C} 126.13$ & K-Ar & SAL $3 A F 1$ & $5822 / S C 22$ & Xisto & Anfíbólio & Grupo Salobo & $-5,7833$ & - & 50.4833 & 20 & 28,29 & Serra Carajás \\
\hline $\mathrm{C} 126.14$ & $K-A T$ & Am & $\mathrm{SB} 22 / \mathrm{SC} 22$ & Xisto & Muscovita & Grupo Salobo & $-5,7833$ & - & 50.4833 & 20 & 28 & Serra Carajás \\
\hline C126.15 & K-Ar & 1097 & SB $2215 C 22$ & Xisto & Muscovita & Grupo Salobo & $-5,7833$ & - & 50.4833 & 20 & 28 & Serra Carajás \\
\hline C 126.16 & K-Ar & $F 17347$ & SB $22 / \mathrm{SC} 22$ & Xisto & Biotita & Grupo Salobo & $-5,7833$ & - & 50.4833 & 20 & 28 & Serra Carajás \\
\hline
\end{tabular}




\begin{tabular}{|c|c|c|c|c|c|c|c|c|c|c|c|c|}
\hline Ordem & Método & $N^{\circ}$. Campo & Folha & Lttologla & Material Anallsado & Unidade Geológica & Latitude & & Longltude & $\begin{array}{l}\text { Prec } \\
(\mathrm{Km}) \\
\end{array}$ & Ref & Referêncla Geográfica \\
\hline C 126.2 & $\mathrm{Rb}-\mathrm{Sr}$ & $F 17.329$ & SB 221SC 22 & Xisto & Rocha total & Grupo Salobo & $-5,7833$ & - & 50.4833 & 20 & 28 & Serra Carajás \\
\hline$C 126.3$ & $\mathrm{Rb}-\mathrm{Sr}$ & $F 17309$ & $S B 22 / S C 22$ & Xisto & Rocha fotal & Grupo Salobo & -5.7833 & - & 50.4833 & 20 & 28 & Serra Carajás \\
\hline$C 126.4$ & $\mathrm{Rb}-\mathrm{Sr}$ & $F 17.367$ & $582215 C 22$ & Xisto & Rocha total & Grupo Salobo & $-5,7833$ & - & 50.4833 & 20 & 28 & Serra Carajás \\
\hline C 126.5 & $\mathrm{Rb}-\mathrm{Sr}$ & $F 17-370$ & $\mathrm{SB} 22 / \mathrm{SC} 22$ & Xisto & Rocha total & Grupo Salobo & $-5,7833$ & - & 50.4833 & 20 & 28 & Serra Carajás \\
\hline C 126.6.1 & $\mathrm{Rb}-\mathrm{Sr}$ & $F 17-381$ & SB 22/SC 22 & Xisto & Rocha total & Grupo Salobo & $-5,7833$ & - & 50.4833 & 20 & 28 & Serra Carajás \\
\hline C 126.6 .2 & K-Ar & $F 17.381$ & $S B 22 / S C 22$ & Xisto & Biotita & Grupo Salobo & $-5,7833$ & - & 50.4833 & 20 & 28 & E Marabá \\
\hline C 126.7 & $\mathrm{Rb}-\mathrm{Sr}$ & F19-161 & SB $22 / S C 22$ & Xisto & Rocha total & Grupo Salobo & $-5,7833$ & $\div$ & 50.4833 & 20 & 28 & Serra Carajass \\
\hline C 126.8 & $\mathrm{Rb}-\mathrm{Sr}$ & F19-181 & SB 22/SC 22 & Xisto & Rocha total & Grupo Sałobo & $-5,7833$ & - & 50.4833 & 20 & 28 & Serra Carajás \\
\hline C 126.9 & $R \mathrm{~b}-\mathrm{Sr}$ & F19-189 & $58221 \mathrm{SC} 22$ & Xisto & Rocha total & Grupo Salobo & $-5,7833$ & - & 50.4833 & 20 & 28 & Serra Carajás \\
\hline C 127.1 & $\mathrm{Rb}-\mathrm{Sr}$ & SNFD 178 & $\mathrm{SB} 221 \mathrm{SC} 22$ & Granodionto & Rocha total & Embasamento & $-9,9333$ & - & 50.7667 & 10 & 28 & Serra Carajás \\
\hline C 128.1 & $\mathrm{Rb}-\mathrm{Sr}$ & SNFD 02 & $\mathrm{SB} 22 / \mathrm{SC} 22$ & Granodiorito & Rocha total & Embasamento & $-10,4833$ & $\because$ & 51.4333 & 10 & 28 & Serra Carajás \\
\hline C 129.1 & $\mathrm{Rb}-\mathrm{SI}$ & SNFD 13 & $\mathrm{SB} 22 / \mathrm{SC} 22$ & Granito & Rocha total & Embasamento & $-8,8833$ & - & 50.8333 & 10 & 28 & Serra Carajás \\
\hline $\mathrm{C} 13.1$ & U-Pb & $K A-15(1)$ & $\mathrm{SB} 221 \mathrm{SC} 22$ & Granito & Zircăo & Grupo Pojuca & $-5,2666$ & - & 50.4833 & 10 & 1 & S Rio ltacaiúnas \\
\hline$C 13.2$ & $\mathrm{U}-\mathrm{Pb}$ & $\mathrm{KA}-15(2)$ & SB 22ISC 22 & Granito & Zircăo & Grupo Pojuca & $-5,2606$ & - & 50.4833 & 10 & $i$ & S Rio ltacaiünas \\
\hline $\mathrm{C} 13.3$ & $\mathrm{U}-\mathrm{Pb}$ & KA-15 (3) & $\mathrm{SB} 221 \mathrm{SC} 22$ & Granito & Zircáo & Grupo Pojuca & $-5,2666$ & - & 50.4833 & 10 & 1 & S Rio ltacaiúnas \\
\hline C 130.1 & $\mathrm{Rb}-\mathrm{Sr}$ & SNFD 01 & $S B 22 / S C 22$ & Granito & Rocha total & Embasamento & $-8,2167$ & - & 50.9 & 10 & 28 & Serra Carajás \\
\hline C 131.1 & $\mathrm{Rb}-\mathrm{Sr}$ & Fo1 (1) & $5 B 22 / S C 22$ & Gnaisse & Rocha total & Embasamento & $-8,5667$ & - & 50.4166 & 10 & 28 & Serra Carajás \\
\hline $\mathrm{C} 131.2$ & K-Ar & FOI (2) & $\mathrm{SB} 221 \mathrm{SC} 22$ & Gnaisse & Biotita & Embasamento & $-8,5667$ & - & 50.4166 & 10 & 28 & Serra Carajás \\
\hline C 133.1 & $\mathrm{~K}-\mathrm{Ar}$ & $485 A Z 196.1$ & SB 22USC 22 & Diorito & Anfibolio & Embasamento & $-8,0667$ & - & 50.0667 & 10 & 28 & Serra Carajás \\
\hline C 134.1 & $\mathrm{~K}-\mathrm{Ar}$ & JW-03 & $\mathrm{SB} 22 / \mathrm{SC} 22$ & Gnaisse & Biotita & Embasamento & 8,3333 & - & 51.6833 & 10 & 28 & Serra Carajás \\
\hline C 135.1 & $\mathrm{Rb}-\mathrm{Sr}$ & $\mathrm{F}-2$ & $\mathrm{SB} 221 \mathrm{SC} 22$ & Granito & Rocha total & Embasamento & $-5, \overline{75}$ & - & 50.4833 & 10 & 28,29 & Serra Carajás \\
\hline C 136.1 & $\mathrm{Rb}-\mathrm{S} t$ & $F-4$ & $\mathrm{SB} 22 / \mathrm{SC} 22$ & Granito & Rocha total & Embasamento & $-5,75$ & - & 50.4833 & 10 & 28,29 & Serra Carajás \\
\hline C 137.1 & $\mathrm{Rb}-\mathrm{Sr}$ & SAL $3 A$ & SB 22/SC 22 & Grantto & Rocha total & Embasamento & $-5,75$ & - & 50.4833 & 10 & 28,29 & Serra Carajás \\
\hline C 137.2 & K-Ar & SAL 3A & SB $22 / S C 22$ & Granito & Rocha total & Embasamento & $-5,7500$ & - & 50.4833 & 10 & 69 & Serra Carajás \\
\hline C 138.1 & K-Ar & N5F7 & SB $22 / S C 22$ & Diabásio & Rocha total & Embasamento & $-6,15$ & - & 50.1333 & 5 & 14 & W Rio Tocantins \\
\hline C 138.2 & $\mathrm{K}-\mathrm{Ar}$ & N5F7 & SB 221SC 22 & Diabásio & Rocha total & Embasamento & $-6,15$ & - & 50.1333 & 5 & 14 & W Rio Tocantins \\
\hline C 139.1 & K-Ar & $6 \sqrt{628109}$ & SB 22/SC 22 & Diabáslo & Rocha total & Embasamento & $-7,8833$ & - & 54.2167 & 5 & 14 & W Rio Tocantins \\
\hline C 14.1 & $\mathrm{U}-\mathrm{Pb}$ & $B A-408(1)$ & $\mathrm{SB} 221 \mathrm{SC} 22$ & Granito & Zircäo & Granito Musa & 7,5833 & - & 50.0833 & 10 & 1 & 5 Rio Itacaiúnas \\
\hline C 14.2 & U.PB & $B \bar{A}-468(2)$ & $582215 C 22$ & Granito & Zircăo & Granito Musa & $-7,5833$ & - & 50.0833 & 10 & 1 & S Rio Itacaiúnas \\
\hline $\mathrm{C} 14.3$ & $\mathrm{U}-\mathrm{Pb}$ & $B A-468(3)$ & SB 22/SC 22 & Granito & Zircăo & Granito Musa & $-7,5833$ & - & 50.0833 & 10 & $i$ & S Rio Itacaiúnas \\
\hline C 14.4 & $\mathrm{U}-\mathrm{Pb}$ & $B A-468(4)$ & $5822 / 5 C 22$ & Granito & Titanita & Granito Musa & $-7,5833$ & - & 50.0833 & 10 & 1 & S Rio ltacaiúnas \\
\hline C140.1 & K-Ar & PÁ393 & SB 22/SC 22 & Diabáslo & Rocha total & Embasamento & $-7,75$ & $\sim$ & 51.2167 & 5 & 14 & W Rio Tocantins \\
\hline C 141.1 & K-Ar & AM 310 & SB 22/SC 22 & Diabásio & Rocha total & Embasamento & $-7,0833$ & - & 52.1833 & 5 & 14 & W Rio Tocantins \\
\hline
\end{tabular}




\begin{tabular}{|c|c|c|c|c|c|c|c|c|c|c|c|c|}
\hline Ordem & Método & No. Campo & Folha & Lftologla & Materlal Anallsado & Unldade Geologlca & Latitude & & Longltude & $\begin{array}{l}\text { Prec } \\
\text { (Km) }\end{array}$ & Ref & Referêncla Geográfica \\
\hline C 142.1 & $\mathrm{~K}-\mathrm{Ar}$ & $23 A 66$ & $5822 / S C 22$ & Gabro & Rocha total & Embasamento & $-7,8167$ & - & 51.2167 & 5 & 14 & W Rio Tocantins \\
\hline C 143.1 & K-AT & EV 14 & SB $22 / S C 22$ & Diabásio & Rocha total & Embasamento & $-5,45$ & - & 49.6 & 5 & 14 & W Rio Tocantins \\
\hline C 144.1 & $\mathrm{~K}-\mathrm{Ar}$ & N4F5 & SB 22/SC 22 & Diabásio & Rocha total & Embasamento & $-6,1333$ & - & 50.2167 & 5 & 14 & W Rio Tocantins \\
\hline C 144.2 & K-Ar & N4F5 & $5 B 221 S C 22$ & Diabasio & Rocha total & Embasamento & $-6,1333$ & - & 50.2167 & 5 & 14 & W Rio Tocantins \\
\hline C 145.1 & $\mathrm{~K}-\mathrm{Ar}$ & 17528 & SB 22/SC 22 & Diabśsio & Rocha total & Embasamento & $-5,5667$ & - & 49.9833 & 5 & 14 & W Rio Tocantins \\
\hline$\overline{C 146.1}$ & K-Ar & 13178 & $\mathrm{SB} 22 / \mathrm{SC} 22$ & Diabásio & Rocha total & Embasamento & $-6,1167$ & - & 50.2667 & 5 & 14 & W Rio Tocantins \\
\hline C 147.1 & $\mathrm{K}-\mathrm{Ar}$ & AD 405 & $\mathrm{SB} 221 \mathrm{SC} 22$ & Diabásio & Rocha total & Embasamento & $-5,5$ & $=$ & 50.8333 & 5 & 14 & W Rio Tocantins \\
\hline$\overline{C 148.1}$ & $\mathrm{~K}-\mathrm{Ar}$ & AT 36 & SB $221 S C 22$ & Gabro & Plagioclásio & Embasamento & $-4,1$ & - & 49.7 & 5 & $\overline{14}$ & W Rio Tocantins \\
\hline C 149.1 & $\mathrm{Rb}-\mathrm{ST}$ & HRM9 & SB 22/SC 22 & Granodionito & Epidoto & Granodiorito Rio Maria & 7,4353 & - & 50.0167 & 5 & 31 & W Serra Andorinhas \\
\hline C 15.1 & $\mathrm{U}-\mathrm{Pb}$ & GB-50-1a & SB 22/SC 22 & Metariolito & Zircăo & Grupo Grăo Pará & $-6,1$ & - & 49.9833 & 10 & 2 & SW Marabá \\
\hline $\bar{C} 15.2$ & $\mathrm{U}-\mathrm{Pb}$ & GB-50-1b & SB 22/SC 22 & Metariolito & Zircăo & Grupo Grăo Pará & $-6,1$ & $=$ & 49.9833 & 10 & 2 & SW Marabá \\
\hline C 15.3 & U-Pb & GB-50-1C - & SB $22 / \mathrm{SC} 22$ & Metariolito & Zircăo & Grupo Grảo Pará & $-6,1$ & - & 49.9833 & 10 & 2 & SW Marabá \\
\hline C 15.4 & $\mathrm{U}-\mathrm{Pb}$ & GB $50-1 d$ & SB $22 / S C 22$ & Metariolito & Zircaso & Grupo Grăo Pará & $-6,1$ & - & 49.9833 & 10 & 2 & SW Maraba \\
\hline C 15.5 & U-Pb & GB-50-1e & $\mathrm{SB} 22 / \mathrm{SC} 22$ & Metariolito & Zircáo & Grupo Grăo Pará & $-6,1$ & $\because$ & 49.9833 & 10 & 2 & SW Marabá \\
\hline C 150.1 & $\mathrm{Rb}-\mathrm{Sr}$ & HRM9 & $S B 22 / S C 22$ & Granodiorito & Plagioclásio & Granodionito Rio Maria & $-7,1833$ & - & 49.9667 & 5 & 31 & W Serra Andorinhas \\
\hline C 151.1 & $\mathrm{Rb}-\mathrm{Sr}$ & HRM 9 & $S B 22 / S C 22$ & Granodionito & Feldspato & Granodionto Rio Maria & $-7,2167$ & - & 49.9833 & 5 & 31 & W Serra Andorinhas \\
\hline C 152.1 & Rb-Sr & HRM9 & $\mathrm{SB} 22 / \mathrm{SC} 22$ & Granodionto & Rocha total & Granodiorito Rio Maria & $-7,25$ & - & 50 & 5 & 31 & W Serra Andorinhas \\
\hline C 153.1 & $\overline{R b-S r}$ & HRM9 & SB 22/SC 22 & Granodiorito & Anfibólio & Granodjorito Rio Maria & $-7,2333$ & - & 50 & 5 & 31 & W Serra Andorinhas \\
\hline C 154.1 & $\mathrm{Rb}-\mathrm{Sr}$ & HRM9 & $582215 C 22$ & Granodionito & Clorita & Granodionito Rio Maria & $-7,2$ & - & 49.9667 & 5 & $\overline{31}$ & W Serra Andorinhas \\
\hline C 155.1 & $\mathrm{Rb}-\mathrm{Sr}$ & HRMS & SB 22/SC 22 & Granodionto & Biolita & Granodiorito Rio Maria & $-7,1833$ & $\because$ & 49.95 & 5 & $\overline{31}$ & W Serra Andorinhas \\
\hline C 156.1 & K-Ar & HRM9 & SB 22/SC 22 & Granodionto & Anfibolio & Granodiorito Rio Maria & $-7,2127$ & $\because$ & 49.9833 & 10 & 31 & W Serra Andorinhas \\
\hline C 156.2 & K-Ar & HRM 9 & SB 22 $15 C 22$ & Granodiontito & Biotita & Granodiorito Rio Maria & $-7,2127$ & - & 49.9833 & 10 & 31 & W Serra Andorinhas \\
\hline C 157.1 & $\mathrm{Rb}-\mathrm{Sr}$ & RMM-17 & SB 22/SC 22 & Tonaitito & Rocha total & Assoc Ton-Tronghemio & $-7,5667$ & - & 49.9 & 10 & 31 & W Serra Andorinhas \\
\hline C 158.1 & $\mathrm{Rb}-\mathrm{Sr}$ & RMM- 09 & $\mathrm{SB} 221 \mathrm{SC} 22$ & Trondhjemito & Rocha total & Assoc Ton Trong herrito & $-7,24$ & - & 50.0167 & 5 & 31 & W Serra Andorinhas \\
\hline C 159.1 & $R b-S r$ & RMM-O3 & SB 22/SC 22 & Trondhjemito & Rocha total & Assoc Ton-Tranghentio & $-7,5667$ & - & 49.9 & 10 & $\overline{31}$ & W Serra Andorinhas \\
\hline $\bar{C} 16.1$ & U-Pb & GB-123-2a & SB 22/SC 22 & Metariolito & Zircăo & Grupo Grăo Pará & $-6,0667$ & - & 49.95 & 10 & 2 & SW Marabá \\
\hline C 16.2 & $\mathrm{U}-\mathrm{Pb}$ & GB-123-2b & $\mathrm{SB} 22 / \mathrm{SC} 22$ & Metariolito & Zircáo & Grupo Grăo Pará & $-6,0667$ & - & 49.95 & 10 & 2 & SW Marabá \\
\hline C 160.1 & $R \mathrm{R}-\mathrm{Sr}$ & RMM-65 & SB $221 \mathrm{SC} 22$ & Granodlorito & Rocha total & Assoc Tor-Tronchem to & $-7,5667$ & - & 49.9 & 10 & 31 & W Serra Andorinhas \\
\hline C 161.1 & $\mathrm{Rb}-\mathrm{Sr}$ & RMM 31 & SB $22 / \mathrm{SC} 22$ & Trondhjemito & Rocha total & Assoc Ton-Trond herrito & -7.5667 & - & 49.9 & 10 & 31 & W Serra Andorinhas \\
\hline$\overline{C 162.1}$ & Rb-Sr & RMM-23 & $\mathrm{SB} 221 \mathrm{SC} 22$ & Tonalito & Rocha total & Assoc Ton-Tronchernio & $-7,5667$ & - & 49.9 & 10 & 31 & W Serra Andorinhas \\
\hline C 163.1 & $\mathrm{Rb}-\mathrm{Sr}$ & AH-796-2 & SB 22/SC 22 & Granodionito & Rocha total & Granodionito Rio Maria & $-7,2333$ & - & 50.2833 & 5 & 32 & SE Serra Seringa \\
\hline C 163.2 & $R \mathrm{R}-\mathrm{Sr}$ & AH-796-3 & SB 221SC 22 & Granodiorito & Rocha total & Granodiorito Rio Maria & $-7,2333$ & - & 50.2833 & 5 & 32 & SE Serra Seringa \\
\hline C 163.3 & $\mathrm{Rb}-\mathrm{Sr}$ & AH-796-4 & SB 22/SC 22 & Granodionto & Rocha total & Granodionto Rio Maria & $-7,2333$ & - & 50.2833 & $\overrightarrow{5}$ & 32 & SE Serra Seringa \\
\hline
\end{tabular}




\begin{tabular}{|c|c|c|c|c|c|c|c|c|c|c|c|c|}
\hline Ordem & Método & $\mathbf{N}^{\circ}$. Campo & Folha & Litologla & Material Analisado & Unidade Geológlca & Latitude & & Longltude & $\begin{array}{l}\text { Prec } \\
\text { (Km) }\end{array}$ & Ref & Referêncla Geográfica \\
\hline c 163.4 & $R b-S r$ & AH-796-7 & SB $221 \mathrm{SC} 22$ & Granodionito & Rocha total & Granodionto Rio Maria & $-7,2333$ & - & 50.2833 & 5 & 32 & SE Serra Seringa \\
\hline C 163.5 & $\mathrm{Sm}-\mathrm{Nd}$ & AH 796-4 & $\mathrm{SB} / \mathrm{SC} 22$ & Granodionito & Rocha total & Granodionito Rio Maria & $-7,2333$ & - & 50.2833 & o & 79 & SE Serra Seringa \\
\hline C 163.6 & Sm-Nd & AH 7963 & $S B / S C 22$ & Granodionto & Rocha total & Granodiorito Rio Maria & $-7,2333$ & - & 50.2833 & of & 79 & SE Serra Seringa \\
\hline C 164.1 & $R b-S t$ & AH-799-1 & SB $2215 C 22$ & Granodionito & Rocha toial & Granodionito Rio Maria & $-7,2333$ & - & 50.2833 & 5 & 32 & SE Serra Seringa \\
\hline C 165.1 & $R b-S r$ & AH-858-D1 & SB 221SC 22 & Granitóde & Rocha total & Trondih Mogno & $-7,1166$ & $\because$ & 50.1833 & 5 & 32 & SE Serra Seringa \\
\hline C 166.2 & $\mathrm{Rb}-\mathrm{Sr}$ & AH-858-D2 & $\mathrm{SB} 22 / \mathrm{SC} 22$ & Granitoide & Rocha total & \begin{tabular}{|l} 
Trondji Mogno \\
\end{tabular} & $-7,1166$ & - & 50.1833 & 5 & 32 & SE Serra Seringa \\
\hline C 167.1 & $\mathrm{Rb}-\mathrm{Sr}$ & AS- $1682-3$ & SB 22JSC 22 & Trondhjemito & Rocha total & Trondjh Mogno & $-7,05$ & - & 50.25 & 5 & 32 & SE Serra Seringa \\
\hline C168.1 & $\mathrm{Rb}-\mathrm{Sr}$ & AS-1683-6 & SB 22ISC 22 & Trondhjemito & Rocha total & Trondjh Mogno & $-\quad 7,0167$ & - & 50.25 & 5 & 32 & SE Serra Seringa \\
\hline C 168.2 & Sm-Nd & AS 1683.6 & $\mathrm{SB} / \mathrm{SC} 2$ & Granodiorito & Rocha total & Trondjh Mogno & $-7,0167$ & - & 50.25 & 0 & 79 & SE Serra Seringa \\
\hline C 169.1 & $\mathrm{Rb}-\mathrm{Sr}$ & AH-855-9 & SB 22/SC 22 & Trondhjemito & Rocha total & Trondigh Mogno & $-7,15$ & - & 50.1333 & 5 & 32 & SE Serra Seringa \\
\hline C 17.1 & $\mathrm{U}-\mathrm{Pb}$ & GB-7itia & $\mathrm{SB} 22 / \mathrm{SC} 22$ & Granito & Zircăo & Granito Carajás & $-6,1167$ & - & 50.4 & 10 & 2 & S Rio Itacaiúnas \\
\hline C 17.2 & U-Pb & GB-71-1b & $\mathrm{SB} 22 / \mathrm{SC} 22$ & Granito & Zircăo & Granito Carajás & $-6,1167$ & - & 50.4 & 10 & 2 & S Rio ltacaiúnas \\
\hline C 17.3 & $\mathrm{U}-\mathrm{Pb}$ & GB-71-1c & SB 22/SC 22 & Granito & Zircăo & Granito Carajás & $-6,1167$ & - & 50.4 & 10 & 2 & S Rio ltacaiúnas \\
\hline C 17.4 & $\mathrm{U}+\mathrm{Pb}$ & GB-71-1d & $\mathrm{SB} 221 \mathrm{SC} 22$ & Granito & Zirczo & Granito Carajás & $-6,1167$ & - & 50.4 & 10 & 2 & S Rio Itacaiunas \\
\hline C 170.1 & $R b-S r$ & $\mathrm{AH}-85-10$ & SB $221 S C 22$ & Trondhjemito & Rocha total & Trondijh Mogno & $-7,15$ & - & 50.1333 & 5 & 32 & SE Serra Seringa \\
\hline $\bar{C} 171.1$ & $\mathrm{Rb}-\mathrm{SI}$ & AH-813-1 & $5822 / S C 22$ & Trondhiemito & Rocha total & Trondifi Mogno & $-7,0667$ & - & 50.45 & 5 & 32 & SE Serra Seringa \\
\hline C171.2 & $\mathrm{S} m-\mathrm{Nd}$ & AH513-1 & $\mathrm{SB} / \mathrm{SC} 22$ & Trondhjemito & Rocha tota! & Trondjh Mogno & $-7,0667$ & - & 50.45 & 0 & 79 & SE Serra Seringa \\
\hline C 172.1 & $\overline{R b}-\mathrm{Sr}$ & AH-877 A2 & $S B 2215 C 22$ & Trondhjemito & Rocha total & Trondjh Mogno & $-7,0833$ & - & 50.15 & 5 & 32 & SE Serra Seringa \\
\hline C. 172.2 & $\mathrm{Rb}-\mathrm{Sr}$ & AH-877 A3 & SB 22/SC 22 & Trandhiemito & Rocha total & Trondifh Mogno & $-7,0833$ & - & 50.15 & 5 & 32 & SE Serra Seringa \\
\hline C 172.3 & $\mathrm{Rb}-\mathrm{Sr}$ & AH-8 77 AB & SB 22ISC 22 & Trondhjemito & Rocha total & Trondigh Mogno & $-7,0833$ & $\therefore$ & 50.15 & 5 & 32 & SE Serra Seringa \\
\hline C 173.1 & $R b-S r$ & $\mathrm{AH}-878-1$ & $\mathrm{SB} 221 \mathrm{SC} 22$ & Trondhiemito & Rocha total & Trondjh Mogno & $-7,0633$ & - & 50.1666 & 5 & 32 & SE Serra Seringa \\
\hline C 173.2 & $\mathrm{Rb}-\mathrm{Sr}$ & AH-B78-1 & $5822 / 5 C 22$ & Trondhjemito & Rocha total & Trondifh Mogno & $-7, \overline{0833}$ & $=$ & 50.1666 & 5 & 32 & S Rio Maria \\
\hline C 174.1 & $\mathrm{Rb}-\mathrm{Sr}$ & HRM-220 & SB 221SC 22 & Granodiorito & Rocha total & Granodionto Rio Maria & -7.5 & - & 50 & 5 & 33 & S Rio Maria \\
\hline C 175.1 & $\mathrm{Rb}-\mathrm{Sr}$ & HRM-284 & $\mathrm{SB} 22 / \mathrm{SC} 22$ & Granodiontto & Rocha total & Granodionito Rio Maria & $-7,35$ & - & 50.1167 & 5 & 33 & S Rio Maria \\
\hline c 176.1 & $R \mathrm{R}-\mathrm{Sr}$ & HRM-278 & $\mathrm{SB} 22 / \mathrm{SC} 22$ & Granodionito & Rocha total & Granodiorito Rio Maria & $-7,3333$ & - & 50.0667 & 5 & 33 & S Rio Mana \\
\hline C $17 \pi .1$ & $\mathrm{Rb}-\mathrm{Sr}$ & HRM 334 & SB 22/SC 22 & Granodiorito & Rocha total & Granodionito Rio Maria & $-7,3833$ & - & 50.1 & 5 & 33 & S Rio Maria \\
\hline C 178.1 & $\mathrm{Rb}-\mathrm{Sr}$ & HRM-349 & $\mathrm{SB} 22 / \mathrm{sC} 22$ & MonzoGranito & Rocha total & Granodionto Rio Maria & $-7,3667$ & - & 50.05 & 5 & 33 & S Rio Maria \\
\hline C 179.4 & Rbusr & CREMU-30 & $5822 J S C 22$ & Dacto & Rocha total & Granito Musa & $-7,5167$ & - & 50.0333 & 5 & 33 & S Rio Maria \\
\hline C 18.1 & $\mathrm{Rb}-\mathrm{Sr}$ & GB-67 & $582215 C 22$ & Basalto & Rocha total & Grupo Grăo Pará & $-6,0167$ & - & 50.2833 & 10 & 2 & S Rio Itacaiunas \\
\hline C 18.2 & $\mathrm{Sm}-\mathrm{Nd}$ & $\mathrm{GB}-67$ & $\mathrm{SB} 22 / \mathrm{SC} 22$ & Basalto & Rocha total & Grupo Grăo Pará & $-6,0167$ & - & 50.2833 & 10 & 2 & S Rio Itacaiúnas \\
\hline C 180.1 & $\mathrm{Rb}-\mathrm{Sr}$ & CREMU-141G & $\mathrm{SB} 22 / \mathrm{SC} 22$ & Dacito & Rocha total & Granito Musa & $-7,5167$ & - & 50.0333 & 5 & 33 & S Rio Maria \\
\hline C 181.1 & $\mathrm{Rb}-\mathrm{Sr}$ & CREMU-106 & SB 22/SC 22 & Dacito & Rocha total & Granito Musa & $-7,5167$ & - & 50 & 5 & 33 & S Rio Maria \\
\hline C 182.1 & $\mathrm{Rb}-\mathrm{Sr}$ & CREMU-103 & SB 22/SC 22 & Dacito & Rocha total & Granito Musa & $-7,5$ & - & 50.0167 & 5 & 33 & S Rio Maria \\
\hline
\end{tabular}




\begin{tabular}{|c|c|c|c|c|c|c|c|c|c|c|c|c|}
\hline Ordem & Método & $N^{\circ}$. Campo & Folha & Litologla & Material Analisado & Unidade Geológlca & Latitude & & Longitude & $\begin{array}{l}\text { Prec } \\
\text { (Km) }\end{array}$ & Ref & Referêncla Geográfica \\
\hline C 183.1 & $\mathrm{Rb}-\mathrm{Sr}$ & CREMU-109 & SB 22/SC 22 & Dacito & Rocha total & Granito Musa & $-7,5167$ & - & 50 & 5 & 33 & S Rio Maria \\
\hline C 184.1 & $\mathrm{Rb}-\mathrm{Sr}$ & KM-81 & SB 22/SC 22 & MonzoGranito & Rocha total & Granito Musa & $-7,5167$ & - & 50.1166 & 5 & 33 & S Rio Maria \\
\hline C 185.1 & $\mathrm{Rb}-\mathrm{Sr}$ & CREMU -37A & S8 22/SC 22 & MonzoGranito & Rocha total & Granito Musa & $-7,5$ & - & 50.0333 & 5 & 33 & S Rio Maria \\
\hline C 185.2 & Rb-Sr & CREMU 37B & SB 221SC 22 & MonzoGranito & Rocha total & Granito Musa & $-7,5$ & - & 50.0333 & 5 & $\overline{33}$ & S Rio Maria \\
\hline C 186.1 & $R \mathrm{R}-\mathrm{Sr}$ & $K M-32$ & SB 22/SC 22 & SienoGranito & Rocha total & Granito Musa & $-7,5167$ & - & 50.0633 & 5 & 33 & S Rio Maria \\
\hline C 187.1 & $R b-S r$ & CREMU-140E & SB 22/SC 22 & SienoGranito & Rocha total & Granito Musa & $-7,5333$ & 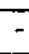 & 50.05 & 5 & 33 & S Rio Maria \\
\hline C 188.1 & $\overline{R b-S r}$ & KM-154 & SB 22/SC 22 & SienoGranito & Rocha total & Granito Musa & $-7,6667$ & - & 50.0833 & 5 & 33 & S Rio Maria \\
\hline C 189.1 & $\mathrm{Rb}-\mathrm{Sr}$ & RF-2 & $\mathrm{SB} 221 \mathrm{SC} 22$ & Granito & Rocha total & Assoc Granitica & $-7,0167$ & - & 52.4167 & 10 & 36 & S Serra Carajás \\
\hline C 19.1 .1 & $\mathrm{Rb}-\mathrm{Sr}$ & $\overline{G B-82-a}$ & SB 22/SC 22 & Basalto & Rocha total & Grupo Grăo Para & -6 & - & 50.5 & 10 & 2 & S Rio Itacaiunas \\
\hline C 19.1 .2 & Sm-Nd & $\mathrm{GB}-82-\mathrm{a}$ & SB 22/SC 22 & Basalto & Rocha total & Grupo Grăo Pará & -6 & - & 50.5 & 10 & 2 & S Rio ltacaiúnas \\
\hline C 19.2.1 & $R \mathrm{~B}-\mathrm{Sr}$ & GB-82-b & SB $22215 C 22$ & Basalto & Rocha total & Grupo Grăo Pará & -6 & - & 50.5 & 10 & 2 & S Rio ltacaiunas \\
\hline C 19.22 & Sm-Nd & GB-82-b & SB 22/SC 22 & Basalto & Rochia total & Grupo Grăo Pará & -6 & - & 50.5 & 10 & 2 & S Rio Itacaiúnas \\
\hline C 19.3.1 & Rb-Sr & GB-85 & SB $22 / S C 22$ & Basalto & Rocha total & Grupo Grăo Pará & -6 & - & 50.5 & 10 & 2 & S Rio ltacaiúnas \\
\hline C 19.3 .2 & Sm-Nd & GB-85 & $S B 22 / S C 22$ & Basalto & Rocha total & Grupo Gráo Pará & -6 & - & 50.5 & 10 & 2 & S Rio ltacaiunas \\
\hline $\bar{C} 19.41$ & $\mathrm{Rb}-\mathrm{Sr}$ & GB-86 & $\mathrm{SB} 22 / \mathrm{SC} 22$ & Basalto & Rocha total & Grupo Grăo Pará & -6 & - & 50.5 & 10 & 2 & S Rio Itacaiúnas \\
\hline C 19.4 .2 & Sm-Nd & GB-86 & SB 22/SC 22 & Basalto & Rocha total & Grupo Gráo Pará & -6 & - & 50.5 & 10 & 2 & S Rio ltacaiúnas \\
\hline C 19.5 .1 & $\mathrm{Rb}-\mathrm{Sr}$ & GB-87 & SB 22/SC 22 & Basalto & Rocha total & Grupo Grăo Pará & -6 & 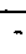 & 50.5 & 10 & 2 & S Rio ltacaiunas \\
\hline C 19.5 .2 & Sm-Nd & GB-87 & SB $2215 \mathrm{C} 22$ & Basalto & Rocha total & Grupo Grăo Pará & -6 & - & 50.5 & 10 & 2 & S Rio itacaiunas \\
\hline C 190.1 & $\mathrm{Rb}-\mathrm{St}$ & AS-250 & SB 22/SC 22 & Granito & Rocha total & Assoc Granitica & $-4,2167$ & - & 54.2167 & 10 & 36 & S Serra Carajás \\
\hline C 191.1 & $\mathrm{Rb}-\mathrm{Sr}$ & JW-04 & SB 22/SC 22 & Granito & Rocha total & Assoc Granflica & $-8,5333$ & $=$ & 52.2833 & 10 & 36 & S Serra Carajás \\
\hline $\bar{C} 192.1$ & $R \mathrm{R}-\mathrm{Sr}$ & 1 & SB $22 / S C 22$ & R. Piroclástica & Rocha total & Grupo Rio Fresco & $-6,0333$ & - & 50.4333 & 10 & 40 & Serra Carajas \\
\hline c 192.10 & $\mathrm{Rb}-\mathrm{Sr}$ & 10 & $\overline{S B} 22 / S C 22$ & Granófiro & Rocha total & Grupo Rio Fresco & -6.00333 & - & 50.4333 & 10 & 40 & Serra Carajás \\
\hline C 192.11 & $R b-s r$ & 11 & SB 221SC 22 & Granofiro & Rocha total & Grupo Rio Fresco & $-6,00333$ & - & 50.4333 & 10 & 40 & Serra Carajás \\
\hline $\bar{C} 192.12$ & K-Ar & 12 & $\mathrm{SB} 22 / \mathrm{SC} 22$ & Granofiro & Antibólio & Grupo Rio Fresco & $-6,0333$ & - & 50.4333 & 10 & $\overline{40}$ & Serra Carajás \\
\hline C 192.13 & $\mathrm{~K}-\overline{\mathrm{A} T}$ & 13 & SB $2215 C 22$ & MetaBasalto & Anfibolio & Grupo Rio Fresco & $-6,0333$ & - & 50.4333 & 10 & 40 & Serra Carajás \\
\hline C 192.14 & $\mathrm{~K}-\mathrm{Ar}$ & 14 & SB 22/SC 22 & MetaBasalto & Antibolio & Grupo Rio Fresco & $-6,0333$ & - & 50.4333 & 10 & 40 & Serra Carajás \\
\hline C 192.2 & $\mathrm{Rb}-\mathrm{Sr}$ & 2 & SB 22/SC 22 & R. Piroclástica & Rocha total & Grupo Rio Fresco & $-6,0333$ & 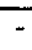 & 50.4333 & 10 & 40 & Serra Carajás \\
\hline C 192.3 & $\overline{R b-S t}$ & 3 & SB 22/SC 22 & R. Pirociástica & Rocha total & Grupo Rio Fresco & $-6,0333$ & $\because$ & 50.4333 & 10 & 40 & Serra Carajás \\
\hline C 192.4 & $\mathrm{Rb}-\mathrm{Sr}$ & 4 & SB 22/SC 22 & R. Piroclástica & Rocha total & Grupo Rio Fresco & $-6,0333$ & - & 50.4333 & 10 & 40 & Serra Carajás \\
\hline C 192.5 & $R b-S t$ & 5 & SB 221SC 22 & R. Piroclástica & Rocha total & Grupo Rio Fresco & $-6,0303$ & $=$ & 50.4333 & 10 & 40 & Serra Carajás \\
\hline C 192.6 & $R b-S r$ & 6 & SB 22/SC 22 & R. Piroclástica & Rocha total & Grupo Rio Fresco & $-6,00303$ & 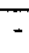 & 50.4333 & 10 & 40 & Serra Carajás \\
\hline C 192.7 & Rb-Sr & 7 & SB 22/SC 22 & R. Piroclástica & Rocha total & Grupo Rio Fresco & $-6,0333$ & $\because$ & 50.4333 & 10 & 40 & Serra Carajás \\
\hline C 192.8 & $\mathrm{Rb}-\mathrm{Sr}$ & 8 & SB $22 / S C 22$ & Granofiro & Rocha total & Grupo Rio Fresco & $-6,0333$ & $=$ & 50.4333 & 10 & 40 & Serra Carajás \\
\hline
\end{tabular}




\begin{tabular}{|c|c|c|c|c|c|c|c|c|c|c|c|c|}
\hline Ordem & Método & N'. Campo & Folha & Lltologia & Materlal Anallsado & Unidade Geológica & Latitude & & Longitude & $\begin{array}{l}\text { Prec } \\
\text { (Km) }\end{array}$ & Ref & Referência Geográfica \\
\hline C 192.9 & $\mathrm{Rb}-\mathrm{Sr}$ & 9 & $\mathrm{SB} 221 \mathrm{SC} 22$ & Granofiro & Rocha total & Grupo Rio Fresco & $-6,0333$ & $=$ & 50.4333 & 10 & 40 & Serra Carajás \\
\hline C 193.1 & $\mathrm{Rb}-\mathrm{Sr}$ & D1/87/PP $06 . A$ & SB $2215 C 22$ & Tonalito & Rocha tota! & Embasamento & $-6,0833$ & - & 49.4 & 10 & 41 & Serra Carajás \\
\hline C 193.2 & $\mathrm{Rb}-\mathrm{Sr}$ & Ф01/87/PP $\overline{\text { OS.H }}$ & SB $2215 C 22$ & Tonalito & Rocha total & Embasamento & $-6,0833$ & - & 49.4 & 10 & 41 & Serra Carajás \\
\hline C 193.3 & Rb-Sr & $00187 / P P 106 . \bar{C}$ & SB 22/SC 22 & Tonalito & Rocha total & Embasamento & $-6,0033$ & - & 49.4 & 10 & 41 & Serra Carajás \\
\hline C 193.4 & $\mathrm{Rb}-\mathrm{Sr}$ & D187/PP106.F & SB 22/SC 22 & Tonalito & Rocha total & Embasamento & $-6,0833$ & - & 49.4 & 10 & 41 & Serra Carajás \\
\hline C 193.5 & Sm-Nd & PPOSA & $\mathrm{SB} / \mathrm{SC} 22$ & Gnaisse & Rocha total & Embasamento & $-6,0833$ & - & 49.4 & of & 79 & Serra Carajás \\
\hline C 193.6 & Sm-Nd & PPOSH & $\mathrm{SB} / \mathrm{SC} 22$ & Tonalito & Rocha total & Embasamento & $-6,0833$ & - & 49.4 & of & 79 & Serra Carajás \\
\hline C194.1 & $\mathrm{Rb}-\bar{S} r$ & OO1/870C LAFP07.1A & $\mathrm{SB} 22 / \mathrm{SC} 22$ & Epidiorto & Rocha total & Embasamento & $-6,0657$ & - & 49.4167 & 10 & 41 & Serra Carajás \\
\hline C 194.2 & $\mathrm{Rb}-\mathrm{St}$ & Dor18700 & $S B 22 / S C 22$ & Epidiortto & Rocha total & Embasamento & $-6,0667$ & - & 49.4167 & 10 & 41 & Serra Carajás \\
\hline C 194.3 & $\mathrm{Rb}-\mathrm{Sr}$ & 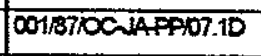 & SB 22/SC 22 & Epidiorito & Rocha total & Embasamento & $-6,0667$ & - & 49.4167 & 10 & 41 & Serra Carajás \\
\hline C 194.4 & $\mathrm{Rb}-\mathrm{Sr}$ & DIBT/OCALPON.TE & SB 221SC 22 & Epidionito & Rocha total & Embasamento & $-6,0667$ & - & 49.4167 & 10 & 41 & Serta Carajás \\
\hline $\bar{C} 196.1$ & $\mathrm{Rb}-\mathrm{Sr}$ & 101/87/PP.52.3B & SB $22 / S C 22$ & Gnaisse & Rocha total & Embasamento & $-6,15$ & - & 49.8167 & 10 & 41 & Serra Carajás \\
\hline $\bar{C} 196.2$ & $\mathrm{Rb}-\mathrm{Sr}$ & (01/87/PP52.34 & SB 22/SC 22 & Gnaisse & Rocha total & Embasamento & $-6,15$ & - & 49.8167 & 10 & 41 & Serra Carajás \\
\hline C 195.3 & $\mathrm{Rb}-\mathrm{Sr}$ & $001 / 87 / P P 52.3 C$ & $5822 / S C 22$ & Gnaisse & Rocha total & Embasamento & $-6,15$ & - & 49.8167 & 10 & 41 & Serra Carajás \\
\hline$C 195.4$ & $\mathrm{Rb}-\mathrm{Sr}$ & D01/87PP/52.3E & SB $221 S C 22$ & Gnaisse & Rocha total & Embasamento & $-6,15$ & - & 49.8167 & 10 & 41 & Serra Carajás \\
\hline C 195.5 & Rb-Sr & $\infty 1 / 87 / P P / 52.3 F$ & SB $22 / S C 22$ & Gnaisse & Rocha total & Embasamento & $-6,15$ & - & 49.8167 & 10 & 41 & Serra Carajás \\
\hline C 195.7 & $\mathrm{Rb}-\mathrm{Sr}$ & ECR-CG-A3A & SB 221SC 22 & MonzoGranito & Rocha total & Granito Cigano & $-6,0167$ & - & 50.2833 & 10 & $\overline{42}$ & W Serra Pelada \\
\hline C 196.1 & $R b-S r$ & DO1B7/PP/39.A & SB $221 \mathrm{sc} 22$ & Granito Catacl. & Rocha total & Embasamento & $-6,0667$ & - & 49.7833 & 10 & 41 & Serra Carajás \\
\hline C 196.2 & $R b-S r$ & D1/88/PP/39.A & SB 22/SC 22 & Granito Catacl. & Rocha total & Embasamento & $-6,0667$ & - & 49.7833 & 10 & 41 & Serra Carajás \\
\hline C 196.3 & $\overline{R b}-\mathrm{Sr}$ & क1/B7/PP/39.C & $\mathrm{SB} 22 / \mathrm{SC} 22$ & Granto Cataci. & Rocha total & Embasamento & $-6,0667$ & - & 49.7833 & 10 & 41 & Serra Carajás \\
\hline C 196.4 & $\mathrm{Rb}-\mathrm{Sr}$ & $00187 / P P / 39.0$ & $S B 22 / S C 22$ & Granito Catacl. & Rocha total & Embasamento & $-6,0667$ & $=$ & 49.7833 & 10 & 41 & Serra Carajás \\
\hline C 196.5 & $\mathrm{Rb}-\mathrm{Sr}$ & क01/87/PP/39.E & SB 22/SC 22 & Granito Catacl. & Rocha total & Embasamento & $-6,0667$ & $=$ & 49.7833 & 10 & 41 & Serra Carajás \\
\hline C 197.1 & $R b-S r$ & ECR-CG-5OC & $S B 2215 C 22$ & MonzoGranito & Rocha total & Granito Cigano & $-5,9166$ & - & 49.85 & 10 & 42 & W Serra Pelada \\
\hline C 197.2 & $\mathrm{Rb}-\mathrm{Sr}$ & ECR-CG-14A & $\mathrm{SB} 22 / \mathrm{SC} 22$ & MonzoGranito & Rocha total & Granito Cigano & 5,9166 & - & 49.85 & 10 & 42 & W Serra Pelada \\
\hline C 197.3 & $\mathrm{Rb}-\mathrm{Sr}$ & ECR-CG-34E & SB $22 / S C 22$ & Monzogranito & Rocha total & Granito Cigano & $-5,9166$ & - & 49.85 & 10 & 42 & W Serra Pelada \\
\hline C 197.4 & Rb-Sr & ECR-CG-34A & SB 22/SC 22 & MonzoGranito & Rocha total & Granito Cigano & $-5,9166$ & - & 49.85 & 10 & 42 & W Serra Pelada \\
\hline $\bar{C} 197.5$ & $\mathrm{Rb}-\mathrm{Sr}$ & ECR-CG-44B & $5822 / S C 22$ & MonzoGranito & Rocha total & Granito Cigano & $-5,9166$ & - & 49.85 & 10 & 42 & W Serra Pelada \\
\hline $\bar{C} 198.1$ & Rb-Sr & $K Z-06$ & SB $221 S C 22$ & Granito & Rocha total & Grupo Rio Fresco & $-7,45$ & - & 50.45 & 10 & 44 & S Rio Maria \\
\hline C 198.2 & $\mathrm{Rb}-\mathrm{Sr}$ & $\overline{K Y-111 B}$ & $\mathrm{SB} 221 \mathrm{SC} 22$ & Granito & Rocha total & Granito Mata Surráo & $-7,45$ & - & 50.45 & 10 & 44 & S Rio Maria \\
\hline C 198.3 & $R b-S t$ & KY-113C & $582215 C 22$ & Granito & Rochra total & Granito Mata Surra & $-7,45$ & - & 50.45 & 10 & 44 & S Rio Maria \\
\hline C 198.4 & $\overline{\mathrm{Rb}}-\mathrm{Sr}$ & $K \gamma-1008$ & $\mathrm{SB} 221 \mathrm{SC} 22$ & Granito & Rocha total & Granito Mata Surrăo & -7.45 & - & 50.45 & 10 & 44 & S Rio Maria \\
\hline C 198.5 & $\mathrm{Rb}-\mathrm{Sr}$ & KY-94A & SB 22/SC 22 & Granito & Rocha total & \begin{tabular}{|l} 
Granito Mata Surrăo \\
\end{tabular} & $-7,45$ & - & 50.45 & 10 & 44 & S Rio Maria \\
\hline C 198.6 & $\mathrm{Rb}-\mathrm{Sr}$ & KYYOBE & SB 22/SC 22 & Granito & Rocha total & Granito Mata Surráo & $-7,45$ & - & 50.45 & 10 & 44 & S Rio Maria \\
\hline
\end{tabular}




\begin{tabular}{|c|c|c|c|c|c|c|c|c|c|c|c|c|}
\hline Ordem & Método & $\mathbf{N}^{\circ}$. Campo & Folha & Litologia & Material Anallsado & Unldade Geológlca & Latifude & & Longltude & $\begin{array}{l}\text { Prec } \\
(\mathrm{Km})\end{array}$ & Ref & Referência Geográfica \\
\hline C 198.7 & $R b-S r$ & KY-9BA & SB $2215 C 22$ & Granito & Rocha total & Granito Mata Surrá & $-7,45$ & - & 50.45 & 10 & 44 & S Rio Maria \\
\hline C 199.1 & $\mathrm{Rb}-\mathrm{Sr}$ & $X M V-78 j$ & SB 22/SC 22 & Riodacito & Rocha total & Embasamento & $-5,7602$ & - & 52.5588 & 10 & 49 & Regiso Rio Iriri \\
\hline C 199.2 & $\mathrm{Rb}-\mathrm{Sr}$ & XMV-78L & SB 22/SC 22 & Riodacito & Rocha total & Embasamento & $-5,7692$ & - & 52.5588 & 10 & 49 & Regiăo Rio lriri \\
\hline C 199.3 & $\mathrm{Rb}-\mathrm{Sr}$ & $X M J-78 M$ & SB 22/SC 22 & Riodacito & Rocha fotal & Embasamento & $-5,7692$ & - & 52.5588 & 10 & 49 & Regiß̊o Rio Iriri \\
\hline C 199.4 & $\mathrm{Rb}-\mathrm{Sr}$ & XMV -78E & SB $221 S C 22$ & Riodacito & Rocha total & Embasamento & $-5,7692$ & $\because$ & 52.5588 & 10 & 49 & Regiáo Rio irini \\
\hline C 199.5 & $\mathrm{Sm}-\mathrm{Nd}$ & XMV-78L & $\mathrm{SB} / \mathrm{SC} 22$ & Riodacito & Rocha total & Embasamento & $-5,7692$ & - & 52.5568 & 0 & 79 & Regiāo Rio Irinj \\
\hline C 199.6 & Sm-Nd & $\mathrm{XMV78M}$ & $\mathrm{SB} / \mathrm{SC} 22$ & Riodacito & Rocha total & Embasamento & $-5,7692$ & - & 52.5568 & 0 & 79 & Regiāo Rio Iriti \\
\hline$C 2.1$ & $\mathrm{U}-\mathrm{Pb}$ & GD-1 & $5822 / 5 C 22$ & Riodacito & Zircăo & Grupo Gráo Pará & $-6,0833$ & - & 49.9666 & 10 & 1 & S Rio ltacaiúnas \\
\hline$C 2.2$ & $\mathrm{U}-\mathrm{Pb}$ & $\mathrm{GD}-2$ & $582215 C 22$ & Riodacito & Zircáo & Grupo Gráo Para & $-6,0833$ & - & 49.9666 & 10 & 1 & S Rio ltacaiunas \\
\hline$C 2.3$ & $\mathrm{U}-\mathrm{Pb}$ & $\mathrm{GD}-3$ & SB 22/SC 22 & Riodacito & Zircaso & Grupo Gráo Pará & $-6,0833$ & - & 49.9606 & 10 & 1 & S Rio ltacaiúnas \\
\hline C 2.4 & $\mathrm{U}-\mathrm{Pb}$ & $\overline{G R-1}$ & $5822 / S C 22$ & Riolito & Zirç̄o & Grupo Grăo Pará & $-6,0833$ & - & 49.9666 & 10 & 1 & S Rio ltacaiunas \\
\hline C 20.1.1 & $\mathrm{Rb}-\mathrm{Sr}$ & GB-93 & SB 22/SC 22 & Basalio & Rocha tota! & Grupo Grăo Pará & $-6,0167$ & $\because$ & 50.5167 & 10 & 2 & S Rio ltacaiúnas \\
\hline C 20.1.2 & Sm-Nd & GB-93 & $\mathrm{SB} 221 \mathrm{SC} 22$ & Basalto & Rocha total & Grupo Grăo Pará & $-6,0167$ & - & 50.5167 & 10 & 2 & S Rio Itacaiúnas \\
\hline C 200.1 & $\mathrm{Rb}-\mathrm{Sr}$ & XMV-157D & $\mathrm{SB} 221 \mathrm{SC} 22$ & Gnaisse & Rocha total & Embasamento & $-4,3846$ & - & 52.5441 & 10 & 49 & Regiāo Rio Irini \\
\hline $\mathrm{C} 200 \overline{2}$ & $\mathrm{Rb}-\mathrm{Sr}$ & XMV-157E & $\mathrm{SB} 221 \mathrm{SC} 22$ & Gnaisse & Rocha total & Embasamento & 4,3846 & $=$ & 52.5441 & 10 & 49 & Regiăo Rjo lrini \\
\hline C 200.3 & $\mathrm{Rb}-\mathrm{Sr}$ & XMV-157G & $\mathrm{SB} 22 / \mathrm{SC} 22$ & Gnaisse & Rocha total & Embasamento & $-4,3846$ & - & 52.5441 & 10 & 49 & Regiăo Rio Iriri \\
\hline$c 200.4$ & $\mathrm{Rb}-\mathrm{Sr}$ & XMV-1571 & SB $22 / S C 22$ & Gnaisse & Rocha total & Embasamento & $-4,3846$ & $\overline{-}$ & 52.5441 & 10 & 49 & Regiáo Rio lini \\
\hline c 200.5 & $\mathrm{Rb}-\mathrm{Sr}$ & XMV-157P & SB 22/SC 22 & Gnaisse & Rocha total & Embasamento & $-4,3846$ & - & 52.5441 & 10 & 49 & Regiáo Roo Iriri \\
\hline C 201.1 & $R b-S r$ & XMV-81C & $S B 2215 C 22$ & Metabásica & Rocha total & Embasamento & $-5,5897$ & $=$ & 52.5441 & 10 & 49 & Regiấo Rio trìi \\
\hline$c 201.2$ & $\mathrm{Rb}-\mathrm{Sr}$ & XMV-81F & SB 22/SC 22 & Metabásica & Rocha total & Embasamento & $-5,5897$ & - & 52.5441 & 10 & 49 & Regiăo Rio lriri \\
\hline C 201.3 & $\mathrm{Rb}-\mathrm{Sr}$ & XMV-81 & $S B 2215 C 22$ & Metabésica & Rocha total & Embasamento & $-5,5897$ & - & 52.5441 & 10 & 49 & Regiấo Rio kriri \\
\hline $\mathrm{C} 201.4$ & $\mathrm{Rb}-\mathrm{Sr}$ & XMV-81P & SB 22/SC 22 & Metabásica & Rocha total & Embasamento & $-5,5897$ & - & 52.5441 & 10 & 49 & Regiăo Rio Iriri \\
\hline c 201.5 & $\mathrm{Rb}-\mathrm{Sr}$ & $X M V-81 Q$ & SB 22/SC 22 & Metabásica & Rocha total & Embasamento & $-5,5897$ & $\because$ & 52.5441 & 10 & 49 & Regiấo Rio Irin \\
\hline C 202.1 & $\mathrm{Rb}-\mathrm{Sr}$ & $X M V-140 B$ & SB $22 / S C 22$ & Calcissilicática & Rocha total & Embasamento & $-4,5897$ & - & 52.6471 & 10 & 49 & Regiăo Rio Irini \\
\hline C 202.2 & $\mathrm{Rb}-\mathrm{Sr}$ & $X \mathrm{MN}-140 \mathrm{D}$ & $S B 22 / S C 22$ & Calcissilicática & Rocha total & Embasamento & $-4,5897$ & - & 52.6471 & 10 & 49 & Regiăo Rio lriri \\
\hline C 202.3 & $\mathrm{Rb}-\mathrm{Sr}$ & $X M V-140 G$ & $S B 2215 C 22$ & Calcissilicática & Rocha total & Embasamento & $-4,5897$ & 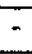 & 52.6471 & 10 & 49 & Regiăo Rio Iriri \\
\hline$C 202.4$ & $\mathrm{Rb}-\mathrm{Sr}$ & XMV-140 & $\mathrm{SB} 22 / \mathrm{SC} 22$ & Calcissilicatica & Rocha total & Embasamento & $-4,5897$ & - & 52.6471 & 10 & 49 & Regiăo Rio Iriri \\
\hline C 202.5 & $\mathrm{Rb}-\mathrm{Sr}$ & XMV-1400 & $\mathrm{SB} 22 / \mathrm{SC} 22$ & Calcissilicática & Rocha total & Embasamento & $-4,5897$ & $=$ & 52.6471 & 10 & 49 & Regiăo Rio Iriri \\
\hline C 203 & K-Ar & $\overline{A M} \overline{960}$ & $S \bar{B} 221 \mathrm{SC} 22$ & Anfibolito & Ánfibolio & Embasamento & $-5,6600$ & - & 52.44 & 10 & 69 & Rio ltacaiunas \\
\hline 6204 & K-Ar & 74 LXI11-11 & $\mathrm{SB} 22 / \mathrm{SC} 22$ & Granito & Biotita & Granito Xinguara & $-7,9000$ & - & 49.91 & 10 & 6 & N Redençăo \\
\hline C 205 & K-Ar & $\overline{A A}-\overline{7}-22$ & SB $221 S C$ & Anfibolito & Anfibollo & Embasamento & $-5,6400$ & - & 496 & 10 & 69 & Rio Paraupebas \\
\hline $\mathrm{C} 206$ & K-Ar & $\overline{A A-7-24}$ & $\mathrm{SB} 22 / \mathrm{SC} 22$ & Gnaisse & Anfíbólio & Embasamento & $-5,8200$ & - & 49.82 & 10 & 69 & Rio Paraupebas \\
\hline 6207 & K-Ar & $34 A-66$ & SB $22 / S C 22$ & Anfibolito & Anfibolio & Embasamento & $-4,6100$ & - & 49.37 & 10 & $\infty$ & S Jacundá \\
\hline
\end{tabular}




\begin{tabular}{|c|c|c|c|c|c|c|c|c|c|c|c|c|}
\hline Ordem & Método & $\mathbf{N}^{\circ}$. Campo & Folha & Litologia & Material Anallsado & Unidade Geológlca & Latlitude & & gitude & $\begin{array}{l}\text { Prec } \\
(\mathrm{Km})\end{array}$ & Ref & Referêncla Geográfica \\
\hline C 208 & K-Ar & $A V-5-7$ & $5 B 22 / 5 C 22$ & Migmatito & Biotita & Embasamento & $-4,5800$ & - & 49.68 & 10 & 69 & W Jacundá \\
\hline $\mathrm{C} 200$ & K-Ar & $A-21-19$ & SB $221 S C 22$ & Granito & Biotita & Granito Carajás & $-5,6200$ & - & 49.59 & 10 & $\infty 9$ & NW S F Xingu \\
\hline C21.1.1 & $R \mathrm{~b}-\mathrm{Sr}$ & GB-94 & SB 22/SC 22 & Basalto & Rocha total & Grupo Grăo Pará & $-6,0167$ & - & 50.5167 & 10 & 2 & S Rio ltacaiúnas \\
\hline C 21.1.2 & $\mathrm{Sm}-\mathrm{Nd}$ & 6894 & SB $221 S C 22$ & Basalto & Rocha total & Grupo Grăo Pará & $-6,0167$ & - & 50.5167 & 10 & 2 & S Rio Itacaiunnas \\
\hline $\mathrm{C} 210$ & $\mathrm{Rb}-\mathrm{Sr}$ & $A V-6-20$ & SB 22/SC 22 & Granito & Rocha total & Embasamento & $-4,4400$ & - & 49.73 & 10 & 69 & NW Jacundá \\
\hline C211.1 & $\mathrm{Rb}-\mathrm{Sr}$ & $A G-7-1$ & SB 22/SC 22 & Granito & Rocha total & & $-5,0100$ & - & 49.73 & 10 & 69 & $S$ Jacundá \\
\hline $\mathrm{C} 211.2$ & $\mathrm{Rb}-\mathrm{Sr}$ & $A g-7-1$ & $5 B 22 / S C 22$ & Granito & Rocha total & & 5,0100 & - & 49.73 & 10 & $\theta 9$ & S Jacundá \\
\hline C 212 & $R b-S r$ & $\bar{A} \bar{A}-132$ & $5822 / S C 22$ & Granito & Rocha total & Embasamento & $-4,5600$ & - & 50.13 & 10 & 69 & W Jacundá \\
\hline$C 213$ & Rb-Sr & $\mathrm{CN}-521$ & $\mathrm{SB} 22 / \mathrm{SC} 22$ & Migmatito & Rocha total & Embasamento & $-4,5600$ & $\sim$ & 50.13 & 10 & $\infty$ & W Jacundá \\
\hline C 214 & $\mathrm{Rb}-\mathrm{Sr}$ & PT $-4 A$ & SB 22/SC 22 & Granito & Rocha total & Embasamento & $-4,9200$ & - & 52.67 & 10 & 69 & Xingu River \\
\hline C 215 & K-Ar & AA-7-23 & SB 22/SC 22 & Gnaisse & Anfíbólio & Embasamento & $-5,7500$ & - & 49.77 & 10 & 69 & Rio Paraupebas \\
\hline$C \overline{216}$ & $\mathrm{~K}-\mathrm{Ar}$ & $36-A-66$ & SB $22 / 5 \mathrm{SC} 22$ & Gnaisse & Biotita & Embasamento & $-4,8500$ & - & 49.46 & 10 & 69 & S Jacundá \\
\hline $\bar{c} 217$ & $\mathrm{~K}-\mathrm{Ar}$ & AA. 213 & $\mathrm{SB} 22 / \mathrm{SC} 22$ & Granito & Biotita & Embasamento & $-5,6600$ & $=$ & 52.44 & 10 & $\infty$ & Rio Itacaiúnas \\
\hline C 218 & $\bar{R} b-S r$ & PA-405 & SB 22/SC 22 & Andesito & Rocha total & Embasamento & $-7,3400$ & - & 51.21 & 10 & 69 & Rio Fresco \\
\hline C 219.1 & $\mathrm{Rb}-\mathrm{Sr}$ & $G \bar{F}-1-22$ & SB $2215 C 22$ & Granito & Rocha fotal & Granito Carajás & $-6,2200$ & - & 50.18 & 10 & 6 & Rio Paraupebas \\
\hline $\mathrm{C219.2}$ & $\mathrm{Rb}-\mathrm{Sr}$ & GF-1-2425M & $582215 C 22$ & Granito & Rocha total & Granito Carajás & $-6,2200$ & - & 50.18 & 10 & 6 & Rio Paraupebas \\
\hline $\mathrm{C} 22.1$ & $R \mathrm{R}-\mathrm{Sr}$ & $G B-\infty$ & $S B 22 / S C 22$ & Basalto & Rocha total & Grupo Grăo Pará & $-6,1$ & - & 50.5167 & 10 & 2 & S Rio ltacaiúnas \\
\hline$C 220$ & $\mathrm{~K}-\mathrm{Ar}$ & $5-6$ & $\mathrm{SB} 22 / \mathrm{SC} 22$ & Granito & Anfibólio & Granito Carajás & $-6,2000$ & - & 50.27 & 10 & 69 & Rio Paraupebas \\
\hline $\mathrm{C} 221.1$ & $\mathrm{~K}-\mathrm{Ar}$ & $A-1185$ & SB 22/SC 22 & Folhelho & Rocha total & Grupo Rio Fresco & $-6,2400$ & - & 51.46 & 10 & 6 & Serra Carajás \\
\hline C 221.2 & $\mathrm{K}-\mathrm{Ar}$ & A-1183 & SB $221 S C 22$ & Folhelko & Rocha total & Grupo Rio Fresco & $-6,2400$ & $\div$ & 54.46 & 10 & 69 & Serra Carajás \\
\hline $\bar{c} 221.3$ & K-Ar & $A-1184$ & $5 B 2215 C 22$ & Folhelho & Rocha total & Grupo Rio Fresco & $-6,2400$ & 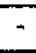 & 51.46 & 10 & 6 & Serra Carajás \\
\hline C 222 & K-Ar & $\mathrm{A}-21,3$ & SB 22ISC 22 & Granito & Anfibolio & Embasamento & $-6,0800$ & - & 52.51 & 10 & 6 & NW S F Xingu \\
\hline$C 223$ & $\bar{K}-\bar{A} \mathbf{r}$ & $6-268-966$ & $5822 / S C 22$ & Diabásio & Rocha total & & $-7,9100$ & - & 51.2 & 10 & 69 & Rio Fresco \\
\hline C 224 & $\mathrm{K}-\mathrm{Ar}$ & $P-A-23$ & $\mathrm{SB} 22 / \mathrm{SC} 22$ & Granito & Rocha total & Embasamento & $-6,6500$ & - & 51.79 & 10 & 69 & SF Xingu \\
\hline C 225 & K-Ar & $23-A-66$ & $5822 / S C 22$ & Gabro & Rocha total & & $-7,7900$ & - & 51.14 & 10 & $\infty 9$ & Rio Fresco \\
\hline$\overline{2} 226$ & K-Ar & $39 \times X V-11-\infty 9$ & $\mathrm{SB} 221 \mathrm{SC} 22$ & Granito & Rocha total & Embasamento & $-7,5100$ & - & 51.82 & 10 & $\infty$ & Rio Riozintho \\
\hline C 227.1 & $\mathrm{Rb}-\mathrm{Sr}$ & $A P-245$ & $\mathrm{SB} 221 \mathrm{SC} 22$ & Granito & Biotita & Embasamento & $-4,5600$ & - & 52.71 & 10 & $\bar{\infty}$ & Xingu River \\
\hline $\mathrm{C} 227.2$ & $\mathrm{Rb}-\mathrm{Sr}$ & $\mathrm{AP}-245$ & $582215 C 22$ & Granito & Feldspato & Embasamento & $-4,5600$ & - & 52.74 & 10 & 69 & Xingu River \\
\hline C 228 & $\mathrm{K}-\overline{A r}$ & $P A-409$ & s̄ $22 / \mathrm{sc} 22$ & Granófiro & Rocha total & Embasamento & $-7,8000$ & - & 50.47 & 10 & 69 & NW Redençao \\
\hline C 220 & $\mathrm{~K}-\mathrm{Ar}$ & $175-250$ & $5 B 2215 C 22$ & Diabásio & Rocha total & & $-5,5500$ & $\sim$ & 49.73 & 10 & 69 & Rio Itacaiúnas \\
\hline$C 23.1 .1$ & $\mathrm{Rb}-\mathrm{Sr}$ & GB-102 & $\mathrm{SB} 22 / \mathrm{SC} 22$ & Riolito & Rocha total & Grupo Gráo Pará & $-6,05$ & - & 50.2333 & 10 & 2 & S Rio ltacaiúnas \\
\hline C 23.1.2 & Sm-Nd & GB-102 & $\mathrm{SB} 22 / \mathrm{SC} 22$ & Riolito & Rocha total & Grupo Grâo Pará & $-6,05$ & - & 50.2333 & 10 & 2 & S Rio ltacaiúnas \\
\hline $\mathrm{C} 230$ & $\mathrm{~K}-\overline{\mathrm{Ar}}$ & AU-665 & $582215 c 22$ & Gabro & Plagioclásio & & $-6,1800$ & - & 49.72 & 10 & 69 & Serra Pelada \\
\hline
\end{tabular}




\begin{tabular}{|c|c|c|c|c|c|c|c|c|c|c|c|c|}
\hline Ordem & Método & N'. Campo & Folha & Litologla & Material Anallsado & Unidade Geológlca & Latitude & & gitude & $\begin{array}{l}\text { Prec } \\
\text { (Km) }\end{array}$ & Ref & Referência Geográflca \\
\hline C 24.1.1 & $\mathrm{Rb}-\mathrm{Sr}$ & GB-104 & SB 221SC 22 & Riolito & Rocha total & Grupo Gráo Pará & $-6,05$ & - & 50.2167 & 10 & 2 & S Rio ltacaiúnas \\
\hline C 24.1 .2 & $\mathrm{Sm}-\mathrm{Nd}$ & $\overline{\text { GB-104 }}$ & SB 22/SC 22 & Riolito & Rocha total & Grupo Gráo Pará & $-6,05$ & - & 50.2167 & 10 & 2 & S Rio ltacaiúnas \\
\hline C 2.5 .1 & $\mathrm{U}-\mathrm{Pb}$ & GB-124 & SB 22ISC 22 & Riolito & Rocha total & Grupo Gráo Pará & $-6,067$ & - & 49.9333 & 10 & 2 & S Rio ltacaiúnas \\
\hline C26.1 & $\mathrm{U}-\mathrm{Pb}$ & $\overline{M L-\infty B(1)}$ & SB 22ISC 22 & Ortognaisse & Zircaso & Embasamento & $-7,7333$ & - & 50.0833 & 10 & 3 & S Rio Maria \\
\hline$\overline{C 26.10}$ & U-PD & $\operatorname{ML-\infty }(10)$ & SB 22/SC 22 & Ortognalsse & Zircaso & Embasamento & $-7,7333$ & - & 50.0833 & 10 & 3 & S Rio Maria \\
\hline C 26.11 & $\mathrm{U}-\mathrm{Pb}$ & $M J-\infty(11)$ & $\mathrm{SB} 22 / \mathrm{SC} 22$ & Ortognaisse & Zircăo & Embasamento & $-7,7333$ & - & 50.0833 & 10 & 3 & S Rio Maria \\
\hline C 26.12 & $\mathrm{U}-\mathrm{Pb}$ & MS-08 (12) & SB 22/SC 22 & Ortognaisse & Zircăo & Embasamento & $-7,7333$ & - & 50.0833 & 10 & 3 & S Rio Maria \\
\hline $\bar{c} 26.2$ & $\mathrm{U}-\mathrm{Pb}$ & MJLO (2) & SB 22/SC 22 & Ortogneisse & Zircăo & Embasamento & $-7,7333$ & - & 50.0833 & 10 & 3 & S Rio Maria \\
\hline C 26.3 & $\mathrm{U}-\mathrm{Pb}$ & MJ-D8 (3) & $\widehat{S B} 22 / S C 22$ & Ortognaisse & Zircঞo & Embasamento & $-7,7333$ & - & 50.0833 & 10 & 3 & S Rio Maria \\
\hline C 26.4 & $\mathrm{U}-\mathrm{Pb}$ & MJLD (4) & SB 22/SC 22 & Ortognaisse & Zircăo & Embasamento & $-7,7333$ & - & 50.0833 & 10 & 3 & S Rio Maria \\
\hline C 26.5 & $\mathrm{U}-\mathrm{Pb}$ & $M d-08(5)$ & $S B 22 / S C 22$ & Ortognaisse & Zircăo & Embasamento & $-7,7333$ & - & 50.0833 & 10 & 3 & S Rio Maria \\
\hline$\overline{26.6}$ & $\mathrm{U}-\mathrm{Pb}$ & $M J-08(6)$ & SB 22/SC 22 & Ortognaisse & Zircăo & Embasamento & $-7,7333$ & - & 50.0833 & 10 & 3 & S Rio Maria \\
\hline C 26.7 & $\mathrm{U}-\mathrm{Pb}$ & $\mathrm{MN}-08(7)$ & SB 22/SC 22 & Ortognaisse & Zircáo & Embasamento & $-7,7333$ & - & 50.0833 & 10 & 3 & S Rio Maria \\
\hline$\overline{C 26.8}$ & $\mathrm{U}-\mathrm{Pb}$ & MJ-OB (8) & SB 22ISC 22 & Ortognaisse & Zircăo & Embasamento & $-7,7333$ & - & 50.0833 & 10 & 3 & S Rio Maria \\
\hline C 26.9 & $\mathrm{U}-\mathrm{Pb}$ & MJ-C8(9) & SB 22/SC 22 & Ortognaisse & Zircăo & Embasamento & $-7,7333$ & - & 50.0833 & 10 & 3 & S Rio Maria \\
\hline C 27.1 & $\mathrm{U}-\mathrm{Pb}$ & RM- $\infty$ (1) & SB 221SC 22 & Granodionito & Zircaso & Granodiorito Rio Maria & $-7,45$ & - & 50.0167 & 10 & $\overline{3}$ & S Rio Maria \\
\hline C 27.10 & U.Pb & $R M-\infty(10)$ & SB 22ISC 22 & Granodiontito & Zircăo & Granodionito Rio Maria & $-7,45$ & - & 50.0167 & 10 & 3 & S Rio Maria \\
\hline C 27.11 & $\mathrm{U}-\mathrm{Pb}$ & $R M-\infty(11)$ & $\mathrm{SB} 22 / \mathrm{SC} 22$ & Granodionito & Zircăo & Gramodionto Rio Maria & $-7,45$ & - & 50.0167 & 10 & 3 & S Rto Maria \\
\hline C 27.2 & $\mathrm{U}-\mathrm{Pb}$ & RM- & SB 22/SC 22 & Granodiorito & Zirço & Granodiorito Rio Maria & $-7,45$ & - & 50.0167 & 10 & 3 & S Rio Maria \\
\hline C 27.3 & $\mathrm{U}-\mathrm{Pb}$ & RM- & $582215 C 22$ & Granodionto & Zirca & Granodiorito Rio Maria & $-7,45$ & $=$ & 50.0167 & 10 & 3 & S Rio Maria \\
\hline C 27.4 & $\mathrm{U}-\mathrm{Pb}$ & RM- $\infty(4)$ & SB 221SC 22 & Granodiorito & Zircáo & Granodionito Rio Maria & $-7,45$ & - & 50.0167 & 10 & $\overline{3}$ & S Rio Maria \\
\hline C 27.5 & U-Pb & $R M-69(5)$ & SB $22 / \mathrm{SC} 22$ & Granodionito & Zircăo & Granodiontito Rio Maria & $-7,45$ & - & 50.0167 & 10 & 3 & S Rio Maria \\
\hline $\bar{C} 27.6$ & $\mathrm{U}-\mathrm{Pb}$ & $R M-\infty(6)$ & SB $22 / S C 22$ & Granodionito & Zircăo & Granodiorito Rio Maria & -7.45 & - & 50.0167 & 10 & 3 & S Rio Maria \\
\hline C 27.7 & $\mathrm{U}-\mathrm{Pb}$ & RM-@ (7) & SB 22/SC 22 & Granodionito & Zurcăo & Granodiorito Rio Maria & -7.45 & - & 50.0167 & 10 & 3 & S Rio Maria \\
\hline C 27.8 & $\mathrm{U}-\mathrm{Pb}$ & $R M-68(8)$ & $S B 221 S C 22$ & Granodionito & Zircáo & Granodiorito Rio Maria & $-7,45$ & - & 50.0167 & 10 & 3 & S Rio Maria \\
\hline$\overline{C 27.9}$ & $\mathrm{U}-\mathrm{Pb}$ & RM-69(9) & SB 22/SC 22 & Granodionto & Zircáo & Granodiorito Rio Maria & $-7,45$ & - & 50.0167 & 10 & 3 & S Rio Maria \\
\hline$\overline{C 28.1}$ & $\mathrm{U}-\mathrm{Pb}$ & MJL-13(1) & SB 22/SC 22 & Metagrauvaca & Zircáo & Grupo Lagoa Seca & $-7,4167$ & - & 49.8667 & 10 & 4 & SE Rio Maria \\
\hline C 28.2 & $\mathrm{U}-\mathrm{Pb}$ & MLL-13(2) & SB 22/SC 22 & Metagrauvaca & Zircăo & Grupo Lagoa Seca & $-7,4167$ & $\because$ & 49.8667 & 10 & 4 & SE Rio Maria \\
\hline$c 28.3$ & U-Pb & MJL-13 (3) & SB 22/SC 22 & Metagrauvaca & Zircáo & Grupo Lagoa Seca & $-7,4167$ & - & 49.8667 & 10 & 4 & SE Rio Maria \\
\hline C 28.4 & $\mathrm{U}-\mathrm{Pb}$ & $M J L-13(4)$ & SB 22/SC 22 & Metagrauvaca & Zircăo & Grupo Lagoa Seca & $-7,4167$ & $=$ & 49.8667 & 10 & 4 & SE Rio Maria \\
\hline C 28.5 & $\mathrm{U}-\mathrm{Pb}$ & MJL-13(5) & SB 221SC 22 & Metagrauvaca & Zircáo & Grupo Lagoa Seca & $-7,4167$ & - & 49.8667 & 10 & 4 & SE Rio Maria \\
\hline C 28.6 & $\mathrm{U}-\mathrm{Pb}$ & MJL-13(6) & SB 22/SC 22 & Metagrauvaca & Zircăo & Grupo Lagca Seca & $-7,4167$ & - & 49.8667 & 10 & 4 & SE Rio María \\
\hline C 28.7 & $\mathrm{U}-\mathrm{Pb}$ & MJL-13(7) & SB 22ISC 22 & Metagrauvaca & Zircăo & Grupo Lagca Seca & $-7,4167$ & - & 49.8667 & 10 & 4 & SE Rio Maria \\
\hline
\end{tabular}




\begin{tabular}{|c|c|c|c|c|c|c|c|c|c|c|c|c|}
\hline Ordern & Método & $\mathbf{N}^{\circ}$. Campo & Folha & Lttologla & Material Analisado & Unldade Geológica & Latitude & & Longitude & $\begin{array}{l}\text { Prec } \\
(\mathbf{K m})\end{array}$ & Ref & Referêncla Geográflca \\
\hline C 20.1 & $\mathrm{U}-\mathrm{Pb}$ & MJL-15(1) & SB $22 / \mathrm{SC} 22$ & Quartzito & Zircăo & Grupo Rio Fresco & $-7,4$ & - & 49.8333 & 10 & 4 & SE Rio Maria \\
\hline $\mathrm{C} 29.2$ & $\mathrm{U}-\mathrm{Pb}$ & MJL-15(2) & $5 B 2215 C 22$ & Quatrito & Zirca & Grupo Rio Fresco & $-7,4$ & - & 49.8333 & 10 & 4 & SE Rio Maria \\
\hline C 29.3 & $\mathrm{U}-\mathrm{Pb}$ & MJL-15 (3) & SB 22/SC 22 & Quartzito & Zirco & Grupo Rio Fresco & $-7,4$ & - & 49.8333 & 10 & 4 & SE Rio Maria \\
\hline C 29.4 & $\mathrm{U}-\mathrm{Pb}$ & MJL-15(4) & $\mathrm{SB} 22 / \mathrm{SC} 22$ & Quarizito & Zircaso & Grupo Rio Fresco & $-7,4$ & - & 49.8333 & 10 & 4 & SE Rio Maria \\
\hline $\mathrm{C} 29.5$ & $\mathrm{U}-\mathrm{Pb}$ & MLL-15(5) & SB 22/SC 22 & Quartzito & Zircăo & Grupo Rio Fresco & $-7,4$ & - & 49.8333 & 10 & 4 & SE Rio Maria \\
\hline C 29.6 & $\mathrm{U}-\mathrm{Pb}$ & MJL-15(6) & $\mathrm{SB} 22 / \mathrm{SC} 22$ & Quartzito & Zircăo & Grupo Rio Fresco & $-7,4$ & $=$ & 49.8333 & 10 & 4 & SE Rio Maria \\
\hline C 29.7 & $\mathrm{U}-\mathrm{Pb}$ & MulL-15(7) & $582215 c 22$ & Quartzito & Zirca & Grupo Rio Fresco & $-7,4$ & - & 49.8333 & 10 & 4 & SE Rio Maria \\
\hline C 29.8 & $\mathrm{U}-\mathrm{Pb}$ & MLL-15 (8) & $\mathrm{SB} 22 / \mathrm{SC} 22$ & Quartzito & Zircāo & Grupo Rio Fresco & $-7,4$ & - & 49.8333 & 10 & 4 & SE Rio Matia \\
\hline C 29.9 & $\mathrm{U}-\mathrm{Pb}$ & MJL-15 (9) & SB 22/SC 22 & Quartzito & Zircăo & Grupo Rio Fresco & $-7,4$ & - & 49.8333 & 10 & 4 & SE Rio Maria \\
\hline C3.1 & $\mathrm{U}-\mathrm{Pb}$ & LU-1 & $58225 \mathrm{C} 22$ & Anortosito & Zircto & intrusăo Luanga & $-5,95$ & - & 49.6 & 10 & 1 & S Rio Itacaiünas \\
\hline C 3.2 & $\mathrm{U}-\mathrm{Pb}$ & LU-2 & $\mathrm{SB} 221 \mathrm{SC} 22$ & Anortosito & Zircäo & Intrusáo Luanga & $-5,56$ & - & 49.6 & 10 & 1 & S Rjo ttacaiúnas \\
\hline C3.3 & $\mathrm{U}-\mathrm{Pb}$ & LU3 & $S B 22 / S C 22$ & Anortosito & Zircáo & Intrusăo Luanga & $-5,96$ & - & 49.6 & 10 & $i$ & S Rio Itacaiúnas \\
\hline $\mathrm{C} 30.1$ & $\mathrm{Rb}-\mathrm{Sr}$ & GO-1 & SB 22/SC 22 & Granito & Rocha total & Grupo Serra Seringa & $-7,005$ & - & 50.6 & 10 & 5 & SW Serra Carajás \\
\hline $\mathrm{C} 31.1$ & $\mathrm{Rb}-\mathrm{Sr}$ & GO-2 & $\mathrm{SB} 22 / \mathrm{SC} 22$ & Granito & Rocha total & Gupo Serra Seringa & $-6,9166$ & - & 50.75 & 10 & 5 & SW Serra Carajás \\
\hline$\overline{32.1}$ & $\mathrm{Rb}-\mathrm{Sr}$ & RM-9 & $\mathrm{SB} 22 / \mathrm{SC} 22$ & Granito & Rocha total & Veho $Q$ Wherme Grante & $-6,7667$ & - & 51.15 & 10 & 5 & SW Serra Carajás \\
\hline C 33.1 & $R \mathrm{~b}-\mathrm{Sr}$ & AA-7.35 & SB 22/SC 22 & Gnaisse & Rocha total & Embasamento & $-5,9667$ & - & 49.8833 & 10 & 5,29 & $\bar{E}$ Serra Sereno \\
\hline $\mathrm{C} 33.2$ & $\mathrm{Rb}-\mathrm{Sr}$ & AA-7-36 & SB 22/SC 22 & Gnaisse & Rocha total & Embasamento & $-5,9667$ & - & 49.8833 & 10 & 5.29 & E Serta Sereno \\
\hline $\mathrm{C} 33.3$ & $\mathrm{Rb}-\mathrm{Sr}$ & AA-7-39 & SB 221SC 22 & Gnaisse & Rocha tołal & Embasamento & $-5,9667$ & - & 49.8833 & 10 & 5,29 & E Serra Sereno \\
\hline C 33.4 & K-Ar & AA-7-37 & SB 221SC 22 & Dlabásio & Rocha total & Dique no Embasamento & $-5,9667$ & - & 49.8833 & 10 & 5 & E Serra Sereno \\
\hline C 34.1 & $\mathrm{Rb}-\mathrm{Sr}$ & $A A-8-7$ & $5 B 221 \mathrm{SC} 22$ & Gnaisse & Rocha total & Embasamento & $-5,8167$ & - & 49.8167 & 10 & 5,29 & NW Serra Sereno \\
\hline C 34.2 & $\mathrm{Rb}-\mathrm{Sr}$ & AA-7-31 & SB 22/SC 22 & Gnaisse & Rocha total & Embasamento & $-5,8167$ & $=$ & 49.8167 & 10 & $5, \overline{20}$ & NW Serra Sereno \\
\hline$c 34.3$ & $\mathrm{Rb}-\mathrm{Sr}$ & AA-7-30(1) & SB 22/SC 22 & Gnaisse & Rocha total & Embasamento & $-5,8167$ & - & 49.8167 & 10 & 5,29 & NW Serra Sereno \\
\hline C $34 . \overline{4}$ & K-AT & AA-730(2) & $S B 2215 C 22$ & Anfibolito & Anfibolio & Embasamento & $-5,8167$ & - & 49.8167 & 10 & 5 & NW Serra Sereno \\
\hline$\overline{35.1}$ & $\bar{R} b-S r$ & AA-7-12 & SB $22 / S C 22$ & Gnaisse & Rocha total & Émbasamento & $-5,6167$ & - & 49.25 & 10 & 5,29 & SW Marabá \\
\hline C 36.1 & $\mathrm{Rb}-\mathrm{Sr}$ & $J W-\infty 8$ & $\mathrm{SB} 221 \mathrm{SC} 22$ & Gnaisse & Rocha total & Embasamento & $-5,6$ & - & 50 & 10 & 5,29 & W Rio ltacaiúnas \\
\hline$\overline{c 37.1}$ & K-Ar & TT-26 & $\mathrm{SB} 22 / \mathrm{SC} 22$ & Anfibolito & Rocha total & Embasamento & $-5,55$ & - & 50.5833 & 10 & 5 & N Serra Cinzento \\
\hline C 38.1 & K-Ar & $A A+7-6$ & $5822 / 5 C 22$ & Anfibolito & Anfibólio & Embasamento & $-5,6333$ & - & 49.4 & 10 & 5 & S Marabá \\
\hline$C 39.1$ & K-Ár & BS-23 & $\mathrm{SB} 22 / \mathrm{SC} 22$ & Gnaisse & Biotita & Embasamento & $-5,7$ & - & 50.3 & 10 & 5 & N Serra Cinzento \\
\hline C 4.1 & $\mathrm{U}-\mathrm{Pb}$ & PA-1 & SB $221 S C 22$ & Anfibolito & Zircaso & Grupo Poluca & $-5,9303$ & - & 50.4167 & 10 & 1 & S Rio ltacaiunas \\
\hline C 40.1 & K-Ar & $\pi-4$ & SB $22 / 5 C 22$ & Anfibolito & Anfibolio & Embasamento & $-5,8167$ & - & 50.1167 & 10 & 5 & N Serra Cinzento \\
\hline C 41.1 & K-Ar & OFS 58 & SB 22SC 22 & Anfibolito & Anfibolio & Embasamento & $-5,6667$ & - & 50.25 & 10 & 5 & S Serra Buritirama \\
\hline $\mathrm{C} 42.1$ & K-Ar & 1007 & SB 22/SC 22 & Xisto & Muscovita & Embasamento & $-5,6833$ & - & 50.7 & 10 & $\overline{5}$ & Serra Buritirama \\
\hline C 43.1 & K-Ar & AAD-7-15 & $\mathrm{SB} 221 \mathrm{SC} 22$ & Granito & Anfibotio & Embasamento & $-5,6$ & - & 49.4667 & 10 & 5 & SW Marabá \\
\hline
\end{tabular}




\begin{tabular}{|c|c|c|c|c|c|c|c|c|c|c|c|c|}
\hline Ordem & Método & $N^{\circ}$. Campo & Folha & Lltologla & Material Anallsado & Unidade Geológica & Latitude & & Longitude & $\begin{array}{l}\text { Prec } \\
\text { (Km) }\end{array}$ & Ref & Referéncia Geográfica \\
\hline $\mathrm{C} 44.1$ & $\mathrm{~K}-\mathrm{Ar}$ & OFS-76 & SB $22 / S C 22$ & Gnaisse & Anfibofio & Embasamento & $-5,6333$ & & 50.2 & 10 & 5 & S Serra Buritirama \\
\hline C 45.1 & $\overline{\mathrm{K}}-\overline{\mathrm{Ar}}$ & 8044 & SB $22 / \mathrm{SC} 22$ & Anfibolito & Anfibolio & Embasamento & $-5,6333$ & & 50.1333 & 10 & 5 & Serra Buritirama \\
\hline C 46.1 & K-At & $A A-7-20$ & SB 22/SC 22 & Migmatito & Biotita & Embasamento & $-5,6333$ & - & 49.7167 & 10 & 5 & SW Marabá \\
\hline C 47.1 & K-Ar & AA-7-4 & SB $22 / 5 C 22$ & Granito & Biotita & Embasamento & $-5,6333$ & & 49.3666 & 10 & 5 & S Marabá \\
\hline C 48.1 & K-Ar & OFS-74 & SB $22 / \mathrm{SC} 22$ & Diabásio & Rocha total & Dique no Embasamento & $-5,6333$ & 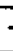 & 50.2333 & 10 & 5 & S Serra Burtirama \\
\hline C 49.1 & $\mathrm{~K}-\mathrm{Ar}$ & $A A-7-2$ & SB $221 \mathrm{SC} 22$ & Diabásio & Rocha total & Dique no Embasamento & $-5,5833$ & - & 49.4667 & 10 & 5 & S Marabá \\
\hline$\overline{C 5.1}$ & $\mathrm{U}-\mathrm{Pb}$ & $S N-1$ & $S B 2215 C 22$ & Gnaisse & Zircaso & Grupo Salobo & $-5,75$ & & 50.5333 & 10 & 1 & S Rio ltacaiunas \\
\hline $\mathrm{C} 5.2$ & $\mathrm{U}-\mathrm{Pb}$ & SN-2 & SB $221 \mathrm{SC} 22$ & Gnaisse & Zircaso & Grupo Salobo & $-5,75$ & 7 & 50.5333 & 10 & 1 & S Rio ltacaiúnas \\
\hline$\overline{C 5.3}$ & $\mathrm{U}-\mathrm{Pb}$ & $\mathrm{SN}-3$ & SB $2215 \mathrm{SC} 22$ & Gnaisse & Zircăo & Grupo Salobo & $-5,75$ & - & 50.5333 & 10 & 1 & S Rio ltacaiunas \\
\hline C50.1 & $\mathrm{K}-\mathrm{Ar}$ & $E A-55$ & $\mathrm{SB} 221 \mathrm{SC} 22$ & Granito & Biotita & Embasamento & $-\overline{6}, 2167$ & 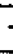 & 50.75 & 10 & 5 & SW Serra Carajás \\
\hline C51.1 & K-Ar & $C G-4$ & SB $2215 C 22$ & $\mathrm{BIF}$ & Rocha total & Grupo Gráo Pará & $-6,0833$ & 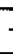 & 50.15 & 10 & 5 & Serra Carajás \\
\hline C 51.2 & $\mathrm{K}-\mathrm{Ar}$ & CG-3 & SB 221SC 22 & BIF & Feldspato & Grupo Gráo Pará & $-6,0833$ & & 50.15 & 10 & 5 & Serra Carajás \\
\hline $\mathrm{C52.1}$ & $\mathrm{K}-\mathrm{Ar}$ & CG-1 (52) & $5822 / S C 22$ & Granito & Anfibolio & Granito Carajás & $-6,15$ & & 50.25 & 10 & 5 & Serra Carajás \\
\hline $\mathrm{C} 52.2$ & K-Ar & CG-2 (56) & $\mathrm{SB} 22 / \mathrm{SC} 22$ & Granito & Anfibolio & Granito Carajás & $-6,15$ & & 50.25 & 10 & 5 & Serra Carajás \\
\hline C 53.1 & $\mathrm{K}-\mathrm{Ar}$ & CG-5 & SB 221SC 22 & BIF & Rocha total & Grupo Grăo Pará & $-6,05$ & & 50.2 & 10 & 5 & Serra Carajás \\
\hline C53.2 & K-Ar & CG-6 & $\mathrm{SB} 22 / \mathrm{SC} 22$ & BIF & Rocha total & Grupo Gráo Pará & $-6,05$ & & 50.2 & 10 & 5 & Serra Carajás \\
\hline C54.1 & K-Ar & HP-11 & $\mathrm{SB} 22 / \mathrm{SC} 22$ & Diabásio & Rocha total & Dique no Gripo Gró Pará & $-6,05$ & & 50.15 & 10 & $\overline{5}, \overline{29}$ & Serra Carajás \\
\hline$c 55.1$ & $\mathrm{~K}-\mathrm{Ar}$ & AA-8-1 (1) & $\mathrm{SB} 221 \mathrm{SC} 22$ & Granito & Anfibolio & Embasamento & $-5,9667$ & - & 49.7833 & 10) & 5,6 & E Serra Sereno \\
\hline $\mathrm{C} 5 \mathrm{5} .2$ & K-Ar & AA-B-1(2) & $S B 2215 C 22$ & Granito & Biotita & Embasamento & $-5,9667$ & $\rightarrow$ & 49.7833 & 10 & $5, \overline{6}$ & E Serra Sereno \\
\hline C 56.1 & $R \mathrm{~b}-\mathrm{Sr}$ & $E G 58-P B-48.1 B$ & SB 22USC 22 & Graisse & Rocha total & Embasamento & $-5,3333$ & 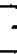 & 50.0833 & 10 & 8 & N Rio Itacaiunas \\
\hline C57.1 & $\mathrm{Rb}-\mathrm{Sr}$ & $E G 58-P B-48.1 C$ & SB 22/SC 22 & Gnaisse & Rocha total & Embasamento & $-5,3333$ & - & 50.0833 & 10 & 8 & N Rio Itacaiúnas \\
\hline C 58.1 & $\mathrm{Rb}-\mathrm{Sr}$ & EG59-PB-49B & SB 22/SC 22 & Gnaisse & Rocha total & Embasamento & $-5,3$ & 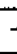 & 50.05 & 10 & 8 & N Rio ltacaiunas \\
\hline C 58.2 & $\mathrm{Rb}-\mathrm{Sr}$ & EGSO-PB-49D & SB $22 / 5 C 22$ & Gnaisse & Rocha total & Embasamento & $-5,3$ & 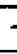 & 50.05 & 10 & 8 & S Rio Maria \\
\hline $\mathrm{C} 58.3$ & $\mathrm{Rb}-\mathrm{Sr}$ & EG59-PB-49F & SB $22 / S C 22$ & Gnaisse & Rocha total & Embasamento & $-5,3$ & . & 50.05 & 10 & 8 & S Rio Maria \\
\hline $\mathrm{C} 59.1$ & $\mathrm{Rb}-\mathrm{Sr}$ & EG64PB-53 & $5 B 22 / S C 22$ & Granito & Rocha total & Embasamento & $-7,0333$ & - & 50.4667 & 10 & 8 & S Rio Maria \\
\hline C 6.1 & $\mathrm{U}-\mathrm{Pb}$ & MA-1 & SB $22 / \mathrm{SC} 22$ & Anfibolito & Zircáo & Grupo Sałobo & $-5,7$ & 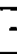 & 50.5833 & 10 & 1 & S Rio Itacaiúnas \\
\hline C6.2 & $\mathrm{U}-\mathrm{Pb}$ & MA-2 & $5822 / S C 22$ & Anfibolito & Titanita & Grupo Salobo & $-5,7$ & 7 & 50.5833 & 10 & 1 & S Rio ltacaiunas \\
\hline $\mathrm{C} 60.1$ & $\mathrm{Rb}-\mathrm{Sr}$ & EG63-PB-52 & $\mathrm{SB} 22 / \mathrm{SC} 22$ & MonzoGrantto & Rocha total & Embasamento & $+7,0033$ & - & 50.0333 & 10 & 8 & S Rio Maria \\
\hline C 61.1 & $\mathrm{Rb}-\mathrm{Sr}$ & EGG6-PB-5S & SB $22 / S C 22$ & Granito & Rocha total & Embasamento & $-7,4167$ & - & 50.0333 & 10 & 8 & S Rio Mara \\
\hline $\mathrm{C} \sigma 2.1$ & $\mathrm{Rb}-\mathrm{S} r$ & EG67-PB-56 & $58221 S C 22$ & Granito & Rocha total & Embasamento & 7,4833 & - & 50.0167 & 10 & 8 & S Rio Maria \\
\hline C 63.1 & $\mathrm{Rb}-\mathrm{Sr}$ & EG.2-PB-2.1C & SB 22/SC 22 & Granodionto & Rocha total & Embasamento & $-7,85$ & - & 50.3833 & 10 & 8 & S Rio Maria \\
\hline $\mathrm{C63.2}$ & $\mathrm{Rb}-\mathrm{Sr}$ & EG.2-PB-2.1D & SB 22/SC 22 & Tonalito & Rocha total & Embasamento & $-7,85$ & - & 50.3833 & 10 & 8 & S Rio Maria \\
\hline C 63.3 & $\mathrm{Rb}-\mathrm{Sr}$ & EG.2-PB-2.IF & SB 22/SC 22 & Tonalito & Rocha total & Embasamento & $-7,85$ & 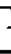 & 50.3833 & 10 & 8 & S Rio Maria \\
\hline
\end{tabular}




\begin{tabular}{|c|c|c|c|c|c|c|c|c|c|c|c|c|}
\hline Ordem & Método & $\mathrm{N}^{\circ}$. Campo & Folha & Litologla & Materlal Analisado & Unidade Geológica & Latifude & & Longltude & $\begin{array}{l}\text { Prec } \\
(\mathbf{K m})\end{array}$ & Ref & Referêncla Geográfica \\
\hline$\overline{c 64.1}$ & $\mathrm{Rb}-\mathrm{Sr}$ & JWO6 & $S B 22 / S C 22$ & Riolito & Rocha total & Vulcånicas Iriri & $-6,9166$ & - & 51.8667 & 10 & 13 & E Marabá \\
\hline $\mathrm{c} \approx 5.1$ & $\mathrm{Rb}-\mathrm{Sr}$ & AVOS & SB 2215C 22 & Riolito & Rocha total & Vulcanicas Inir & $-6,6333$ & $\because$ & 51.5167 & 10 & 13 & E Marabá \\
\hline$C \otimes 6.1$ & $\mathrm{Rb}-\mathrm{Sr}$ & ĀV101 & SB 22/SC 22 & Riolito & Rocha total & Vulcanicas Irini & $-6,9667$ & - & 51.3333 & 10 & 13 & E Marabá \\
\hline C 67.1 .1 & $\mathrm{Rb}-\mathrm{Sr}$ & PA272 & $\mathrm{SB} 22 / \mathrm{SC} 22$ & Andesito & Rocha total & Vulcanicas Iriri & $-6,9667$ & - & 51.5667 & 10 & 13 & E Marabá \\
\hline C 67.1 .2 & K-Ar & PA272 & $582215 C 22$ & Andesito & Rocha total & Vulcânicas Iriri & $-6,9667$ & - & 51.5667 & 10 & 13 & S Rio ltacaiunas \\
\hline $\mathrm{C} 68.1 .1$ & $\mathrm{Rb}-\mathrm{Sr}$ & PA 267 & $\mathrm{SB} 22 / \mathrm{SC} 22$ & Andesito & Rocha total & Vulcánicas Irîi & 7,15 & - & 51.4167 & 10 & 13 & E Marabá \\
\hline $\mathrm{C} \sigma 8.1 .2$ & $\mathrm{~K}-\mathrm{Ar}$ & PA 267 & SB $2215 C 22$ & Andesito & Rocha tofal & Vuicanicas Irini & $-7,015$ & - & 51.4167 & 10 & 13 & E Marabá \\
\hline $\mathrm{C} 69.1 .1$ & $\mathrm{Rb}-\mathrm{Sr}$ & SF 1 & $\mathrm{SB} 22 / \mathrm{SC} 22$ & Ándesito & Rocha total & Vulcânicas Iriri & $-6,6167$ & - & 51.96 & 10 & 13 & $\bar{E}$ Marabá \\
\hline$C \circledast 9.1 .2$ & K-At & SF 1 & $\mathrm{SB} 22 / \mathrm{SC} 22$ & Andesito & Rocha total & Vulcanicas Iriri & $-6,6167$ & - & 51.96 & 10 & 13 & E Marabá \\
\hline$c 7.1$ & U-Pb & MB-1 & $\mathrm{SB} 22 \mathrm{SC} 22$ & Granito & Zircáo & Grupo Salobo & $-5,7333$ & - & 50.5833 & 10 & 1 & S Rio ltacaiúnas \\
\hline C 7.2 & $\mathrm{U}-\mathrm{Pb}$ & $M B-2$ & $\mathrm{SB} 221 \mathrm{SC} 22$ & Granito & Zircáo & Grupo Salobo & -5.7333 & - & 50.5833 & 10 & 1 & S Rio ltacaiúnas \\
\hline 67.3 & $\mathrm{U}-\mathrm{Pb}$ & $\overline{M B-3}$ & SB 221SC 22 & Granito & Titanita & Grupo Salobo & $-5,7333$ & - & 50.5833 & 10 & $i$ & S Rio ltacaiúnas \\
\hline C 7.4 & $\mathrm{U}-\mathrm{Pb}$ & $M B-4$ & SB $22 / S C 22$ & Granito & Titanita & Grupo Salobo & $-5,7333$ & - & 50.5833 & 10 & 1 & S Rio ltacaiúnas \\
\hline C 70.1 & K-Ar & PA 285 & $5822 / 5 C 22$ & Andesito & Rocha total & Vulcanicas Iriri & $-7,2$ & - & 51.083 & 10 & 13 & E Marabá \\
\hline 071.1 & K-A $\bar{r}$ & PA 264 & $\mathrm{SB} 22 / \mathrm{SC} 22$ & Andesito & Rocha total & Vulcánicas Irin & $-\overline{6,4}$ & - & 52 & 10 & 13 & E Marabá \\
\hline$C 72.1$ & $K-\hat{A r}$ & PA 281 & SB 22/SC 22 & Andesito & Rocha total & Vulcanicas Iriri & $-7,7$ & - & 51.0167 & 10 & 13 & E Marabá \\
\hline C 73.1 & K-Ar & PA214 & SB 22/SC 22 & Tufo & Rocha total & Vulcanicas Irii & $-5,2833$ & - & 54.25 & 10 & 13 & E Marabá \\
\hline C 74.1 & $\mathrm{Rb}-\mathrm{Sr}$ & JMLA & SB $2215 C 22$ & Granodiorito & Rocha total & Granodionito Cumaru & $-7,6$ & $=$ & 50.85 & 20 & 23 & S Serra Carajás \\
\hline C 74.2 & $R b-\bar{S} r$ & JMU4A & SB $22 / 5 C 22$ & Granodionito & Rocha total & Granodiorito Cumaru & $-7,6$ & - & 50.85 & 20 & 23 & S Serra Carajás \\
\hline $67 \overline{3}$ & $R b-S_{T}$ & JML8 & SB 22/SC 22 & Granodionito & Rocha total & Granodiorito Cumaru & $-7, \overline{6}$ & - & 50.85 & 20 & 23 & S Serra Carajás \\
\hline c 74.4 & $R \mathrm{~B}-\mathrm{Sr}$ & JMLS & SB 22/SC 22 & Granodionito & Rocha total & Granodiorito Cumaru & $-7,6$ & $\because$ & 50.85 & 20 & 23 & S Serra Carajás \\
\hline $\mathrm{C} 74.5$ & $\mathrm{Rb}-\mathrm{Sr}$ & JMU $/ 7$ & SB 22/SC 22 & Granodionto & Rocha total & Granodiorito Cumary & $-\overline{7,6}$ & - & 50.85 & 20 & 23 & S Serra Carajás \\
\hline C 74.6 & $\mathrm{Rb}-\mathrm{Sr}$ & VS & SB 221SC 22 & Granodionito & Rocha total & Granodiorito Cumaru & $-7,6$ & - & 50.85 & 20 & 23 & S Serra Carajás \\
\hline C 75.1 & $\overrightarrow{\mathrm{K}-\mathrm{Ar}}$ & G0.514 & SB $221 \mathrm{SC} 22$ & Quartzito & Muscovita & Grupo Estrondo & $-6,35$ & - & 48.35 & 10 & 53 & SE Marabá \\
\hline C 76.1 & $\mathrm{Rb}-\mathrm{sr}$ & Vili-75 & $5822 / 5 C 22$ & Gnaisse & Rocha total & Gnaisse Estrela & 6,1333 & - & 49.9667 & 10 & 25 & SW Marabá \\
\hline $\mathrm{c} \pi 7.1$ & $\mathrm{Rb}-\mathrm{Sr}$ & VIII-14 & $\mathrm{SB} 22 / \mathrm{SC} 22$ & Gnaisse & Rocha total & Gnaisse Estrela & -6.1333 & - & 49.9667 & 10 & 25 & SW Marabá \\
\hline C 78.1 & $\mathrm{Rb}-\mathrm{Sr}$ & Vill-82 & SB $22 / S \bar{C} 22$ & Gnaisse & Rocha total & Gnaisse Estrela & $-6,1333$ & - & 49.9667 & 10 & 25 & SW Marabá \\
\hline $\mathrm{C} 79.1$ & $\overline{R b}-\mathrm{Sr}$ & $\overline{C N}-104$ & $\mathrm{SB} 22 / \mathrm{SC} 22$ & Graisse & Rocha total & Gnaisse Estrela & $-6,1333$ & - & 49.9667 & 10 & 25 & SW Marabá \\
\hline C 8.1 & $\mathrm{U}-\mathrm{Pb}$ & $S G-1$ & $582215 C 22$ & Granito & Zircáo & Grupo Salobo & $-5,7833$ & - & 50.5333 & 10 & 1 & S Rio Itacaiúnas \\
\hline$\overline{c 8.2}$ & $\mathrm{U}-\mathrm{Pb}$ & SG-2 & SB $22 / S C 22$ & Granito & Zircaso & Grupo Salobo & $-5, \overline{7833}$ & - & 50.5333 & 10 & 1 & S Rio ltacaiúnas \\
\hline $\mathrm{C} 80.1$ & $\mathrm{Rb}-\mathrm{Sr}$ & Vill-22 & SB 22/SC 22 & Gnaisse & Rocha total & Gnaisse Estrela & $-6,1333$ & - & 49.9667 & 10 & 25 & SW Marabá \\
\hline C81.1 & $\overline{R b}-\mathrm{Sr}$ & Vl-11 & $\mathrm{SB} 221 \mathrm{SC} 22$ & Gnaisse & Rocha total & Gnaisse Estrela & $-6,1333$ & - & 49.9667 & 10 & 25 & SW Marabá \\
\hline$C 82.1$ & $R \mathrm{~b}-\mathrm{Sr}$ & IV-74 & SB $221 \mathrm{SC} 22$ & Gnaisse & Rocha total & Gnaisse Estrela & $-6,1333$ & - & 49.9667 & 10 & 25 & SW Marabá \\
\hline
\end{tabular}




\begin{tabular}{|c|c|c|c|c|c|c|c|c|c|c|c|c|}
\hline Ordem & Método & $N^{\circ}$. Campo & Folha & Litologla & Material Analisado & Unidade Geológlca & Latitude & & Longltude & $\begin{array}{l}\text { Prec } \\
\text { (Km) }\end{array}$ & Ref & Referência Geográfica \\
\hline $\mathrm{C} 83.1$ & $R b-S r$ & CRN 8D & $582215 \mathrm{SC} 22$ & Gnaisse & Rocha total & Gnaisse Estrela & $-6,1333$ & - & 49.9667 & 10 & 25 & SW Marabá \\
\hline C84.1 & $\mathrm{Rb}-\mathrm{Sr}$ & $\mathrm{CN}-100$ & SB 22ISC 22 & Gnaisse & Rocha total & Gnaisse Estrela & $-6,1333$ & - & 49.9667 & 10 & 25 & SW Marabá \\
\hline C 85.1 & $R b-S r$ & $1 \mathrm{~V}-77$ & SB $2215 \mathrm{SC} 22$ & Gnaisse & Rocha total & Gnaisse Estrela & $-6,1333$ & - & 49.9667 & 10 & 25 & SW Marabá \\
\hline $\mathrm{C} 86.1$ & $\mathrm{Rb}-\mathrm{Sr}$ & $\mathrm{CN}-40$ & $\mathrm{SB} 221 \mathrm{SC} 22$ & Gnaisse & Rocha total & Gnaisse Estrela & $-6,1333$ & - & 49.9667 & 10 & 25 & SW Marabá \\
\hline $\mathrm{C} 87.1$ & $K-A r$ & 13178 & SB 221SC 22 & Basalto & Rocha total & Dique no Embasamento & $-6,1167$ & - & 50.8167 & 10 & 26 & Serra Carajás \\
\hline $\mathrm{C} 88.1$ & Rb-sr & $E M-199$ & SB $22 / S C 22$ & Gnaisse & Rocha total & Embasamento & $-6,6167$ & - & 51.95 & 20 & 27 & W Serra Seringa \\
\hline C89.1 & Rb-Sr & EM-200 & SB $2215 C 22$ & Gnaisse & Rocha total & Embasamento & $-6,6167$ & - & 51.95 & 20 & 27 & W Serra Seringa \\
\hline C9.1 & U-Pb & $F E-1$ & SB $2215 C 22$ & Anfibolito & Zircso & Grupo Salobo & $-5,85$ & - & 50.5333 & 10 & 1 & S Rio ltacaiúnas \\
\hline $\bar{c} 9.2$ & U-Pb & FE్-2 & $5822 / 5 C 22$ & Anfibolito & Zircăo & Grupo Salobo & $-5,85$ & - & 50.5333 & 10 & 1 & S Rio itacaiúnas \\
\hline $\mathrm{C} 9.3$ & $\mathrm{U}-\mathrm{Pb}$ & FES-3 & SB 22/SC 22 & Anfibolito & Zircáo & Grupo Salobo & $-5,85$ & - & 50.5333 & 10 & 1 & S Rio Itacaiunas \\
\hline$C 90.1$ & $R b-S t$ & $E M-190 B$ & SB 22/SC 22 & Gnaisse & Rocha total & Embasamento & $-6,6167$ & - & 51.95 & 20 & 27 & W Serra Seringa \\
\hline C 91.1 & $R b-S r$ & EM-189A & SB $221 S C 22$ & Gnaisse & Rocha total & Embasamento & $-6,6167$ & - & 51.95 & 20 & 27 & W Serra Seringa \\
\hline $\mathrm{C} 92.1$ & $\mathrm{RD}-\mathrm{Sr}$ & EM-193C & $\mathrm{SB} 221 \mathrm{SC} 22$ & Gnaisse & Rocha total & Embasamento & $-6,6167$ & - & 51.95 & 20 & 27 & W Serra Seringa \\
\hline C 93.1 & $\mathrm{Rb}-\mathrm{Sr}$ & $E M-190 A$ & SB $221 \mathrm{SC} 22$ & Gnaisse & Rocha total & Embasamento & $-6,6167$ & - & 51.96 & 20 & 27 & W Serra Seringa \\
\hline C94.1 & $\mathrm{Rb}-\mathrm{Sr}$ & EM-193D & SB 22/SC 22 & Gnaisse & Rocha total & Embasamento & $-6,6167$ & - & 51.95 & 20 & 27 & W Serra Seringa \\
\hline C95.1 & $\mathrm{Rb}-\mathrm{Sr}$ & AVR-158C & SB 22/SC 22 & Tonalito & Rocha total & Granodiorito Rio Maria & $-6,7333$ & - & 51.067 & 20 & $2 \overline{7}$ & Serra Seringa \\
\hline C 96.1 & $\mathrm{Rb}-\mathrm{Sr}$ & AVR-161 & SB 22/SC 22 & Tonalito & Rocha total & Granodiorito Rio Maria & $-6,7333$ & $\because$ & 51.067 & 20 & 27 & Serra Seringa \\
\hline C 97.1 & $R b-S r$ & AVR-69A & SB $2215 \mathrm{SC} 22$ & Tonalito & Rocha total & Granodiorito Rio Maria & $-6,7333$ & - & 51.067 & 20 & 27 & Serra Seringa \\
\hline$C 98.1$ & $\mathrm{Rb}-\mathrm{Sr}$ & AVR-69G & SB 22/SC 22 & Tonalito & Rocha total & Granodionito Rio Maria & $-6,7333$ & - & 51.067 & 20 & 27 & Serra Seringa \\
\hline C 99.1 & $\mathrm{Rb}-\mathrm{Sr}$ & AVR- $-9 F$ & SB $22 / S C 22$ & Tonalito & Rocha total & Granodionito Rio Maria & $-6,7333$ & - & 51.067 & 20 & 27 & Serra Seringa \\
\hline $\mathrm{CB} 10$ & $\mathrm{Rb}-\mathrm{S} r$ & $537 /$ AM-MR/87.3 & SD 21 & Granito & Rocha total & Embasamento & $-15,1986$ & - & 58.3261 & 10 & 62 & Região Rio Aguapel \\
\hline CB 100 & $\mathrm{~Pb}-\mathrm{Pb}$ & AM 66 & 5021 & Granitoide & Rocha total & Embasamento & $-15,3000$ & - & 58.3667 & 10 & 66 & Regiâo Rio Jauru \\
\hline$C 8101$ & $\mathrm{~Pb}-\mathrm{Pb}$ & AM 79 & $\mathrm{SD} 21$ & Granitóide & Rocha total & Embasamento & $-15,4667$ & - & 58.1833 & 10 & 66 & Regiăo Rio Jauru \\
\hline CB 102 & $\mathrm{~Pb}-\mathrm{Pb}$ & AM 87-1 & SD 21 & Granitoide & Rocha total & Embasamento & $-15,2500$ & - & 58.3667 & 10 & $\overline{66}$ & \begin{tabular}{|l} 
Regiăo Rio Jauru \\
\end{tabular} \\
\hline CB 103 & $\mathrm{~Pb}-\mathrm{Pb}$ & AM 101.1 & SD 21 & Granitoide & Rocha total & Embasamento & $-15,0500$ & - & 58.3833 & 10 & 66 & Regiăo Rio Jauru \\
\hline CB 104 & $\mathrm{Pb}-\mathrm{Pb}$ & AM 107 & SD 21 & Granitoide & Rocha total & Embasamento & $-14,9833$ & - & 58.45 & 10 & 66 & Regiáo Rio Jauru \\
\hline CB 105.1 & $\mathrm{Rb}-\mathrm{Sr}$ & $\mathrm{CJ}-16$ & SD 21 & Migmatito & Rocha total & Embasamento & $-15,2300$ & - & 58.5 & 10 & 65 & Regiáo Rio Branco \\
\hline$C \bar{B} 105.2$ & $\mathrm{Rb}-\mathrm{Sr}$ & G.19 & SD 21 & Migmatito & Rocha total & Embasamento & $-15,2300$ & - & 58.5 & 10 & 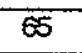 & Regiśo Rio Branco \\
\hline CB 105.3 & Rb-Sr & C.J-20 & SD 21 & Migmatito & Rocha total & Embasamento & $-15,2300$ & $\because$ & 58.5 & 10 & 65 & Regiáo Rio Branco \\
\hline CB 105.4 & Rb-Sr & CJ-21 & 5021 & Migmatito & Rocha total & Embasamento & $-15,2300$ & - & 58.5 & 10 & 65 & Regiăo Rio Branco \\
\hline CB 105.5 & $\mathrm{Rb}-\mathrm{Sr}$ & $\mathrm{CJ}-68$ & SD 21 & Migmatito & Rocha total & Embasamento & $-15,2300$ & - & 58.5 & 10 & 6 & Regižo Rio Branco \\
\hline CB 105.6 & $\mathrm{Rb}-\mathrm{Sr}$ & $\mathrm{Cu}-70$ & SD 21 & Migmatito & Rocha total & Embasamento & $-15,2300$ & - & 58.5 & 10 & 65 & Regiáo Rio Branco \\
\hline $\mathrm{CB} 106.1$ & $\mathrm{Rb}-\mathrm{Sr}$ & C. -25 & SD 21 & Metadacito & Rocha total & Vulcanicas Rio Branco & $-15,4100$ & - & 58.41 & 10 & 5 & Regiáo Rio Branco \\
\hline
\end{tabular}




\begin{tabular}{|c|c|c|c|c|c|c|c|c|c|c|c|c|}
\hline Ordem & Método & $N^{\circ}$. Campo & Folha & Litologla & Material Anallsado & Unidade Geológlca & Latltude & & Longitude & $\begin{array}{l}\text { Prec } \\
(\mathrm{Km})\end{array}$ & Ref & Referência Geográflca \\
\hline CB 106.2 & $R b-S r$ & C. -26 & SD 21 & Metadacito & Rocha total & Vulcanicas Rio Branco & $-15,4100$ & - & 58.41 & 10 & 65 & Regiáo Rio Branco \\
\hline $\mathrm{CB} 106.3$ & $\mathrm{Rb}-\mathrm{Sr}$ & $\mathrm{CJ}-27$ & SD 21 & Metadacito & Rocha total & Vulcănicas Rio Branco & $-15,4100$ & - & 58.41 & 10 & 65 & Regiăo Rio Branco \\
\hline CB 106.4 & $\mathrm{Rb}-\mathrm{Sr}$ & $\mathrm{C}-29$ & SD 21 & Metadacito & Rocha total & Vulcanicas Rio Branco & $-15,4100$ & - & 58.41 & 10 & 65 & Regiza Rio Branco \\
\hline $\mathrm{CB} 106.5$ & $\mathrm{Rb}-\mathrm{Sr}$ & $\mathrm{CJ}-30$ & SD 21 & Metadacito & Rocha total & Vulcânicas Rio Branco & $-15,4100$ & - & 58.41 & 10 & 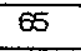 & Regiâo Rio Branco \\
\hline CB 107.1 & $\mathrm{Rb}-\mathrm{Sr}$ & $0 . \sqrt{37}$ & $\mathrm{SD} 21$ & Metatonalito & Rocha total & Fm. Mata Preta & $-15,1900$ & - & 58.45 & 10 & 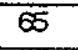 & Regiáo Rio Branco \\
\hline CB $10 \overline{7} .2$ & $R b-S r$ & $\mathrm{CJ}-38$ & 5021 & Metatonalito & Rocha total & Fm. Mata Preta & $-15,1900$ & - & 58.45 & 10 & 65 & Regiáo Rio Branco \\
\hline CB 107.3 & $\mathrm{Rb}-\mathrm{Sr}$ & $\mathrm{CJ}-30$ & 5021 & Metatonalito & Rocha total & Fm. Mata Preta & $-15,1900$ & - & 58.45 & 10 & 65 & Regižo Rio Branco \\
\hline CB 107.4 & $\mathrm{Rb}-\mathrm{Sr}$ & $\mathrm{CJ}-42$ & SD 21 & Metatonalito & Rocha total & Fm. Mata Preta & $-15,1900$ & - & 58.45 & 10 & 65 & Regiáo Rio Branco \\
\hline CB 108.1 & Rb-Sr & 0.50 & SD21 & Metagranodionito & Rocha total & Fm. Mata Preta & $-15,1900$ & - & 58.45 & 10 & 65 & Regiáo Rio Branco \\
\hline CB 108.2 & $\mathrm{Rb}-\mathrm{Sr}$ & $\mathrm{C} J-63$ & 5021 & Metagranodiorito & Rocha total & Fm. Mata Preta & $-15,1900$ & - & 58.45 & 10 & 65 & Regiǎo Rio Branco \\
\hline$\overline{C B} 108.3$ & $R b-S r$ & CJ-64 & SD 21 & Metagranodiorito & Rocha total & Fm. Mata Preta & $-15,1900$ & - & 58.45 & 10 & 65 & Regiazo Rio Branco \\
\hline $\mathrm{CB} 108.4$ & $\mathrm{Rb}-\mathrm{Sr}$ & C. 66 & SD 21 & Metagranodiorito & Rocha total & Fm. Mata Preta & $-\quad 15,1900$ & - & 58.45 & 10 & 65 & Regiáo Rio Branco \\
\hline CB 100 & $\mathrm{Sm}-\mathrm{Nd}$ & 537 AMMR 79 & SD 21 & Granito & Rocha total & Embasamento & $-15,6$ & - & 58.8333 & 10 & 79 & Jaurú \\
\hline $\mathrm{CB} 11$ & $\mathrm{Rb}-\mathrm{Sr}$ & $537 / A M-M R / 79$ & SD 21 & Granito & Rocha total & Embasamento & $-15,4416$ & - & 58.1871 & 10 & 62 & Regiáo Rio Aguapel \\
\hline $\mathrm{CB} 110$ & $\mathrm{Sm}-\mathrm{Nd}$ & 537 AMMR 101.2 & $\mathrm{SD} 21$ & Granodionito & Rocha total & Embasamento & $-15,6$ & - & 58.4 & 10 & 79 & Regiăo Rio Águapel \\
\hline $\mathrm{CB} 111$ & Sm-Nd & POCS & SD 21 & Tonalito & Rocha total & Embasamento & $-15,5385$ & - & 58.8462 & 10 & 79 & Jaurú \\
\hline$C B 12$ & $R b-S r$ & WF-405 & 5021 & Granito & Rocha total & Embasamento & $-15,8388$ & $=$ & 59.1893 & 10 & 62 & $S$ Mato Grosso \\
\hline CB 13 & $\mathrm{Rb}-\mathrm{Sr}$ & $3 B$ & 5021 & Biotita gnaisse & Rocha total & Embasamento & -15.1987 & - & 58.8727 & 10 & 62 & SE Mato Grosso \\
\hline $\bar{C} \overline{14}$ & $\mathrm{Rb}-\mathrm{Sr}$ & 58 & SD 21 & Granito & Rocha total & Embasamento & $-15,1278$ & - & 58.9407 & 10 & 62 & E Mato Grosso \\
\hline $\mathrm{CB} 15$ & $\mathrm{Rb}-\mathrm{Sr}$ & $6 B$ & SD 21 & Granito & Rocha total & Embasamento & $-15,0626$ & - & 58.9741 & 10 & 62 & Regiăo Rio Aguapel \\
\hline $\mathrm{CB} 16.1$ & $\mathrm{Rb}-\mathrm{Sr}$ & KK-MB-79.1 & $S D 21$ & Granito & Rocha total & Embasamento & $-15,4431$ & - & 59.0612 & 10 & 62 & SE Mato Grosso \\
\hline $\mathrm{CB} 16.2$ & K-Ar & KK-MB 79.1 & SD 21 & Granito & Biotita & Embasamento & -15.4431 & - & 59.0612 & 10 & 62 & SE Mato Grosso \\
\hline $\mathrm{CB} 17$ & K-AT & 9 & SD 21 & Gnaisse & Ānfibólio & Embasamento & $-15,7127$ & - & 58.575 & 10 & 62 & Regiăo Rio Aguapel \\
\hline $\mathrm{CB} 18$ & $\bar{K}-\bar{A}$ & 4 & SD 21 & Anfibolito & Anfibólo & Embasamento & $-15,5429$ & - & 58.9702 & 10 & 62 & SE Mato Grosso \\
\hline $\mathrm{CB} 19$ & K-Ar & AEF-190 & $\operatorname{so21}$ & Greisen & Muscovita & Embasamento & $-14,6900$ & - & 59.2585 & 10 & 62 & NE Mato Grosso \\
\hline $\mathrm{CB} 20$ & K-Ar & AJ-65 & SD 21 & Adamelito & Biotita & Embasamento & $-15,3525$ & - & 58.3747 & 10 & 62 & Regiăo Rio Aguapel \\
\hline $\mathrm{CB} 21$ & K-As & Ad-189 & SD 21 & Granito & Biotita & Embasamento & $-15,5064$ & - & 58.1862 & 10 & 62 & Regiåo Rio Aguapei \\
\hline$\overline{\mathrm{C}} \overline{\mathrm{B} 22}$ & $\mathrm{~K}-\mathrm{Ar}$ & JG-14 & SD 21 & Anfibolito & Anfibolio & Embasamento & $-15,5451$ & - & 58.3356 & 10 & 62 & Regiāo Rio Aguapel \\
\hline $\mathrm{CB} 23$ & K-Ar & 537/AM-MR 51 & SD 21 & Granito & Biotita & Embasamento & $-15,8378$ & - & 58.567 & 10 & 62 & Regiăo Rio Aguapel \\
\hline $\mathrm{CB} 24$ & $\mathrm{~Pb}-\mathrm{Pb}$ & Onça II (B) & SD 21 & $\mathrm{Qz}$ de veio & Galena & & & & & 10 & 68 & SE Mato Grosso \\
\hline CB 26 & K-Ar & 537/AM-MR/63.1 & SD 21 & Anfiboltto & Anfibolio & Suge intusiva Rio Alggre & $-15,2796$ & - & 58.4844 & 10 & 62 & Regiăo Rio Aguapel \\
\hline $\mathrm{CB} 27$ & K-Ar & WF/408.A & SD 21 & Gabro & Plagioclásio & Scie litrusiva Rio Alegre & $-15,8845$ & - & 59.2453 & 10 & 62 & $S$ Mato Grosso \\
\hline$\overline{C B} \overline{28}$ & $\mathrm{~K}-\mathrm{Ar}$ & $A R-51$ & 5021 & Anfibolito & Anfibolio & Scie intrusia Rio Alogre & $-15,6793$ & $\because$ & 50.2287 & 10 & 62 & S Mato Grosso \\
\hline
\end{tabular}




\begin{tabular}{|c|c|c|c|c|c|c|c|c|c|c|c|c|}
\hline Ordem & Método & $\mathbf{N}^{\circ}$. Campo & Folha & Litologia & Material Anallsado & Unidade Geológlea & Latitude & & Longltude & $\begin{array}{l}\text { Prec } \\
(\mathrm{Km})\end{array}$ & Ref & Referēncia Geográfica \\
\hline $\operatorname{CB} 29$ & $\mathrm{Rb}-\mathrm{Sr}$ & $J G-70$ & SD 21 & Riodacito & Rocha total & Grupo Rio Branco & $-15,2776$ & - & 58.3014 & 10 & 62 & Regiăo Rio Aguapel \\
\hline CB 30 & $\mathrm{Rb}-\mathrm{Sr}$ & $A \sqrt{ }-138$ & SD 21 & Riodacito & Rocha total & Grupo Rio Branco & $-15,3541$ & - & 58.2913 & 10 & 62 & Região Rio Aguapel \\
\hline $\mathrm{CB} 31$ & $\mathrm{Rb}-\mathrm{Sr}$ & $592 M R$-AM/15. 1 & SD 21 & Riodacito & Rocha total & Grupo Rio Branco & $-14,8167$ & - & 58.0514 & 10 & 62 & Regiăo Rio Aguapel \\
\hline$\overline{C B 32}$ & K-AI & JG-52 & SD 21 & Diabásio & Rocha total & Grupo Rio Branco & $-15,2125$ & - & 58.1618 & 10 & 62 & Região Rio Aguapei \\
\hline CB 33 & K-Ar & WF-716.B & SD 21 & Diabásio & Plagioclásio & Grupo Rio Branco & $-15,0695$ & - & 58.1843 & 10 & 62 & Regiăo Rio Aguapef \\
\hline $\mathrm{CB} 35$ & $\mathrm{~K}-\mathrm{Ar}$ & $592 / M R-A M / 113$ & SD21 & Diabásio & Rocha total & Grupo Rio Branco & $-14,575$ & - & 57.8514 & 10 & 62 & Chapada Parecis \\
\hline CB 36 & $\mathrm{~K}-\mathrm{Ar}$ & $502 / M R-A M / 153$ & SD 21 & Gabro & Plagiockásio & Grupo Rio Branco & $-14,7834$ & - & 57.987 & 10 & 62 & Reģiǎo Rio Aguapel \\
\hline $\mathrm{CB} 37$ & K-Ar & $592 M R-A M / 126$ & SD 21 & Diabásio & Plagioclásio & Grupo Rio Branco & $-14,5247$ & - & 58.0694 & 10 & 62 & Chapada Parecis \\
\hline $\mathrm{CB} 38$ & $\mathrm{~K}-\mathrm{Ar}$ & $532 M R$ R-AM 154.3 & SD 21 & Gabro & Plagioclásio & Grupo Rio Branco & $-14,8476$ & - & 57.9776 & 10 & 62 & Regiăo Rio Aguapeí \\
\hline $\mathrm{CB} 39$ & $\mathrm{Rb}-\mathrm{Sr}$ & $7-8$ & SD 21 & Granito & Rocha total & Suite Intrusiva Guapé & $-15,0063$ & - & 50.0469 & 10 & 61,52 & E Mato Grosso \\
\hline $\mathrm{CB} 40$ & $R b-S r$ & AEF-201 & SD 21 & Granito & Rocha total & Suite Intrusiva Guapé & $-14,6931$ & - & 59.3342 & 10 & 62 & NE Mato Grosso \\
\hline CB 41.1 & $\mathrm{Rb}-\mathrm{Sr}$ & $2-P$ & SD 21 & Granito & Rocha total & Suite Intrusiva Guapé & $-15,5601$ & - & 58.7056 & 10 & 62 & Regiăo Rio Aguapel \\
\hline $\mathrm{CB} 41.2$ & $\mathrm{~K}-\overline{\mathrm{Ar}}$ & $2-P$ & SD 21 & Granito & Biotita & Sute Intrusiva Guapé & $-15,5601$ & 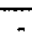 & 58.7056 & 10 & $\overline{62}$ & Regiăo Rio Aguapel \\
\hline CB 42 & $\mathrm{~K}-\mathrm{Ar}_{\mathrm{r}}$ & AEF-230 & SD 21 & Gabro & Plagioclásio & Suite Intrusiva Guapé & $-14,4271$ & - & 59.5385 & 10 & 62 & NE Mato Grosso \\
\hline CB 43 & $\bar{K}-\bar{A} \mathrm{r}$ & 10 & 5021 & Pegmatito & Muscovita & Suite Intrusiva Guapé & $-15, \overline{2349}$ & - & 59.2776 & 10 & 52 & SE Mato Grosso \\
\hline CB 44 & $\mathrm{Rb}-\mathrm{St}$ & 4034/AM-OC/234 & SD 21 & Filito & Rocha total & Grupo Cuiabá & $-15,6706$ & - & 56.5464 & 10 & 62 & Regiăo Rio Aguapel \\
\hline $\mathrm{CB} 45$ & $\mathrm{Rb}-\mathrm{Sr}$ & $4034 / A M-O C / 196$ & SD 21 & Filito & Rocha total & Grupo Cuiabá & $-15,50 \overline{5}$ & - & 56.1842 & 10 & 52 & Regiăo Rio Aguapel \\
\hline $\mathrm{CB} 46$ & $\mathrm{Rb}-\mathrm{Sr}$ & $4034 / A M-O C / 194$ & SD 21 & Filito & Rocha total & Grupo Cuiabá & $-15,5530$ & - & 56.1638 & 10 & $\overline{62}$ & Região Rio Aguapel \\
\hline$\overline{\mathrm{CB}} 47$ & $R b-S r$ & 4034AM-OC/207.3 & SD 21 & Filito & Rocha total & Grupo Cuiabá & $-15,3641$ & - & 56.2168 & 10 & 62 & Regiăo Rio Aguapel \\
\hline $\mathrm{CB} 48$ & $R b-s r$ & $\mathrm{CB}-62 \mathrm{~A}$ & SD 21 & Folhelho & Rocha total & Fm. Sepotuba & $-14,4192$ & $=$ & 56.3644 & 10 & 62 & Regiăo Rio Aguapel \\
\hline CB5 & $\mathrm{Rb}-\mathrm{Sr}$ & 537/AM-MR/101.1 & SD 21 & Granodiorito & Rocha total & Embasamento & $-15,0435$ & - & 58.3941 & 10 & 62 & Regiâo Rio Aguapel \\
\hline $\mathrm{CB} 50$ & $\mathrm{Rb}-\mathrm{Sr}$ & $\operatorname{cs}-88$ & SD 21 & Folhelho & Rocha total & Fm. Sepotuba & $-14,4724$ & - & 56.3711 & 10 & 62 & Regiano Rio Aguapel \\
\hline $\mathrm{CB} 54$ & $\mathrm{Rb}-\mathrm{Sr}$ & SV-O1 B & SD 21 & Granito & Rocha total & Granito Såo Vicente & $-15,7236$ & $=$ & 55.2937 & 10 & 62 & Regiăo Rio Aguapel \\
\hline $\mathrm{CB} 5$ & $\mathrm{Rb}-\mathrm{Sr}$ & SV-O4 B & SD 21 & Granito & Rocha total & Granito Săo Vicente & $-15,7670$ & + & 55.6748 & 10 & 62 & Regizo Rio Aguapel \\
\hline CB 56 & $\mathrm{Rb}-\mathrm{Sr}$ & SV-IVB & SD21 & Granito & Rocha total & Granito Săo Vicente & $-15,7916$ & - & 55.6118 & 10 & 62 & Região Rio Aguapel \\
\hline $\mathrm{CB} 57$ & $R b-S r$ & SVOSB & SD21 & Granito & Rocha total & Granito Săo Vicente & $-15,8145$ & - & 55.5548 & 10 & 62 & Regiaxo Rio Aguapef \\
\hline$\overline{C B 58}$ & K-AT & WP-20 & SD 21 & Basalto & Rocha total & Fm. Tapirapua & $-14,6692$ & - & 57.3389 & 10 & 62 & Chapada Parecis \\
\hline $\mathrm{CB} 59$ & K-Ar & Tapirapua 1 & SD 21 & Basalto & Rocha total & Fm. Tapirapua & $-14,6125$ & - & 57.4518 & 10 & 62 & Chapada Parecis \\
\hline $\mathrm{CB} 6$ & $\mathrm{Rb}, \mathrm{Sr}$ & 53 TAM-MR/66(+) & SD 21 & Granito & Rocha total & Embasamento & - 15,2714 & - & 58.3839 & 10 & 52 & Regiăo Rio Aguapel \\
\hline $\mathrm{CBO}$ & $K-A r$ & Tapirapua 2 & SD 21 & Basatto & Rocha total & Fm. Tapirapuá & $-14,6125$ & - & 57.4518 & 10 & 62 & Regiáo Rio Aguapel \\
\hline CB 61.1 & $\mathrm{Rb} S \mathrm{r}$ & MAC-102B1 & SD21 & Biot gnaisse & Rocha total & Embasamento & $-15,4060$ & - & 58.1726 & 10 & 67 & Regiăo Rio Aguapel \\
\hline CB 61.2 & $\mathrm{Rb}-\mathrm{Sr}$ & MAC-102B2 & SD 21 & Gnaisse & Rocha total & Embasamento & $-15,4960$ & - & 58.1726 & 10 & 67 & Regiăo Rio Aguapel \\
\hline $\mathrm{CB} 61.3$ & $\mathrm{Rb}-\mathrm{Sr}$ & MAC-102B3 & SD 21 & Biot graisse & Rocha total & Embasamento & $-15,4960$ & - & 58.1726 & 10 & 67 & Regiao Rio Aguapel \\
\hline
\end{tabular}




\begin{tabular}{|c|c|c|c|c|c|c|c|c|c|c|c|c|}
\hline Ordem & Método & $N^{\circ}$. Campo & Folha & Litologla & Materlal Anallsado & Unldade Geológlca & Latitude & & gitude & $\begin{array}{l}\text { Prec } \\
\text { (Km) }\end{array}$ & Ref & Referêncla Geográfica \\
\hline$C B 61.4$ & $\mathrm{Rb}-\mathrm{Sr}$ & MAC-10284 & $50 \overline{21}$ & Biot gnaisse & Rocha total & Embasamento & $-15,4960$ & - & 58.1726 & 10 & 67 & Regižo Rio Aguapel \\
\hline$\overline{C B} \overline{61.5}$ & $\mathrm{Rb}-\mathrm{Sr}$ & MAC-102B5 & SD 21 & Gnaisse & Rocha total & Embasamento & $-15,4960$ & - & 58.1726 & 10 & 67 & Regiăo Rio Aguapel \\
\hline $\mathrm{CB} 61.6$ & $\mathrm{Rb}-\mathrm{Sr}$ & MAC-102B6 & SD 21 & Biot gnaisse & Rocha total & Embasamento & $-15,4960$ & - & 58.1726 & 10 & 67 & Regizo Rio Aguapel \\
\hline $\mathrm{CB} 62$ & $\mathrm{Rb}-\mathrm{Sr}$ & MAC-23 & SD 21 & Granito & Rocha total & Suite Intrusiva Guapé & $-15,5114$ & - & 58.1530 & 10 & 67 & Regiāo Rio Aguapel \\
\hline $\mathrm{CB} 63$ & Rb-Sr & MAC-06 & SD 21 & Granito & Rocha total & Suite Intrusiva Guapé & $-15,5590$ & - & 58.1694 & 10 & 67 & Regiāo Rio Aguapel \\
\hline $\mathrm{CB} \overline{\mathrm{A}}$ & $\mathrm{Rb}-\mathrm{Sr}$ & MAC-66.1 & SD 21 & Granito & Rocha fotal & Suite Intrusiva Guapé & $-15,5666$ & - & 58.1648 & 10 & 67 & Regiăo Rio Aguapel \\
\hline$\overline{C B} \overline{5}$ & $\mathrm{Rb}-\mathrm{Sr}$ & MAC-87 & SD21 & Granodionito & Rocha total & Embasamento & $-15,5973$ & - & 58.1761 & 10 & 67 & Regižo Rio Aguapel \\
\hline $\mathrm{CB} 66$ & $\mathrm{Rb}-\mathrm{Sr}$ & MAC-89.1 & 5021 & Tonalito & Rocha total & Embasamento & $-15,5838$ & - & 58.1835 & 10 & 67 & Regiảo Rio Aguapei \\
\hline $\mathrm{CB} 67$ & $\mathrm{Rb}-\mathrm{Sr}$ & MAC- $63.1 B$ & SD 21 & Tonalito & Rocha total & Embasamento & $-15,6032$ & - & 58.1779 & 10 & 67 & Regico Rio Aguapel \\
\hline$\overline{C B} \approx 8$ & $\mathrm{Rb}-\mathrm{Sr}$ & MAC-79.1 & SD 24 & Granito & Rocha total & Suite Intrusiva Guapé & $-15,5296$ & - & 58.1758 & 10 & 67 & Regiáo Rio Aguapei \\
\hline $\mathrm{CB} \oplus 9$ & $\mathrm{Rb}-\mathrm{Sr}$ & MAC-60 & SD 21 & Granito & Rocha total & Surte Intrusiva Guapé & $-15,5774$ & - & 58.138 & 10 & 67 & Regiáo Rio Aguapel \\
\hline $\mathrm{CB} 70$ & $\mathrm{Rb}-\mathrm{Sr}$ & MAC-84 & SD 21 & Granito & Rocha total & Suite Intrusiva Guapé & $-15,5151$ & - & 58.1967 & 10 & 67 & Regiáo Rio Aguapel \\
\hline CB 71.1 & $\mathrm{K}-\mathrm{Ar}$ & MAC- $\overline{2 B}$ & SD 21 & Biot hn gnaisse & Biotita & Embasamento & $-15,6101$ & - & 58.1742 & 10 & 67 & Regiāo Rio Aguaper \\
\hline CB 71.2 & K-Ar & MAC-62B & SD 21 & Biof hin gnaisse & Anfibolio & Embasamento & $-15,6101$ & - & 58.1742 & 10 & 67 & Regiáo Rio Aguapel \\
\hline$\overline{C B} 71.3$ & $\overrightarrow{K-A r}$ & MAC-62C & SD 21 & Hn gnaisse & Anfibólio & Embasamento & $-15,6101$ & - & 58.1742 & 10 & $\overline{67}$ & Regiăo Rio Aguapei \\
\hline $\mathrm{CB} 71.4$ & K-Ar & MAC-62C & SD 21 & Hn gnaisse & Biotita & Embasamento & $-15,6101$ & - & 58.1742 & 10 & 67 & Regizó Rio Aguapei \\
\hline CB 71.5 & $\mathrm{K}-\mathrm{Ar}$ & MAC-62D & SD 21 & Biot gnaisse & Anfibolio & Embasamento & $-15,6101$ & - & 58.1742 & 10 & 67 & Regiăo Rio Äguapel \\
\hline$\overline{\mathrm{CB}} 71.6$ & $\mathrm{~K}-\mathrm{Ar}$ & MAC-E2D & SD 21 & Biot gnaisse & Biotita & Embasamento & $-15,6101$ & - & 58.1742 & 10 & 67 & Regizăo Rio Aguapef \\
\hline $\mathrm{CB} 72$ & K-Ar & MAC-07 & 5021 & Anfibolito & Anfibolio & Embasamento & $-15,4579$ & - & 58.3856 & 10 & 67 & Regiăo Rio Aguapel \\
\hline CB 73 & $\bar{K}-\bar{A} T$ & MAC-DB & SD 21 & Anfibolito & Anfibólio & Embasamento & $-15,4684$ & - & 58.392 & 10 & 67 & Regiño Rio Aguapel \\
\hline $\mathrm{CB} 74$ & K-AT & MAC 34d & SD 21 & Anfibolito & Anfibolio & Embasamento & $-15,4111$ & - & 58.3853 & 10 & 67 & Regizo Rio Aguapel \\
\hline$C B 75.1$ & K-Ar & MAC-51b1 & SD 21 & Anfibofito & Anfibolio & Embasamento & $-15,2710$ & - & 58.374 & 10 & 67 & Regiăo Rio Aguapel \\
\hline CB 75.2 & K-Ar & MAC-51b2 & SD 21 & Anfibolito & Anfibolio & Embasamento & $-15,2710$ & - & 58.374 & 10 & 67 & Regiăo Rio Aguapel \\
\hline $\mathrm{CB} 76$ & K-Ar & $\overline{M A C-44}$ & SD 21 & Anfibolito & Anfibolio & Embasamento & $-15,2844$ & - & 58.3793 & 10 & 67 & Regiāo Rio Aguapel \\
\hline$\overline{C B} \overline{77}$ & K-Ar & MAC- 66.2 & SD 21 & Anfibolito & Anfibólio & Embasamento & $-15,5392$ & - & 58.1858 & 10 & 67 & Rio Sepotuba \\
\hline $\mathrm{CB} 78$ & $\mathrm{~K}-\mathrm{Ar}$ & MAC-59 & SD 21 & Anfibolito & Anfibolio & Embasamento & $-15,5804$ & - & 58.1114 & 10 & 67 & Rio Sepotuba \\
\hline $\mathrm{CB} 79$ & K-Ar & MAC-89.2 & SD 21 & Anfibolito & Anfibolio & Embasamento & 15,5510 & - & $58.20 \% 5$ & 10 & 67 & Regiăo Rio Aguapel \\
\hline $\bar{C} B \overline{8}$ & $R b-S r$ & 44O/AM-MR/37.1 & $\mathrm{SD} 21$ & Migmatito & Rocha total & Embasamento & $-13,9079$ & - & 59.6586 & 10 & 62 & Regiåo Rio Aguapel \\
\hline CB 80 & Sm-Nd & $\mathrm{Ba}-01$ & SD 21 & MetaBasalto & Rocha total & Sequiencia Pontes o Lacerda & $-15,5$ & - & 50.36 & 10 & $\overline{\sigma 8}$ & SE Mato Grosso \\
\hline $\mathrm{CB} 81$ & Sm-Nd & $\mathrm{Ba}-02$ & SD 21 & MetaBasalto & Rocha total & Sequéncia Pontes o Lacerta & $-15,5$ & - & 59.36 & 10 & $\infty$ & SE Mato Grosso \\
\hline$\overline{C B 82}$ & $\mathrm{Sm}-\mathrm{Nd}$ & $8 a-\infty 3$ & 5021 & MetaBasalto & Rocha total & Sequencia Pontes e Lacerda & $-15,5$ & - & 59.36 & 10 & $\infty$ & SE Mato Grosso \\
\hline $\mathrm{CB} 83$ & $\mathrm{Rb}-\mathrm{Sr}$ & SD-01 & SD 21 & Granito gnaisse & Rocha total & Gerib-Graisze Santiol Hetera & $-15,5$ & - & 59.36 & 10 & $\infty 8$ & SE Mato Grosso \\
\hline CB 84 & $\overline{R b-S r}$ & SD-02 & SD 21 & Granito gnaisse & Rocha total & Gronio-Graisse Sartitidena & $-15,5$ & - & 59.36 & 10 & 68 & SE Mato Grosso \\
\hline
\end{tabular}




\begin{tabular}{|c|c|c|c|c|c|c|c|c|c|c|c|c|}
\hline Orden & Método & N. Campo & Folha & Litologia & Material Anallsado & Unidade Geológlca & Latitude & & Longitude & $\begin{array}{l}\text { Prec } \\
\text { (Km) }\end{array}$ & Ref & Referência Geográfica \\
\hline CB 85 & $\mathrm{Rb}-\mathrm{Sr}$ & JG-1006 & $\mathrm{SD} 21$ & Granito gnaisse & Rocha total & Granto-Gnaisse Santiol Helena & $-15,5$ & - & 59.36 & 10 & 68 & SE Mato Grosso \\
\hline CB 86 & $R b-S r$ & JG-100e & SD 21 & Granito gnaisse & Rocha total & Ganb-Graisso Sarta Hetera & $-\quad 15,5$ & - & 59.36 & 10 & 68 & SE Mato Grosso \\
\hline $\mathrm{CB} 87$ & Rb-Sr & JG-109f & SD 21 & Granito gnaisse & Rocha total & GrancGrasse Sartithelene & $-15,5$ & - & 59.36 & 10 & 68 & SE Mato Grosso \\
\hline $\mathrm{CB} 88$ & $\mathrm{Rb}-\mathrm{Sr}$ & $8 \mathrm{~h}$ & SD 21 & Granito & Rocha total & Granito Maraboa & $-15,2$ & - & 59.51 & 10 & 68 & SE Mato Grosso \\
\hline $\mathrm{CB} 89$ & $\mathrm{Rb}-\mathrm{Sr}$ & $8 i$ & SD 21 & Granito & Rocha total & Granito Maraboa & $-15,2$ & - & 59.51 & 10 & 68 & SE Mato Grosso \\
\hline$\overline{C B 9}$ & $\mathrm{Rb}-\mathrm{Sr}$ & $537 / A M-M R / 103$ & SD 21 & Granito & Rocha total & Embasamento & $-14,9441$ & - & 58.4487 & 10 & 62 & Regiăo Rio Aguapel \\
\hline$\overline{C B} 90$ & $\mathrm{Rb}-\mathrm{Sr}$ & $8 j$ & SD 21 & Granito & Rocha total & Granito Maraboa & $-15,2$ & - & 59.51 & 10 & 68 & SE Mato Grosso \\
\hline CB91 & $\mathrm{Rb}-\mathrm{Sr}$ & $8 k$ & SD 21 & Granito & Rocha total & Granito Maraboa & $-\quad 15,2$ & - & 59.51 & 10 & 68 & SE Mato Grosso \\
\hline $\mathrm{CB} 92$ & $\mathrm{Rb}-\mathrm{Sr}$ & 81 & SD 21 & Granito & Rocha total & Granito Maraboa & $-15,2$ & - & 59.51 & 10 & 68 & SE Mato Grosso \\
\hline$\overline{C B} \overline{93}$ & $\mathrm{Rb}-\mathrm{Sr}$ & $8 n$ & SD 21 & Granito & Rocha total & Granito Maraboa & $-15,2$ & - & 59.51 & 10 & $\$$ & SE Mato Grosso \\
\hline CB 94 & $\mathrm{~K}-\mathrm{Ar}$ & PLO3 & SD 21 & $Q z$ de veio & Sericita & & $-15,36$ & - & 59.29 & 10 & 68 & SE Mato Grosso \\
\hline $\mathrm{CB} 95$ & $\overline{\mathrm{K}}-\overline{\mathrm{Ar}}$ & PLOS & SD 21 & $Q z$ de veio & Sericita & & $-15,36$ & - & 59.29 & 10 & 68 & SE Mato Grosso \\
\hline$\overline{\mathrm{CB} 96}$ & K-Ar & PL 06 & SD 21 & Qz de veio & Sericita & & $-15,36$ & - & 59.29 & 10 & 68 & SE Mato Grosso \\
\hline $\mathrm{CB} 97$ & $\mathrm{~Pb}-\mathrm{Pb}$ & Onçal & SD 21 & Qz de veio & Gaiena & & $-15,36$ & - & 59.29 & 10 & 68 & SE Mato Grosso \\
\hline CB 98 & $\mathrm{Pb}-\mathrm{Pb}$ & Onça II (A) & 5021 & Qz de veio & Galena & & $-15,36$ & $\because$ & 59.29 & 10 & 68 & SE Mato Grosso \\
\hline $\mathrm{CB} 99$ & $\mathrm{~Pb}-\mathrm{Pb}$ & AM 37.1 & $\overline{S D} 21$ & Granitoide & Rocha total & Embasamento & $-13,9666$ & - & 59.6667 & 10 & $\infty 6$ & Regiáo Rio Jauru \\
\hline GP 1 & $\mathrm{Rb}-\mathrm{Sr}$ & PT-10 & $\mathrm{SD} 20$ & Granito & Rocha total & Embasamento & $-12,8183$ & - & 62.2012 & 10 & 61,75 & N Rio Guaporé \\
\hline GP 10.1 & $\mathrm{~K}-\mathrm{Ar}$ & PT 19 & $\operatorname{SD} 20$ & Diorito & Plagioclásio & \begin{tabular}{|l} 
Embasamento \\
\end{tabular} & $-12,7143$ & - & 61.6044 & 10 & $64, \sqrt{5}$ & W Vilhena \\
\hline GP 10.2 & $\mathrm{Sm}-\mathrm{Nd}$ & PT 19 & 5020 & Dionto & Rocha total & Embasamento & $-12,7143$ & - & 61.6044 & 30 & 79 & W Vilhena \\
\hline GP 11 & $\overline{R b}-\mathrm{Sr}$ & PT 05 (SD-20-XA) & 5020 & Granito Rapakivi & Rocha total & Grupo Costa Marques & $-12,1396$ & - & 62.6750 & 10 & 61,75 & N Rio Guaporé \\
\hline GP 12 & $\mathrm{Rb}-\mathrm{Sr}$ & GU-MR-OS & 5020 & Granito & Rocha total & Grupo Costa Marques & $-12,1483$ & - & 63.2092 & 10 & 61,75 & Rio Săo Miguel \\
\hline GP 13 & $\mathrm{Rb}-\mathrm{Sr}$ & PT 14 & 5020 & Granito & Rocha total & Grupo Costa Marques & $-12,9291$ & $\because$ & 60.7723 & 10 & 61.75 & SW Vilhena \\
\hline GP 14 & $\mathrm{Rb}-\mathrm{Sr}$ & GU-MR-03.4 & SD 20 & Riolito & Rocha total & Plutonismo Vulcanico & $-12,4351$ & - & 63.8306 & 10 & 61,75 & N Rio Guaporé \\
\hline GP 15 & $\mathrm{Rb}-\mathrm{Sr}$ & CMR-401 F & 5020 & Andesito & Rocha total & Plutonismo Vulcanico & $-12,2012$ & - & 62.4001 & 10 & 61,75 & N Rio Guaporé \\
\hline GP 16 & $R b-S r$ & PT-05.2 & SD 20 & Quartzo & Rocha total & Plutonismo Vulcanico & $-12,3098$ & - & 6.550 & 10 & 61,75 & N Rio Guaporé \\
\hline GP 17.1 & $\mathrm{Rb}-\mathrm{Sr}$ & GU-MR-04.4 & $\overline{S D} \overline{20}$ & Granófiro & Rocha total & Plutonismo Vulcanico & $-12,4776$ & - & 64.2941 & 10 & 61,75 & N Rio Guaporé \\
\hline GP $17 . \overline{2}$ & $\mathrm{Rb}-\mathrm{Sr}$ & GU-MR-04.8 & 5020 & Granbfiro & Rocha total & Plutonismo Vulcanico & $-12,4776$ & - & 64.2941 & 10 & $61, \overline{75}$ & N Rio Guaporé \\
\hline GP 19 & $\mathrm{~K}-\mathrm{Ar}$ & PT 18.1 & $5 D 20$ & Diabásio & Plagioclásio & Basalto Anari & $-12,5477$ & - & 61.6213 & 10 & 61,75 & W Vithena \\
\hline GP 2 & $\mathrm{Rb}-\mathrm{Sr}$ & $05-52$ & SD 20 & Gnaisse & Rocha total & Embasamento & $-13,8734$ & - & 60.0511 & 10 & 61,75 & NW Posto Vale do Glaporé \\
\hline GP 20 & K-Ar & GUMR 04.2 & $5 D 20$ & Basalto & Rocha total & & $-12,4776$ & - & 64.2941 & 10 & 61,75 & N Rio Guaporé \\
\hline GP 21.1 & K-Ar & PTO2-A & SD 20 & Basalto & Rocha fotal & Basalto Anati & $-12,5802$ & - & 61.4481 & 10 & 61,75 & W Vilhena \\
\hline $\mathrm{GP} 21.2$ & Sm-Nd & PT 02A & $5 D 20$ & Basalto & Rocha total & Basalto Anari & $-12,5802$ & - & 61.4481 & 30 & 79 & W Vithena \\
\hline GP 22 & $\mathrm{~K}+\mathrm{Ar}$ & OS $16-A$ & $\mathrm{SD} 20$ & Basalto & Rocha total & Basalto Anari & $-12,5441$ & - & 61.0965 & 10 & 61,75 & W Vilhena \\
\hline
\end{tabular}




\begin{tabular}{|c|c|c|c|c|c|c|c|c|c|c|c|c|}
\hline Ordem & Método & $N^{\circ}$. Campo & Folha & Lltologla & Material Anallsado & Unldade Geológlca & Latifude & & Congitude & $\begin{array}{l}\text { Prec } \\
(\mathbf{K m})\end{array}$ & Ref & Referência Geográfica \\
\hline GP 23 & $\mathrm{~K}-\mathrm{Ar}$ & PT 18-A2 & $S D 20$ & Gabro & Plagioclásio & Basalto Anari & $-12,5572$ & $\because$ & 61.5506 & 10 & 61,75 & W Vilhena \\
\hline GP 24 & $\mathrm{~K}-\mathrm{Ar}$ & PT $\infty$ & SD 20 & Gabro & Plagioclásio & Suite Rio Alegre & $-12,8139$ & - & 62.3531 & 10 & 61,75 & N Rio Guaporé \\
\hline GP 25 & K-Ar & PTO2 & $\overline{S D} 20$ & Basalto & Rocha total & Basalto Anari & $-12,5254$ & - & 61.4158 & 10 & 61,75 & W Vilhena \\
\hline GP 26 & $\mathrm{~K}-\overline{A r}$ & GU MR 31 & $5 \mathrm{SD} 20$ & Gabro & Plagiockásio & & $-14,0790$ & - & 60.4136 & 10 & 61,75 & W Posto Vale do Guaporé \\
\hline GP 27 & K-Ar & $05 \sqrt{33}$ & SD 20 & Gabro/Metabasito & Plagioclásio & & $-13,2333$ & - & 60.3194 & 10 & 61,75 & S Vilhena \\
\hline GP 28 & K-ÂI & os-36 & SD 20 & GabroMetabasito & Plagiociásio & & $-13,1751$ & - & 60.2852 & 10 & 61,75 & S vilhena \\
\hline GP 3.1 & K-Ar & PT 04.1 & SD 20 & Anfibolito & Rocha total & Embasamento & $-12,2517$ & - & 63.6901 & 10 & 61,75 & N Rio Guaporé \\
\hline GP 3.2 & Sm-Nd & PT-04-1 & 5020 & Anfibolito & Rocha total & Embasamento & $-\quad 12,2517$ & - & 63.6991 & 30 & 79 & N Rio Guaporé \\
\hline$\widehat{G P 4}$ & K-Ar & PT 05 (SD-2O-XD) & 5020 & Änfibolito & Anfifibolio & Embasamento & $-13,1759$ & - & 60.3850 & 10 & 61,75 & S vilhena \\
\hline GP 5.1 & $\mathrm{~K}-\mathrm{Ar}$ & PTOB-A.1 & $\overline{S D} 20$ & Anfibolito & Anfibolio & Embasamento & $-12,6465$ & - & 61.4545 & 10 & 61,75 & W vilhena \\
\hline $\mathrm{GP} 5.2$ & $\mathrm{Sm}-\mathrm{Nd}$ & PT-DBA1 & 5020 & Anfibolito & Anfibolio & Embasamento & $-12,6405$ & - & 61.4545 & 10 & 79 & W Vilhena \\
\hline$\overline{G P} 6$ & K-Ar & PT06 & $5 D 20$ & Gnaisse & Anfibolio & Embasamento & $-12,8964$ & - & 61.2617 & 10 & 61,75 & SW Vilhena \\
\hline GP7 & $\mathrm{K}-\mathrm{Ar}$ & PT 12-A.6 & SD20 & Anfibolito & Anfíbolio & Embasamento & $-12,9578$ & - & 60.8698 & 10 & 61,75 & SW Vilhena \\
\hline GP 8 & $\mathrm{~K}-\mathrm{A} \boldsymbol{r}$ & 0554.3 & SD 20 & Granito & Biodita & Embasamento & $-13,3363$ & - & 0.1203 & 10 & 61,75 & S vithena \\
\hline GP 9.1 & K-Ar & PTO3.1 & SD20 & Anfibolito & Anfibolio & Embasamento & $-13,0750$ & $\because$ & 6.6729 & 10 & 61,75 & sw Vilhena \\
\hline GP 9.2 & $\mathrm{Sm}-\mathrm{Nd}$ & PT.03 & 5020 & Anfibolito & Rocha total & Embasamento & $-13,0759$ & - & 60.6729 & 30 & 79 & sw Vilhena \\
\hline 11 & $\mathrm{Rb}-\mathrm{Sr}$ & PTCOSSP-CO & NA 19 & Granito & Rocha total & Granito Tiquié & +0.1833 & - & 69.5667 & 30 & 19 & S Rio Tiquié \\
\hline 110 & $\mathrm{Rb}-\mathrm{Sr}$ & UAVSP/41 & NA 19 & Adamelito & Rocha total & Embasamento & $+1,1667$ & - & 69.75 & 10 & 9.10 & Rio Uaupés \\
\hline 111 & $R \mathrm{~b}-\mathrm{Sr}$ & UAVEWIEVOOB & NA 19 & Adamelito & Rocha fotal & Embasamento & $+0,0500$ & - & 67.6833 & 10 & 10 & S Rio Uaupés \\
\hline 112 & $\mathrm{Rb}-\mathrm{Sr}$ & NERPF/29.A & NA 19 & Gnaisse & Rocha total & Embasamento & $+0,5000$ & - & 66.7833 & 10 & 10 & Rio Negro \\
\hline 113 & $R b-S r$ & PT.35 & NA 19 & Granito & Rocha total & Embasamento & $+0,5500$ & - & 66.1333 & 10 & 10 & N Rio Negro \\
\hline 114 & $\mathrm{Rb}-\mathrm{Sr}$ & PT.23 & NA 19 & Gnaisse & Rocha total & Embasamento & $+0,4833$ & - & 66.45 & 10 & 10 & N Rio Negro \\
\hline 115 & $\mathrm{Rb}-\mathrm{Sr}$ & PT.07.1 & NA 19 & Granito & Rocha total & Embasamento & $+1,5833$ & - & 68.15 & 10 & 10 & N Rio Içana \\
\hline 116 & $\mathrm{Rb}-\mathrm{Sr}$ & PI-EV-01 & NA 19 & Gnaisse & Rocha total & Embasamento & $+0,8000$ & - & 67.5333 & 10 & 10 & N Rio Cubate \\
\hline 117 & $\mathrm{Rb}-\mathrm{Sr}$ & CU/RM/AP/16 & NA 19 & Adamelito & Rocha total & Embasamento & $+0,8500$ & - & 68.3333 & 10 & 10 & Rio Cubate \\
\hline 118 & $R \mathrm{~b}-\mathrm{Sr}$ & PVIEV-O4 & NA 19 & Gnaisse & Rocha total & Embasamento & $+0,8500$ & - & 67.6 & 10 & 10 & N Rio Cubate \\
\hline 119 & $\mathrm{Rb}-\mathrm{Sr}$ & PT.32 & NA 19 & Granito & Rocha total & Embasamento & $+0,9333$ & - & $\$ 8.0667$ & 10 & 10 & N Rio Cubate \\
\hline 12 & $\mathrm{Rb}-\mathrm{Sr}$ & SE14/PT29 & NA 19 & Granito & Rocha total & Embasamento & $+0,5000$ & - & 66.2 & 10 & 19 & N Rio Negro \\
\hline 120.1 & $R \mathrm{~b}-\mathrm{Sr}$ & RMNO2A & SA 19 & Adamellto & Rocha total & Embasamento & $-0,1333$ & - & 67.0833 & 10 & 10 & Rio Negro \\
\hline 120.2 & $\mathrm{Rb}-\mathrm{Sr}$ & RMO2A1 & SA 19 & Adamelito & Rocha total & Embasamento & $-0,1333$ & - & 67.0833 & 10 & 10 & Rio Negro \\
\hline 120.3 & $\mathrm{Rb}-\mathrm{Sr}$ & RMO2A2 & SA 19 & Adamelito & Rocha total & Embasamento & $-0,1333$ & - & 67.0833 & 10 & 10 & Rio Negro \\
\hline 120.4 & $\mathrm{Rb}-\mathrm{Sr}$ & RMO2A3 & SA 19 & Adamelito & Rocha total & Embasamento & $-0,1333$ & - & 67.0833 & 10 & 10 & Rio Negro \\
\hline 120.5 & $\overline{R b}-\mathrm{Sr}$ & RM/O2A4 & SA 19 & Adamelito & Rocha total & Embasamento & $-0,1333$ & - & 67.0833 & 10 & 10 & Rio Negro \\
\hline
\end{tabular}




\begin{tabular}{|c|c|c|c|c|c|c|c|c|c|c|c|c|}
\hline Ordem & Método & $N^{\circ}$. Campo & Folha & Ettologla & Material Analisado & Unidade Geológica & Latltude & & Longltude & $\begin{array}{l}\text { Prec } \\
\text { (Km) }\end{array}$ & Ref & Referëncia Gecográflca \\
\hline $120 . \overline{6}$ & K-AI & RMOZZA & SA 19 & Adamelito & Biotita & Embasamento & $-0,1333$ & - & 67.0833 & 10 & 10 & Rio Negro \\
\hline 121 & $\mathrm{Rb}-\mathrm{Sr}$ & $1 A S-42-A M$ & SA 19 & Granito & Rocha total & Embasamento & $-2,1500$ & - & 69.5167 & 10 & 10 & Fronteira Brasit-Colômbia \\
\hline 122.1 & $\overline{R b}-\overline{S r}$ & UA/SP/18 & NA 19 & Granito & Rocha total & Embasamento & $+0,9333$ & - & 69.1333 & 10 & 10 & Rio Uaupés \\
\hline 1222 & $\overline{\mathrm{K}-\mathrm{Ar}}$ & UASPP/18A & NA 19 & Anfibolito & Anfibólio & Embasamento & $+0,9333$ & - & 90.1333 & 10 & 19 & Rio Uaupés \\
\hline 123 & $\mathrm{Rb}-\mathrm{Sr}$ & UAVSPI13 & NA 19 & Granito & Rocha total & Embasamento & $+0,8833$ & 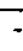 & 6.1 & 10 & 10 & Rio Uaupés \\
\hline 124 & $R b-S r$ & IÇ/EA/15 & NA 19 & Gnalsse & Rocha total & Embasamento & $+1,3833$ & - & 67.9167 & 10 & 10 & Rio lçana \\
\hline$\overline{25}$ & $\mathrm{Rb}-\mathrm{Sr}$ & IC /EA 20 & NA 19 & Granito & Rocha total & Embasamento & $+1, \sqrt[6333]{3}$ & - & $\varnothing 8.7167$ & 10 & 10 & Rio lçana \\
\hline 126 & $\mathrm{Rb}-\mathrm{Sr}$ & IÇ/EA/12 & NA 19 & Granito & Rocha total & Embasamento & $+1,2333$ & 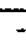 & 67.8 & 10 & 10 & Rio Içana \\
\hline 127 & $\mathrm{Rb}-\mathrm{Sr}$ & IÇ/EAß5 & NA 19 & Granito & Rocha total & Embasamento & $+1,6833$ & - & 68.85 & 10 & 10 & Rio Içana \\
\hline 128 & $R \mathrm{R}-\mathrm{Sr}$ & IÇ/EA & NA 19 & Granito & Rocha total & Embasamento & $+1,4667$ & . & 68.3167 & 10 & 10 & Rio lçana \\
\hline$\overline{129}$ & $\mathrm{Rb}-\mathrm{Sr}$ & PT.10M18 & NA 19 & Sienito & Rocha total & Embasamento & $+1,5000$ & ? & 67.8167 & 10 & 10 & Rio lçana \\
\hline 13.1 & $\mathrm{Rb}-\mathrm{Sr}$ & PAISP/ZS & NA 19 & Gnaisse & Rocha total & Embasamento & $+0,6333$ & - & 69.7667 & 10 & 19 & Ftonteira Brasil-Colômbia \\
\hline 13.2 & K-Ar & PAISPIZ5A & NA 19 & Anfibolito & Anfibolio & Embasamento & $+0,6333$ & - & 69.7667 & 10 & 19 & Fronteira Brasil-Colómbia \\
\hline 130 & $\mathrm{Rb}-\mathrm{Sr}$ & SESPTOS & NA 19 & Granito & Rocha total & Embasamento & $+0,0167$ & - & 67.0333 & 30 & 10 & N Rio Negro \\
\hline 131 & $\mathrm{Rb}-\mathrm{Sr}$ & PASPPN2 & NA 19 & Granito & Rocha total & Embasamento & $+0,6000$ & - & 69.2167 & 30 & 10 & Rio Uaupés \\
\hline$\longdiv { 3 2 . 1 }$ & $\mathrm{Rb}-\mathrm{Sr}$ & $\overline{P A} . \overline{S P B}$ & NA 19 & Adamelito & Rocha total & Embasamento & $+0,6000$ & - & 69.75 & 30 & 10 & Fronteira Brasil-Colómbia \\
\hline 132.2 & K-Ar & PA/SP/32B & NA 19 & Anfibolito & Anfibólio & Embasamento & $+0,0000$ & 7 & 60.75 & 10 & 78 & Fronteira Brasil-Colómbia \\
\hline 133 & $\mathrm{Rb}-\mathrm{Sr}$ & UA/SPIO2 & NA 19 & Granito & Rocha total & Embasamento & +0.0333 & - & $\$ 9.1667$ & 30 & 10 & Rio Uaupés \\
\hline 134 & Rb-Sr & PASPPO1 & NA 19 & Granito & Rocha total & Embasamento & $+0,5833$ & - & 60.1833 & 30 & 10 & Rio Uaupés \\
\hline 135 & $R b-S r$ & IÇ/EA-44 & NA 19 & Granito & Rocha total & Granito Tiquié & $+1,7000$ & 7 & 69.6833 & 30 & 19 & Fronteira Brasil-Colómbia \\
\hline 136.1 & $\mathrm{Rb}-\mathrm{Sr}$ & PT.26D & SA 19 & Riolito & Rocha total & Vicarismo Regional Traíra & $-0,9167$ & - & 69.55 & 10 & 10 & Fronteira Brasil-Colômbia \\
\hline 136.2 & $\mathrm{Rb}-\mathrm{Sr}$ & PT.26A & SA 19 & Riolito & Rocha total & Vucan'smo Regional Traira & $-0,9167$ & 7 & 69.55 & 10 & 10 & Fronteira Brasil-Colômbia \\
\hline$\longdiv { 3 6 . 3 }$ & $R \mathrm{~b}-\mathrm{Sr}$ & PT.26B & SA 19 & Riolito & Rocha total & Vitcarismo Regional Traía & $-0,9167$ & - & 69.55 & 10 & 10 & Fronteira Brasil-Colombia \\
\hline$\longdiv { 1 3 6 . 4 }$ & $R b-S r$ & TR-HM-101.1 & SA 19 & Dacito & Rocha total & Vikanismo Regional Traira & $-0,9167$ & - & 6.5 & 10 & 10 & Fronteira Brasil-Colômbia \\
\hline$\longdiv { 3 6 . 5 }$ & $\mathrm{Rb}-\mathrm{Sr}$ & PT.CO & $\operatorname{se} 19$ & Rioito & Rocha fotal & Vicarismo Regional Traira & $-0,9167$ & - & 69.55 & 10 & 10 & Fronteira Brasil-Colómbia \\
\hline 137 & $\overline{\mathrm{K}-\mathrm{Ar}}$ & PT.06-1 & SA 19 & Xisto & Muscovita & Grupo Tunul & $-0,1000$ & 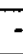 & 67.0667 & 30 & 10 & Rio Negro \\
\hline 138 & $\bar{K}-\overline{A r}$ & LP4.1 PT.06 & NA 19 & Filonito & Muscovita & Grupo Tunui & $+1,5167$ & 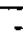 & $\varpi 8.15$ & 30 & 10 & Rio I̧̧ana \\
\hline 139 & $\mathrm{Rb}-\mathrm{Sr}$ & UAJEVI23 & NA 19 & LeucosienoGranito & Rocha total & Granito Rio Uaupés & $+0,0500$ & - & 68.1667 & 30 & 11 & Rio Uaupés \\
\hline 14.1 & $\mathrm{Rb}-\mathrm{Sr}$ & PA/SP/43 & NA 19 & Gnaisse & Rocha total & Embasamento & $+0,5000$ & . & 69.9167 & 10 & 9,10 & Fronteira Brasil-Colómbia \\
\hline $14 . \overline{2}$ & $\mathrm{~Pb}-\mathrm{Pb}$ & PASPI43 & NA 19 & Gnaisse & Rocha total & Embasamento & $+0,5000$ & - & 69.9167 & 10 & 9.10 & Fronteira Brasil-Colombia \\
\hline 140 & $R \mathrm{R}-\mathrm{Sr}$ & UAVEVIZO & NA 19 & Biotita-Granodionto & Rocha total & Granito Rio Uaupés & $+0,1000$ & - & 08.1667 & 30 & 11 & Rio Uaupes \\
\hline$\overline{41}$ & $\mathrm{Rb}-\mathrm{Sr}$ & UAVEVIOB & NA 19 & ThanbiothonzoGrarlo & Rocha total & Granito Rio Uaupés & $+0,1167$ & 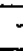 & 67.6833 & 30 & 11 & Rio Uaupés \\
\hline$\longdiv { 1 4 2 }$ & $\mathrm{Sm}-\mathrm{Nd}$ & UA-6W-6N & NA 19 & Then Biot VonzóGrento & Rocha total & Granito Rio Uaupes & $+0,1167$ & - & 67.6833 & 30 & 79 & Rio Uaupés \\
\hline
\end{tabular}




\begin{tabular}{|c|c|c|c|c|c|c|c|c|c|c|c|c|}
\hline Ordem & Método & $N^{\circ}$. Campo & Folha & Litologia & Materlal Analisado & Unłdade Geológica & Latitude & & Longitude & $\begin{array}{l}\text { Prec } \\
(\mathrm{Km})\end{array}$ & Ref & Referéncia Geográfica \\
\hline 142 & $\mathrm{Rb}-\mathrm{Sr}$ & UAVEV/13 & NA 19 & LelocomanzoGrantio & Rocha total & Granito Rio Uaupes & $+0,1667$ & 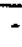 & 67.9 & 301 & 11 & Rio Uaupés \\
\hline 143.1 & $\mathrm{Rb}-\mathrm{Sr}$ & PT $33-A 3$ & NA 19 & TtenBictivarzoGrario & Rocha total & Granito Rio Uaupés & $+0,2167$ & - & 67.9167 & 30 & 11 & Rio Uaupes \\
\hline 143.2 & Rb-Sr & РT-33-A5 & NA 19 & Than BidtMorzo Granto & Rocha total & Granito Rio Uaupés & $+0,2167$ & - & 67.9167 & 30 & 11 & Rio Uaupés \\
\hline 143.3 & $\mathrm{Sm}-\mathrm{Nd}$ & PT 33 ASU & NA 19 & ThanBictikarzoGranto & Rocha total & Granito Rio Uaupes & $+0,2167$ & - & 67.9167 & 30 & 79 & Rio Uaupés \\
\hline 143.4 & Sm-Nd & PT $33 \mathrm{ASW}$ & NA 19 & ThanBictMonzóGranto & Rocha total & Granito Rio Uaupes & $+0,2167$ & - & 67.9167 & 30 & 79 & Rio Uaupés \\
\hline 144.1 & $\mathrm{Rb}-\mathrm{Sr}$ & CUIIEAO2 & NA 19 & Gnaisse & Rocha total & Embasamento & $+1,5167$ & 7 & 68.2167 & 10 & 19 & Rio lçana \\
\hline 144.2 & $\bar{K}-\overline{A r}$ & CUIIEAN2 & NA 19 & Gnaisse & Biotita & Embasamento & $+1,5167$ & - & 68.2167 & 10 & 78 & Rio lçana \\
\hline 145 & $\mathrm{Rb}-\mathrm{Sr}$ & CU/RM-APIO2A & NA 19 & Granito & Rocha total & Embasamento & $+0,5167$ & - & 67.45 & 10 & 19 & Rio Cubate \\
\hline 146 & $\mathrm{Rb}-\mathrm{Sr}$ & NE/PF/11.1 & NA 19 & Granito & Rocha total & Embasamento & $+0,0667$ & - & 67.3167 & 10 & 19 & Rio Negro \\
\hline 147 & $\mathrm{Rb}-\mathrm{Sr}$ & TO/EW/EV57 & NA 19 & Adamelito & Rocha total & Embasamento & +0.1667 & - & 69.1833 & 10 & 19 & Rio Tiqué \\
\hline 148 & K-Ar & SAISPOO1 & NA 19 & Gnaisse & Biotita & Embasamento & $+0,5667$ & - & 69.8323 & 10 & 19 & N Rio Tiqué \\
\hline 49 & K-Ar & PA/SPBB. & NA 19 & Gnaisse & Biotita & Embasamento & $+0,5667$ & - & 69.8667 & 10 & 19 & N Rio Tiqué \\
\hline 15 & $\mathrm{Rb}-\mathrm{Sr}$ & PAISPIOS & NA 19 & Gnaisse & Rocha total & Embasamento & $+0,6500$ & - & 69.1667 & 10 & 9 & Rio Uaupés \\
\hline 150 & K-Ar & SE1OPT17 & NA 19 & Metadiabásio & Anfibolio & Embasarnento & $+0,0333$ & - & 67.0333 & 10 & 19 & N Rio Negro \\
\hline 151 & K-Ar & AN/SPDO1A & NA 19 & Anfibolito & Anfibólio & Embasamento & $+0,5000$ & - & $\$ 9.95$ & 10 & 19 & N Rio Tiqué \\
\hline 152 & K-AT & PT14/E/AP25 & NA 19 & Gnaisse & Biotita & Embasamento & $\pm 0,2500$ & - & 66.6333 & 10 & 19 & N Rio Negro \\
\hline 153 & K-Ar & $25-A-66$ & NA 19 & Gnaisse & Biotita & Embasamento & $+0,2833$ & 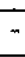 & 69.07 & 10 & 16 & Rio Tiqué \\
\hline 154 & K-Ar & $27-A-66$ & NA 19 & Gnaisse & Muscovita & Embasamento & $+0,2500$ & - & 69.7833 & 10 & 16 & Rio Tiqué \\
\hline 15 & $\mathrm{~K}-\overline{\mathrm{Ar}}$ & $A M-49$ & NA 19 & Gnaisse & Anfibóllo & Embasamento & $+1,1667$ & - & 69.75 & 10 & 16 & Fronteira Brasil-Cołómbia \\
\hline 158 & K-Ar & PT 26E & SA 19 & Diabásio & Rocha tofal & & $-0,5161$ & - & 69.6129 & 10 & 69 & E Rio Traira \\
\hline 158 & $\mathrm{~K}-\mathrm{Ar}$ & PT 35A & SA 19 & Diabásio & Plagioclásio & & $-0,7419$ & - & 69.4839 & 10 & 69 & E Rio Tralra \\
\hline $1 \overline{6.1}$ & $\mathrm{Rb}-\mathrm{St}$ & PASPP/22 & NA 19 & Granito & Rocha total & Embasamento & $+0,8000$ & - & 69.25 & 30 & 9,10 & Fronteira Brasil-Colómbia \\
\hline 16.2 & $\mathrm{~Pb}-\mathrm{Pb}$ & PAISP/22 & NA 19 & Granito & Rocha total & Embasamento & $+0,8000$ & - & 69.25 & 10 & 9 & Fronteira Brasil-Col6mbia \\
\hline 16.3 & K-Ar & $\mathrm{PA} / \mathrm{SP} / 22$ & NA 19 & Granito & Biofita & Embasamento & $+0,8000$ & - & 63.25 & 10 & 19 & Fronteira Brasil-Colömbia \\
\hline 16.4 & $\mathrm{U}-\mathrm{Pb}$ & PASPPR2 (NM -2) & NA 19 & Granito & Zirca & Embasamento & $+0,8000$ & - & 69.25 & 10 & 66 & Fronteira Brasil-Colómbia \\
\hline 16.5 & $\mathrm{U}-\mathrm{Pb}$ & PA/SPIZ2 (M-2) & NA 19 & Granito & Zircăo & Embasamento & $+0,8000$ & - & 69.25 & 10 & 66 & Fronteira Brasil-Colómbia \\
\hline 16.6 & $\mathrm{U} \cdot \mathrm{Pb}$ & PAISP/22 (MO) & NA 19 & Granito & Zitcáo & Embasamento & $+0,8000$ & - & 69.25 & 10 & 66 & Fronteira Brasil-Colómbia \\
\hline 16.7 & $\mathrm{U}-\mathrm{Pb}$ & PA/SP/22 (NM-2) & NA 19 & Granito & Zircăo & Embasamento & $+0,8000$ & - & 69.25 & 10 & 66 & Rio Papuri \\
\hline 16.8 & $\overline{\mathrm{U}}-\overline{\mathrm{Pb}}$ & PA/SPID2 (M-2) & NA 19 & Granito & Zircăo & Embasamento & $+0,8000$ & - & 69.25 & 10 & 66 & Rio Papuri \\
\hline 16.9 & U-Pb & PAVSP/22 (MO) & NA 19 & Granito & Zircá & Embasamento & $+0,8000$ & - & 69.25 & 10 & 66 & Rio Papuri \\
\hline 160 & $\mathrm{Rb}-\mathrm{Sr}$ & JT-1-AM & SA 19 & Gnaisse & Rocha total & Embasamento & $-3,8061$ & - & 67.7951 & 10 & 69 & W Rio Juta! \\
\hline 161 & $\mathrm{Rb}-\mathrm{Sr}$ & SN-1-AM & SA 19 & Granito & Rocha total & & $-2,6553$ & - & 67.9106 & 10 & $\infty$ & N Rio Solimoes \\
\hline 162 & K-Ar & PASPN1 & NA 19 & Tonalito & Biotita & Embasamento & $+0,6936$ & - & 69.185 & 10 & 78 & Fronteira Brasil-Colombia \\
\hline
\end{tabular}




\begin{tabular}{|c|c|c|c|c|c|c|c|c|c|c|c|c|}
\hline Ordem & Método & No. Campo & Folha & Litologia & Material Analisado & Unidade Geológlca & Latitude & & gltude & $\begin{array}{l}\text { Prec } \\
\text { (Km) }\end{array}$ & Ref & Referêncla Geogrática \\
\hline 163.1 & $\mathrm{U}-\mathrm{Pb}$ & MS-6000-1 & NA 19 & Gnaisse & Zirca & Embasamento & $-9,5$ & - & 66.67 & 10 & 66 & Regiăo E Rlo Jamari \\
\hline 163.2 & $\mathrm{U}-\overline{\mathrm{Pb}}$ & $M S 6030-2$ & NA 19 & Gnaisse & Zircăo & Embasamento & $-9,5$ & - & 66.67 & 10 & 66 & Regiăo E Rio Jamari \\
\hline 163.3 & $\mathrm{U}-\mathrm{Pb}$ & MSE0003 & NA 19 & Gnaisse & Zircăo & Embasamento & $-9,5$ & - & 66.67 & 10 & 66 & Regiåo E Rio Jamari \\
\hline 163.4 & $\mathrm{U}-\mathrm{Pb}$ & $\mathrm{MS} \sigma 000-4$ & NA 19 & Gnaisse & Zircăo & Embasamento & $-9,5$ & - & 66.67 & 10 & 66 & Regiăo E Rio Jamari \\
\hline 164.1 & $\mathrm{U}-\mathrm{Pb}$ & A-358A-1 & NA 19 & Metadionito & Zircáo & Embasamento & $-\overline{9}, 4$ & - & 66.03 & 10 & 66 & Regiăo E Rio Jamari \\
\hline 64.2 & $U-\overline{P b}$ & A-338A-2 & NA 19 & Metadiorito & Zircáo & Embasamento & $-9,4$ & - & 66.03 & 10 & 66 & Regiáo E Rio Jamari \\
\hline 64.3 & $\mathrm{U}-\mathrm{Pb}$ & A-338A-3 & NA 19 & Metadiorito & Zircăo & Embasamento & 9,4 & - & 66.03 & 10 & 66 & Regiāo E Rio Jamari \\
\hline 64.4 & $\mathrm{U}-\mathrm{Pb}$ & $A-338-4$ & NA 19 & Metadionito & Zircăo & Embasamento & $-9,4$ & - & 66.03 & 10 & 66 & Regiáo E Rio Jamari \\
\hline 17.1 & $\mathrm{Rb}-\mathrm{Sr}$ & PAISP/BS & NA 19 & Gnaisse & Rocha total & Embasamento & $+0,6567$ & - & 69.6333 & 30 & 9,10 & Fronteira Brasil-Col6mbia \\
\hline 17.2 & $\mathrm{~Pb}-\mathrm{Pb}$ & PAISPIBS & NA 19 & Gnaisse & Rocha total & Embasamento & $+0,6667$ & - & 69.5333 & 10 & 9,10 & Fronteira Brasil-Col6mbia \\
\hline 17.3 & Sm-Nd & PA-SP-35 & NA 19 & Tonalito & Rocha total & Embasamento & $+0,6667$ & - & 69.6333 & 10 & 79 & Fronteira Brasil-Colombia \\
\hline 8.1 & $\mathrm{Rb}-\mathrm{Sr}$ & UAVSPBI & NA 19 & Gnaisse & Rocha fotal & Embasamento & $+1,1667$ & - & 69.5333 & 10 & 9,10 & Rio Uaupés \\
\hline 18.2 & $\mathrm{~Pb}-\mathrm{Pb}$ & UAISPB1 & NA 19 & Gnaisse & Rocha total & Embasamento & $+1,1667$ & - & 69.5333 & 10 & 9,10 & Rio Uaupés \\
\hline 18.3 & K-Ar & UAVSPBI & NA 19 & Gnaisse & Biotita & Embasamento & $+1,1667$ & - & 69.5333 & 10 & 78 & Rio Uatipés \\
\hline 19.1 & $\mathrm{Rb}-\mathrm{Sr}$ & UAVSPBS & NA 19 & Granodionto & Rocha total & Embasamento & $+1,2000$ & - & 69.5833 & 10 & 9,10 & Rio Uaupés \\
\hline 19.2 & $\overline{\mathrm{Pb}}-\mathrm{Pb}$ & UAVSPIOS & NA 49 & Granodionito & Rocha total & Embasamento & $+1,2000$ & - & 69.5833 & 10 & 9.10 & Rio Uaupés \\
\hline 19.3 & $\mathrm{U}-\mathrm{Pb}$ & UAISPIO (NM -2) & NA 19 & Granodionito & Zirčso & Embasamento & $+1,2000$ & - & $\overline{69.5833}$ & 10 & 66 & Rio Uaupés \\
\hline 19.4 & K-Ar & UAISPIBOA & NA 19 & Anfibolito & Anfibólio & Embasamento & $+1,2000$ & - & 69.5833 & 10 & 19 & Rio Uaupés \\
\hline 19.4 & $\mathrm{U}-\mathrm{Pb}$ & UASPB $39(M-2)$ & NA 19 & Granodiorito & Zircáo & Embasamento & $+1,2000$ & - & 60.5833 & 10 & 66 & Rio Uaupés \\
\hline 19.5 & $\mathrm{U}-\mathrm{Pb}$ & UASSP/BO(M-1) & NA 19 & Granodionito & Zircaso & Embasamento & $+1,2000$ & $=$ & 69.5833 & 10 & 66 & Rio Llaupés \\
\hline 19.6 & $\mathrm{U}-\mathrm{Pb}$ & UASSPIB9 (NM-2) & NA 19 & Gnaisse & Zirca & Embasamento & $+1,2000$ & - & 69.5833 & 10 & 66 & Rio Uaupés \\
\hline 19.7 & U-Pb & UA/SP/BO $(M-2)$ & NA 19 & Gnaisse & Zirço & Embasamento & $+1,2000$ & - & 69.5833 & 10 & 6 & Rio Uaupés \\
\hline 9.8 & $\mathrm{U}-\mathrm{Pb}$ & UA/SP/SO $(M-1)$ & NA 19 & Gnaisse & Zircăo & Embasamento & $+1,2000$ & - & 60.5833 & 10 & 66 & Rio Uaupés \\
\hline JA 1.1 & $\mathrm{Rb}-\mathrm{Sr}$ & CAPDOQIA1 & $\mathrm{SB} / \mathrm{SC} 18$ & Sienito & Rocha total & Sienito República & $-7,3272$ & - & 73.6909 & 10 & 64 & Serra Divisor \\
\hline JA 1.2 & K-Ar & CAPDOAA1 & SB/SC 18 & Sienito & Rocha total & Sienito República & $-7,3272$ & - & 73.6909 & 10 & 64 & Serra Divisor \\
\hline JA 1.3 & $\mathrm{Rb}-\mathrm{Sr}$ & CAPROAA1 & SB/SC 18 & Traquito & Rocha total & Sienito República & $-7,3272$ & - & 73.0909 & 10 & 64 & Serra Divisor \\
\hline JA 1.4 & K-Ar & CAP-30-A-1 & SB/SC 18 & Sienito & Rocha total & Sienito República & $-7,3272$ & - & 73.6909 & 10 & 68 & Serra Divisor \\
\hline JA 2.1 & Rb-Sr & CDG-1-AC & $\mathrm{SB} / \mathrm{SC} 18$ & Gnaisse & Rœcha total & Embasamento & $-7,5466$ & - & 72.513 & 10 & 57 & SE Cruz do Sul \\
\hline JA 2.2 & $\mathrm{~K}-\mathrm{Ar}$ & ATCDS-1-AC-1 & $\mathrm{SB} / \mathrm{SC} 18$ & Graisse & Feldspato & Embasamento & $-7,5466$ & - & 72.5135 & 10 & 69 & SE Cruzeiro do Sul \\
\hline JA 3.1 & $\mathrm{~K}-\overline{\mathrm{A}} \mathrm{r}$ & DCL.467 & SB/SC 18 & Granulito & Rocha total & Embasamento & $=7,2202$ & - & 73.6009 & 10 & 69 & Rio Ipixuna \\
\hline JA 3.2 & K-As & $D C L-495$ & $\mathrm{SB} / \mathrm{SC} 18$ & Granufito & Rocha total & Embasamento & $-7,2202$ & - & 73.6009 & 10 & 69 & Rio Ipixuna \\
\hline JR 1 & $\mathrm{Rb}-\mathrm{Sr}$ & PT-40 & SC 21 & Biot gnaisse & Rocha total & Embasamento & $-9,8481$ & - & 59.1988 & 10 & 72 & N Aripuană \\
\hline $\mathrm{JR} 10$ & $\mathrm{Rb}-\mathrm{Sr}$ & PT-42 & $\operatorname{SC~} 21$ & Dionito & Rocha total & Embasamento & $-10,0467$ & - & 59.3215 & 10 & 72 & N Aripuană \\
\hline
\end{tabular}




\begin{tabular}{|c|c|c|c|c|c|c|c|c|c|c|c|c|}
\hline Ordem & Método & $N^{\circ}$. Campo & Folha & Lltologia & Material Analisado & Unidade Geológica & Latitude & & Longitude & $\begin{array}{l}\text { Prec } \\
(\mathrm{Km})\end{array}$ & Ref & Referência Geográfica \\
\hline JR 100 & $R b-S r$ & $W / \sqrt{-75}$ & $\operatorname{sc} 21$ & Gnaisse & Rocha total & Embasamento & $-9,8595$ & - & 58.2553 & 30 & 69,76 & Rio Juruena \\
\hline JR 101 & $\mathrm{Rb}-\mathrm{Sr}$ & WI-J-78 & $\operatorname{sc~} 21$ & Gnaisse & Rocha total & Embasamento & $-9,9091$ & - & 58.2045 & 30 & 69,76 & Rio Juruena \\
\hline JR 102.1 & $\mathrm{Rb}-\mathrm{Sr}$ & WIJ-79 & $\operatorname{sc} 21$ & Gnaisse & Rocha total & Embasamento & $-9,9745$ & - & 58.2275 & 30 & $\infty 9,76$ & Rio Jurvena \\
\hline JR 102.2 & $\mathrm{Rb}-\mathrm{Sr}$ & WI-J-81 & SC 21 & Gnaisse & Rocha total & Embasamento & $-9,9745$ & - & 58.2275 & 30 & $\oplus 8,76$ & Rio Juruena \\
\hline JR 102.3 & $\mathrm{Rb}-\mathrm{Sr}$ & WI-J-82 & $5 \mathrm{sc} 21$ & Gnaisse & Rocha total & Embasamento & $-9,9746$ & - & 58.2275 & 30 & $\infty 9,76$ & Rio Juruena \\
\hline JR 103.1 & $\mathrm{Rb}-\mathrm{Sr}$ & WI- $1-80$ & $5 C 21$ & Gnaisse & Rocha total & Embasamento & $-9,9861$ & - & 58.2787 & 30 & $\Phi, 76$ & Rio Juruena \\
\hline $\mathrm{JR} 103.2$ & $\mathrm{Rb}-\mathrm{Sr}$ & Wh-J-81-A & $\operatorname{sc} 21$ & Granito & Rocha total & \begin{tabular}{|l|} 
Embasamento \\
\end{tabular} & $-9,9861$ & - & 58.2787 & 30 & 69,76 & Rio Jurvena \\
\hline $\mathrm{JR} 104$ & $\mathrm{Rb}-\mathrm{Sr}$ & Wh-J-71 & SC 21 & Gnaisse & Rocha total & Embasamento & $-9,6674$ & - & 58.2969 & 30 & 69,76 & Rio Juruena \\
\hline JR 105 & $\mathrm{Rb}-\mathrm{Sr}$ & PT-04A & $S C 21$ & Dacito & Rocha total & Vulcarnicas Teles Pires & $-8,1479$ & - & 59.6785 & 30 & 69,76 & N Rio Aripuana \\
\hline IR 106 & $\mathrm{Rb}-\mathrm{Sr}$ & PT-29-03 & SC 21 & Riolito & Rocha total & Vulcanicas Teles Pires & $-8,2045$ & - & 55.1136 & 30 & 69 & Rjo Curuá \\
\hline JR 107 & $\mathrm{~K}-\mathrm{Ar}$ & WJ-8-A & $S C 21$ & Gabro & Anfibolio & & $-9,4052$ & - & 58.5050 & 30 & $\infty 8$ & Rio Juruena \\
\hline JR 108 & K-Ar & $5-753$ & SC 21 & Diabásio & Plagioclásio & & $-8,117 \overline{5}$ & - & 59.6001 & 30 & 99 & N Rio Aripuană \\
\hline JR 109 & K-Ar & W-417 & SC 21 & Fonolito & Rocha total & Vulcanicas Teles Pires & $-8,6337$ & - & 59.0778 & 30 & 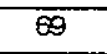 & Serra do Sucunduri \\
\hline $\mathrm{JR} 11$ & $\mathrm{Rb}-\mathrm{Sr}$ & PT-03 & $\operatorname{sc} 21$ & Granito & Rocha total & Embasamento & $-9,1667$ & - & 50.7206 & 10 & 72 & N Aripuanå \\
\hline JR 110 & $\mathrm{K}-\mathrm{Ar}$ & WJ-70 & $\operatorname{sc21}$ & Gnalsse & Biotita & Embasamento & $-9,7367$ & - & 58.2258 & 30 & 69 & Rio Juruena \\
\hline JR 111 & K-AI & W365 & $\operatorname{sc21}$ & Diabásio & Rocha total & & $-8,5352$ & - & 59.0409 & 30 & 69 & Serra do Sucunduri \\
\hline JR 112 & K-Ar & PT.36 & $\operatorname{sen} 21$ & Gnaisse & Biotita & Embasamento & - 9,0682 & - & 54.4091 & 30 & 69 & N Serra do Cachimbo \\
\hline JR 113 & $\bar{K}-A r$ & $\mathrm{DB}-07$ & $\operatorname{SC2} 21$ & Anfibolito & Anfibolio & & $=10,8441$ & - & 57.9283 & 30 & 69 & Rio Arinos \\
\hline JR 114 & $\mathrm{~K}-\mathrm{Ar}$ & PT -37 & $5 \mathrm{SC} 21$ & Gnaisse & Biotita & Embasamento & $-9,7955$ & - & 59.3409 & 30 & 69 & E Rio Aripuana \\
\hline JR 115 & $\mathrm{~K}-\mathrm{AI}$ & W-511 & $5 C 21$ & Diabásio & Rocha total & & $-8,5165$ & - & 58.9353 & 30 & 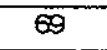 & Serra do Sucunduri \\
\hline JR 116 & $\mathrm{~K}-\mathrm{Ar}$ & PT 39 & $\operatorname{sc} 21$ & Anfibolito & Anfibofio & & $-9,5427$ & - & 59.4562 & 30 & $\infty$ & Rio Aripuana \\
\hline JR 117 & $\mathrm{Rb}-\mathrm{Sr}$ & $5-642$ & Sc 21 & Brecha Andesito & Rocha total & Vuicanicas Teles Pires & $-8,2091$ & - & 59.3545 & 10 & 76 & Serra do Sucunduri \\
\hline JR 118 & $\mathrm{Rb}-\mathrm{Sr}$ & $5-683$ & Sc 21 & Brecha Riolito & Rocha total & Vulcanicas Teles Pires & $-8,2091$ & - & 59.295 & 10 & 76 & Serra do Sucunduri \\
\hline$J R 119$ & $\mathrm{Rb}-\mathrm{Sr}$ & $5-692$ & Sc 21 & Riolito & Rocha total & Vulcanicas Teles Pires & $-8,1818$ & - & 59.15 & 10 & 76 & Serra do Sucunduri \\
\hline JR 12.1 & $\mathrm{Rb}-\mathrm{Sr}$ & $\mathrm{PT}-41$ & SC 21 & Diorito & Rocha total & Embasamento & $-10,1093$ & - & 50.2844 & 10 & 72 & N Áripuana \\
\hline $\mathrm{JR} 12 . \overline{2}$ & $\mathrm{~Pb}-\mathrm{Pb}$ & PT-4i & $\operatorname{sc} 21$ & Gnaisse & Rocha total & Embasamento & $-10,1093$ & - & 59.2844 & 10 & 9 & N Aripuană \\
\hline JR 120 & $\mathrm{Rb}-\mathrm{Sr}$ & C.558 & $S C 21$ & Sienito & Rocha total & Vulcanicas Teles Pires & $-8,1773$ & - & 59.0636 & 10 & 76 & Serra do Sucunduri \\
\hline JR 121 & $K-\overline{A r}$ & WI-S-493 & Sc 21 & Diabásio & Rocha total & & $-8,1818$ & - & 58.9091 & 10 & 76 & Serra do Sucunduri \\
\hline JR 122 & $\mathrm{Sm}-\mathrm{Nd}$ & PT 19 & SD 21 & Gnaisse & Rocha total & Embasamento & $-9,1667$ & - & 59.25 & 10 & 79 & Regiāo Rio Aripuană \\
\hline JR 123 & $\mathrm{Sm}-\mathrm{Nd}$ & PT-7 & SD 21 & Gnaisse & Rocha total & Embasamento & $-10,1667$ & - & 59.25 & 10 & 79 & Serra Dardanelos \\
\hline JR 13 & $\mathrm{Rb}-\mathrm{Sr}$ & PT-11A & $\operatorname{se~} 21$ & Gnaisse & Rocha total & Embasamento & $-9,8449$ & - & 56.4857 & 10 & 72 & E Rio Apiacá \\
\hline JR 14 & $\mathrm{Rb}-\mathrm{Sr}$ & PT-29E & SC 21 & Granito gnaisse & Rocha total & Embasamento & -9.8811 & - & 55.457 & 10 & 72 & Serra do Cachimbo \\
\hline JR 15 & Rb-Sr & PT-29D & $\operatorname{sc} 21$ & Granito & Rocha total & Embasamento & $-9,7963$ & - & 56.6374 & 10 & 72 & Serra do Cachimbo \\
\hline
\end{tabular}




\begin{tabular}{|c|c|c|c|c|c|c|c|c|c|c|c|c|}
\hline Ordem & Método & $N^{\circ}$. Campo & Folha & Littologla & Material Analisado & Unidade Geológlca & Latifude & & ngitude & $\begin{array}{l}\text { Prec } \\
(\mathrm{Km})\end{array}$ & Ref & Referéncla Geográfica \\
\hline JR 16 & $\mathrm{Rb}-\mathrm{Sr}$ & PT-11 & 5021 & MicroGranito & Rocha total & Embasamento & $-8,8147$ & - & 54.1868 & 10 & 72 & N Serra do Cachimbo \\
\hline $\mathrm{JR} 17$ & $\mathrm{Rb}-\mathrm{Sr}$ & PT-15 & SC 21 & Biotita Granito & Rocha total & Embasamento & $-8,1874$ & - & 54.1002 & 10 & 72 & N Serra do Cachimbo \\
\hline$J R 18.1$ & $\mathrm{Rb}-\mathrm{Sr}$ & PT-06B1 & $\operatorname{sc} 21$ & Granodiorito & Rocha total & Embasamento & $-10,0760$ & - & 54.7604 & 10 & 72 & Serra do Cachimbo \\
\hline JR 18.2 & $\mathrm{~K}-\mathrm{Ar}$ & PTO6-82 & $\operatorname{sc} 21$ & Diabásio & Plagioctásio & & $-10,0760$ & - & 54.7604 & 10 & 72 & Serra do Cachimbo \\
\hline $\mathrm{JR} 19$ & $R \mathrm{~B}-\mathrm{Sr}$ & PT-14.1 & SC 21 & Adamelito & Rocha total & Embasamento & $-8,9599$ & $\because$ & 54.2722 & 10 & 72 & N Serra do Cachimbo \\
\hline JR 2.1 & $\mathrm{Rb}-\mathrm{Sr}$ & PT-47 & SC 21 & Biot gnaisse & Rocha total & Embasamento & $-9,8016$ & - & 59.2387 & 10 & 72 & N Aripuanå \\
\hline JR 2.2 & K-Ar & PT-47 & Sc 21 & Gnaisse & Bictita & Embasamento & $-9,8016$ & - & 59.2387 & 10 & 72 & N Aripuana \\
\hline JR 2.3 & $\mathrm{~Pb}-\mathrm{Pb}$ & PT-47 & SC 21 & Gnaisse & Rocha total & Embasamento & $-9,8016$ & - & 59.2387 & 10 & 9 & N Aripuană \\
\hline$\sqrt{R 2} 20$ & $\mathrm{Rb}-\mathrm{Sr}$ & PT-0B & SC 21 & Granito gnaisse & Rocha total & Embasamento & $-9,4185$ & - & 59.6095 & 10 & 72 & N Áripuaná \\
\hline JR 21.1 & $\mathrm{Rb}-\mathrm{Sr}$ & PT.34 & SC 21 & Granito gnaisse & Rocha total & Embasamento & $-9,9141$ & - & 59.2193 & 10 & 72 & N Aripuaná \\
\hline $\operatorname{JR} 21.2$ & $\mathrm{~Pb}-\mathrm{Pb}$ & PT 34 & $\operatorname{sc} 21$ & Gnaisse & Rocha total & Embasamento & $-9,9141$ & - & 59.2193 & 10 & 9 & N Aripuana \\
\hline$\sqrt{R 22}$ & $R \mathrm{~b}-\mathrm{Sr}$ & PT- 49 & $\operatorname{sc} 21$ & Riodacito & Rocha total & Vulcánicas Teles Pires & $-10,0300$ & $\div$ & 59.2414 & 10 & 72 & N Aripuana \\
\hline JR 23 & Rb-Sr & $6.500 \mathrm{HB}$ & $\operatorname{se~} 21$ & Dacito & Rocha total & Vulcanicas Teles Pires & $-10,1505$ & - & 59.4131 & 10 & 72 & N Aripuană \\
\hline $\mathrm{JR} 24$ & $\mathrm{Rb}-\mathrm{Sr}$ & $7.300 \mathrm{HB}$ & $\operatorname{sen} 21$ & Dacito & Rocha total & Vulcanicas Teles Pires & $-10,1496$ & - & 59.4651 & 10 & 72 & N Aripuană \\
\hline JR 25 & $\overline{R b}-S r$ & PT.38 & $\mathrm{Sc} 21$ & Riolito & Rocha total & Vulcanicas Teles Pires & $-10,1964$ & - & 59.317 & 10 & 72 & N Áripuaná \\
\hline JR 26.1 & $R b-S r$ & PT-21AB & $\operatorname{sc} 21$ & Riolito & Rocha total & Vulcanicas Teles Pires & $-9,2670$ & - & 57.1546 & 10 & 72 & Rio Apiacá \\
\hline $\mathrm{JR} 26.2$ & $R b-S r$ & PT-21AA & $\operatorname{se} 21$ & Riolito & Rocha total & Vulcânicas Teles Pires & $-9,2670$ & - & 57.1546 & 10 & 72 & Rio Apiacá \\
\hline $\mathrm{JR27}$ & $\mathrm{Rb}-\mathrm{Sr}$ & PT-10B2 & $5 \mathrm{SC} 21$ & Riolito & Rocha total & Vulcånicas Teles Pires & $-10,2625$ & - & 59.5553 & 10 & 72 & N Aripuana \\
\hline $\mathrm{dR} 28$ & $\overline{R b}-\mathrm{Sr}$ & $4.90 \mathrm{OHB}$ & $\operatorname{sc} 21$ & Riodacito & Rocha total & Vulcánicas Teles Pires & $-10,1857$ & - & 59.3718 & 10 & 72 & N Aripuanā \\
\hline$J R 29$ & $\mathrm{Rb}-\mathrm{Sr}$ & $7.320 \mathrm{HB}$ & $\operatorname{sc21}$ & Dacito & Rocha total & Vulcanicas Teles Pires & $-10,0806$ & - & 59.5289 & 10 & 72 & N Aripuană \\
\hline JR 3.1 & $\overline{R b}-\mathrm{Sr}$ & PT52 & $5 C 21$ & Biot gnaisse & Rocha total & Embasamento & $-9,6026$ & $\because$ & 59.3043 & 10 & 72 & N Aripuană \\
\hline JR3.2 & $\bar{K}-\overline{A r}$ & PT-52 & SC 21 & Graisse & Biotita & Embasamento & $-9, \infty 026$ & $\because$ & 59.3043 & 10 & 72 & N Aripuanå \\
\hline JR 3.3 & $\overline{P b}-\overline{P b}$ & PT-52 & SC 21 & Graisse & Rocha total & Embasamento & $-9,6026$ & - & 59.3043 & 10 & 9 & N Aripuană \\
\hline $\mathrm{JR} 30.1$ & $\mathrm{Rb}-\mathrm{Sr}$ & $7.050 \mathrm{HB}$ & $5 \mathrm{SC} 21$ & Riolito & Rocha total & Vulcánicas Teles Pires & $-10,1397$ & - & 59.5136 & 10 & 72 & N Aripuană \\
\hline $\mathrm{JR} 30.2$ & $\mathrm{Rb}-\overline{\mathrm{Sr}}$ & $7.050 \mathrm{HB}$ & SC 21 & Riolito & Rocha total & Vulcánicas Teles Pires & $-10,1397$ & $\div$ & 59.5136 & 10 & 72 & N Aripuana \\
\hline $\mathrm{JR} 31$ & $\mathrm{Rb}-\mathrm{Sr}$ & PT.44 & $5 c 21$ & Tufo & Rocha total & Vulcánicas Teles Pires & $-9,9746$ & - & 59.1857 & 10 & 72 & N Aripuană \\
\hline $3 R 32$ & $\mathrm{Rb}-\mathrm{St}$ & $W-251$ & $\operatorname{se~} 21$ & Riolito & Rocha total & Vulcanicas Teles Pires & $-8,2655$ & 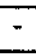 & 58.9645 & 10 & 72 & Serra do Sucunduri \\
\hline JR 33 & $\mathrm{Rb}-\mathrm{St}$ & PT-22-1 & $\operatorname{sc21}$ & Riolito & Rocha total & Vulcanicas Teles Pires & $-10,6898$ & - & 54.3171 & 10 & 72 & Serra do Cachimbo \\
\hline JR 34.1 & $\mathrm{Rb}-\mathrm{Sr}$ & PT-29.03 & $\operatorname{Sc} 21$ & Riolito & Rocha total & Vulcanicas Teles Pires & $-8,1262$ & - & 50.0045 & 10 & 72 & Rio Curuá \\
\hline JR 34.2 & $\mathrm{Sm}-\mathrm{Nd}$ & PT 293 & $\operatorname{sc} 21$ & Riolito & Rocha total & Vulcanicas Teles Pires & $-8,1262$ & - & 55.0045 & 30 & 79 & Rio Curuá \\
\hline $\mathrm{JR36}$ & $\mathrm{Rb}-\mathrm{Sr}$ & PT 59 & Sc 21 & Riodacito & Rocha total & Vulcánicas Teles Pires & $-8,9224$ & - & 58.4327 & 30 & 72 & E Rio Juruena \\
\hline $\mathrm{JR} 36$ & $\mathrm{Rb}-\mathrm{Sr}$ & PT-61 & $5 \overline{21}$ & Tufo & Rocha total & Vulcanicas Teles Pires & $-9,0298$ & - & 58.473 & 30 & 72 & E Rio Juruena \\
\hline JR 37 & $\mathrm{Rb}-\mathrm{Sr}$ & PT-33A & $\operatorname{sc21}$ & Rioitito & Rocha total & Vulcanicas Teles Pires & $-9,1057$ & - & 58.4922 & 30 & 72 & E Rio Juruena \\
\hline
\end{tabular}




\begin{tabular}{|c|c|c|c|c|c|c|c|c|c|c|c|c|}
\hline Ordem & Método & $N^{\circ}$. Campo & Folha & Litologia & Material Analisado & Unidade Geológica & Latitude & & ngitude & $\begin{array}{l}\text { Prec } \\
\text { (Km) }\end{array}$ & Ref & Referência Geográfica \\
\hline $\mathrm{JR} 38$ & $\mathrm{Rb}-\mathrm{Sr}$ & PT-20A2 & Sc 21 & Riolito & Rocha total & Vulcanicas Teles Pires & $-8,6576$ & - & 54.9249 & 30 & 72 & Rio Curuá \\
\hline JR 39.1 & Rb-Sr & $\overline{\mathrm{PT}-13.2}$ & $\operatorname{se} 21$ & Riolito & Rocha total & Vulcánicas Teles Pires & $-10,5530$ & - & 55.9843 & 10 & 72 & SW Rio Peicto de Azevedo \\
\hline $\mathrm{JR} 39.2$ & Sm-Nd & PT 13-2 & $\operatorname{sc} 21$ & Riolito & Rocha total & Embasamento & $-10,5530$ & - & 55.9843 & 30 & 79 & SW Rio Peicoto de Azevedo \\
\hline$J R 4.1$ & $\mathrm{Rb}-\mathrm{Sr}$ & PT-51-A & $\operatorname{sc} 21$ & Biot gnaisse & Rocha total & Embasamento & $-9,6538$ & - & 59.3487 & 10 & 72 & N Aripuana \\
\hline $\mathrm{JR} 4.2$ & $\mathrm{Rb}-\mathrm{Sr}$ & PT-51-B & $\operatorname{sc} 21$ & Biot gnaisse & Rocha total & Embasamento & $-9,6538$ & - & 59.3487 & 10 & 72 & N Áripuană \\
\hline $\operatorname{JR} 4.3$ & $\mathrm{Rb}-\mathrm{Sr}$ & PT-51-C & $\operatorname{sc} 21$ & Gnaisse & Rocha total & Embasamento & $-9,6691$ & - & 59.4550 & 30 & 69 & NÁpipuaná \\
\hline JR 4.4 & $\mathrm{Rb}-\mathrm{Sr}$ & PT51-D & Sc 21 & Biot gnaisse & Rocha total & Embasamento & $-9,6538$ & 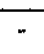 & 59.3487 & 10 & 72 & N Aripuaná \\
\hline $\operatorname{JR} 4.5$ & $\mathrm{Rb}-\mathrm{Sr}$ & PT-51-E & Sc 21 & Biot gnaisse & Rocha total & Embasamento & $-9,6538$ & - & 59.3487 & 10 & $\overline{72}$ & N Aripuana \\
\hline $\operatorname{JR} 4.6$ & $\overline{\mathrm{Pb}-\mathrm{Pb}}$ & PT-51-A & $\operatorname{sc} 21$ & Gnaisse & Rocha total & Embasamento & $-9,6538$ & - & $59 . \overline{3487}$ & 10 & $\overline{9}$ & N Aripuană \\
\hline $\operatorname{JR} 4 . \overline{7}$ & $\mathrm{~Pb}-\mathrm{Pb}$ & PT-51-D & $\operatorname{sc} 21$ & Gnaisse & Rocha total & Embasamento & $-9,6538$ & - & 59.3487 & 10 & $\overline{9}$ & N Aripuana \\
\hline JR 40 & $\mathrm{Rb}-\mathrm{Sr}$ & PT-50 & Sc 21 & Riolito & Rocha total & Vulcanicas Teles Pires & $-9,5835$ & - & 54.7318 & 10 & 72 & Serra do Cachimbo \\
\hline JR 41 & $\mathrm{Rb}-\mathrm{Sr}$ & PT-26 & Sc 21 & Riolito & Rocha total & Vuicanicas Teles Pires & $-9,4836$ & - & 55.6501 & 10 & 72 & Serra do Cachimbo \\
\hline JR 42 & $\bar{R} \bar{b}-S r$ & PT-G.05 & Sc 21 & Riodacito & Rocha total & Vulcanicas Teles Pires & -10.1754 & - & 59.5608 & 10 & 72 & N Aripuanå \\
\hline JR 43 & $R b-S r$ & CB-56 & Sc 21 & Riolito & Rocha total & Vukcánicas Teles Pires & $-9,5847$ & - & 54.7979 & 10 & 72 & Serra do Cachimbo \\
\hline JR 44 & $\mathrm{Rb}-\mathrm{Sr}$ & $\mathrm{CB} 39$ & Sc 21 & Riolito & Rocha total & Vulcánicas Teles Pires & $-9,6318$ & - & 54.8156 & 10 & 72 & Serra do Cachimbo \\
\hline JR 45 & $\mathrm{Rb}-\mathrm{Sr}$ & $\mathrm{CB}-55$ & $\operatorname{sc~} 21$ & Riolito & Rocha total & Vulcánicas Teles Pires & $-9,5215$ & - & 54.7886 & 10 & 72 & Serra do Cachimbo \\
\hline JR 46 & $\mathrm{Rb}-\mathrm{Sr}$ & $\mathrm{CB}-34$ & $\operatorname{sc21}$ & Riolito & Rocha total & Vulcanicas Teles Pires & $-9,6950$ & - & 54.8115 & 10 & 72 & Serra do Cachimbo \\
\hline JR 47 & Rb-Sr & $\mathrm{CB}-36$ & 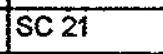 & Riolito & Rocha total & Vulcánicas Teles Pires & $-9,8552$ & $\because$ & 54.8154 & 10 & 72 & Serra do Cachimbo \\
\hline JR 48 & $\mathrm{Rb}-\mathrm{Sr}$ & TP-10 & $\operatorname{sc} 21$ & Riolito & Rocha total & Vulcánicas Teles Pires & $-9,8454$ & - & 56.8307 & 10 & 72 & E Rio Apiaca \\
\hline JR 49 & $\mathrm{Rb}-\mathrm{Sr}$ & $\mathrm{CB}-37$ & Sc 21 & Riolito & Rocha total & Vulcánicas Tetes Pires & $-9,7729$ & - & 54.8827 & 10 & 72 & Serra do Cachimbo \\
\hline $\mathrm{JR} 5$ & $\mathrm{Rb}-\mathrm{Sr}$ & PT-07 & Sc 21 & Granófiro & Rocha total & Embasamento & $-9,2722$ & - & 57.9332 & 10 & $\overline{72}$ & E Rio Juruena \\
\hline JR 50 & $R b-S r$ & PT-27 & $\operatorname{sc} 21$ & Granito & Rocha total & Granito Teles Pires & $-9,5644$ & - & 54.4872 & 10 & 72 & Serra do Cachimbo \\
\hline$\sqrt{R 51}$ & $\mathrm{Rb}-\mathrm{Sr}$ & PT-41GL & $\operatorname{se~} 21$ & Granito & Rocha total & Granito Teles Pires & $-9,7977$ & - & 54.764 & 10 & 72 & Serra do Cachimbo \\
\hline JR 52 & $\mathrm{Rb}-\mathrm{Sr}$ & PT. 09 & Sc 21 & Granito & Rocha total & Granito Teles Pires & $-9,3925$ & - & 57.852 & 10 & 72 & Serra do Cachimbo \\
\hline$J \bar{R} 53.1$ & $R b-S r$ & $\mathrm{PT}-17$ & Sc 21 & MicroGranito & Rocha tokal & Granito Teles Pires & $-9,4555$ & - & 57.3947 & 10 & 72 & W Rio Apiacá \\
\hline JR 53.2 & $\mathrm{Rb}-\mathrm{Sr}$ & PT-17.2 & $\operatorname{sc} 21$ & Granito Rapakivi & Rocha total & Granito Teles Pires & $-9,4555$ & - & 57.3947 & 10 & 72 & W Rio Apiacá \\
\hline $\mathrm{JR} 54$ & $\mathrm{Rb}-\mathrm{Sr}$ & $5-68.2$ & Sc 21 & Granito & Rocha total & Granito Teles Pires & -8.1977 & - & 59.3836 & 30 & $45,69,76$ & N Rio Aripuaná \\
\hline$J R 55$ & $\mathrm{Rb}-\mathrm{Sr}$ & PT-21AS & $\operatorname{sc} 21$ & Granito Rapakivi & Rocha total & Granito Teles Pires & $-9,4335$ & - & 57.1990 & 10 & 72 & W Rio Apiacá \\
\hline JR 56 & $\overline{R b-S r}$ & PT 33 & SC 21 & Adamelito & Rocha total & Granito Teles Pires & $-10,5187$ & - & 55.0447 & 10 & 72 & S Rio Peixoto de Azevedo \\
\hline JR57 & $\mathrm{Rb}-\mathrm{Sr}$ & PT-19A1 & Sc 21 & Adamelito & Rocha total & Granito Teles Pires & $-10,3149$ & - & 54.4863 & 10 & 72 & Serra do Cachimbo \\
\hline$J R 58$ & $R \mathrm{R}-\mathrm{Sr}$ & PT-25.2 & $S C 21$ & MicroGranito & Rocha total & Granito Teles Pires & $-10,5685$ & - & 54.2213 & 10 & 72 & Serra do Cachimbo \\
\hline $\operatorname{JR} 50$ & $\mathrm{Rb}-\mathrm{ST}$ & PT.53 & Sc 21 & Granito Rapakivi & Rocha total & Granito Teles Pires & $-9,9087$ & - & 54.786 & 10 & 72 & Serra do Cachimbo \\
\hline$\sqrt{R} 6$ & $R B-S r$ & PT-04 & $\operatorname{sc} 21$ & Gnaisse & Rocha total & Embasamento & $-9,8837$ & - & 58.1617 & 10 & 72 & E Rio Junuena \\
\hline
\end{tabular}




\begin{tabular}{|c|c|c|c|c|c|c|c|c|c|c|c|c|}
\hline Ordem & Método & $N^{\circ}$. Campo & Folha & Litologia & Material Analisado & Unidade Geołógica & Latitude & & gitude & $\begin{array}{l}\text { Prec } \\
\text { (Km) }\end{array}$ & Ref & Referēncia Geográfica \\
\hline $\operatorname{JR} 60$ & $\mathrm{Rb}-\mathrm{Sr}$ & PT-23.1 & $\operatorname{sc} 21$ & MicroGranito & Rocha fotal & Granito Teles Pires & $-10,1321$ & - & 54.2279 & 10 & 72 & Serra do Cachimbo \\
\hline JR61 & $\mathrm{Rb}-\mathrm{Sr}$ & PT-45 & $\operatorname{sc} 21$ & Granodionito & Rocha tokal & Granito Teles Pires & $-10,7805$ & - & 55.1800 & 10 & 72 & S Rio Peixoto de Azevedo \\
\hline JR 62 & $R \mathrm{~B}-\mathrm{ST}$ & PT-24 & $\operatorname{se} 21$ & Granito & Rocha total & Granito Teles Pires & $-\overline{9,0928}$ & - & 54.5627 & 10 & 72 & Serra do Cachimbo \\
\hline JR $\widetilde{3}$ & Rb-Sr & PT-54 & $\operatorname{sc} 21$ & Granito & Rocha total & Granito Teles Pires & $-9,7000$ & - & 54.7455 & 10 & 72 & Serra do Cachimbo \\
\hline JR 64 & $\mathrm{Rb}-\mathrm{Sr}$ & PT- 05 & SC 21 & Granito & Rocha total & Granito Teles Pires & $-8,1517$ & - & 58.948 & 10 & 72 & Serra do Sucunduri \\
\hline JR & $\mathrm{Rb}-\mathrm{Sr}$ & $\overline{\mathrm{PT}}-\overline{06.2}$ & SC 21 & Granito & Rocha total & Granito Teles Pires & $\mid-11,4787$ & - & 59.6286 & 10 & 72 & S Chapada de Dardanelos \\
\hline $\mathrm{JR} 66.1$ & $\mathrm{Rb}-\mathrm{Sr}$ & HS-DS & SC 21 & Granito & Rocha total & Alc Canama & $-10,0372$ & - & 58.6167 & 10 & $\overline{72}$ & W Rio Juruena \\
\hline $\mathrm{JR} 66.2$ & $\mathrm{Rb}-\mathrm{Sr}$ & HS-06 & SC 21 & Sienito & Rocha total & Alc Canamá & $-10,0372$ & - & 58.6167 & 10 & 72 & W Rio Juruena \\
\hline $\operatorname{JR} 66 . \overline{3}$ & $\overline{R b}-\mathrm{Sr}$ & GG-01P1 & sc 21 & Sienito & Rocha total & Alc Canamá & $-10,0372$ & - & 58.6167 & 10 & 72 & W Rio Juruena \\
\hline $\operatorname{JR} 66.4$ & $\mathrm{Rb}-\mathrm{Sr}$ & GG-01P2 & $\operatorname{sc} 21$ & Sienito & Rocha total & Alc Canama & $-10,0372$ & - & 58.6167 & 10 & 72 & W Rio Juruena \\
\hline$J R 66.5$ & $\mathrm{Rb}-\mathrm{Sr}$ & GG-06-1 & $5 \mathrm{SC} 21$ & Sienito & Rocha total & Alc Canama & $-10,0372$ & - & 58.6167 & 10 & 72 & W Rio Juruena \\
\hline $\operatorname{JR} 66.6$ & $R \mathrm{R}-\mathrm{Sr}$ & $G G-\infty-2$ & $\operatorname{sc} 21$ & Sienito & Rocha total & Alc Canama & $-10,0372$ & - & 58.6167 & 10 & 72 & W Rio Juruena \\
\hline $\mathrm{JR} 66 . \overline{7}$ & $\bar{K}-\mathrm{Ar}$ & GG01-P2 & SC 21 & Sienito & Biotita & Alc Canama & $-10,0372$ & $=$ & 58.6167 & 10 & 72 & W Rio Juruena \\
\hline $\mathrm{JR} 6 \overline{7}$ & $\overline{R b}-\mathrm{Sr}$ & $\overline{M-02}$ & sc 21 & Sienito & Rocha total & Alc Canama & $-8,2052$ & - & 58.9018 & 10 & 72 & Serra do Sucunduri \\
\hline $\mathrm{JR} \overline{68}$ & $\overline{R B}-\mathrm{Sr}$ & $W-129$ & SC 21 & Fonolito & Rocha total & Alc Canama & $-8,0977$ & - & 58.9289 & 10 & 72 & Serra do Sucunduri \\
\hline$J R \notin 9$ & $\mathrm{Rb}-\mathrm{Sr}$ & PT-50 & $\operatorname{sc} 21$ & Sienito & Rocha total & Alc Canamá & $-9,6072$ & $\because$ & 55.7255 & 10 & 72 & Serta do Cachimbo \\
\hline JR 7 & $\mathrm{Rb}-\mathrm{Sr}$ & PT-16 & $\operatorname{sc} 21$ & Granodionito & Rocha total & Embasamento & $-9,6347$ & - & 57.6875 & 10 & 72 & E Rio Juruena \\
\hline JR TO & $\overline{\mathrm{K}-\mathrm{Ar}}$ & PTOA4 & $\overline{s c 21}$ & Anfibolito & Anfibótio & Embasamento & $-9,7158$ & - & 58.1353 & 10 & 72 & E Rio Juruena \\
\hline JR 71 & K-Ar & PT 51 & SC 21 & Gnaisse & Biotita & Embasamento & $-9,6913$ & $\because$ & 59.256 & 10 & 72 & N Aripuană \\
\hline JR 72 & $\mathrm{~K}-\mathrm{Ar}$ & PT-54 & $\operatorname{sc} 21$ & Anfibolito & Anfibólio & Embasamento & $-9,4924$ & - & 50.2794 & 10 & 72 & N Aripuana \\
\hline $5 R 73$ & K-Ar & PT-14.3 & $\operatorname{SC21}$ & Diabásio & Rocha total & & $-10,4158$ & - & 58.0667 & 10 & 72 & E Rio Juruena \\
\hline JR 74 & $\overline{K-A r}$ & $\overline{P T-\overline{75}}$ & SC 21 & Diabásio & Plagiociásio & & $-8,2731$ & - & 58.1704 & 10 & 72 & E Rio Juruena \\
\hline JR 75 & $K-A T$ & PT31.3A & $\operatorname{sc} 21$ & Dlabásio & Plagiociásio & & $-8,8337$ & - & 58.4922 & 10 & 72 & Rio Juruena \\
\hline JR 76 & K-Ar & $\overline{\mathrm{PT}}-12.2$ & $\overline{s c} 21$ & Diabáslo & Roctia total & & $-10,3244$ & - & 58.1157 & 10 & 72 & E Rio Juruena \\
\hline $\mathrm{JR} 77$ & $\mathrm{~K}-\mathrm{Ar}$ & PT.02.2 & SC 21 & Basalto & Rocha tota! & Vulcánicas Teles Pires & $-10,1393$ & - & 56.7682 & 10 & 72 & E Rio Apiacá \\
\hline JR 78 & $\bar{K}-\overline{A r}$ & $\overline{\mathrm{CB}-11}$ & $\operatorname{SC} 21$ & Diabásio & Rocha total & & $-10,2296$ & - & 54.895 & 10 & 72 & Serra do Cachimbo \\
\hline JR 79 & $\mathrm{~K}-\mathrm{Ar}$ & CB-15 & $\overline{\operatorname{sc} 21}$ & Diabásio & Rocha total & & $-10,3342$ & - & 54.9190 & 10 & 72 & Rio Peixoto de Azevedo \\
\hline JR 8 & $\mathrm{Rb}-\mathrm{Sr}$ & PT.49 & $\operatorname{sc21}$ & Gnaisse & Rocha total & Embasamento & $-9,7361$ & - & 59.3095 & 10 & 72 & N Aripuană \\
\hline$\sqrt{\mathrm{R} 80}$ & K-Ar & $\overline{C B-19}$ & SC 21 & Gabro & Plagioclásio & & $-10,4149$ & - & 54.9550 & 10 & 72 & S Rio Peixoto de Azevedo \\
\hline JR 81 & $\mathrm{Rb}-\mathrm{Sr}$ & $M-\infty$ & $\operatorname{sc} 21$ & Granito & Rocha total & Granito Teles Pires & $-8,5682$ & - & 58.9773 & 30 & 45.69 & Serra do Sucunduri \\
\hline JR 82.1 & $\mathrm{Rb}-\mathrm{Sr}$ & WI-43 & SC 21 & Granodionito & Rocha total & Embasamento & $-8,1136$ & - & 58.9545 & 30 & $45, \overline{69}$ & Serra do Sucunduri \\
\hline$\sqrt{R 82.2}$ & $\mathrm{Rb}-\mathrm{Sr}$ & WI-S-132 & $\overline{S C 21}$ & Sienito & Rocha total & Vulcanicas Teles Pires & $-8,1136$ & - & 58.9545 & 30 & 69,76 & Serra do Sucunduri \\
\hline $\mathrm{JR} 83$ & $\mathrm{Rb}-\mathrm{Sr}$ & WI-44 & SC 21 & Granito & Rocha total & Embasamento & $-9,5$ & - & 58.4318 & 10 & 45 & E Rio Teles Pires \\
\hline
\end{tabular}




\begin{tabular}{|c|c|c|c|c|c|c|c|c|c|c|c|c|}
\hline Ordem & Método & $\mathrm{N}^{\circ}$. Campo & Folha & Litologla & Material Anallsado & Unidade Geológlca & Latitude & & gitude & $\begin{array}{l}\text { Prec } \\
(\mathrm{Km})\end{array}$ & Ref & Referêncla Geográfica \\
\hline JR 84.1 & $\mathrm{Rb}-\mathrm{Sr}$ & W1-53 & $\operatorname{sc} 21$ & Granito & Rocha total & Embasamento & $-9,4773$ & - & 58.4318 & 30 & 45,69 & Rio Juruena \\
\hline$\sqrt{R 84.2}$ & $\mathrm{Rb}-\mathrm{Sr}$ & WI-J-62 & $\operatorname{SC21}$ & Riolite & Rocha total & Vukcánicas Teles Pires & $-9,4773$ & - & 58.4318 & 30 & 69,76 & Rio Juruena \\
\hline $\mathrm{JR} 84.3$ & Rb-Sr & $W !-\sqrt{60}$ & $S C 21$ & Dacito & Rocha total & Vulcanicas Teles Pires & $-9,4773$ & 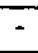 & 58.4318 & 30 & 99,76 & Rio Juruena \\
\hline JR 85 & $\mathrm{Rb}-\mathrm{Sr}$ & $w 1-64$ & $\operatorname{sc} 21$ & Granito & Rocha fotal & Embasamento & $-9,4773$ & - & 58.3864 & 30 & 45,69 & Rio Juruena \\
\hline JR 86.1 & $\mathrm{Rb}-\mathrm{Sr}$ & Wi-65 & $\operatorname{sc~} 21$ & Granodiorito & Rocha total & Embasamento & $-9,4773$ & - & 58.3182 & 30 & 45,69 & Rio Juruena \\
\hline JR 86.2 & $\mathrm{Rb}-\mathrm{Sr}$ & W1-66 & $\operatorname{sc~} 21$ & Granodionto & Rocha total & Embasamento & $-9,4773$ & - & 58.3182 & 30 & 45,69 & Rio Juruena \\
\hline JR 86.3 & Rb-Sr & W1-68 & $\operatorname{sc} 21$ & Granodionto & Rocha total & Embasamento & $-9,4773$ & - & 58.3182 & 30 & $45, \pi$ & Rio Juruena \\
\hline JR 87.1 & $\mathrm{Rb}-\mathrm{Sr}$ & Who & $\operatorname{sc} 21$ & Granito & Rocha total & Embasamento & $-9,0682$ & - & 58.5455 & 30 & $45,69,76$ & Rio Juruena \\
\hline JR 87.2 & $\mathrm{Rb}-\mathrm{Sr}$ & WI-12 & SC 21 & Granito & Rocha total & Embasamento & $-9,0682$ & - & 58.5455 & 30 & $45,69,76$ & Rio Juruena \\
\hline JR 87.3 & $\mathrm{Rb}-\mathrm{Sr}$ & W!-15 & $\operatorname{sc} 21$ & Granito & Rocha total & Embasamento & $-9,0682$ & $\therefore$ & 58.5455 & 30 & $45,69,76$ & Rio Juruena \\
\hline JR 88.1 & $\mathrm{Rb}-\mathrm{Sr}$ & WI-40 & Sc 21 & Granito & Rocha total & Embasamento & $-9,3182$ & - & 58.5682 & 30 & $45,69,76$ & Rio Juruena \\
\hline JR 88.2 & $\mathrm{Rb}-\mathrm{Sr}$ & WI-41 & $\operatorname{sc~} 21$ & Granito & Rocha total & Embasamento & $-9,3182$ & $\because$ & 58.5682 & 30 & $45, \infty 9,76$ & Rio Juruena \\
\hline JR 89.1 & $\mathrm{Rb}-\mathrm{Sr}$ & Wi-48 & $\operatorname{Sc} 21$ & Granito & Rocha total & Embasamento & $-9,2727$ & - & 58.6364 & 30 & $45,69,76$ & Rio Juruena \\
\hline JR 89.2 & $\overline{R b}-\mathrm{Sr}$ & WI-49 & Sc 21 & Granito & Rocha total & Embasamento & $-9,2727$ & 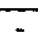 & 58.6364 & 30 & $45,69,76$ & Rio Jurvena \\
\hline JR 9.1 & $\mathrm{Rb}-\mathrm{Sr}$ & PT-07-A & $5 C 21$ & Gnaisse & Rocha total & Embasamento & $-9,4612$ & - & 59.3756 & 10 & 72 & N Aripuaná \\
\hline $\operatorname{sR} \overline{9} . \overline{2}$ & $\mathrm{~Pb}-\mathrm{Pb}$ & PT-O7-A & sc 21 & Gnaisse & Rocha total & Embasamento & $-9,4612$ & - & 59.3756 & 10 & 9 & N Aripuaná \\
\hline $\mathrm{JR} \overline{\mathbf{O}}$ & $\mathrm{Rb}-\mathrm{Sr}$ & WL-50 & SC 21 & Granito & Rocha total & Embasamento & $-9,2955$ & - & 58.5682 & 30 & $45,69,76$ & Rio Juruena \\
\hline JR91 & $R \mathrm{~b}-\mathrm{Sr}$ & PT-34 & $\longdiv { \operatorname { s e } 2 1 }$ & Gnaisse & Rocha total & Embasamento & $-10,1364$ & - & 59.3977 & 10 & 69 & N Áripuaná \\
\hline JR 92.1 & $\mathrm{Rb}-\mathrm{Sr}$ & W-129-A & SC 21 & Fonolito & Rocha total & Vulcanicas Teles Pires & $-8,0078$ & - & 58.9549 & 10 & 76 & Rio Sucunduri \\
\hline SR 92.2 & K-Ar & $W-129-A$ & $S C 21$ & Fonotito & Rocha total & Vulcánicas Teles Pires & $-8,0078$ & - & 58.9549 & 10 & $\overline{69}, 76$ & Rio Sucunduri \\
\hline JR 93.1 & Rb-Sr & Wt-S-418 & $\operatorname{sc} 21$ & Fonolito & Rocha total & Vulcanicas Teles Pires & $-8,5932$ & - & 59.0463 & 30 & $\infty 9$ & Serra do Sucunduri \\
\hline JR $93 . \overline{2}$ & $\mathrm{~K}-\mathrm{Ar}$ & WI-S-418 & sc 21 & Fonolito & Rocha total & Vulcánicas Teles Pires & $-8,5932$ & - & 59.0463 & 10 & 76 & Serra do Sucunduri \\
\hline$J R 94$ & $\mathrm{Rb}-\mathrm{Sr}$ & PT-15 & Sc 21 & Adamelito & Rocha total & Embasamento & $-8,1558$ & - & 54.2029 & 301 & 69 & N Serra do Cachimbo \\
\hline $\mathrm{JR} 95$ & $\mathrm{Rb}-\mathrm{Sr}$ & Wh-J-O1 & $S \mathrm{SC} 21$ & Riolito & Rocha total & Vulcánicas Teles Pires & $-8,9092$ & - & 58.6871 & 30 & 69,76 & E Rio Juruena \\
\hline JR 96 & $\mathrm{Rb}-\mathrm{Sr}$ & WI-j-21 & Sc 21 & Riodacito & Rocha total & Vulcatnicas Teles Pires & $-8,9006$ & - & 58.5845 & 30 & 69,76 & Rio Juruena \\
\hline $\mathrm{JR} 97$ & $\mathrm{Rb}-\mathrm{Sr}$ & $M-336$ & SC 21 & Riolito & Rocha total & Vulcanicas Teles Pires & $-8,2215$ & - & 59.8545 & 30 & 69,76 & N Rio Aripuană \\
\hline JR 98 & $\mathrm{Rb}-\mathrm{Sr}$ & PT.43 & $\operatorname{sc} 21$ & Riolito & Rocha total & Vulcánicas Teles Pires & $-9,8006$ & - & 54.8681 & 30 & 69 & Serra do Cachimbo \\
\hline$\sqrt{R} 99$ & $\mathrm{Rb}-\mathrm{St}$ & $W 1-J-73$ & SC 21 & Gnaisse & Rocha total & Embasamento & $-9,7975$ & - & 58.2539 & 30 & 69,76 & Rio Juruena \\
\hline JU1.1 & K-Ar & FGst-1-AM & SB 19 & Basalto & Rocha total & & $-7,2583$ & - & 70.1683 & 10 & 14 & S Rio Juruá \\
\hline JU 1.2 & K-Ar & FGst-1-AM & SB 19 & Basalto & Rocha total & & $-7,2583$ & - & 70.1683 & 10 & 14,26 & S Rio Juruá \\
\hline JU 2.1 & $\bar{K}-\overline{A r}$ & JAst-1-AM & SB 19 & Granito & Feldspato & & - 4,9347 & - & 67.2628 & 10 & 16 & Rio Jưuá \\
\hline JU 2.2 & $\mathrm{Rb}-\mathrm{Sr}$ & JA-1-AM & SB 19 & Granito & Rocha total & & $-\quad 4,9347$ & - & 67.2628 & 10 & 69 & Rio Juruá \\
\hline 503 & K-Ar & ATJP-2425 & SB 19 & Diabásio & Plagiocḱsío & & $-4,8380$ & - & 66.2847 & 10 & 69 & Rio Juruá \\
\hline
\end{tabular}




\begin{tabular}{|c|c|c|c|c|c|c|c|c|c|c|c|c|}
\hline Ordem & Método & $N^{\circ}$. Carnpo & Folha & Lifologla & Material Anallsado & Unldade Geológlca & Latltude & & Longltude & $\begin{array}{l}\text { Prec } \\
\text { (Km) }\end{array}$ & Ref & Referéncia Geográfica \\
\hline $50 \overline{4}$ & $\mathrm{~K}-\overline{A r}$ & $B T-1-A M$ & SB 19 & Dacito & Rocha total & & $-4,3571$ & - & 69.9436 & 10 & $\infty 9$ & N Benjamim Constant \\
\hline JU5 & $\mathrm{K}-\mathrm{Ar}$ & $M V-1-A M$ & SB 19 & Dacito & Rocha total & & $-4,7466$ & - & 66.758 & 10 & 6 & Rio Juruá \\
\hline 506 & $\mathrm{Rb}-\overline{S r}$ & FG-1-AM & $\mathrm{SB} 19$ & Granito & Rocha total & & $-6,7107$ & - & 70.3585 & 10 & 69 & N Rio Juruá \\
\hline JU 7 & K-Ar & FG-1-AM & SB 19 & Granito & Biotita & & $-6,7767$ & - & 70.648 & 10 & 69 & N Rio Juruá \\
\hline 108 & $\mathrm{~K}-\mathrm{Ar}$ & JTST-AM-1 & SB 19 & Granito & Rocha total & Embasamento & $-4,2312$ & - & $\infty$ & 10 & 78 & Rio Jutai \\
\hline$\overline{M 1}$ & $\mathrm{Rb}-\mathrm{Sr}$ & PT-139/321 & NANB 22 & Granulito & Rocha total & Embasamento & $+0,8833$ & - & 52.96 & 10 & 24 & Serra do Iratapuru \\
\hline$M 10$ & K-Ar & JLR $667 \mathrm{~B} / 2693$ & NANB 22 & Diabásio & Plagioclásio & Diab Cassiporé & $+2,1833$ & - & 51.3167 & 10 & 24 & SW Calçoene \\
\hline M11 & $\mathrm{K}-\overline{\mathrm{Ar}}$ & CR/AO $372 / 2703$ & NANB 22 & Diabásio & Plagioclásio & Diab Cassiporé & $+3,7833$ & - & 51.5 & 10 & 24,56 & E Oiapoque \\
\hline$M 12$ & $\mathrm{~K}-\mathrm{Ar}$ & GS 08/2825 & NANB 22 & Diabásio & Plagioclásio & Diab Cassiporé & $+3,6333$ & - & 51.3333 & 10 & 24 & E Oiapoque \\
\hline $\bar{M} 13$ & $\overline{\mathrm{K}}-\overline{\mathrm{Ar}}$ & JLR 5142827 & NANB 22 & Diabásio & Plagioclásio & Diab Cassiporé & $+2,8167$ & - & 51.5333 & 10 & 14 & Rio Caciporé \\
\hline$M 14$ & $\mathrm{~K}-\mathrm{Ar}$ & JLR $530 / 2784$ & NANNB 22 & Diabásio & Plagioclásio & Diab Cassiporé & $+2,2167$ & - & 51.1 & 10 & 24 & s Calçoene \\
\hline$\overline{M 15}$ & $\bar{K}-\overline{A r}$ & MFC $60 \sqrt{2} 112$ & NANB 22 & Diorito & Biotita & Embasamento & $+3,0833$ & - & 52.2167 & 10 & 24 & E Rio Oiapoque \\
\hline $\bar{M} 16.1$ & $\mathrm{Rb}-\mathrm{Sr}$ & EG.18/AM/281.2 & NANB 22 & Gnaisse & Rocha total & Embasamento & $+0,6667$ & - & 52.15 & 10 & 52 & Regizo de Cupixi \\
\hline M 16.2 & $\mathrm{Rb}-\mathrm{Sr}$ & EG.02nP/62 & NANB 22 & Gnaisse & Rocha total & Embasamento & $+0,6667$ & 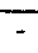 & 52.15 & 10 & 52 & Regizó de Cupixi \\
\hline M 16.3 & $\mathrm{Rb}-\mathrm{Sr}$ & EG.55/AP/365.2 & NAINB 22 & Tonalitio & Rocha total & Embasamento & $+0,6667$ & - & 52.15 & 10 & 52 & Regiło de Cupixi \\
\hline$M 16.4$ & $\mathrm{Rb}-\mathrm{Sr}$ & EG.99/JA/198 & NAINB 22 & Migmatito & Rocha total & Embasamento & $+0,6667$ & $\overline{-}$ & 52.15 & 10 & 52 & Regiấo de Cupixj \\
\hline M 16.5 & $S m-N d$ & EG 18 AM 281 & NANB 22 & Tonalito & Rocha total & Embasamento & $+0,6667$ & - & 52.15 & 30 & 79 & Regiāo de Cupixi \\
\hline$M 16.6$ & $\mathrm{Sm-Nd}$ & EGO2LPG2 & NANB 22 & Tonalito & Rocha total & Embasamento & $+0,6667$ & - & 52.15 & 30 & 79 & Regiăo de Cupixj \\
\hline$M 17$ & $\mathrm{~K}-\mathrm{Ar}$ & GM-A-1/712 & NANA 22 & Xisto & Muscovita & Grupo Serra do Navio & $+1,1000$ & - & 52.0833 & 10 & 16 & Serra do Navio \\
\hline $\bar{M} 1 \overline{8}$ & $\mathrm{~K}-\mathrm{Ar}$ & $55-A-67981$ & NANB 22 & Granito & Biotita & Embasamento & $+2,4000$ & - & 51.35 & 10 & 16 & Cunani \\
\hline$\overline{M 19}$ & K-Ar & $54 B-A-67 / 1044$ & NANB 22 & Gnaisse & Biotita & Embasamento & $+2,1333$ & $=$ & 50.9667 & 10 & 16 & NW Amapá \\
\hline$\overline{\mathrm{M} 2}$ & Rb-Sr & PT-145/343 & NA/NB 22 & Gnaisse & Rocha total & Tumucumaque Gneiss & $+1,9500$ & - & 53.4667 & 10 & 24 & Serra do Iratapuru \\
\hline$M 20$ & $\mathrm{~K}-\mathrm{Ar}$ & $56 \mathrm{C}-\mathrm{A}-67 / 1062$ & NANB 22 & Gnaisse & Biotita & Embasamento & $+3,8667$ & - & 51.7833 & 10 & 16 & N Oiapoque \\
\hline $\bar{M} 21$ & K-Ar & 1 JST-1-PA/1376 & NANB 22 & Granito & Biotita & Embasamento & $+0,5333$ & - & 50.1167 & 10 & 16 & Iha Tamanco \\
\hline $\bar{M} \overline{22}$ & $\bar{K}-\overline{A r}$ & $\mathrm{~B}-21-\infty 911784$ & NANB $\overline{22}$ & Granitoide & Biotita & Embasamento & $+2,5833$ & - & 52.2667 & 10 & 16 & E Rio Oiapoque \\
\hline $\bar{M} \overline{23}$ & K-Ar & $\mathrm{B}-21-0211785$ & NANB 22 & Granitoide & Biotita & Embasamento & $+2,8330$ & - & 52.35 & 10 & 16 & E Rio Oiapoque \\
\hline$\overline{M 24}$ & K-Ar & A-21-07/1791 & NANB 22 & Granitoide & Rocha total & Embasamento & $+2,5000$ & - & 52.5333 & 10 & 16 & Rio Oiapoque \\
\hline $\bar{M} \overline{25}$ & $\mathrm{~K}-\overline{\mathrm{Ar}}$ & $J L R 6652691$ & NA/NB 22 & Diabásio & Rocha total & Dique & $+2,0833$ & - & 51.3667 & 10 & 24 & W Amapá \\
\hline$M 26.1$ & $\mathrm{Rb}-\mathrm{Sr}$ & HAR-147 & NANB 22 & End Granulito & Rocha total & Charnoquito Cuatá & $+1,5167$ & - & 51.3333 & 10 & 43 & N Ferreira Gomes \\
\hline$M 26.2$ & $\mathrm{Rb}-\mathrm{Sr}$ & AV. $3 . A$ & NATNB 22 & Granoblastito & Rocha total & Enderbito Cobra & $+1,5167$ & - & 51.3333 & 10 & 43 & N Ferreira Gomes \\
\hline M26.3 & $\mathrm{Rb}-\mathrm{Sr}$ & HA. $15 . B$ & NATNB 22 & Granoblastito & Rocha total & Enderblto Cobra & $+1,5167$ & - & 51.3333 & 10 & 43 & N Ferreira Gomes \\
\hline$M 26.4$ & $\mathrm{Rb}-\mathrm{Sr}$ & AV.24 & NA/NB 22 & End Granulito & Rocha total & Enderbito Cobra & $+1,5167$ & - & 51.3333 & 10 & 43 & N Ferreira Gomes \\
\hline M26.5 & $R \mathrm{~b}-\mathrm{Sr}$ & HAR-149 & NANB 22 & Chamoquito & Rocha total & Chamoquito Cuatá & $+1,5167$ & - & 54.3333 & 10 & 43 & N Ferreira Gomes \\
\hline
\end{tabular}




\begin{tabular}{|c|c|c|c|c|c|c|c|c|c|c|c|c|}
\hline Ordem & Método & $N^{\circ}$. Campo & Folha & Litologla & Material Analisado & Unidade Geológlica & Lattiude & & Longitude & $\begin{array}{l}\text { Prec } \\
\text { (Km) }\end{array}$ & Ref & Referêncla Geográfica \\
\hline$M 26.6$ & $\mathrm{Rb}-\mathrm{Sr}$ & HAR-173 & NAINB 22 & Granblst & Rocha total & Charnoquito Cuatá & $+1,5167$ & - & 51.3533 & 10 & 43 & N Ferreira Gomes \\
\hline M 27.1 & $\mathrm{Rb}-\mathrm{Sr}$ & A-E5-2c CID3 $45 \mathrm{~m}$ & NANB 22 & Metavulcanosedim & Rocha total & Supergnupo Uatumă & $+0,9333$ & $\sim$ & 52 & 10 & 16,24 & Serra do Navio \\
\hline M 27.2 & $\mathrm{Rb}-\mathrm{Sr}$ & $A-6536 \mathrm{CID} 3172 \mathrm{~m}$ & NANB 22 & Metavulcanosedim & Rocha total & Supergrupo Uatuma & $+0,9033$ & - & 52 & 10 & 16,24 & Serra do Navio \\
\hline$M 27.3$ & $\mathrm{Rb}-\mathrm{Sr}$ & $A-E 5-4$ CID3 & NANB 22 & Metavulcanosedim & Rocha total & Supergrupo Uatuma & $+0,9333$ & - & 52 & 10 & 16 & Serra do Navio \\
\hline$M 2 \overline{7.4}$ & $\mathrm{Rb}-\mathrm{Sr}$ & $\mathrm{A}-65-2 \mathrm{~b}$ CID $385 \mathrm{~m}$ & NANB 22 & Metavulcanosedim & Rocha total & Supergrupo Uatuma & $+0,9333$ & $=$ & 52 & 10 & 16,24 & Serra do Navio \\
\hline$M 27.5$ & $\mathrm{Rb}-\mathrm{Sr}$ & $A-\infty 5-1 b$ CID $384 m$ & NANNB 22 & Metavulcanosedim & Rocha total & Supergrupo Uatuma & $+0,9333$ & - & 52 & 10 & 16,24 & Serra do Navio \\
\hline$M 27.6$ & $\mathrm{Rb}-\mathrm{Sr}$ & $\mathrm{A}-65-1 \mathrm{~d} \mathrm{CID} 34 \mathrm{Am}$ & NAINB 22 & Metavulcanosedim & Rocha total & Supergrupo Uatumå & $+0,9333$ & - & 52 & 10 & 16,24 & Serra do Navio \\
\hline $\bar{M} 28.1$ & $\mathrm{Rb}-\mathrm{Sr}$ & AP $/ 19 \mathrm{~A}$ & NANB 22 & Granito & Rocha total & Suite Intrusiva Cupixi & $+0,6667$ & ? & 52.15 & 10 & 52 & Regiáo de Cupixi \\
\hline$M 28.2$ & $\mathrm{Rb}-\mathrm{Sr}$ & AP/ 684.2 & NANB 22 & Granito & Rocha total & Suite intrusiva Cupixi & $+0,6667$ & - & 52.15 & 10 & 52 & Regiǎo de Cupixi \\
\hline M 28.3 & $\mathrm{Rb}-\mathrm{Sr}$ & JA112 & NANB 22 & Granito & Rocha total & Suite Intrusiva Cupixi & $+0,6667$ & - & 52.15 & 10 & 52 & Regiâo de Cupixi \\
\hline$\overline{\mathrm{M} 28.4}$ & $R b-S r$ & AM312.3 & NANB 22 & Granito & Rocha total & Suite Intrusiva Cupixi & $+0,6667$ & - & 52.15 & 10 & 52 & Regián de Cupixi \\
\hline M 28.5 & $\mathrm{Rb}-\mathrm{Sr}$ & EG 81/AP/OB2 & NAINB 22 & Gnaisse & Rocha total & Suite Intrusiva Cupixi & $+0,6667$ & - & 52.15 & 10 & 52 & Regiăo de Cupixj \\
\hline M 28.6 & $\mathrm{Rb}-\mathrm{Sr}$ & JAV211 & NA/NB 22 & Granito & Rocha total & Suite Intrusiva Cupixi & $+0,6667$ & 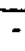 & 52.15 & 10 & 52 & Regiăo de Cupixi \\
\hline M 28.7 & Sm-Nd & EG 83 AP 684 & NANB 22 & Granito & Rocha total & Suite Intrusiva Cupixa & $+0,6667$ & - & 52.15 & 30 & 79 & Regiăo de Cupixi \\
\hline$M 29$ & $\overline{R b}-\overline{S r}$ & $101 / 694$ & NA/NB 22 & Nefelina Sienito & Rocha total & Alc Mapari & +1.0166 & - & 53.05 & 30 & 24,39 & Serra do Iratapuru \\
\hline M3 & $\mathrm{Rb}-\mathrm{Sr}$ & PT-137/318 & NAINB 22 & Granito & Rocina total & Embasamento & $+0,7167$ & - & 53.05 & 10 & 24 & Serra do Iratapuru \\
\hline $\mathrm{M} \mathbf{3 0}$ & K-Ar & JLR 5302690 & NANB 22 & Diabásio & Rocha total & Diab Cassiporé & $+2,2167$ & $=$ & 51.1 & 10 & 55 & s Calçoene \\
\hline M 31 & K-Ar & GM-A-2/716 & NA/NB 22 & Xisto & Biotita & Gupo Serra do Navio & $+1,1000$ & - & 52.0833 & 10 & 16 & Serra do Navio \\
\hline M 32 & $\mathrm{Rb}-\mathrm{Sr}$ & AV.19.B & NANNB 22 & Chamoquto Grando & Rocha total & Chamoquito Cuatá & $+1,5167$ & - & 51.3333 & 10 & 43 & N Ferreira Gomes \\
\hline$M 33$ & $R b-S T$ & $A-65-1 a C_{103} 136 \mathrm{~m}$ & NANA 22 & Metavulcanosedín & Rocha total & Supergrupo Uatuma & $+0,9333$ & - & 52 & 10 & 16,24 & Serra do Navio \\
\hline M4 & $\mathrm{Rb}-\mathrm{S} r$ & PT-1431322 & NA1NB 22 & Grantitoide & Rocha total & Embasarnento & $+1,7167$ & - & 53.4667 & 10 & 24 & Rio Amapari \\
\hline M6 & $\mathrm{Rb}-\mathrm{Sr}$ & AA-73/319 & NANB 22 & Granitbide & Rocha total & Embasamento & $+1,4667$ & - & 50.0833 & 10 & 24 & Rio Amapari \\
\hline M8.1 & $\mathrm{Rb}-\mathrm{Sr}$ & $\mathrm{CN} 371156560$ & NA/NB 22 & Granodionto & Rocha total & Granodiorito Falsino & $+1,6500$ & - & 51.36 & 10 & 24 & Serra Lombarda \\
\hline M8.2 & $R b-S r$ & CN 391156561 & NANB 22 & Granodionito & Rocha total & Granodionto Falsino & $+1,6500$ & - & 51.35 & 10 & 24 & Serra Lombarda \\
\hline$M 8.3$ & $\mathrm{Rb}-\mathrm{Sr}$ & EV161156562 & NANB 22 & Granodionito & Rocha total & Granodionito Falsino & $+1,6500$ & - & 51.35 & 10 & 24 & Serra Lombarda \\
\hline M8.4 & $R D-S r$ & $\mathrm{CN} 381156563$ & NAVNB 22 & Granodionito & Rocha total & Granodionito Falsino & $+1,6500$ & - & 51.35 & 10 & 24 & Serra Lombarda \\
\hline M91 & $\mathrm{Rb}-\mathrm{Sr}$ & $1 0 2 \longdiv { 6 9 2 }$ & NA/NB 22 & Litchineldito & Rocha total & Alc Mapari & $+1,0166$ & - & 53.05 & 30 & 24,39 & Serra do Iratapuru \\
\hline M9.2 & $\mathrm{Rb}-\mathrm{Sr}$ & $103 / 693$ & NANNB 22 & Alc Sienito & Rocha total & Alc Mapari & $+1,0166$ & - & 53.05 & 30 & 24,39 & Serra do Iratapuru \\
\hline MN 1 & K-Á & PT 06 & $\overline{S A} 20$ & Gabro & Plagloclásio & Gabbro Suretama & $-1,7167$ & - & 60.1333 & 10 & 14 & W Rio Uatumá \\
\hline MN 10 & $R \mathrm{~b}-\mathrm{St}$ & MA-RL-19 & SA 20 & Gnaisse & Rocha total & Embasamento & -0.2500 & - & 65.1 & 10 & $\overline{47}$ & Rio Negro \\
\hline MN 11.1 & $\mathrm{Rb}-\mathrm{Sr}$ & DA-RM-RL-24.A & $5 A 20$ & Diorito & Rocha total & Embasamento & $-0,0633$ & - & 64.5989 & 10 & 47.69 & N Rio Negro \\
\hline MN 11.2 & $\mathrm{~K}-\mathrm{Ar}$ & DA-RM-RL-24.A & $5 A 20$ & Dionto & Biotita & Embasamento & $-0,0633$ & $=$ & 64.5989 & 10 & 47,69 & N Rio Negro \\
\hline MN 12 & $\mathrm{Rb}-\mathrm{Sr}$ & Mi-AB-16.1 & SA 20 & Granodionito & Rocha total & Embasamento & $-0,2500$ & - & 65.5167 & 10 & 47 & Rio Negro \\
\hline
\end{tabular}




\begin{tabular}{|c|c|c|c|c|c|c|c|c|c|c|c|c|}
\hline Ordem & Método & $N^{\circ}$. Campo & Folha & Liftologla & Material Anallsado & Unidade Geológlca & Latitude & & gitude & $\begin{array}{l}\text { Prec } \\
(\mathrm{Km})\end{array}$ & Ref & Referēncla Geográflca \\
\hline MN 12.2 & $\mathrm{Sm}-\mathrm{Nd}$ & MI-AB-16-1 & $S A 20$ & Granodionito & Rocha total & Embasamento & $-0,2500$ & - & 65.5167 & 30 & 79 & Rio Negro \\
\hline MN 13.1 & $\mathrm{Rb}-\mathrm{Sr}$ & MA-RL-13 & SA 20 & Granito & Rocha tofal & Embasamento & $-0,4167$ & $\because$ & 6.15 & 10 & 47 & Rio Negro \\
\hline MN 13.2 & K-Ar & MA-RL-13 & SA 20 & Granito & Biotita & Embasamento & $-0,4167$ & - & 6.15 & 10 & 47 & Rio Negro \\
\hline MN 14 & $\mathrm{Rb}-\mathrm{Sr}$ & NE-CA-73 & SA 20 & Granitóide & Rocha total & Embasamento & $-0,4500$ & - & 64.6167 & 10 & 47 & Rio Negro \\
\hline MN 15 & $\mathrm{Rb}-\mathrm{Sr}$ & DA-RM-RL-02.A & $5 A 20$ & Granodiorito & Rocha total & Embasamento & $-0,4833$ & - & 64.75 & 10 & 47 & Rio Negro \\
\hline$\overline{M N} 16.1$ & $\mathrm{Rb}-\mathrm{Sr}$ & MA-RL-31 & SA 20 & Graisse & Rocha tofal & Embasamento & $-0,0667$ & - & 6.1167 & 10 & 47 & Rio Negro \\
\hline MN $1 \overline{6} .2$ & Sm-Nd & MR-RL-31 & SA 20 & Gnaisse & Rocha total & Embasamento & $-0,0667$ & - & 65.1167 & 30 & 79 & Rio Negro \\
\hline MN 17 & $\mathrm{Rb}-\mathrm{Sr}$ & NE-CA-32 & $5 A 2 O$ & Granito & Rocha total & Embasamento & $-0,5000$ & - & 64.55 & 10 & 47 & Rio Negro \\
\hline MN 18 & $\bar{K}-A r$ & NE-CA-54 & SA 20 & Diorito & Biotita & Embasamento & $-0,2667$ & - & 65.8833 & 10 & 47 & Rio Negro \\
\hline MN 19 & K-Ar & Mi-AB-40.2 & SA 20 & Granito & Biotita & Embasamento & $-0,1667$ & - & 65.8167 & 10 & 47 & Rio Negro \\
\hline MN2 & K-Ar & 1520 HM 319 & SA 20 & Gabro & Plagioclásio & Gabbro Suretama & $-1,8167$ & - & 60.4167 & 10 & 14 & W Rio Uatuma \\
\hline MN 20 & $\mathrm{Rb}-\mathrm{Sr}$ & PT.10.A & SA 20 & Granito & Rocha total & Embasamento & $-1,4382$ & - & 60.1573 & 10 & 47 & W Rio Uakuma \\
\hline MN 21.1 & $\mathrm{Rb}-\mathrm{Sr}$ & PT.25 & $5 A 20$ & Granito & Rocha total & Embasamento & $-0,1167$ & - & 60.2333 & 10 & 47 & N Rio Uatumă \\
\hline MN 21.2 & $\mathrm{Sm}-\mathrm{Nd}$ & PT-25 & $\overline{S A 2 O}$ & Granito & Rocha total & Embasamento & $-0,1167$ & - & 60.2333 & 30 & 79 & N Rio Uatuma \\
\hline MN 22 & $\mathrm{Rb}-\mathrm{Sr}$ & BR-174RL-07 & SA 20 & Gnaisse & Rocha total & Embasamento & $=0,7500$ & - & 60.7333 & 10 & 47 & W Rio Uatuma \\
\hline MN 23.1 & $\mathrm{Rb}-\mathrm{Sr}$ & PT.17.A & SA 20 & Granito & Rocha total & Embasamento & 1,2800 & - & 61.6667 & 10 & 47 & Rio Negro \\
\hline MN 23.2 & K-Ar & PT.17.A & $\mathrm{SA} 2 \mathrm{O}$ & Granito & Biotita & Embasamento & $-1,3833$ & - & 61.6667 & 10 & 47 & Rio Negro \\
\hline MN 24 & $\mathrm{Rb}-\mathrm{Sr}$ & PT.08.1 & SA 20 & Granito & Rocha total & Embasamento & $-1,9009$ & - & 60.109 & 10 & 47,69 & E Uurbu river \\
\hline MN 25 & $\mathrm{Rb}-\mathrm{Sr}$ & PT.00.1 & $5 A 2 O$ & Granito & Rocha total & Embasamento & $-1,9646$ & - & 60.0859 & 10 & 47,69 & E Rio Urubu \\
\hline MN 26 & $\mathrm{Rb}-\mathrm{Sr}$ & NE-CA-DO & $5 A 20$ & Alc granito & Rocha total & Embasamento & $-1,0500$ & - & 60.7333 & 10 & 47 & Rio Negro \\
\hline MN 27.1 & $\mathrm{Rb}-\mathrm{Sr}$ & NE-CA-01 & SA 20 & Migmatito & Rocha total & Embasamento & $-1,2800$ & - & 61.7667 & 10 & 47 & Rio Negro \\
\hline MN 27.2 & $\mathrm{~K}-\mathrm{Ar}$ & NE-CA-01 & $5 A 20$ & Migmatito & Biotita & Embasamento & $-1,3500$ & - & 61.7667 & 10 & 47 & Rio Negro \\
\hline MN 28 & $\mathrm{Rb}-\mathrm{Sr}$ & PT.01 A (JA-RL-37) & $5 A 20$ & Granito & Rocha total & Embasamento & $-1,5833$ & - & 61.3708 & 10 & 47 & Rio Negro \\
\hline MN 29.1 & $\mathrm{Rb}-\mathrm{Sr}$ & BR-174RL-04 & SA 20 & Granito & Rocha total & Embasamento & $-1,1167$ & - & 60.4167 & 10 & 47 & W Rio Uatuma \\
\hline MN 29.2 & $K-\overline{A r}$ & BR-174-RL-04 & $5 \overline{20}$ & Granito & Biotita & Embasamento & $-1,1167$ & - & 60.4167 & 10 & 47 & W Rio Uatuma \\
\hline $\mathrm{MN} 3$ & K-Ar & MIAB 32 & $5 A 20$ & Diabásio & Plagioclásio & Dique & $-0,2000$ & - & 65.7 & 10 & 14 & Rio Negro \\
\hline MN 30.1 & $\mathrm{Rb}-\mathrm{Sr}$ & PT.26 & SA 20 & Granodionito & Rocha total & Embasamento & -0.4000 & - & 60.25 & 10 & 47 & N Rio Uatuma \\
\hline MN 30.2 & $\mathrm{~K}-\mathrm{Ar}$ & PT.26 & SA 20 & Granodiorito & Biotita & Embasamento & $-0,4000$ & - & 60.25 & 10 & 47 & N Rio Uatuma \\
\hline MN 30.3 & $\mathrm{sm}-\mathrm{Nd}$ & PT-26 & SA 20 & Granodiorito & Rocha total & Embasamento & $-0,4000$ & - & 60.25 & 30 & 79 & N Rio Uatumá \\
\hline MN31 & $\overline{\mathrm{Rb}}-\mathrm{Sr}$ & PT.10.B & SA 20 & Gnaisse & Rocha total & Embasamento & $-0,2148$ & - & 61.922 & 10 & 47,69 & Regizo Rio Branco \\
\hline MN 32 & $\mathrm{Rb}-\mathrm{Sr}$ & PT.24.B & $5 A 20$ & Granito & Roche total & Embasamento & $-1,6667$ & $\sim$ & 00.4833 & 10 & 47 & W Rio Uatuma \\
\hline MN 33 & $\mathrm{Rb}-\mathrm{Sr}$ & HA-013 & $5 A 20$ & Granito & Rocha total & Embasamento & $-1,8229$ & - & 60.5781 & 10 & 47,69 & E Rio Negro \\
\hline MN 34.1 & $R b-S r$ & HA-168.A & $5 A 20$ & Granito & Rocha total & Embasamento & $-1,5167$ & - & 60.75 & 10 & 47 & W Rio Uatuma \\
\hline
\end{tabular}




\begin{tabular}{|c|c|c|c|c|c|c|c|c|c|c|c|c|}
\hline Ordem & Método & $N^{\circ}$. Campo & Folha & Lltologia & Material Anallsado & Unidade Geológica & Latifude & & Longltude & $\begin{array}{l}\text { Prec } \\
(\mathrm{Km})\end{array}$ & Ref & Referêncla Geográfica \\
\hline MN 34.2 & K-Ar & HA-168.B & $5 A 20$ & Tonalito & Biotita & Embasamento & $-1,5167$ & 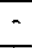 & $\infty 0.75$ & 10 & 47 & W Rio Uatuma \\
\hline MN 35 & $K-\bar{A} r$ & PT.27 & $5 A 20$ & Granodionito & Biotita & Embasamento & $-0,5333$ & 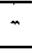 & $\infty 0.4$ & 10 & 47 & N Rio Uatuma \\
\hline MN 36 & $\mathrm{Rb}-\mathrm{S} r$ & PT.29 & $5 A 20$ & Dacito & Rocha total & Vulcånicas Iricoumé & $-0,6000$ & - & 60.2 & 10 & 47 & N Rio Uatuma \\
\hline MN 37 & $\mathrm{Rb}-\mathrm{Sr}$ & PT.30 & $5 A 20$ & Dacito & Rocha total & Vulcanicas licoumé & $-0,6500$ & - & 60.1667 & 10 & 47 & N Rio Uatumá \\
\hline$M N 4$ & K-AT & PT O2A (NERL 63) & $5 A 20$ & Diabásio & Rocha total & Dique & $-2,1208$ & - & 61.276 & 10 & 14,69 & Rio Negro \\
\hline MN 41 & $R b-S t$ & PT.07 & $5 A 20$ & Riolito & Rocha total & Vulcânicas lricoumé & $-1,6500$ & - & 60.1667 & 10 & 47 & W Rio Uatuma \\
\hline MN 42 & $\mathrm{Rb}-\mathrm{Sr}$ & PT.06 & SA 20 & \begin{tabular}{|l} 
Riodacito \\
\end{tabular} & Rocha total & Vulcanicas Iricoumé & $-1,3500$ & - & 60.2667 & 30 & 47 & W Rio Uatuma \\
\hline MN 43 & $\mathrm{Rb}-\mathrm{Sr}$ & BR-174RL-02 & $5 A 20$ & Vulcanica & Rocha total & Vulcanicas Iricoumé & $-1,2333$ & - & $\infty .4$ & 10 & 47 & W Rio Uatuma \\
\hline MN 44 & $R \mathrm{~b}-\mathrm{Sr}$ & NE-CA-79 & $5 A 20$ & Granito & Rocha total & Intrusivas Mapuera & $-1,1685$ & - & 62.7528 & 10 & 47 & Rio Negro \\
\hline MN 45 & $\mathrm{Rb}-\mathrm{Sr}$ & PT.0S & SA 20 & Granito & Rocha total & Intrusivas Mapuera & $-1,7667$ & - & $\$ .1333$ & 10 & 47 & W Rio Uatuma \\
\hline MN 46 & $\mathrm{Rb}-\mathrm{Sr}$ & CU-RL-35 & $5 A 20$ & Granito & Rocha total & Intrusivas Mapuera & $-1,7340$ & $\cdot$ & 60.9754 & 10 & 47,69 & E Rio Negro \\
\hline MN 47 & $\mathrm{Rb}-\mathrm{Sr}$ & BR-174RL-01 & $5 A 20$ & Granito & Rocha total & Intrusivas Mapuera & $-1,2667$ & $\because$ & 60.3833 & 10 & 47 & W Rio Uatuma \\
\hline MN 48 & $\mathrm{Rb}-\mathrm{Sr}$ & HA-1E9 & $5 A 20$ & Granito & Rocha total & Intrusivas Mapuera & $-1,4500$ & - & 60.7333 & 10 & 47 & W Rio Uatuma \\
\hline MN 49 & K-Ar & PiC-SE-RL-30.II & $5 A 20$ & Metabasito & Plagiockásio & Embasamento & $-0,1500$ & - & 65.0667 & 10 & 47 & Rio Negro \\
\hline MN5 & $\mathrm{K}-\mathrm{Ar}_{\mathrm{r}}$ & $\operatorname{cs} 2 A M$ & $5 A 20$ & Basalto & Rocha total & & $-3,7833$ & - & 62.5833 & 10 & 14 & Rio Solimbes \\
\hline MN 50 & K-Ar & PT.05-B.2 & SA 20 & Metabasito & Piroxenio & Embasamento & $-0,2000$ & $\because$ & 65.2167 & 10 & 47 & Rio Negro \\
\hline MN 51 & K-Ar & NE-CA-58 & $5 A 20$ & Metabasito & Plagioclásio & Embasamento & $-0,3167$ & - & 65.5833 & 10 & 47 & Rio Negro \\
\hline MN 53 & K-Ar & HA-115 & SA 20 & Diabásio & Anfibolio & Dique & $-1,5833$ & - & 60.65 & 10 & 47 & W Rio Uatumã \\
\hline MN 54.1 & $\mathrm{Rb}-\mathrm{Sr}$ & HT- $-01 \mathrm{~A}$ & SA 20 & Granito & Feldspato & Intrusivas Abonari & $-1,8652$ & - & 60.1346 & 10 & 48,69 & E Rio Urubu \\
\hline MN 54.2 & $\mathrm{Rb}-\mathrm{Sr}$ & HT-OOTB & $5 A 20$ & Granito & Feldspato & Intrusivas Abonari & $-1,8652$ & - & 60.1346 & 10 & 48,69 & E Rio Urubu \\
\hline MN 54.3 & $\mathrm{Rb}-\mathrm{Sr}$ & HT-OO1C & SA 20 & Granito & Feldspato & Intrusivas Abonari & $-1,8652$ & - & 60.1346 & 10 & 48,69 & E Rio Urubu \\
\hline MN 57 & $K-\bar{A} r$ & HM-289A & $5 A 20$ & Granodionito & Biottla & Embasamento & $-1,8132$ & - & 60.4601 & 10 & 48,69 & E Rio Negro \\
\hline MN 58 & $\mathrm{~K}-\mathrm{Ar}$ & $1520-H A-082$ & $5 A 20$ & Diorito & Anfibollo & Embasamento & -1.4650 & - & 60.8474 & 10 & 69 & E Rio Negro \\
\hline MN 59 & K-Ar & $1520-\mathrm{HM}-298$ & $5 A 20$ & Chamoquito & Anfibólio & Embasamento & $-1,8734$ & - & 60.3892 & 10 & $\infty 9$ & E Rio Negro \\
\hline MN 6 & $R b-S r$ & NE-CA $38 . A$ & $5 A 20$ & Granitoide & Rocha total & Embasamento & $-0,5667$ & - & 64.96 & 10 & 47 & Rio Negro \\
\hline MN 60 & K-Ar & $1520-\mathrm{HM}-115$ & SA 20 & Gabro & Plagioclásio & & $-0,9018$ & $\because$ & 60.5238 & 10 & 69 & E Rio Jauaperi \\
\hline MN 62 & K-Ar & $1182-\$ S-47$ & $5 A 20$ & Charnoquito & Feldspato & Embasamento & $-1,7826$ & - & 00.9226 & 10 & 69 & E Rio Negro \\
\hline MN 7 & $\mathrm{Rb}-\mathrm{Sr}$ & DA-RM-RL-24.B & $5 A 20$ & Granito & Rocha total & Embasamento & 0,0491 & - & 64.5989 & 10 & 47,69 & N Rio Negro \\
\hline MN 8 & $\mathrm{Rb}-\mathrm{Sr}$ & MI-AB-7 & SA 20 & Granodiorito & Rocha total & Embasamento & $-0,3167$ & - & 65.4333 & 10 & 47 & Rio Negro \\
\hline MN9 & $\mathrm{Rb}-\mathrm{Sr}$ & MA-RL-03 & $5 A 20$ & Gnaisse & Rocha total & Embasamento & $-0,3833$ & $\because$ & 65.1833 & 10 & 47 & Rio Negro \\
\hline PU1.1 & K-Ar & PT-25 & $S B 20$ & Adamelito & Biotita & Embasamento & $-7,9060$ & - & 61.5919 & 10 & 59 & SE Rio Maria \\
\hline PU 1.2 & $\mathrm{Rb}-\mathrm{Sr}$ & PT-25 & $\mathrm{SB} 20$ & Adamelito & Rocha total & Embasamento & $-7,9060$ & - & 61.5919 & 10 & 59 & SE Rio Maria \\
\hline PU 10 & $\mathrm{Rb}-\mathrm{Sr}$ & PT-60 & $5 B 20$ & Granito & Rocha total & Embasamento & $-7,5914$ & - & 60.7915 & 10 & 59 & SE Rio Maria \\
\hline
\end{tabular}




\begin{tabular}{|c|c|c|c|c|c|c|c|c|c|c|c|c|}
\hline Ordem & Método & $N^{\circ}$. Campo & Folha & Litologla & Material Analisado & Unidade Geológica & Latitude & & Longitude & $\begin{array}{l}\text { Prec } \\
(\mathrm{Km})\end{array}$ & Ref & Referêncla Geográflca \\
\hline PU11 & $\mathrm{Rb}-\mathrm{Sr}$ & $\mathrm{PT}-138$ & 5820 & Granito & Rocha total & Embasamento & $-7,0365$ & - & 61.1997 & 10 & 59 & SE Rio Maria \\
\hline PU12 & $\mathrm{Rb}-\mathrm{Sr}$ & PT-139 & $5 B 20$ & Granito & Rocha total & Enbasamento & $-7,0914$ & - & 61.1337 & 10 & 59 & SE Rio Maria \\
\hline PU13 & $\mathrm{Rb}-\mathrm{Sr}$ & PT-142 & $\mathrm{SB} 20$ & Granito & Rocha total & Embasamento & $-7,1553$ & - & 61.2563 & 10 & 59 & SE Rio Maria \\
\hline PU 14 & $\mathrm{Rb}-\mathrm{Sr}$ & PT-149 & 5820 & Adamelito & Rocha total & Embasamento & $-7,2133$ & - & 61.2336 & 10 & 59 & SE Rio Maria \\
\hline PU 15 & $\mathrm{Rb}-\mathrm{Sr}$ & PT31 & SB 20 & Riolito Tufo & Rocha total & Fm Roosevelt & $-6,9102$ & - & 60.5656 & 10 & 59 & SE Rio Maria \\
\hline PU 16 & $\mathrm{Rb}-\mathrm{Sr}$ & PT.37 & $\mathrm{SB} \mathrm{2O}$ & Riolito & Rocha total & Fm Roosevelt & $-6,6608$ & - & 60.4419 & 10 & 59 & SE Rio Maria \\
\hline PU 17 & $\mathrm{Rb}-\mathrm{Sr}$ & PT-66 & $5 B 20$ & Riolito & Rocha total & Fin Roosevelt & $-\quad 6,8744$ & - & 61.0627 & 10 & 59 & SE Rio Maria \\
\hline PU 18 & $\mathrm{Rb}-\mathrm{Sr}$ & PT-06-1 & $5 B 20$ & Riolito & Rocha total & Fm Roosevelt & $-7,3875$ & - & ळ.8471 & 10 & 59 & SE Rio Maria \\
\hline PU 19 & $\mathrm{Rb}-\mathrm{Sr}$ & PT-22-11 & $S B 20$ & Riolito & Rocha total & Fm Roosevelt & $-7,0791$ & - & 60.3178 & 10 & 59 & SE Rio Maria \\
\hline $\mathrm{PU} 2.1$ & $\bar{K}-\overline{A r}$ & PT-11A & $5 B 20$ & MetaRiodacito & Biotita & Embasamento & $-7,7005$ & - & 60.9537 & 10 & 59 & SE Rio Maria \\
\hline PU 2.2 & $\mathrm{Rb}-\mathrm{Sr}$ & PT-11A & $5 B 20$ & MetaRioctacito & Rocha total & Embasamento & $-7,7095$ & - & 60.9537 & 10 & 59 & SE Rio Maria \\
\hline PU 20 & $\mathrm{Rb}-\mathrm{Sr}$ & PT- & $S B 20$ & Riolito & Rocha total & Fm Roosevelt & $-7,3381$ & - & 60.653 & 10 & 59 & SE Rio Maria \\
\hline PU 21 & $\mathrm{Rb}-\mathrm{Sr}$ & PT-89c & $\mathrm{SB} 20$ & Riolito & Rocha total & Fm Roosevelt & $-7,6961$ & - & 60.5492 & 10 & 59 & SE Rio Maria \\
\hline$P \cup 22$ & $\mathrm{Rb}-\mathrm{Sr}$ & PT 3.2 & $S B 20$ & Granito & Rocha total & Granito Rondoniano & $-7,8728$ & - & 61.7821 & 10 & 59 & SE Rio Maria \\
\hline PU 23 & $\overline{R b}-\mathrm{Sr}$ & PT-8.3 & $S B 20$ & Granito & Rocha total & Granito Rondoniano & $-7,8319$ & - & 61.6853 & 10 & 59 & SE Rio Maria \\
\hline PU 24 & $\mathrm{Rb}-\mathrm{Sr}$ & PT-22 & $\mathrm{SB} 20$ & Biotita Granito & Rocha total & Granifo Rondoniano & $-7,9379$ & - & 62.0187 & 10 & 59 & SE Rio Maria \\
\hline PU25.1 & $\mathrm{Rb}-\mathrm{Sr}$ & PT 36 & $5 B 20$ & Biotita Granito & Rocha total & Granito Rondoniano & $-6,7133$ & - & 50.4047 & 10 & 59 & SE Rio Maria \\
\hline PU 25.2 & $\mathrm{~K}-\mathrm{Ar}$ & PT-36 & SB 2O & Metadiabásio & Rocha total & Rochas Intrusivas & $-7,9719$ & - & 61.8245 & 10 & 59 & SE Rio Maria \\
\hline PU 25.3 & $\mathrm{Sm}-\mathrm{Nd}$ & PT 36 & $5 \mathrm{~B} 20$ & Diabás lo & Rocha total & Rochas Intrusivas & $-7,9719$ & - & 61.8245 & 10 & 79 & SE Rio Maria \\
\hline $\mathrm{PU26}$ & $\mathrm{Rb}-\mathrm{Sr}$ & PT-38 & SB 20 & Granito & Rocha total & Granito Rondoniano & -7.957 & - & 61.7666 & 10 & 59 & SE Rio Maria \\
\hline PU 27 & $\mathrm{Rb}-\mathrm{St}$ & PT-41 & 5820 & Granito & Rocha total & Granito Rondoniano & $-7,9003$ & - & 61.6737 & 10 & 59 & SE Rio Maria \\
\hline $\mathrm{PU} 28$ & $\mathrm{Rb}-\mathrm{Sr}$ & PT-89D & SB 20 & Granito & Rocha total & Granito Rondoniano & $-7,7707$ & - & 00.5542 & 10 & 59 & SE Rio Maria \\
\hline$P \cup 29$ & $\mathrm{~K}-\mathrm{Ar}$ & PT-26.2 & $5 B 20$ & Diabásio & Rocha total & Diab Penatecaua & $-7,5557$ & - & 90.1038 & 10 & 59 & SE Rio Maria \\
\hline PU3.1 & K-Ar & PT-84 & $\mathrm{SB} 20$ & Granito & Biotita & Embasamento & $-7,9054$ & - & 60.8124 & 10 & 50 & SE Rio Maria \\
\hline $\mathrm{PU} 3.2$ & $\mathrm{Rb}-\mathrm{Sr}$ & PT 84 & $\mathrm{SB} 2 \mathrm{O}$ & Adamelito & Rocha total & Embasamento & $-7,9054$ & - & 60.8124 & 10 & 59 & SE Rio Maria \\
\hline PU 30 & K-AT & PT-18.1 & SB 20 & Diabásio & Plagioclásio & Rochas Intrusivas & $-6,8008$ & - & 60.2766 & 10 & 59 & SE Rio Maria \\
\hline PU 31 & K-AT & PTळOII & $5 B 20$ & Metadiabásio & Plagioclásio & Rochas Intrusivas & $-7,0464$ & 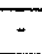 & 60.6224 & 10 & 59 & SE Rio Maria \\
\hline PU 32 & K-Ar & PT 11 ili & $S B 20$ & Diabásio & Plagioclásio & Diab Penatecaua & $-7,2338$ & - & 60.5476 & 10 & 59 & SE Rio Maria \\
\hline PU 33 & K-Ar & PT2311 & $S B 20$ & Diabásio & Rocha total & Diab Penatecaua & $-7,1546$ & 2 & 60.268 & 10 & 59 & SE Rio Maria \\
\hline $\mathrm{PU} 34$ & K-AT & PT 6611 & $\mathrm{SB} 2 \mathrm{O}$ & Diabásio & Plagiociásio & Diab Penatecaua & $-7,2699$ & - & $\infty .6501$ & 10 & 59 & SE Rio Maria \\
\hline PU 35 & K-Ar & AM 104 & $\mathrm{SB20}$ & Diabásio & Rocha total & Diab Penatecaua & $-7,3421$ & - & 60.6606 & 10 & 59 & SE Rio Maria \\
\hline PU 36 & $\mathrm{Rb}-\mathrm{St}$ & PT-26.1 & SB 20 & Granito & Rocha fotal & Granito Rondoniano & $-7,5557$ & - & 60.1038 & 10 & 59 & SE Rio Maria \\
\hline PU 37 & $\mathrm{Rb}-\mathrm{Sr}$ & PT 21 & $S \bar{B} 20$ & Tufo & Rocha total & Fm Roosevelt & $-6,6300$ & - & 60.44 & 10 & 69 & Rio Aripunha \\
\hline
\end{tabular}




\begin{tabular}{|c|c|c|c|c|c|c|c|c|c|c|c|c|}
\hline Ordem & Método & $N^{\circ}$. Campo & Folha & Litologla & Material Anallsado & Unldade Geológlca & Latitude & & Longltude & $\begin{array}{l}\text { Prec } \\
(\mathrm{Km})\end{array}$ & Ref & Referēncla Geográfica \\
\hline PU 38 & $\mathrm{Rb}-\mathrm{Sr}$ & PT5 & $\mathrm{SB} \mathrm{2O}$ & Metavulcanica & Rocha total & Fm Roosevelt & $-7,7300$ & - & 60.92 & 10 & 69 & Rio Aripunha \\
\hline$P \cup 39$ & $\mathrm{Rb}-\mathrm{Sr}$ & PT 89 & $5 B 20$ & Granito & Rocha total & & $-7,7600$ & - & 60.53 & 10 & 69 & Rio Guariba \\
\hline $\mathrm{PU} 4$ & $\mathrm{Rb}-\mathrm{Sr}$ & PT-68 & $5 B 20$ & NetaRiodacito & Rocha total & Embasamento & $-6,9054$ & - & 61.1002 & 10 & 59 & SE Rio Maria \\
\hline PU 40 & $\mathrm{~K}-\mathrm{Ar}$ & PT 26-2 & SB 20 & Diabásio & Rocha total & & $-7,4900$ & - & 60.16 & 10 & 69 & N Samauma \\
\hline PU 41 & $\mathrm{Rb}-\mathrm{Sr}$ & PTOB & 5820 & Granito & Rocha total & & $-7,8400$ & 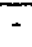 & 61.78 & 10 & 69 & W Samauma \\
\hline PU 42 & $\mathrm{~K}-\mathrm{Ar}$ & PT $4 \mathrm{~A}$ & $\mathrm{SB} 20$ & Anfibolito & Anfibólio & \begin{tabular}{|l} 
Embasamento \\
\end{tabular} & $-7,0000$ & - & 50.3 & 10 & 81 & Rio Aripuana \\
\hline PU 43 & K-Ar & PT 1411 & SB 20 & Nefelina Sienito & K Feldspato & & $-7,2800$ & - & 60.2 & 10 & 81 & Rio Aripuană \\
\hline PU5 & $\mathrm{Rb}-\mathrm{Sr}$ & PT-6 & $S B 20$ & Adamelito & Rocha total & Embasamento & -6.9954 & - & 61.1304 & 10 & 59 & SE Rio Maria \\
\hline PU 6.1 & $\mathrm{Rb}-\mathrm{Sr}$ & PT.33 & $\mathrm{SB} 20$ & Biotita Granito & Rocha total & Embasamento & -7.7834 & - & 60.5209 & 10 & 59 & SE Rio Maria \\
\hline PU 6.2 & $\mathrm{Rb}-\mathrm{Sr}$ & PT 33 & $\overline{S B} 20$ & Riolito & Rocha total & Embasamento & $-7,9203$ & - & 60.159 & 10 & 59 & SE Rio Maria \\
\hline PU 7 & $\mathrm{Rb}-\mathrm{Sr}$ & PT 53 & $S B 20$ & Adamelito & Rocha total & Embasamento & $-7,8676$ & - & 60.9701 & 10 & 59 & SE Rio Maria \\
\hline PU8 & $\mathrm{Rb}-\mathrm{Sr}$ & PT-54 & $S B 20$ & Biotita Granito & Rocha total & Embasamento & $-7,7834$ & - & 61.0166 & 10 & 59 & SE Rio Maria \\
\hline PU9 & $\overline{R b}-S r$ & PT-56II & $\mathrm{SB} 20$ & Granodionito & Rocha total & Embasamento & $-7,7916$ & - & 60.9278 & 10 & 59 & SE Rio Maria \\
\hline PV 10.1 & $\mathrm{Rb}-\mathrm{Sr}$ & PT-04 & $\operatorname{sen} 20$ & Adamelito & Rocha total & Embasamento & $-10,3496$ & - & 61.0263 & 10 & 72 & Regiāo Rio Branco \\
\hline PV 10.2 & K-Ar & PT-04 & $\operatorname{se} 20$ & Adamelito & Rocha total & Embasamento & 10,4636 & - & 61.2479 & 10 & 72 & Regiăo Rio Branco \\
\hline PV 102.1 & $\mathrm{Rb}-\mathrm{Sr}$ & PT $45 \mathrm{IF}$ & $5 \mathrm{sc} 20$ & Riodacito & Rocha total & Vulcanicas Săo Lourenço & $-9,2517$ & - & 64.4371 & 10 & 12 & Rio Madeira \\
\hline PV 102.2 & $\mathrm{Rb}-\mathrm{Sr}$ & PT 45 IA & $5 \mathrm{C} 20$ & Riodacito & Rocha total & Vucéricas Sto Lavenço & $-9,2517$ & - & 64.4371 & 10 & 12 & Rio Madeira \\
\hline PV 102.3 & $\mathrm{Rb}-\mathrm{Sr}$ & PT $45 \mathrm{IC}$ & $\operatorname{sc} 20$ & Riodacito & Rocha total & Vucaricas Sto Lourenço & $-9,2517$ & - & 64.4371 & 10 & 12 & Rio Madeira \\
\hline PV 102.4 & $\mathrm{Rb}-\mathrm{Sr}$ & PT 4518 & $\operatorname{se~} 20$ & Riodacito & Rocha total & Vucanicas Sto Larenço & -9.2517 & - & 64.4371 & 10 & 12 & Rio Madeira \\
\hline PV 102.5 & $\mathrm{Rb}-\mathrm{Sr}$ & PT 45ID & sc 20 & Riodacito & Rocha fotal & Vulcenicas Sáo Lourenço & $-9,2517$ & $\because$ & 64.4371 & 10 & 12 & Rio Madeira \\
\hline PV 103 & $\mathrm{Rb}-\mathrm{Sr}$ & SR $62 \mathrm{C}$ & $\operatorname{sen} 20$ & Riolito & Rocha total & Vicaricas Sto Larenco & $-9,1405$ & - & 64.7333 & 10 & 12 & N Rio Madeira \\
\hline PV 104.1 & $\mathrm{Rb}-\mathrm{Sr}$ & MSL 4 & Sc 20 & Riolito & Rocha total & Vucaricas Sáo Lourenco & $-9,3321$ & - & 64.71 & 10 & 12 & Rio Madeira \\
\hline PV 1042 & K-Ar & MSL 4 & $5 C 20$ & Riolito & Rocha total & Embasamento & $-9,3321$ & - & 64.71 & 10 & 12 & Rio Madeira \\
\hline PV 105.1 & $\mathrm{Rb}-\mathrm{Sr}$ & 1153 CR 61 & $\operatorname{sc} 20$ & Riolito & Rocha total & Vulcáricas S3a Larenpo & $-9,2795$ & - & 64.8423 & 10 & 12 & Rio Madeira \\
\hline PV 105.2 & K-Ar & $\mathrm{SL}$ & $\operatorname{sen} 20$ & Riolito & Rocha total & Embasamento & $-9,2795$ & - & 64.8423 & 10 & 12 & Rio Madeira \\
\hline PV 108 & $\mathrm{Rb}-\mathrm{Sr}$ & MSL-7 & $\operatorname{sen} 20$ & & Rocha total & & $-9,2539$ & - & 65.0335 & 10 & 16 & N Rio Madeira \\
\hline PV 100.1 & $\mathrm{Rb}-\mathrm{Sr}$ & RON 15 & $\operatorname{sen} 20$ & & Biotita & & $-10,2670$ & - & 62.8966 & 10 & 16 & SE Ariquemes \\
\hline PV 109.2 & K-Ar & RON 15 & $\operatorname{sc} 20$ & Gnaisse & Biotita & & $-10,2670$ & - & 62.8966 & 10 & 16 & SE Ariquemes \\
\hline PV 11.1 & $\mathrm{Rb}-\mathrm{Sr}$ & PT-OB-A & Sc 20 & Granulito & Rocha total & Embasamento & $-10,1883$ & - & 60.891 & 10 & 72 & Regiáo Rio Branco \\
\hline PV 11.2 & $\bar{K}-\overline{A r}$ & PT-06A & $\operatorname{sc} 20$ & Granulito & Biotita & & -10.1883 & - & 60.891 & 10 & 72 & Regiáo Rio Branco \\
\hline$P \vee 110$ & $K-A r$ & RON 14 & $\operatorname{sc} 20$ & Norito & Homblenda & & $-10,1713$ & - & 62.979 & 10 & 16 & SE Ariquemes City \\
\hline PV 112 & $\mathrm{~K}-\mathrm{Ar}$ & RON 16 & 5020 & Gabro & Homblenda & & $-9,9642$ & - & 63.079 & 10 & 16 & Ariquemes \\
\hline PV 113 & K-Ar & MS-1 & $\operatorname{sc20}$ & Gnaisse & Anfibolio & Embasamento & $-9,7439$ & - & 62.3159 & 10 & 16 & Rio Machadinho \\
\hline
\end{tabular}




\begin{tabular}{|c|c|c|c|c|c|c|c|c|c|c|c|c|}
\hline Ordem & Método & $N^{\circ}$. Campo & Folha & Litologla & Material Anallsado & Unidade Geológica & Latifude & & Longitude & $\begin{array}{l}\text { Prec } \\
\text { (Km) }\end{array}$ & Ret & Referêncla Geográfica \\
\hline PV 114 & K-Ar & PT 26.1 & SC 20 & Basalto & Rocha total & & $-9,7631$ & - & 61.1849 & 10 & 14 & E Rio Madeirinha \\
\hline PV 115 & K-AT & $1518 \overline{A A 143}$ & $\operatorname{sen} 20$ & Gabro & Rocha total & & $-9,7007$ & - & 65.3051 & 10 & 14 & Rio Madeira \\
\hline PV 116 & $\mathrm{~K}-\mathrm{Ar}$ & PT 60.2 & $5 \mathrm{C} 20$ & Diabásio & Rocha total & & $-8,8615$ & 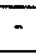 & 65.1983 & 10 & 14 & Serra dos Trés Irmăos \\
\hline PV 117 & K-Ar & 1518.JA257 & $\operatorname{sc~} 20$ & Diabásio & Rocha total & & $-9,0560$ & - & 65.3929 & 10 & 14 & Rio Madeira \\
\hline PVI18 & $\mathrm{K}-\overline{A r}$ & PT 26.7 & 5020 & Diabásio & Rocha total & & $-10,5124$ & - & 62.1715 & 10 & 14 & N Ouro Preto D'Oeste \\
\hline PV 119.1 & K-Ar & PT 73.2 & $5 \mathrm{SC} 20$ & LeucoGabro & Plagioclásio & & $-8,5748$ & - & 65.2888 & 10 & 14 & W Rio Ciriquirui \\
\hline PV 119.2 & $\mathrm{~K}-\mathrm{Ar}$ & PT 73.1/1 & $\operatorname{SC} 20$ & Diabásio & Rocha total & & $-8,5748$ & - & 65.2888 & 10 & 14 & W Rio Ciriquirui \\
\hline$P \vee 12$ & $R \mathrm{~b}-\mathrm{Sr}$ & PT-88 & $\sec 20$ & Granulito & Rocha total & Embasamento & $-10,0391$ & 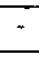 & 60.9841 & 10 & 72 & W Regiăo Rio Branco \\
\hline PV 120.1 & $K-\overline{A r}$ & PT 74 & $\operatorname{sc} 20$ & Basalto & Rocha tofal & Fm Nova Floresta & $-10,5281$ & - & 63.8243 & 10 & 14 & Rio Candeias \\
\hline$P V 120.2$ & $\mathrm{Sm}-\mathrm{Nd}$ & PT 74 & 5020 & Basatto & Rocha total & & -10.5281 & - & 53.8243 & 30 & 79 & Rio Candeias \\
\hline PV 121.1 & K-Ar & PT 81.2 & $\operatorname{sc~} 20$ & Basalto & Rocha total & Fm Nova Floresta & $-10,7025$ & - & 63.4461 & 10 & 14 & W Rio Jamari \\
\hline PV 121.2 & $\mathrm{~K}-\mathrm{Ar}$ & PT $81 \mathrm{~A}$ & $\operatorname{sc} 20$ & Basalto & Rocha total & Fm Nova Floresta & $-10,7025$ & - & 63.4461 & 10 & 14 & W Rio Jamari \\
\hline PV 122.1 & $\mathrm{Rb}-\mathrm{Sr}$ & PT 46A2 & $\operatorname{sc} 20$ & Sienito & Rocha total & Teotónio Alk & $-8,8525$ & - & 63.8634 & 10 & 14 & E Porto Velho \\
\hline PV 122.2 & $\mathrm{Rb}-\mathrm{Sr}$ & PT 46 & $\operatorname{sc~} 20$ & Sienito & Rocha total & Teotônio Alk & $-8,8525$ & - & 63.8634 & 10 & 14 & E Porto Vekho \\
\hline PV 123 & $\mathrm{Rb}-\mathrm{Sr}$ & AFR 214 & $5 \mathrm{sc} 20$ & Traquito & Rocha total & & $-8,9113$ & - & 65.0887 & 10 & 14 & N Rio Madeira \\
\hline PV 124.1 & $\mathrm{K}-\mathrm{Ar}$ & PT 77.3 & $\operatorname{sc~} 20$ & Traquito & Rocha total & & $-\overline{9,4314}$ & - & 64.7305 & 10 & 14 & S Rio Madeira \\
\hline PV 124.2 & $\overline{R b}-\mathrm{Sr}$ & PT 77.3 & $\operatorname{se~} 20$ & Traquito & Rocha total & & $-9,4314$ & - & 64.7305 & 30 & 69 & S Rio Madeira \\
\hline PV 125.1 & K-Ar & 1453 CM $233 \mathrm{~A}$ & $\operatorname{se} 20$ & Basalto & Rocha total & Fm Nova Floresta & $-10,4830$ & " & 64.5374 & 10 & 14 & N Sema dos Pacá́s Novos \\
\hline PV 125.2 & K-Ar & 1153 AAR332 & $\operatorname{sen} 20$ & Basalto & Rocha total & Fm Nova Floresta & $-10,4830$ & $\because$ & 64.5374 & 10 & 14 & N Serra dos Paczás Nowos \\
\hline$P V 125.3$ & $\mathrm{~K}-\overline{\mathrm{Ar}}$ & 1153 CMR 232 & $5 C 20$ & Basalto & Rocha total & Fm Nova Floresta & $-10,4830$ & - & 64.5374 & 10 & 14 & N Serma dos Pacás Novos \\
\hline$P V 125.4$ & K-Ar & 1153 AAR335 & $5 \mathrm{SCO}$ & Basalto & Rocha total & Fm Nova Floresta & $-10,4830$ & - & 64.5374 & 10 & 14 & N Serta dos Pacáás Novos \\
\hline PV 127.1 & $\mathrm{Rb}-\mathrm{Sr}$ & PT $72 E 1$ & SC 20 & Granulito & Rocha total & Embasamento & $-10,3279$ & 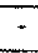 & 62.3275 & 10 & 73 & Rio Jaru \\
\hline PV 127.2 & $\mathrm{Sm}-\mathrm{Nd}$ & PT 72EI & $\operatorname{sc~} 20$ & Granulito & Rocha total & Embasamento & $=10,3279$ & - & 62.3275 & 30 & 79 & Rio Jaru \\
\hline PV 128 & $R \mathrm{~B}-\mathrm{Sr}$ & SR/R219 & Sc 20 & Diorito & Rocha total & Embasamento & -9.0456 & - & 64.5286 & 10 & 73 & N Rio Madeira \\
\hline$P \vee 129$ & $\mathrm{Rb}-\mathrm{Sr}$ & $\bar{R} 26$ & $\operatorname{sc} 20$ & Gnaisse & Rocha total & Embasamento & $-9,3581$ & - & 64.7323 & 10 & 73 & Rio Madeira \\
\hline PV 13 & $\mathrm{Rb}-\mathrm{Sr}$ & PT-67 & $\operatorname{sc} 20$ & Gnaisse & Rocha total & Embasamento & $-9,4504$ & - & 61.816 & 10 & 72,69 & Jiparaná river \\
\hline PV 130.1 & $\mathrm{Rb}-\mathrm{Sr}$ & PT 16 & $\operatorname{se~} 20$ & Gnaisse & Rocha total & Embasamento & $-10,1675$ & - & 65.2429 & 10 & 73 & Rio Madeira \\
\hline PV 130.2 & $\mathrm{~K}-\mathrm{Ar}$ & PT 16 & $5 \mathrm{SC} 20$ & Gnaisse & Biofita & Embasamento & $-10,1675$ & $\because$ & 65.2429 & 10 & 73 & Rio Madeira \\
\hline PV 131.1 & $\mathrm{Rb}-\mathrm{Sr}$ & PT 46 & $5 \mathrm{sc} 20$ & Gnaisse & Rocha total & Embasamento & $-10,5815$ & - & 62.9374 & 30 & 73,63 & N Rio Jaru \\
\hline PV 131.2 & K-Ar & PT 46 & $5 \mathrm{sc} 20$ & Gnaisse & Biodita & Embasamento & $-10,8178$ & - & 63.0977 & 30 & 73,69 & N Rio Jaru \\
\hline PV 132 & $\mathrm{Rb}-\mathrm{Sr}$ & PT 65.2 & $\operatorname{se~} 20$ & Gnaisse & Rocha total & Embasamento & $-9,1092$ & - & 65.5467 & 10 & 73,69 & N Serra dos Três Immăos \\
\hline PV 133 & Rb-Sr & PT 37 & $5 \mathrm{sc} 20$ & Gnaisse & Rocha total & Embasamento & $-8,6779$ & - & 85.9049 & 10 & 73 & Rio lituxi \\
\hline PV 134.1 & $\mathrm{Rb}-\mathrm{Sr}$ & PT 02.1 & $5 \mathrm{~s} 20$ & Gnaisse & Rocha total & Embasamento & $-10,0091$ & - & 62.9697 & 10 & 73 & SE Ariquemes \\
\hline
\end{tabular}




\begin{tabular}{|c|c|c|c|c|c|c|c|c|c|c|c|c|}
\hline Ordem & Método & $N^{0}$. Campo & Folha & Litologia & Material Analisado & Unidade Geológlca & Latitude & & Longltude & $\begin{array}{l}\text { Prec } \\
\text { (Km) }\end{array}$ & Ref & Referêncla Geográfica \\
\hline PV $134 . \overline{2}$ & $\mathrm{Rb}-\mathrm{Sr}$ & PT-O2-A-1 & $\operatorname{sc} 20$ & Granulito & Rocha fotal & Embasamento & $-10,0391$ & - & 62.9697 & 30 & 69 & SE Ariquemes \\
\hline PV 134.3 & K-Ar & PT-O2-A-1 & $\operatorname{sc} 20$ & Granulito & Rocha total & Embasamento & $-10,0091$ & - & 62.9697 & 30 & 69 & SE Ariquemes \\
\hline PV135 & $\mathrm{Rb}-\mathrm{Sr}$ & PT 33 & $5 C 20$ & Adamelito & Rocha total & Embasamento & $-10,2736$ & - & 63.4343 & 10 & 73 & W Rio Jamari \\
\hline$P \vee 136$ & $\mathrm{Rb}-\mathrm{Sr}$ & PT 21 & $\operatorname{sc~} 20$ & Gnaisse & Rocha total & Embasamento & $-10,0310$ & - & 63.2485 & 10 & 73 & SW Ariquemes \\
\hline PV 137 & $\mathrm{Rb}-\mathrm{Sr}$ & PT 59 & $5 C 20$ & Charnoquito & Rocha total & Embasamento & $-10,3228$ & - & 63.7527 & 10 & 73 & Rio Candeias \\
\hline PV 138 & $\mathrm{Rb}-\mathrm{Sr}$ & PT 27.2 & $5 C 20$ & Gnaisse & Rocha total & Embasamento & -11.6637 & - & 63.0459 & 10 & 73 & W Serra dos Parecis \\
\hline PV 139 & $\mathrm{Rb}-\mathrm{ST}$ & PT 43.1 & 5020 & Granulito & Rocha total & Embasamento & $-9,9886$ & - & 62.6622 & 10 & 73 & E Ariquemes \\
\hline$P \vee 14$ & $R \mathrm{~B}-\mathrm{Sr}$ & PT-16A & SC 20 & Kinzigito & Rocha total & Embasamento & $-9,1187$ & - & 61.8061 & 10 & 72 & Rio Machadinho \\
\hline PV 140 & Rb-Sr & PT 19.2 & $5 \mathrm{sc} 20$ & Adamelito & Rocha total & Embasamento & $-10,2767$ & - & 64.6393 & 10 & 73 & N Serta dos Pacás Novos \\
\hline PV 141 & K-AT & PT 15 & 5020 & Gnaisse & Biotita & Embasamento & 8,5191 & - & 60.715 & 10 & 73 & E Rio Roosevelt \\
\hline PV 144.1 & K-Ar & PT57.1 & $5 \mathrm{C} 20$ & Gnaisse & Biotita & Embasamento & $-9,9297$ & - & 63.7982 & 10 & 73 & W Rio Candeias \\
\hline PV 144.2 & $\mathrm{Rb}-\mathrm{Sr}$ & PT 57.1 & $\operatorname{sen} 20$ & Gnaisse & Rocha total & Embasamento & $-9,9297$ & - & 63.7982 & 30 & 69 & W Rio Candeias \\
\hline PV 15 & $\mathrm{Rb}-\mathrm{Sr}$ & PT-29 & $\operatorname{sc} 20$ & Granito & Rocha total & Embasamento & $-9,3429$ & - & 61.782 & 10 & 72 & Rio Machadinto \\
\hline$P V 150$ & $\mathrm{Rb}-\mathrm{Sr}$ & 1154 FF-21 & $\operatorname{sc20}$ & Quartzo Porfiro & Rocha total & & $-11,8885$ & - & 61.0158 & 30 & 69 & SE Pimenta Bueno \\
\hline PV 151.1 & $\mathrm{Rb}-\mathrm{Sr}$ & PT 55 & $5 \mathrm{sc} 20$ & Gnaisse & Rocha total & Embasamento & $-9,5650$ & - & 65.9254 & 30 & 09 & E Rio Marmelo \\
\hline PV 151.2 & K-Ar & PT 55 & $\operatorname{sc~} 20$ & Gnaisse & Biotita & Embasamento & $-9,5650$ & - & 65.9254 & 30 & $\infty$ & E Rio Marmelo \\
\hline PV 153 & $\mathrm{Rb}-\mathrm{Sr}$ & 1154 HT-165 & $\operatorname{sc~} 20$ & Riodacito & Rocha total & & $-11,5215$ & - & 60.2864 & 30 & 6 & E Rio Roosevelt \\
\hline PV 154 & $\mathrm{Rb}-\mathrm{Sr}$ & 1154 OL-161 & 5020 & Riolito & Rocha total & & $-11,4891$ & - & 60.3887 & 30 & 69 & E Rio Roosevelt \\
\hline PV157 & $\mathrm{Rb}-\mathrm{Sr}$ & 1154-HT-AB-B & $5 \mathrm{sc} 20$ & Riodacito & Rocha total & & $-11,4568$ & - & 60.4226 & 30 & $\infty$ & E Rio Roosevelt \\
\hline PV 158 & K-Ar & PT-47-A & 5020 & Gnaisse & Anfibólio & Embasamento & $-9,8989$ & - & 63.1453 & 30 & 69 & N Ariquemes \\
\hline PV 159 & $\mathrm{Rb}-\mathrm{Sr}$ & $1154 \mathrm{AF}-117$ & $5 \mathrm{SC} 20$ & Migmatto & Rocha total & Embasamento & $-11,3553$ & 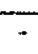 & 61.5624 & 30 & 69 & W Cacoal \\
\hline PV 16.1 & $\mathrm{Rb}-\mathrm{Sr}$ & PT-61 & 5020 & Granulito & Rocha total & Embasamento & $-9,2254$ & - & 61.8464 & 10 & 72 & Rio Machadinho \\
\hline PV 16.2 & Sm-Nd & PT 61 & $5 \mathrm{sc} 20$ & Granulito & Rocha total & Embasamento & $-9,2254$ & - & 61.8464 & 30 & 79 & Rio Machadinho \\
\hline PV 160 & $R \mathrm{~b}-\mathrm{Sr}$ & $1751-V C-159$ & $\operatorname{sc} 20$ & Gnaisse & Rocha total & Embasamento & - 11.8292 & - & 62.9904 & 30 & 69 & W Serra dos Parecis \\
\hline PV 161 & K-Ar & 1518-AA-168 & $\operatorname{sen} 20$ & Anfibolito & Anfibólio & & $-10,0790$ & - & 64.4768 & 30 & $\oplus$ & W Jaciparaná river \\
\hline PV 162.1 & $\mathrm{~K}-\mathrm{Ar}$ & PT-42-A-4 & $\mathrm{SC} 20$ & Andesito & Plagiocláslo & & $-8,3322$ & - & 65.2093 & 30 & 6 & Rio Ciriquirui \\
\hline PV 162.2 & $\mathrm{~K}-\mathrm{Ar}$ & CIMR-42-A & $\operatorname{se~} 20$ & Gabro & Plagioclásio & & $-8,3322$ & 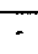 & 6.2093 & 30 & 69 & Rio Ciriquirui \\
\hline PV 162.3 & $\mathrm{~K}-\bar{A} \mathrm{r}$ & PT-42-A-10 & $\operatorname{se~} 20$ & Gabro & Plagioclásio & & $-8,3322$ & - & 65.2003 & 30 & 69 & Rio Ciriquirui \\
\hline PV 162.4 & $\mathrm{~K}-\mathrm{Ar}$ & PT-42-A-6 & 5020 & Gabro & Plagiociásio & & $-8,3322$ & 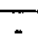 & 65.2093 & 30 & 69 & Rio Ciriquiryi \\
\hline PV163 & $\mathrm{K}-\mathrm{Ar}$ & CUMR-158 & $\operatorname{SC~} 20$ & Diabásio & Rocha total & & $-8,6466$ & - & 65.3305 & 30 & 69 & W Rio Ciriquirui \\
\hline PV 164 & $\mathrm{~K}-\mathrm{Ar}$ & ITMR-61 & $5 C 20$ & Granodionito & Biotita & Embasamento & $-8,7601$ & - & 64.7843 & 30 & 69 & W Arauã river \\
\hline PV 165 & $\mathrm{Rb}-\mathrm{Sr}$ & PT-96B & $5 \mathrm{SC} 20$ & Riodacito & Rocha total & Vucanicas Sso Larenço & $-9,4075$ & - & 65.0686 & 30 & 69 & N Rio Madeira \\
\hline PV 166 & $\mathrm{Rb}-\mathrm{Sr}$ & PT 50 & Sc 20 & Tufo & Rocha total & Vucánicas Szo Larenço & $-8,6103$ & - & 65.0115 & 30 & 69 & Rio Ciriquirui \\
\hline
\end{tabular}




\begin{tabular}{|c|c|c|c|c|c|c|c|c|c|c|c|c|}
\hline Ordem & Método & $N^{\circ}$. Campo & Folha & Lltologla & Material Anallsado & Unidade Geológica & Latifude & & ongifude & $\begin{array}{l}\text { Prec } \\
\text { (Km) }\end{array}$ & Ref & Referēncia Geográfica \\
\hline PV 167 & $\mathrm{Rb}-\mathrm{Sr}$ & $1518-\sqrt{A}-256$ & SC 20 & Riodacito & Rocha total & Vucaricas Sto Larenco & $-9,4175$ & 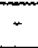 & 64.8738 & 30 & 69 & Rio Madeira \\
\hline PV 168 & K-Ar & $1154 \overline{A F}-234$ & $\operatorname{SC} 20$ & Gabro & Plagioclásio & & $-11,1461$ & - & 60.6742 & 30 & 69 & Serra Quatorze de Abril \\
\hline PV 160 & K-Ar & $A F-303-B$ & $5 \mathrm{~S} 20$ & Dionito & Anfibolio & & $-11,1070$ & - & 62.3745 & 30 & 69 & Rio Urupá \\
\hline PV 17 & $\mathrm{Rb}-\mathrm{Sr}$ & $\mathrm{PT}-16$ & $\operatorname{sc~} 20$ & Granito & Rocha total & Embasamento & $-9,3776$ & - & 60.5419 & 10 & 72 & E Rio Roosevelt \\
\hline PV 170 & $\mathrm{Rb}-\mathrm{Sr}$ & $1154 \mathrm{FB}-180$ & $\operatorname{sen} 20$ & Gnaisse & Rocha lotal & Embasamento & $-11,8215$ & - & 61.7254 & 30 & 69 & Pardo river \\
\hline PV171 & K-Ar & $M A-52$ & 5020 & Granito & Biotita & & $-9,9638$ & - & 63.7574 & 30 & 69 & Rio Candeias \\
\hline PV 172 & K-Ar & SL.34 & $5 \mathrm{Sc} 20$ & Riolito & Rocha total & Vúchricas Sá Lourenço & $-9,2300$ & - & 65.0572 & 10 & $\infty 9$ & N Rio Madeira \\
\hline$P V 173$ & $\mathrm{Rb}-\mathrm{Sr}$ & $1154 \mathrm{FB}-185$ & $\operatorname{sen} 20$ & Granulito & Rocha total & Embasamento & $-11,7869$ & - & 61.8231 & 10 & 69 & W Pardo river \\
\hline PV 174.1 & $\mathrm{Rb}-\mathrm{Sr}$ & RON $101 \mathrm{~A}$ & $\operatorname{sc} 20$ & Granito & Rocha total & Intrusso Grantica Caibiana & $-9,4215$ & - & 63.1786 & 10 & 74 & Rio Jamari \\
\hline PV 174.2 & $\mathrm{Rb}-\mathrm{Sr}$ & RON $101 \mathrm{~B}$ & $\operatorname{sc} 20$ & Granito & Rocha total & Intosto Granlica Cariana & $-9,4215$ & - & 63.1786 & 10 & 74 & Rio Jamari \\
\hline PV 174.3 & $\mathrm{Rb}-\mathrm{Sr}$ & RON $101 \mathrm{C}$ & $\operatorname{se~} 20$ & Granito & Rocha total & Intusto Ganfica Cariana & $-9,4215$ & - & 63.1786 & 10 & 74 & Rio Jamari \\
\hline PV 174.4 & $\mathrm{Rb}-\mathrm{Sr}$ & RON 102 & $\operatorname{sen} 20$ & Granito & Rocha total & hotusso Grantica Cariara & $-9, \overline{4215}$ & - & 63.1786 & 10 & 74 & Rio Jamari \\
\hline PV 174.5 & $\mathrm{Rb}-\mathrm{Sr}$ & RON 103 & $\sec 20$ & Granito & Rocha total & Intrusto Granfica Cariena & $-9,4215$ & - & 63.1786 & 10 & 74 & Rio Jamari \\
\hline PV 174.6 & $\mathrm{Rb}-\mathrm{Sr}$ & RON 104 & 5020 & Granito & Rocha total & Intussoso Grantica Cartiana & $-9,4215$ & - & 63.1786 & 10 & 74 & Rio Jamari \\
\hline$P V 175.1$ & $\mathrm{Rb}-\mathrm{Sr}$ & RON 107 & $\sec 20$ & Granito & Rocha total & Cpolintrusino S30 Carios & $-9,7328$ & - & 63.1193 & 10 & 74 & Rio Jamari \\
\hline PV 175.2 & $R b-S r$ & RON 108 & $\operatorname{sc} 20$ & Granito & Rocha total & Cpox Intrusivo Säo Carios & $-9,7328$ & - & 5.1193 & 10 & 74 & Rio Jamari \\
\hline PV 175.3 & $\mathrm{Rb}-\mathrm{S} r$ & RON 142 & $\operatorname{se~} 20$ & Granito & Rocha total & Cpo Intrusivo Sáo Carios & $-9,7328$ & - & 63.1193 & 10 & 74 & Rio Jamari \\
\hline PV 175.4 & $\mathrm{Rb}-\mathrm{Sr}$ & RON 143 & 5020 & Granito & Rocha total & Cpx Intusino Sao Carios & $-9,7328$ & - & 63.1193 & 10 & 34 & Rio Jamari \\
\hline PV 175.5 & $\mathrm{Rb}-\mathrm{St}$ & RON 144 & 5020 & Granito & Rocha total & Cpx intusivio Sao Carlos & -9.7328 & - & 63.1193 & 10 & 74 & Rio Jamani \\
\hline PV 175.6 & $\mathrm{Rb}-\mathrm{Sr}$ & RON 145 & $5 \mathrm{Sc} 20$ & Granito & Rocha total & Cpx Inthusivo S5o Carlos & $-9,7328$ & - & 63.1193 & 10 & 74 & Rio Jamari \\
\hline PV175.7 & $R b-S r$ & RON 146 & $\operatorname{sc~} 20$ & Granito & Rocha total & Cpx Intrusivo Sto Carbs & $-9,7328$ & - & 63.1193 & 10 & 74 & Rio Jamari \\
\hline PV 176.1 & $\mathrm{Rb}-\mathrm{Sr}$ & RON 114A & $\operatorname{sc} 20$ & Monzonito & Rocha total & Intrusão Granitica & $-9,7152$ & - & 62.6254 & 10 & 74 & NE Ariquemes \\
\hline PV 176.2 & Rb-Sr & RON $114 \bar{B}$ & $\operatorname{se~} 20$ & Monzonito & Rocha total & Intrusāo Granltica & $-9,7152$ & - & 52.6254 & 10 & 74 & NE Ariquemes \\
\hline PV 176.3 & $R b-S r$ & RON $114 \mathrm{C}$ & $5 \mathrm{SC} 20$ & Monzonito & Rocha total & Intrusão Granitica & $-9,7152$ & - & 52.6254 & 10 & 74 & NE Ariquemes \\
\hline PV 176.4 & $\mathrm{Rb}-\mathrm{Sr}$ & RON $114 \mathrm{D}$ & $\operatorname{sc} 20$ & Monzonito & Rocha total & Intrusăo Granitica & $-9,7152$ & - & 62.6254 & 10 & 74 & NE Árquemes \\
\hline PV 177.1 & $\mathrm{Rb}-\mathrm{Sr}$ & RON 115A & $\sec 20$ & Granito & Rocha total & Intrusáo Granitica & $-9,0920$ & - & 62.5411 & 10 & 74 & NE Ariquemes \\
\hline PV 177.2 & $\mathrm{Rb}-\mathrm{Sr}$ & RON $115 \mathrm{~B}$ & $\operatorname{sen} 20$ & Granito & Rocha total & Intrusão Granitica & $-9,0920$ & - & 62.5411 & 10 & 74 & NE Ariquernes \\
\hline PV 177.3 & $\overline{\mathrm{R}} \mathrm{b}-\mathrm{Sr}$ & RON $115 \mathrm{C}$ & $5 \mathrm{C} 20$ & Granito & Rocha total & Intrusāo Granitica & $-9,6920$ & - & 62.5411 & 10 & 74 & NE Ariquemes \\
\hline PV 177.4 & $R b-S t$ & RON $115 \mathrm{D}$ & $5 \mathrm{SC} 20$ & Granito & Rocha total & Intrusăo Granitica & $-9,0020$ & - & 52.5411 & 10 & 74 & NE Ariquemes \\
\hline$P \vee 178.1$ & $\mathrm{Rb}-\mathrm{Sr}$ & RON $116 \bar{A}$ & 5020 & Mangerito & Rocha total & Intrusaso Granitica & $-9,7009$ & - & 62.2512 & 10 & 74 & Rio Machadinho \\
\hline PV 178.2 & $\mathrm{Rb}-\mathrm{Sr}$ & RON $116 \mathrm{~B}$ & $5 \mathrm{~s} 20$ & Mangerito & Rocha total & Intrusão Granitica & $-9,7009$ & - & 62.2512 & 10 & 74 & Rio Machadinho \\
\hline PV 178.3 & $\mathrm{Rb}-\mathrm{Sr}$ & RON $116 \mathrm{C}$ & $5 \mathrm{~S} 20$ & Mangerito & Rocha total & Intrusáo Granltica & - 9.7009 & - & 62.2512 & 10 & 74 & Rio Machadinho \\
\hline PV 178.4 & $\mathrm{Rb}-\mathrm{Sr}$ & RON 1160 & 5020 & Mangerito & Rocha total & Intrusao Granitica & $-9,7009$ & - & 62.2512 & 10 & 74 & Rio Machadinho \\
\hline
\end{tabular}




\begin{tabular}{|c|c|c|c|c|c|c|c|c|c|c|c|c|}
\hline Ordem & Método & $N^{\circ}$. Campo & Folha & L.ftologila & Material Analisado & Unidade Geológlca & Latitude & & Longitude & $\begin{array}{l}\text { Prec } \\
(\mathbf{K m})\end{array}$ & Ref & Referência Geográfica \\
\hline PV 179.1 & $\mathrm{Rb}-\overline{\mathrm{S} r}$ & RON $118 \mathrm{~A}$ & $\operatorname{sen} 20$ & Gnaisse & Rocha total & Embasamento & $-9,8636$ & - & 62.5350 & 10 & 74 & Rio Machadinho \\
\hline PV 179.2 & $\mathrm{Rb}-\mathrm{Sr}$ & RON 118B & $\operatorname{sc} 20$ & Gnaisse & Rocha total & Embasamento & $-9,8636$ & - & 62.5350 & 10 & 74 & Rio Machadinho \\
\hline PV 179.3 & $\mathrm{Rb}-\mathrm{Sr}$ & RON $118 \mathrm{C}$ & $5 \mathrm{SC} 20$ & Gnaisse & Rocha total & Embasamento & $-9,8636$ & - & 62.5359 & 10 & 74 & Rio Machadinho \\
\hline PV 179.4 & $\mathrm{Rb}-\mathrm{Sr}$ & RON 1180 & 5020 & Gnaisse & Rocha total & Embasamento & $-9,8636$ & - & 62.5359 & 10 & 74 & Rio Machadinho \\
\hline PV 179.5 & $\mathrm{Rb}-\mathrm{Sr}$ & RON $118 \mathrm{E}$ & 5020 & Gnaisse & Rocha total & Embasamento & $-9,8636$ & - & 52.5359 & 10 & 74 & Rio Machadintho \\
\hline PV 18 & $\mathrm{Rb}-\mathrm{Sr}$ & PT-18 & $\operatorname{se~} 20$ & Dacito & Rocha total & Vulcanicas Teles Pires & $-11,1438$ & - & 60.3754 & 10 & 72 & Capitáo Cardoso \\
\hline PV 180.1 & $\mathrm{Rb}-\mathrm{Sr}$ & RON $119 \bar{A}$ & 5020 & Granito & Rocha total & Cpox intusivo Oriente Nowo & $-9,6122$ & - & 62.411 & 10 & 74 & S Serra de Săo Sebastiáo \\
\hline PV 180.2 & $\mathrm{Rb}-\mathrm{Sr}$ & RON 119D & SC 20 & Granito & Rocha total & Cpx Intursivo Oriente Novo & $-9,6122$ & - & 62.411 & 10 & 74 & S Serra de Săo Sebastião \\
\hline PV 180.3 & $\mathrm{Rb}-\mathrm{Sr}$ & RON $120 \mathrm{~A}$ & $\operatorname{se~} 20$ & Granito & Rocha total & Cpx Intusisio Oriente Novo & $-9,6122$ & - & 62.411 & 10 & 74 & S Serra de Sáo Sebastiáo \\
\hline PV 180.4 & $\mathrm{Rb}-\mathrm{Sr}$ & RON $120 \bar{B}$ & $\operatorname{sc~} 20$ & Granito & Rocha total & Cpo Intusino Oriente Nowo & $-9,6122$ & - & 62.411 & 10 & 74 & S Serra de Săo Sebastiáo \\
\hline PV 180.5 & $\mathrm{Rb}-\mathrm{Sr}$ & RON 120 C & $\operatorname{sc} 20$ & Granito & Rocha total & Cpxx Intusivo Oriente Nowo & $-9,6122$ & - & 62.411 & 10 & 74 & S Serra de Săo Sebastiáo \\
\hline PV 180.6 & $\mathrm{Rb}-\mathrm{Sr}$ & RON 123 & $5 \mathrm{C} 20$ & Granito & Rocha total & Cpo intusivo Oriente Novo & $-9,6122$ & - & 62.411 & 10 & 74 & S Serra de Sro Sebastiá \\
\hline PV 180.7 & $\mathrm{Rb}-\mathrm{Sr}$ & RON $125 \mathrm{~A}$ & $5 \mathrm{~S} 20$ & Granito & Rocha total & Cpol Intusivo Oriente Novo & -9.6122 & - & 62.411 & 10 & 74 & S Serra de Săo Sebastiăo \\
\hline PV 180.8 & $\mathrm{Rb}-\mathrm{Sr}$ & RON $125 \mathrm{C}$ & 5020 & Granito & Rocha total & Cppolitusivo Orierte Nowo & $-9,6122$ & - & 62.411 & 10 & 74 & S Serra de Săo Sebastiáo \\
\hline PV 181.1 & $\mathrm{Rb}-\mathrm{Sr}$ & RON $126 \mathrm{~A}$ & $\operatorname{sc} 20$ & Granito & Rocha total & Intrusáo Granitica & $-9,5042$ & - & 52.3306 & 10 & 74 & S Serra de São Sebastiáa \\
\hline PV 181.2 & $\mathrm{Rb}-\mathrm{Sr}$ & RON $126 \bar{B}$ & 5020 & Granito & Rocha total & Intrusăo Granitica & $-9,5042$ & - & 62.3306 & 10 & 74 & S Serra de Săo Sebastiðo \\
\hline PV 181.3 & $\mathrm{Rb}-\mathrm{Sr}$ & RON $126 \mathrm{C}$ & SC 20 & Granito & Rocha total & Intrusāo Granitica & -9.5042 & - & 62.3306 & 10 & 74 & S Serra de Săo Sebastiáo \\
\hline PV 181.4 & $\mathrm{Rb}-\mathrm{Sr}$ & RON $126 \mathrm{D}$ & $\operatorname{se~} 20$ & Granito & Rocha total & Intrusáo Granltica & $-9,5042$ & - & 62.3306 & 10 & 74 & S Serra de Săo Sebastiăo \\
\hline PV 181.5 & $\mathrm{Rb}-\mathrm{Sr}$ & RON $126 \mathrm{E}$ & $\operatorname{sc} 20$ & Granito & Rocha total & Intrusăo Granifica & $-9,5042$ & - & 62.3306 & 10 & 74 & S Serra de São Sebastiăo \\
\hline PV 182.1 & $R b-S r$ & RON 127 & $5 \mathrm{~S} 20$ & Granito & Rocha total & 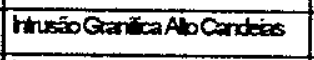 & $-10,4842$ & - & 63.5527 & 10 & 74 & W Rio Jamari \\
\hline PV 182.2 & $\mathrm{Rb}-\mathrm{Sr}$ & RON $128 \mathrm{~A}$ & 5020 & Granito & Rocha total & 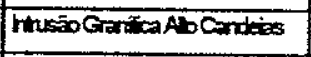 & $-10,4842$ & - & 53.5527 & 10 & 74 & W Rio Jamari \\
\hline PV 182.3 & $\mathrm{Rb}-\mathrm{Sr}$ & RON $128 B$ & $5 \mathrm{SC} 20$ & Granito & Rocha total & 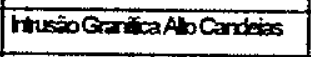 & $-10,4842$ & $\because$ & 63.5527 & 10 & 74 & W Rio Jamari \\
\hline PV 182.4 & Rb-St & RON 130 & Sc 20 & Granito & Rocha tołal & Ithus & $-10,4842$ & - & 63.5527 & 10 & 74 & W Rio Jamari \\
\hline PV 183.1 & $R b-S r$ & RON 132 & $5 \mathrm{~s} 20$ & Granito & Rocha total & 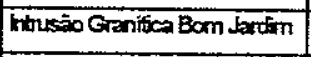 & $-9,9521$ & - & 63.5119 & 10 & 74 & E Rio Candeias \\
\hline PV 183.2 & $\overline{R b}-S_{r}$ & RON 133A & $5 \mathrm{SC} 20$ & Granito & Rocha total & 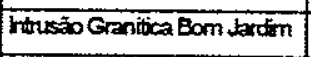 & $-9,9521$ & - & 63.5119 & 10 & 74 & E Rio Candeias \\
\hline PV 183.3 & $\overline{R b}-\mathrm{Sr}$ & RON $133 \mathrm{~B}$ & Sc 20 & Granito & Rocha total & Etrusāo Granitica Bom dactim & $-9,9521$ & - & 63.5119 & 10 & 74 & E Rio Candeias \\
\hline PV 183.4 & $\mathrm{Rb}-\mathrm{Sr}$ & RON 136B & SC 20 & Granito & Rocha total & Thusão Granitica Bom Larem & $-9,9521$ & - & 63.5119 & 10 & 74 & E Rio Candeias \\
\hline PV 183.5 & $\mathrm{Rb}-\mathrm{Sr}$ & RON 137 & $\operatorname{sc} 20$ & Granito & Rocha total & Hrušo Granitica Born Jartion & $-9,5521$ & - & 63.5119 & 10 & 74 & E Rio Candeias \\
\hline PV 184.1 & Rb-St & RON 135 & $5 \mathrm{C} 20$ & Granito & Rocha total & 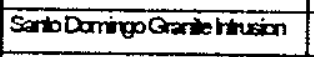 & $-10,0400$ & + & 63.4451 & 10 & 74 & Rio Massangana \\
\hline PV 184.2 & Rb-Sr & RON 138 & SC 20 & Granito & Rocha total & Sonto Damingo Garis thation & $-10,0400$ & - & 53.4451 & 10 & 74 & Rio Massangana \\
\hline PV 185.1 & Rb-Sr & RON 139 & $5 \mathrm{~s} 20$ & Granito gnaisse & Rocha total & Embasamento & $-10,0403$ & - & 63.255 & 10 & 74 & SW Atiquemes \\
\hline PV 185.2 & $\mathrm{Rb} \cdot \mathrm{Sr}$ & RON 140 & $5 C 20$ & Granito gnaisse & Rocha total & Embasamento & $-10,0403$ & - & 63.25 & 10 & 74 & SW Ariquemes \\
\hline PV 185.3 & $\mathrm{Rb}-\mathrm{Sr}$ & RON $141 \mathrm{~A}$ & $5 \mathrm{sc} 20$ & Granito gnaisse & Rocha total & Embasamento & $-10,0403$ & - & 63.255 & 10 & 74 & SW Ariquemes \\
\hline
\end{tabular}




\begin{tabular}{|c|c|c|c|c|c|c|c|c|c|c|c|c|}
\hline Ordem & Método & $\mathbf{N}^{\circ}$. Campo & Folha & Lttologia & Material Analisado & Unidade Geológlca & Latitude & & Longitude & $\begin{array}{l}\text { Prec } \\
(\mathrm{Km})\end{array}$ & Ref & Referência Geográfica \\
\hline PV 185.4 & $\mathrm{Rb}-\mathrm{Sr}$ & RON $141 \mathrm{~B}$ & $\operatorname{se~} 20$ & Granito gnaisse & Rocha fotal & Embasamento & $-10,0403$ & - & 63.255 & 10 & 74 & SW Ariquemes \\
\hline PV 186.1 & $\mathrm{Rb}-\mathrm{Sr}$ & RON 149A & $\operatorname{sc~} 20$ & Granito & Rocha total & Intrusǎo Granitica & 8,7924 & - & 63.4877 & 10 & 74 & E Porto Velho \\
\hline PV 186.2 & $R b-S r$ & RON $149 \mathrm{~B}$ & $\mathrm{SC} 20$ & Granito & Rocha total & Intrusăo Granitica & $-8,7924$ & - & 63.4877 & 10 & 74 & E Porto Velho \\
\hline PV 186.3 & $R b-S r$ & RON $140 \mathrm{C}$ & $5 \mathrm{sen}$ & Granito & Rocha total & Intrusåo Granfica & $-8,7924$ & - & 63.4877 & 10 & 74 & E Porto Velho \\
\hline PV 186.4 & $\mathrm{Rb}-\mathrm{Sr}$ & RON 1490 & $5 c 20$ & Granito & Rocha total & Intrusáo Granltica & $-8,7924$ & - & 63.4877 & 10 & 74 & E Porto Velho \\
\hline PV 187.1 & $\mathrm{Rb}-\mathrm{Sr}$ & RON 152 & $\operatorname{sc} 20$ & Granito & Rocha total & Cpx Intrusivo Macisa & $-9,3447$ & - & 65.0860 & 10 & 74 & N Rio Madeira \\
\hline PV 187.2 & $\mathrm{Rb}-\mathrm{Sr}$ & RON $153 \mathrm{~A}$ & $5 \mathrm{sc} 20$ & Granito & Rocha total & Cpx Intrusivo Macisa & $-9,3447$ & - & 65.0869 & 10 & 74 & N Rio Madeira \\
\hline PV 187.3 & $\mathrm{Rb}-\mathrm{Sr}$ & RON 154 & $5 \mathrm{SCO}$ & Granito & Rocha total & Cpx Intrusivo Macisa & $-9,3447$ & 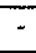 & 6.0869 & 10 & 74 & N Rio Madeira \\
\hline PV 188.1 & Rb-Sr & RON 155 & $5 \mathrm{~s} 20$ & Granito & Rocha total & Cpx intursivo sabo Larerxo & $-9,4062$ & - & 65.1674 & 10 & 74 & N Rio Madeira \\
\hline PV 188.2 & $\mathrm{Rb}-\mathrm{Sr}$ & RON 156 & $\operatorname{sc} 20$ & Granito & Rocha total & Cpa Intusivio sao Larenço & $-9,4062$ & - & 65.1674 & 10 & 74 & N Rio Madeira \\
\hline$P \vee 188.3$ & $\mathrm{Rb}-\mathrm{Sr}$ & RON 157 & $\operatorname{sen} 20$ & Granito & Rocha total & Cpox trousivo sà Lavenço & -9.4062 & $\because$ & 65.1674 & 10 & 74 & N Rio Madeira \\
\hline $\mathrm{PV} 188.4$ & $\mathrm{Rb}-\mathrm{Sr}$ & RON 160 & $5 \mathrm{sc} 20$ & Granito & Rocha total & Cpox intrusiva säo Larencio & $-9,4062$ & - & 65.1674 & 10 & 74 & N Rio Madeira \\
\hline PV 188.5 & $\mathrm{RbmSr}$ & RON 161 & $5 \mathrm{SC} 20$ & Granito & Rocha total & Cpox Intrusivo sado Larenço & $-9,4062$ & - & 55.1674 & 10 & 74 & N Rio Madeira \\
\hline PV 189.1 & $\mathrm{Rb}-\mathrm{Sr}$ & RON 162B & 5020 & Granito & Rocha total & Granito Pedra Branca & $-9,4144$ & - & 62.9139 & 10 & 74 & E Rio Jamari \\
\hline PV 189.2 & Rb-Sr & RON $162 \mathrm{C}$ & $5 \mathrm{sc} 20$ & Granito & Rocha total & Granito Pedra Branca & $-9,4144$ & - & 62.9139 & 10 & 74 & E Rio Jamari \\
\hline PV 189.3 & $\mathrm{Rb}-\mathrm{Sr}$ & RON $162 \mathrm{D}$ & $\operatorname{sen} 20$ & Granito & Rocha total & Granito Pedra Branca & $-9,4144$ & + & 62.9139 & 10 & 74 & E Rio Jamari \\
\hline PV 189.4 & $\mathrm{Rb}-\mathrm{Sr}$ & RON $163 \mathrm{~A}$ & $\operatorname{sic} 20$ & Granito & Rocha total & Granito Pedra Branca & $-9,4144$ & - & 62.9130 & 10 & 74 & E Rio Jamari \\
\hline PV 189.5 & $\mathrm{Rb}-\mathrm{Sr}$ & RON $163 \mathrm{~B}$ & $5 \mathrm{SC} 20$ & Granito & Rocha total & Granito Pedra Branca & $-9,4144$ & - & 62.9139 & 10 & 74 & E Rio Jamari \\
\hline PV 189.6 & $\mathrm{Rb}-\mathrm{Sr}$ & RON $153 \mathrm{C}$ & $5 \mathrm{SC} 20$ & Granito & Rocha total & Granito Pedra Branca & $-9,4144$ & $\sim$ & 62.9139 & 10 & 74 & E Rio Jamari \\
\hline PV 189.7 & Rb-St & RON $164 \mathrm{~A}$ & $5 \mathrm{~S} 20$ & Granito & Rocha total & Granito Pedra Branca & $-9,4144$ & - & 62.9139 & 10 & 74 & E Rio Jamari \\
\hline PV 189.8 & $\mathrm{Rb}-\mathrm{Sr}$ & RON 164B & $5 \mathrm{~s} 20$ & Granito & Rocha total & Granito Pedra Branca & $-9,4144$ & - & 62.9139 & 10 & 74 & E Rio Jamari \\
\hline PV 19 & $\mathrm{Rb}-\mathrm{Sr}$ & PT-71 & $\operatorname{sc} 20$ & Riodacito & Rocha total & Vulcanicas Teles Pires & $-10,7658$ & - & 60.3871 & 10 & 72 & Flor do Prado \\
\hline PV 190.1 & $R b-s r$ & RON $16 \bar{A}$ & $\operatorname{se~} 20$ & Granito Rapakivi & Rocha total & Cpx Intrusivo Caripunas & $-9,0130$ & - & 64.9131 & 10 & 74 & N Rio Madeira \\
\hline PV 190.2 & $\mathrm{Rb}-\mathrm{Sr}$ & RON $165 \mathrm{C}$ & $\operatorname{sen} 20$ & Granito Rapakivi & Rocha total & Cpx Intrusivo Caripunas & $-9,0139$ & - & 64.9131 & 10 & 74 & N Rio Madeira \\
\hline PV 190.3 & $\mathrm{RD}-\mathrm{Sr}$ & RON 1650 & $5 \mathrm{SC} 20$ & Granito Rapakivi & Rocha total & Cpx Intrusivo Caripunas & $-9,0139$ & - & 64.9131 & 10 & 74 & N Rio Madeira \\
\hline PV 190.4 & $\mathrm{Rb}-\mathrm{Sr}$ & RON $165 \mathrm{~F}$ & 5020 & Granito Rapakivi & Rocha total & Cpx Intrusivo Caripunas & $-9,0139$ & - & 64.9131 & 10 & 74 & N Rio Madeira \\
\hline PV 191.1 & $\mathrm{Rb}-\mathrm{Sr}$ & RON $166 \mathrm{~A}$ & $\operatorname{sc} 20$ & Granito Rapakivi & Rocha total & Cpx Intrusivo Caripunas & $-8,9608$ & - & 64.8182 & 10 & 74 & N Rio Madeira \\
\hline PV 191.2 & $\mathrm{Rb}-\mathrm{Sr}$ & RON $166 \mathrm{~B}$ & $\operatorname{se~} 20$ & Granito Rapakivi & Rocha total & Cpx Intrusivo Caripunas & $-8,9608$ & - & 64.8182 & 10 & 74 & N Rio Madeira \\
\hline PV 192.1 & $\overline{R b}-S r$ & RON 167A & $5 \mathrm{SCO}$ & Granito Rapakivi & Rocha total & Cpx Intrusivo Caripunas & $-9,0910$ & - & 64.9355 & 10 & 74 & N Rio Madeira \\
\hline PV 192.2 & $R b-S r$ & RON $167 \mathrm{C}$ & $5 \mathrm{~S} 20$ & Granito Rapakivi & Rocha total & Cpx Intrusivo Caripunas & 9.0910 & - & 64.9355 & 10 & 74 & N Rio Madeira \\
\hline PV 193.1 & $\mathrm{Rb}-\mathrm{Sr}$ & RON $168 \mathrm{~A}$ & $\operatorname{se~} 20$ & Granito Rapakivi & Rocha total & Cpx Intrusivo Caripunas & $-9,0275$ & - & 64.761 & 10 & 74 & N Rio Madeira \\
\hline PV 193.2 & $\overline{R b}-\mathrm{Sr}$ & RON $168 \mathrm{C}$ & $\operatorname{sc} 20$ & Granito Rapakivi & Rocha total & Cpx Intrusivo Caripunas & 9,0275 & - & 64.761 & 10 & 74 & N Rio Madeira \\
\hline PV 194.1 & $R b-S r$ & RON $169 \mathrm{~A}$ & $\operatorname{sen} 20$ & Granito Rapakivi & Rocha total & Cpx Intrusivo Caripunas & 9,0032 & - & 64.7622 & 10 & 74 & N Rio Madeira \\
\hline
\end{tabular}




\begin{tabular}{|c|c|c|c|c|c|c|c|c|c|c|c|c|}
\hline Ordem & Método & $N^{\circ}$. Campo & Folha & Litologia & Material Anallsado & Unidade Geológica & Latitude & & Longitude & $\begin{array}{l}\text { Prec } \\
(\mathrm{Km})\end{array}$ & Ref & Referência Geográflca \\
\hline PV 194.2 & $\mathrm{Rb}-\mathrm{Sr}$ & RON $169 \mathrm{~B}$ & $\operatorname{sc~} 20$ & Granito Rapakivi & Rocha total & Cpx Intrusivo Caripunas & $-9,0932$ & - & 64.7622 & 10 & 74 & N Rio Madeira \\
\hline PV 2.1 & Rb-Sr & PT 20 & $5 \mathrm{~s} 20$ & Gnaisse & Rocha total & Embasamento & $-9,8568$ & - & 65.3096 & 10 & 60,69 & Rio Madeira \\
\hline PV 2.2 & $\mathrm{K}-\mathrm{Ar}$ & PT 20 & $\operatorname{sc} 20$ & Gnaisse & Biotita & Embasamento & $-\overline{9}, 8568$ & - & 65.3095 & 10 & 73 & Rio Madeira \\
\hline PV20.1 & $\mathrm{Rb}-\mathrm{Sr}$ & PT51 & $\sec 20$ & Dacito & Rocha total & Vulcânicas Teles Pires & $-8,2608$ & - & 60.9643 & 10 & 72 & Rio Rooseveit \\
\hline PV 20.2 & $\mathrm{Sm}-\mathrm{Nd}$ & PT51 & $\operatorname{sc} 20$ & Dacito & Rocha fotal & Vulcanicas Teles Pires & $-8,2698$ & - & 60.9643 & 30 & 79 & Rio Rooseveit \\
\hline PV 200 & $\mathrm{Rb}-\mathrm{Sr}$ & $11 B$ & 5020 & Gnaisse & Rocha total & Embasamento & $-9,2852$ & - & 65.0519 & 10 & 81 & Regiáo lttuxi-Abuna \\
\hline PV 201 & $\mathrm{Rb}-\mathrm{Sr}$ & PT 19.2 & $\operatorname{sc~} 20$ & Gnaisse & Rocha total & Embasamento & $-9,5451$ & 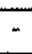 & 64.9828 & 10 & 81 & Regiáo Ituxi-Abună \\
\hline $\mathrm{PV} 202$ & Rb-Sr & $\mathrm{R}-26$ & $\operatorname{se~} 20$ & Gnaisse & Rocha total & Embasamento & $-9,6205$ & - & 65.0849 & 10 & 81 & Regiăo lfuxj-Abună \\
\hline PV 203 & $\mathrm{Rb}-\mathrm{Sr}$ & PT 65.2 & $\sec 20$ & Calcissillicática & Rocha total & Embasamento & $-9,0934$ & - & 55.5644 & 10 & 81 & Regiăo ltuxi-Abuna \\
\hline PV 204 & $\mathrm{Rb}-\mathrm{Sr}$ & PT 64.2 & $\operatorname{sc} 20$ & Gnaisse & Rocha total & Embasamento & $-9,6431$ & - & 65.6454 & 10 & 81 & Regiăo ltuxi-Abunā \\
\hline PV 205 & $\mathrm{Rb}-\mathrm{Sr}$ & DLR 123 & $5 c 20$ & Gnaisse & Rocha total & Embasamento & $-9,8790$ & - & 65.7576 & 10 & 81 & Regiso Ituxi-Abuná \\
\hline PV 206 & $\mathrm{Rb}-\mathrm{Sr}$ & PT-16 & $5 \mathrm{se} 20$ & Gnaisse & Rocha total & Embasamento & $-10,4186$ & 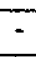 & 55.4239 & 10 & 81 & Regiăo ltuxi-Abună \\
\hline $\mathrm{PV} 207$ & Rb-Sr & $17 \mathrm{~B}$ & $\operatorname{sen} 20$ & Granito & Rocha total & Embasamento & $-10,4946$ & $\sim$ & 64.8888 & 10 & 81 & Região ittuxi-Abuná \\
\hline PV 208 & $\mathrm{Rb}-\mathrm{Sr}$ & $20 \mathrm{~B}$ & $\operatorname{se~} 20$ & Granito & Rocha total & Embasamento & $-10,0566$ & - & 64.3743 & 10 & 81 & Regiǎo ituxi-Abuna \\
\hline PV 209 & $\mathrm{Rb}-\mathrm{Sr}$ & VB-R-18R & $\operatorname{sc} 20$ & Granito & Rocha total & Embasamento & $-9,9642$ & - & 64.8749 & 10 & 81 & Regiăo ltuxi-Abună \\
\hline PV 21 & $R \mathrm{~b}-\mathrm{Sr}$ & PT-63 & $\operatorname{sc~} 20$ & Tufo & Rocha total & Vulcanicas Teles Pires & $-10,5626$ & - & 60.4112 & 10 & 72 & Regiâo Rio Branco \\
\hline PV 210 & $\mathrm{Rb}-\mathrm{Sr}$ & PT 57.1 & $\sec 20$ & Gnaisse & Rocha total & Embasamento & $-9,9872$ & - & 64.242 & 10 & 81 & Regiăo ltuxi-Abuna \\
\hline PV211 & Rb-Sr & PT.33 & $\operatorname{sc} 20$ & Adamelito & Rocha total & Embasamento & $-9,9705$ & “ & 64.1004 & 10 & 81 & Regiâo ltuxi-Abună \\
\hline PV 212 & $\mathrm{Rb}-\mathrm{Sr}$ & PT 50 & $\operatorname{se~} 20$ & Charnoquito & Rocha total & Embasamento & $-10,3765$ & - & 65.1917 & 10 & 81 & Regiåo ltuxi-Abunå \\
\hline PV 213 & $\mathrm{Rb}-\mathrm{Sr}$ & PT 27-2 & $\operatorname{sen} 20$ & Gnaisse & Rocha total & Embasamento & $-11,6930$ & - & 62.8236 & 10 & 81 & Regiáo ltuxi-Abuna \\
\hline PV 214 & $\mathrm{Rb}-\mathrm{Sr}$ & PT 46 & 5020 & Gnaisse & Rocha total & Embasamento & \begin{tabular}{|l|} 
\\
\end{tabular} & - & 65.5372 & 10 & 81 & Regizo Ituxi-Abuna \\
\hline PV 215 & $\mathrm{Rb}-\mathrm{Sr}$ & $15 B$ & $\operatorname{sc} 20$ & Granito & Rocha total & Embasamento & $-10,5529$ & - & 63.9302 & 10 & 81 & Regiào lluxi-Abuná \\
\hline$P V 216$ & Rb-Sr & BOUAD E2 & $\operatorname{sc~} 20$ & Leptinito & Rocha total & Embasamento & $-10,5373$ & - & 63.5467 & 10 & 81 & Regiāo Ituxi-Abună \\
\hline $\mathrm{PV} 217$ & $\mathrm{Rb}-\mathrm{Sr}$ & BOLIAD 85 & $\operatorname{sc} 20$ & Leptinito & Rocha total & Embasamento & $-10,7427$ & - & 63.3932 & 10 & 81 & Regiă ituxi-Abuna \\
\hline PV 22 & $\mathrm{Rb}-\mathrm{Sr}$ & PT 38 & $\operatorname{sc} 20$ & Tufo & Rocha total & Vulcånicas Teles Pires & $-10,8834$ & - & 60.5399 & 10 & 72 & N Serra Quatorze de Abril \\
\hline$P \vee 23$ & $\mathrm{Rb}-\mathrm{St}$ & PT-67 & $\operatorname{sc} 20$ & Dacito & Rocha total & Vulcánicas Teles Pires & $-10,6828$ & - & 60.4256 & 10 & 72 & N Rio Flor do Prado \\
\hline PV 24 & $\mathrm{Rb}-\mathrm{Sr}$ & PT-54 & $\operatorname{se~} 20$ & Biotita Granito & Rocha total & Granito Rondoniano & $-8,5892$ & - & 60.8049 & 10 & 72 & E Rio Roosevelt \\
\hline PV 25.1 & $\mathrm{Rb}-\mathrm{Sr}$ & PT-21.1 & $S C 20$ & Biotita Granito & Rocha total & Granito Rondoniano & $-9,8665$ & - & 61.4868 & 10 & 72,78 & Rio Madeirinha \\
\hline PV $25 . \overline{2}$ & $\mathrm{Sm}-\mathrm{Nd}$ & PT 21-1 & $5 \mathrm{sc} 20$ & Granito & Rocha total & Granito Rondoniano & $-9,8665$ & - & 61.4868 & 30 & 79 & Rio Madeirinha \\
\hline PV 26 & $\mathrm{Rb}-\mathrm{Sr}$ & PT- $\infty .1$ & SC 20 & Granito & Rocha total & Granito Rondoniano & $-11,1762$ & - & 80.9215 & 10 & 72,78 & Serra Quatorze de Abril \\
\hline$P \vee 27.1$ & $\mathrm{Rb}-\mathrm{Sr}$ & PT-26 & $\operatorname{sen} 20$ & Granito & Rocha total & Granito Rondoniano & $-9,7489$ & $\div$ & 60.9939 & 10 & 72,78 & E Rio Madeirinha \\
\hline PV 27.2 & K-Ar & PT-26.1 & $5 \mathrm{SC} 20$ & Basica & Rocha tołal & & $-9,7489$ & - & 60.9939 & 10 & 72 & E Rio Madeirinha \\
\hline PV 28.1 & $\mathrm{Rb}-\mathrm{Sr}$ & PT-66.1 & $\operatorname{sc~} 20$ & Sienito & Rocha total & Alc Canama & $-8,7633$ & - & 6.0021 & 10 & 72 & W Serra da Fortaleza \\
\hline
\end{tabular}




\begin{tabular}{|c|c|c|c|c|c|c|c|c|c|c|c|c|}
\hline Ordem & Método & $N^{\circ}$. Campo & Folha & Lttologla & Material Anallsado & Unidade Geológlca & Latitude & & Longitude & $\begin{array}{l}\text { Prec } \\
(\mathrm{Km})\end{array}$ & Ref & Referêncla Geográfica \\
\hline PV 28.2 & K-AT & PT 66.1 & 5020 & Sienito & Anfibólio & Alc Canama & $-8,7633$ & - & $\infty 0.0021$ & 10 & 45 & W Serta da Fortaleza \\
\hline$P V 28.3$ & $\mathrm{Rb}-\mathrm{Sr}$ & PT-66B & $\operatorname{SC~} 20$ & Granito & Rocha total & Alc Canamá & 8,7633 & - & 60.0021 & 10 & 72 & W Serra da Fortaleza \\
\hline $\mathrm{PV} 28.4$ & Rb-Sr & PT-66A3 & $\widehat{S C 20}$ & Sienito & Rocha total & Alc Canamă & $-8,7633$ & 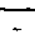 & 60.0021 & 10 & 72 & W Serra da Fortaleza \\
\hline PV 28.5 & $\mathrm{Rb}-\mathrm{Sr}$ & PT-66A1 & 5020 & Sienito & Rocha total & Alc Canama & -8.7633 & - & 60.0021 & 10 & 72 & W Serra da Fortaleza \\
\hline PV3 & $\mathrm{Rb}-\mathrm{Sr}$ & PT 64.2 & $\operatorname{se~} 20$ & Gnaisse & Rocha total & Embasamento & $-8,9942$ & - & 65.5709 & 10 & 60,69 & N Serra dos Tłês limåos \\
\hline PV 32 & $\mathrm{Rb}-\mathrm{Sr}$ & PT-54.1 & $\mathrm{Sc} 20$ & Granito Rapakivi & Rocha total & Grantor Sena ca Providencia & $-10,3576$ & - & 61.5052 & 10 & 72 & Ganto Serra da Providencia \\
\hline PV 33 & $\mathrm{Rb}-\mathrm{Sr}$ & PT-64.1 & $5 \mathrm{sc} 20$ & Gran6firo & Rocha total & Grantios Serra di Providencia & $-10,6554$ & - & 61.5695 & 10 & 72 & Granto Serra da Providencia \\
\hline PV 34 & $\mathrm{Rb}-\mathrm{Sr}$ & PT-28.A & $\operatorname{sc} 20$ & Granofiro & Rocha total & Grasiatss Serra da Providéncia & $-10,0914$ & - & 61.7473 & 10 & 72 & Granko Serta da Providéncia \\
\hline PV 35.1 & $\mathrm{Rb}-\mathrm{Sr}$ & PT $39 . A$ & $5 \mathrm{~S} 20$ & Granito Rapakivi & Rocha total & Grentos Serra da Providencia & $-10,6852$ & - & 61.5478 & 10 & 72 & Granto Serra da Providencia \\
\hline PV 35.2 & $\mathrm{Sm}-\mathrm{Nd}$ & PT $39 \mathrm{~A}$ & $\operatorname{SC20}$ & Granito & Rocha total & Granto Serra da Prandéricia & $-10,6852$ & - & 61.5478 & 30 & 79 & Granto Serla da Providencia \\
\hline PV 36 & $\mathrm{Rb}-\mathrm{Sr}$ & PT-63 & $\operatorname{se~} 20$ & Granito Rapakivi & Rocha total & Granos Serra da Providéncia & $-10,7552$ & - & 61.5592 & 10 & 72 & Ganto Serta da Providencia \\
\hline PV 37 & $R b-S r$ & PT-57 & $\operatorname{sc} 20$ & Granito Rapakivi & Rocha total & Grantor Senz da Providercia & $-10,8289$ & $=$ & 61.603 & 10 & 72 & Granto Serra da Pravidéncia \\
\hline PV 38 & $\mathrm{Rb}-\mathrm{Sr}$ & PT-40 & $\operatorname{sc} 20$ & Granito & Rocha total & Grantos Serra da Providencia & $-10,9002$ & - & 61.4563 & 10 & 72 & Granto Serra da Providéncia \\
\hline PV 39 & $\mathrm{Rb}-\mathrm{Sr}$ & PT-47 & 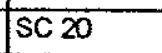 & Granito Rapakivi & Rocha total & Grendos Serra da Providencia & $-8,4392$ & - & 60.9324 & 10 & 72 & Rio Roosevelt \\
\hline PV 4 & $\mathrm{Rb}-\mathrm{Sr}$ & PT 17.2 & Sc 20 & Gnaisse & Rocha total & Embasamento & $-8,8486$ & - & 63.7265 & 10 & 60,69 & E Porto Velho \\
\hline$P \vee 40$ & $\mathrm{Rb}-\mathrm{Sr}$ & PT-3583 & $\operatorname{sen} 20$ & Granito Rapakivi & Rocha total & Graibs Senta da Providencia & $-8,3689$ & - & 60.9716 & 10 & 72 & Rio Roosevelt \\
\hline PV 41 & K-Ar & PT-87 & Sc 20 & Dionito & Plagioclásio & Embasamento & $-10,2492$ & 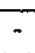 & 61.3008 & 10 & 72 & Granito Serra da Providencia \\
\hline PV 43 & K-AT & PT-52 & $\operatorname{sc} 20$ & Basic & Plagioclásio & & $-11,4194$ & - & 61.1863 & 10 & 72 & E Cacoal \\
\hline PV 44.1 & $R \mathrm{~b}-\mathrm{Sr}$ & $1154 \mathrm{FB}-221$ & $\operatorname{se} 20$ & Granito & Rocha total & & $-11,0261$ & - & 60.7544 & 30 & 45,69 & N Serra Quatorze de Abril \\
\hline PV 44.2 & $\mathrm{Rb}-\mathrm{Sr}$ & $1154-S-22-A$ & $\operatorname{sc} 20$ & Granófiro & Rocha total & Embasamento & $-11,0261$ & - & 60.7544 & 30 & 69 & N Serra Quatorze de Abrit \\
\hline PV 45 & $\mathrm{Rb}-\mathrm{Sr}$ & $1154 \mathrm{FB}-158$ & $\operatorname{sc} 20$ & Monzonito & Rocha total & & $-11,0136$ & - & 60.8985 & 10 & 45 & N Serra Quatorze de Abril \\
\hline PV 46 & $R \mathrm{~b}-\mathrm{Sr}$ & $1154 \mathrm{SR}-263$ & $\operatorname{sc} 20$ & Granito & Rocha total & & $-11,2588$ & - & 60.6426 & 10 & 45 & Serra Quatorze de Abril \\
\hline PV 47 & $\mathrm{Rb}-\mathrm{Sr}$ & $1154 \overline{A F} 165$ & $\overline{\operatorname{sc} 20}$ & Granito & Rocha total & & $-11,1482$ & - & 60.8338 & 10 & 45 & Serra Quatorze de Abril \\
\hline PV 48 & $\mathrm{Rb}-\mathrm{Sr}$ & $1154 \overline{F B ~ 85 A}$ & 5020 & Granito & Rocha total & Embasamento & $-11,3644$ & - & 61.5624 & 10 & 45 & W Cacoal \\
\hline PV 49 & $R b-S r$ & 1751 LA 184 & $5 \mathrm{sc} 20$ & Granito & Rocha total & & $-11,1708$ & $\sim$ & 60.0454 & 10 & 45 & Rio Capitâo Cardoso \\
\hline PV5.1 & U-Pb & MS-6000-1 & $\operatorname{sc} 20$ & Granito gnaisse & Zircáo & Embasamento & $-9,5000$ & - & 62.3833 & 10 & 66 & S Serra de Săo Sebastiăo \\
\hline PV 5.2 & U-Pb & MS- $-\infty 030-2$ & $\operatorname{sc~} 20$ & Granito gnaisse & Zirc\%o & Embasamento & $-9,5000$ & - & 62.3833 & 10 & 66 & S Serra de São Sebastiaxo \\
\hline PV 5.3 & $\mathrm{U}-\mathrm{Pb}$ & MS-6030-3 & $\operatorname{sc} 20$ & Granito gnaisse & Zircáo & Embasamento & $-9,5000$ & - & 62.3833 & 10 & 66 & S Serra de Såo Sebastiáo \\
\hline PV 5.4 & $\mathrm{U}-\mathrm{Pb}$ & MS-6030-4 & $\operatorname{sc~} 20$ & Granito gnaisse & Zircảo & Embasamento & $-9,5000$ & - & 62.3833 & 10 & 66 & S Serra de Săo Sebastiăo \\
\hline PV 50 & Rb-Sr & PT 15.1 & $\mathrm{sc} 20$ & Adamelito & Rocha total & Embasamento & $-8,7218$ & - & 63.4365 & 10 & 45 & E Porto Velho \\
\hline PV 52 & $\mathrm{Rb}-\mathrm{Sr}$ & PT 23 & $\operatorname{sc~} 20$ & Adamelito & Rocha total & Granito Rondoniano & $-8,5728$ & - & 62.6141 & 10 & 45 & Rio Jiparaná \\
\hline PV 53 & $\mathrm{Rb}-\mathrm{Sr}$ & $O A / R-67 A$ & $\operatorname{sc~} 20$ & Granófiro & Rocha fotal & Granito Rondoniano & $-9,2514$ & 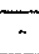 & 64.9914 & 30 & 45,69 & N Rio Madeira \\
\hline PV54.1 & $\mathrm{Rb}-\mathrm{Sr}$ & PT 90.11 & $\operatorname{sc} 20$ & Monzonito & Rocha total & Intr Siriquiquil & $-8,6184$ & - & 5.0515 & 10 & 45 & Rio Ciriquirui \\
\hline
\end{tabular}




\begin{tabular}{|c|c|c|c|c|c|c|c|c|c|c|c|c|}
\hline Ordem & Método & $\mathrm{N}^{\circ}$. Campo & Folha & Litologla & Materfal Analisado & Unidade Geológica & Latftude & & Longitude & $\begin{array}{l}\text { Prec } \\
(\mathrm{Km})\end{array}$ & Ref & Referêncla Geográfica \\
\hline PV 54.2 & K-AI & PT 90 & $\operatorname{sc} 20$ & Gabro & Plagioclásio & & 8.6184 & + & 65.0515 & 10 & 14 & Rio Ciriquirui \\
\hline PV 54.3 & $\mathrm{K}-\mathrm{Ar}$ & PT 99.10 & $\operatorname{se~} 20$ & Gabro & Plagioclásio & & $-8,6184$ & - & 6.0515 & 10 & 14 & Rio Ciriquirui \\
\hline PV 54.4 & K-Ar & PT 99.6 & $5 \mathrm{~S} 20$ & Gabro & Plagioclásio & & $-8,6184$ & - & 65.0515 & 10 & 14 & Rio Ciriquirui \\
\hline PVS & $\mathrm{Rb}-\mathrm{Sr}$ & PT 4481 & 5020 & Granito & Rocha total & Maciço Sắo Cartos & $-9,5935$ & - & 53.1441 & 10 & 45 & Rio Jamari \\
\hline PV 56 & $\mathrm{Rb}-\mathrm{Sr}$ & PT 37A & $5 \mathrm{SC} 20$ & Granito & Rocha total & Maciço Santa Bárbar & $-8,9750$ & 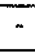 & 62.9432 & 10 & 45 & Rio Preto \\
\hline PV 57 & $\mathrm{Rb}-\overline{\mathrm{Sr}}$ & PT 93 & $\operatorname{sc} 20$ & MicroGranito & Rocha total & & $-9,4607$ & " & 5.0112 & 30 & 45,69 & N Rio Madeira \\
\hline PV 58 & $\mathrm{Rb}-\mathrm{Sr}$ & PT 52 & $\operatorname{sc~} 20$ & Granito & Rocha total & Maciço Abuna & $-9,6295$ & $\div$ & 55.5847 & 30 & $45, \overline{69}$ & N Rio Madeira \\
\hline PV 59 & $\mathrm{Rb}-\mathrm{Sr}$ & PT 43A & $\operatorname{sc} 20$ & Granito & Rocha total & Maciço Sáo Carlos & $-9,7585$ & $\because$ & 63.0857 & 30 & 45,69 & E Rio Jamari \\
\hline PV 6.1 & $\mathrm{U} \cdot \mathrm{Pb}$ & A $338 \mathrm{~A}-1$ & $5 \mathrm{sc} 20$ & Metadiorito & Zircaso & & $-9,4000$ & 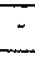 & 63.0333 & 10 & 66 & E Rio Jamari \\
\hline PV 6.2 & $\mathrm{U}-\mathrm{Pb}$ & A.338A-2 & $5 \mathrm{~s} 20$ & Metadiorito & Zircáo & & $-9,4000$ & - & 63.0333 & 10 & 66 & E Rio Jamari \\
\hline PV 6.3 & $\mathrm{U}-\mathrm{Pb}$ & $A-338 A-3$ & $\mathrm{Sc} 20$ & Metadiorito & Zircáo & & $-9,4000$ & - & 63.0333 & 10 & 66 & E Rio Jamari \\
\hline PV 6.4 & $\mathrm{U}-\mathrm{Pb}$ & A-338A-4 & $\mathrm{Sc} 20$ & Metadiorito & Zircáo & & $-9,4000$ & - & 63.0333 & 10 & 66 & E Rio Jamari \\
\hline$P \vee 60$ & $\mathrm{Rb}-\mathrm{Sr}$ & PT 95C & $5 \mathrm{~S} 20$ & Granito & Rocha total & Maciço Săo Lourenço & $-9,3688$ & - & 65.0799 & 30 & 45,69 & N Rio Madeira \\
\hline PV61 & $\mathrm{Rb}-\mathrm{Sr}$ & PT 105B & 5020 & Granito & Rocha total & Maciço Oriente & $-9,3678$ & - & 62.2432 & 30 & 45,69 & Serra de S־o Sebastiāo \\
\hline PV 62 & $R b-S r$ & PT 48A1 & SC 20 & Granito & Rocha total & Maciço Santa Bárbar & -8.9330 & - & 62.943 & 30 & 45,69 & Rio Preto \\
\hline PV & $R b-S r$ & PT 10E & $5 \mathrm{~s} 20$ & Granito & Rocha total & Granito Rondoniano & $-8,7854$ & - & 63.6896 & 30 & $45,69,78$ & E Porto Velho \\
\hline PV 64 & $\mathrm{Rb}-\mathrm{Sr}$ & PT 82.2 & $\operatorname{sc} 20$ & Granito & Rocha total & Granito Rondoniano & $=9,2494$ & - & 64.7314 & 30 & $45,69,78$ & N Rio Madeira \\
\hline PVES & $\mathrm{Rb}-\mathrm{Sr}$ & RR-R 32 & 5020 & Granito & Rocha total & Granito Rondoniano & $-9,3424$ & - & 65.2261 & 30 & 45,69 & N Rio Madeira \\
\hline PV 66 & $\mathrm{Rb}-\mathrm{Sr}$ & PT 87 & $\operatorname{sc} 20$ & Granito & Rocha total & Granito Rondoniano & $-9,8724$ & - & 64.4217 & 30 & 45,69 & W Rio Jaciparaná \\
\hline PV 67 & $\mathrm{Rb}-\mathrm{Sr}$ & PT 79.2 & $\operatorname{sen} 20$ & Granito & Rocha total & Granito Rondoniano & $-9,2951$ & - & 64.8660 & 30 & 45,63 & N Rio Madeira \\
\hline PV 68.1 & $\mathrm{Rb}-\mathrm{Sr}$ & PT $50 B$ & $\operatorname{sc} 20$ & Granito & Rocha total & Granito Rondoniano & $-9,4690$ & - & 64.8282 & 30 & 45,69 & Rio Madeira \\
\hline $\mathrm{PV} \approx 8.2$ & K-Ar & PT 50B & $\operatorname{sc~} 20$ & Granito & Biotita & Granito Rondoniano & $-9,4600$ & - & 64.8282 & 30 & 45,69 & Rio Madeira \\
\hline$P \vee \approx 9$ & $\mathrm{Rb}-\mathrm{Sr}$ & PT 17A & 5020 & Granito & Rocha total & Granito Rondoniano & $-9,2135$ & - & 63.7303 & 30 & $45,69,78$ & S Porto Velho \\
\hline PV 7.1 & $\mathrm{U}-\mathrm{Pb}$ & $C R-48-1$ & $\operatorname{sc~} 20$ & Granitoide & Zircáo & Grantioserra da Providencia & $-11,1333$ & - & 62.55 & 10 & 66 & Rio Urupá \\
\hline PV 7.2 & $\mathrm{U}-\mathrm{Pb}$ & $C R-48-2$ & $\operatorname{sc} 20$ & Granitóde & Zircaso & Grand Serm da Providencia & $-11,1333$ & - & 62.55 & 10 & 66 & Rio Urupá \\
\hline PV 7.3 & $\mathrm{U}-\mathrm{Pb}$ & $C R-48.3$ & $\operatorname{sc} 20$ & Granitóide & Zircăo & Granto Serra da Pravidencia & $-11,1333$ & - & 62.55 & 10 & 66 & Rio Urupá \\
\hline PV7.4 & $\mathrm{U}-\mathrm{Pb}$ & CR-48-4 & $5 \mathrm{c} 20$ & Granitoide & Zircăo & Granto Serra da Providercia & $-11,1333$ & $\therefore$ & 62.55 & 10 & 66 & Rio Urupá \\
\hline PV 7.5 & $\mathrm{U}-\mathrm{Pb}$ & CR-48-5 & $\operatorname{sc} 20$ & Granit6ide & Zircaso & Grento Serra do Providencin & $-11,1333$ & - & 62.55 & 10 & 66 & Rio Urupá \\
\hline$P \vee 7 . \overline{6}$ & U-Pb & $C R-48-6$ & $5 \mathrm{SC} 20$ & Granitoide & Zircáo & Grenio Serra do Rrovidencia & -11.4333 & - & 62.55 & 10 & 66 & Rio Urupá \\
\hline$P \vee 70$ & $\mathrm{Rb}-\mathrm{Sr}$ & AFR 150 & $\operatorname{sc} 20$ & Granito & Rocha total & Granito Rondoniano & $-8,9196$ & - & 645601 & 30 & $45,69,78$ & N Rio Madeira \\
\hline PV 71 & $\mathrm{Rb}-\mathrm{Sr}$ & PT 78 & $\operatorname{sen} 20$ & Granito & Rocha total & Granito Rondoniano & $-9,0090$ & - & 64.6567 & 30 & $45,69,78$ & N Rio Madeira \\
\hline$P \vee 72$ & $\mathrm{Rb}-\mathrm{Sr}$ & PT 56 & 5020 & Granito & Rocha total & Granito Rondoniano & -8.7619 & - & 63.9048 & 10 & 45,78 & Rio Madeira \\
\hline$P V 73$ & $\mathrm{Rb}-\mathrm{Sr}$ & PT 89.1 & $\operatorname{se~} 20$ & Granito & Rocha total & Granito Rondoniano & $-8,8485$ & - & 64.7313 & 30 & $45,69,78$ & W Rio Araua \\
\hline
\end{tabular}




\begin{tabular}{|c|c|c|c|c|c|c|c|c|c|c|c|c|}
\hline Ordem & Método & $N^{\circ}$. Campo & Folha & Litologia & Material Analisado & Unidade Geológica & Latitude & & Longitude & $\begin{array}{l}\text { Prec } \\
(\mathrm{Km})\end{array}$ & Ref & Referēncla Geográfica \\
\hline PV 74 & $\mathrm{Rb}-\mathrm{Sr}$ & PT 88.2 & $5 \mathrm{SC} 20$ & Granito & Rocha total & Granito Rondoniano & $-8,9601$ & $\cdot$ & 64.7294 & 30 & $45,69,78$ & N Rio Madeira \\
\hline PV 75 & $\mathrm{Rb}-\mathrm{Sr}$ & AFR 182 & Sc 20 & Adamelito & Rocha total & & $-9,3382$ & 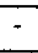 & 64.9643 & 30 & 45,69 & N Rio Madeira \\
\hline PV 76 & $\mathrm{Rb}-\mathrm{Sr}$ & PTO4 & $\operatorname{sc} 20$ & Granito & Rocha total & Granito Rondoniano & $-\quad 9,1540$ & - & 64.3632 & 30 & $45,69,78$ & Rio Madeira \\
\hline PV 77 & Rb-Sr & DLR 302 & $\operatorname{se~} 20$ & Granito & Rocha total & & $-9,2666$ & - & 64.8232 & 30 & 45,69 & N Rio Madeira \\
\hline PV 78 & $\mathrm{Rb}-\mathrm{St}$ & PT 79.3 & $5 \mathrm{~S} 20$ & Granito & Rocha total & & $-10,7566$ & - & 63.5052 & 30 & 45,69 & N Serta dos Pacás Novos \\
\hline PV8 & $\mathrm{Rb}-\mathrm{Sr}$ & PT-86 & SC 20 & Adamelito & Rocha total & Embasamento & $-10,2553$ & - & 61.0781 & 10 & 72 & Granto Serra da Providéncia \\
\hline PV 80 & $R \mathrm{R}-\mathrm{Sr}$ & ECR-10 & $\operatorname{sc} 20$ & Granito & Rocha total & Cpx Santo António & $-8,7780$ & - & 63.9903 & 30 & 45,69 & Rio Madeira \\
\hline PV 81 & $\mathrm{Rb}-\mathrm{Sr}$ & RON 13 & $5 c 20$ & Granito & Rocha total & Cpx Săo Carlos & $-9,5054$ & - & 53.1505 & 30 & 45,69 & Rio Jamari \\
\hline PV82.1 & $\mathrm{Rb}-\mathrm{Sr}$ & RON 1 & $\operatorname{se~} 20$ & Granito & Rocha total & Santa Maria Cpx & $-8,8670$ & - & 62.875 & 30 & 45,69 & Rio Preto \\
\hline PV 82.2 & $\mathrm{Rb}-\mathrm{Sr}$ & RON 1 & $5 \mathrm{sc} 20$ & Granito & Biotita & Cpx Saubinha & $-8,8670$ & - & 62.875 & 30 & 45,69 & Rio Preto \\
\hline PV 82.3 & K-Ar & RON 1 & 5020 & Granito & Biotita & Cpx Santa Maria & $-8,8670$ & - & 62.875 & 30 & 45.69 & Rio Preto \\
\hline PV83.1 & $\mathrm{Rb}-\mathrm{Sr}$ & RON 10 & $5 \mathrm{SC} 20$ & Granito & Rocha total & Cpx Oriente & $-9,3322$ & - & 62.4565 & 30 & 45,69 & W Serra de S3o Sebastiá \\
\hline PV 83.10 & K-Ar & RON9 & $5 C 20$ & Granito & Biotita & Cpx Oriente & $-9,3322$ & - & 62.4565 & 30 & 45,69 & W Serra de São Sebastião \\
\hline PV 83.2 & $\mathrm{Rb}-\mathrm{St}$ & RON 11 & $\operatorname{sc} 20$ & Granito & Rocha total & Cpx Oriente & $-9,3322$ & - & 62.4565 & 30 & 45,69 & W Serra de São Sebastião \\
\hline PV83.3 & $\mathrm{Rb}-\mathrm{Sr}$ & RON 6 & $\operatorname{sc~} 20$ & Granito & Biotita & Cpx Oriente & $-9,3322$ & - & 62.4565 & 30 & 45,69 & W Serra de Săo Sebastiâo \\
\hline PV83.4 & $R b-S r$ & RON 7 & $\operatorname{sc} 20$ & Monzonito & Rocha total & Cpx Oriente & $-9,3322$ & - & 52.4565 & 30 & $45, \infty$ & W Serra de São Sebastiāo \\
\hline PV83.5 & $\mathrm{Rb}-\mathrm{S} r$ & RON 7 & $5 \mathrm{sc} 20$ & Monzonito & Biotita & Cpx Oriente & $-9,3322$ & - & 62.4565 & 30 & $45, \infty 9$ & W Serra de São Sebastiāo \\
\hline PV 83.6 & $\mathrm{Rb}-\mathrm{Sr}$ & RON 8 & $\operatorname{sc} 20$ & Sienito & Rocha total & Cpx Oriente & $-9,3322$ & - & 62.4565 & 30 & 45,69 & W Serra de Sāo Sebastiāo \\
\hline PV 83.7 & $\mathrm{Rb}-\mathrm{Sr}$ & RONG & $5 c 20$ & Granito & Biotita & Cpx Oriente & $-9,3322$ & - & 52.4565 & 30 & $45, \infty 9$ & W Serra de Săo Sebastião \\
\hline PV 83.8 & $\mathrm{~K}-\mathrm{Ar}$ & RON 6 & $\operatorname{sc} 20$ & Greisen & Biotita & Cpx Oriente & $-\overline{9}, 3322$ & - & 62.4565 & 30 & 45,69 & W Serra de São Sebastiảo \\
\hline PV83.9 & K-Ar & RON 7 & $\operatorname{sc} 20$ & Monzonito & Biotita & Cpx Oriente & $-9,3322$ & - & 62.4565 & 30 & 45,69 & W Serra de São Sebastião \\
\hline PV9 & $\mathrm{Rb}-\mathrm{Sr}$ & PT-OB & $\operatorname{sen} 20$ & Granito gnaisse & Rocha total & Embasamento & $-10,6483$ & - & 61.2905 & 10 & 72 & Granto Serra de Providencia \\
\hline PV92 & $\mathrm{K}-\mathrm{Ar}$ & POMBAL-2 & 5020 & Granito & Bjotita & Embasamento & $-10,5476$ & - & 5.3005 & 10 & 45,78 & Rio Jamari \\
\hline PV93 & K-Ar & RF-2 & $\operatorname{sc} 20$ & Granito & Biofita & Embasamento & $-10,4706$ & - & 63.3000 & 10 & 45,78 & Rio Jamari \\
\hline PV94 & K-Ar & $R F-3$ & $\operatorname{sc} 20$ & Granito & Biotita & Embasamento & $-8,6190$ & - & 63.3005 & 10 & 45,78 & E Porto Velho \\
\hline PV 95 & K.Ar & MA-30 & $5 \mathrm{SC} 20$ & Granito & Biotita & Cpx Massangana & -9.8614 & - & 63.7261 & 30 & 45,69 & Rio Candeias \\
\hline PV96 & $\mathrm{K}-\mathrm{Ar}$ & MA-48 & $5 \mathrm{SC} 20$ & Granito & Biodita & Cpx Massangana & $-9,8445$ & - & 64.8023 & 30 & 45,69 & N Mutum Rio Pará \\
\hline PV 97.1 & $\mathrm{~K} \cdot \mathrm{Ar}$ & $M A-32$ & $\operatorname{sen} 20$ & Granilo & Biotita & Cpx Massangana & -9.9531 & $\sim$ & 63.7313 & 10 & 45 & Rio Candeias \\
\hline PV97.2 & $\mathrm{Rb}-\mathrm{Sr}$ & MA-32 & 5020 & Grantto & Rocha total & Cpx Massangana & - 9,9531 & - & 63.7313 & 10 & 16 & Rio Candeias \\
\hline RB 1 & K-Ar & REst-1-AC & Sc 19 & Xisto & Rocha total & Embasamento & 9,3008 & - & 71.0033 & 10 & $16, \infty$ & Rio Envira \\
\hline RB 10 & $\mathrm{Rb}-\mathrm{Sr}$ & PT 15D & Sc 19 & Granito & Rocha total & Embasamento & $-\quad 8,5847$ & - & 66.0057 & 10 & 60 & W Rio Siriquiqui \\
\hline RB 11 & $\mathrm{Rb}-\mathrm{Sr}$ & IT/MR $/ 6(29)$ & $\operatorname{sc~} 19$ & Gnaisse & Rocha total & Embasamento & -8.9913 & - & 66.3589 & 10 & $\infty$ & Rio Aiquiri \\
\hline $\mathrm{RB} 12$ & $\mathrm{Rb}-\mathrm{St}$ & PT 15E2 & SC 19 & Granito & Rocha total & Embasamento & $-8,6075$ & - & 66.2542 & 10 & 60 & W Rio Siriquiqui \\
\hline
\end{tabular}




\begin{tabular}{|c|c|c|c|c|c|c|c|c|c|c|c|c|}
\hline Ordem & Método & $N^{\circ}$. Campo & Folha & Lltologia & Materlal Anallsado & Unidade Geológica & Latltude & & Longltude & $\begin{array}{l}\text { Prec } \\
(\mathbf{K m}) \\
\end{array}$ & Ref & Referência Geográfica \\
\hline RB 13 & $\mathrm{Rb}-\mathrm{Sr}$ & PT 10 & SC 19 & Gnaisse & Rocha total & Embasamento & $-9,3816$ & - & 66.1235 & 10 & 60 & E Rio Acre \\
\hline $\mathrm{RB} 14$ & $\mathrm{Rb}-\mathrm{Sr}$ & ITAR/103(43) & SC 19 & Gnaisse & Rocha total & Embasamento & $-8,8760$ & - & 66.1948 & 10 & 60 & Rio Aqquiri \\
\hline RB 15 & $\mathrm{Rb}-\mathrm{Sr}$ & EN/MR/108(47) & Sc 19 & Gnaisse & Rocha total & Embasamento & $-8,8120$ & - & 66.1213 & 10 & 50 & Rio Endimari \\
\hline $\mathrm{RB} 16$ & K-Ar & ENMR 123(21) & SC 19 & Gnaisse & Biotita & Embasamento & $-8,9189$ & - & 66.635 & 10 & 60 & Rio Endimari \\
\hline RB 17 & K-Ar & ITMRB1(16) & sc 19 & Xisto & Biotita & Embasamento & $-9,2741$ & - & 66.5614 & 10 & 60 & Rio Aiquiri \\
\hline$R B 18$ & K-Ar & ENMR 110(39) & SC 19 & Gnaisse & Biotita & Embasamento & $-8,8111$ & - & 66.201 & 10 & 60 & Rio Endimari \\
\hline$R B 19$ & $\mathrm{~K}-\mathrm{Ar}$ & ITMR/B5(20) & Sc 19 & Xisto & Muscovita & Embasamento & $-9,3375$ & - & 66.6401 & 10 & 60 & Rio Aiquiri \\
\hline RB 2.1 & Rb-St & PT 14F2 & SC 19 & Granulito & Rocha total & Embasamento & $-8,5506$ & - & 66.2392 & 10 & $\infty$ & W Rio Siriquiqui \\
\hline $\mathrm{RB} 2.2$ & $\mathrm{Rb}-\mathrm{Sr}$ & PT 1453 & SC 19 & Gnaisse & Rocha total & Embasamento & $-8,5506$ & - & 66.2392 & 10 & 60 & W Rio Siriquiqui \\
\hline RB 2.3 & $\mathrm{Rb}-\mathrm{Sr}$ & PT 15/2 & SC 19 & Granito & Rocha total & Embasamento & - 8,5506 & - & 66.2392 & 10 & 60 & W Rio Siriquiqui \\
\hline RB 2.4 & Sm-Nd & PT 14F-2 & SC 19 & Granulito & Rocha total & Embasamento & 8,5506 & - & 66.2392 & 30 & 79 & W Rio Siriquiqui \\
\hline $\mathrm{RB} 2.5$ & $\mathrm{Sm}-\mathrm{Nd}$ & PT 14F-3 & Sc 19 & Trondhjemito & Rocha fotal & Embasamento & $-8,5506$ & - & 66.2392 & 30 & 79 & W Rio Siriquiqui \\
\hline RB 20 & K-Ar & ITMR/B $(18)$ & $\operatorname{sc~} 19$ & Gnaisse & Biotita & Embasamento & $-9,3158$ & - & 66.6026 & 10 & 60 & Rio Alquiri \\
\hline RB 21 & Sm-Nd & PT 143 INT & $\operatorname{sc} 19$ & Granulito & Rocha total & Embasamento & $-9,75$ & - & 66.8333 & 10 & 79 & Região Rio Abună \\
\hline RB 4.1 & $\mathrm{Rb}-\mathrm{Sr}$ & PT 15F & SC 19 & Granulito & Rocha total & Embasamento & $-8,6331$ & - & 66.2738 & 10 & 60 & W Rio Siriquiqui \\
\hline RB 4.2 & Sm-Nd & PT 15F & $\operatorname{sc~} 19$ & Granulito & Rocha total & Embasamento & $-8,6331$ & - & 66.2738 & 30 & 79 & W Rio Siriquiqui \\
\hline RB 4.2 & Sm-Nd & PT 15F & SC 19 & Granulito & Rocha total & Embasamento & $-8,6331$ & $\div$ & 66.2738 & 10 & 80 & W Sriquiquil River \\
\hline RB 5 & $\mathrm{Rb}-\mathrm{Sr}$ & PT 14A & SC 19 & Gnaisse & Rocha total & Embasamento & $-8,3519$ & - & 66.1315 & 10 & $\infty$ & W Rio Siriquiqui \\
\hline RB 6 & $\mathrm{Rb}-\mathrm{Sr}$ & PT 141 & $\operatorname{sc} 19$ & Gnaisse & Rocha total & Embasamento & $-8,4593$ & - & 66.1977 & 10 & 60 & W Rio Siriquiqui \\
\hline $\mathrm{RB} 7$ & $\mathrm{Rb} S \mathrm{Sr}$ & PT 14D & SC 19 & Gnaisse & Rocha total & Embasamento & $-8,3909$ & - & 66.1302 & 10 & 60 & W Rio Siriquiqui \\
\hline RB 8 & $\mathrm{Rb}-\mathrm{Sr}$ & ITMR $\sqrt{72}(41)$ & $\operatorname{sc} 19$ & Gnaisse & Rocha total & Embasamento & 8,9298 & - & 66.1952 & 10 & 60 & Rio Aiquiri \\
\hline RR 1 & K-Ar & $\mathrm{PT} 292 \bar{B}$ & $\mathrm{NB} 20$ & Gnaisse & Biotita & Embasamento & +2.9667 & 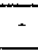 & 63.7167 & 10 & 15 & E Rio Parima \\
\hline RR 10 & $\mathrm{Rb}-\mathrm{Sr}$ & $M 88$ & $\mathrm{NB} 20$ & Homblendito & Rocha total & Embasamento & $+2,0167$ & - & 61.25 & 10 & 15 & Regiáo Rio Branco \\
\hline RR 100.1 & $\mathrm{Rb}-\mathrm{Sr}$ & PL-R5 & $\mathrm{NB} 2 \mathrm{O}$ & Granulito & Rocha total & Embasamento & $+2,6667$ & - & 61.8333 & 30 & 79.80 & SW Rio Negro \\
\hline RR 100.2 & $\mathrm{Rb}-\mathrm{Sr}$ & PL-R18 & $\mathrm{NB} 20$ & Granulito & Rocha total & Embasamento & $+2,6667$ & - & 61.8333 & 30 & 79,80 & SW Rio Negro \\
\hline $\operatorname{RR} 100.3$ & $\mathrm{Sm}-\mathrm{Nd}$ & PL-R5 & NB 20 & Granulito & Rocha total & Embasamento & $+2,6667$ & - & 61.8333 & 30 & 79 & SW Rio Negro \\
\hline RR 100.4 & $\mathrm{Sm}-\mathrm{Nd}$ & PL-R18 & $\mathrm{NB} 20$ & Granulito & Rocha total & Embasamento & $+2,6667$ & $\because$ & 61.8333 & 30 & 79 & SW Rio Negro \\
\hline RR 11 & $\mathrm{Rb}-\mathrm{Sr}$ & 305 A-MI 41.1 & NB 20 & Gnaisse & Rocha total & Embasamento & $+2,0167$ & - & 63.4333 & 10 & 15 & N Rio Demeni \\
\hline RR 12.1 & $\mathrm{Rb}-\mathrm{Sr}$ & $M 86$ & NB 20 & Granulito & Rocha total & Embasamento & $+1,9833$ & $\therefore$ & 61.15 & 10 & 15 & Regiáo Rio Branco \\
\hline RR 12.2 & $\mathrm{Sm}-\mathrm{Nd}$ & $M 68$ & NB 20 & Granulito & Rocha total & Embasamento & $+1,9833$ & - & 61.15 & 30 & 79 & Região Rio Branco \\
\hline RR 13 & K-Ar & PT 210A & NB 20 & Anfibolito & Rocha total & Embasamento & $+1,9667$ & - & 0.3833 & 10 & 15 & Serra Anauá \\
\hline $\mathrm{RR} 14$ & $\mathrm{Rb}-\mathrm{Sr}$ & $276 \mathrm{~B}$ & NB 2 & Gnaisse & Rocha total & Embasamento & $+1,8833$ & - & 62.0333 & 10 & 15 & S Serra do Mucajal \\
\hline RR 15 & $\bar{K}-\overline{A r}$ & PNJF 04 & NB 20 & Gabro & Plagioclásio & Embasamento & $+1,8833$ & - & 61.2333 & 10 & 15 & Regiso Rio Branco \\
\hline
\end{tabular}




\begin{tabular}{|c|c|c|c|c|c|c|c|c|c|c|c|c|}
\hline Ordem & Método & $\mathrm{N}^{\circ}$. Campo & Folha & Lttologia & Material Anallsado & Unidade Geológlca & Latitude & & Longifude & $\begin{array}{l}\text { Prec } \\
(\mathrm{Km})\end{array}$ & Ref & Referência Geográfica \\
\hline RR 16 & $\mathrm{Rb}-\mathrm{Sr}$ & $326 \mathrm{E}$ & $\mathrm{NB} 20$ & Charnoquito & Rocha total & Embasamento & $+1,5500$ & - & 63.4833 & 10 & 15 & N Rio Demeni \\
\hline RR 17 & $\mathrm{Rb}-\mathrm{Sr}$ & SE 3PTO2 & $\mathrm{NB} 20$ & Granodiorito & Rocha total & Embasamento & $+3,5667$ & - & 63.8167 & 10 & 15 & SE Rio Urariquera \\
\hline RR 18 & $\mathrm{Rb}-\mathrm{Sr}$ & 367 & $\mathrm{NB} 20$ & Aplito & Rocha total & Embasamento & +0.4500 & - & 64.6 & 10 & 15 & SW Posto Aliança \\
\hline RR 19.1 & $\mathrm{Rb}-\mathrm{Sr}$ & $363 \mathrm{~A}$ & NB 20 & Gnaisse & Rocha total & Embasamento & +0.4333 & $\because$ & 65.5 & 10 & 15 & N Rio Negro \\
\hline RR 19.2 & $\mathrm{Rb}-\mathrm{Sr}$ & $363 \mathrm{~A} .1$ & NB 20 & Gnaisse & Rocha total & Embasamento & $+0,4333$ & + & 65.5 & 10 & 35 & N Rio Negro \\
\hline$R R 2$ & $\mathrm{Rb}-\mathrm{Sr}$ & BE-1 & NB 20 & Adamelifo & Rocha total & Embasamento & $+2,9000$ & - & 63.75 & 10 & 15 & E Rio Parima \\
\hline RR 20 & $\mathrm{~K}-\mathrm{Ar}$ & PT $294 \mathrm{C}$ & $\mathrm{NB} 20$ & Anfibolito & Anfibolio & Embasamento & $+2,7667$ & - & 63.25 & 10 & 15 & Rio Mucajaí \\
\hline RR 21.1 & $\mathrm{U}-\mathrm{Pb}$ & WO-14 5MT & $\mathrm{NB} 20$ & Conglomerado & Zirço & Grupo Roraima & $+4,5833$ & - & 60.3833 & 10 & 18 & E Rio Cotingo \\
\hline RR 21.2 & U-Pb & WO-14 IMT & NB 20 & Conglomerado & Zircaso & Grupo Roraima & $+4,5833$ & - & 60.3833 & 10 & 18 & E Rio Cotingo \\
\hline RR 21.3 & $\mathrm{U}-\mathrm{Pb}$ & WO-14 OMT & NB 20 & Conglomerado & Zircăo & Grupo Roraima & $+4,5833$ & - & 60.3833 & 10 & 18 & E Rio Cotingo \\
\hline$R R 21.4$ & U-PB & WO-14 ONMT & $\mathrm{NB} 20$ & Conglomerado & Zircaro & Grupo Roraima & $+4,5833$ & - & 60.3833 & 10 & 18 & E Rio Cotingo \\
\hline RR 22.1 & U-Pb & WO-23 2MT & $\mathrm{NB} 20$ & Gnaisse & Zircáo & Gnaisse Taiano & $+3,2833$ & 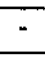 & 61.25 & 10 & 18 & S Rio Urariquera \\
\hline RR 22.2 & U-PB & WO-23 IMT & $\mathrm{NB} 20$ & Gnaisse & Zircăo & Gnaisse Taiano & +3.2833 & $\therefore$ & 61.25 & 10 & 18 & S Rio Urariquera \\
\hline $\operatorname{RR22.3}$ & $\mathrm{U}-\mathrm{Pb}$ & WO-23 OMT & $N B 20$ & Gnaisse & Zircáa & Gnaisse Taiano & +3.2833 & - & 61.25 & 10 & 18 & S Rio Urariquera \\
\hline RR 22.4 & $\mathrm{U}-\mathrm{Pb}$ & WO-23 ONMT & NB 20 & Gnaisse & Zircâo & Gnaisse Taiano & +3.2833 & - & 61.25 & 10 & 18 & S Rio Urariquera \\
\hline RR 23.1 & U-Pb & WO-2C 5M & $\mathrm{NB} 20$ & Sedimento de rio & Zircăo & Secimentos do Rio Apiau & $+2,7000$ & - & 61.5 & 10 & 18 & S Rio Mucajal \\
\hline$R R 23.2$ & $\mathrm{U}-\mathrm{Pb}$ & WO-2C $4 M$ & $\mathrm{NB} 2 \mathrm{O}$ & Sedimento de rio & Zirço & Sectimertos do Rio Apiau & $+2,7000$ & $\because$ & 61.05 & 10 & 18 & S Rio Mucajal \\
\hline RR 23.3 & $\mathrm{U}-\mathrm{Pb}$ & WO-2C OM & $\mathrm{NB} 20$ & Sedimento de rio & Zircáo & Sectmertos do Rio Apiaú & $+2,7000$ & - & 61.5 & 10 & 18 & S Rio Mucajal \\
\hline RR 23.4 & $\mathrm{U}-\mathrm{Pb}$ & WO-2C-2M & $\mathrm{NB} 20$ & Sedimento de rio & Zircăo & Sectimertos do Rib Apdai & $+2,7000$ & - & 61.65 & 10 & 18 & S Rio Mucajal \\
\hline RR 24.1 & U-Pb & WO-3 2MT & $\mathrm{NB} 20$ & Gnaisse & Zircăo & Gnaisse Apiaú & $+2,6667$ & - & 61.75 & 10 & 18 & S Rio Mucajal \\
\hline$R R 24.2$ & $\mathrm{U}-\mathrm{Pb}$ & WO-3 IMT & $\mathrm{NB} 20$ & Gnaisse & Zircão & Gnaisse Apiaú & $+2,6667$ & - & 61.75 & 10 & 18 & S Rio Mucajaí \\
\hline $\operatorname{RR~} 24.3$ & $\mathrm{U}-\mathrm{Pb}$ & WO-3 OMT & NB 20 & Gnaisse & Zircăo & Gnaisse Apiaú & $+2,6667$ & - & 61.75 & 10 & 18 & S Rio Mucajal \\
\hline RR 24.4 & $\mathrm{U}-\mathrm{Pb}$ & WO 3 ONMT & $\mathrm{NB} 20$ & Gnaisse & Zircáo & Gnaisse Apiaú & $+2,6667$ & - & 61.75 & 10 & 18 & S Rio Mucajal \\
\hline RR 25.1 & U-Pb & $\mathrm{JO}-1 \quad \mathrm{MT}$ & NB 2O & Gnaisse & Zircăo & Cpx Kanuku & $+2,4667$ & - & 60.3333 & 10 & 18 & E Regižo Rio Branco \\
\hline$R R 25.2$ & $\mathrm{U}-\mathrm{Pb}$ & $\mathrm{JO}-1 \mathrm{OM}+$ & $\mathrm{NB} 20$ & Gnaisse & Zircáo & Cpx Kanuku & $+2,4667$ & - & 60.3333 & 10 & 18 & E Regiăo Rio Branco \\
\hline $\operatorname{RR~} 25.3$ & $\mathrm{U}-\mathrm{Pb}$ & $10-10 M$ & $\mathrm{NB} 20$ & Gnaisse & Zircaro & Cpx Kanuku & +2.4667 & - & 60.3333 & 10 & 18 & E Regiäo Rio Branco \\
\hline RR 25.4 & $\mathrm{~L}-\overline{\mathrm{Pb}}$ & JO-1 -1MT & $\mathrm{NB} 20$ & Gnaisse & Zircăo & Cpx Kanuku & $+2,4667$ & - & 60.3333 & 10 & 18 & E Regiáo Rio Branco \\
\hline RR 26.1 & $R b-S r$ & $F F-18$ & $\mathrm{NB} 20$ & Granulito & Rocha total & Cpx Kanuku & $+2,5500$ & - & 61.6495 & 10 & 18 & Serra do Mucaial \\
\hline $\mathrm{RR} 26.2$ & $\mathrm{Sm}-\mathrm{Nd}$ & $F F-18$ & NB 20 & Granulito & Rocha total & Cpx Kanuku & $+2,5500$ & - & 61.95 & 10 & 18 & Serra do Mucaja! \\
\hline RR 27.1 & $\mathrm{Rb}-\mathrm{Sr}$ & RB-24 & $N B 20$ & Granulito & Rocha total & Cpx Kanuku & $+2,0500$ & - & 61.3667 & 10 & 18 & W Regiáo Rio Branco \\
\hline RR 27.2 & $\mathrm{Sm}-\mathrm{Nd}$ & RB-24 & NB 20 & Granulito & Rocha total & Cpx Kanuku & $+2,0500$ & - & 61.3667 & 10 & 18 & W Região Rio Branco \\
\hline $\mathrm{RR} 28.1$ & $\mathrm{Rb}-\overline{\mathrm{Sr}}$ & $\mathrm{PL}-24$ & $\mathrm{NB} 20$ & Granulito & Rocha total & Cpx Kanuku & $+2,3500$ & - & 62.1667 & 10 & 18 & Serra do Mucajal \\
\hline$R R 28.2$ & $\mathrm{Sm}-\mathrm{Nd}$ & PL-24 & $N B 20$ & Granulito & Rocha total & Cpx Kanuku & $+2,3500$ & - & 62.1667 & 10 & 18 & Serra do Mucajal \\
\hline
\end{tabular}




\begin{tabular}{|c|c|c|c|c|c|c|c|c|c|c|c|c|}
\hline Ordem & Método & $N^{\circ}$. Campo & Folha & Litologia & Materlal Analisado & Unidade Geológica & Latitude & & Longitude & $\begin{array}{l}\text { Prec } \\
(\mathrm{Km})\end{array}$ & Ref & Referêncla Geográfica \\
\hline RR 29.1 & $R b-S r$ & $M P-39$ & NB 20 & Granulito & Rocha total & Cpx Kanuku & $+2,0500$ & - & 61.3667 & 10 & 18 & W Regiáo Rio Branco \\
\hline RR 29.2 & Sm-Nd & $M P-39$ & NB 20 & Granulito & Rocha total & Cpx Kanuku & $+2,0500$ & - & 62.3667 & 10 & 18 & W Regiá Rio Branco \\
\hline RR 3.1 & $\mathrm{K}-\mathrm{Ar}$ & PT 253 MI 28 & NB 20 & Gnaisse & Biotita & Embasamento & $+2,7833$ & - & 62.05 & 10 & 15 & Rio Mucajal \\
\hline RR 3.2 & $K-\bar{A} r$ & PT 253 MI 28.1 & $\mathrm{NB} 20$ & Anfibolito & Biotita & Embasamento & $+2,7833$ & - & 62.05 & 10 & 15 & Rio Mucajal \\
\hline RR 30.1 & $\mathrm{Rb}-\mathrm{Sr}$ & MP-27 & NB 20 & Granulito & Rocha fotal & Cpx Kanuku & $+2,2167$ & - & 61.9667 & 10 & 18 & Serra do Mucajal \\
\hline RR 30.2 & Sm-Nd & MP-27 & $\mathrm{NB} 2 \mathrm{O}$ & Granulito & Rocha total & Cpx Kanuku & $+2,2167$ & 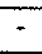 & 61.9667 & 10 & 18 & Serra do Mucajal \\
\hline RR 31.1 & $\mathrm{U}-\mathrm{Pb}$ & WO-10 3MT & NB 20 & Chamoquito & Zircaso & Embasamento & $+2,0500$ & - & 61.8333 & 10 & 18 & W Regiao Rio Branco \\
\hline RR 31.2 & U.Pb & WO-10 2MT & $\mathrm{NB} 2 \mathrm{O}$ & Chamoquito & Zircăo & Embasamento & $+2,0500$ & - & 61.8333 & 10 & 18 & W Regiáo Rio Branco \\
\hline $\operatorname{RR} 31.3$ & $\mathrm{U}-\mathrm{Pb}$ & WO-10 $1 M$ & NB 20 & Chamoquito & Zircăo & Embasamento & $+2,0500$ & - & 61.8333 & 10 & 18 & W Regiao Rio Branco \\
\hline $\operatorname{RR} 31.4$ & $\mathrm{U}-\mathrm{Pb}$ & WO-10 INMT & $\mathrm{NB} 20$ & Chamoquito & Zircra & Embasamento & $+2,0500$ & 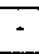 & 61.8333 & 10 & 18 & W Regiáa Rio Branco \\
\hline$R R 32.1$ & $\mathrm{U}-\mathrm{Pb}$ & WO-8 5MT & NB 20 & Gnaisse & Zircxo & Embasamento & $+2,1000$ & - & 61.6333 & 10 & 18 & W Regiăo Rio Branco \\
\hline $\operatorname{RR} 32.2$ & U-Pb & WO-8 $2 \mathrm{MT}$ & NB 20 & Gnaisse & Zircăo & Embasamento & $+2,1000$ & - & 61.6333 & 10 & 18 & W Regiǎa Rio Branco \\
\hline $\operatorname{RR} 32.3$ & $\mathrm{U}-\mathrm{Pb}$ & WO-8 1M & $N B 20$ & Gnaisse & Zircáo & Embasamento & $+2,1000$ & - & 61.6333 & 10 & 18 & W Regiăo Rio Branco \\
\hline RR 32.4 & $\mathrm{U}-\mathrm{Pb}$ & WO-8 ONMT & NB 20 & Gnaisse & Zircăo & Embasamento & $+2,1000$ & - & 61.6333 & 10 & 18 & W Regiáo Rio Branco \\
\hline RR 33.1 & U-Pb & WO-7 3MT & NB 20 & Cham. Gnaisse & Zircăo & Embasamento & $\pm 2,0500$ & - & 61.5167 & 10 & 18 & W Regiăo Rio Branco \\
\hline RR 33.2 & $\mathrm{D}-\mathrm{Pb}$ & WO-7 1MT & $\mathrm{NB} 20$ & Charn. Gnaisse & Zircáa & Embasamento & $+2,0500$ & - & 61.5167 & 10 & 18 & W Regiáo Rio Branco \\
\hline $\operatorname{RR} 33.3$ & U-Pb & WO-7 OMT & NB 20 & Charn. Gnaisse & Zircáo & Embasamento & $+2,0500$ & - & 61.5167 & 10 & 18 & W Regiáo Rio Branco \\
\hline RR 33.4 & $\mathrm{U}-\mathrm{Pb}$ & WO-7 ONMT & NB 20 & Cham. Gnaisse & Zircăo & Embasamento & $+2,0500$ & - & 61.5167 & 10 & 18 & W Regiăo Rio Branco \\
\hline RR 34 & $\mathrm{Rb}-\mathrm{Sr}$ & SE 10PT 01A & NB 20 & Gabro & Rocha total & Embasamento & $+3,5833$ & - & 63.9167 & 10 & 15 & N Rio Urariquera \\
\hline$R R 35$ & $\mathrm{Rb}-\mathrm{Sr}$ & SE 22 PTO2 & NB 20 & Granito & Rocha total & Embasamento & $+3,5000$ & - & 63.8667 & 10 & 15 & N Rio Urariquera \\
\hline RR 36 & $\mathrm{Rb}-\mathrm{Sr}$ & FB-OO & NB 20 & Granulito & Rocha total & Cpx Apiaú & +2.4500 & 2 & 61.1833 & 10 & 21 & SW Boa Vista \\
\hline RR 37.1 & $\mathrm{Rb}-\mathrm{Sr}$ & PL-36 & $\mathrm{NB} 20$ & Granulito & Rocha total & Cpx Apiaú & $+1,2833$ & - & 60.4833 & 10 & 21 & Rio Anauá \\
\hline RR 37.2 & K-Ar & PL-36 & $\mathrm{NB} 20$ & Granulito & Biotita & Cpx Apiaú & $+1,2833$ & - & 60.4833 & 10 & 21 & Rio Anauá \\
\hline $\operatorname{RR} 38.1$ & $\mathrm{Rb}-\mathrm{Sr}$ & ES-18 & NB 20 & Granulito & Rocha total & Cpx Apiaú & $+2,0333$ & - & 61.15 & 10 & 21 & Regiăo Rio Branco \\
\hline RR 38.2 & K-Ar & ES-18 & $\mathrm{NB} 20$ & Granulito & Biotita & Cpx Apiaú & $+2,0333$ & - & 61.15 & 10 & 21 & Regiazo Rio Branco \\
\hline $\mathrm{RR} 39$ & Rb-Sr & PL.DS & NB 20 & Granulito & Rocha total & Cpx Apiaú & $+1,9833$ & - & 61.3833 & 10 & 21 & W Região Rio Branco \\
\hline RR 4 & $\overline{R b-S r}$ & $265 \bar{B}$ & NB 20 & Gnaisse & Rocha total & Embasamento & $+2,4500$ & $\because$ & 62.3333 & 10 & 15 & S Rio Mucajai \\
\hline $\operatorname{RR} 40$ & $\mathrm{Rb}-\mathrm{Sr}$ & PL-02 & $\mathrm{NB} 20$ & Piriclas & Rocha total & Cpx Apiaú & $+1,9667$ & - & 61.3167 & 10 & 21 & W Regiáo Rio Branco \\
\hline RR 41 & $\mathrm{~K}-\mathrm{Ar}$ & $50-100$ & NB 20 & & Biotita & Cpx Apiaú & $+1,9333$ & - & 61.1 & 10 & 21 & E Região Rio Branco \\
\hline RR 42 & $R b-S r$ & PL-24 & NB 20 & Granulito & Rocha total & Cpx Apiaú & $+0,9167$ & - & 61.0033 & 10 & 21 & Rio Anauś \\
\hline RR 43 & $\mathrm{Rb}-\mathrm{Sr}$ & PT 297 & NB 20 & Granito & Rocha total & Granito Surucucu & $+2,6333$ & 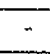 & 64.0667 & 10 & 15 & Fronteira Brasit-Venezuela \\
\hline RR 44 & $\mathrm{Rb}-\mathrm{Sr}$ & JMR 110 & NB 20 & Riolito & Rocha total & Vulcánicas Surumu & $+4,5667$ & - & 60.55 & 10 & 12,13 & N Boa Vista \\
\hline RR 45 & $\mathrm{Rb}-\mathrm{Sr}$ & MM 76 & $\mathrm{NB} 20$ & Riolito & Rocha total & Vulcánicas Surumu & $+4,4167$ & - & 61.0667 & 10 & 12,13 & N Boa Vista \\
\hline
\end{tabular}




\begin{tabular}{|c|c|c|c|c|c|c|c|c|c|c|c|c|}
\hline Ordem & Método & $N^{\circ}$. Campo & Folha & Lltologla & Materlal Analisado & Unidade Geológica & Latitude & & Longitude & $\begin{array}{l}\text { Prec } \\
\text { (Km) }\end{array}$ & Ref & Referēncła Geográfica \\
\hline $\operatorname{RR} 46$ & $\mathrm{Rb}-\mathrm{Sr}$ & $M 28$ & NB 20 & Dacito & Rocha total & Vulcânicas Surumu & $+4,2167$ & - & 60.9833 & 10 & 12,13 & N Boa Vista \\
\hline $\operatorname{RR} 47$ & $\mathrm{Rb}-\mathrm{Sr}$ & MM 64 & NB 20 & Riodacito & Rocha total & Vulcannicas Surumu & $+4,0667$ & 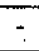 & 60.9167 & 10 & 12,13 & N Boa Vista \\
\hline$R R 48$ & $\mathrm{Rb}-\mathrm{Sr}$ & M 47B & $\mathrm{NB} 20$ & Riolito & Rocha total & Vulcánicas Surumu & $+4,5000$ & - & 61.1333 & 10 & 12,13 & N Boa Vista \\
\hline RR 49 & $\mathrm{Rb}-\mathrm{Sr}$ & $M 73$ & NB 20 & Riolito & Rocha total & Vulcånicas Surumu & $+4,5167$ & - & 50.2 & 10 & 12,13 & N Boa Vista \\
\hline RR 5 & $\mathrm{Rb}-\mathrm{Sr}$ & $M 80$ & NB 20 & Gnaisse & Rocha total & Embasamento & $+2,4333$ & - & 60.95 & 10 & 15 & Regiáo Rio Branco \\
\hline RR 50.1 & $\mathrm{Rb}-\mathrm{Sr}$ & M 54C & $\mathrm{NB} 20$ & Filonito & Rocha total & Vulcânicas Surumu & $+4,5500$ & - & 61.1333 & 10 & 12,13 & N Boa Vista \\
\hline $\mathrm{RR} 50.2$ & K-Ar & M54C & NB 20 & Filonito & Rocha tofal & Vulcånicas Surumu & $+4,5500$ & - & 61.1333 & 10 & 12,13 & N Boa Vista \\
\hline RR 51 & $\mathrm{Rb}-\mathrm{Sr}$ & M 41 & NB 2O & Dacito & Rocha total & Vulcanicas Surumu & $+4,3167$ & - & 61.0333 & 10 & $\{2,13$ & N Boa Vista \\
\hline RR 52 & $\mathrm{Rb}-\mathrm{Sr}$ & RR 72 & NB 20 & Riolito & Rocha total & Vulcánicas Surumu & $+4,1000$ & - & 60.7333 & 10 & $12,13,16$ & N Boa Vista \\
\hline RR 53 & $\mathrm{Rb}-\mathrm{Sr}$ & RR 64 & NB 20 & Riolito & Rocha total & Vulcănicas Surumu & $+4,4343$ & - & 60.6167 & 10 & $12,13,16$ & N Boa Vista \\
\hline $\mathrm{RR} 54$ & $\mathrm{Rb}-\mathrm{Sr}$ & RR 61 & NB 20 & Riolito & Rocha total & Vulcånicas Surumu & $+4,5500$ & - & 60.7167 & 10 & $12,13,16$ & N Boa Vista \\
\hline$R R 55$ & $\mathrm{Rb}-\mathrm{Sr}$ & RR 76 & NB 20 & Riolito & Rocha total & Vulcânicas Surumu & $+4,5353$ & - & 60.9167 & 10 & 12,13 & N Boa Vista \\
\hline$R R 56$ & $\mathrm{~K}-\overline{A r}$ & RR 96 & NB 20 & Riolito & Rocha total & Vulcânicas Surumu & $+4,2500$ & - & 59.7833 & 10 & $12,13,16$ & NE Boa Vista \\
\hline RR 57 & K-Ar & RR 95 & NB 20 & Riolito & Rocha total & Vuicanicas Surumu & $+4,3000$ & - & 50.8 & 10 & $12,13,16$ & NE Boa Vista \\
\hline RR 58 & K-Ar & RR 68 & $N B 20$ & Diabásio & Rocha fotal & Diab Preta Preta & $+4,5167$ & - & 60.5167 & 10 & 14,16 & N Boa Vista \\
\hline RR 59 & K-Ar & RR 67.3 & $\overline{N B} 20$ & Diabásio & Rocha total & Diab Preta Preta & $+4,3500$ & - & 60.5167 & 10 & 14,16 & N Boa Vista \\
\hline RR 6 & $\mathrm{Rb}-\mathrm{Sr}$ & M81 & NB 20 & Gnaisse & Rocha total & Embasamento & $+2,3500$ & - & 61.0167 & 10 & 15 & Regiáo Rio Branco \\
\hline$R \bar{R} \sigma 0$ & K-Ar & $R R 148$ & NB 20 & Gabro & Rocha total & Embasamento & $+4,4500$ & - & 60.85 & 10 & 14,16 & N Boa Vista \\
\hline $\mathrm{RR} 61$ & $\mathrm{~K}-\overline{A r}$ & RR 70.1 & $\mathrm{NB} 2 \mathrm{O}$ & Diabásio & Rocha total & Diab Preta Preta & $+4,7500$ & - & $\infty .15$ & 10 & 14 & NE Boa Vista \\
\hline $\operatorname{RR} \overline{62.1}$ & $\mathrm{Rb}-\mathrm{Sr}$ & MM 96 & NB 20 & Homfels & Rocha total & Diab Preta Preta & $+4,3833$ & - & 60.35 & 10 & 14,15 & N Boa Vista \\
\hline RR 62.2 & $\mathrm{Rb}-\mathrm{Sr}$ & MMSS & NB 20 & Hornfels & Rocha total & Diab Preta Preta & $+4,3833$ & $\because$ & 60.35 & 10 & 14,15 & N Boa Vista \\
\hline RR 62.3 & $\mathrm{Rb}-\mathrm{Sr}$ & MM 34 & $\mathrm{NB} 20$ & Homfels & Rocha total & Diab Preta Preta & $+4,3833$ & - & 60.35 & 10 & 14,15 & N Boa Vista \\
\hline RR 63 & $\bar{R} \mathrm{~b}-\mathrm{Sr}$ & SURU1 & NB 20 & Granito & Rocha total & Granito Surucucu & $+2,8667$ & $\because$ & 63.85 & 10 & 15,17 & N Boa Vista \\
\hline $\mathrm{RR} 64$ & $\mathrm{Rb}-\mathrm{Sr}$ & SURU2 & NB 20 & Granito & Rocha total & Granito Surucucu & $+2,8167$ & - & 63.8167 & 10 & 15,17 & N Boa Vista \\
\hline RR ES & $\mathrm{Rb}-\mathrm{Sr}$ & PTO1A & NB 20 & Granito & Rocha total & Granito Surucucu & $+2,9333$ & - & 64.1833 & 10 & 15,17 & N Boa Vista \\
\hline RR 66 & $R b-S T$ & PT 301 MI 40 & NB 20 & Adamelito & Rocha total & Granito Surucucu & $+2,3667$ & 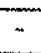 & 536833 & 10 & 15,17 & N Boa Vista \\
\hline RR 67 & K-Ar & PT $292 \mathrm{D}$ & NB 20 & Diabásio & Plagioclásio & Diab Preta Preta & $+2,6667$ & - & 63.5667 & 10 & 14 & N Boa Vista \\
\hline RR 68 & K-Ar & $\mathrm{CUJ-1}$ & $\mathrm{NB} 20$ & Diabásio & Rocha total & Diab Preta Preta & $+3,2000$ & - & 63.7167 & 10 & 14,16 & W Boa Vista \\
\hline $\mathrm{RR} \otimes 9$ & $\mathrm{~K}-\mathrm{Ar}$ & RR 143 & NB 2O & Diabásio & Rocha total & Diab Preta Preta & $+3,5000$ & - & 60.9833 & 10 & 14,16 & N Boa Vista \\
\hline RR 7 & $\mathrm{Rb}-\mathrm{Sr}$ & $203 \mathrm{MI} 4.1$ & NB 20 & Granulito & Rocha total & Embasamento & $+2,3333$ & - & 61.3167 & 10 & 15 & Serra do Mucajaí \\
\hline RR 70 & K-Ar & $\mathrm{RR} 226$ & $\mathrm{NB} 20$ & Diabásio & Rocha total & Diab Preta Preta & $+3,2000$ & - & 61.0167 & 10 & 14 & NW' Boa Vista \\
\hline RR 72.1 & $\mathrm{~K}-\overline{\mathrm{Ar}}$ & NOVA OLINDA (R) & $\mathrm{NB} 20$ & Basalto & Rocha total & Embasamento & $+2,9167$ & - & 60.7333 & 10 & 14,16 & N Boa Vista \\
\hline $\operatorname{RR} 72.2$ & K-AT & NOVA OLINDA & $\mathrm{NB} 2 \mathrm{O}$ & Basalto & Rocha total & Embasamento & $+2,9167$ & $\cdot$ & 60.7333 & 10 & 14,16 & N Boa Vista \\
\hline
\end{tabular}




\begin{tabular}{|c|c|c|c|c|c|c|c|c|c|c|c|c|}
\hline Ordem & Método & $N^{\circ}$. Campo & Folha & Lltologla & Material Anallsado & Unidade Geológlica & Latltude & & Longitude & $\begin{array}{l}\text { Prec } \\
(\mathbf{K m})\end{array}$ & Ref & Referèncla Geográfica \\
\hline RR 74 & K-Ar & RR 202.1 & NB 20 & Basalto & Rocha total & Embasamento & $+3,1667$ & $\because$ & 60.1333 & 10 & 14,16 & NE Boa Vista \\
\hline $\mathrm{RR} 76$ & $\mathrm{~K}-\mathrm{Ar}$ & BV-CARAC & NB 20 & Basalto & Rocha total & Embasamento & $+2,4833$ & - & $\infty 8$ & 10 & 14,16 & S Boa Vista \\
\hline RR 77 & K-Ä $\bar{T}$ & $2-67-34$ & NB 20 & Basalto & Rocha total & Embasamento & $+3,3333$ & - & 60.1833 & 10 & 14 & N Boa Vista \\
\hline $\operatorname{RR} 78$ & $\mathrm{~K}-\mathrm{Ar}$ & RR 221.1 & $\mathrm{NB} 20$ & Basalto & Rocha total & Embasamento & $+2,7500$ & - & 61 & 10 & 14,16 & W Boa Vista \\
\hline $\operatorname{RR} 79$ & $\mathrm{~K}-\mathrm{Ar}$ & RR 223.1 & $\mathrm{NB} 20$ & Basalto & Rocha total & Embasamento & $+2,7167$ & - & 60.9167 & 10 & 14,16 & W Boa Vista \\
\hline RR 8 & K-Ar & PT $303 \mathrm{H}$ & NB 20 & Gnaisse & Piroxênio & Embasamento & $+2,2667$ & - & 63.0667 & 10 & 15 & Serra do Catrimani \\
\hline RR 81 & $\mathrm{~K}-\mathrm{Ar}$ & RR 156 & NB 20 & Basalto & Rocha total & Embasamento & $+4,3167$ & - & 60.1667 & 10 & 14 & N Boa Vista \\
\hline RR 82.1 & $\mathrm{Rb}-\mathrm{Sr}$ & $1156-130$ & $\mathrm{NB} 2 \mathrm{O}$ & Nefelina Sienito & Rocha total & Embasamento & $+0,6500$ & - & 62.0333 & 30 & 14 & Rio Catrimani \\
\hline RR 82.2 & $\mathrm{Rb}-\mathrm{Sr}$ & $1156-130$ & NB 20 & Nefelina Sienito & Rocha total & Embasamento & $+0,6500$ & - & 62.0333 & 30 & 14 & Rio Catrimani \\
\hline $\mathrm{RR} 83$ & $\mathrm{~K}-\mathrm{Ar}$ & RR 78 & NB 2O & Sienito & Rocha total & Embasamento & $+3,9000$ & - & 60.5167 & 30 & 34 & N Boa Vista \\
\hline RR 85 & K-Ar & RR-70 & NB 20 & Granito & Rocha total & Embasamento & $+4,3167$ & - & 60.9333 & 10 & 16 & N Boa Vista \\
\hline RR 86 & K-Ar & RR-10 & NB 20 & Anfibolito & Anfibólio & Embasamento & $+3,2500$ & - & 60.5 & 10 & 16 & N Boa Vista \\
\hline RR 87 & K-Ar & RR-3 & NB 20 & Anfibolito & Rocha total & Embasamento & $+3,4833$ & - & 61.4833 & 10 & 16 & NW Boa Vista \\
\hline RR 88 & K-Ar & RR-4 & NB 20 & Anfibolito & Rocha total & Embasamento & $+3,6333$ & $=$ & 61.3167 & 10 & 16 & NW Boa Vista \\
\hline RR 89 & K-Ar & $R R-2$ & $\mathrm{NB} 20$ & Anfibolito & Rocha total & Embasamento & $+3,0000$ & - & 61.2167 & 10 & 16 & NW Boa Vista \\
\hline $\mathrm{RR} 9$ & $R b-S r$ & $258 \mathrm{~A}-\mathrm{M} / 31$ & NB 20 & Granulito & Rocha total & Embasamento & $+2,2833$ & - & 62.6 & 10 & 15 & Serra do Catrimani \\
\hline RR 90 & $\mathrm{~K}-\mathrm{Ar}$ & RR-15 & $\mathrm{NB} 20$ & Anfibolito & Rocha total & Embasamento & $+3,2333$ & - & 62.45 & 10 & 16 & NW Boa Vista \\
\hline$R R 91$ & $\mathrm{~K}-\mathrm{Ar}$ & $R R-464$ & NB 20 & Diorito & Biotita & Embasamento & $+2,8833$ & - & 53.7167 & 10 & 16 & W Boa Vista \\
\hline$R R 92$ & K-Ar & RR-141 & NB 20 & Anfibolito & Rocha total & Embasamento & $+2,9000$ & - & 60.1 & 10 & 16 & E Boa Vista \\
\hline RR 93 & K-Ar & RR-286 & $\mathrm{NB} 20$ & Granito & Feldspato & Embasamento & $+1,2333$ & - & 60.1333 & 10 & 16 & 5 Boa Vista \\
\hline$R R 95$ & $\mathrm{~K} \cdot \mathrm{Ar}$ & RR-264 & NB 20 & Granito & Biotita & Embasamento & $+0,9833$ & - & 60.4667 & 10 & 16 & S Boa Vista \\
\hline RR 96 & $\mathrm{Rb}-\mathrm{Sr}$ & $M 103$ & NB 20 & Granodiorito & Rocha total & Embasamento & $+4,2500$ & - & 60.95 & 10 & 15 & Surumu river \\
\hline RR 97 & $\mathrm{Rb}-\mathrm{St}$ & MM 61 & $\overline{N B} 20$ & Granito & Rocha total & Embasamento & $+3,9667$ & - & 60.95 & 10 & 15 & N Rio Urariquera \\
\hline$R \overline{98}$ & K-Ar & PT 177 MI 9.1 & NB 20 & Anfibolito & Anfibólio & Embasamento & $+3,0500$ & - & 61.2167 & 10 & 15 & N Rio Utariquera \\
\hline$R R 99$ & K-Ar & $R 273 A$ & NB 20 & Anfibolito & Anfibólio & Embasamento & $+4,1667$ & - & 64.25 & 10 & 15 & Fronteira Brasil-Venezuela \\
\hline$\overline{\mathrm{SA} 1.1}$ & $\mathrm{Rb}-\mathrm{Sr}$ & PT 11B & SA 21 & Granodionito & Rocha total & Embasamento & $-0,2500$ & - & 56.0833 & 10 & 37 & Rio Trombetas \\
\hline SA 1.2 & $\mathrm{~K}-\mathrm{Ar}$ & PT 11B & SA 21 & Granodionto & Biotita & Embasamento & $-0,2500$ & - & 56.6833 & 10 & 37 & Rio Trombetas \\
\hline SA 10 & K-Ar & $11 \bar{A} \bar{E}$ & SA 21 & Riolito & Rocha total & Embasamento & $-0,4333$ & - & 55.0167 & 10 & 37 & Rio Curuá \\
\hline SA 11.1 & $K-A_{I}$ & $W-1$ & SA 21 & Riolito & Rocha total & Grupo Iricoumé & $-1,4000$ & - & 58.45 & 10 & 37 & Rio Jatapu \\
\hline SA 11.2 & $\mathrm{Rb}-\mathrm{SP}$ & W-1 & SA 21 & Riolito & Rocha total & Grupo Iricoumé & $-1,4000$ & - & 58.45 & 10 & 37 & Rio Jatapu \\
\hline$S A 12$ & K-AT & A $21-20$ & SA 21 & Granilo & Rocha total & Embasamento & $-1,1000$ & $\sim$ & 55.0333 & 10 & 37 & W Rio Curuá \\
\hline$\overline{S A} 13$ & K-Ar & $\bar{A} 21-17$ & SA 21 & Granito & Rocha total & Embasamento & $-0,9167$ & 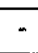 & 54.8833 & 10 & 37 & W Rí Curuá \\
\hline SA 14 & K-Ar & CA 78 & SA 21 & Granito & Rocha total & Embasamento & $-0,9667$ & $\because$ & 54.96 & 10 & 37 & W Rio Curvá \\
\hline
\end{tabular}




\begin{tabular}{|c|c|c|c|c|c|c|c|c|c|c|c|c|}
\hline Ordem & Método & $\mathbf{N}^{\circ}$. Campo & Folha & Litologla & Material Analisado & Unidade Geológica & Latftude & & Longitude & $\begin{array}{l}\text { Prec } \\
\text { (Km) }\end{array}$ & Ref & Referêncla Geográflca \\
\hline SA 15 & K-Ar & A 11-02 & SA 21 & Granito & Rocha total & Embasamento & $-1,8667$ & - & 59.5333 & 10 & 37 & Rio Uatuma \\
\hline SA 16 & K-Ar & $\mathrm{MP}-10$ & $\mathrm{SA} 21$ & Granito & Rocha total & Embasamento & $-0,6667$ & - & 57.85 & 10 & 37 & N Rio Mapuera \\
\hline SA 17 & K-Ar & A 21-16 & $S A 21$ & Granito & Rocha total & Embasamento & $-0,9500$ & - & 56.8167 & 10 & 37 & E Rio Trombetas \\
\hline SA 18 & K-Ar & ER-36 & SA 21 & Granito & Rocha total & Embasamento & $-0,2833$ & - & 56.2 & 10 & 37 & W Rio Paru de Oeste \\
\hline SA $1 \overline{9}$ & $\mathrm{Rb}-\mathrm{Sr}$ & PT 27A & SA 21 & Tufo & Rocha total & Grupo lricoumé & $-1,0457$ & - & 58.4791 & 10 & 37 & Rio Nhamundá \\
\hline $\mathrm{SA} 2$ & $\mathrm{Rb}-\mathrm{Sr}$ & PT 596 & SA 21 & Gnaisse & Rocha total & Embasamento & $-1,2000$ & - & 55.1 & 10 & 37 & Cuminapanema \\
\hline$S A 20$ & $R b-S r$ & PTO4 & SA 21 & Riodacito & Rocha total & Grupo lricoumé & $-0,2667$ & - & 58.0167 & 10 & 37 & Serra do Cachorro \\
\hline SA21 & $\mathrm{Rb}-\mathrm{Sr}$ & PT $\sqrt{3}$ & SA 21 & Andesito & Rocha total & Grupo Iricoumé & $-1,0993$ & - & 58.6007 & 10 & 37 & Rio Jatapu \\
\hline SA 22 & $\mathrm{Rb}-\mathrm{Sr}$ & PT 29A & SA 21 & Dacito & Rocha total & Grupo Iricoumé & $-1,4167$ & - & 58.8333 & 10 & 37 & W Rio Jatapu \\
\hline SA 23 & $\mathrm{Rb}-\mathrm{Sr}$ & PT 14 & SA 21 & Riodacito & Rocha total & Grupo lricoumé & - 0,8333 & - & 57.5667 & 10 & 37 & Rio Mapuera \\
\hline SA 24 & $\mathrm{Rb}-\mathrm{Sr}$ & PT 25 & SA 21 & Riolito & Rocha total & Grupo lricoumé & $-0,0032$ & - & 57.3 & 10 & 37 & Serra do Cachorro \\
\hline$S A \overline{25}$ & $\mathrm{Rb}-\mathrm{Sr}$ & $\mathrm{PT} 20 \mathrm{AO}$ & SA 21 & Riolito & Rocha total & Grupo Iricoumé & $-0,2000$ & - & 57.2333 & 10 & 37 & Serra do Cachorro \\
\hline SA 26 & $\mathrm{Rb}-\mathrm{sr}$ & CAMPT D6A & SA 21 & Riolito & Rocha total & Grupo Iricoumé & $-0,9500$ & - & 56.1333 & 10 & 37 & W Rio Paru de Oeste \\
\hline SA 27 & $\mathrm{Rb}-\mathrm{St}$ & SP 004 & SA 21 & Riolito & Rocha total & Grupo Iricoumé & -0.1167 & - & 56.9 & 10 & 37 & W Rio Trombetas \\
\hline SA 28 & $\mathrm{Rb}-\mathrm{Sr}$ & PT/B2 & SA 21 & Riolito & Rocha total & Grupo licoumé & $-1,9667$ & - & 59.9667 & 10 & 37 & Rio Uatumá \\
\hline$\overline{S A} 29$ & $\mathrm{Rb}-\mathrm{Sr}$ & PT 31 & SA 21 & Riolito & Rocha total & Grupo lricoumé & $-0,1333$ & 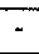 & 50.3 & 10 & 12 & Rio Jatapu \\
\hline $\mathrm{SA} 3$ & $\mathrm{Rb}-\mathrm{Sr}$ & PT 9268 & SA 21 & Granodionto & Rocha total & Embasamento & $-0,8500$ & 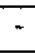 & 54.75 & 10 & 37 & E Rio Curuá \\
\hline SA 30 & $R b-S r$ & PTDBAO & SA 21 & Riolito & Rocha total & Grupo Iricoumé & $-0,7333$ & - & 59.7 & 10 & 37,54 & W Rio Jatapu \\
\hline$S A 31$ & $R b-S r$ & PT.32 & SA 21 & Riodacito & Rocha total & Grupo Iricoumé & -1.0667 & - & 58.7167 & 10 & 37 & Rio Jatapu \\
\hline SA 32 & $\mathrm{Rb}-\mathrm{Sr}$ & PT 10A & SA 21 & Granito & Rocha total & Granito Mapuera & $-0,8333$ & - & 57.7333 & 10 & 37 & Rio Mapuera \\
\hline SA 33 & $\mathrm{Rb}-\mathrm{Sr}$ & CALPTOB & SA 21 & Graniko & Rocha total & Granito Mapuera & $-0,8167$ & - & 56.2 & 10 & 37 & W Rio Paru de Oeste \\
\hline$S A 34$ & $\mathrm{Rb}-\mathrm{St}$ & PT B3 & SA 21 & Granito & Rocha total & Granito Mapuera & $-1,8167$ & - & 59.8333 & 10 & 37 & W Rjo Uatuma \\
\hline SA 35 & $\mathrm{Rb}-\mathrm{Sr}$ & $P T \sqrt{2}$ & SA 21 & Granito & Rocha total & Granito Mapuera & $-1,2500$ & - & 58.5167 & 10 & 37 & Rio Jatapu \\
\hline SA 36 & $R \mathrm{R}-\mathrm{S} \mathrm{r}$ & PT 30 & SA 21 & Adamelito & Rocha total & Granito Mapuera & $-0,2333$ & - & 59.2 & 10 & 37 & Rio Jatapu \\
\hline SA 37 & $\mathrm{Rb}-\mathrm{Sr}$ & PT 13 & $\overline{S A} 21$ & Granófiro & Rocha total & Granito Mapuera & $-0,5833$ & $\because$ & 59.1573 & 10 & 37 & E Rio Jatapu \\
\hline SA 38 & K-AI & PTDO & SA 21 & Monzonito & Feldspato & Grupo Iricoumé & $-0,9333$ & - & 59.6667 & 10 & 37 & W Rio Jatapu \\
\hline$S A B$ & $\mathrm{~K}-\mathrm{Ar}$ & $M 143$ & SA 21 & Diabásio & Plagioclásio & Diab Penatecaua & $-1,9000$ & - & 54.0167 & 10 & 37 & NE Santarém \\
\hline SA 4 & $\mathrm{Rb}-\mathrm{Sr}$ & PTO3 & SA 21 & Granodiorito & Rocha total & Embasamento & $-0,5833$ & - & 55.2 & 10 & 37 & W Rio Curuá \\
\hline $\mathrm{SA} 40$ & $\mathrm{~K}-\mathrm{Ar}$ & $M 114$ & SA 21 & Diabásio & Plagiociásio & Diab Penatecaua & $-1,5833$ & - & 55.0333 & 10 & 37 & Rio Curuá \\
\hline SA 41 & K-AT & PTX & SA 21 & Diabásio & Plagioclásio & Diab Penatecaus & $-1,4167$ & - & 54.65 & 10 & 37 & E Rio Curuá \\
\hline SA 42 & $\mathrm{~K}-\mathrm{Ar}$ & PTOOB & SA 21 & Diabásio & Rocha total & Dique & $-1,4167$ & $\because$ & 56.5333 & 10 & 37 & Rio Trombetas \\
\hline$S A 43$ & K-Ar & AM 7 AM & SA 21 & Diabásio & Rocha total & Dique & $-3,1833$ & $=$ & 59.7333 & 10 & 37 & E Manaus \\
\hline SA 44 & K-Ar & $C A 110$ & SA 21 & Diabásio & Rocha total & Dique & $-0,6833$ & - & 54.8333 & 10 & 37 & E Rio Curuá \\
\hline
\end{tabular}




\begin{tabular}{|c|c|c|c|c|c|c|c|c|c|c|c|c|}
\hline Ordem & Método & $N^{\circ}$. Campo & Folha & Litologia & Material Analisado & Unidade Geológica & Lattlude & & Longitude & $\begin{array}{l}\text { Prec } \\
\text { (Km) }\end{array}$ & Ref & Referèncla Geográfica \\
\hline SA 45 & $\mathrm{~K}-\mathrm{Ar}$ & $\mathrm{PT}-29$ & SA 21 & Diabásio & Plagioclásio & Dique & $-0,6333$ & - & 58.8833 & 10 & 37 & E Rio Jatapu \\
\hline SA 46 & K-Ar & PT $21 \mathrm{~B}$ & SA 21 & Diabásio & Plagioclásio & Dique & $-0,7667$ & $\therefore$ & 58.6 & 10 & 37 & E Rio Jałapu \\
\hline$\widehat{S A ~} 47$ & K-Ar & PT 17 & SA 21 & Diabásio & Plagioclásio & Dique & $-0,4000$ & - & 57.3667 & 10 & 37 & Serra do Cachorro \\
\hline SA 48 & $\mathrm{~K}-\mathrm{A} \mathrm{r}$ & $\mathrm{PT}-18$ & SA 21 & Diabásio & Plagioclásio & Dique & $-0,7167$ & - & 58.9667 & 10 & 37 & E Rio Jatapu \\
\hline $\mathrm{SA} 49$ & $\mathrm{~K}-\mathrm{Ar}$ & PT- 7 & SA 21 & Diabásio & Rocha total & Dique & $-0,9000$ & 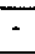 & 58.6833 & 10 & 37 & E Rio Jatapu \\
\hline SA5 & $\mathrm{Rb}-\mathrm{Sr}$ & PT OBA & SA 21 & Granodionito & Rocha total & Embasamento & $-1,0500$ & - & 55.0333 & 10 & 37 & W Rio Curuá \\
\hline SA 50 & $\mathrm{~K}-\mathrm{Ar}$ & TR 79 & SA 21 & Diabásio & Rocha total & Dique & $-0,8833$ & - & 56.85 & 10 & 37 & Rio Trombetas \\
\hline SA 51 & K-Ar & AN 84C & SA 21 & Diabásio & Plagioclásio & Dique & $-0,3333$ & - & 58.3167 & 10 & 39 & W Rio Jatapu \\
\hline$S A \overline{52}$ & $\mathrm{~K}-\mathrm{Ar}$ & JF 01 & SA 21 & Diabásio & Plagioclásio & Dique & $-1,7667$ & - & 59.5833 & 10 & 39 & Rio Uatuma \\
\hline SA 53 & $\mathrm{Rb}-\mathrm{Sr}$ & RCM $\infty$ & SA 21 & Nordmarkito & Rocha fotal & Cachorro & $-0,9500$ & - & 55.5 & 10 & 39 & W Rio Cuminapanema \\
\hline SA 54 & K-Ar & A-21-11 & SA 21 & Granito & Anfibólio & Granito Mapuera & $-0,8333$ & - & 54.85 & 10 & 16 & Rio Curuá \\
\hline SA5 & K-Ar & TR-80 & SA 21 & Andesito & Rocha total & Grupo Iricoumé & $-0,7500$ & - & 56.9 & 10 & 16 & W Rio Trombetas \\
\hline SA 57 & K-Ar & MA 1 PA 40 & SA 21 & Basalto & Plagioclásio & Episódio Penatecaua & $-2,3000$ & - & 54.7333 & 10 & 14 & NW Santarém \\
\hline SA 58 & K-Ar & MA 1 PA 35 & SA 21 & Basalto & Rocha total & Episódio Penatecaua & $-2,3000$ & - & 54.7333 & 10 & 14 & NW Santarém \\
\hline SA 59 & $\mathrm{~K}-\dot{A} r$ & MA $1 \overline{P A} 31$ & SA 21 & Basalto & Plagiociásio & Episodio Penatecaua & $-2,3000$ & - & 54.7333 & 10 & 14 & NW Santarém \\
\hline$\overline{S A} 6$ & Rb-Sr & CAPTO2 & SA 21 & Granodionito & Rocha total & Embasamento & $-1,1667$ & - & 56.0667 & 10 & 37 & W Rio Paru de Oeste \\
\hline$S A Q D$ & $\mathrm{~K}-\mathrm{Ar}$ & MA 2 AM & SA 21 & Basalto & Plagioclásio & Episodio Penatecaua & $-2,3333$ & - & 54.3 & 10 & 14 & NE Santarém \\
\hline SA 61 & $\mathrm{~K}-\mathrm{Ar}$ & $A M \mid A M$ & SA 21 & Riolito & Rocha total & Grupo Iricoumé & $-3,3167$ & - & 59.9167 & 10 & 12 & SE Manaus \\
\hline SA 62 & $\mathrm{Rb}-\mathrm{Sr}$ & $A D 230$ & SA 21 & Riolito & Rocha total & Grupo Iricoumé & $-1,1833$ & - & 58.6833 & 10 & 12 & W Rio Jatapu \\
\hline SA 63 & $\mathrm{Rb}-\mathrm{St}$ & MA 35A & SA 21 & Dacito & Rocha total & Grupo Iricoumé & $-0,1333$ & - & 58.15 & 10 & 12 & NW Serra do Cachorro \\
\hline$S A 64$ & $\mathrm{Rb}-\mathrm{Sr}$ & PT 04A & SA 21 & Riodacito & Rocha total & Grupo Iricoumé & $-\quad 0,3167$ & $\dot{*}$ & 58.0667 & 10 & 12 & Serra do Cachorro \\
\hline SA 65 & $\mathrm{Rb}-\mathrm{Sr}$ & MA 6173A & SA 21 & Riolito & Rocha total & Grupo lricoumé & $-0,7667$ & - & 56.9167 & 10 & 12 & W Rio Trombetas \\
\hline SA 66 & $\mathrm{Rb}-\mathrm{Sr}$ & HICR-4-1 & SA 21 & Granito & Rocha total & & $-0,9258$ & - & 54.6824 & 10 & $\mathscr{9 9}$ & W Rio Maecuru \\
\hline SA 67 & $R b-S r$ & HSR-GB-PI & SA 21 & Monzonito & Rocha total & & -1.1552 & 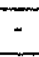 & 56.0557 & 10 & $\oplus$ & Paru Rio de Oeste \\
\hline$S A 6$ & $\mathrm{Rb}-\mathrm{Sr}$ & RCA-50 & SA 21 & Granito & Rocha total & & $-0,6732$ & - & 55.0814 & 10 & $\infty$ & E Rio Curuá \\
\hline SA 69 & $\overline{R b}-\mathrm{Sr}$ & PT-24 & SA 21 & Granito & Rocha total & & $-0,4079$ & - & 57.3022 & 10 & 69 & S Serra do Cachorro \\
\hline SA 7 & $\mathrm{Rb}-\mathrm{Sr}$ & PT 11A & SA 21 & Granito & Rocha total & Embasamento & $-0,3667$ & - & 56.6333 & 10 & 37 & Rio Trombetas \\
\hline$S \overline{S A} 70$ & $\mathrm{Rb}-\mathrm{Sr}$ & $\mathrm{RC}-33$ & SA 21 & Sienito & Rocha total & & $-0,6054$ & - & 55.0082 & 10 & $\infty$ & Rio Curuá \\
\hline SA 71 & $\mathrm{~K}-\mathrm{Ar}$ & RB-38 & SA 21 & Andesitio & Feldspato & & $-0,5746$ & - & 54.9949 & 10 & $\infty$ & E Rio Curuá \\
\hline$S A \overline{72}$ & $\mathrm{Rb}-\mathrm{Sr}$ & $\mathrm{HIC} \overline{\mathrm{R}-1-3}$ & SA 21 & Riolito & Rocha total & & - 0,3969 & - & 54.8746 & 10 & 69 & W Rio Maecuru \\
\hline SA 73 & K-Ar & LR-04 & SA 21 & Vogesito & Rocha total & & $-1,2281$ & - & 55.262 & 10 & 69 & W Rio Curuá \\
\hline SA 74 & $\mathrm{~K}-\mathrm{Ar}$ & LR-10 & SA 21 & Vogesito & Feldspato & & $-1,2548$ & - & 55.2491 & 10 & 69 & W Rio Curuá \\
\hline SA 75 & $\mathrm{~K}-\mathrm{Ar}$ & PT-01 & SA 21 & Basalto & Rocha total & & $-0,3646$ & $\overline{-}$ & 56.9812 & 10 & 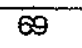 & W Rio Trombetas \\
\hline
\end{tabular}




\begin{tabular}{|c|c|c|c|c|c|c|c|c|c|c|c|c|}
\hline Ordem & Método & $N^{\circ}$. Campo & Folha & Litologla & Material Analisado & Unidade Geológica & Latitude & & Longitude & $\begin{array}{l}\text { Prec } \\
(\mathrm{Km})\end{array}$ & Ref & Referêncla Geográfica \\
\hline SA 76 & K-At & RCA-111 & SA 21 & EPs & Rocha total & & $-0,9573$ & - & 54.8957 & 10 & 69 & Rio Curuá \\
\hline SA 77.1 & $\mathrm{~K}-\mathrm{AT}$ & AT-CM-1 & SA 21 & Piroxenito & Rocha total & & $-1,5446$ & - & 55.8886 & 10 & 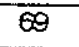 & N Oroximiná \\
\hline SA 77.2 & $\mathrm{~K}-\overline{A r}$ & CM-1-PA & SÄ 21 & Piroxenito & Rocha total & & -1.5446 & - & 55.8886 & 10 & 69 & N Oroximiná \\
\hline SA 77.3 & $\mathrm{~K}-\mathrm{Ar}$ & $A Q-1-A M$ & SA 21 & Diabásio & Rocha total & & $-1,5446$ & - & 55.8886 & 10 & 69 & N Oroximiná \\
\hline$S A 78$ & $\mathrm{~K}-\mathrm{Ar}$ & Q-1-ĀM & SA 21 & Diabásio & Plagioclásio & & $-3,915$ & - & 57.8426 & 10 & 69 & W Rio Maues \\
\hline SA 79 & $\mathrm{~K}-\mathrm{Ar}$ & ATMUL-12 & SA 21 & Diabásio & Plagioclásio & & $-2,0245$ & - & 54.5605 & 10 & 69 & E Alenque \\
\hline SAB & K-Ar & PT $20 A$ & SA 21 & Granodionito & Biotita & Embasamento & $-0,2167$ & - & 54.0167 & 10 & 37 & Rio Paru \\
\hline$S A \overline{B O}$ & $\mathrm{~K}-\mathrm{Ar}$ & AT-161 & SA 21 & Diabásio & Plagioclásio & & $-2,1088$ & - & 54.1338 & 10 & 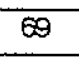 & Rio Amazonas \\
\hline SA9 & $\mathrm{K}-\mathrm{Ar}$ & A $21-22$ & SA 21 & Riolito & Rocha total & Embasamento & $-1,1333$ & - & 55.1833 & 10 & 37 & E Rio Cuminapanema \\
\hline T $47 . \overline{2}$ & $\mathrm{Rb}-\mathrm{Sr}$ & RON-4.B & $\operatorname{sc} 22$ & Riodacito & Rocha total & Fm Iriri & $-10,3833$ & - & 51.3333 & 5 & 45 & S Serra Cubencraquem \\
\hline T1 & K-Ar & GO-495 & $\operatorname{sc} 22$ & Gnaisse & Biotita & Cpx Goiano & $-8,9667$ & $\because$ & 48.5833 & 5 & 45 & SE Conceiçăo Araguaia \\
\hline 110 & K-Ar & $525-A Z-160$ & $\operatorname{sc} 22$ & Granito & Biotita & Cpx Goiano & $-10,3667$ & - & 48.2167 & 5 & 45 & SE Conceiçăo Araguraia \\
\hline$T 11$ & $\mathrm{Rb}-\mathrm{Sr}$ & $\mathrm{CO}-63 \mathrm{~A}$ & Sc 22 & Granito & Rocha total & Cpx Goiano & - 10,3667 & - & 48.2167 & 10 & 45 & SE Conceiçăc Araguaia \\
\hline $\mathrm{T} 12$ & $\mathrm{Rb}-\mathrm{Sr}$ & $C 0.63 B$ & 5022 & Granito & Rocha total & Cpx Goiano & $-10,3667$ & - & 48.2167 & 10 & 45 & SE Conceiçăco Araguaia \\
\hline$T 13$ & $R b-\overline{s r}$ & 00.64 & $5 \mathrm{sc} 22$ & Granito & Rocha lotal & Cpx Goiano & $-10,6667$ & - & 48.8167 & 5 & 45 & SE Conceiçăo Araguaia \\
\hline T14 & Rb-Sr & $100-69$ & $\operatorname{sc} 22$ & Granito & Rocha total & Cpx Golano & $-10,3$ & - & 48.9667 & 5 & 45 & SE Conceiçăo Araguaia \\
\hline T15 & $\mathrm{R} \mathrm{b}-\mathrm{Sr}$ & $C O-6 B A$ & 5022 & Granito & Rocha total & Cpx Goiano & $-10,3167$ & - & 49.9833 & 5 & 45 & SE Conceiçăo Araguaia \\
\hline T16 & $\mathrm{Rb}-\mathrm{Sr}$ & $485-A Z-R M 201$ & Sc 22 & Migmatito & Rocha total & Sute trtusiva Rendençáo & $-8,15$ & - & 50.0333 & 5 & 45 & E Serra Gradaus \\
\hline 117 & $\mathrm{Rb}-\mathrm{Sr}$ & RM-SP-DS & $\operatorname{sc~} 22$ & Gnaisse & Rocha total & Cpx Goiano & $-11,45$ & - & 49.05 & 5 & 45 & N Gurupi \\
\hline T 18 & $\mathrm{Rb}-\mathrm{Sr}$ & GO-BN-413 & Sc 22 & Gnaisse & Rocha total & Cpx Goiano & $-10,9833$ & $\sim$ & 48.5667 & 5 & 45 & SE Cristalandia \\
\hline$\overline{\mathrm{T}} 19$ & $R b-S t$ & GO527 & $\operatorname{sc} 22$ & Gnaisse & Rocha total & Cpx Goiano & - 10,9667 & - & 48.6667 & 5 & 45 & SE Cristalandia \\
\hline $\mathrm{T2}$ & $\mathrm{K}-\mathrm{Ar}$ & GO-PN-419 & Sc 22 & Gnaisse & Biotita & Cpx Goiano & 10,4667 & - & 49.005 & 5 & 45 & SE Conceiçăo Araguaia \\
\hline T 20.1 & Rb-Sr & G0-529-B & $\operatorname{sc} 22$ & Gnaisse & Rocha total & Cpx Goiano & $-10,8333$ & - & 48.8667 & 5 & 45 & SE Cristalandia \\
\hline 120.2 & $\mathrm{Rb}-\mathrm{Sr}$ & G0-529-A & $\mathrm{SC} 22$ & Gnaisse & Rocha total & Cpx Goiano & $-10,8333$ & - & 48.8667 & 5 & 45 & SE Cristalandia \\
\hline T21 & $R b-S r$ & $c 0-66$ & $5 \mathrm{sc} 22$ & Gnaisse & Rocha total & Cpx Goiano & $-10,6167$ & - & 49.0167 & 5 & 45 & E Cristalandia \\
\hline $\mathrm{T} 22.1$ & $\mathrm{Rb}-\mathrm{Sr}$ & PT-DOA & $\operatorname{sc} 22$ & Granito & Rocha total & Embasamento & $-9,75$ & - & 50.65 & 5 & 45 & S Serra inajá \\
\hline$T 22.2$ & Sm-Nd & PT $\triangle A A$ & $\operatorname{sc} 22$ & Granito & Rocha total & Embasamento & $-9,75$ & - & 50.65 & 5 & 79 & S Serra Inajá \\
\hline$T 23$ & Rb-Sr & $476 B C$ PB228 & $\mathrm{sc} 22$ & Granito & Rocha total & Embasamento & 10.6333 & - & 50.9 & 5 & 45 & S Rio Cubencraquem \\
\hline T24 & $\mathrm{Rb}-\mathrm{Sr}$ & RON 18 & $5 \mathrm{sc2}$ & Migmatito & Rocha total & \begin{tabular}{|l|} 
Embasamento \\
\end{tabular} & $-10,1$ & - & 51.1333 & 5 & 45 & SE Serra Cubencraquem \\
\hline T25.1 & $\mathrm{Rb}-\mathrm{Sr}$ & RON $13 C$ & Sc 22 & Migmatito & Rocha total & Embasamento & $-10,35$ & - & 51.25 & 5 & 45 & SE Serra Cubencraquem \\
\hline T25.2 & $\mathrm{K}-\mathrm{Ar}$ & RON 13 & $\operatorname{sc} 22$ & Migmatito & Biotita & Embasamento & $-10,35$ & $\dot{-}$ & 51.25 & 5 & 45 & SE Serra Cubencraquem \\
\hline$T 26.1$ & $R b-S r$ & RON $14 E$ & $\operatorname{sc} 22$ & Migmatito & Rocha total & Embasamento & $-9,8667$ & $\because$ & 51.2 & 5 & 45 & SE Serra Cubencraquem \\
\hline T 26.2 & K-Ar & RON 14 & $5 \mathrm{~s} 22$ & Migmatito & Biotita & Embasamento & $-9,8667$ & - & 51.2 & 5 & 45 & SE Serra Cubencraquem \\
\hline
\end{tabular}




\begin{tabular}{|c|c|c|c|c|c|c|c|c|c|c|c|c|}
\hline Ordem & Método & $N^{\circ}$. Campo & Folha & Litologla & Material Analisado & Unidade Geológica & Latifude & & Longitude & $\begin{array}{l}\text { Prec } \\
(\mathrm{Km})\end{array}$ & Ref & Referência Geográfica \\
\hline T26.3 & K-Ar & RON 14B & Sc 22 & Migmatito & Anfibólio & Embasamento & $-9,8667$ & - & 51.2 & 5 & 45 & SE Serra Cubencraquem \\
\hline T27.1 & $\mathrm{Rb}-\mathrm{Sr}$ & RON 178 & $\operatorname{sc~} 22$ & Migmatito & Rocha total & Embasamento & -10 & - & 51.1667 & 5 & 45 & SE Serra Cubencraquem \\
\hline $\mathrm{T} 27.2$ & K-Ar & RON 17 & $5 \mathrm{~S} 22$ & Migmatito & Biotita & Embasamento & -10 & - & 51.1667 & 5 & 45 & SE Serra Cubencraquem \\
\hline $\mathrm{T} 28$ & $\mathrm{Rb}-\mathrm{Sr}$ & RON 16 & $\operatorname{sc~} 22$ & Granito & Rocha total & Embasamento & $-9,9167$ & - & 51.1833 & 5 & 45 & SE Serta Cubencraquem \\
\hline$T 29.1$ & K-Ar & TS & $\operatorname{sc} 22$ & Pegmatito & Muscovita & Embasamento & $-10,3333$ & - & 50.7667 & 5 & 45 & SE Serra Cubencraquem \\
\hline$T 29.2$ & K-Ar & ST-2 & SC 22 & Gnaisse & Biotita & Embasamento & $-10,3333$ & $\because$ & 50.7667 & 5 & 45 & NW Santa Terezinha \\
\hline T3 & K-Ar & GO-PN-427 & $\operatorname{sc~} 22$ & Gnaisse & Biotita & Cpx Goiano & $-10,05$ & - & 48.7667 & 5 & 45 & SE Conceição Araguaia \\
\hline T30 & K-Âr & IR-214 & $\operatorname{sc~} 22$ & Gnaisse & Biotita & Embasamento & $-8, \sqrt{5}$ & - & 53.35 & 5. & 45 & NW Santa Terezinha \\
\hline T31 & $\mathrm{K}-\mathrm{Ar}$ & $334 \mathrm{E}$ & Sc 22 & Diorito & Rocha total & Embasamento & $-8,3833$ & - & 48.7167 & 5 & 45 & N Rio Iriri \\
\hline T 32 & K-Ar & G0-511 & Sc 22 & Gnaisse & Biotita & Embasamento & $-8,4$ & - & 50.1833 & 5 & 45 & Rio Rio Fresco Region \\
\hline T 33 & K-Ar & $424 \mathrm{BC}-148$ & SC 22 & Granito & Anfibólio & Embasamento & -8.05 & - & 52.6833 & 5 & 45 & SE SerraGradaus \\
\hline T34 & K-Ár & $424-B C-147$ & $\operatorname{sc~} 22$ & Mangerito & Plagiociásio & Embasamento & $-8,05$ & - & 52.75 & 5 & 45 & Rio Xingu \\
\hline$T 35.1$ & $\mathrm{Rb}-\mathrm{Sr}$ & CM- 06 & $\operatorname{sc~} 22$ & Migmatito & Rocha total & Cpx Colméia & $-8,7333$ & 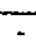 & 48.7167 & 5 & 45 & rio Xingu \\
\hline T 35.2 & $\mathrm{Rb}-\mathrm{Sr}$ & CM-07 & $\operatorname{sc} 22$ & Migmatito & Rocha total & Cpx Colméia & $-8,7333$ & - & 48.7167 & 5 & 45 & Serra do Estrondo \\
\hline T 35.3 & $\mathrm{Rb}-\mathrm{Sr}$ & CM-09 & $\operatorname{sen} 2$ & Migmatito & Rocha total & Cpx Colméia & $-8,7333$ & - & 48.7167 & 5 & 45 & Serra do Estrondo \\
\hline T 35.4 & $\overline{R b}-\mathrm{Sr}$ & HS-CM-2O & $\operatorname{sc} 22$ & Migmatito & Rocha total & Cpx Colméia & $-8,7333$ & - & 48.7167 & 5 & 45 & Serra do Estrondo \\
\hline T 35.5 & $\mathrm{Rb}-\mathrm{Sr}$ & HS-CM-21 & 5022 & Migmatito & Rocha total & Cpx Colméia & $-8,7333$ & - & 48.7167 & 5 & 45 & Serra do Estrondo \\
\hline T35.6 & $\mathrm{Rb}-\mathrm{Sr}$ & HS-CM-22 & SC 22 & Migmatito & Rocha total & Cpx Colméia & $-8,7333$ & 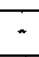 & 48.7167 & 5 & 45 & Serra do Estrondo \\
\hline T36 & Rb-Sr & 485 AZRM164.2 & 5022 & Granito & Rocha total & Cpx Colméia & $-8,6667$ & $\because$ & 48.8 & 5 & 45 & Serra do Estrondo \\
\hline T37 & $\mathrm{Rb}-\mathrm{Sr}$ & $497-B C-38.2$ & $5 \mathrm{SC22}$ & Migmatito & Rocha total & Cpx Colméia & $-8,5333$ & - & 48.8333 & 5 & 45 & Serra do Estrondo \\
\hline T38 & $\mathrm{Rb}-\mathrm{Sr}$ & $497-B C-35$ & Sc 22 & Migmatito & Rocha total & Cpx Colméia & $-8,3833$ & - & 48.7167 & 5 & 45 & Serra do Estrondo \\
\hline T 39 & $\mathrm{Rb}-\mathrm{Sr}$ & 497-BC-37.1 & $\operatorname{sen} 22$ & Migmatito & Rocha total & Cpx Colmeia & -8.45 & 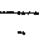 & 48.6833 & 5 & 45 & Serra do Estrondo \\
\hline T4 & K-AT & GO-MN-445 & Sc 22 & Gnaisse & Biotita & Cpx Goiano & $-9,7167$ & - & 48.8333 & 5 & 45 & SE Conceição Araguaia \\
\hline$T 40$ & $\mathrm{Rb}-\mathrm{Sr}$ & $497-B C-21$ & Sc 22 & Migmatito & Rocha total & Cpx Colméia & $-8,5167$ & - & 48.6333 & 5 & 45 & Serra do Estrondo \\
\hline T 41 & $\mathrm{Rb}-\mathrm{Sr}$ & $497-B C-04$ & $\operatorname{sc~} 22$ & Migmatito & Rocha total & Cpx Colméia & $-8,6333$ & $\because$ & 48.6833 & 5 & 45 & Serra do Estrondo \\
\hline$T 42.1$ & $\mathrm{Rb}-\mathrm{Sr}$ & $\mathrm{CO}-67 \mathrm{~B}$ & SC 22 & Xisto & Rocha total & Grupo Estrondo & $-10,35$ & - & 49.0166 & 5 & 45 & W Rio Tocantins \\
\hline $\mathrm{T} 42.2$ & $\mathrm{Rb}-\mathrm{Sr}$ & $C 0-67 A$ & $5 \mathrm{sc2}$ & Xisto & Rocha total & Grupo Estrondo & $-10,35$ & - & 49.0166 & 5 & 45 & W Rio Tocantins \\
\hline T 43.1 & $\mathrm{Rb}-\mathrm{Sr}$ & Co-70 & Sc 22 & Gnaisse & Rocha total & Grupo Estrondo & $-10,2667$ & - & 48.9333 & 5 & 45 & W Rio Tocantins \\
\hline$T 43.2$ & $\mathrm{Rb}-\mathrm{Sr}$ & GO-PN-422 & $\operatorname{sc} 22$ & Gnaisse & Rocha total & Grupo Estrondo & $-10,2667$ & $\because$ & 48.9333 & 5 & 45 & W Rio Tocantins \\
\hline T44 & $\mathrm{Rb}-\mathrm{Sr}$ & $00-530$ & $\operatorname{sen} 22$ & Gnaisse & Rocha total & Grupo Estrondo & $-10, \sqrt{5}$ & - & 48.8833 & 5 & 45 & W Rio Tocantins \\
\hline T 45 & $\mathrm{Rb}-\mathrm{Sr}$ & $\mathrm{C}-68 \mathrm{~B}$ & $\operatorname{sc} 22$ & Xisto & Rocha total & Grupo Estrondo & $-10,3$ & - & 48.9667 & 5 & 45 & E Rio Araguaia \\
\hline T 46 & $\mathrm{Rb}-\mathrm{Sr}$ & OH-LT-2 & $\operatorname{sc~} 22$ & Quartzo Porfiro & Rocha total & Grupo Estrondo & $-10,7167$ & - & 53.9667 & 5 & 45 & SE SerraCachimbo \\
\hline T 47.1 & $\overline{R b}-\mathrm{Sr}$ & RON-4.A & $\operatorname{sc~} 22$ & Riodacito & Rocha total & Fm Iriti & $-10,3833$ & - & 51.3333 & 5 & 45 & S SerraCubencraquem \\
\hline
\end{tabular}




\begin{tabular}{|c|c|c|c|c|c|c|c|c|c|c|c|c|}
\hline Ordem & Método & $\mathrm{N}^{\circ}$. Campo & Folha & Lltologla & Material Analisado & Unidade Geológica & Latitude & & Longitude & $\begin{array}{l}\text { Prec } \\
(\mathbf{K m})\end{array}$ & Ref & Referêncla Geográfica \\
\hline$T 48$ & $\mathrm{Rb}-\mathrm{Sr}$ & RON-5 & $\operatorname{sc} 22$ & Riodacito & Rocha tokal & Fm Iriri & $-10,45$ & - & 51.55 & 5 & 45 & S Porto Nacional City \\
\hline T 49 & $\mathrm{Rb}-\mathrm{Sr}$ & $511-A Z-22.1$ & SC 22 & Riolito & Rocha total & Fm iriri & $-8,1833$ & - & 48.3167 & 5 & 45 & S Porto Nacional City \\
\hline T5 & $\mathrm{K}-\mathrm{Ar}$ & GO-MN-425 & SC 22 & Granito & Muscovita & Cpx Goiano & $-10,1$ & - & 48.8333 & 5 & 45 & SE Conceição Araguaia \\
\hline T50 & $\mathrm{Rb}-\mathrm{Sr}$ & $476-\mathrm{BC}-\mathrm{PB}-261$ & $5 \mathrm{sc} 2$ & Riodacito & Rocha total & Fm ririt & $-10,35$ & - & 51.5333 & 5 & 45 & S Serra Cubencraquem \\
\hline T51 & $\mathrm{Rb}-\mathrm{Sr}$ & $476-B C-P B-217$ & Sc 22 & Granófiro & Rocha total & Fm riri & $-11,4167$ & - & 51.05 & 5 & 45 & W Rio Araguaia \\
\hline 552 & $\mathrm{Rb}-\mathrm{Sr}$ & SNFD-AZ-23.5 & $5 \mathrm{~s} 22$ & Riolito & Rocha total & Fm Iniri & $-8,3833$ & - & 52.8333 & 5 & 45 & Regiăo Rio Xingu \\
\hline$T 53$ & $\mathrm{Rb}-\mathrm{Sr}$ & SNFD-BG-207.1 & 5022 & Granito & Rocha total & $F m$ lrini & $-8,0033$ & - & 51.9167 & 5 & 45 & Cubencraquem Range \\
\hline$T 54$ & $\mathrm{Rb}-\mathrm{Sr}$ & SNFD-LT-30 & 5022 & Granito & Rocha total & Fm Iriri & 8.6 & - & 51.7833 & 5 & 45 & Serra Cubencraquem \\
\hline$T 55$ & $\mathrm{Rb}-\mathrm{Sr}$ & SNFD-1T-32 & $\operatorname{SC~} 22$ & MonzoGranito & Rocha total & Fm lriti & $-8,7333$ & - & 52.6167 & 5 & 45 & Regiăo Rio Xingu \\
\hline$T 56$ & $\mathrm{Rb}-\mathrm{Sr}$ & $\mathrm{OH}-\mathrm{BG}-21$ & SC 22 & Granito & Rocha total & Suite Intrusiva Rio Dourado & $-9,4333$ & - & 52.9 & 5 & 45 & Regiăo Rio Xingu \\
\hline T57 & $\mathrm{Rb}-\mathrm{Sr}$ & 424BG-113 & $\mathrm{SC} 22$ & Granito & Rocha total & Sulte intrusiva Rio Dourado & $-8, \overline{7667}$ & - & 53.3 & 5 & 45 & Regiăo Rio Xingu \\
\hline T58 & $\mathrm{Rb}-\mathrm{Sr}$ & PT-21 & $5 \mathrm{c} 22$ & Granito & Rocha total & Suite Intrusiva Tarumä & $-9,9166$ & - & 51.5333 & 5 & 45 & S Serra Cubencraquem \\
\hline T59.1 & $\mathrm{Rb}-\mathrm{Sr}$ & $424 B C-151$ & $\operatorname{sc} 22$ & Granito & Rocha total & Suite Intrusiva Rio Dourado & $-7,9833$ & - & 52.6833 & 5 & 45 & Regiťo Rio Xingu \\
\hline $\mathrm{T} 59.2$ & Sm-Nd & $424 \overline{B C} 151$ & SC 22 & Granito & Rocha total & Suite intrusiva Rio Dourado & $-7,9833$ & - & 52.6833 & 5 & 79 & Regiăo Rio Xingu \\
\hline T6 & K-Ar & GO-BN-402 & $\operatorname{Sc} 22$ & Xisto & Biotita & Cpx Goiano & $-11,5667$ & $\because$ & 48.85 & 5 & 45 & SE Conceiçă Araguaia \\
\hline$T 60$ & $R \mathrm{~B}-\mathrm{Sr}$ & PT-DO & $5 \mathrm{sc2}$ & Granito & Rocha total & Sute intrusiva Rio Darado & $-9,75$ & - & 50.6 & 5 & 45 & S Serra Inajáa \\
\hline $\mathrm{T} 61$ & $\mathrm{Rb}-\mathrm{Sr}$ & PT-20 & SC 22 & Granito & Rocha total & Suce hitusiva Rio Dourado & $-9,75$ & - & 51.8833 & 5 & 45 & Regiao Rio Xingu \\
\hline T62 & $\mathrm{Rb}-\mathrm{Sr}$ & $424 B C-65$ & $5 \mathrm{~s} 22$ & Granito & Rocha total & Sule intusiva Rio Dourado & $-9,7833$ & $\dot{*}$ & 52.2167 & 5 & 45 & Regiåo Rio Xingu \\
\hline 163 & $\mathrm{Rb}-\mathrm{Sr}$ & OH-DO-LT3.1 & $\operatorname{sc} 22$ & Granito & Rocha total & Suthe htrusiva Tauma & $-9,4833$ & - & 53.8167 & 5 & 45 & Regiåo Rio Xingu \\
\hline 764 & $\mathrm{Rb}-\mathrm{St}$ & RON-11 & $\operatorname{sc~} 22$ & Granito & Rocha total & Sute intusina Rio Darado & $-10,6$ & - & 51.55 & 5 & 45 & SClbencraquem M Range \\
\hline$T 65.1$ & $\mathrm{Rb}-\mathrm{Sr}$ & RON-12E & SC 22 & Granodionito & Rocha total & Sulde hrusia Rio Dourado & $-10,4333$ & - & 51.4167 & 5 & 45 & S Cubencraquem M Range \\
\hline$T 65.2$ & $\mathrm{Rb}-\mathrm{Sr}$ & RON-12A & $\operatorname{sc} 22$ & Granodiorito & Rocha total & Suche Intrusiva Rio Dourado & $-10,4333$ & - & 51.55 & 5 & 45 & $S$ Cubencraquern M Range \\
\hline T 66.1 & $\mathrm{Rb}-\mathrm{Sr}$ & RONOA & Sc 22 & Granito & Rocha total & Sulte nousiva Rio Dourado & $-10,5833$ & - & 51.5 & 5 & 45 & S Cubenctaquen M Range \\
\hline T 66.2 & Sm-Nd & RON 9A & $5 \mathrm{SC2}$ & Granito & Rocha total & Suthe intusiva Rio Dourado & $-10,5833$ & - & 51.5 & 5 & 79 & S Cubencraquem M Range \\
\hline$T 67$ & $\mathrm{Rb}-\mathrm{Sr}$ & $\mathrm{CO}-5 B A$ & $5 \mathrm{~S} 22$ & Granito & Rocha total & Sute Intusiva Rio Dourado & $-11,00333$ & - & 48.2667 & 5 & 45 & 5 Porto Nacional City \\
\hline$T ळ 8$ & $\mathrm{Rb}-\mathrm{Sr}$ & 0059 & $\operatorname{sc} 22$ & Granito & Rocha total & Sulte Itrusiva Rio Darado & $-10,9833$ & - & 48.2833 & 5 & 45 & S Porto Nacional City \\
\hline $\mathrm{T} \oplus$ & $\mathrm{Rb}-\mathrm{St}$ & $525-A Z-110$ & SC 22 & Granito & Rocha total & Sune Intrusiva Rio Dourado & $-10,3167$ & - & 48.6667 & 5 & 45 & NW Porto Nacional City \\
\hline T7.1 & K-Ar & GO-MN-428 & $5 \mathrm{C} 22$ & Gnaisse & Biotita & Cpx Goiano & $-9,9667$ & - & 48.7167 & 5 & 45 & SE Conceiçăo Araguaia \\
\hline$T 7.2$ & $\mathrm{~K}-\mathrm{Ar}$ & GO-MN-429 & $\operatorname{sc~} 22$ & Xisto & Biotita & Cpx Goiano & $-9,9667$ & - & 48.7167 & 5 & 45 & SE Conceiçăo Araguaia \\
\hline 170 & $\mathrm{Rb}-\mathrm{Sr}$ & $511-A Z-44$ & $\operatorname{sc~} 22$ & Granito & Rœcha total & Suite Intrusiva Ipueiras & $-11,3167$ & - & 48.5333 & 5 & 45 & W Rio Tocantins \\
\hline T 71.1 & $\mathrm{Rb}-\mathrm{Sr}$ & 470-PB-PR-02 & SC 22 & Granito & Rocha total & Suite Intrusiva Taruma & -8.5833 & - & 50.9833 & 5 & 45 & Inaja $M$. Range \\
\hline$T 71.2$ & $\mathrm{Sm}-\mathrm{Nd}$ & 470 PBK 02 & $5 \mathrm{~s} 22$ & Granito & Rocha total & Suite Intrusiva Tarumă & $-8,5833$ & - & 50.9833 & 5 & 79 & lnajá M. Range \\
\hline$T 72$ & $\mathrm{Rb}-\mathrm{Sr}$ & $B C-97.2$ & $5 \mathrm{sc} 2$ & Brecha Vulcanica & Rocha total & Fm Monte do Carmo & $-10,5833$ & - & 48.25 & 5 & 45 & NE Porto Nacional City \\
\hline
\end{tabular}




\begin{tabular}{|c|c|c|c|c|c|c|c|c|c|c|c|c|}
\hline Ordem & Método & $N^{\circ}$. Campo & Folha & Litologia & Material Anallsado & Unidade Geológica & Latitude & & Longitude & $\begin{array}{l}\text { Prec } \\
\text { (Km) }\end{array}$ & Ref & Referêncla Geográfica \\
\hline$T 73$ & $\mathrm{Rb}-\mathrm{Sr}$ & $A Z-137$ & $5 \mathrm{se} 22$ & Riolito & Rocha fotal & Fm Monte do Carmo & $-10,9$ & - & 48.1333 & 5 & 45 & SW Porto Nacional City \\
\hline$T 74$ & $\mathrm{Rb}-\mathrm{Sr}$ & $B C-98.1$ & Sc 22 & Metadacito & Rocha total & Fm Monte do Carmo & $-10,4833$ & - & 48.1166 & 5 & 45 & NE Porto Nacional City \\
\hline$T 75$ & K-Ar & MI-FO.3 & $\operatorname{sc} 22$ & Diabásio & Rocha total & 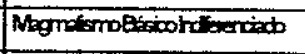 & $-8,25$ & - & 51.4833 & 5 & 45 & Rio Rio Fresco \\
\hline$T 76$ & K-Ar & $61268-69$ & $5 \mathrm{~S} 22$ & Diabásio & Rocha total & 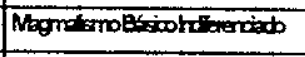 & -8 & - & 51.4667 & 5 & 45 & SW Gorotise Range \\
\hline 177 & $\mathrm{~K}-\mathrm{Ar}$ & Arag & $5 \mathrm{~s} 22$ & Diabásio & Rocha total & 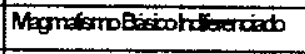 & $-9,9333$ & - & 49.0333 & 5 & 45 & Serra do Estrondo \\
\hline 778 & $\mathrm{~K}-\mathrm{Ar}$ & Co-71 & $\operatorname{sc~} 22$ & Diabásio & Rocha total & 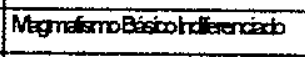 & $-8,75$ & - & 49.4667 & 5 & 45 & W Conceição Araguaia \\
\hline 179 & $\mathrm{~K}-\overline{A r}$ & $\mathrm{co}-81$ & $\operatorname{sc~} 22$ & Gabro & Plagioclásio & Magnismoliciohd & $-8,25$ & - & 49.4833 & 5 & 45 & W Conceiçăo Araguaia \\
\hline$T 8$ & $\mathrm{~K}-\mathrm{Ar}$ & GO-PN-443 & $\operatorname{sc} 22$ & Gnaisse & Biotita & Cpx Goiano & $-7,7833$ & - & 48.8333 & 5 & 45 & SE Conceiçăo Araguaia \\
\hline 780.1 & $\mathrm{~K}-\mathrm{Ar}$ & $C O-80 A$ & $5 \mathrm{SC2}$ & Gabro & Røcha total & 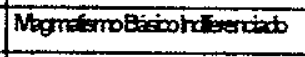 & $-8,2667$ & - & 48.3667 & 5 & 45 & W Conceiçăo Araguaia \\
\hline T 80.2 & $K-A r$ & $C 0-808$ & $\operatorname{sc~} 22$ & Gabro & Rocha total & 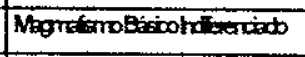 & $-8,2667$ & - & 49.3667 & 5 & 45 & W Conceiçăa Araguaia \\
\hline 781 & K-Ar & SNFD-AZ31.1 & $\operatorname{sc} 22$ & Diabásio & Rocha fotal & Magntesnolisicotrifercind & $-8,6833$ & - & 50.9833 & 5 & 45 & Inajá Range \\
\hline$T 82$ & $\mathrm{~K}-\mathrm{Ar}$ & $60-490$ & $\operatorname{sc~} 22$ & Metabasito & Rocha total & 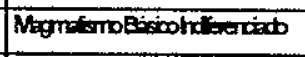 & 10,9333 & - & 48.4 & 5 & 45 & S Porto Nacional City \\
\hline$T 83$ & K-Ar & GO-PN-411 & $5 \mathrm{SC} 22$ & Metabasito & Rocha total & 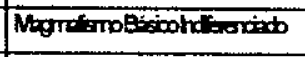 & $-10,9333$ & - & 48.5333 & 5 & 45 & SW Porto Nacional City \\
\hline T84 & $K-A r$ & $485-\bar{A} Z-196.1$ & $S C 22$ & Dionto & Antibólio & Embasamento & 7,15 & 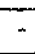 & 48.4167 & 10 & 45 & SE Gradaus $M$. Range \\
\hline 185 & $\mathrm{Rb}-\mathrm{Sr}$ & SNFDBC-178 & $\operatorname{sc} \overline{22}$ & Granodionito & Rocha total & Embasamento & $-9,9917$ & - & 50.7345 & 10 & $\infty$ & N Luciara \\
\hline$T 86$ & $\mathrm{Rb}-\mathrm{Sr}$ & SNFDAZZ 13 & $\operatorname{sc} 22$ & Granito & Rocha total & Embasamento & $-8,8703$ & - & 50.7876 & 10 & $\infty$ & NW Araguacui \\
\hline$T 87$ & $\mathrm{Rb}-\mathrm{Sr}$ & SNFDAZZ 01 & $\operatorname{sc} 22$ & Granodiorito & Rocha total & Embasamento & $-8,1287$ & - & 50.8623 & 10 & 69 & W Redenç̧o \\
\hline T88 & Rb-Sr & SNFDAZ 2 & Sc 22 & Granodionito & Rocha total & Embasamento & $-8,0710$ & $\because$ & 50.5705 & 10 & 69 & W Redençăo \\
\hline 789.1 & $\mathrm{~K}-\mathrm{Ar}$ & $\overline{\mathrm{FO}}$ & $\operatorname{sc~} 22$ & Gnaisse & Biotita & Embasamento & $\sim 8,5750$ & - & 50.3853 & 10 & 69 & W Araguacena \\
\hline T89.2 & $\mathrm{Rb}-\mathrm{Sr}$ & Fot & $\mathrm{Sc} 22$ & Gnaisse & Rocha total & Embasamento & $-8,5750$ & - & 50.3853 & 10 & 69 & W Araguacena \\
\hline T9 & $\mathrm{K}-\mathrm{Ar}$ & RM-SP-DO & $\operatorname{sc} 22$ & Anfibolito & Anfibólio & Cpx Goiano & $-11,15$ & - & 48.5333 & 5 & 45 & SE Conceiçã̃o Araguaia \\
\hline$T 90$ & $\mathrm{~K}-\mathrm{Ar}$ & ST5 & $\operatorname{sc~} 22$ & Pegmatito & Muscovita & Embasamento & $-10,4569$ & - & 50.7373 & 10 & 69 & N Luciara \\
\hline T91 & $\mathrm{Rb}-\mathrm{Sr}$ & 476 BC BP 228 & Sc 22 & Migmatito & Rocha total & Embasamento & $-10,5539$ & - & 50.985 & 10 & 69 & NW Luciara \\
\hline T92.1 & $\mathrm{Rb}-\mathrm{Sr}$ & $\mathrm{JW} 03$ & Sc 22 & Granito & Rocha total & Embasamento & $-8,2446$ & $\because$ & 51.5008 & 10 & 69 & Rio Fresco \\
\hline$T 93$ & $\mathrm{~K}-\overline{A r}$ & 60485 & $\operatorname{sc~} 22$ & Pegmatito & Muscovita & Embasamento & $-11,4629$ & - & 48.241 & 10 & 69 & NE Gurupi \\
\hline T94 & K-Ar & $525 \mathrm{~PB} 160$ & $\operatorname{sc} 22$ & Granito & Biotita & Embasamento & $-10,4227$ & - & 48.1841 & 10 & $\infty 9$ & NE National Park \\
\hline$T 96$ & $\mathrm{~K}-\mathrm{Ar}$ & GO BN-1402 & $\operatorname{sc} 22$ & Xisto & Biotita & & $-11,5706$ & - & 48.8869 & 10 & 69 & NE Gurupi \\
\hline$T 96$ & $\bar{K}-A_{r}$ & GOMN 471 & $\operatorname{sc} 22$ & Gnaisse & Biotita & Embasamento & $-9,9343$ & - & 48.7491 & 10 & 69 & SW Rio Tocantins \\
\hline T97 & K-Ar & GO MN 429 & $\operatorname{sc~} 22$ & Xisto & Biotita & & $-9,9343$ & $=$ & 48.7491 & 10 & $\infty 9$ & sw Rio Tocantins \\
\hline$T 98$ & K-Ar & GO MN 429 & $\operatorname{sc~} 22$ & Gnaisse & Biotita & Embasamento & $-9,7866$ & - & 48.8479 & 10 & 69 & SW Rio Tocantins \\
\hline 199 & K-Ar & OB AR 52 & $\operatorname{sc} 22$ & Diabásio & Rocha total & & $-9,8945$ & - & 49.0147 & 10 & 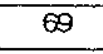 & N Pium \\
\hline T92.2 & $\mathrm{K}-\mathrm{Ar}$ & JW03 & $5 \mathrm{SC} 22$ & Granto & Biotita & Embasamento & -8.2446 & - & 51.5008 & 10 & 69 & Rio Fresco \\
\hline$T \dot{P} 1$ & $\mathrm{Rb}-\mathrm{Sr}$ & PT20 BDS/47 & SB 21 & Granito & Rocha total & Suche intusiva Maloquintra & $-5,6910$ & $\because$ & 56.283 & 15 & 70,71 & Rio Tapajós \\
\hline
\end{tabular}




\begin{tabular}{|c|c|c|c|c|c|c|c|c|c|c|c|c|}
\hline Ordem & Método & $\mathbf{N}^{\circ}$. Campo & Folha & Lttologia & Materlal Analisado & Unidade Geológlca & Latitude & & Longltude & $\begin{array}{l}\text { Prec } \\
(\mathrm{Km})\end{array}$ & Ref & Referēncla Geográfica \\
\hline TP 10 & $\mathrm{Rb}-\mathrm{Sr}$ & AP $133 A$ & SB 21 & Granito & Rocha total & Granito Pós-Orogénico & 4,2033 & - & 54.6935 & 10 & 70 & Variante, Transamazonia \\
\hline TP 11 & $\mathrm{Rb}-\mathrm{Sr}$ & AP $133 C$ & SB 21 & Granito & Rocha total & Granito Pós-Orogénico & $-4,1644$ & - & 54.6699 & 10 & 70 & Variante, Transamazonia \\
\hline TP 12 & $R \mathrm{R}-\mathrm{Sr}$ & AK 156 & SB 21 & Granito & Rocha total & Intr Granite & $-4,6748$ & - & 57.4516 & 10 & 70 & Rio Tapajós \\
\hline TP 13 & Rb-Sr & $4 / 66266$ & SB 21 & Granito & Rocha total & 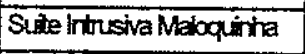 & $-4,6748$ & - & 57.4516 & 10 & 70 & Rio Tapajós \\
\hline TP 14 & $\mathrm{Rb}-\mathrm{Sr}$ & SAC/RX/252 & SB 21 & Alc granito & Rocha total & Suke Intusiva Neboquinta & $-4,7708$ & - & 56.3113 & 10 & 70 & Rio Tapajós \\
\hline TP 15 & $\mathrm{Rb}-\mathrm{Sr}$ & SACIRX 770 & $\mathrm{SB} 21$ & Granito & Rocha total & Suce intusiva Meloquintra & $-6,5100$ & $\cdot$ & 55.7298 & 10 & 70 & Rio Tapajós \\
\hline TP 16 & $\overline{R b}-\mathrm{Sr}$ & SAC $/ R \times 588$ & SB 21 & Granito & Rocha total & Granito Pós-tectónico & $-6,5100$ & - & 55.7298 & 10 & 69 & Rio Tapajós \\
\hline TP 17 & K-Ar & $\operatorname{IR} 35$ & $5 \overline{S B}$ & Granito & Biotita & Sule Intusiva Naloquinta & $-5,7656$ & - & 54.112 & 10 & 70 & Rio thin \\
\hline TP 18 & K-Ar & $466-175$ & 5821 & Granito & Rocha total & Suche intrusiva Maloquinha & $-4,6193$ & - & 57.2661 & 10 & 70 & Rio Tapaíos \\
\hline TP 19 & $\mathrm{~K}-\mathrm{Ar}$ & $C-48$ & $\overline{S B} 21$ & Granodiortto & Ánfibólio & Sute Intusiva Madoquinta & $-6,0721$ & 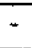 & 54.4783 & 10 & 70 & Rio lriri \\
\hline TP 2 & $\mathrm{Rb}-\mathrm{Sr}$ & PTOB AAS41 & SB 21 & Granito & Rocha total & Sute lntusia Maloquinha & $-5,6906$ & - & 56.2828 & 10 & 70,71 & Rio Tapajós \\
\hline TP 20 & K-Ar & EB-139 & $S \bar{B} 21$ & Granito & Feldspato & Sure Intusiva Maloquinha & $-5,7656$ & - & 54.112 & 10 & 70 & Rio Irisi \\
\hline TP 21 & Rb-Sr & $A K-128$ & $\mathrm{SB} 21$ & Granito & Rocha total & Embasamento & $-4,4592$ & - & 55.02 & 10 & 70 & Rio Tapajós \\
\hline TP 22 & $\mathrm{Rb}-\mathrm{Sr}$ & $A L 90$ & SB 21 & Rilodacito & Rocha tctal & Fm Iniri & $-4,2206$ & - & 55.1038 & 10 & 71 & Rio Tapajos \\
\hline IP 23 & K-AT & $\mathrm{AS}-229 \mathrm{~B}$ & SB 21 & Diabásio & Rocha total & & 5,0008 & - & 54.5448 & 10 & 71 & Rio trini \\
\hline TP 24.1 & $\mathrm{Rb}-\mathrm{Sr}$ & AM-122 & SB 21 & Granito & Rocha total & Sute ifirusiva Meloging & $-5,2702$ & - & 58.1029 & 10 & 71,13 & Rio Tapajós \\
\hline TP 24.2 & $\mathrm{Rb}-\mathrm{Sr}$ & $A M-122$ & $S B 21$ & Riolito & Rocha total & Vulcanicas Teles Pires & $-5,2702$ & - & 58.1029 & 10 & 71,13 & Rio Tapajós \\
\hline TP 25 & $R \dot{b}-\mathrm{Sr}$ & AL-96-1 & $\mathrm{SB} 21$ & Riollto & Rocha total & Fm Irini & $-4,3836$ & - & 55.5807 & 10 & 6,13 & Rio Cupari \\
\hline TP 26 & $\mathrm{Rb}-\mathrm{Sr}$ & AS-230 & SB 21 & Riolito & Rocha total & Fm Iriti & $-4,8320$ & - & 54.5385 & 10 & 6,13 & Rio Iriri \\
\hline TP 27 & $\mathrm{Rb}-\mathrm{Sr}$ & AM-137 & SB 21 & Granito & Rocha total & & $-4,8902$ & - & 54.4411 & 10 & 71 & Transamazorica Rod km 428 \\
\hline TP 28 & $\mathrm{Rb}-\mathrm{Sr}$ & PT O4A & SB 21 & Dacito & Rocha fotal & Vulcánicas Teles Pires & $-7,8023$ & - & 59.5618 & 10 & 13 & Rio Aripuană \\
\hline TP 29 & $\mathrm{Rb}-\mathrm{Sr}$ & $\overline{A M} 7$ & SB 21 & Riolito & Rocha total & Vulcânicas Teles Pires & $-5,4150$ & - & 58.0532 & 10 & 13 & Rio Tapajós \\
\hline TP 3 & $\mathrm{Rb}-\mathrm{Sr}$ & PT10 AS3B & $\mathrm{SB} \overline{21}$ & Granito & Rocha total & Sute intrusiva Maloquinha & $-6,0375$ & - & 56.7262 & 10 & 70,71 & Rio Tapajós \\
\hline TP 30 & $R b-S r$ & AM 32 & SB 21 & Riolito & Rocha total & Vulcånicas Teles Pires & $-5,0837$ & - & 58.0351 & 10 & 13 & Rio Tapajós \\
\hline TP 31 & $\mathrm{Rb}-\mathrm{Sr}$ & $A M-122$ & SB 21 & Riolito & Rocha total & Vulcánicas Teles Pires & $-5,2702$ & - & 58.0447 & 10 & 13,69 & Rio Tapaios \\
\hline TP 32 & $\mathrm{Rb}-\mathrm{Sr}$ & PA 207 & SB 21 & Tufo & Rocha total & Fm Iriri & $-4,7808$ & - & 56.6757 & 10 & 13 & Rio Tapajos \\
\hline $\operatorname{TP} 33$ & $\mathrm{Rb}-\mathrm{Sr}$ & PA 210 & $5 \overline{8} 21$ & Tufo & Rocha total & Fm friri & $-4,4809$ & - & 56.0912 & 10 & 13 & Rio Tapajós \\
\hline TP 34 & Rb-Sr & PT16 AAS5O & SB 21 & Tufo & Rocha total & Fm Iriri & -5.4250 & - & 53.9137 & 10 & 13 & Rio Tapajos \\
\hline TP 35 & K-Ar & IR6 & $\overline{S B} 21$ & Ignibrito & Rocha total & Embasamento & $-5,2791$ & - & 54.2466 & 10 & 13 & Rio Iriri \\
\hline TP 36 & K-Ar & IR 48 & $S \bar{B} 21$ & Riolito & Rocha total & Embasamento & $-5,9189$ & - & 54.0027 & 10 & 13 & Rio Iriri \\
\hline TP 37 & K-Ar & 4601163 & SB 21 & Riolito & Rocha total & Fm Iriri & $-4,9097$ & - & 57.0003 & 10 & 13 & Rio Tapajos \\
\hline TP 38 & K-Ar & AM 70 & SB 21 & Riolito & Rocha total & Fm Irin & $-5,0681$ & - & 57.0623 & 10 & 13 & Rio Tapajós \\
\hline TP 39 & K-Ar & $J \times 12$ & $\mathrm{SB} 21$ & Riolito & Rocha total & Fm Irini & $-5,2084$ & - & 56.3509 & 10 & 13 & Rio Tapajos \\
\hline
\end{tabular}




\begin{tabular}{|c|c|c|c|c|c|c|c|c|c|c|c|c|}
\hline Ordem & Métodio & $N^{\circ}$. Campo & Folha & Lftologla & Materlal Anallsado & Unidade Geológica & Latitude & & Longitude & $\begin{array}{l}\text { Prec } \\
(\mathrm{Km})\end{array}$ & Ref & Referência Geográfica \\
\hline TP 4 & $\mathrm{Rb}-\mathrm{Sr}$ & $A V 160$ & SB 21 & Granito & Rocha total & Granito Parautari & $-4,4118$ & - & 54.9443 & 10 & 70 & Rio Tapajós \\
\hline TP 40 & K-Ar & $\operatorname{liR} 47$ & SB 21 & Dacito & Rocha total & Fm Iriri & $-6,0983$ & - & 53.9148 & 10 & 13 & Rio Irini \\
\hline IP 41 & $K-A r$ & $\mathrm{SACHX263}$ & SB 21 & Dolerito & Plagiociásio & Fm Crepori & $-5,1712$ & - & 50.9714 & 10 & 39 & Rio Tapajós \\
\hline TP 42 & $\mathrm{~K}-\mathrm{Ar}$ & CREI 10 & SB 21 & Diabásio & Plagiockásio & & $-7,0367$ & $\therefore$ & 56.7162 & 10 & 39 & Rio Tapajós \\
\hline TP 43 & $\mathrm{~K}-\mathrm{Ar}$ & $1510 \mathrm{MP100}$ & $\overline{S B} \overline{21}$ & Tractolito & Rocha total & & $-5,8064$ & - & 56.3141 & 10 & 39 & Rio Tapajós \\
\hline $\mathrm{TP} 44$ & K-Ar & $1510 \mathrm{MP} 26$ & $\widehat{S B 21}$ & Tractolito & Plagioclásio & & $-5,8064$ & - & 56.3141 & 10 & 39 & Rio Tapajos \\
\hline TP 45 & $\mathrm{Rb}-\mathrm{Sr}$ & AM 52A & SB 21 & & & & 4,9699 & - & 58.032 & 10 & 16 & Rio Tapajós \\
\hline TP 46 & $\mathrm{Rb}-\mathrm{Sr}$ & AM 52B & $\overline{S B} 21$ & & & & $-4,9690$ & $\because$ & 58.032 & 10 & 16 & Rio Tapajós \\
\hline TP 48 & K-Ar & AM 82 & SB 21 & Riolito & Rocha total & Vulcánicas Teles Pires & $-5,1105$ & - & 58.0534 & 10 & 16 & Rio Tapajós \\
\hline TP 49 & $\mathrm{~K}+\mathrm{Ar}$ & SUB-2 & SB 21 & Ádamelito & Biotita & Vulcanicas Teles Pires & $-6,6501$ & - & 56.1254 & 10 & 16 & Rio Tapajos \\
\hline TP 5 & Rb-Sr & AP 130.1 & SB 21 & Granito & Rocha total & Granito Paravari & $-4,2705$ & - & 55.1785 & 10 & 70 & Rio Cupari \\
\hline TP 50 & $\mathrm{Rb}-\mathrm{Sr}$ & $2-\bar{A}-\overline{-6}$ & SB 21 & & Rocha total & & $-6,4155$ & - & 57.4079 & 10 & 16 & Rio Tapajos \\
\hline TP51 & $\mathrm{Rb}-\mathrm{Sr}$ & $3-A-66$ & $S B 21$ & & Rocha total & & $-6,3324$ & $\because$ & 57.2224 & 10 & 16 & Rio Tapajós \\
\hline TP 52 & Rb-Sr & 4601170 & SB 21 & & Rocha total & & $-4,6610$ & - & 57.2224 & 10 & 16 & Rio Tapajós \\
\hline TP 53 & $\mathrm{Rb}-\mathrm{Sr}$ & 466265 & SB 21 & & Rocha total & & $-4,7231$ & - & 57.4136 & 10 & 16 & Rio Tapajós \\
\hline TP 54 & K-Ar & PA 204A & 5821 & & Rocha total & & $-4,8585$ & - & 56.6955 & 10 & 16 & Rio Tapajós \\
\hline TP5 & $\mathrm{Rb}-\mathrm{Sr}$ & PA 2048 & $\overline{\mathrm{SB}} 21$ & & Rocha total & & $-4,8585$ & - & 56.605 & 10 & 16 & Rio Tapaijos \\
\hline TP 56 & K-Ar & $5-A-66$ & $\mathrm{SB} 21$ & Graisse & Biotita & Embasamento & $-6,3297$ & $\div$ & 57.4381 & 10 & 16 & Rio Tapajós \\
\hline TP 57 & K-Ar & AAst-1-AM & $S B 21$ & Granito & Rocha total & Embasamento & $-5,0050$ & $\div$ & 60.3035 & 10 & 16 & Rio Tapajós \\
\hline TP 58 & $\mathrm{~K}-\overline{\mathrm{Ar}}$ & $A M-104$ & SB 21 & Diabásio & Rocha total & & $-7,2052$ & - & 60.4084 & 10 & 16 & Rio Tapajós \\
\hline TP 59 & $K-A r$ & R-47 & SB 21 & Dacito & Rocha total & & $-5,9112$ & - & 54.1077 & 10 & 16 & Rio Tapajós \\
\hline TP6 & $\mathrm{Rb}-\mathrm{Sr}$ & $\mathrm{AP} 130 \mathrm{~B}$ & SB 21 & Granito & Rocha total & Granito Parauari & $-4,2705$ & - & 55.1785 & 10 & 70 & Rio Cupari \\
\hline TP 61 & K-Ar & $1510-w p-416$ & $S B 21$ & Granito & Anfibólio & & $-5,1240$ & - & 56.56 & 10 & 69 & Rio Jamanxim \\
\hline TP 62 & K-Ar & A-2105 & $\mathrm{SB} 21$ & Granito & Anfibólio & & 4,0521 & - & 55.6113 & 10 & 69 & NE Itaituba \\
\hline TP 63 & $\mathrm{Rb}-\mathrm{Sr}$ & $Y \overline{R A-12}$ & SB 21 & Dacito & Rocha total & Fm Iriri & $-7,4239$ & - & 59.4941 & 10 & 60 & NE Samauma \\
\hline TP 64 & $\mathrm{Rb}-\mathrm{Sr}$ & YRA-774 & SB 21 & Dacito & Rocha total & Fm lrin & $-7,4845$ & - & 58.4368 & 10 & $\otimes$ & Rio Acari \\
\hline TP 65 & $\mathrm{Rb}-\mathrm{Sr}$ & KN 9099 & SB 21 & Lat & Rocha total & & $-7,4805$ & $\sim$ & 58.8056 & 10 & 69 & Rio Sucunduri \\
\hline TP 66 & $\mathrm{Rb}-\mathrm{Sr}$ & $\mathrm{KN} \mathscr{9 \mathrm { A }}$ & SB 21 & Lat & Rocha total & & $-7,5187$ & - & 58.8083 & 10 & $\infty 9$ & Rio Sucunduri \\
\hline TP 67 & $\mathrm{Rb}-\mathrm{Sr}$ & 1510 E BRO 59 & 5821 & Granodionto & Rocha total & & $-5,7382$ & - & 55.6357 & 10 & 69 & SE Itaituba \\
\hline TP 68 & $R \mathrm{~b}-\mathrm{Sr}$ & 1510 EB 054 & SB 21 & Granito & Rocha total & Sule hrousiva Maboqutra & $-5,6764$ & - & 55.6692 & 10 & 69 & SE ltaituba \\
\hline TP 69 & $\mathrm{Rb}-\mathrm{Sr}$ & $1510 \mathrm{~EB} 0460$ & SB 21 & Granito & Rocha tofal & Sute Intusiva Maloquinta & $-5,6257$ & - & 55.6745 & 10 & $\oplus$ & SE Itaituba \\
\hline TP 7 & $\mathrm{Rb}-\mathrm{Sr}$ & AS 250 & SB 21 & Granito & Rocha total & Granito Parauari & 4,7821 & - & 54.3716 & 10 & 70 & Rio lini \\
\hline TP TO & $R b-s r$ & $P 3703$ & 5821 & Granito & Rocha total & Sufe htrusiva Maloging & $-7,2470$ & - & 59.9530 & 10 & 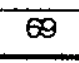 & NE Samauma \\
\hline
\end{tabular}




\begin{tabular}{|c|c|c|c|c|c|c|c|c|c|c|c|c|}
\hline Ordem & Método & $N^{\circ}$. Campo & Folha & Litologia & Material Analisado & Unidade Geológica & Latitude & & Longltude & $\begin{array}{l}\text { Prec } \\
\text { (Km) }\end{array}$ & Ref & Referēncia Geográflca \\
\hline TP 71 & $\mathrm{Rb}-\mathrm{Sr}$ & 1510 HTPL $1 \mathrm{~A}$ & SB 21 & Granito & Feldspato & Sule lnowsiva Maloquintra & $-5,2260$ & - & 55.9845 & 10 & 69 & $B R-163$ \\
\hline TP 72 & $\mathrm{~K}-\mathrm{Ar}$ & CRS- $1-40$ & SB 21 & Diabásio & Feldspato & & $-6,7630$ & - & 56.6390 & 10 & 69 & Rio Crepori \\
\hline TP 73 & K-Ar & $1510 \mathrm{JV} 007$ & SB 21 & Andesito & Plagioclásio & Fm Iriri & $-5,2392$ & $\because$ & 55.8906 & 10 & 69 & S ltaituba \\
\hline TP 74 & $\widehat{\mathrm{K}-\mathrm{A} r}$ & $R X-408$ & SB 21 & Vogesito & Rocha total & & $-5,2178$ & - & 55.6345 & 10 & 69 & Rio Crepori \\
\hline TP 75 & K-Ar & $1510-$ wp-380 & $S \bar{B} 21$ & Anfibolito & Anfibólio & Embasamento & -5.9123 & - & 56.9845 & 10 & 69 & Rio Crepori \\
\hline TP 76.1 & $\mathrm{Rb}-\mathrm{Sr}$ & $1510-m p-61 A$ & SB 21 & Granito & Rocha total & Suthe Irtrusiva Meloquinta & $-5,1012$ & - & 56.9074 & 10 & 69 & Rio Tapajós \\
\hline TP 76.2 & K-A $T$ & 1510 -mp-61A & $\overline{S B 21}$ & Granito & Rocha total & Sute Intrusiva Meloquina & 5,1012 & - & 56.9074 & 10 & 6 & Rio Tapajós \\
\hline TP 77 & $R b-S r$ & $1510 \mathrm{~EB} 30$ & SB 21 & Riodacito & Rocha total & Fm Iriti & $-5,5848$ & - & 55.539 & 10 & $\infty 9$ & SE Itaituba \\
\hline TP 78 & $\mathrm{Rb}-\mathrm{Sr}$ & PA $3036 \mathrm{~A}$ & SB 21 & Pelito & Rocha total & Grupo Beneficente & $-6,3728$ & - & 58.8092 & 10 & 69 & Rio Canuma \\
\hline $\operatorname{TP} 79$ & Rb-Sr & PA-3036C & $\overline{\mathrm{SB}} \overline{21}$ & Pelito & Rocha total & Grupo Beneficente & $-6,3728$ & - & 58.8092 & 10 & 99 & Rio Canuma \\
\hline TP 8 & $\mathrm{Rb}-\mathrm{Sr}$ & AP 133 & SB 21 & Granito & Rocha total & Granito Pós-Orogénico & $-4,2226$ & - & 54.7083 & 10 & 70 & Variante, Transamazonia \\
\hline TP 80 & $\mathrm{Rb}-\mathrm{Sr}$ & PA $3036 \mathrm{~F}$ & SB 21 & Pelito & Rocha total & Grupo Beneficente & $-6,3728$ & - & 58.8092 & 10 & $\notin 9$ & Rio Canuma \\
\hline TP 81 & $\mathrm{Rb}-\mathrm{Sr}$ & $5-820 A$ & $\overline{S B} 21$ & Pelito & Rocha total & Grupo Beneficente & $-7,5300$ & - & 58.8852 & 10 & 69 & Rio Sucunduri \\
\hline TP 82 & K-Á & $J P-R X-\infty 08$ & SB 21 & Basatto & Rocha total & & $-6,3457$ & - & 55.4964 & 10 & $\infty$ & $B R-163$ \\
\hline TP 83 & K-Ar & $1510-\mathrm{CB}-139$ & SB 21 & Granito & Feldspato & & $-5,4112$ & - & 558122 & 10 & $\infty$ & Rio Jamanxim \\
\hline TP 84 & $\mathrm{Rb}-\mathrm{Sr}$ & PA.3036H & $S B 21$ & Pelito & Rocha total & Grupo Beneficente & $-6,3728$ & - & 58.8092 & 10 & 69 & Rio Canuma \\
\hline TP 85 & K-Ar & $4-66-163$ & SB 21 & Riolito & Rocha total & Vulcánicas Teles Pires & $-4,2740$ & - & 56.7 & 10 & $\bar{\epsilon}$ & W Itaituba \\
\hline TP 86 & K-AT & $L-1214$ & SB 21 & Diabásio & Rocha total & & $-7,2169$ & 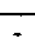 & 58.9950 & 10 & 69 & Rio Sucunduri \\
\hline TP 87 & K-Ar & N-96064 & SB 21 & Latito & Rocha total & & $-7,4806$ & - & 58.8056 & 10 & $\infty$ & Rio Sucunduri \\
\hline TP 88 & K-Ar & $\mathrm{RX}-561$ & SB 21 & Granito & Rocha total & & $-6,5428$ & $\cdot$ & 55.5109 & 10 & 69 & BR-163 \\
\hline TP 89 & K-Ar & $1-47$ & $S B 21$ & Dacito & Rocha total & Fm iriti & $-5,9315$ & - & 54.214 & 10 & 69 & Rio Iriti \\
\hline TP9 & $R b-S r$ & $A \bar{P} 133.1$ & SB 21 & Granito & Rocha total & Granito Pós-Orogénico & -4.1515 & - & 55.4145 & 10 & 70 & Variante, Transamazonia \\
\hline TP 90 & $\mathrm{~K}-\overline{A r}$ & PT $11 \mathrm{~A}$ & $\mathrm{SB} 21$ & Dlabásio & Rocha total & & $-4,3598$ & - & 55.8816 & 10 & 89 & Cururu River \\
\hline TP91 & K-Ar & PT $17 \mathrm{C}$ & $S B 21$ & Diabásio & Rocha total & & $-7,4707$ & - & 57.8243 & 10 & $\infty$ & W itaituba \\
\hline TP 94 & K-AT & AS-296 & $S B 21$ & Basalto & Rocha total & Fm liri & $-4,8320$ & $\because$ & 54.5385 & 15 & 71 & Rio Irifi \\
\hline TPOS & K-Ar & AS-297 & SB 21 & Basalto & Rocha total & Fm rivi & $-4,8320$ & - & 54.5385 & 15 & 71 & Rio Iriri \\
\hline TP 96 & $\mathrm{Rb}-\mathrm{Sr}$ & SAC 720 & $S \overline{S B} 21$ & Riolito & Rocha total & Fm Irini & $-4,7855$ & 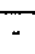 & 56.0201 & 10 & 69 & S S. L. Tapajós \\
\hline TU1 & $\mathrm{Rb}-\mathrm{Sr}$ & PT 556 & NANNB 21 & Gnaisse & Rocha total & Embasamento & $+1,9000$ & - & 55.05 & 10 & 37 & Rio Paru de Oeste \\
\hline TU 10 & $R b-S r$ & PTXA & NANB 21 & Gnaisse & Rocha total & Embasamento & $+1,0167$ & - & $\infty$ & 10 & 37 & S Rio Anauá \\
\hline TU 11 & $R \mathrm{~b}-\mathrm{Sr}$ & CAPT 12 & NAINB 21 & Hornfels & Rocha total & Embasamento & $+0,1000$ & - & 56.0333 & 10 & 37,40 & Rio Paru de Oeste \\
\hline TU 12 & K-Ar & PT 13 & NANNB 21 & Anfibolito & Anfibolio & Embasamento & $+1,7000$ & - & 54.4 & 10 & 37 & S Rio Jari \\
\hline TU13 & K-Ar & PT 24B & NA/NB 21 & Anfibolito & Rocha total & Embasamento & $+0, \overline{4667}$ & - & 54.0833 & 10 & 37 & W Rio Paru \\
\hline TU14 & K-Ar & PT 550 & NANNB 21 & Anfibolito & Biotita & Embasamento & $+1,03033$ & - & 55 & 10 & $\overline{37}$ & SW Rio Paru de Oeste \\
\hline
\end{tabular}




\begin{tabular}{|c|c|c|c|c|c|c|c|c|c|c|c|c|}
\hline Ordem & Método & $N^{\circ}$. Campo & Folha & Ltołogia & Material Anallsado & Unidade Geológica & Latifude & & Longitude & $\begin{array}{l}\text { Prec } \\
(\mathrm{Km})\end{array}$ & Ref & Referência Geográfica \\
\hline TU15 & K-AT & PT 18A & NANNB 21 & Gnaisse & Anfibolio & Embasamento & $+0,5500$ & - & 54.4167 & 10 & 37 & W Rio Paru \\
\hline TU 16.1 & K-Át & $R \times \overline{3}$ & NANB 21 & Granito & Anfíbolio & Embasamento & $+0,6667$ & - & 55.0667 & 10 & 37 & SW Rio Paru de Oeste \\
\hline TU 16.2 & $\mathrm{Rb}-\mathrm{Sr}$ & $\mathrm{R} \times 3$ & NA/NB 21 & Granito Pórfiro & Rocha total & Vulcanicas lricoumé & $+0,6667$ & 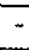 & 55.0667 & 10 & 37 & SW Rio Paru de Oeste \\
\hline TU 17 & K-Är & RR-325 & NAINB 21 & Gnaisse & Biotita & Embasamento & $+1,3000$ & $\because$ & 59.5833 & 10 & 37 & N Rio Anauá \\
\hline TU 18.1 & $R b-S r$ & ASA 6 & NANB 21 & Tufo & Rocha total & Vulcanicas Iricoumé & $+1,5333$ & - & 58.05 & 10 & 37 & N Rio Patu de Oeste \\
\hline TU 18.2 & $\mathrm{Rb}-\mathrm{Sr}$ & ASA 6.1 & NAINB 21 & Tufo & Rocha total & Vulcanicas lricoumé & $+1,5333$ & - & 58.05 & 10 & 37 & N Rio Paru de Oeste \\
\hline TU 19 & $\mathrm{Rb}-\mathrm{Sr}$ & PT 01A & NANB 21 & Tufo & Rocha total & Vulcanicas Iricoumé & $+0,7667$ & - & 58.45 & 10 & 37 & S Serra Acari \\
\hline TU2 & $\mathrm{Rb}-\mathrm{Sr}$ & PT 10 & NANB 21 & Granodiorito & Rocha total & Embasamento & $+1,4833$ & - & 54.0667 & 10 & 37 & W Rio Paru de Oeste \\
\hline TU 20 & K-Ärr & RR-95 & NANB 21 & Riolito & Rocha total & Vulcánicas Iricoumé & $+4,0667$ & - & 59.65 & 10 & 16 & Fronteira Brasil-Guiana \\
\hline TU21 & $\mathrm{Rb}-\mathrm{Sr}$ & PT 27 & NANB 21 & Metandesito & Rocha total & Vulcánicas Iricoumé & $+0,6000$ & - & 59.3 & 10 & 37 & SW Serra Acari \\
\hline TU 22 & $\mathrm{Rb}-\mathrm{Sr}$ & PT OSA & NANB 21 & Riodacito & Rocha total & Vulcánicas lricoumé & $+1,0500$ & 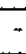 & 54.6333 & 10 & 37 & S Rio Paru de Oeste \\
\hline TU $\overline{23}$ & $\mathrm{Rb}-\mathrm{Sr}$ & PT 464 & NANB 21 & Tufo & Rocha total & Vulcánicas iricoumé & $+0,9500$ & - & 58.7333 & 10 & 37 & S Serra Acari \\
\hline TU24 & $R b-S r$ & $8 A 65$ & NANB 21 & Riolito & Rocha total & Vuicánicas iricoumé & $+0,9167$ & - & 55.6667 & 10 & 37 & N Rio Paru de Oeste \\
\hline TU 25 & $\mathrm{Rb}-\mathrm{Sr}$ & $\mathrm{SP} \bigcirc 7$ & NA/NB 21 & Riolito & Rocha total & Vulcânicas Uatumá & $+0,0667$ & $\therefore$ & 56.65 & 10 & 37 & E Rio Trombetas \\
\hline TU26 & $R b-s r$ & PT 61 A & NANB 21 & Granito & Rocha total & Granito Mapuera & $+1,6833$ & - & 55.8 & 10 & 37 & N Rio Paru de Oeste \\
\hline Tบ 27 & $\mathrm{Rb}-\mathrm{Sr}$ & $\mathrm{PT} 462 \mathrm{A1}$ & NAINB 21 & Granito Pórfiro & Rocha total & Vulcânicas Iricoumé & $+0,8000$ & - & 59 & 10 & 37 & S Serra Acari \\
\hline TU 28 & $\mathrm{Rb}-\mathrm{Sr}$ & $\mathrm{P} 225$ & NA/NB 21 & Granito Pórfiro & Rocha total & Vulcânicas liricoumé & $+0,6667$ & - & 55.0667 & $10 \mid$ & 37 & SW Rio Paru de Oeste \\
\hline TU 29 & K-Ar & $\mathrm{RR}-96$ & NANNB 21 & Riolito & Rocha total & Vulcánicas lricoumé & +3.9500 & - & 59.6667 & 10 & 16 & W Frantera Brasi-Gisana \\
\hline TU3 & $\mathrm{Rb}-\mathrm{Sr}$ & PT 12A & NAINB 21 & Gnaisse & Feldspato & Embasamento & $+1,1000$ & - & 54.3 & 10 & 37 & W Rio Pitinga \\
\hline 1030 & $\mathrm{Rb}-\mathrm{Sr}$ & PT 10.1 & NANNB 21 & Granito & Rocha total & Granito Mapuera & $+0,0587$ & $\because$ & 58.0974 & 10 & 37,69 & E Rio Mapuera \\
\hline TU 31 & $\mathrm{Rb}-\mathrm{Sr}$ & PT 16 & NAINB 21 & Quartzito & Rocha total & Vulcánicas Iricoumé & $+1,0667$ & - & 55.7 & 10 & 37 & N Rio Paru de Oeste \\
\hline TU 32 & $\mathrm{Rb}-\mathrm{Sr}$ & PT 02 & NANNB 21 & Granito & Rochia total & Granito Mapuera & $+1,7500$ & - & 57.0167 & 10 & 37 & N Rio Trombetas \\
\hline TU 33 & $\mathrm{Rb}-\mathrm{Sr}$ & PT D3A & NAINB 21 & Granito & Rocha total & Vulcânicas Iricoumé & $+1,9333$ & - & 54.4833 & 10 & 37 & E Rio Jari \\
\hline TU 34 & $\mathrm{Rb}-\mathrm{Sr}$ & PT 40 & NANB 21 & Quartzito & Rocha total & Granito Mapuera & $+0,4667$ & - & 57.5833 & 10 & 37 & 5 Serra do Mapuera \\
\hline TU35 & $\mathrm{Rb}-\mathrm{Sr}$ & PTOBA & NA/NB 21 & Adamelito & Rocha total & Vulcânicas Iricoumé & $+1,3167$ & - & 57.5667 & 10 & 37 & N Serra lricoumé \\
\hline TU 36 & $\mathrm{Rb}-\mathrm{St}$ & PT 10A & NANNB 21 & Granito & Rocha total & Granito Mapuera & $+0,0833$ & $=$ & 58.0667 & 10 & 37 & NW Serra do Cachorro \\
\hline TU 37 & $\mathrm{Rb}-\mathrm{Sr}$ & PT 27 AO & NA/NB 21 & Granito & Rocha total & Granito Mapuera & $+1,6500$ & $\because$ & 56.6833 & 10 & 37 & N Rio Trombetas \\
\hline TU 38 & Rb-Sr & PT 63 & NA/NB 21 & Granito & Rocha total & Granito Mapuera & $+1,2833$ & - & 55.7 & 10 & 37 & N Rio Paru de Oeste \\
\hline TU 39 & K-Ar & PT 14 & NANB 21 & Nefelina Sienito & Feldspato & Sienito Mutum & $+1,7833$ & - & 57.3833 & 10 & 37 & Fronteira Brasil-Guiana \\
\hline TU 4 & $\mathrm{Rb}-\mathrm{Sr}$ & PT01 & NATNB 21 & Leptito & Rocha total & Embasamento & +2.0167 & - & 55.8333 & 10 & 37 & Fronteira Brasil-Suriname \\
\hline $\mathrm{TU} 40$ & $\mathrm{~K}-\mathrm{Ar}$ & ASA 02 (PTO2) & NAVNB 21 & Diabásio & Plagloclásio & Dique & $+2,0833$ & - & 54.5667 & 10 & 37 & E Rio Jari \\
\hline TU 41 & K-Ar & $\mathrm{PT}-\mathrm{B} / \mathrm{UC} / 19$ & NA/NB 21 & Diabásio & Plagiociásio & Dique & $+0,3226$ & - & 58 & 10 & 37,14 & N Serra do Cachotro \\
\hline TU 43 & K-Är & IMM $30 \mathrm{C}$ & NANAB 21 & Basatto & Rocha total & Vulcanicas licoumé & $+1,2333$ & - & 55.7 & 10 & 39 & N Rio Paru de Oeste \\
\hline
\end{tabular}




\begin{tabular}{|c|c|c|c|c|c|c|c|c|c|c|c|c|}
\hline Ordem & Método & $N^{0}$. Campo & Folha & Lttologia & Materlal Analisado & Unidade Geológlca & Latitude & & gitude & $\begin{array}{l}\text { Prec } \\
(\mathrm{Km})\end{array}$ & Ref & Referêncla Geográfica \\
\hline TU 44 & $\mathrm{~K}-\mathrm{Ar}$ & $\overline{R R}-203-4$ & NA/NB 21 & Gabro & Rocha total & Gabro Suretama & $+4,4500$ & - & 59.8333 & 10 & 16 & Fronteira Brasil-Guiana \\
\hline TU 45 & $\mathrm{~K}-\mathrm{Ar}$ & $R R-203-1$ & NANAB 21 & Granito & Anfibólio & Granito Mapuera & $+4,4833$ & - & 59.9333 & 10 & 16 & Fronteira Brasil-Guiana \\
\hline TU 46 & K-Ar & RTG-467 & NANB 21 & Basalto & Rocha total & & $+3,5906$ & - & 59.9833 & 10 & 16 & S Rio Tacuku \\
\hline TU 47 & $\mathrm{K}-\mathrm{Ar}$ & RTG-2-67 & NANB 21 & Basalto & Rocha total & & $+3,5906$ & - & 59.9833 & 10 & 16 & S Rio Tacutu \\
\hline TU 48 & K-Ar & $11 \mathrm{~A} 66$ & NAINB 21 & Riolito & Rocha total & Vulcánicas licoumé & $+0,5806$ & - & 55 & 10 & $\overline{\oplus 9}$ & E Rio Curuá \\
\hline TU 49 & K-Ar & HSR-115-PI & NA/NB/21 & Diorito & Anfibolio & Embasamento & $+1,4758$ & - & 55.6819 & 10 & 69 & Rio Paru de Oeste \\
\hline TU5 & $\mathrm{Rb}-\mathrm{Sr}$ & ASA 58 & NANB 21 & Granodiorito & Rocha total & Embasamento & $+1,1833$ & - & 56.15 & 10 & 37 & N Rio Paru de Oeste \\
\hline TUS 50 & $\mathrm{Rb}-\mathrm{Sr}$ & TRRM-66 & NAINB/21 & Gnaisse & Rocha total & Embasamento & $+0,2205$ & - & 56.8823 & 10 & 69 & Rio Trombetas \\
\hline TU51 & $\mathrm{Rb}-\mathrm{Sr}$ & TR-RJM-22 & NANNB/21 & Gnaisse & Rocha total & Embasamento & $+0,2835$ & - & 57.0504 & 10 & $\infty 9$ & W Rio Trombetas \\
\hline TUि52.1 & $\mathrm{Rb}-\mathrm{Sr}$ & HSTR-124C & NAINB/21 & MicroGranlito & Rocha total & & $+0,3756$ & - & 57.0158 & 10 & 69 & W Rio Trombetas \\
\hline TU 52.2 & K-Ar & HSTR-124D & NANBRI & Espessartito & Biotita & & $+0,3756$ & - & 57.0158 & 10 & $\infty 9$ & W Rio Trombetas \\
\hline TU 53 & $\mathrm{Rb}-\mathrm{Sr}$ & HSTR-0OE-PI & NAINB/21 & Leucoporfito & Rocha total & & $+0,9273$ & - & 55.8662 & 10 & $\overline{6}$ & Rio Paru de Oeste \\
\hline TU 54 & $\mathrm{Rb}-\mathrm{Sr}$ & A-4R-2 & NAINB/21 & Granito & Rocha total & & $+0,6930$ & - & 55.9377 & 10 & 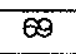 & Rio Paru de Oeste \\
\hline TU55 & $\mathrm{Rb}-\mathrm{Sr}$ & AGR-63 & NANB/21 & Granito & Rocha total & & $+1,3133$ & - & 55.9486 & 10 & $\overline{6}$ & N Rio Paru de Oeste \\
\hline TU56 & K-Ar & HMRT-118-B & NANB/21 & Ignibrito & Biotita & Vulcánicas Iricoumé & $+0,6852$ & - & 56.3577 & 10 & 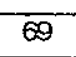 & E Rio Trombetas \\
\hline TU57 & K-Ar & HSR-72-B-PI & NANB $/ 21$ & Espessartito & Rocha total & & $+0,9434$ & - & 55.8491 & 10 & 69 & Rio Paru de Oeste \\
\hline TU 58 & K-Ar & HSR $93-P I$ & NAINBRI & Monzonito & Biotita & & $+1,2488$ & - & 55.5779 & 10 & 69 & E Rio Paru de Oeste \\
\hline TU 50 & $\mathrm{Rb}-\mathrm{Sr}$ & EMTR-01 & NA/NB/21 & Granito & Rocha total & & $+0,0200$ & $\because$ & 56.8721 & 10 & 69 & Rio Trombetas \\
\hline TU6 & $R \vec{b}-S r$ & SP 029 & NA/NB 21 & Leptito & Rocha total & Embasamento & $+1,1500$ & - & 57.2667 & 10 & 37 & NE Serra lricoumé \\
\hline$T \cup 6$ & $\mathrm{~K}-\overline{\mathrm{Ar}}$ & $A G R-80-B$ & NA/NB/21 & Adamelito & Rocha total & & $+1,1872$ & - & 55.9308 & 10 & 69 & W Rio Paru de Oeste \\
\hline TU61 & K-Ar & SR-36 & NANB 21 & Granito & Rocha total & & $+0,3254$ & - & 56.1324 & 10 & 69 & Rio Paru de Oeste \\
\hline TU 7 & $\mathrm{Rb}-\mathrm{Sr}$ & PTDS & NA/NB 21 & Granodionto & Rocha total & Embasamento & $+1,2000$ & - & 59.6333 & 10 & 37 & N Rio Anauá \\
\hline TU 8 & $\mathrm{Rb}-\mathrm{Sr}$ & $\mathrm{SPO} 015$ & NANNB 21 & Granito & Rocha total & Embasamento & $+0,3500$ & $\because$ & 56.8667 & 10 & 37 & W Rio Trombetas \\
\hline TU9 & $\mathrm{Rb}-\mathrm{Sr}$ & ASA 17 & NAINB 21 & Gnaisse & Rocha total & Embasamento & $+1,0333$ & - & 56.4333 & 10 & 37 & E Rio Trombetas \\
\hline & & & & & & & & & & & & \\
\hline
\end{tabular}




\section{Referências}

1- Machado, N.; Lindenmayer, Z; Krogh, T.E.; Lindenmayer, D.- 1991- U-Pb geochronology of Archean magmatism and basement reactivation in the Carajás area, Amazon shield, Brazil. In: Precambriam Research, 49:329-354.

2- Olszewski, W.J.; Wirth, K.R.; Gibbs, A.K.; Gaudette, H.E. -1989- The age, origin and tectonics of the Grão Pará Group and associated rocks, Serra dos Carajás, Brazil. Archean continental volcanism and rifting. Precambrian Research 42:229-254.

3- Macambira, M.J.B. \& Lancelot, J. -1991a- Em busca do embasamento arqueano da região de Rio Maria, Sudeste do Estado do Pará. Anais III Simpósio de Geologia da Amazónia. Belém/SBG p. 49-69.

4- Macambira, M.J.B. \& Lancelot, J. -1991b- História arqueana da região de Rio Maria, Sudeste Estado do Pará. Anais III Simpósio Geologia da Amazónia, Belém, Pará. SBG. p. 59-69.

5- Gomes, C.B.; Cordani, U.G.; Basei, M.A.S. -1975- Radiometric ages from the Serra dos Carajás area, Northern Brazil. Geological Society of America Bulletin. v.86, p. 939-942.

6- Almaraz, J.S.V. -1967- Determinações K-Ar na região do curso médio do Tocantins. Boletim da Sociedade Brasileira de Geologia. São Paulo, 16(1):121-126.

7- Basei, M.A.S.; Estudo Geocronológico do magmatismo ácido da região meridional da Amazônia. In: Anais $28^{\circ}$ Congresso Brasileiro de Geologia, Porto Alegre, 1974. Porto Alegre, Sociedade Brasileira de Geologia, out. 1974, v.6, p. $287-296$

8- Montalvão, R.M.G.; Tassinari, C.C.G.; Bezerra, P.E.L -1984Geocronologia dos granitóides e gnaisses das regiões do Rio Maria, Fazenda Mata Geral e Rio Itacaiúnas, Sul do Pará (Distrito Carajás-Cumaru). Anais XXXIII Congresso Brasileiro de Geologia,Rio de Janeiro, v.6, p.2757-2766.

9- Tassinari, C.C.G.-1984- A porção ocidental do Cráton Amazônico: evidências isotópicas de acreção continental no Proterozóico Médio. Anais do // Symposium Amazônico, Manaus, AM, p.439-446.

10- Projeto RADAMBRASIL -1977- Levantamento dos Recursos Naturais, Folha SA.19 IÇÁ. Geologia, Geomorfologia, Pedologia, Vegetação e Uso Potencial da terra, v.14, p.28-69.

11- Dall'Agnol, R.; Macambira, M.J.B.. Titanita-biotita granitos do baixo Rio Uaupés, Provincia Rio Negro, Amazonas (relatório interno). 
12- Basei, M.A.S.-1977-Idade do vulcanismo ácido-intermediário na região Amazônica. Dissertação de mestrado. IGUSP, 133p.

13- Basei, M.A.S.-1978- O vulcanismo ácido-intermediário na região Amazônica. In: Anais XXX Cong. Bras. Geol., Recife, v.3, p. 2408-2422.

14- Teixeira, W.-1978- Significação tectônica do magmatismo anorogênico básico e alcalino na região Amazônica. IGUSP- Dissertação de mestrado, 99 p.

15- Basei, M.A.S.; Teixeira, W.-1975 - Geocronologia do Território de Roraima. X Conferência Geológica Interguianas, v.1, Belém. Projeto RADAM, banco de dados (relatório interno).

16- Amaral, G.-1974- Geologia Pré-Cambriana da Região Amazônica, Tese de Livre Docência,IG-USP, 212 p.

17- Projeto RADAMBRASIL- 1975- Levantamento dos Recursos Naturais, Geologia, Geomorfologia, Pedologia, Vegetação e Uso Potencial da terra, Folhas NA 20 Boa Vista e parte das Folhas NA 21 Tumucumaque, NB 20 Roraima a NB 21, v.8. Rio de Janeiro, R.J., 428p., 6 mapas.

18- Gaudette, H.E.; Olszewski, W.J.; Santos, J.O.S.. -1989-Geochronology of Precambrian rocks from the northern part of the Guiana Shield, State of Roraima, Brasil (relatório interno).

19- Projeto RADAMBRASIL -1976- Levantamento dos Recursos Naturais, Geologia, Geomorfologia, Pedologia, Vegetação e Uso Potencial da terra, Folha NA.19 Pico da Neblina, v.11, R.J., 380 p., 6 mapas.

20- Dall'Agnol, R.; Abreu, A.S.-1976- Características Petrográficas e Petrológicas do Complexo Guianense na folha NA 19 Pico da Neblina. In: Anais XXIX CONG. BRAS. GEOL., v.2, pt.2, p.321-350.

21- Lima, M.I.C. de; Santos, J.O.S.; Siga Júnior, O.-1988 - Os terrenos de alto grau do Cráton Amazônico (relatório interno).

22- Projeto RADAMBRASIL-1974- Folha SB 22 Araguaia e parte da folha SC 22 Tocantins, Levantamento de recursos naturais, Geologia, Geomorfologia, Pedologia, Vegetação e Uso Potencial da terra, v. 4, R.J..

23- Lafon, J.M.; Macambira, J.B.; Pereira, E.D.; Scheller, T. -1990Geocronologia $\mathrm{Rb} / \mathrm{Sr}$ em rochas totais e minerais do Granodiorito Cumaru, Serra dos Gradaus, PA. Anais $36^{\circ}$ Congresso Brasileiro de Geologia, v.6, p. $2929-2940$

24- Projeto RADAMBRASIL, 1974. Folha NANB.22 Macapá. Levantamento de recursos naturais, Geologia, Geomorfologia, Pedologia, Vegetação e Uso Potencial da terra, v.6., 6 mapas. Rio de Janeiro. 
25- Barros, C.E. de M.; Dall'Agnol, R.; Lafon, J.M.; Teixeira, N.P.; Ribeiro, J.W. -1992- Geologia e geocronologia Rb-Sr do Gnaisse Estrela, Curinópolis, PA. Boletim do Museu Paraense Emílio Goeldi, série Ciências da Terra, 4:85102.

26- Thomaz Filho, A; Cordani, U.G.; Marino, O.-19 - Idades K-Ar de rochas basálticas da bacia amazônica e significação tectônica regional. Anais XXVIII Congresso Brasileiro de Geologia, V. p. 273-278.

27- Lafon, J.M.; Pereira, E.D.; Macambira, E.M.B.; Vale, A.G.; Barradas, J.A.da S. -1991- Geocronologia $\mathrm{Rb}-\mathrm{Sr}$ da região de São Felix do Xingu: resultados preliminares. Anais III Simpósio de Geologia da Amazónia. Belém/SBG, p. 21-35.

28- Tassinari, C.C.G.; Hirata, W.K.; Kawashita, K -1982- Geologic evolution of the Serra dos Carajás, Pará, Brazil. Revista Brasileira de Geociências 12(13):263-267.

29- Comentários sobre as determinações geocronológicas existentes na região dos Carajás. Relatório interno Cpgeo.

30- Wirth, K.R.; Gibbs, A.K.; Olszewski Jr, W.J. -1986- U-Pb ages of zircons from the Grão Pará Group and Serra dos Carajás Granite, Pará, Brazil. Revista Brasileira de Geociências, 16 (2):195-200.

31- Macambira, M.B.; Pereira, E.D.; Kawashita, K; Medeiros, H. de -1988Contribuição à históriaOtectono-termal da região da Serra das Andorinhas (SE do Pará) com base em dados geocronológicos. Anais $X X X V$ Congresso Brasileiro de Geologia, Belém/SBG. v.3, p. 1468-1477.

32- Montalvão, R.M.G.; Tassinari, C.C.G.; Teixeira, W.; Vasconi, A.V.-1988Caracterização geocronológica $\mathrm{Rb}-\mathrm{Sr}$ dos terrenos granodioríticos e trondjemíticos da região de Rio Maria, sul da Serra dos Carajás. Anais $X X X V$ Congresso Brasileiro de Geologia, Belém/SBG. v.3, p. 1478-1487.

33- Gastal, M.C.P.; Macambira, M.J.B.; et al. -1987-Idades e Geoquímica isotópica Rb-Sr do granito Musa e do Granodiorito Rio Maria, Amazonia Oriental. Geochimica Brasilienses 1(2):247-259.

36- Basei, M.A.S.- 1974- Estudo geocronológico preliminar do magmatismo ácido da região meridional da amazônia. Anais XXVIII Congresso Brasileiro Geologia , v.6, p. 287-296, Porto Alegre.

37- Teixeira, W.; Basei, M.A.S.; Tassinari, C.C.G.-1976-Geocronologia das folhas Tumucumaque e Santarém. Apresentado no XXIX Cong. Bras. Geol.. Relatório CPGeo. 
38- Teixeira, W.; Basei, M.A.S.-1975- Geocronologia da folha NA.21Tumucumaque. Projeto RADAMBRASIL, Belém (relatório interno).

39- Teixeira, W.-1978- Significação Tectônica do Magmatismo Anorogénico Pré-Cambriano Básico e Alcalino na Região Amazônica. Anais do $X X X$ Cong. Bras. Geol., Recife, v.1, p.491-505.

40- Ferreira Filho, C.F.; Cordani, U.G.; Teixeira, W.; Danni, J.C.M. -1987Geochronology of the Bahia prospect copper deposit- Carajás ProvinceBrazil. Precambrian Evolution of the Amazonian Region. Final Meeting of working group. Project 204 IUGS/UNESCO. Extended Abstracts. Carajás, Pará. p.32-39.

41- Siga Junior, 0-1988- Caracterização geocronológica em parte do setor Centro Oriental do Cráton Amazônico. Projeto Carajás/Núcleo Marabá. IBGE. Relatório interno Cpgeo.

42- Gonçalvez, M.G.B.; Dall'Agnol, R.; Vieira, E.A.R.; Macambira, M.J.B.; Della Senta, N. - 1988- Geologia do Maciço Anorogênico Cigano, vale do rio Paraupebas- PA. Anais XXXV Congresso Brasileiro de Geologia/SBG. V.3, p. 1132-1146. Belém.

43- Teixeira, W.; Siga Jr., O.. Breves Comentários a respeito dos dados Radiométricos em Granulitos do Amapá ( relatório interno at CPGeo).

44- Duarte, K.D; Pereira, E.D.; Dall'Agnol, R; Lafon, J.M. - 1991- Geologia e geocronologia do granito Mata Surrão- Sudoeste de Rio Maria (PA). Anais III Simpósio Geologia Amazônia, Belém, Pará. p. 7-20.

45- Caracterização geocronológica dos granitos da Amazônia. Centro de Pesquisas Geocronológicas (relatório interno).

46- Almeida, F.F.M. de; Melcher, G.C.; Cordani, U.G.; Kawashita, K.; Vandoros, P.-1968- Radiometric age determinations from Northern Brazil. Centro de Pesquisas Geocronológicas USP.In: Boletim Sociedade Brasileira de Geologia, v.17(1): 3-14.

47- Projeto RADAMBRASIL-1978- Folha SA.20 Manaus. Levantamento dos Recursos Naturais. Geologia, Geomorfologia, Pedologia, Vegetação e Uso Potencial da terra, v.18, 628p, 7 mapas, R.J..

49- Santos, M.V.; Sousa Filho, E.E. de; Tassinari, C.C.G.; Teixeira, W.; Ribeiro, A.C.O.; Payolla, B.L.; Vasconi, A.V.-1988- Litoestratigrafia das rochas pré-Cambrianas na Bacia do Rio Médio Xingu - Altamira - PA. Anais VII Congresso Latino-Americano de Geologia, Belém, Pará, V.1. p.363-377.

50- Hasui, Y.; Tassinari, C.C.G.; Siga Jr., O; Teixeira, W.; Almeida, F.F.M. de; Kawashita, K. -1980- Datações Rb-Sr e K-Ar do Centro Norte do Brasil e seu 
significado Geológico-Geotectônico. Anais $X X X I$ Congresso Brasileiro de Geologia, Balneário de Camboriú, SC, v.5, p. 2659-2676.

51- Barros, A.M.; Alves, E.D. de O.; Araújo, J.F.V.; Lima, M.I.C. de; Fernandes, C.A.C.-1977- Projeto RADAMBRASIL. Folhas SB/SC 18 Javari/Contamana. Levantamento de Recursos Naturais, Geologia, Geomorfologia, Pedologia, Vegetação e Uso Potencial da Terra, v.13, 413 p., Rio de Janeiro.

52- Montalvão, R.M.G.; Tassinari, C.C.G.-1984- Geologia Pré-Cambriana do Território Federal do Amapá. // Symposium Amazonico, Manaus, p. 53-58.

53- Hasui, Y; Hennies,W.T.; I.W. - 1975- Idade Potássio-Argônio do precambriano da região do Centro-Norte do Brasil. Boletim do Instituto de Geociências. USP, v. 6 p. 77-83

54- Projeto RADAMBRASIL-1975- Levantamento dos Recursos Naturais, Geologia, Geomorfologia, Pedologia, Vegetação e Uso Potencial da terra, Folhas NA.21 Tumucumaque e parte da Folha NB 21, v.9, 370p, 6 mapas.

55- Basei, M.A.S.-1973- Geocronologia do Bloco III, Amapá. Belém (relatório interno do $\mathrm{CPGeo}$ ).

56- Abreu, A.S.; Guimarães, G.; Araújo, J.F.V.; Dall'Agnol, R.. Petrografia e Amostragem do Bloco B-III, Relatório Analítico. Relatório Interno RADAMBRASIL. (relatório interno at CPGeo).

57- Dados Petrobrás/ CPGeo.

58- Lafon, J.M.; Macambira, J.B.; Macambira, M.J.B.; Moura, C.A.V.; Gaudette, H.E.; Souza, A.C.C.-19 - A faixa de dobramentos Araguaia (TO), novos dados geocronológicos. In:

59- Araujo, H.J.T. de; Rodarte, J.B.M.; Del'Arco, J.O.; Santos, D.B. dos; Barros, A.M.; Tassinari, C.C.G.; Lima, M.I.C. de; Abreu, A.S.; Fernandes, C.A.C.-1978- Projeto RADAMBRASIL. Folha SB 20 Purus. Geologia, Geomorfologia, Pedologia, Vegetação e Uso Potencial da Terra, v.17, 566 p., 7 mapas, Brasília.

60- Projeto RADAMBRASIL.-1976- Levantamento de recursos naturais, Geologia, Geomorfologia, Pedologia, Vegetação e Uso Potencial da terra. Folha SC 19 Rio Branco, v.12., 464p, 7 mapas, Rio de Janeiro.

61- Tassinari, C.C.G.; Teixeira, W.; Siga Jr., O.-1978- Estudo geocronológico $\mathrm{Rb} / \mathrm{Sr}$ e K/Ar da Folha SD.20 Guaporé. (relatório interno)

62- Projeto RADAMBRASIL.-1982- Levantamento de recursos naturais, Geologia, Geomorfologia, Pedologia, Vegetação e Uso Potencial da terra. Folha SD.21 Cuiabá, v.26, 544p, 5 mapas, Rio de Janeiro. 
63- Projeto RADAMBRASIL. Levantamento de recursos naturais, Geologia, Geomorfologia, Pedologia, Vegetação e Uso Potencial da terra. Folha SB 21 Tapajós. (relatório interno)

64- Projeto RADAMBRASIL.-1977- Levantamento de recursos naturais, Geologia, Geomorfologia, Pedologia, Vegetação e Uso Potencial da terra. Folha SB/SC 18 Javari/Contamana, v.13, 420p., 7 mapas. Rio de Janeiro.

\section{5-}

66- Tassinari, C.C.G.; Cordani, U.G.; Nutman, A.P.; Van Schumus, M.R.; Bettencourt, J.S.; Taylor, P.N.-1996- Geochronogical Systematics on Basement Rocks from the Rio Negro-Juruena Province (Amazonian Craton), and tectonic implications. International Geology Review.

67- Carneiro, M.A.-1985- Contribuição à Geologia da Região de São José dos Quatro Marcos- MT. Dissertação de Mestrado, IGUSP. 156p.

68- Geraldes, M.C.-1996- Estudos Geoquímicos e isotópicos das mineralizações auriferas e rochas associadas da Região de Pontes de Lacerda (MT). Dissertação de Mestrado, IGcUNICAMP. 104p.

69- Listagem das determinações radiométricas $\mathrm{Rb}-\mathrm{Sr}$ e $\mathrm{K}-\mathrm{Ar}$ e mapa 1:2.500.000. (relatório interno)

70- Santos, D.B. dos; Fernandes, P.E.C.A.; Dreher, A.M.; Cunha, F.M.B. da; Basei, M.A.S.; Teixeira, J.B.G.-1975- Projeto RADAMBRASIL. Folha SB 21 Tapajós, v.7, 418 p., 6 mapas, R.J..

71- Relatório interno designado Docegeo-Terraservice (1973-1974). CPGeo. IGUSP.

72- Tassinari, C.C.G.; Teixeira, W.; Siga Jr., O.-1978- Considerações cronoestratigráficas da Região das Chapadas do Cachimbo e Dardanelos. In: Anais do XXX Congresso Brasileiro de Geologia, v.1, Recife, p. 477-490.

73- Projeto RADAMBRASIL.-1978- Levantamento de recursos naturais, Geologia, Geomorfologia, Pedologia, Vegetação e Uso Potencial da terra. Folha SC.20 Porto Velho. 668p., 7 mapas, Rio de Janeiro.

74- Priem, H.N.A.; Bon, E.H.; Verdumen, E.A.Th. and Bettencourt, J.S.-1989$\mathrm{Rb}-\mathrm{Sr}$ chronology of Precambrian crustal evolution in Rondonia (western margin of the Amazonian Craton), Brazil. In: Journal of South American Earth Sciences, vol.2, n.2, pp. 163-170.

75- Projeto RADAMBRASIL.-1979- Levantamento de recursos naturais, Geologia, Geomorfologia, Pedologia, Vegetação e Uso Potencial da terra. Folha SD.20 Guaporé, v. 19., 368p, 7 mapas, Rio de Janeiro. 
76- Iwanuch, W.-1981- Geologia da Região do Domo do Sucunduri. Dissertação de Mestrado, São Paulo. IGUSP.

77- Bettencourt, J.S.- 1992- Pesquisas Geológica, Metalogenética e Mineral no Cráton Amazônico (sistematização crítica de parte da obra no período compreeendido entre 1980 e 1992). Tese de livre-docência, São Paulo. IGUSP. 163p.

78- Tassinari, C.C.G.-1981- Evolução Geotectônica da Província Rio NegroJuruena na Região Amazônica. Dissertação de Mestrado. IGUSP. São Paulo, $99 p$.

79- Sato, $\mathrm{K}$ e Tassinari C.C.G.-1996- Principais eventos de acreção continental no Cráton Amazônico baseado em idade modelo Sm-Nd.

80- Vignol, L.M.-1987- Etudes geochimiques des granulites du Bresil et la zone d'lvree: Les elements ( $\mathrm{K}, \mathrm{Rb}, \mathrm{Sr}, \mathrm{Sm}, \mathrm{Nd})$ et les isotopes radiogeniques $(\mathrm{Sr}$ et $\mathrm{Nd}$ ). Diplome d'estudes approfondies de geochemie. Université Paris VII, Inst. de Physique du Globe de Paris.

81- Teixeira, W. e Tassinari, C.C.G.-1984- Caracterização geocronológica da Província Rondoniana e suas implicações geotectônicas. Anais II Symposium Amazônico, Manaus - AM. p. 87-101.

82- 


\section{APÊNDICE 2}

TABELAS DE DADOS ANALÍTICOS DAS AMOSTRAS

DATADAS

( SISTEMAS Rb - Sr; K - Ar; Sm - Nd; U - Pb; Pb - Pb) 


\begin{tabular}{|c|c|c|c|c|c|c|c|c|c|c|}
\hline Ordem & $\begin{array}{c}\mathrm{Rb} \\
(\mathrm{ppm})\end{array}$ & $\begin{array}{c}\mathrm{Sr} \\
(\mathrm{ppm})\end{array}$ & ${ }^{87} \mathrm{Rb} /{ }^{86} \mathrm{Sr}$ & ${ }^{87} \mathrm{Sr} /{ }^{86} \mathrm{Sr}$ & $\begin{array}{c}\text { Idade } \\
\text { (Ma) }\end{array}$ & Erro & $\mathrm{Ri}$ & Erro & MSWD & Observação \\
\hline$C 100.1$ & 120.67 & 531.6 & 0.658 & 0.726327 & 2677 & 50 & 0.70161 & 0.00022 & 5.21 & \\
\hline C 101.1 & 132.08 & 531.3 & 0.721 & 0.728929 & 2677 & 50 & 0.70161 & 0.00022 & 5.21 & \\
\hline C 102.1 & 128.19 & 512.5 & 0.725 & 0.729082 & 2677 & 50 & 0.70161 & 0.00022 & 5.21 & \\
\hline$C 103.1$ & 137.95 & 525.6 & 0.761 & 0.731929 & 2677 & 50 & 0.70161 & 0.00022 & 5.21 & \\
\hline$\overline{C 104.1}$ & 177.56 & 580.6 & 0.886 & 0.725946 & 2532 & 130 & 0.70198 & 0.00063 & 45.6 & \\
\hline C 104.2 & 178.14 & 576.5 & 0.896 & 0.726285 & 2532 & 130 & 0.70198 & 0.00063 & 45.6 & \\
\hline C 105.1 & 137.57 & 245.1 & 1.631 & 0.752064 & 2532 & 130 & 0.70198 & 0.00063 & 45.6 & \\
\hline C 106.1 & 11.23 & 168 & 0.193 & 0.710438 & 2739 & 23 & 0.70283 & 0.00019 & 1.54 & \\
\hline C 107.1 & 101.49 & 325.9 & 0.904 & 0.739808 & 2739 & 23 & 0.70283 & 0.00019 & 1.54 & \\
\hline C 108.1 & 182.83 & 263 & 2.026 & 0.784503 & 2739 & 23 & 0.70283 & 0.00019 & 1.54 & \\
\hline C 108.1 & 184.93 & 246.7 & 2.186 & 0.789847 & 2739 & 23 & 0.70283 & 0.00019 & 1.54 & \\
\hline C 110.1 & 194.46 & 242.1 & 2.344 & 0.793179 & 2739 & 23 & 0.70283 & 0.00019 & 1.54 & \\
\hline C 1111.1 & 206.47 & 252.2 & 2.389 & 0.797253 & 2739 & 23 & 0.70283 & 0.00019 & 7.54 & \\
\hline C 112.1 & 197.71 & 230.1 & 2.509 & 0.801659 & 2739 & 23 & 0.70283 & 0.00019 & 1.54 & \\
\hline C 113.1 & 230.63 & 212.8 & 3.172 & 0.828349 & 2739 & 23 & 0.70283 & 0.00019 & 1.54 & \\
\hline C 114.1 & 231.55 & 150.6 & 4.522 & 0.877513 & 2739 & 23 & 0.70283 & 0.00019 & 1.54 & \\
\hline C 115.1 & 255.87 & 133.8 & 5.641 & 0.905501 & 2739 & 23 & 0.70283 & 0.00019 & 1.54 & \\
\hline C 116.1 & 414.9 & 27.1 & 49.3 & 1.8804 & 1653 & 14 & 0.70823 & 0.0236 & 1.71 & \\
\hline C 117.1 & 437.26 & 12.4 & 154.3 & 5.8936 & 1653 & 14 & 0.70823 & 0.0236 & 1.71 & \\
\hline C 118.1 & 398.32 & 9.5 & 187.7 & 6.2291 & 1653 & 14 & 0.70823 & 0.0236 & 1.71 & \\
\hline C 118.2 & 501.88 & 9.9 & 223.7 & 6.0895 & 1653 & 14 & 0.70823 & 0.0236 & 1.71 & \\
\hline C 119.1 & 504.83 & 9 & 257.4 & 6.6517 & 1653 & 14 & 0.70823 & 0.0236 & 1.71 & \\
\hline C 120.1 & 495.89 & 8.5 & 283.5 & 7.5667 & 1653 & 14 & 0.70823 & 0.0236 & 1.71 & \\
\hline C 121.1 & 494.69 & 6.2 & 507.4 & 12.9293 & 1653 & 14 & 0.70823 & 0.0236 & 1.71 & \\
\hline C 122.1 & 549.51 & 6.6 & 551.8 & 13.8099 & 1653 & 14 & 0.70823 & 0.0236 & 1.71 & \\
\hline C 123.1 & 520.12 & 5.8 & 638 & 15.4959 & 1653 & 14 & 0.70823 & 0.0236 & 1.71 & \\
\hline C 124.1 & 600.39 & 6.7 & 659.3 & 16.5894 & 1653 & 14 & 0.70823 & 0.0236 & 1.71 & \\
\hline C $\{25.1$ & 545.01 & 6 & 681.6 & 16.9725 & 1653 & 14 & 0.70823 & 0.0236 & 1.71 & \\
\hline C 126.1 .1 & 109.3 & 59.3 & 5.41 & 0.9477 & 2700 & 150 & 0.717 & & & \\
\hline C 126.10 .1 & 108.6 & 152.2 & 2.08 & 0.7879 & 2700 & 150 & 0.717 & & & \\
\hline C 126.11 & 117 & 32 & 10.86 & 0.9725 & 2700 & 150 & 0.717 & & & \\
\hline C 126.12.1 & 131 & 31.8 & 12.44 & 1.1637 & 2700 & 150 & 0.717 & & & \\
\hline C 126.2 & 198.4 & 18.4 & 17.96 & 1.282 & 2700 & 150 & 0.717 & & & \\
\hline C 126.3 & 60.4 & 37 & 4.85 & 0.9763 & 2700 & 150 & 0.717 & & & \\
\hline C 126.4 & 125.8 & 70.8 & 5.22 & 0.8711 & 2700 & 150 & 0.717 & & & \\
\hline C 126.5 & 136.7 & 45.1 & 8.03 & 1.004 & 2700 & 150 & 0.717 & & & \\
\hline C 126.6 .1 & 127.7 & 45.5 & 8.4 & 1.05 & 2700 & 150 & 0.717 & & & \\
\hline C 126.7 & 13.5 & 47.9 & 0.82 & 0.7506 & 2700 & 150 & 0.717 & & & \\
\hline C 126.8 & 114.2 & 43.4 & 7.77 & 0.0985 & 2700 & 150 & 0.717 & & & \\
\hline C 126.9 & 135.4 & 129.3 & 3.07 & 0.8306 & 2700 & 150 & 0.717 & & & \\
\hline C 127.1 & 83.1 & 354.3 & 0.68 & 0.7268 & 2750 & & 0.701 & & & \\
\hline C 128.1 & 145.3 & 395.7 & 1.07 & 0.7471 & 2750 & & 0.701 & & & \\
\hline C 129.1 & 217.5 & 160.3 & 3.99 & 0.8599 & 2750 & & 0.701 & & & \\
\hline C 130.1 & 246.6 & 115.9 & 6.22 & 0.9347 & 2750 & & 0.701 & & & \\
\hline C 131.1 & 315.5 & 150.9 & 6.18 & 0.9116 & 2750 & & 0.701 & & & \\
\hline C 135.1 & 197.5 & 34.9 & 17.12 & 1.1641 & 1700 & 45 & 0.7104 & 0.0028 & & \\
\hline C 136.1 & 204.6 & 43.3 & 14.16 & 1.0601 & 1700 & 45 & 0.7104 & 0.0028 & & \\
\hline C 137.1 & 196.4 & 220 & 2.6 & 0.7756 & 1700 & 45 & 0.7104 & 0.0028 & & \\
\hline C149.1 & 7.11 & 3253 & 6 & 0.715798 & 1798 & 16 & 0.7129 & 14 & 1.7 & \\
\hline C 150.1 & 68.9 & 1037.2 & 0.192 & 0.717839 & 1798 & 16 & 0.7129 & 14 & 1.7 & \\
\hline C 151.1 & 77.94 & 330.5 & 0.684 & 0.730863 & 1798 & 16 & 0.7129 & 14 & 1.7 & \\
\hline
\end{tabular}




\begin{tabular}{|c|c|c|c|c|c|c|c|c|c|c|}
\hline Ordem & $\begin{array}{c}\mathbf{R b} \\
(\mathrm{ppm})\end{array}$ & $\begin{array}{c}\mathrm{sr} \\
(\mathrm{ppm})\end{array}$ & ${ }^{87} \mathrm{Rb} /{ }^{86} \mathrm{Sr}$ & ${ }^{87} \mathrm{Sr} r^{86} \mathrm{Sr}$ & $\begin{array}{c}\text { Idade } \\
\text { (Ma) }\end{array}$ & Erro & $\mathbf{R i}$ & Erro & MSWD & Observação \\
\hline C 152.1 & 126.9 & 450.7 & 0.817 & 0.733955 & 1798 & 16 & 0.7129 & 14 & 1.7 & \\
\hline C 153.1 & 25.27 & 86.78 & 0.845 & 0.734717 & 1798 & 16 & 0.7129 & 14 & 1.7 & \\
\hline C 154.1 & 37.79 & 7.18 & 15.847 & 1.1201 & 1798 & 16 & 0.7129 & 14 & 1.7 & \\
\hline C 155.1 & 840 & 15.75 & 253.6 & 7.2844 & 1798 & 16 & 0.7129 & 14 & 1.7 & \\
\hline C 157.1 & 28.58 & 564.1 & 0.147 & 0.709153 & 2564 & 126 & 0.7028 & 18 & & \\
\hline C 158.1 & 43.99 & 565.6 & 0.225 & 0.710444 & 2564 & 126 & 0.7028 & 18 & & \\
\hline C 159.1 & 44.67 & 427.7 & 0.302 & 0.7134 & 2564 & 126 & 0.7028 & 18 & & \\
\hline C 160.1 & 56.61 & 449.1 & 0.365 & 0.714911 & 2564 & 126 & 0.7028 & 18 & & \\
\hline C 161.1 & 101.4 & 733.3 & 0.401 & 0.718556 & 2564 & 126 & 0.7028 & 18 & & \\
\hline C 162.1 & 58.24 & 323.3 & 0.522 & 0.72238 & 2564 & 126 & 0.7028 & 18 & & \\
\hline C 163.1 & 135.4 & 572.3 & 0.689 & 0.73265 & 3100 & & 0.7 & & & \\
\hline C 163.2 & 122.4 & 586.3 & 0.605 & 0.72802 & 3100 & & 0.7 & & & \\
\hline C 163.3 & 149.5 & 556.3 & 0.78 & 0.73188 & 3100 & & 0.7 & & & \\
\hline C 163.4 & 150 & 588.1 & 0.74 & 0.73269 & 3100 & & 0.7 & & & \\
\hline C 164.1 & 114 & 646.5 & 0.511 & 0.72096 & 2675 & 65 & 0.7009 & 0.0006 & & \\
\hline C 165.1 & 77.7 & 517.4 & 0.435 & 0.71817 & 2400 & & & & & \\
\hline C 166.2 & 122.9 & 502.7 & 0.709 & 0.72787 & 2400 & & & & & \\
\hline C 167.1 & 45.9 & 521.9 & 0.255 & 0.71191 & 2680 & 60 & 0.7017 & 0.0002 & & \\
\hline C 168.1 & 48.2 & 878.5 & 0.149 & 0.70814 & 2680 & 60 & 0.7017 & 0.0002 & & \\
\hline C 169.1 & 57.6 & 536.4 & 0.311 & 0.71467 & 2680 & 60 & 0.7017 & 0.0002 & & \\
\hline C 170.1 & 47.3 & 575.1 & 0.238 & 0.71108 & 2680 & 60 & 0.7017 & 0.0002 & & \\
\hline C 171.1 & 43 & 506.8 & 0.246 & 0.71246 & 2680 & 60 & 0.7017 & 0.0002 & & \\
\hline C 172.1 & 51.2 & 513.7 & 0.289 & 0.71338 & 2680 & 60 & 0.7017 & 0.0002 & & \\
\hline C 172.2 & 40.1 & 561.2 & 0.207 & 0.7095 & 2680 & 60 & 0.7017 & 0.0002 & & \\
\hline C 172.3 & 99.7 & 580.4 & 0.498 & 0.72175 & 2680 & 60 & 0.7017 & 0.0002 & & \\
\hline C 173.1 & 105.1 & 544.1 & 0.56 & 0.7225 & 2400 & & & & & \\
\hline C 173.2 & 81.1 & 644.6 & 0.364 & 0.71735 & 2680 & 60 & 0.7017 & 0.0002 & 2.45 & \\
\hline C 174.1 & 115 & 594 & 0.558 & 0.723249 & 2564 & 68 & 0.70288 & 0.00092 & 2.45 & \\
\hline C 175.1 & 157 & 420 & 1.086 & 0.7431 & 2564 & 68 & 0.70288 & 0.00092 & 2.45 & \\
\hline C 176.1 & 192 & 335 & 1.671 & 0.76321 & 2564 & 68 & 0.70288 & 0.00092 & 2.45 & \\
\hline C 177.1 & 146 & 427 & 0.994 & 0.739161 & 2564 & 68 & 0.70288 & 0.00092 & 2.45 & \\
\hline C 178.1 & 185 & 344 & 1.564 & 0.761423 & 2564 & 68 & 0.70288 & 0.00092 & 2.45 & \\
\hline C 179.1 & 130 & 267 & 1.416 & 0.7421 & 1692 & 11 & 0.70777 & 0.00023 & 1.89 & \\
\hline C 18.1 & 79 & 130 & 1.776 & 0.77515 & 2687 & 54 & 0.7057 & 0.001 & & \\
\hline C 180.1 & 85 & 277 & 0.89 & 0.729149 & 1692 & 11 & $\begin{array}{l}0.70777 \\
\end{array}$ & 0.00023 & 1.89 & \\
\hline C 181.1 & 87 & 286 & 0.877 & 0.7293 & 1692 & 11 & 0.70777 & 0.00023 & 1.89 & \\
\hline C 182.1 & 241 & 152 & 4.628 & 0.820998 & 1692 & 11 & 0.70777 & 0.00023 & 1.89 & \\
\hline C 183.1 & 193 & 185 & 3.045 & 0.78259 & 1692 & 11 & 0.70777 & 0.00023 & 1.89 & \\
\hline C 184.1 & 168 & 250 & 1.955 & 0.754027 & 1692 & 11 & 0.70777 & 0.00023 & 1.89 & \\
\hline C 185.1 & 244 & 140 & 5.083 & 0.832077 & 1692 & 11 & 0.70777 & 0.00023 & 1.89 & \\
\hline C 185.2 & 203 & 67 & 8.97 & 0.930297 & 1692 & 11 & $\begin{array}{l}0.70777 \\
\end{array}$ & 0.00023 & 1.89 & \\
\hline C 186.1 & 200 & 177 & 3.291 & 0.788747 & 1692 & 11 & 0.70777 & 0.00023 & 1.89 & \\
\hline C 187.1 & 272 & 52 & 15.58 & 1.08056 & 1692 & 11 & 0.70777 & 0.00023 & 1.89 & \\
\hline C 188.1 & 217 & 46 & 13.9 & 1.0445 & 1692 & 71 & 0.70777 & 0.00023 & 1.89 & \\
\hline C 189.1 & 345.6 & 71.9 & 14.42 & 1.073 & 1791 & & 0.705 & & & \\
\hline C 19.1.1 & 20 & 79 & 0.7338 & 0.73456 & 2687 & 54 & 0.7057 & 0.001 & & \\
\hline C 19.2.1 & 18 & 112 & 0.4668 & 0.72214 & 2687 & 54 & 0.7057 & 0.001 & & \\
\hline C 19.3.1 & 78 & 99 & 2.282 & $\begin{array}{l}0.79817 \\
\end{array}$ & 2687 & 54 & 0.7057 & 0.001 & & \\
\hline C 19.4.1 & 36 & 127 & 0.8286 & 0.73841 & 2687 & 54 & 0.7057 & 0.001 & & \\
\hline C 19.5.1 & 41 & 131 & 0.9204 & 0.75241 & 2687 & 54 & 0.7057 & 0.001 & & \\
\hline C 190.1 & 246.3 & 48.6 & 15.2 & 1.09 & 1791 & & 0.705 & & & \\
\hline C 191.1 & 613 & 20.73 & 107.7 & 3.445 & 1791 & & 0.705 & & & \\
\hline
\end{tabular}




\begin{tabular}{|c|c|c|c|c|c|c|c|c|c|c|}
\hline Ordem & $\underset{(\mathrm{ppm})}{\mathrm{Rb}}$ & $\begin{array}{c}\mathrm{Sr} \\
(\mathrm{ppm})\end{array}$ & ${ }^{87} \mathrm{Rb} b^{86} \mathrm{Sr}$ & ${ }^{87} \mathrm{Sr} /{ }^{86} \mathrm{Sr}$ & $\begin{array}{c}\text { Idade } \\
\text { (Ma) }\end{array}$ & Erro & $\mathbf{R} \mathbf{i}$ & Erro & MSWD & Observação \\
\hline C 192.1 & 40.6 & 12 & 10.878 & 1.0916 & 2330 & 60 & 0.715 & 0.03 & & \\
\hline C 192.10 & 128 & 46.8 & 8.17 & 1.0335 & 2577 & 72 & 0.702 & 0.01 & & \\
\hline C 192.11 & 83.5 & 59.7 & 4.106 & 0.8529 & 2577 & 72 & 0.702 & 0.01 & & \\
\hline C 192.2 & 89.7 & 9.4 & 29.673 & 1.6881 & 2330 & 60 & 0.715 & 0.03 & & \\
\hline C 192.3 & 34.1 & 14 & 8.105 & 0.9964 & 2330 & 60 & 0.715 & 0.03 & & \\
\hline C 192.4 & 41.5 & 10.2 & 13.098 & 1.1511 & 2330 & 60 & 0.715 & 0.03 & & \\
\hline C 192.5 & 19.2 & 21.7 & 2.332 & 0.7904 & 2330 & 60 & 0.715 & 0.03 & & \\
\hline C 192.6 & 53.9 & 20.5 & 14.895 & 1.2393 & 2330 & 60 & 0.715 & 0.03 & & \\
\hline C 192.7 & 7.4 & 25.7 & 2.01 & 0.7893 & 2330 & 60 & 0.715 & 0.03 & & \\
\hline C 192.8 & 66.4 & 98.2 & 1.97 & 0.7734 & 2577 & 72 & 0.702 & 0.01 & & \\
\hline C 192.9 & 58.7 & 104.7 & 1.631 & 0.7617 & 2577 & 72 & 0.702 & 0.01 & & \\
\hline C 193.1 & & & & & 2700 & & 0.7018 & & & \\
\hline C 193.2 & & & & & 2700 & & 0.7018 & & & \\
\hline C 193.3 & & & & & 2700 & & 0.7018 & & & \\
\hline C 193.4 & & & & & 2700 & & 0.7018 & & & \\
\hline C 194.1 & & & & & 2670 & 115 & 0.7003 & 0.0009 & & \\
\hline C 194.2 & & & & & 2670 & 115 & 0.7003 & 0.0009 & & \\
\hline C 194.3 & & & & & 2670 & 115 & 0.7003 & 0.0009 & & \\
\hline C 194.4 & & & & & 2670 & 115 & 0.7003 & 0.0009 & & \\
\hline C 195.1 & & & & & 2600 & & 0.704 & & & \\
\hline C 195.2 & & & & & 2600 & & 0.704 & & & \\
\hline C 195.3 & & & & & 2600 & & 0.704 & & & \\
\hline C 195.4 & & & & & 2600 & & 0.704 & & & \\
\hline C 195.5 & & & & & 2600 & & 0.704 & & & \\
\hline C 195.7 & 130.3 & 205.4 & 0.63 & 1.843 & 1731 & 28 & 0.70697 & 0.0008 & 2.6 & \\
\hline C 196.1 & & & & & 2220 & 112 & 0.7201 & 0.0081 & 9.49 & \\
\hline C 196.2 & & & & & 2220 & 112 & 0.7201 & 0.0081 & 9.49 & \\
\hline C 196.3 & & & & & 2220 & 112 & 0.7201 & 0.0081 & 9.49 & \\
\hline C 196.4 & & & & & 2220 & 112 & 0.7201 & 0.0081 & 9.49 & \\
\hline C 196.5 & & & & & 2220 & 112 & 0.7201 & 0.0081 & 9.49 & \\
\hline C 197.1 & 86.2 & 212 & 1.18 & 0.735664 & 1731 & 28 & 0.70697 & 0.0081 & 2.6 & \\
\hline C 197.2 & 94 & 182 & 1.5 & 0.74486 & 1731 & 28 & 0.70697 & 0.0081 & 2.6 & \\
\hline C 197.3 & 142.6 & 184 & 2.256 & 0.764027 & 1731 & 28 & 0.70697 & 0.0081 & 2.6 & \\
\hline C 197.4 & 165.2 & 168 & 2.865 & 0.778002 & 1731 & 28 & 0.70697 & 0.0081 & 2.6 & \\
\hline C 197.5 & 169.1 & 112.1 & 4.41 & 0.816191 & 1731 & 28 & 0.70697 & 0.0081 & 2.6 & \\
\hline C 198.1 & 127.94 & 174.4 & 2.139 & 0.791049 & 2541 & 74 & 0.71049 & 0.00343 & 2.8 & ponto fora da isócrona \\
\hline C 198.2 & 178.12 & 222.4 & 2.337 & 0.793506 & 2541 & 74 & 0.71049 & 0.00343 & 2.8 & ponto fora da isócrona \\
\hline C 198.3 & 176.36 & 160.5 & 3.217 & 0.826443 & 2541 & 74 & 0.71049 & 0.00343 & 2.8 & ponto fora da isócrona \\
\hline C 198.4 & 239.11 & 172 & 4.085 & 0.866458 & 2541 & 74 & 0.71049 & 0.00343 & 2.8 & ponto fora da is 6 crona \\
\hline C 198.5 & 208.03 & 104.9 & 5.854 & 0.918841 & 2541 & 74 & 0.71049 & 0.00343 & 2.8 & ponto fora da isócrona \\
\hline $\bar{C} 198.6$ & 267.04 & 106.6 & 7.447 & 0.987429 & 2541 & 74 & 0.71049 & 0.00343 & 2.8 & ponto fora da isócrona \\
\hline C 198.7 & 268.2 & 104.1 & 7.661 & 0.993752 & 2541 & 74 & 0.71049 & 0.00343 & 2.8 & ponto fora da is 6 crona \\
\hline C 199.1 & 98.6 & 336.3 & 0.85 & 0.72823 & 1820 & 100 & 0.7062 & 0.002 & 2.555 & \\
\hline C 199.2 & 154 & 311.5 & 1.436 & 0.7419 & 1820 & 100 & 0.7062 & 0.002 & 2.555 & \\
\hline C 199.3 & 143 & 314.9 & 1.319 & 0.74089 & 1820 & 100 & 0.7062 & 0.002 & 2.555 & \\
\hline C 199.4 & 127 & 301.9 & 1.221 & 0.73935 & 1820 & 100 & 0.7062 & 0.002 & 2.555 & \\
\hline C 20.1.1 & 43 & 146 & 0.8604 & 0.74011 & 2687 & 54 & 0.7057 & 0.001 & & \\
\hline C 200.1 & 124.3 & 127.7 & 2.819 & 0.79405 & 1820 & 200 & 0.7197 & 0.001 & 0.1517 & \\
\hline C200.2 & 108.6 & 141.2 & 2.243 & 0.78315 & 1820 & 200 & 0.7197 & 0.001 & 0.1517 & \\
\hline$C 200.3$ & 119.3 & 126.1 & 2.76 & 0.79116 & 1820 & 200 & 0.7197 & 0.001 & 0.1517 & \\
\hline C200.4 & 109.5 & 123.5 & 2.571 & 0.7876 & 1820 & 200 & 0.7197 & 0.001 & 0.1517 & \\
\hline C200.5 & 102.2 & 132.5 & 2.251 & 0.77869 & 1820 & 200 & 0.7197 & 0.001 & 0.1517 & \\
\hline
\end{tabular}




\begin{tabular}{|c|c|c|c|c|c|c|c|c|c|c|}
\hline Ordem & $\begin{array}{c}\mathrm{Rb} \\
(\mathrm{ppm})\end{array}$ & $\begin{array}{c}\mathrm{Sr} \\
(\mathrm{ppm})\end{array}$ & ${ }^{87} \mathrm{Rb} /{ }^{86} \mathrm{Sr}$ & ${ }^{87} \mathrm{Sr} /{ }^{86} \mathrm{Sr}$ & $\begin{array}{c}\text { Idade } \\
\text { (Ma) }\end{array}$ & Erro & $\mathrm{Ri}$ & Erro & MSWD & Observação \\
\hline C 201.1 & & & 0.108 & 0.7064 & 1990 & 80 & 0.7032 & 0.0002 & 3.044 & \\
\hline C 201.2 & 25.4 & 650 & 0.121 & 0.70669 & 1990 & 80 & 0.7032 & 0.0002 & 3.044 & \\
\hline C201.3 & 41.9 & 526.7 & 0.23 & 0.71021 & 1990 & 80 & 0.7032 & 0.0002 & 3.044 & \\
\hline C201.4 & 42.2 & 593.7 & 0.206 & 0.7088 & 1990 & 80 & 0.7032 & 0.0002 & 3.044 & \\
\hline C201.5 & 48.9 & 534.5 & 0.265 & 0.71059 & 1990 & 80 & 0.7032 & 0.0002 & 3.044 & \\
\hline C 202.1 & 192.2 & 160.8 & 3.494 & 0.8084 & 1930 & 40 & 0.7116 & 0.0007 & 0.0857 & \\
\hline C 202.2 & 31.6 & 151.8 & 0.604 & 0.7284 & 1930 & 40 & 0.7116 & 0.0007 & 0.0857 & \\
\hline C 202.3 & 109.4 & 165.1 & 1.929 & 0.7651 & 1930 & 40 & 0.7116 & 0.0007 & 0.0857 & \\
\hline C202.4 & 114.7 & 145.6 & 2.295 & 0.7758 & 1930 & 40 & 0.7116 & 0.0007 & 0.0857 & \\
\hline C 202.5 & 114.4 & 132.9 & 2.51 & 0.7821 & 1930 & 40 & 0.7116 & 0.0007 & 0.0857 & \\
\hline C 21.1.1 & 48 & 7 & 22.25 & 1.48964 & 2497 & 62 & 0.7152 & 0.0052 & & \\
\hline C 210 & 0.8 & 2.8 & 2.81 & 0.7363 & 2000 & 75 & 0.702 & & & \\
\hline C 211.1 & 252.6 & 750 & 0.98 & 0.7321 & 2000 & 75 & 0.702 & & & \\
\hline C 211.2 & 107.6 & 815 & 0.38 & 0.8153 & 2000 & 75 & 0.702 & & & \\
\hline C212 & 84 & 326 & 0.75 & 0.7242 & 2000 & 75 & 0.702 & & & \\
\hline C 213 & 122.8 & 298.4 & 1.19 & 0.7336 & 2000 & 75 & 0.702 & & & \\
\hline C214 & 176.4 & 109.6 & 4.72 & 0.8433 & 2000 & 75 & 0.702 & & & \\
\hline C218 & & & 0.4 & 0.7172 & 1860 & 21 & 0.705 & & & \\
\hline C219.1 & 116.1 & 71.7 & 4.74 & 0.8199 & 1700 & 45 & 0.71 & & & \\
\hline C219.2 & 104.2 & 120.3 & 2.52 & 0.7718 & 1700 & 45 & 0.71 & & & \\
\hline C22.1 & 62 & 12 & 16.39 & 1.2998 & 2497 & 62 & 0.7152 & 0.0052 & & \\
\hline C 227.1 & 697 & 10 & 288.94 & \begin{tabular}{l|l|}
5.0928 \\
\end{tabular} & 1060 & 14 & 0.719 & & & \\
\hline C 227.2 & 78.6 & 329.1 & 0.69 & 0.7302 & 1060 & 14 & 0.719 & & & \\
\hline C 23.1.1 & 101 & 130 & 2.274 & 0.79519 & 2687 & 54 & 0.7057 & 0.001 & & \\
\hline C 24.1.1 & 120 & 155 & 2.27 & \begin{tabular}{|c|}
0.79237 \\
\end{tabular} & 2497 & 62 & 0.7152 & 0.0052 & & \\
\hline C 30.1 & 338 & 17.8 & 54.4 & 2.089 & 1760 & & 0.715 & & & \\
\hline C 31.1 & 199 & 38.7 & 14.84 & 1.061 & 1760 & & 0.715 & & & \\
\hline C 32.1 & 447 & 2.63 & 472 & 10.41 & 1760 & & 0.715 & & & \\
\hline C 33.1 & 310 & 68.5 & 13.8 & 1.093 & 2029 & 21 & 0.7025 & & & \\
\hline C 33.2 & 119 & 115 & 3.05 & 0.7885 & 2029 & 21 & 0.7025 & & & \\
\hline C 33.3 & 32.4 & 90.8 & 1.048 & 0.7303 & 2029 & 21 & 0.7025 & & & \\
\hline C 34.1 & 120 & 247 & 1.424 & 0.7407 & 2029 & 21 & 0.7025 & & & \\
\hline C 34.2 & 56.5 & 268 & 0.618 & $\begin{array}{l}0.7132 \\
\end{array}$ & 2029 & 21 & 0.7025 & & & \\
\hline C 34.3 & 36.4 & 178.1 & 0.6 & 0.7186 & 2029 & 21 & 0.7025 & & & \\
\hline C 35.1 & 60.8 & 186.9 & 0.961 & 0.733 & 2029 & 21 & 0.7025 & & & \\
\hline C 36.1 & 83.8 & 286 & \begin{tabular}{c|}
0.85 \\
\end{tabular} & 0.7289 & 2029 & 21 & 0.7025 & & & \\
\hline C 56.1 & 105.9 & 79.8 & 3.892 & 0.84336 & 2480 & 40 & 0.7072 & 0.00023 & 0.3342 & \\
\hline C 57.1 & 86.1 & 111 & 2.263 & 0.789 & 2480 & 40। & 0.7072 & 0.00023 & 0.3342 & \\
\hline C 58.1 & 156.2 & 64.7 & 7.163 & 0.96277 & 2480 & 40 & 0.7072 & 0.00023 & 0.3342 & \\
\hline C 58.2 & 145.6 & 64.7 & 6.666 & 0.94635 & 2480 & 40 & 0.7072 & 0.00023 & 0.3342 & \\
\hline C 58.3 & 155.4 & 63 & 7.326 & 0.97304 & 2480 & 40 & 0.7072 & 0.00023 & 0.3342 & \\
\hline C 59.1 & 185.9 & 386.9 & 1.397 & 0.75586 & 2660 & 40 & 0.7009 & 0.0004 & 0.335 & \\
\hline C 60.1 & 148.6 & 381.2 & 1.132 & 0.74371 & 2660 & 40 & 0.7009 & 0.0004 & 0.335 & \\
\hline C61.1 & 191.2 & 340.2 & 1.636 & 0.76424 & 2660 & 40 & 0.7009 & 0.0004 & 0.335 & \\
\hline C 62.1 & 155.2 & 504.4 & 0.893 & 0.73473 & 2660 & 40 & 0,7009 & 0.0004 & 0.335 & \\
\hline C 63.1 & 91.9 & 527.4 & 0.505 & 0.7205 & 2660 & 40 & 0.7009 & 0.0004 & 0.335 & \\
\hline C 63.2 & 87.9 & 570.7 & 0.446 & 0.71833 & 2660 & 40 & 0.7009 & 0.0004 & 0.335 & \\
\hline C 63.3 & 88.4 & 615.7 & 0.416 & 0.71672 & 2660 & 40 & 0.7009 & 0.0004 & 0.335 & \\
\hline C 64.1 & 124.6 & 33 & 0.9794 & 0.9794 & 1756 & 72 & 0.7058 & 0.00031 & 1.038 & \\
\hline C 65.1 & 168.1 & 23.5 & 1.174 & 1.174 & 1756 & 72 & 0.7058 & 0.00031 & 1.038 & \\
\hline C 66.1 & 213.5 & 20.1 & 1.449 & 1.449 & 1756 & 72 & 0.7058 & 0.00031 & 1.038 & \\
\hline C 67.1.1 & & & 0.382 & \begin{tabular}{l|l}
0.7142 \\
\end{tabular} & 1756 & 72 & 0.7058 & 0.00031 & 1.038 & \\
\hline
\end{tabular}




\begin{tabular}{|c|c|c|c|c|c|c|c|c|c|c|}
\hline Ordem & $\begin{array}{c}\mathbf{R b} \\
(\mathrm{ppm})\end{array}$ & $\begin{array}{c}\mathrm{Sr} \\
(\mathrm{ppm})\end{array}$ & ${ }^{87} \mathrm{Rb} /{ }^{88} \mathrm{Sr}$ & ${ }^{87} \mathrm{Sr} /{ }^{86} \mathrm{Sr}$ & $\begin{array}{c}\text { Idade } \\
\text { (Ma) }\end{array}$ & Erro & $\mathbf{R i}$ & Erro & MSWD & Observação \\
\hline C 68.1.1 & & & 2.21 & 0.7598 & 1756 & 72 & 0.7058 & 0.00031 & 1.038 & \\
\hline C 69.1.1 & & & 7.6 & 0.8957 & 1756 & 72 & 0.7058 & 0.00031 & 1.038 & \\
\hline C 74.1 & 76 & 606 & 0.361 & 0.716421 & 2543 & 53 & 0.70311 & 0.00034 & 1.87 & \\
\hline C 74.2 & 76 & 635 & 0.347 & 0.715909 & 2543 & 53 & 0.70311 & 0.00034 & 1.87 & \\
\hline C 74.3 & 87 & 463 & 0.546 & 0.723022 & 2543 & 53 & 0.70311 & 0.00034 & 1.87 & \\
\hline C 74.4 & 79 & 607 & 0.377 & 0.716573 & 2543 & 53 & 0.70311 & 0.00034 & 1.87 & \\
\hline C 74.5 & 81 & 534 & 0.441 & 0.719197 & 2543 & 53 & 0.70311 & 0.00034 & 1.87 & \\
\hline C 74.6 & 88 & 453 & 0.561 & 0.723954 & 2543 & 53 & 0.70311 & 0.00034 & 1.87 & \\
\hline C 76.1 & 36 & 41 & 2.56 & 0.79523 & 2527 & 34 & 0.7018 & 0.00197 & 1.5 & \\
\hline C 77.1 & 124 & 141 & 2.57 & 0.79691 & 2527 & 34 & 0.7018 & 0.00197 & 1.5 & \\
\hline C 78.1 & 104 & 83 & 3.68 & 0.82206 & 2527 & 34 & 0.7018 & 0.00197 & 1.5 & \\
\hline C 79.1 & 128 & 90 & 4.21 & 0.8714 & 2527 & 34 & 0.7018 & 0.00197 & 1.5 & \\
\hline C 80.1 & 74 & 45 & 4.83 & 0.87725 & 2527 & 34 & 0.7018 & 0.00197 & 1.5 & \\
\hline C 81.1 & 158 & 73 & 6.39 & 0.92824 & 2527 & 34 & 0.7018 & 0.00197 & 1.5 & \\
\hline C 82.1 & 179 & 70 & 7.65 & 0.98497 & 2527 & 34 & 0.7018 & 0.00197 & 1.5 & \\
\hline C 83.1 & 98 & 32 & 9.02 & 1.00001 & 2527 & 34 & 0.7018 & 0.00197 & 1.5 & \\
\hline C 84.1 & 237 & 75 & 9.4 & 1.03888 & 2527 & 34 & 0.7018 & 0.00197 & 1.5 & \\
\hline C 85.1 & 209 & 51 & 12.5 & 1.16938 & 2527 & 34 & 0.7018 & 0.00197 & 1.5 & \\
\hline C 86.1 & 269 & 57 & 14.32 & 1.23327 & 2527 & 34 & 0.7018 & 0.00197 & 1.5 & \\
\hline C 88.1 & 72.57 & 630.7 & 0.333 & 0.716823 & 2574 & 57 & 0.70416 & 0.00054 & 5.06 & \\
\hline C 89.1 & 120.7 & 602 & 0.581 & 0.724329 & 2574 & 57 & 0.70416 & 0.00054 & 5.06 & \\
\hline C 90.1 & 97.32 & 363.4 & 0.777 & 0.733559 & 2574 & 57 & 0.70416 & 0.00054 & 5.06 & \\
\hline C 91.1 & 150.18 & 178.1 & 2.461 & 0.798738 & 2574 & 57 & 0.70416 & 0.00054 & 5.06 & \\
\hline C 92.1 & 185.53 & 196.1 & 2.763 & 0.803815 & 2574 & 57 & 0.70416 & 0.00054 & 5.06 & \\
\hline C 93.1 & 176.1 & 125.3 & 4.129 & 0.859979 & 2574 & 57 & 0.70416 & 0.00054 & 5.06 & \\
\hline C 94.1 & 195.73 & 128.3 & 4.482 & 0.86903 & 2574 & 57 & 0.70416 & 0.00054 & 5.06 & \\
\hline C 95.1 & 48.39 & 2504.9 & 0.056 & 0.703833 & 2574 & 57 & 0.70416 & 0.00054 & 5.06 & \\
\hline C 96.1 & 65.33 & 1015.1 & 0.186 & 0.708804 & 2677 & 50 & 0.70161 & 0.00022 & 5.21 & \\
\hline C 97.1 & 86.96 & 918.1 & 0.274 & 0.711911 & 2677 & 50 & 0.70161 & 0.00022 & 5.21 & \\
\hline C98.1 & 90.59 & 633.1 & 0.414 & 0.718736 & 2677 & 50 & 0.70161 & 0.00022 & 5.21 & \\
\hline C 99.1 & 121.17 & 581.5 & 0.604 & 0.725087 & 2677 & 50 & 0.70161 & 0.00022 & 5.21 & \\
\hline CB 10 & 95 & 139.4 & 1.98 & 0.7452 & 1415 & 85 & 0.705 & & & idade convencional \\
\hline CB 105.1 & & & 0.424 & 0.70956 & 1567 & 31 & 0.70202 & 0.00008 & 15.37 & \\
\hline $\mathrm{CB} 105.2$ & & & 0.212 & 0.70653 & 1567 & 31 & 0.70202 & 0.00008 & 15.37 & \\
\hline CB 105.3 & & & 1.494 & 0.73782 & 1567 & 31 & 0.70202 & 0.00008 & 15.37 & \\
\hline CB 105.4 & & & 0.151 & 0.70542 & 1567 & 31 & 0.70202 & 0.00008 & 15.37 & \\
\hline CB 105.5 & & & 0.064 & 0.70339 & 1567 & 31 & 0.70202 & 0.00008 & 15.37 & \\
\hline CB 105.6 & & & 0.318 & 0.70857 & 1567 & 31 & 0.7020 & 0.00008 & 15.37 & \\
\hline CB 106.1 & & & 66.33 & 1.76038 & 1064 & 20 & 0.73847 & 0.01413 & 3.081 & \\
\hline CB 106.2 & & & 49.697 & 1.53572 & 1064 & 20 & 0.73847 & 0.01413 & 3.081 & \\
\hline CB 106.3 & & & 31.601 & 1.23543 & 1064 & 20 & 0.73847 & 0.01413 & 3.081 & \\
\hline CB 106.4 & & & 86.114 & 2.12611 & 1064 & 20 & 0.73847 & 0.01413 & 3.081 & \\
\hline CB 106.5 & & & 69.991 & 1.82468 & 1064 & 20 & 0.73847 & 0.01413 & 3.081 & \\
\hline CB 107.1 & & & 0.249 & 0.70894 & 1917 & 78 & 0.70208 & 0.00022 & 7.1868 & \\
\hline $\mathrm{CB} 107.2$ & & & 0.248 & 0.70842 & 1917 & 78 & 0.70208 & 0.00022 & 7.1868 & \\
\hline CB 107.3 & & & 0.213 & 0.70759 & 1917 & 78 & 0.70208 & 0.00022 & 7.1868 & \\
\hline CB 107.4 & & & 0.150 & 0.70616 & 1917 & 78 & 0.70208 & 0.00022 & 7.1868 & \\
\hline CB 108.1 & & & 0.649 & 0.71557 & 1449 & 65 & 0.70326 & 0.00049 & 3.372 & \\
\hline CB 108.2 & & & 0.844 & 0.72018 & 1449 & 65 & 0.70326 & 0.00049 & 3.372 & \\
\hline CB 108.3 & & & 0.370 & 0.71075 & 1449 & 65 & 0.70326 & 0.00049 & 3.372 & \\
\hline $\mathrm{CB} 108.4$ & & & 0.665 & 0.71725 & 1449 & 65 & 0.70326 & 0.00049 & 3.372 & \\
\hline $\mathrm{CB} 11$ & 72.8 & 100.2 & 2.11 & 0.7499 & 1481 & 84 & 0.705 & & & idade convencional \\
\hline
\end{tabular}




\begin{tabular}{|c|c|c|c|c|c|c|c|c|c|c|}
\hline Ordem & $\begin{array}{c}\mathbf{R b} \\
(\mathrm{ppm})\end{array}$ & $\underset{(\mathrm{ppm})}{\mathrm{Sr}}$ & ${ }^{87} \mathrm{Rb} /{ }^{89} \mathrm{Sr}$ & ${ }^{87} \mathrm{Sr} /^{86} \mathrm{Sr}$ & $\begin{array}{c}\text { Idade } \\
\text { (Ma) }\end{array}$ & Erro & $\mathbf{R i}$ & Erro & MSWD & Observação \\
\hline $\mathrm{CB} 12$ & 149.6 & 8.5 & 54.5 & 1.677 & 1241 & 37 & 0.705 & & & idade convencional \\
\hline CB 13 & 113.4 & 315.7 & 1.04 & 0.7213 & 1430 & 69 & 0.701 & 0.001 & & \\
\hline CB 14 & 187.9 & 785.7 & 0.69 & 0.7121 & 1430 & 69 & 0.701 & 0.001 & & \\
\hline CB 15 & 173.1 & 581 & 0.86 & 0.7158 & 1430 & 69 & 0.701 & 0.001 & & \\
\hline CB 16.1 & 293.8 & 25.8 & 35.878 & 1.4324 & 1430 & 69 & 0.701 & 0.001 & & \\
\hline CB 29 & 157.6 & 47.2 & 9.82 & 0.8644 & 1130 & 72 & 0.708 & 0.006 & & \\
\hline $\mathrm{CB} 30$ & 167.5 & 82.4 & 5.94 & 0.808 & 1130 & 72 & 0.708 & 0.006 & & \\
\hline CB 31 & 166 & 146 & 3.31 & 0.7602 & 1130 & 72 & 0.708 & 0.006 & & \\
\hline$C B 39$ & 251.5 & 300.7 & 2.42 & 0.7362 & 1018 & 76 & 0.704 & 0.003 & 1.6815 & \\
\hline CB 40 & 451.2 & 104.8 & 12.6 & 0.8586 & 835 & 32 & 0.705 & & & idade convencional \\
\hline CB 41.1 & 264.2 & 29.03 & 28.02 & 1.2867 & 1450 & & 0.705 & & & idade convencional \\
\hline CB 44 & 177.2 & 137.3 & 3.76 & 0.7665 & 484 & 19 & 0.743 & & 0.995 & \\
\hline CB 45 & 190.4 & 63.8 & 8.71 & 0.8028 & 484 & 19 & 0.743 & & 0.995 & \\
\hline CB 46 & 233.4 & 79.6 & 8.56 & 0.8019 & 484 & 19 & 0.743 & & 0.995 & \\
\hline CB 47 & 216.4 & 33.01 & 19.271 & 0.8739 & 484 & 19 & 0.743 & & 0.995 & \\
\hline CB 48 & 168 & 56.6 & 8.7 & 0.7813 & 547 & 5 & 0.711 & & & \\
\hline$C B 5$ & 95.2 & 441.9 & 0.62 & 0.7158 & 1430 & 69 & 0.701 & 0.001 & & \\
\hline CB 50 & 55 & 127 & 1.254 & 0.7212 & 547 & 5 & 0.711 & & & \\
\hline CB 54 & 291 & 16.71 & 49.9 & 1.062 & 500 & 4 & 0.709 & 0.002 & & \\
\hline CB 55 & 378 & 41.4 & 15.7 & 0.821 & 500 & 4 & 0.709 & 0.002 & & \\
\hline CB 56 & 382 & 69.7 & 26.7 & 0.901 & 500 & 4 & 0.709 & 0.002 & & \\
\hline CB 57 & 436 & 12.46 & 99.9 & 1.425 & 500 & 4 & 0.709 & 0.002 & & \\
\hline CB 6 & 110.6 & 344.8 & 0.93 & 0.7234 & 1430 & 69 & 0.701 & 0.001 & & \\
\hline CB 61.1 & 41.4 & 209 & 0.574 & 0.71816 & 1971 & 70 & 0.7017 & 0.0005 & 0.1875 & \\
\hline $\mathrm{CB} 61.2$ & 22 & 130.9 & 0.487 & 0.71551 & 1971 & 70 & 0.7017 & 0.0005 & 0.1875 & \\
\hline CB 61.3 & 32.2 & 172.5 & 0.541 & 0.71679 & 1971 & 70 & 0.7017 & 0.0005 & 0.1875 & \\
\hline CB 61.4 & 37.2 & 291.3 & 0.355 & 0.71177 & 1971 & 70 & 0.7017 & 0.0005 & 0.1875 & \\
\hline CB 61.5 & 41.1 & 202 & 0.589 & 0.7192 & 1971 & 70 & 0.7017 & 0.0005 & 0.1875 & \\
\hline $\mathrm{CB} 61.6$ & 31.2 & 140.8 & 0.641 & 0.71867 & 1971 & 70 & 0.7017 & 0.0005 & 0.1875 & \\
\hline $\mathrm{CB} 62$ & 124.9 & 123.3 & 2.948 & 0.76442 & 1472 & 19 & 0.7037 & 0.0004 & 0.282 & \\
\hline CB 63 & 94.6 & 412.6 & 0.664 & 0.71764 & 1472 & 19 & 0.7037 & 0.0004 & 0.282 & \\
\hline CB 64 & 118.2 & 107.4 & 3.206 & 0.77266 & 1472 & 19 & 0.7037 & 0.0004 & 0.282 & \\
\hline CB 65 & 104.8 & 347.4 & 0.874 & 0.72335 & 1734 & 226 & 0.7019 & 0.0008 & 0.7451 & \\
\hline CB 66 & 42.7 & 564 & 0.219 & 0.7076 & 1505 & 226 & 0.7019 & 0.0008 & 0.7451 & \\
\hline CB 67 & 45.9 & 722.2 & 0.184 & 0.70596 & 1505 & 226 & 0.7019 & 0.0008 & 0.7451 & \\
\hline CB 68 & 142 & 191.4 & 2.156 & 0.74911 & 1472 & 19 & 0.7037 & 0.0004 & 0.282 & \\
\hline $\mathrm{CB} 69$ & 131.5 & 243.2 & 1.569 & 0.73685 & 1472 & 19 & 0.7037 & 0.0004 & 0.282 & \\
\hline CB 70 & 133.9 & 290.2 & 1.493 & 0.7355 & 1472 & 19 & 0.7037 & 0.0004 & 0.282 & \\
\hline $\mathrm{CB} 8$ & 104 & 584.5 & 0.52 & 0.7134 & 1430 & 69 & 0.701 & 0.001 & & \\
\hline CB 83 & 206 & 28 & 25.2046 & 1.18962 & 1318 & 23 & 0.711 & 0.008 & 4.677 & \\
\hline CB 84 & 220 & 33 & 28.1245 & 1.234448 & 1318 & 23 & 0.711 & 0.008 & 4.677 & \\
\hline CB 85 & 253.31 & 42.92 & 17.639 & 1.04358 & 1318 & 23 & 0.711 & 0.008 & 4.677 & \\
\hline $\mathrm{CB} 86$ & 257.64 & 16 & 51.371 & 1.75314 & 1318 & 23 & 0.711 & 0.008 & 4.677 & \\
\hline CB 87 & 290.75 & 13.21 & 71.955 & 2.0288 & 1318 & 23 & 0.711 & 0.008 & 4.677 & \\
\hline CB 88 & 211.6 & 31.15 & 20.2043 & 1.10704 & 1257.5 & 125.8 & 0.711 & 0.036 & 152.644 & \\
\hline $\mathrm{CB} 89$ & 127.2 & 21.4 & 17.7445 & 1.04019 & 1257.5 & 125.8 & 0.711 & 0.036 & 152.644 & \\
\hline $\mathrm{CB} 9$ & 151.3 & 351.8 & 1.25 & 0.7293 & 1430 & 69 & 0.701 & 0.001 & & \\
\hline CB 90 & 220.6 & 30.6 & 21.6885 & 1.11711 & 1257.5 & 125.8 & 0.711 & 0.036 & 152.644 & \\
\hline $\mathrm{CB} 91$ & 210.6 & 30.6 & 20.6439 & 1.0937 & 1257.5 & 125.8 & 0.711 & 0.036 & 152.644 & \\
\hline CB 92 & 229.23 & 33.3 & 20.6636 & 1.0885 & 1257.5 & 125.8 & 0.711 & 0.036 & 152.644 & \\
\hline $\mathrm{CB} 93$ & 217.5 & 20.1 & 30.2935 & 1.15968 & 1257.5 & 125.8 & 0.711 & 0.036 & 152.644 & \\
\hline GP 1 & 169.1 & 52.1 & 9.55 & 0.8712 & 1225 & 40 & 0.701 & 0.0009 & 1.0509 & \\
\hline
\end{tabular}




\begin{tabular}{|c|c|c|c|c|c|c|c|c|c|c|}
\hline Ordem & $\underset{(\mathrm{ppm})}{\mathrm{Rb}}$ & $\begin{array}{c}\mathrm{Sr} \\
(\mathrm{ppm})\end{array}$ & ${ }^{87} \mathrm{Rb} /{ }^{86} \mathrm{Sr}$ & ${ }^{87} \mathrm{Sr} r^{86} \mathrm{Sr}$ & $\begin{array}{c}\text { Idade } \\
\text { (Ma) }\end{array}$ & Erro & RI & Erro & MSWD & Observação \\
\hline GP 11 & 170.7 & 94.1 & 5.29 & 0.7756 & 1018 & 76 & 0.704 & 0.003 & 1.6815 & \\
\hline GP 12 & 147.9 & 128.1 & 3.36 & 0.7478 & 1018 & 76 & 0.704 & 0.003 & 1.6815 & \\
\hline GP 13 & 170.5 & 222.2 & 2.23 & 0.7424 & 1018 & 76 & 0.704 & 0.003 & 1.6815 & \\
\hline GP 14 & 201.5 & 42.5 & 13.93 & 0.9043 & 1018 & 76 & 0.704 & 0.003 & 1.6815 & \\
\hline GP 15 & 121.7 & 45.9 & 7.75 & 0.8088 & 1018 & 76 & 0.704 & 0.003 & 1.6815 & \\
\hline GP 16 & 197.3 & 64.1 & 9.03 & 0.836 & 1018 & 76 & 0.704 & 0.003 & 1.6815 & \\
\hline GP 17.1 & 212 & 103.1 & 6 & 0.7915 & 1018 & 76 & 0.704 & 0.003 & 1.6815 & \\
\hline GP 17.2 & 174.8 & 108 & 4.72 & 0.7737 & 1018 & 76 & 0.704 & 0.003 & 1.6815 & \\
\hline GP 2 & 338.5 & 26.2 & 39.96 & 1.393 & 1225 & 40 & 0.701 & 0.0009 & 1.0509 & \\
\hline 11 & 214.1 & 106.2 & 5.915 & 0.8432 & 1645 & & 0.705 & & & idade convencional \\
\hline 110 & 162.2 & 341.6 & 1.379 & 0.7368 & 1769 & 18 & 0.703 & 0.001 & 0.0001 & \\
\hline 111 & 245.3 & 238.6 & 2.995 & 0.7712 & 1698 & 27 & 0.703 & 0.001 & & \\
\hline$\longdiv { 1 1 2 }$ & 176.7 & 340 & 1.51 & 0.7416 & 1698 & 27 & 0.703 & 0.001 & & \\
\hline 113 & 281.4 & 142.9 & 5.775 & 0.8378 & 1698 & 27 & 0.703 & 0.001 & & \\
\hline 114 & 204 & 144.4 & 4.13 & 0.8045 & 1698 & 27 & 0.703 & 0.001 & & \\
\hline 115 & 288 & 405.8 & 1.632 & 0.7427 & 1698 & 27 & 0.703 & 0.001 & & \\
\hline 116 & 204.4 & 154 & 3.875 & 0.7921 & 1698 & 27 & 0.703 & 0.001 & & \\
\hline 117 & 138.2 & 268.3 & 1.497 & 0.7422 & 1698 & 27 & 0.703 & 0.001 & & \\
\hline 118 & 226.2 & 214.3 & 3.078 & 0.7878 & 1698 & 27 & 0.703 & 0.001 & & \\
\hline 119 & 195.4 & 321.8 & 1.765 & 0.7457 & 1698 & 27 & 0.703 & 0.001 & & \\
\hline 12 & 251.1 & 68.9 & 10.805 & 0.9507 & 1568 & 26 & 0.705 & & & \\
\hline 120.1 & 252.1 & 232.9 & 3.156 & 0.7773 & 1698 & 27 & 0.703 & 0.001 & & \\
\hline 120.2 & 258.3 & 205.4 & 3.669 & 0.7842 & 1698 & 27 & 0.703 & 0.001 & & \\
\hline 120.3 & 288.9 & 198.6 & 4.249 & 0.797 & 1698 & 27 & 0.703 & 0.001 & & \\
\hline 120.4 & 289.8 & 214.3 & 3.947 & 0.788 & 1698 & 27 & 0.703 & 0.001 & & \\
\hline 120.5 & 268.5 & 222.1 & 3.542 & 0.7824 & 1698 & 27 & 0.703 & 0.001 & & \\
\hline 121 & 195.5 & 172.5 & 3.302 & 0.771 & 1408 & & 0.705 & & & idade convencional \\
\hline 122.1 & 214.4 & 250.6 & 2.49 & 0.7591 & 1268 & 24 & 0.714 & 0.0018 & & \\
\hline 123 & 253.7 & 517.3 & 1.424 & 0.7342 & 1268 & 24 & 0.714 & 0.0018 & & \\
\hline 124 & 308.3 & 119.3 & 7.591 & 0.855 & 1268 & 24 & 0.714 & 0.0018 & & \\
\hline 125 & 340.5 & 100.3 & 10.013 & 0.8966 & 1268 & 24 & 0.714 & 0.0018 & & \\
\hline 126 & 290.8 & 167.9 & 5.064 & 0.8062 & 1268 & 24 & 0.714 & 0.0018 & & \\
\hline 127 & 344.5 & 98.5 & 10.319 & 0.8997 & 1268 & 24 & 0.714 & 0.0018 & & \\
\hline 128 & 300.6 & 49.4 & 10.31 & 0.982 & 1036 & 32 & 0.715 & & & idade convencional \\
\hline 129 & 659.4 & 168.5 & 11.565 & 0.917 & 1268 & 24 & 0.714 & 0.0018 & & \\
\hline 13.1 & 104.9 & 255 & 1.193 & 0.7253 & 1198 & & 0.705 & & & idade convencional \\
\hline 130 & 352.3 & 105.5 & 9.866 & 0.9147 & 1364 & 23 & 0.722 & 0.0018 & & \\
\hline 131 & 303 & 112.5 & 7.929 & 0.8777 & 1364 & 23 & 0.722 & 0.0018 & & \\
\hline 32.1 & 141.6 & 106.7 & 3.877 & 0.7981 & 1364 & 23 & 0.722 & 0.0018 & & \\
\hline 133 & 384 & 189.9 & 5.929 & 0.8367 & 1364 & 23 & 0.722 & 0.0018 & & \\
\hline 134 & 336.6 & 156.8 & 6.301 & 0.8474 & 1364 & 23 & 0.722 & 0.0018 & & \\
\hline 135 & 241.9 & 89.7 & 7.94 & 0.8787 & 1541 & & 0.705 & & & idade convencional \\
\hline 36.1 & 115.5 & 135.8 & 2.476 & 0.7641 & 1498 & 30 & 0.71 & & & \\
\hline 136.2 & 116.3 & 52.8 & 6.465 & 0.8472 & 1498 & 30 & 0.71 & & & \\
\hline 136.3 & 193.7 & 33.8 & 17.197 & 1.076 & 1498 & 30 & 0.71 & & & \\
\hline 36.4 & 96.9 & 130 & 2.166 & 0.7542 & 1498 & 30 & 0.71 & & & \\
\hline 136.5 & 112 & 49.9 & 6.599 & 0.8553 & 1498 & 30 & 0.71 & & & \\
\hline 139 & 203.1 & 305 & 1.933 & 0.746736 & 1459 & 32 & 0.70631 & 0.00117 & 1.1 & \\
\hline 14.1 & 119.2 & 196.2 & 1.766 & 0.7458 & 1769 & 18 & 0.703 & 0.001 & 0.0001 & \\
\hline 140 & 204 & 248.9 & 2.382 & 0.755869 & 1459 & 32 & 0.70631 & 0.00117 & 1.1 & \\
\hline 141 & 210.8 & 251.2 & 2.441 & 0.75769 & 1459 & 32 & 0.70631 & 0.00117 & 1.1 & \\
\hline 142 & 323.3 & 222.5 & 4.24 & 0.793652 & 1459 & 32 & 0.70631 & 0.00117 & 1.1 & \\
\hline
\end{tabular}




\begin{tabular}{|c|c|c|c|c|c|c|c|c|c|c|}
\hline Ordem & $\begin{array}{c}\mathbf{R b} \\
(\mathrm{ppm})\end{array}$ & $\begin{array}{c}\mathrm{Sr} \\
(\mathrm{ppm})\end{array}$ & ${ }^{87} \mathrm{Rb} /{ }^{86} \mathrm{Sr}$ & ${ }^{87} \mathrm{Sr} /{ }^{86} \mathrm{Sr}$ & $\begin{array}{c}\text { Idade } \\
\text { (Ma) }\end{array}$ & Erro & $\mathbf{R i}$ & Erro & MSWD & Observação \\
\hline 143.1 & 248 & 260 & 2.717 & 0.762149 & 1459 & 32 & 0.70631 & 0.00117 & 1.1 & \\
\hline 143.2 & 248.2 & 217 & 3.318 & 0.776715 & 1459 & 32 & 0.70631 & 0.00117 & 1.1 & \\
\hline 144.1 & 197.7 & 290.4 & 1.98 & 0.7549 & 1775 & & 0.705 & & & idade convencional \\
\hline 145 & 307.7 & 116.3 & 7.784 & 0.87106 & 1502 & & 0.705 & & & idade convencional \\
\hline 146 & 306.9 & 118.2 & 7.637 & 0.869 & 1512 & & 0.705 & & & idade convencional \\
\hline 147 & 281.2 & 318.2 & 2.574 & 0.762 & 1559 & & 0.705 & & & idade convencional \\
\hline 15 & 112.6 & 451.6 & 0.723 & 0.7221 & 1769 & 18 & 0.703 & 0.001 & 0.0001 & \\
\hline 6.1 & 153.6 & 275.3 & 1.621 & 0.7411 & 1769 & 18 & 0.703 & 0.001 & 0.0001 & \\
\hline 160 & 23.2 & 110.2 & 0.61 & 0.7192 & 1620 & & 0.705 & & & idade convencional \\
\hline 161 & 797 & 39.8 & 61.62 & 1.3492 & 732 & & 0.705 & & & idade convencional \\
\hline 17.1 & 62.4 & 386.8 & 0.467 & 0.7156 & 1769 & 18 & 0.703 & 0.001 & 0.0001 & \\
\hline 8.1 & 215.7 & 118.3 & 5.346 & 0.8347 & 1769 & 18 & 0.703 & 0.001 & 0.0001 & \\
\hline 19.1 & 171.5 & 515.3 & 0.965 & 0.7265 & 1769 & 18 & 0.703 & 0.001 & 0.0001 & \\
\hline JA 1.1 & 132.3 & 204 & 1.878 & 0.7158 & 217 & 99 & 0.71 & & & \\
\hline JA 1.3 & 124.3 & 98.6 & 3.652 & 0.7187 & 168 & 53 & 0.71 & & & \\
\hline JA 2.1 & 146.9 & 59 & 7.31 & 0.8544 & 1425 & & 0.705 & & & idade convencional \\
\hline JR 1 & 145.5 & 105.4 & 4.038 & 0.8039 & 1728 & 44 & 0.701 & 0.0007 & 1.2111 & \\
\hline JR 10 & 55.9 & 173.3 & 0.935 & 0.7245 & 1728 & 44 & 0.701 & 0.0007 & 1.2111 & \\
\hline JR 100 & 137.3 & 308.7 & 1.29 & 0.7382 & 1700 & 21 & 0.705 & & & \\
\hline JR 101 & 110.1 & 262 & 1.22 & 0.7352 & 1700 & 21 & 0.705 & & & \\
\hline JR 102.1 & 163.5 & 365.2 & 1.3 & 0.7356 & 1700 & 21 & 0.705 & & & \\
\hline JR 102.2 & 186.5 & 159.5 & 3.41 & 0.7883 & 1700 & 21 & 0.705 & & & \\
\hline JR 102,3 & 140.9 & 345.6 & 1.18 & 0.7334 & 1700 & 21 & 0.705 & & & \\
\hline JR 103.1 & 121.8 & 476 & 0.74 & 0.7242 & 1700 & 21 & 0.705 & & & \\
\hline JR 103.2 & 155.8 & 142.7 & 3.18 & 0.7855 & 1700 & 21 & 0.705 & & & \\
\hline JR 104 & 132.1 & 372.9 & 1.03 & 0.7296 & 1700 & 21 & 0.705 & & & \\
\hline JR 105 & 204.4 & 177.9 & 3.35 & 0.7814 & 1680 & 13 & 0.705 & & & \\
\hline JR 106 & 114.9 & 477 & 0.7 & 0.7231 & 1800 & & 0.705 & & & \\
\hline JR 11 & 223.6 & 162.2 & 4.03 & 0.8056 & 1728 & 44 & 0.701 & 0.0007 & 1.2111 & \\
\hline JR 117 & 121.6 & 110.6 & 3.21 & 0.784 & 1641 & 14 & 0.7079 & 0.0008 & 0.1335 & \\
\hline JR 118 & 152 & 46.7 & 9.63 & 0.9339 & 1641 & 14 & 0.7079 & 0.0008 & 0.1335 & \\
\hline JR 119 & 123.4 & 119 & 3.02 & 0.7783 & 1641 & 14 & 0.7079 & 0.0008 & 0.1335 & \\
\hline JR 12.1 & 73.3 & 195.9 & 1.091 & 0.7275 & 1728 & 44 & 0.701 & 0.0007 & 1.2111 & \\
\hline JR 120 & 63.1 & 7.7 & 24.82 & 1.21 & 1447 & 15 & 0.7051 & 0.0014 & 0.4821 & \\
\hline JR 13 & 163.3 & 145.9 & 3.267 & 0.7896 & 1860 & 94 & 0.704 & 0.002 & 0.8483 & \\
\hline JR 14 & 112.8 & 232.5 & 1.409 & 0.7415 & 1860 & 94 & 0.704 & 0.002 & 0.8483 & \\
\hline JR 15 & 105.2 & 99 & 3.102 & 0.7914 & 1860 & 94 & 0.704 & 0.002 & 0.8483 & \\
\hline JR 16 & 354.6 & 77.1 & 13.789 & 1.0674 & 1860 & 94 & 0.704 & 0.002 & 0.8483 & \\
\hline JR 17 & 212.2 & 166 & 3.738 & 0.8076 & 1860 & 94 & 0.704 & 0.002 & 0.8483 & \\
\hline JR 18.1 & 180.1 & 338.4 & 1.55 & 0.7456 & 1860 & 94 & 0.704 & 0.002 & 0.8483 & \\
\hline JR 19 & 187.8 & 163.6 & 3.35 & 0.7856 & 1728 & 44 & 0.701 & 0.0007 & 1.2111 & \\
\hline JR 2.1 & 146.6 & 205 & 2.081 & 0.7563 & 1728 & 44 & 0.701 & 0.0007 & 1.2111 & \\
\hline$\sqrt{J R 20}$ & 199.3 & 48.8 & 12.16 & 0.9967 & 1728 & 44 & 0.701 & 0.0007 & 1.2111 & \\
\hline$J R 21.1$ & 120 & 315.3 & 1.104 & 0.7286 & 1728 & 44 & 0.701 & 0.0007 & 1.2111 & \\
\hline JR22 & 161.7 & 243.1 & 1.934 & 0.7499 & 1676 & 36 & 0.704 & 0.001 & 1.3532 & \\
\hline JR 23 & 76.6 & 73.9 & 3.021 & 0.7739 & 1676 & 36 & 0.704 & 0.001 & 1.3532 & \\
\hline JR 24 & 38.3 & 47.9 & 2.318 & 0.7485 & 1263 & 151 & 0.705 & & & idade convencional \\
\hline JR25 & 57.9 & 28.3 & 5.985 & 0.848 & 1676 & 36 & 0.704 & 0.001 & 1.3532 & \\
\hline$J R 26.1$ & 156.5 & 31.2 & 14.89 & 1.059 & 1676 & 36 & 0.704 & 0.001 & 1.3532 & \\
\hline JR 26.2 & 159.5 & 19.7 & 24.38 & 1.258 & 1676 & 36 & 0.704 & 0.001 & 1.3532 & \\
\hline JR 27 & 180.7 & 12 & 47.4 & 1.798 & 1676 & 36 & 0.704 & 0.001 & 1.3532 & \\
\hline$J R 28$ & 113.5 & 48.4 & 6.897 & 0.8669 & 1676 & 36 & 0.704 & 0.001 & 1.3532 & \\
\hline
\end{tabular}




\begin{tabular}{|c|c|c|c|c|c|c|c|c|c|c|}
\hline Ordem & $\begin{array}{c}\mathrm{Rb} \\
(\mathrm{ppm})\end{array}$ & $\begin{array}{c}\mathrm{sr} \\
(\mathrm{ppm})\end{array}$ & ${ }^{87} \mathrm{Rb} /{ }^{86} \mathrm{Sr}$ & ${ }^{87} \mathrm{Sr} /{ }^{86} \mathrm{Sr}$ & $\begin{array}{c}\text { Idade } \\
\text { (Ma) }\end{array}$ & Erro & RI & Erro & MSWD & Observação \\
\hline JR 29 & 75.2 & 31.9 & 6.9 & 0.8607 & 1676 & 36 & 0.704 & 0.001 & 1.3532 & \\
\hline JR 3.1 & 169.1 & 163.3 & 2.839 & 0.7738 & 1728 & 44 & 0.701 & 0.0007 & 1.2111 & \\
\hline$\sqrt{R 230.1}$ & 132.2 & 17.7 & 22.72 & 1.22 & 1676 & 36 & 0.704 & 0.001 & 1.3532 & \\
\hline JR 30.2 & 129.7 & 19.1 & 20.594 & 1.1882 & 1578 & 47 & 0.705 & & & idade convencional \\
\hline JR 31 & 169 & 88.6 & 6.589 & 0.8281 & 1676 & 36 & 0.704 & 0.001 & 1.3532 & \\
\hline JR 32 & 227.4 & 91.4 & 7.326 & 0.8792 & 1599 & 54 & 0.705 & & & idade convencional \\
\hline JR 33 & 243.4 & 22.3 & 33.638 & 1.4314 & 1453 & 36 & 0.705 & & & idade convencional \\
\hline JR 34.1 & 114.9 & 477 & 0.7 & 0.7231 & 1676 & 36 & 0.704 & 0.001 & 1.3532 & \\
\hline JR 35 & 141.7 & 527.9 & 0.78 & 0.7224 & 1676 & 36 & 0.704 & 0.001 & 1.3532 & \\
\hline JR 36 & 78.1 & 634.9 & 0.36 & 0.7105 & 1676 & 36 & 0.704 & 0.001 & 1.3532 & \\
\hline JR 37 & 156.5 & 51.8 & 8.97 & 1.0292 & 2416 & 52 & 0.705 & & & idade convencional \\
\hline JR 38 & 153.1 & 59.3 & 7.61 & 0.8893 & 1676 & 36 & 0.704 & 0.001 & 1.3532 & \\
\hline JR 39.1 & 62.1 & 333.1 & 0.64 & 0.7151 & 1676 & 36 & 0.704 & 0.001 & 1.3532 & \\
\hline JR 4.1 & 178.6 & 175.2 & 2.97 & 0.7774 & 1728 & 44 & 0.701 & 0.0007 & 1.2111 & \\
\hline JR 4.2 & 179.3 & 177.2 & 2.98 & 0.7792 & 1728 & 44 & 0.701 & 0.0007 & 1.2111 & \\
\hline JR 4.3 & 175.1 & 165.2 & 3.09 & 0.7707 & 1700 & 21 & 0.705 & & & \\
\hline JR 4.4 & 193.3 & 176.1 & 3.202 & 0.7823 & 1728 & 44 & 0.701 & 0.0007 & 1.2111 & \\
\hline JR 4.5 & 180.8 & 172.7 & 3.053 & 0.7816 & 1728 & 44 & 0.701 & 0.0007 & 1.2111 & \\
\hline JR 40 & 214.6 & 11.9 & 58.63 & 2.14 & 1676 & 36 & 0.704 & 0.001 & 1.3532 & \\
\hline JR 41 & 259.8 & 13.8 & 57.85 & 2.1579 & 1676 & 36 & 0.704 & 0.001 & 1.3532 & \\
\hline JR 42 & 153.9 & 135.2 & 3.322 & 0.7871 & 1676 & 36 & 0.704 & 0.001 & 1.3532 & \\
\hline JR 43 & 179.5 & 11.8 & 49.24 & 1.884 & 1676 & 36 & 0.704 & 0.001 & 1.3532 & \\
\hline$J R 44$ & 174.7 & 11.7 & 48.13 & 1.817 & 1676 & 36 & 0.704 & 0.001 & 1.3532 & \\
\hline JR 45 & 204.3 & 11 & 60.96 & 2.041 & 1676 & 36 & 0.704 & 0.001 & 1.3532 & \\
\hline$\sqrt{R} 46$ & 230.5 & 5.2 & 178.6 & 4.762 & 1676 & 36 & 0.704 & 0.001 & 1.3532 & \\
\hline$J R 47$ & 248 & 8.4 & 108.9 & 3.45 & 1695 & 45 & 0.705 & & & idade convencional \\
\hline$J R 48$ & 260.5 & 27.4 & 28.951 & 1.2318 & 1227 & 39 & 0.705 & & & idade convencional \\
\hline $\mathrm{JR} 49$ & 226.8 & 7.1 & 121 & 3.871 & 1766 & 50 & 0.705 & & & idade convencional \\
\hline JR 5 & 151.7 & 232.5 & 1.987 & 0.7499 & 1728 & 44 & 0.701 & 0.0007 & 1.2111 & \\
\hline JR 50 & 312.8 & 20 & 49.8 & 1.869 & 1602 & 30 & 0.707 & 0.001 & 1.043 & \\
\hline $\mathrm{JR} 51$ & 159.8 & 22.2 & 21.612 & 1.1971 & 1602 & 30 & 0.707 & 0.001 & 1.043 & \\
\hline JR 52 & 170.6 & 41.1 & 12.358 & 0.994 & 1602 & 30 & 0.707 & 0.001 & 1.043 & \\
\hline JR 53.1 & 357.8 & 15 & 78.919 & 2.2241 & 1302 & 35 & 0.705 & & & idade convencional \\
\hline JR 53.2 & 366.1 & 109.9 & 9.854 & 0.9274 & 1602 & 30 & 0.707 & 0.001 & 1.043 & \\
\hline JR 54 & 200.7 & 55.5 & 10.72 & 0.9552 & 1624 & 48 & 0.705 & & & \\
\hline JR 55 & 358 & 61.7 & 17.478 & 1.1169 & 1602 & 30 & 0.707 & 0.001 & 1.043 & \\
\hline JR 56 & 153.9 & 105.8 & 4.25 & 0.8009 & 1602 & 30 & 0.707 & 0.001 & 1.043 & \\
\hline JR 57 & 136.8 & 291.8 & 1.36 & 0.7376 & 1602 & 30 & 0.707 & 0.001 & 1.043 & \\
\hline JR 58 & 159.9 & 199.3 & 2.34 & 0.7613 & 1602 & 30 & 0.707 & 0.001 & 1.043 & \\
\hline$J R 59$ & 155.9 & 302.6 & 1.5 & 0.7408 & 1602 & 30 & 0.707 & 0.001 & 1.043 & \\
\hline JR 6 & 223.9 & 68.6 & 9.665 & 0.938 & 1728 & 44 & 0.701 & 0.0007 & 1.2111 & \\
\hline$J R 60$ & 164.1 & 388 & 1.15 & 0.7326 & 1602 & 30 & 0.707 & 0.001 & 1.043 & \\
\hline JR 61 & 200.7 & 87.8 & 6.72 & 0.8561 & 1602 & 30 & 0.707 & 0.001 & 1.043 & \\
\hline$\sqrt{R} 62$ & 179.8 & 56.5 & 9.42 & 0.9319 & 1602 & 30 & 0.707 & 0.001 & 1.043 & \\
\hline$J R 63$ & 161 & 14.3 & 34.826 & 1.4912 & 1602 & 30 & 0.707 & 0.001 & 1.043 & \\
\hline JR 64 & 289.6 & 35.1 & 25.238 & 1.28 & 1602 & 30 & 0.707 & 0.001 & 1.043 & \\
\hline JR 65 & 278.7 & 44.8 & 18.715 & 1.1028 & 1431 & 43 & 0.705 & & & idade convencional \\
\hline JR 66.1 & 249.7 & 14.4 & 54.31 & 1.673 & 1216 & 32 & 0.7038 & 0.0011 & 0.6373 & \\
\hline $\mathrm{JR} 66.2$ & 88.4 & 284.3 & 0.9 & 0.7202 & 1216 & 32 & 0.7038 & 0.0011 & 0.6373 & \\
\hline$J R 66.3$ & 102.8 & 149.6 & 1.986 & 0.738 & 1216 & 32 & 0.7038 & 0.0011 & 0.6373 & \\
\hline JR 66.4 & 95.8 & 178.6 & 1.557 & 0.7301 & 1216 & 32 & 0.7038 & 0.0011 & 0.6373 & \\
\hline$J R 66.5$ & 100.2 & 14.9 & 19.82 & 1.049 & 1169 & 33 & 0.71 & & & idade convencional \\
\hline
\end{tabular}




\begin{tabular}{|c|c|c|c|c|c|c|c|c|c|c|}
\hline Ordem & $\begin{array}{c}\mathbf{R b} \\
(\mathrm{ppm})\end{array}$ & $\begin{array}{c}\mathrm{Sr} \\
(\mathrm{ppm})\end{array}$ & ${ }^{87} \mathrm{Rb} /{ }^{86} \mathrm{Sr}$ & ${ }^{87} \mathrm{Sr} r^{86} \mathrm{Sr}$ & $\begin{array}{c}\text { Idade } \\
\text { (Ma) }\end{array}$ & Erro & $\mathbf{R} \mathbf{i}$ & Erro & MSWD & Observação \\
\hline JR 66.6 & 98.7 & 14 & 19.48 & 1.033 & 1216 & 32 & 0.7038 & 0.0011 & 0.6373 & \\
\hline $\mathrm{JR} 67$ & 178.2 & 8.4 & 69.219 & 2.1376 & 1216 & 32 & 0.7038 & 0.0011 & 0.6373 & \\
\hline JR 68 & 271.5 & 10.5 & 85.736 & 2.1798 & 1160 & 36 & 0.71 & & & idade convencional \\
\hline JR 69 & 355.9 & 48.8 & 22.02 & 1.1405 & 1332 & 29 & 0.71 & & & idade convencional \\
\hline$J R 7$ & 172.8 & 43.9 & 11.48 & 0.9872 & 1728 & 44 & 0.701 & 0.0007 & 1.2111 & \\
\hline JR 8 & 128.2 & 87 & 4.305 & 0.7995 & 1477 & 68 & 0.705 & & & idade convencional \\
\hline JR 81 & 289.6 & 35.1 & 25.24 & 1.28 & 1599 & 50 & 0.707 & & & \\
\hline JR 82.1 & 108 & 519 & 0.6 & 0.7188 & 1977 & 67 & 0.702 & 0.001 & & \\
\hline JR 82.2 & 39.2 & 119.4 & 0.95 & 0.7247 & 1450 & & 0.705 & & & idade convencional \\
\hline JR 83 & 125 & 225 & 1.61 & 0.748 & 1977 & 67 & 0.702 & 0.001 & & \\
\hline JR 84.1 & 139 & 476 & 0.85 & 0.7254 & 1977 & 67 & 0.702 & 0.001 & & \\
\hline JR 84.2 & 170 & 61 & 8.18 & 0.8462 & 1210 & & 0.705 & & & idade convencional \\
\hline $\mathrm{JR} 84.3$ & 128.5 & 441 & 0.84 & 0.7256 & 1680 & 13 & 0.705 & & & \\
\hline$J R 85$ & 135 & 296 & 7.32 & 0.7394 & 1977 & 67 & 0.702 & 0.001 & & \\
\hline JR 86.1 & 138 & 467 & 0.86 & 0.7253 & 1977 & 67 & 0.702 & 0.001 & & \\
\hline$J R 86.2$ & 105.4 & 530.4 & 0.58 & 0.7202 & 1977 & 67 & 0.702 & 0.001 & & \\
\hline $\mathrm{JR} 86.3$ & 106.2 & 461.5 & 0.67 & 0.7213 & 1977 & 67 & 0.702 & 0.001 & & \\
\hline$J R 87.1$ & 183.4 & 109.8 & 4.89 & 0.8185 & 1676 & 19 & 0.7052 & 0.0004 & & \\
\hline JR 87.2 & 192.7 & 192.7 & 2.65 & 0.7684 & 1676 & 19 & 0.7052 & 0.0004 & & \\
\hline JR 87.3 & 170 & 159 & 3.12 & 0.7807 & 1676 & 19 & 0.7052 & 0.0004 & & \\
\hline JR 88.1 & 108.7 & 364.8 & 0.86 & 0.7258 & 1676 & 19 & 0.7052 & 0.0004 & & \\
\hline JR 88.2 & 138.5 & 220 & 1.83 & 0.7488 & 1676 & 19 & 0.7052 & 0.0004 & & \\
\hline JR 89.1 & 177 & 285 & 1.8 & 0.7487 & 1676 & 19 & 0.7052 & 0.0004 & & \\
\hline JR 89.2 & 178 & 258 & 2.01 & 0.754 & 1676 & 19 & 0.7052 & 0.0004 & & \\
\hline JR 9.1 & 204.4 & 143.3 & 4.17 & 0.8051 & 1728 & 44 & 0.701 & 0.0007 & 1.2111 & \\
\hline JR 90 & 185 & 315 & 1.71 & 0.7469 & 1676 & 19 & 0.7052 & 0.0004 & & \\
\hline JR 91 & 128.2 & 87 & $\begin{array}{ll}4.3 \\
\end{array}$ & 0.7995 & 1530 & & 0.705 & & & idade convencional \\
\hline $\mathrm{JR} 92.1$ & 271.5 & 10.5 & 85.74 & 2.18 & 1201 & 31 & 0.705 & & & idade convencional \\
\hline JR 93.1 & 216 & 38.8 & 16.66 & 1.0551 & 1465 & & 0.705 & & & idade convencional \\
\hline $\mathrm{JR} 94$ & 440 & 14.3 & 111.23 & 3.2336 & 1585 & 18 & 0.705 & & & idade convencional \\
\hline JR 95 & 139 & 23.6 & 17.75 & 1.128 & 1680 & 13 & 0.705 & & & \\
\hline $\mathrm{JR} 96$ & 165 & 111 & 4.35 & 0.809 & 1680 & 13 & 0.705 & & & \\
\hline $\mathrm{JR} 97$ & 158.6 & 63.3 & 7.38 & 0.8852 & 1680 & 13 & 0.705 & & & \\
\hline $\mathrm{JR} 98$ & 126.6 & 77.4 & 4.79 & 0.8237 & 1680 & 13 & 0.705 & & & \\
\hline JR 99 & 134.8 & 317.4 & 1.23 & 0.7346 & 1700 & 21 & 0.705 & & & \\
\hline $\mathrm{JU} 2.2$ & 334.9 & 62.1 & 16.14 & 1.0541 & 1510 & & 0.705 & & & idade convencional \\
\hline JU6 & 172.4 & 109 & 6.63 & 0.8083 & 1560 & & 0.705 & & & idade convencional \\
\hline M1 & 173 & 86.6 & 5.91 & 0.9288 & 2617 & 34 & 0.705 & & & idade convencional \\
\hline M 16.1 & 54 & 430 & 0.364 & 0.7167 & 2944 & & 0.701 & & & \\
\hline M 16.2 & 52.9 & 449.3 & 0.341 & 0.7136 & 2944 & & 0.701 & & & \\
\hline M 16.3 & 54.1 & 81.9 & 0.89 & 0.7536 & 2944 & & 0.701 & & & \\
\hline M 16.4 & 135.4 & 252.2 & 1.56 & 0.7676 & 2944 & & 0.701 & & & \\
\hline M2 & 5.7 & 1030 & 0.0095 & 0.7049 & & & & & & \\
\hline M 26.1 & 165.8 & 26.2 & 19.6 & 1.4246 & 2450 & 74 & 0.7063 & 0.0018 & 17.9984 & \\
\hline M 26.2 & 79.3 & 268.9 & \begin{tabular}{l|l}
0.86 \\
\end{tabular} & 0.7393 & 2450 & 74 & 0.7063 & 0.0018 & 17.9984 & \\
\hline M26.3 & 102.1 & 255.2 & 1.16 & 0.7439 & 2450 & 74 & 0.7063 & 0.0018 & 17.9984 & \\
\hline $\mathrm{M} 26.4$ & 71.5 & 481.1 & 0.43 & 0.7198 & 2450 & 74 & 0.7063 & 0.0018 & 17.9984 & \\
\hline M26.5 & 170.2 & 39.4 & 13.04 & 1.1478 & 2450 & 74 & 0.7063 & 0.0018 & 17.9984 & \\
\hline $\mathrm{M} 26.6$ & 166 & 13.9 & 39.41 & 2.1078 & 2450 & 74 & 0.7063 & 0.0018 & 17.9984 & \\
\hline M27.1 & & & 1.485 & 0.7522 & 2164 & & & & & \\
\hline M27.2 & & & 0.74 & 0.7255 & 2164 & & & & & \\
\hline M 27.3 & & & 1.938 & 0.7056 & & & & & & \\
\hline
\end{tabular}




\begin{tabular}{|c|c|c|c|c|c|c|c|c|c|c|}
\hline Ordem & $\begin{array}{c}\mathrm{Rb} \\
(\mathrm{ppm})\end{array}$ & $\begin{array}{c}\mathrm{Sr} \\
(\mathrm{ppm})\end{array}$ & ${ }^{87} \mathrm{Rb} /{ }^{86} \mathrm{Sr}$ & ${ }^{87} \mathrm{Sr} r^{86} \mathrm{Sr}$ & $\begin{array}{c}\text { Idade } \\
\text { (Ma) }\end{array}$ & Erro & $\mathbf{R i}$ & Erro & MSWD & Observação \\
\hline $\mathrm{M} 27.4$ & & & 1.746 & 0.7605 & 2164 & & & & & \\
\hline M27.5 & & & 2.725 & 0.7897 & 2164 & & & & & \\
\hline M27.6 & & & 0.559 & 0.725 & 2164 & & & & & \\
\hline M 28.1 & 295.8 & 53.8 & 16.715 & 1.219 & 2166 & & 0.705 & & & idade convencional \\
\hline M 28.2 & 194.2 & 117.4 & 4.879 & 0.9017 & 2060 & & 0.76 & & & \\
\hline M28.3 & 181.2 & 84.8 & 6.329 & 0.945 & 2060 & & 0.76 & & & \\
\hline M 28.4 & 351.2 & 92.4 & 11.418 & 1.0928 & 2060 & & 0.76 & & & \\
\hline M28.5 & 211.8 & 81.7 & 7.06 & 1.009 & 2060 & & 0.76 & & & \\
\hline M28.6 & 308.8 & 73.9 & 12.601 & 1.1497 & 2060 & & 0.76 & & & \\
\hline M29 & 250.2 & 60.1 & 11.64 & 0.9357 & 1382 & 40 & 0.705 & & & idade convencional \\
\hline $\mathrm{M3}$ & 130.4 & 61.5 & 6.19 & 0.7907 & 969 & 28 & 0.705 & & & idade convencional \\
\hline M 32 & 139.4 & 84.4 & 4.89 & 0.9426 & 3350 & & 0.705 & & 17.9984 & idade convencional \\
\hline M 33 & & & 282 & 8.555 & 1975 & & & & & idade convencional \\
\hline M4 & 128 & 560 & 0.662 & 0.7208 & 2164 & & 0.705 & & & \\
\hline M6 & 62.5 & 287.3 & 0.63 & 0.7263 & 2164 & & 0.705 & & & \\
\hline M 8.1 & 304.1 & 103.7 & 8.677 & 0.9296 & 1807 & & & & & \\
\hline M 8.2 & 195.5 & 270.5 & 2.105 & 0.7697 & 1807 & & & & & \\
\hline$\overline{M 8.3}$ & 278.2 & 174.6 & 4.671 & 0.8348 & 1807 & & & & & \\
\hline M 8.4 & 187.4 & 34.3 & 16.5 & 1.1435 & 1807 & & & & & \\
\hline M9.1 & 219.1 & 33 & 18.64 & 1.171 & 1739 & 65 & 0.705 & & & idade convencional \\
\hline M9.2 & 108.4 & 20.2 & 14.93 & 1.046 & 1591 & 39 & 0.705 & & & idade convencional \\
\hline MN 10 & 213.3 & 166.2 & 2.267 & 0.755 & 1534 & 127 & 0.705 & & 1.0937 & idade convencional \\
\hline MN 11.1 & 149.4 & 392.4 & 1.105 & 0.7312 & 1652 & 206 & 0.705 & & 1.0937 & idade convencional \\
\hline MN 12 & 113.5 & 341.4 & 0.964 & 0.7231 & 1377 & 62 & 0.706 & 0.001 & 1.0937 & \\
\hline MN 13.1 & 168.3 & 357 & 1.368 & 0.7324 & 1377 & 62 & 0.706 & 0.001 & 1.0937 & \\
\hline $\mathrm{MN} 14$ & 272.1 & 86.1 & 9.307 & 0.8808 & 1377 & 62 & 0.705 & & 1.0937 & \\
\hline MN 15 & 186.1 & 256.1 & 2.113 & 0.7502 & 1377 & 62 & 0.706 & 0.001 & 1.0937 & \\
\hline MN 16.1 & 77 & 493 & 0.453 & 0.7141 & 1377 & 62 & 0.706 & 0.001 & 1.0937 & \\
\hline MN 17 & 260 & 39.9 & 19.445 & 1.0181 & 1119 & 34 & 0.705 & & & idade convencional \\
\hline MN 20 & 342.7 & 25.5 & 43.153 & 1.8129 & 1843 & & 0.704 & & & \\
\hline MN 21.1 & 155.1 & 149.7 & 3.012 & 0.7797 & 1843 & & 0.704 & & & \\
\hline MN 22 & 190.2 & 139.8 & 3.98 & 0.8132 & 1553 & & 0.704 & & & \\
\hline MN 23.1 & 259.4 & 104.2 & 7.316 & 0.8588 & 1466 & 48 & 0.705 & & & idade convencional \\
\hline MN 24 & 190.7 & 62.5 & 8.984 & 0.9431 & 1843 & & 0.704 & & & \\
\hline MN 25 & 169.3 & 106.8 & $\begin{array}{ll}4.642 \\
\end{array}$ & 0.8229 & 1843 & & 0.704 & & & \\
\hline MN 26 & 300.3 & 70.9 & 12.442 & 0.9168 & 1182 & 36 & 0.705 & & & idade convencional \\
\hline MN 27.1 & 230.8 & 149.5 & 4.509 & 0.7962 & 1246 & 19 & 0.705 & & & idade convencional \\
\hline MN 28 & 228.1 & 194.4 & 3.42 & \begin{tabular}{l|l|}
0.7765 \\
\end{tabular} & 1553 & & 0.704 & & & \\
\hline MN 29.1 & 164.8 & 156.7 & 3.067 & 0.7797 & 1843 & & 0.704 & & & \\
\hline MN 30.1 & 105.6 & 585.7 & 0.522 & 0.7161 & 1843 & & 0.704 & & & \\
\hline MN 31 & 247.1 & 79.6 & 9.162 & 0.9041 & 1553 & & 0.704 & & & \\
\hline MN 32 & 149 & 22.9 & 30.114 & 1.4052 & 1553 & & 0.704 & & & \\
\hline MN 33 & 184.9 & 115.3 & 4.694 & 0.818 & 1675 & 57 & 0.705 & & & idade convencional \\
\hline MN 34.1 & 171.1 & 158.6 & 3.148 & 0.7861 & 1843 & & 0.704 & & & \\
\hline MN 36 & 170.7 & 327.4 & 1.52 & 0.7496 & 2044 & 116 & 0.705 & & 1.5429 & idade convencional \\
\hline MN 37 & 188.2 & 134.2 & 4.094 & 0.7904 & 1508 & 75 & 0.707 & 0.0007 & 1.5429 & \\
\hline MN 41 & 169.5 & 66.7 & 7.462 & 0.8512 & 1366 & 43 & 0.705 & & & idade convencional \\
\hline $\mathrm{MN} 42$ & 190.8 & 56.1 & 10.011 & 0.8757 & 1190 & 37 & 0.705 & & & idade convencional \\
\hline MN 43 & 258.1 & 61.8 & 12.36 & 0.9323 & 1284 & 38 & 0.705 & & & idade convencional \\
\hline MN 44 & 234.2 & 51.2 & 13.55 & 0.942 & 1222 & 28 & 0.705 & & & idade convencional \\
\hline MN 45 & 204.4 & 52.7 & 11.54 & 0.9894 & 1714 & 42 & 0.705 & & & idade convencional \\
\hline $\mathrm{MN} \mathrm{46}$ & 142.9 & 104.1 & 3.997 & 0.7638 & 1029 & 54 & 0.705 & & & idade convencional \\
\hline
\end{tabular}




\begin{tabular}{|c|c|c|c|c|c|c|c|c|c|c|}
\hline Ordem & $\begin{array}{c}\mathbf{R b} \\
(\mathrm{ppm})\end{array}$ & $\begin{array}{c}\mathrm{Sr} \\
(\mathrm{ppm})\end{array}$ & ${ }^{87} \mathrm{Rb} /{ }^{88} \mathrm{Sr}$ & ${ }^{87} \mathrm{~S} r r^{86} \mathrm{Sr}$ & $\begin{array}{l}\text { Idade } \\
\text { (Ma) }\end{array}$ & Erro & $\mathbf{R i}$ & Erro & MSWD & Observação \\
\hline MN 47 & 156.8 & 95.2 & 4.83 & 0.8385 & 1919 & 55 & 0.705 & & & idade convencional \\
\hline MN 48 & 169.2 & 55.7 & 8.696 & 0.9078 & 1574 & 49 & 0.705 & & & idade convencional \\
\hline MN 54.1 & 204.4 & 55.2 & 10.94 & 0.9139 & 1225 & & 0.706 & & & \\
\hline $\mathrm{MN} 54.2$ & 315.9 & 30.2 & 31.94 & 1.2615 & 1225 & & 0.706 & & & \\
\hline MN 54.3 & 299.7 & 29.5 & 30.89 & 1.2161 & 1225 & & 0.706 & & & \\
\hline MN6 & 212.9 & 205.3 & 3.018 & 0.7596 & 1377 & 62 & 0.706 & 0.001 & 1.0937 & \\
\hline MN7 & 291 & 158.3 & 5.377 & 0.8111 & 1377 & 62 & 0.706 & 0.001 & 1.0937 & \\
\hline MN 8 & 168.8 & 269 & 1.8239 & 0.744 & 1492 & 93 & 0.705 & & 1.0937 & idade convencional \\
\hline $\mathrm{MN} 9$ & 214.8 & 281 & 2.223 & 0.7517 & 1465 & 79 & 0.705 & & 1.0937 & idade convencional \\
\hline PU 1.2 & 247.6 & 269.1 & 2.677 & 0.755 & 1401 & 111 & 0.706 & 0.002 & & \\
\hline PU 10 & 280.3 & 33.4 & 25.624 & 1.3245 & 1401 & 111 & 0.706 & 0.002 & & \\
\hline PU 11 & 179.6 & 158.2 & 3.299 & 0.7713 & 1401 & 111 & 0.706 & 0.002 & & \\
\hline PU 12 & 234.6 & 71.8 & 9.65 & 0.9089 & 1401 & 111 & 0.706 & 0.002 & & \\
\hline PU 13 & 137.7 & 89.9 & 4.521 & 0.7902 & 1401 & 111 & 0.706 & 0.002 & & \\
\hline PU 14 & 193.9 & 159.7 & 3.541 & 0.78 & 1401 & 111 & 0.706 & 0.002 & & \\
\hline PU 15 & 170.4 & 60.9 & 8.25 & 0.898 & 1627 & 41 & 0.705 & & & idade convencional \\
\hline$P \cup 16$ & 162.7 & 213.5 & 2.22 & 0.7473 & 1431 & 83 & 0.703 & 0.003 & & idade convencional \\
\hline PU 17 & 225.5 & 91.6 & 7.23 & 0.8528 & 1431 & 83 & 0.703 & 0.003 & & \\
\hline PU 18 & 197.8 & 40.3 & 14.57 & 0.9928 & 1431 & 83 & 0.703 & 0.003 & & \\
\hline PU 19 & 234.9 & 57.3 & 12.17 & 0.9849 & 1601 & 37 & 0.71 & & & idade convencional \\
\hline PU 2.2 & 210.2 & 310.5 & 1.97 & 0.7456 & 1401 & 111 & 0.706 & 0.002 & & \\
\hline PU 20 & 247.8 & 102.3 & 7.113 & 0.8511 & 1431 & 83 & 0.703 & 0.003 & & \\
\hline PU 21 & 189.1 & 117.9 & 4.69 & 0.8032 & 1431 & 83 & 0.703 & 0.003 & & \\
\hline PU 22 & 27.5 & 95.7 & & & 1164 & 37 & 0.71 & & & idade convencional \\
\hline PU 23 & 447.3 & 44 & & & 1252 & 27 & 0.71 & & & idade convencional \\
\hline PU 24 & 479.7 & 138 & & & 1159 & 36 & 0.71 & & & idade convencional \\
\hline PU 25.1 & 507.3 & 40.6 & & & 1304 & 29 & 0.71 & & & idade convencional \\
\hline PU 26 & 476.5 & 42.9 & & & 1498 & 51 & 0.71 & & & idade convencional \\
\hline PU 27 & 337.9 & 68 & & & 1467 & 32 & 0.71 & & & idade convencional \\
\hline PU 28 & 191.2 & 50.8 & & & 1501 & 41 & 0.71 & & & idade convencional \\
\hline PU 3.2 & 258 & 137.5 & 5.478 & 0.8086 & 1401 & 119 & 0.706 & 0.002 & & \\
\hline PU 36 & 236 & 89.4 & & & 1304 & 29 & 0.71 & & & idade convencional \\
\hline PU 37 & 170.4 & 60.9 & 8.25 & 0.898 & 1623 & 36 & 0.703 & & & \\
\hline PU 38 & 200.9 & 316.6 & 1.84 & 0.7455 & 1560 & 80 & 0.701 & & & \\
\hline PU 39 & 191.2 & 50.8 & 11.15 & 0.9495 & 1530 & & 0.705 & & & idade convencional \\
\hline PU 4 & 121.1 & 77.8 & 4.539 & 0.78 & 1401 & 111 & 0.706 & 0.002 & & \\
\hline PU 41 & 275 & 95.7 & 8.43 & 0.843 & 1150 & & 0.705 & & & idade convencional \\
\hline PU 5 & 172 & 130 & 3.859 & 0.781 & 1401 & 111 & 0.706 & 0.002 & & \\
\hline PU 6.1 & 222.6 & 277.8 & 2.331 & 0.7549 & 1401 & 111 & 0.706 & 0.002 & & \\
\hline PU 6.2 & 135 & 84.9 & 4.65 & 0.8134 & 1622 & 58 & 0.705 & & & \\
\hline PU7 & 179.5 & 266.1 & 1.961 & 0.7487 & 1401 & 111 & 0.706 & 0.002 & & \\
\hline PU 8 & 235.4 & 147.7 & 4.655 & 0.7968 & 1401 & 111 & 0.706 & 0.002 & & \\
\hline PU 9 & 126 & 238.2 & 1.536 & 0.7342 & 1401 & 111 & 0.706 & 0.002 & & \\
\hline PV 10.1 & 80 & 291.8 & 0.795 & 0.7212 & 1728 & 44 & 0.701 & 0.0007 & 1.2111 & \\
\hline PV 102.1 & 94.8 & 211.9 & 1.297 & 0.7472 & 1180 & 48 & 0.7197 & 0.0039 & 3.62 & \\
\hline PV 102.2 & 153 & 174.5 & 2.553 & 0.7658 & 1180 & 48 & 0.7197 & 0.0039 & 3.62 & \\
\hline PV 102.3 & 182.8 & 164.7 & 3.235 & 0.7741 & 1180 & 48 & 0.7197 & 0.0039 & 3.62 & \\
\hline PV 102.4 & 195 & 142.3 & 3.999 & 0.787 & 1180 & 48 & 0.7197 & 0.0039 & 3.62 & \\
\hline PV 102.5 & 212.9 & 124 & 5.021 & 0.8088 & 1180 & 48 & 0.7197 & 0.0039 & 3.62 & \\
\hline PV 103 & 225 & 53.6 & 12.37 & 0.9074 & 1180 & 48 & 0.7197 & 0.0039 & 3.62 & \\
\hline PV 104.1 & & & 77 & 2.04 & 1180 & 48 & 0.7197 & 0.0039 & 3.62 & \\
\hline PV 105.1 & 236.1 & 120.3 & 5.744 & 0.8165 & 1180 & 48 & 0.7197 & 0.0039 & 3.62 & \\
\hline
\end{tabular}




\begin{tabular}{|c|c|c|c|c|c|c|c|c|c|c|}
\hline Ordem & $\begin{array}{c}\mathbf{R b} \\
(\mathrm{ppm})\end{array}$ & $\begin{array}{c}\mathrm{Sr} \\
(\mathbf{p p m})\end{array}$ & ${ }^{87} \mathrm{Rb} /{ }^{86} \mathrm{Sr}$ & ${ }^{87} \mathrm{Sr} r^{88} \mathrm{Sr}$ & $\begin{array}{c}\text { Idade } \\
\text { (Ma) }\end{array}$ & Erro & $\mathbf{R i}$ & Erro & MSWD & Observação \\
\hline PV 108 & & & 6.52 & 0.8315 & 1276 & & & & & \\
\hline PV 109.1 & 639 & 7.26 & & 7.171 & 1049 & & & & & \\
\hline PV 11.1 & 116.7 & 215.7 & 1.072 & 0.7249 & 1728 & 44 & 0.701 & 0.0007 & 1.2111 & \\
\hline PV 12 & 129.4 & 78.4 & 4.815 & 0.7841 & 1108 & 45 & 0.705 & & & idade convencional \\
\hline PV 122.1 & 112.8 & 102.8 & 3.195 & 0.7642 & 1293 & 62 & 0.705 & & & \\
\hline PV 122.2 & 77.3 & 142.2 & 1.578 & 0.7331 & 1243 & 108 & 0.705 & & & \\
\hline PV 123 & 163.2 & 45.9 & 10.451 & 0.8612 & 983 & 32 & 0.705 & & & \\
\hline PV 124.2 & 173.8 & 331.1 & 1.52 & 0.746 & 1870 & & 0.705 & & & Idade convencional \\
\hline PV 127.1 & 4.6 & 236.3 & 0.056 & 0.7056 & 1521 & 56 & 0.7033 & 0.001 & 4.0883 & \\
\hline PV 128 & 167.5 & 272.1 & 1.789 & 0.7447 & 1521 & 56 & 0.7033 & 0.001 & 4.0883 & \\
\hline PV 129 & 192.7 & 234.2 & 2.394 & 0.757 & 1521 & 56 & 0.7033 & 0.001 & 4.0883 & \\
\hline PV 13 & 128.7 & 49.7 & 7.602 & 0.8488 & 1275 & 41 & 0.705 & & & idade convencional \\
\hline PV 130.1 & 199.4 & 175 & 3.319 & 0.7678 & 1521 & 56 & 0.7033 & 0.001 & 4.0883 & \\
\hline PV 131.1 & 168.8 & 130.4 & 3.777 & 0.7865 & 1521 & 56 & 0.7033 & 0.001 & 4.0883 & \\
\hline PV 132 & 117 & 47.3 & 7.277 & 0.8701 & 1521 & 56 & 0.7033 & 0.001 & 4.0883 & \\
\hline PV 133 & 194.7 & 82.6 & 6.926 & 0.8571 & 1521 & 56 & 0.7033 & 0.001 & 4.0883 & \\
\hline PV 134.1 & 205.6 & 83.8 & 7.208 & 0.8565 & 1521 & 56 & 0.7033 & 0.001 & 4.0883 & \\
\hline PV 134.2 & 160.6 & 104.3 & 4.49 & 0.7954 & 1500 & & 0.705 & & & idade convencional \\
\hline PV 135 & 335.8 & 60.9 & 16.458 & 1.02 & 1521 & 56 & 0.7033 & 0.001 & 4.0883 & \\
\hline PV 136 & 129.4 & 37.7 & 9.709 & 0.9191 & 1521 & 56 & 0.7033 & 0.001 & 4.0883 & \\
\hline PV 137 & 21.3 & 256.2 & 0.241 & 0.7118 & 1521 & 56 & 0.7033 & 0.001 & 4.0883 & \\
\hline PV 138 & 199 & 266.4 & 2.169 & 0.7366 & 1521 & 56 & 0.7033 & 0.001 & 4.0883 & \\
\hline PV 139 & 201.9 & 82.4 & 7.179 & 0.9282 & 1521 & 56 & 0.7033 & 0.001 & 4.0883 & \\
\hline PV 14 & 183.5 & 107.9 & 4.977 & 0.817 & 1728 & 44 & 0.701 & 0.0007 & 1.2111 & \\
\hline PV 140 & 122.5 & 172.8 & 2.06 & 0.7442 & 1521 & 56 & 0.7033 & 0.001 & 4.0883 & \\
\hline PV 144.2 & 219.6 & 81.6 & 7.91 & 0.866 & 1420 & & 0.705 & & & idade convencional \\
\hline PV 15 & 461.7 & 60.9 & 22.8 & 1.0999 & 1168 & 34 & 0.705 & & & idade convencional \\
\hline PV 150 & 153.8 & 84.6 & 5.33 & 0.8442 & 1820 & & 0.705 & & & idade convencional \\
\hline PV 151.1 & 190.5 & 102 & 5.47 & 0.8321 & 1620 & & 0.705 & & & idade convencional \\
\hline PV 153 & 304.7 & 86.2 & 10.47 & 0.9415 & 1572 & 51 & 0.705 & & & idade convencional \\
\hline PV 154 & 231.7 & 30.8 & 21.58 & 1.1833 & 1572 & 51 & 0.705 & & & idade convencional \\
\hline PV 157 & 249.3 & 150.8 & 4.83 & 0.8032 & 1420 & & 0.705 & & & idade convencional \\
\hline PV 159 & 71.8 & 163.9 & 1.27 & 0.7329 & 1293 & 51 & 0.71 & & & idade convencional \\
\hline PV 16.1 & 49.8 & 448.1 & 0.322 & 0.71 & 1728 & 44 & 0.701 & 0.0007 & 1.2111 & \\
\hline PV 160 & 174.3 & 374.3 & 1.35 & 0.7297 & 1293 & 51 & 0.71 & & & idade convencional \\
\hline PV 165 & 221.5 & 94.9 & 6.84 & 0.8286 & 1105 & 30 & 0.725 & & & idade convencional \\
\hline PV 166 & 203.7 & 59.4 & 10.1 & 0.8835 & 1105 & 30 & 0.725 & & & idade convencional \\
\hline PV 167 & 183.4 & 86.2 & 6.23 & 0.8245 & 1105 & 30 & 0.725 & & & idade convencional \\
\hline PV 17 & 245.6 & 49 & 14.622 & 1.054 & 1728 & 44 & 0.701 & 0.0007 & 1.2111 & \\
\hline PV 170 & 261.8 & 136.8 & 5.58 & 0.7846 & 1000 & & 0.705 & & & idade convencional \\
\hline PV 173 & 123.1 & 137 & 2.61 & 0.7386 & 900 & & 0.705 & & & idade convencional \\
\hline PV 174.1 & 452 & 6.93 & 252 & 4.16486 & 956 & 9 & 0.7104 & 0.0056 & 9.2 & \\
\hline PV 174.2 & 626 & 12.3 & 184.1 & 3.21752 & 956 & 9 & 0.7104 & 0.0056 & 9.2 & \\
\hline PV 174.3 & 613 & 13.1 & 165.6 & 2.98235 & 956 & 9 & 0.7104 & 0.0056 & 9.2 & \\
\hline PV 174.4 & 725 & 14.8 & 176.2 & 3.12365 & 956 & 9 & 0.7104 & 0.0056 & 9.2 & \\
\hline PV 174.5 & 709 & 8.85 & 336.9 & 5.3456 & 956 & 9 & 0.7104 & 0.0056 & 9.2 & \\
\hline PV 174.6 & 508 & 17.4 & 95.26 & 2.02842 & 956 & 9 & 0.7104 & 0.0056 & 9.2 & \\
\hline PV 175.1 & 263 & 22.2 & 36.05 & 1.19383 & 956 & 9 & \begin{tabular}{l|l}
0.7104 \\
\end{tabular} & 0.0056 & 9.2 & \\
\hline PV 175.2 & 510 & 2.65 & 1880 & 26.3664 & 956 & 9 & 0.7104 & 0.0056 & 9.2 & \\
\hline PV 175.3 & 229 & 40.1 & 16.9 & 0.940975 & 956 & 9 & 0.7104 & 0.0056 & 9.2 & \\
\hline PV 175.4 & 210 & 7.31 & 92.99 & 1.9951 & \begin{tabular}{l|l}
956 \\
\end{tabular} & 9 & 0.7104 & 0.0056 & 9.2 & \\
\hline PV 175.5 & 291 & 10.7 & 89.39 & 2.06971 & 1063 & & 0.71 & & & idade convencional \\
\hline
\end{tabular}




\begin{tabular}{|c|c|c|c|c|c|c|c|c|c|c|}
\hline Ordem & $\underset{(\mathrm{ppm})}{\mathrm{Rb}}$ & $\begin{array}{c}\mathrm{Sr} \\
(\mathrm{ppm})\end{array}$ & ${ }^{87} \mathrm{Rb} r^{86} \mathrm{Sr}$ & ${ }^{87} \mathrm{Sr} /{ }^{86} \mathrm{Sr}$ & $\begin{array}{l}\text { Idade } \\
\text { (Ma) }\end{array}$ & Erro & Ri & Erro & MSWD & Observação \\
\hline PV 175.6 & 309 & 24.4 & 38.7 & 1.23743 & 956 & 9 & 0.7104 & 0.0056 & 9.2 & \\
\hline PV 175.7 & 228 & 28 & 24.3 & 1.03708 & 956 & 9 & 0.7104 & 0.0056 & 9.2 & \\
\hline PV 176.1 & 324 & 147 & 6.424 & 0.80681 & 1025 & 24 & 0.7117 & 0.0026 & 22 & \\
\hline PV 176.2 & 351 & 123 & 8.384 & 0.836786 & 1025 & 24 & 0.7117 & 0.0026 & 22 & \\
\hline PV 176.3 & 208 & 226 & 2.68 & 0.750246 & 1025 & 24 & 0.7117 & 0.0026 & 22 & \\
\hline PV 176.4 & 226 & 188 & 3.482 & 0.761802 & 1025 & 24 & 0.7117 & 0.0026 & 22 & \\
\hline PV 177.1 & 208 & 180 & 3.367 & 0.760607 & 1025 & 24 & 0.7117 & 0.0026 & 22 & \\
\hline PV 177.2 & 306 & 58.1 & 15.61 & 0.939776 & 1025 & 24 & 0.7117 & 0.0026 & 22 & \\
\hline PV 177.3 & 455 & 108 & 12.47 & 0.901085 & 1025 & 24 & 0.7117 & 0.0026 & 22 & \\
\hline PV 177.4 & 214 & 189 & 3.288 & 0.759363 & 1025 & 24 & 0.7117 & 0.0026 & 22 & \\
\hline PV 178.1 & 205 & 262 & 2.279 & 0.75057 & 1408 & & 0.705 & & & idade convencional \\
\hline PV 178.2 & 175 & 316 & 1.602 & 0.737627 & 1434 & & 0.705 & & & Idade convencional \\
\hline PV 178.3 & 153 & 193 & 2.303 & 0.75365 & 1488 & & 0.705 & & & idade convencional \\
\hline PV 178.4 & 149 & 264 & 1.637 & 0.739542 & 1486 & & 0.705 & & & idade convencional \\
\hline PV 179.1 & 10.6 & 417 & 0.0752 & 0.70404 & 1539 & 36 & 0.7035 & 0.001 & 9.5 & \\
\hline PV 179.2 & 144 & 158 & 2.647 & 0.763903 & 1539 & 36 & 0.7035 & 0.001 & 9.5 & \\
\hline PV 179.3 & 5.71 & 328 & 0.0503 & 0.70353 & 1539 & 36 & 0.7035 & 0.001 & 9.5 & \\
\hline PV 179.4 & 160 & 184 & 2.542 & 0.760004 & 1539 & 36 & 0.7035 & 0.001 & 9.5 & \\
\hline PV 179.5 & 7.97 & 327 & 0.0722 & 0.70475 & 1539 & 36 & 0.7035 & 0.001 & 9.5 & \\
\hline PV 18 & 92.8 & 206.4 & 0.7324 & 1.305 & 1676 & 36 & 0.704 & 0.001 & 1.3532 & \\
\hline PV 180.1 & 332 & 181 & 5.345 & 0.786049 & 1025 & 24 & 0.7117 & 0.0026 & 22 & \\
\hline PV 180.2 & 387 & 120 & 9.472 & 0.856357 & 1025 & 24 & 0.7117 & 0.0026 & 22 & \\
\hline PV 180.3 & 418 & 108 & 11.4 & 0.876109 & 1025 & 24 & 0.7117 & 0.0026 & 22 & \\
\hline PV 180.4 & 340 & 139 & 7.143 & 0.819671 & 1025 & 24 & 0.7117 & 0.0026 & 22 & \\
\hline PV 180.5 & 451 & 73.9 & 18.12 & 0.981243 & 1025 & 24 & 0.7117 & 0.0026 & 22 & \\
\hline PV 180.6 & 1283 & 5.46 & 14295 & 198.493 & 1025 & 24 & 0.7117 & 0.0026 & 22 & \\
\hline PV 180.7 & 591 & 14.7 & 139.6 & 2.71954 & 1025 & 24 & 0.7117 & 0.0026 & 22 & \\
\hline PV 180.8 & 396 & 28.4 & 42.28 & 1.16728 & 757 & & 0.71 & & & idade convencional \\
\hline PV 181.1 & 210 & 110 & 5.623 & 0.828821 & 1473 & & 0.71 & & & idade convencional \\
\hline PV 181.2 & 188 & 231 & 2.367 & 0.755631 & 1506 & & 0.705 & & & idade convencional \\
\hline PV 181.3 & 197 & 185 & 3.101 & 0.768695 & 1446 & & 0.705 & & & idade convencional \\
\hline PV 181.4 & 118 & 310 & 1.104 & 0.726361 & 1363 & & 0.705 & & & idade convencional \\
\hline PV 181.5 & 229 & 192 & 3.476 & 0.773856 & 1395 & & 0.705 & & & idade convencional \\
\hline PV 182.1 & 186 & 105 & 5.194 & 0.803851 & 1300 & & 0.705 & & & \\
\hline PV 182.2 & 201 & 75.4 & 7.802 & 0.855832 & 1300 & & 0.705 & & & \\
\hline PV 182.3 & 299 & 63.6 & 13.99 & 0.977194 & 1300 & & 0.705 & & & \\
\hline PV 182.4 & 246 & 77.1 & 9.405 & 0.881569 & 1300 & & 0.705 & & & \\
\hline PV 183.1 & 642 & 9.66 & 257.7 & 4.1682 & 956 & 9 & 0.7104 & 0.0056 & 9.2 & \\
\hline PV 183.2 & 714 & 5.96 & 640.1 & 9.5919 & 956 & 9 & 0.7104 & 0.0056 & 9.2 & \\
\hline PV 183.3 & 361 & 33.6 & 32.44 & 1.15056 & 956 & 9 & 0.7104 & 0.0056 & 9.2 & \\
\hline PV 183.4 & 326 & 42.3 & 22.98 & 1.0263 & 956 & 9 & 0.7104 & 0.0056 & 9.2 & \\
\hline PV 183.5 & 354 & 108 & 9.611 & 0.817479 & 783 & & 0.71 & & & idade convencional \\
\hline PV 184.1 & 351 & 50 & 20.91 & 1.00765 & 956 & 9 & 0.7104 & 0.0056 & 9.2 & \\
\hline PV 184.2 & 596 & 7.16 & 356.2 & 5.68708 & 956 & 9 & 0.7104 & 0.0056 & 9.2 & \\
\hline PV 185.1 & 298 & 43.8 & 20.54 & 1.14645 & 1539 & 36 & 0.7035 & 0.001 & 9.5 & \\
\hline PV 185.2 & 106 & 457 & 0.6717 & 0.71844 & 1539 & 36 & 0.7035 & 0.001 & 9.5 & \\
\hline PV 185.3 & 4.45 & 106 & 0.1201 & 0.70694 & 1539 & 36 & 0.7035 & 0.001 & 9.5 & \\
\hline PV 185.4 & 170 & 145 & 3.409 & 0.779858 & 1539 & 36 & 0.7035 & 0.001 & 9.5 & \\
\hline PV 186.1 & 264 & 86 & 9.053 & 0.906859 & 1545 & & 0.705 & & & \\
\hline PV 186.2 & 288 & 155 & 5.445 & 0.824439 & 1545 & & 0.705 & & & \\
\hline PV 186.3 & 194 & 153 & 3.711 & 0.785642 & 1545 & & 0.705 & & & \\
\hline PV 186.4 & 221 & 38.9 & 16.95 & 1.03896 & 1300 & & 0.705 & & & \\
\hline
\end{tabular}




\begin{tabular}{|c|c|c|c|c|c|c|c|c|c|c|}
\hline Ordem & $\begin{array}{c}\mathbf{R b} \\
(\mathrm{ppm})\end{array}$ & $\begin{array}{c}\mathrm{Sr} \\
(\mathrm{ppm})\end{array}$ & ${ }^{87} \mathrm{Rb} /{ }^{86} \mathrm{Sr}$ & ${ }^{87} \mathrm{Sr} r^{86} \mathrm{Sr}$ & $\begin{array}{c}\text { Idade } \\
\text { (Ma) }\end{array}$ & Erro & Ri & Erro & MSWD & Observação \\
\hline PV 187.1 & 712 & 14.1 & 197.2 & 4.28655 & 1268 & 15 & 0.7071 & 0.0024 & 16 & \\
\hline PV 187.2 & 321 & 2.44 & 1235 & 23.4877 & 1268 & 15 & 0.7071 & 0.0024 & 16 & \\
\hline PV 187.3 & 342 & 28.5 & 36.97 & 1.35339 & 1268 & 15 & 0.7071 & 0.0024 & 16 & \\
\hline$P V \uparrow 88.1$ & 779 & 17.5 & 167.2 & 3.72663 & 1268 & 15 & 0.7071 & 0.0024 & 16 & \\
\hline PV 188.2 & 254 & 68.6 & 10.93 & 0.905303 & 1268 & 15 & 0.7071 & 0.0024 & 16 & \\
\hline PV 188.3 & 797 & 19.2 & 154.2 & 3.56586 & 1268 & 15 & 0.7071 & 0.0024 & 16 & \\
\hline PV 188.4 & 343 & 16.3 & 68.33 & 1.95618 & 1268 & 15 & 0.7071 & 0.0024 & 16 & \\
\hline PV 188.5 & 64.4 & 526 & 0.3546 & 0.712044 & 1268 & 15 & 0.7071 & 0.0024 & 16 & \\
\hline PV 189.1 & 475 & 30 & 48.86 & 1.37666 & 956 & 9 & 0.7104 & 0.0056 & 9.2 & \\
\hline PV 189.2 & 512 & 33.8 & 46.63 & 1.34638 & 956 & 9 & 0.7104 & 0.0056 & 9.2 & \\
\hline PV 189.3 & 471 & 35.6 & 40.54 & 1.26447 & 956 & 9 & 0.7104 & 0.0056 & 9.2 & \\
\hline PV 189.4 & 477 & 30.8 & 47.71 & 1.36371 & 956 & 9 & 0.7104 & 0.0056 & 9.2 & \\
\hline PV 189.5 & 440 & 26.4 & 51.56 & 1.3969 & 956 & 9 & 0.7104 & 0.0056 & 9.2 & \\
\hline PV 189.6 & 541 & 20.6 & 84.42 & 1.82141 & 956 & 9 & 0.7104 & 0.0056 & 9.2 & \\
\hline PV 189.7 & 556 & 15.1 & 124.5 & 2.4058 & 956 & 9 & 0.7104 & 0.0056 & 9.2 & \\
\hline PV 189.8 & 553 & 11.2 & 176.1 & 3.11607 & 956 & 9 & 0.7104 & 0.0056 & 9.2 & \\
\hline PV 19 & 125.1 & 322.5 & 0.7304 & 1.126 & 1676 & 36 & 0.704 & 0.001 & \begin{tabular}{|l|}
1.3532 \\
\end{tabular} & \\
\hline PV 190.1 & 279 & 45.1 & 18.51 & 1.04355 & 1268 & 15 & 0.7071 & 0.0024 & 16 & \\
\hline PV 190.2 & 252 & 89.3 & 8.304 & 0.860215 & 1268 & 15 & 0.7071 & 0.0024 & 16 & \\
\hline PV 190.3 & 234 & 103 & 6.67 & 0.829352 & 1268 & 15 & 0.7071 & 0.0024 & 16 & \\
\hline PV 190.4 & 225 & 110 & 6 & 0.820334 & 1268 & 15 & 0.7071 & 0.0024 & 16 & \\
\hline PV 191.1 & 318 & 112 & 8.334 & 0.881587 & 1492 & & 0.705 & & & idade convencional \\
\hline PV 191.2 & 347 & 108 & 9.442 & 0.903954 & 1484 & & 0.705 & & & idade convencional \\
\hline PV 192.1 & 321 & 34.7 & 28.22 & 1.22593 & 1268 & 15 & 0.7071 & 0.0024 & 16 & \\
\hline PV 192.2 & 327 & 27.8 & 36.28 & 1.36835 & 1268 & 15 & 0.7071 & 0.0024 & 16 & \\
\hline PV 193.1 & 293 & 38.6 & 22.84 & 1.12138 & 1268 & 15 & 0.7071 & 0.0024 & 16 & \\
\hline PV 193.2 & 309 & 39.1 & 23.85 & 1.13916 & 1268 & 15 & 0.7071 & 0.0024 & 16 & \\
\hline PV 194.1 & 511 & 16.7 & 104.3 & 2.50418 & 1268 & 15 & 0.7071 & 0.0024 & 16 & \\
\hline PV 194.2 & 304 & 31.8 & 29.18 & 1.23705 & 1268 & 15 & 0.7071 & 0.0024 & 16 & \\
\hline PV 2.1 & 199 & 14.9 & 41.812 & 1.61979 & 1529 & 13 & 0.706 & 0.001 & & \\
\hline PV 20.1 & 91.6 & 320.7 & 0.7278 & 0.829 & 1676 & 36 & 0.704 & 0.001 & 1.3532 & \\
\hline PV 200 & & & 4.2 & 0.7918 & 1490 & & 0.708 & & & \\
\hline PV 201 & & & 2.06 & 0.7442 & 1490 & & 0.708 & & & \\
\hline PV 202 & & & 2.39 & 0.757 & 1490 & & 0.708 & & & \\
\hline PV 203 & & & 7.28 & 0.8701 & 1490 & & 0.708 & & & \\
\hline PV 204 & & & 4.4 & 0.8019 & 1490 & & 0.708 & & & \\
\hline PV 205 & & & 6.93 & 0.8665 & 1490 & & 0.708 & & & \\
\hline PV 206 & & & 3.32 & 0.7678 & 1450 & & 0.704 & & & \\
\hline PV 207 & & & 3.15 & 0.7662 & 1450 & & 0.704 & & & \\
\hline PV 208 & & & 24.32 & 1.206 & 1450 & & 0.704 & & & \\
\hline PV 209 & & & 2 & 0.7436 & 1450 & & 0.704 & & & \\
\hline PV 21 & 123.7 & 101.8 & 0.7868 & 3.546 & 1676 & 36 & 0.704 & 0.001 & $\begin{array}{l}1.3532 \\
\end{array}$ & \\
\hline PV 210 & & & 7.91 & 0.866 & 1450 & & 0.704 & & & \\
\hline PV 211 & & & 16.46 & 1.02 & 1450 & & 0.704 & & & \\
\hline PV 212 & & & 0.24 & 0.7118 & 1450 & & 0.704 & & & \\
\hline PV 213 & & & 2.17 & 0.7366 & 1450 & & 0.704 & & & \\
\hline PV 214 & & & 3.78 & 0.7867 & 1450 & & 0.704 & & & \\
\hline PV 215 & & & 1.93 & 0.7483 & 1450 & & 0.704 & & & \\
\hline PV216 & & & 1.498 & 0.73904 & 1450 & & 0.704 & & & \\
\hline PV 217 & & & 1.557 & 0.73677 & 1450 & & 0.704 & & & \\
\hline PV 22 & 89.8 & 403.8 & 0.7177 & 0.645 & 1676 & 36 & 0.704 & 0.001 & 1.3532 & \\
\hline PV 23 & 79.6 & 211.7 & 0.7291 & 1.091 & 1676 & 36 & 0.704 & 0.001 & 1.3532 & \\
\hline
\end{tabular}




\begin{tabular}{|c|c|c|c|c|c|c|c|c|c|c|}
\hline Ordem & $\begin{array}{c}\mathrm{Rb} \\
(\mathrm{ppm})\end{array}$ & $\begin{array}{c}\mathrm{Sr} \\
(\mathrm{ppm})\end{array}$ & ${ }^{87} \mathrm{Rb} /{ }^{86} \mathrm{Sr}$ & $\left.{ }^{87} \mathrm{Sr}\right|^{86} \mathrm{Sr}$ & $\begin{array}{c}\text { Idade } \\
\text { (Ma) }\end{array}$ & Erro & $\mathbf{R i}$ & Erro & MSWD & Observação \\
\hline PV 24 & 464.8 & 89.3 & 15.495 & 0.9934 & 1255 & 39 & 0.705 & & & idade convencional \\
\hline PV 25.1 & 176.9 & 143.9 & 3.582 & 0.7704 & 1232 & 52 & 0.705 & & & idade convencional \\
\hline PV 26 & 215 & 45.1 & 14.049 & 0.888 & 880 & 28 & 0.705 & & & idade convencional \\
\hline PV 27.1 & 185.6 & 194 & 2.786 & 0.7647 & 1443 & 72 & 0.705 & & & idade convencional \\
\hline PV 28.1 & 204.3 & 31.2 & 19.62 & 1.063 & 1270 & 34 & 0.705 & & & idade convencional \\
\hline PV 28.3 & 390.3 & 12.8 & 105.7 & 2.896 & 1444 & 36 & 0.705 & & & idade convencional \\
\hline PV 28.4 & 180.2 & 130.6 & 4.02 & 0.7711 & 1148 & 54 & 0.705 & & & idade convencional \\
\hline PV 28.5 & 133.4 & 340.7 & 1.136 & 0.7267 & 1334 & 185 & 0.705 & & & idade convencional \\
\hline PV 3 & 155.2 & 136 & 4.403 & 0.80194 & 1529 & 13 & 0.706 & 0.001 & & \\
\hline PV 32 & 185.7 & 128.2 & 4.232 & 0.7982 & 1372 & 53 & 0.715 & & & idade convencional \\
\hline PV 33 & 207.5 & 25.2 & 24.849 & 1.1361 & 1184 & 35 & 0.715 & & & idade convencional \\
\hline PV 34 & 281.8 & 20.2 & 43.463 & 1.4784 & 1228 & 36 & 0.715 & & & idade convencional \\
\hline PV 35.1 & 174.7 & 162.4 & 3.135 & 0.7746 & 1326 & 61 & 0.715 & & & idade convencional \\
\hline PV 36 & 197.1 & 75 & 7.726 & 0.8628 & 1336 & 45 & 0.715 & & & idade convencional \\
\hline PV 37 & 205.1 & 78.8 & 7.645 & 0.8544 & 1273 & 43 & 0.715 & & & idade convencional \\
\hline PV 38 & 199.1 & 140.6 & 4.136 & 0.7951 & 1353 & 86 & 0.715 & & & idade convencional \\
\hline PV 39 & 248.9 & 132.2 & 5.518 & 0.8308 & 1464 & 49 & 0.715 & & & idade convencional \\
\hline PV 4 & 289.2 & 98.1 & 8.695 & 0.89615 & 1529 & 13 & 0.706 & 0.001 & & \\
\hline PV 40 & 225.9 & 89.2 & 7.415 & 0.8312 & 1095 & 39 & 0.715 & & & idade convencional \\
\hline PV 44.1 & 337.9 & 38.6 & 25.2 & 1.2366 & 1472 & 36 & 0.71 & & & \\
\hline PV 44.2 & 156 & 73.9 & 6.18 & 0.8187 & 1280 & & 0.705 & & & idade convencional \\
\hline PV 45 & 122.8 & 113 & 3.2 & \begin{tabular}{|c|}
0.7774 \\
\end{tabular} & 1483 & 69 & 0.71 & & & \\
\hline PV 46 & 170 & 156.6 & 3.2 & 0.7637 & 1072 & 39 & 0.715 & & & \\
\hline PV 47 & 188.5 & 126.7 & 4.35 & 0.3081 & 1588 & 58 & 0.71 & & & \\
\hline PV 48 & 105.1 & 145.7 & 2.1 & 0.7471 & 1412 & 42 & 0.705 & & & \\
\hline PV 49 & 214.9 & 159.4 & 3.9 & 0.785 & 1263 & 50 & 0.715 & & & \\
\hline PV 50 & 223.5 & 128.6 & 5.1 & 0.8176 & 1544 & 54 & 0.705 & & & \\
\hline PV 52 & 303.5 & 114.1 & 7.8 & 0.8451 & 1175 & 41 & 0.715 & & & \\
\hline PV 53 & 248.2 & 117.5 & 6.2 & 0.8162 & 1150 & 34 & 0.715 & & & \\
\hline PV 54.1 & 364.5 & 58.1 & 18.8 & \begin{tabular}{|c|}
1.0606 \\
\end{tabular} & 1320 & 38 & 0.705 & & & \\
\hline PV 55 & 225.4 & 49.98 & 13.2 & 0.8872 & 916 & 34 & 0.715 & & & \\
\hline PV 56 & 757.8 & 12.4 & 228.4 & 3.857 & 969 & 21 & 0.715 & & & \\
\hline PV 57 & 430.7 & 40 & 33 & 1.3129 & 1274 & 37 & 0.715 & & & \\
\hline PV 58 & 298.9 & 30 & 27.7 & 1.2168 & 1272 & 37 & 0.715 & & & \\
\hline PV 59 & 353.6 & 34.8 & 30.6 & 1.1286 & 951 & 29 & 0.715 & & & \\
\hline PV 60 & 383.6 & 24.8 & 47.6 & 1.4777 & 1128 & 25 & 0.715 & & & \\
\hline PV61 & 414.8 & 75.6 & 16.3 & 0.9485 & 1011 & 33 & 0.715 & & & \\
\hline PV 62 & 627.8 & 15.6 & 138.8 & 2.689 & 1001 & 21 & 0.715 & & & \\
\hline PV 63 & 161.8 & 130.9 & 3.6 & 0.7769 & 1210 & 63 & 0.715 & & & \\
\hline PV 64 & 202.2 & 138.5 & 4.3 & 0.7922 & 1276 & 54 & 0.715 & & & \\
\hline PV 65 & 230.9 & 133.4 & 5 & 0.7882 & 1020 & 45 & 0.715 & & & \\
\hline PV 66 & 214.4 & 114.6 & 5.5 & \begin{tabular}{|c|}
0.7895 \\
\end{tabular} & 1018 & 44 & 0.715 & & & \\
\hline PV 67 & 212.8 & 114.1 & 5.5 & 0.8129 & 1264 & 51 & 0.715 & & & \\
\hline PV 68.1 & 220.8 & \begin{tabular}{l|}
48 \\
\end{tabular} & 13.6 & 0.9559 & 1243 & 39 & 0.715 & & & \\
\hline PV 69 & 136.6 & \begin{tabular}{l|l}
54.8 \\
\end{tabular} & \begin{tabular}{l|l}
7.3 \\
\end{tabular} & 0.8485 & 1284 & 52 & 0.715 & & & \\
\hline PV 70 & 233.5 & 103.9 & 6.6 & 0.8307 & 1237 & 46 & 0.715 & & & \\
\hline PV 71 & 240.3 & 45.3 & 7.4 & 0.8437 & 1224 & 42 & 0.715 & & & \\
\hline PV 72 & 266.5 & 101.3 & $\begin{array}{l}7.7 \\
\end{array}$ & 0.8543 & 1269 & 44 & 0.715 & & & \\
\hline PV 73 & 305.9 & 34.9 & 26.6 & 1.185 & 1245 & 37 & 0.715 & & & \\
\hline PV 74 & 316.6 & 32.2 & 29.9 & 1.212 & 1171 & 36 & 0.715 & & & \\
\hline PV 75 & 242.1 & 68.6 & 10.4 & \begin{tabular}{|l|}
0.876 \\
\end{tabular} & 1092 & 40 & 0.715 & & & \\
\hline PV 76 & 515.6 & 16.5 & 103.5 & 2.1766 & 994 & 30 & 0.715 & & & \\
\hline
\end{tabular}




\begin{tabular}{|c|c|c|c|c|c|c|c|c|c|c|}
\hline Ordem & $\begin{array}{c}\mathrm{Rb} \\
(\mathrm{ppm})\end{array}$ & $\begin{array}{c}\mathrm{Sr} \\
(\mathrm{ppm})\end{array}$ & ${ }^{87} \mathrm{Rb} /{ }^{86} \mathrm{Sr}$ & ${ }^{87} \mathrm{Sr} r^{86} \mathrm{Sr}$ & $\begin{array}{c}\text { Idade } \\
(\mathrm{Ma})\end{array}$ & Erro & $\mathrm{Ri}$ & Erro & MSWD & Observaçăo \\
\hline PV 77 & 289.9 & 21.9 & 40.9 & 1.4059 & 1188 & 27 & 0.715 & & & \\
\hline PV 78 & 141.3 & 122.1 & 3.4 & 0.7588 & 915 & 45 & 0.715 & & & \\
\hline PV 8 & 144.8 & 222.8 & 1.889 & 0.7448 & 1728 & 44 & 0.701 & 0.0007 & 1.2111 & \\
\hline PV 80 & 282 & 94.3 & 8.4 & 0.861 & 1225 & 37 & 0.715 & & & \\
\hline PV 81 & 209 & 18.5 & 31.98 & 1.165 & 1000 & & 0.715 & & & \\
\hline PV 82.1 & 883 & 8.6 & 419 & 6.418 & 960 & & 0.715 & & & \\
\hline PV 82.2 & 6086 & 24.7 & 13171 & 179.3 & 955 & & 0.715 & & & \\
\hline PV 83.1 & 664 & 24.3 & 94.6 & 2.12 & 1050 & & 0.715 & & & \\
\hline PV 83.2 & 336 & 266 & 3.7 & 0.765 & 950 & & 0.715 & & & \\
\hline$\overline{\text { PV } 83.3}$ & 5537 & 23.55 & 13860 & 198.6 & 1000 & & 0.715 & & & \\
\hline PV 83.4 & 356 & 201 & 5.2 & 0.7919 & 1040 & & 0.715 & & & \\
\hline PV 83.5 & 1342.5 & 15.5 & 399 & 6.7952 & 1070 & & 0.715 & & & \\
\hline PV 83.6 & 266.5 & 15.3 & 54.9 & 1.4605 & 960 & & 0.715 & & & \\
\hline PV 83.7 & 1130.5 & 16.3 & 282 & 4.8115 & 1023 & & 0.715 & & & \\
\hline PV 9 & 185.9 & 113.9 & 4.776 & 0.815 & 1728 & 44 & 0.701 & 0.0007 & 1.2111 & \\
\hline PV 97.2 & & & 18.3 & 0.8893 & 671 & & & & & \\
\hline RB 10 & 306.1 & 58 & 15.797 & 1.04974 & 1529 & 13 & 0.706 & 0.001 & & \\
\hline RB 11 & 123 & 234 & 1.527 & 0.74058 & 1529 & 13 & 0.706 & 0.001 & & \\
\hline RB 12 & 273.7 & 129 & 6.223 & 0.83865 & 1529 & 13 & 0.706 & 0.001 & & \\
\hline RB 13 & 350.9 & 36.5 & 26.639 & 1.27623 & 1529 & 13 & 0.706 & 0.001 & & \\
\hline RB 14 & 363.3 & 26.3 & 43.598 & 1.68833 & 1529 & 13 & 0.706 & 0.001 & & \\
\hline RB 15 & 179 & 136.8 & 3.819 & 0.78988 & 1529 & 13 & 0.706 & 0.001 & & \\
\hline RB 2.1 & 368.7 & 75.6 & 14.549 & 1.01502 & 1529 & 13 & 0.706 & 0.001 & & \\
\hline RB 2.2 & 220.7 & 184.2 & 3.495 & 0.78225 & 1529 & 13 & 0.706 & 0.001 & & \\
\hline RB 2.3 & 282.9 & 130.2 & 6.379 & 0.84841 & 1529 & 13 & 0.706 & 0.001 & & \\
\hline RB 4.1 & 268.5 & 73 & 10.905 & 0.9509 & 1529 & 13 & 0.706 & 0.001 & & \\
\hline RB 5 & 305.1 & 125.3 & 7.158 & 0.86264 & 1529 & 13 & 0.706 & 0.001 & & \\
\hline RB 6 & 243.9 & 87.8 & 8.185 & 0.88656 & 1529 & 13 & 0.706 & 0.001 & & \\
\hline$\overline{R B 7}$ & 479.2 & 89.2 & 16.075 & 1.04691 & 1529 & 13 & 0.706 & 0.001 & & \\
\hline RB 8 & 98.8 & 50.4 & 5.762 & 0.86196 & 1828 & 59 & 0.705 & & & idade convencional \\
\hline RR 10 & 148 & 168 & 2.56 & 0.7717 & 1853 & 31 & 0.705 & & & \\
\hline RR 100.1 & 65.11 & 107.89 & 1.77 & 0.7543 & 1860 & 10 & 0.708954 & 0.00296 & & \\
\hline RR 100.2 & 88.49 & 337.73 & 0.77 & 0.724941 & 1860 & 10 & 0.708954 & 0.00296 & & \\
\hline RR 11 & 144 & 177 & 2.37 & 0.7643 & 1853 & 31 & 0.705 & & & \\
\hline RR 12.1 & 163 & 150 & 3.18 & 0.7898 & 1853 & 31 & 0.705 & & & \\
\hline $\operatorname{RR~} 14$ & 354 & 40.2 & 27.1 & 1.425 & 1853 & 31 & 0.705 & & & \\
\hline RR 16 & 112 & \begin{tabular}{l|l|}
488 \\
\end{tabular} & 0.667 & 0.7188 & 1853 & 31 & 0.705 & & & \\
\hline RR 17 & 73.9 & 671 & 0.319 & 0.7101 & 1118 & & 0.705 & & & idade convencional \\
\hline RR 18 & 260 & 59.3 & 13.1 & 1.053 & 1853 & 31 & 0.705 & & & \\
\hline RR 19.1 & 222 & 89.3 & 7.32 & 0.885 & 1853 & 31 & 0.705 & & & \\
\hline RR 19.2 & 217 & 86.1 & 7.43 & 0.8879 & 1853 & 31 & 0.705 & & & \\
\hline RR 2 & 155 & 141 & 3.19 & 0.7818 & 1677 & & 0.705 & & & Idade convencional \\
\hline RR 26.1 & 6.2 & 401.7 & 0.045 & 0.70689 & 2019 & 71 & 0.7059 & 0.0016 & 22.9 & \\
\hline RR 27.1 & 28.5 & 436.5 & 0.189 & 0.7113 & 2019 & 71 & 0.7059 & 0.0016 & 22.9 & \\
\hline RR 28.1 & 130.6 & 176.3 & 2.157 & 0.77369 & 2019 & 71 & 0.7059 & 0.0016 & 22.9 & \\
\hline RR 29.1 & 132.3 & 153.7 & 2.506 & 0.77381 & 2019 & 71 & 0.7059 & 0.0016 & 22.9 & \\
\hline RR 30.1 & 373.6 & 38.7 & 30.325 & 1.58175 & 2019 & 71 & 0.7059 & 0.0016 & 22.9 & \\
\hline RR 34 & 103 & 426 & 0.703 & 0.7213 & 1615 & & 0.705 & & & idade convencional \\
\hline RR 35 & 139 & 45.4 & 9.09 & 0.9349 & 1760 & & 0.705 & & & idade convencional \\
\hline RR 36 & 175.2 & 151.8 & 3.369 & 0.7935 & 1850 & 45 & 0.702 & 0.0007 & 1.35 & \\
\hline RR 37.1 & 87.7 & 491 & 0.517 & 0.7162 & 1850 & 45 & 0.702 & 0.0007 & 1.35 & \\
\hline RR 38.1 & 109.1 & 352.7 & 0.897 & 0.7254 & 1850 & 45 & 0.702 & 0.0007 & 1.35 & \\
\hline
\end{tabular}




\begin{tabular}{|c|c|c|c|c|c|c|c|c|c|c|}
\hline Ordem & $\begin{array}{c}\mathrm{Rb} \\
(\mathrm{ppm})\end{array}$ & $\underset{(p p m)}{\mathrm{Sr}}$ & ${ }^{87} \mathrm{Rb} r^{86} \mathrm{Sr}$ & ${ }^{87} \mathrm{Sr} /^{86} \mathrm{Sr}$ & $\begin{array}{c}\text { Idade } \\
\text { (Ma) }\end{array}$ & Erro & Ri & Erro & MSWD & Observação \\
\hline RR 39 & 76.3 & 106 & 2.093 & 0.7556 & 1850 & 45 & 0.702 & 0.0007 & 1.35 & \\
\hline RR 4 & 213 & 132 & 4.73 & 0.8313 & 1853 & 31 & 0.705 & & & \\
\hline RR 40 & 97.5 & 88 & 3.244 & 0.784 & 1715 & & 0.705 & & 1.35 & idade convencional \\
\hline RR 42 & 137 & 176.1 & 2.264 & 0.7637 & 1850 & 45 & 0.702 & 0.0007 & 1.35 & \\
\hline RR 43 & 438 & 30.1 & 45.9 & 1.634 & 1408 & & 0.705 & & & idade convencional \\
\hline RR 44 & 74 & 254.1 & 0.845 & 0.7276 & 1925 & 25 & 0.7041 & 0.0005 & 0.4273 & \\
\hline RR 45 & 159 & 24.03 & 19.95 & 1.26 & 1925 & 25 & 0.7041 & 0.0005 & 0.4273 & \\
\hline RR 46 & 153.8 & 62 & 7.324 & 0.9078 & 1925 & 25 & 0.7041 & 0.0005 & 0.4273 & \\
\hline RR 47 & 175.8 & 57.03 & 9.09 & 0.9526 & 1925 & 25 & 0.7041 & 0.0005 & 0.4273 & \\
\hline RR 48 & 168.7 & 19.78 & 26.1 & 1.435 & 1925 & 25 & 0.7041 & 0.0005 & 0.4273 & \\
\hline RR 49 & 125.5 & 45.55 & 14.76 & 1.063 & 1708 & & 0.705 & & 0.4273 & idade convencional \\
\hline RR 5 & 198 & 112 & 5.22 & 0.8421 & 1853 & 31 & 0.705 & & & \\
\hline RR 50.1 & 426.7 & 17.05 & 87.11 & 2.97 & 1831 & & 0.705 & & 0.4273 & idade convencional \\
\hline RR 51 & 445.1 & 14.03 & 116.9 & 3.734 & 1825 & & 0.705 & & 0.4273 & idade convencional \\
\hline RR 52 & & & 1.73 & 0.7557 & 1925 & 25 & 0.7041 & 0.0005 & 0.4273 & \\
\hline RR 53 & & & 5.76 & 0.8563 & 1925 & 25 & 0.7041 & 0.0005 & 0.4273 & \\
\hline RR 54 & & & 4.69 & 0.8181 & 1698 & & 0.705 & & 0.4273 & idade convencional \\
\hline RR 55 & & & 2.76 & 0.7811 & 1942 & & 0.705 & & 0.4273 & idade convencional \\
\hline RR6 & 210 & 100 & 6.17 & 0.8696 & 1853 & 31 & 0.705 & & & \\
\hline RR 62.1 & 219.1 & 101.9 & 6.33 & 0.8778 & 1868 & & 0.705 & & & \\
\hline RR 62.2 & 211.8 & 122.5 & 5.07 & 0.8412 & 1868 & & 0.705 & & & \\
\hline RR 62.3 & 203.4 & 132.3 & 4.5 & 0.8254 & 1868 & & 0.705 & & & \\
\hline RR 63 & 458 & 21.2 & 7.2 & 2.32 & 1542 & & 0.708 & & & \\
\hline RR 64 & 334 & 95.7 & 10.3 & 0.933 & 1542 & & 0.708 & & & \\
\hline RR 65 & 289 & 37.9 & 23.1 & 1.186 & 1466 & & 0.705 & & & idade convencional \\
\hline RR 66 & 205 & 160 & 3.74 & 0.7883 & 1542 & & 0.708 & & & \\
\hline RR 7 & 132 & 160 & 2.4 & 0.7657 & 1853 & 31 & 0.705 & & & \\
\hline RR 82.1 & 466.9 & 35.2 & 38.4 & 0.7668 & 106 & 6 & 0.705 & & & Idade convencional \\
\hline RR 82.2 & 466.9 & 35.2 & 38.61 & 0.7649 & 98 & 8 & 0.705 & & & idade convencional \\
\hline RR 9 & 183 & 56.4 & 9.59 & 0.9297 & 1625 & & 0.705 & & & idade convencional \\
\hline RR 96 & 106 & 222 & 1395 & 0.7414 & 1811 & & 0.705 & & & \\
\hline RR 97 & 208 & 4.55 & 189 & 5.54 & 1811 & & 0.705 & & & \\
\hline SA 1.1 & 137.8 & 311.1 & 1.287 & 0.7404 & 1977 & 72 & 0.7038 & 0.0011 & & \\
\hline SA 11.2 & & & 0.873 & 0.726 & 1754 & 41 & 0.705 & & & \\
\hline SA 19 & 117.1 & 529.7 & 0.641 & 0.7193 & 1755 & 41 & 0.7032 & 0.0012 & & \\
\hline SA 2 & 199.3 & 223.6 & 2.599 & 0.7776 & 1977 & 72 & 0.7038 & 0.0011 & & \\
\hline SA 20 & 151 & 336.6 & 1.303 & 0.7386 & 1755 & 41 & 0.7032 & 0.0012 & & \\
\hline SA 21 & 139.9 & 457.9 & 0.886 & 0.7278 & 1755 & 41 & 0.7032 & 0.0012 & & \\
\hline SA 22 & 112 & 155 & 2.102 & 0.7574 & 1755 & 41 & 0.7032 & 0.0012 & & \\
\hline SA 23 & 157.5 & 209.7 & 2.185 & $\begin{array}{ll}0.7576 \\
\end{array}$ & 1755 & 41 & 0.7032 & 0.0012 & & \\
\hline SA 24 & 185.2 & 65.4 & 8.367 & 0.915 & 1755 & 41 & 0.7032 & 0.0012 & & \\
\hline SA 25 & 163.9 & 136.9 & 3.494 & 0.7891 & 1755 & 41 & 0.7032 & 0.0012 & & \\
\hline SA 26 & 203.6 & 39.4 & 15.55 & 1.108 & 1755 & 41 & 0.7032 & 0.0012 & & \\
\hline SA 27 & 169.6 & 74.5 & 6.701 & 0.876 & 1755 & 41 & 0.7032 & 0.0012 & & \\
\hline SA 28 & 248.2 & 35.7 & 21.181 & 1.2368 & 1755 & 41 & 0.7032 & 0.0012 & & \\
\hline$\widehat{S A} 29$ & 270 & 95.6 & 8.326 & 0.8919 & 1563 & 52 & 0.705 & & & idade convencional \\
\hline $\mathrm{SA3}$ & 171.6 & 488.9 & 1.019 & 0.7329 & 1977 & 72 & 0.7038 & 0.0011 & & \\
\hline SA 30 & 243.7 & 67.5 & 10.7 & 0.9425 & 1542 & 52 & 0.705 & & & idade convencional \\
\hline SA 31 & 157.7 & 97 & 4.465 & 0.8319 & 1755 & 41 & 0.7032 & 0.0012 & & \\
\hline SA 32 & 300.6 & 32 & 29.115 & 1.422 & 1755 & 41 & \begin{tabular}{l|l|}
0.705 \\
\end{tabular} & & & \\
\hline SA 33 & 197.1 & 238.7 & 2.405 & 0.7692 & 1853 & 104 & 0.705 & & & idade convencional \\
\hline SA 34 & 269.8 & 90.8 & 8.772 & 0.9064 & 1594 & 52 & 0.705 & & & idade convencional \\
\hline
\end{tabular}




\begin{tabular}{|c|c|c|c|c|c|c|c|c|c|c|}
\hline Ordem & $\begin{array}{c}\mathrm{Rb} \\
\text { (ppm) }\end{array}$ & $\begin{array}{c}\mathrm{Sr} \\
(\mathrm{ppm})\end{array}$ & ${ }^{87} \mathrm{Rb} /{ }^{36} \mathrm{Sr}$ & ${ }^{87} \mathrm{Sr} r^{86} \mathrm{Sr}$ & $\begin{array}{c}\text { Idade } \\
\text { (Ma) }\end{array}$ & Erro & $\mathbf{R} \mathbf{I}$ & Erro & MSWD & Observação \\
\hline SA 35 & 337.9 & 37.8 & 27.34 & 1.278 & 1460 & 93 & 0.705 & & & idade convencional \\
\hline SA 36 & 141.5 & 253.9 & 1.619 & 0.7416 & 1574 & 135 & 0.705 & & & idade convencional \\
\hline SA 37 & 207.2 & 146.3 & 4.144 & 0.81416 & 1831 & 74 & 0.705 & & & idade convencional \\
\hline SA 4 & 90.9 & 705.9 & 0.373 & 0.7158 & 1977 & 72 & 0.7038 & 0.0011 & & \\
\hline SA 5 & 96.4 & 614.1 & 0.455 & 0.7144 & 1977 & 72 & 0.7038 & 0.0011 & & \\
\hline SA 53 & 743.6 & 33.5 & 74.58 & 2.3345 & 1522 & 35 & & & & idade convencional \\
\hline SA6 & 112.2 & 325.8 & 1 & 0.7325 & 1977 & 72 & 0.7038 & 0.0011 & & \\
\hline SA 62 & 212 & 84.6 & 7.74 & 0.9038 & 1775 & 33 & 0.7039 & 0.0009 & 1.068 & \\
\hline SA 63 & 164.1 & 67.3 & 6.887 & 0.878 & 1775 & 33 & 0.7039 & 0.0009 & 1.068 & \\
\hline SA 64 & 151 & 336.6 & 1.303 & 0.7386 & 1775 & 33 & 0.7039 & 0.0009 & 1.068 & \\
\hline SA 65 & 279.1 & 74.2 & 9.954 & 0.9683 & 1775 & 33 & 0.7039 & 0.0009 & 1.068 & \\
\hline SA 66 & 306 & 38.1 & 24.89 & 1.426 & 2000 & & 0.705 & & & idade convencional \\
\hline SA 67 & 181.3 & 236.3 & 2.23 & 0.7669 & 1890 & 25 & 0.704 & & & idade convencional \\
\hline SA 68 & 364.1 & 103.2 & 10.48 & 0.9795 & 1860 & 28 & 0.707 & & & idade convencional \\
\hline SA 69 & 306.8 & 231.4 & 3.87 & 0.8046 & 1810 & & 0.704 & & & idade convencional \\
\hline SA 7 & 129.2 & 253.8 & 1.479 & 0.7442 & 1977 & 72 & 0.7038 & 0.0011 & & \\
\hline SA 70 & 147.5 & 125.2 & 3.44 & 0.7923 & 1770 & & 0.705 & & & idade convencional \\
\hline SA 72 & 318.8 & 90 & 10.51 & 0.9613 & 1700 & & 0.705 & & & idade convencional \\
\hline T 47.2 & 279.1 & 64.6 & 12.93 & 1.0507 & 1856 & 29 & 0.704 & 0.002 & & fora da isócrona \\
\hline T11 & 108.7 & 206.8 & 1.52 & 0.7232 & 631 & 18 & 0.709 & 0.001 & & \\
\hline T12 & 110.1 & 267.8 & 1.19 & 0.7199 & 631 & 18 & 0.709 & 0.001 & & \\
\hline$T 13$ & 157.5 & 147.4 & 3.1 & 0.7348 & 631 & 18 & 0.709 & 0.001 & & \\
\hline$T 14$ & 83.9 & 381.4 & 0.64 & 0.7134 & 631 & 18 & 0.709 & 0.001 & & \\
\hline$T 15$ & 93.3 & 199.4 & 1.36 & 0.7213 & 631 & 18 & 0.709 & 0.001 & & \\
\hline$T 16$ & 212.3 & 124.5 & 4.96 & 0.7535 & 631 & 18 & 0.709 & 0.001 & & \\
\hline$T 17$ & 134.8 & 172.7 & 2.27 & 0.7387 & 587 & 85 & 0.712 & 0.004 & & fora da isócrona \\
\hline$T 18$ & 78.4 & 125.1 & 1.82 & 0.7244 & 587 & 85 & 0.712 & 0.004 & & fora da isócrona \\
\hline$T 19$ & 154.3 & 176.6 & 2.54 & 0.7345 & 587 & 85 & 0.712 & 0.004 & & fora da isócrona \\
\hline$T 20.1$ & 197 & 150.2 & 3.81 & 0.74 & 587 & 85 & 0.712 & 0.004 & & fora da isócrona \\
\hline$T 20.2$ & 151 & 88.3 & 4.97 & 0.7542 & 587 & 85 & 0.712 & 0.004 & & fora da isócrona \\
\hline $\mathrm{T} 21$ & 184 & 237.3 & 2.25 & 0.7336 & 587 & 85 & 0.712 & 0.004 & & fora da isocrona \\
\hline T22.1 & 265.3 & 150.9 & 5.17 & 0.8571 & 2000 & & 0.705 & & & idade convencional \\
\hline T23 & 183.3 & 279 & 1.94 & 0.7598 & 2000 & & 0.705 & & & idade convencional \\
\hline T24 & 203.2 & 253.6 & 2.33 & 0.772 & 2000 & & 0.705 & & & idade convencional \\
\hline T25.1 & 95.6 & 373 & 0.74 & 0.7252 & 2000 & & 0.705 & & & idade convencional \\
\hline$T 26.1$ & 172 & 227.6 & 2.2 & 0.7646 & 2000 & & 0.705 & & & idade convencional \\
\hline T27.1 & 101.6 & 267.2 & 1.1 & 0.7444 & 2000 & & 0.705 & & & idade convencional \\
\hline T28 & 66.5 & 279 & 0.62 & 0.7252 & 2000 & & 0.705 & & & \\
\hline $\mathrm{T} 35.1$ & 134.8 & 367.9 & 1.07 & 0.7469 & 2591 & 64 & 0.705 & 0.001 & & fora da isócrona \\
\hline$T 35.2$ & 66.7 & 501.3 & 0.39 & 0.7204 & 2591 & 64 & 0.705 & 0.001 & & fora da isócrona \\
\hline T35.3 & 80.6 & 379.6 & 0.62 & 0.7285 & 2591 & 64 & 0.705 & 0.001 & & \\
\hline T 35.4 & 217.9 & 394.6 & 1.61 & 0.7587 & 1834 & 39 & 0.715 & 0.001 & & fora da isócrona \\
\hline T 35.5 & 154.6 & 351 & 1.28 & 0.7532 & 2591 & 64 & 0.705 & 0.001 & & \\
\hline T35.6 & 201.7 & 302 & 1.95 & 0.7684 & 1834 & 39 & 0.715 & 0.001 & & fora da isócrona \\
\hline T36 & 163.6 & 316.9 & 1.5 & 0.7609 & 2591 & 64 & 0.705 & 0.001 & & \\
\hline T37 & 187.8 & 107.7 & \begin{tabular}{|l|}
5.39 \\
\end{tabular} & 0.8533 & 1834 & 39 & 0.715 & 0.001 & & fora da isócrona \\
\hline T38 & 186.2 & 362.3 & 1.5 & 0.7608 & 2591 & 64 & 0.705 & 0.001 & & fora da isócrona \\
\hline T39 & 109.4 & 94.8 & 3.38 & 0.831 & 2591 & 64 & 0.705 & 0.001 & & \\
\hline T 40 & 99.1 & 477.7 & 0.6 & 0.7248 & 2591 & 64 & 0.705 & 0.001 & & fora da isócrona \\
\hline T41 & 55.1 & 583.3 & 0.27 & \begin{tabular}{|c|}
0.7216 \\
\end{tabular} & 1834 & 39 & 0.715 & 0.001 & & \\
\hline$T 42.1$ & 78.4 & 231.2 & 0.98 & 0.7189 & 974 & 95 & 0.707 & 0.003 & & \\
\hline T 42.2 & 363.7 & 180.5 & 5.86 & 0.7572 & 550 & & 0.71 & & & idade convencional \\
\hline
\end{tabular}




\begin{tabular}{|c|c|c|c|c|c|c|c|c|c|c|}
\hline Ordem & $\begin{array}{c}\mathrm{Rb} \\
(\mathrm{ppm})\end{array}$ & $\begin{array}{c}\mathrm{Sr} \\
(\mathrm{ppm})\end{array}$ & ${ }^{87} \mathrm{Rb} /{ }^{86} \mathrm{Sr}$ & ${ }^{87} \mathrm{Sr} r^{86} \mathrm{Sr}$ & $\begin{array}{c}\text { Idade } \\
\text { (Ma) }\end{array}$ & Erro & RI & Erro & MSWD & Observação \\
\hline T 43.1 & 390.6 & 93.9 & 12.26 & 0.8909 & 974 & 95 & 0.707 & 0.003 & & fora da isócrona \\
\hline T 43.2 & 18.5 & 1007 & 0.05 & 0.7572 & 974 & 95 & 0.707 & 0.003 & & \\
\hline T44 & 168.8 & 145.9 & 3.36 & 0.7461 & 974 & 95 & 0.707 & 0.003 & & fora da is 6 crona \\
\hline T45 & 186.8 & 162.8 & 3.33 & 0.7379 & 550 & & 0.71 & & & idade convencional \\
\hline$T 46$ & 156.9 & 180.9 & 2.53 & 0.7712 & 1856 & 29 & 0.704 & 0.002 & & \\
\hline T 47.1 & 397.4 & 42.71 & 28.17 & 1.4516 & 1856 & 29 & 0.704 & 0.002 & & \\
\hline T48 & 166 & 218.5 & 2.21 & 0.7619 & 1856 & 29 & 0.704 & 0.002 & & \\
\hline T49 & 139 & 382.7 & 1.05 & 0.7344 & 1856 & 29 & 0.704 & 0.002 & & \\
\hline T50 & 290.2 & 90.5 & 9.52 & 0.9647 & 1856 & 29 & 0.704 & 0.002 & & fora da isócrona \\
\hline T51 & 224.7 & 104.3 & 6.34 & 0.874 & 1856 & 29 & 0.704 & 0.002 & & \\
\hline T52 & 140.3 & 234.3 & 1.74 & 0.7523 & 1856 & 29 & 0.704 & 0.002 & & \\
\hline T 53 & 160 & 135 & 3.46 & 0.7905 & 1856 & 29 & 0.704 & 0.002 & & fora da is ócrona \\
\hline T54 & 153.4 & 46.05 & 9.84 & 0.9511 & 1856 & 29 & 0.704 & 0.002 & & fora da isócrona \\
\hline T55 & 152 & 34.08 & 13.28 & 1.0667 & 1856 & 29 & 0.704 & 0.002 & & fora da isócrona \\
\hline T56 & 203.9 & 34.6 & 17.77 & 1.1821 & 1737 & 50 & 0.719 & 0.008 & & \\
\hline$T 57$ & 177.8 & 86.6 & 6.04 & 0.8706 & 1737 & 50 & 0.719 & 0.008 & & \\
\hline$T 58$ & 207.1 & 141.8 & 4.27 & 0.8146 & 1737 & 50 & 0.719 & 0.008 & & fora da isócrona \\
\hline T59.1 & 130.6 & 198.6 & 1.92 & 0.7697 & 1737 & 50 & 0.719 & 0.008 & & \\
\hline T60 & 284.8 & 47.5 & 18.32 & 1.165 & 1737 & 50 & 0.719 & 0.008 & & \\
\hline T61 & 242.8 & 111.3 & 6.42 & 0.8668 & 1641 & 22 & 0.703 & 0.003 & & fora da isócrona \\
\hline T62 & 224.5 & 93.6 & 7.07 & 0.8887 & 1737 & $50:$ & 0.719 & 0.008 & & fora da isocrona \\
\hline T63 & 279.7 & 101.6 & 8.12 & 0.8958 & 1641 & 22 & 0.703 & 0.003 & & \\
\hline T64 & 315.7 & 85.6 & 10.97 & 0.9816 & 1737 & 50 & 0.719 & 0.008 & & fora da isócrona \\
\hline T 65.1 & 190.5 & 268.6 & 2.06 & 0.7518 & 1641 & 22 & 0.703 & 0.003 & & \\
\hline T 65.2 & 247.5 & 569.2 & 1.26 & 0.7278 & 1641 & 22 & 0.703 & 0.003 & & fora da isócrona \\
\hline T 66.1 & 459 & 44.2 & 32.2 & 1.4681 & 1641 & 22 & 0.703 & 0.003 & & fora da isócrona \\
\hline T 67 & 258.5 & 35.4 & 21.95 & 1.2208 & 1641 & 22 & 0.703 & 0.003 & & \\
\hline T68 & 281.2 & 47.1 & 18.2 & 1.122 & 1641 & 22 & 0.703 & 0.003 & & \\
\hline T69 & 103.8 & 240.5 & 1.25 & 0.7275 & 1641 & 22 & 0.703 & 0.003 & & fora da isócrona \\
\hline$T 70$ & 159.3 & 136.8 & 3.4 & 0.8065 & 1737 & 50 & 0.719 & 0.008 & & \\
\hline T 71.1 & 75.1 & 385.9 & 0.56 & 0.7176 & 1641 & 22 & 0.703 & 0.003 & & \\
\hline T72 & 35.9 & 857.4 & 0.12 & 0.7051 & 1100 & & 0.702 & & & idade convencional \\
\hline T73 & 120.4 & 272.9 & 1.28 & 0.7171 & 1100 & & 0.702 & & & idade convencional \\
\hline T74 & 89.1 & 248.4 & 1.04 & 0.7249 & 1100 & & 0.702 & & & idade convencional \\
\hline T 85 & 83.1 & 354.3 & 0.68 & 0.7268 & 2640 & 35 & 0.703 & & & \\
\hline T 86 & 217.5 & 160.3 & 3.99 & 0.8599 & 2640 & 35 & 0.703 & & & \\
\hline T 87 & 243.6 & 115.9 & 6.22 & 0.9347 & 2640 & 35 & 0.703 & & & \\
\hline T 88 & 145.3 & 395.7 & 1.07 & 0.7471 & 2640 & 35 & 0.703 & & & \\
\hline T 89.2 & 315.5 & 150.9 & 6.17 & 0.9097 & 2300 & & 0.705 & & & idade convencional \\
\hline T91 & 186.3 & 279 & 1.94 & 0.7598 & 1827 & 44 & 0.711 & & & \\
\hline T92.1 & 593 & 11.8 & 222.5 & 6.081 & 1680 & & 0.705 & & & idade convencional \\
\hline TP 1 & 300.7 & 62.3 & 14.47 & 1.065 & 1760 & 41 & 0.7072 & & & \\
\hline TP 10 & 198.5 & 169.6 & 3.42 & 0.7984 & 1853 & & 0.705 & & & idade convencional \\
\hline TP 11 & 240.3 & 157 & 4.48 & 0.8245 & 1853 & & 0.705 & & & idade convencional \\
\hline TP 12 & 122 & 427 & 0.826 & 0.7255 & 1407 & 352 & & & & \\
\hline TP 13 & & & 6.23 & 0.8557 & 1760 & 41 & 0.7072 & & & \\
\hline TP 14 & 340 & 37.1 & 28.38 & 1.4163 & 1760 & 41 & 0.7072 & & & \\
\hline TP 15 & 277.7 & 71.6 & 11.58 & 1.0201 & 1760 & 41 & 0.7072 & & & \\
\hline TP 16 & 153.1 & 110.9 & 4.05 & 0.8156 & 1760 & 41 & 0.7072 & & & \\
\hline TP 2 & 250.3 & 121 & 6.08 & 0.8553 & 1760 & 41 & 0.7072 & & & \\
\hline TP 21 & 213 & 146 & 4.26 & 0.8184 & 1900 & 41 & 0.7052 & & & \\
\hline TP 22 & 222 & 118 & 5.43 & 0.847 & 1755 & 72 & 0.7058 & 0.0031 & 1.038 & \\
\hline
\end{tabular}




\begin{tabular}{|c|c|c|c|c|c|c|c|c|c|c|}
\hline Ordem & $\begin{array}{c}\mathrm{Rb} \\
(\mathrm{ppm})\end{array}$ & $\begin{array}{c}\mathrm{Sr} \\
(\mathrm{ppm})\end{array}$ & ${ }^{87} \mathrm{Rb} /{ }^{86} \mathrm{Sr}$ & ${ }^{87} \mathrm{Sr} /{ }^{86} \mathrm{Sr}$ & $\begin{array}{c}\text { Idade } \\
\text { (Ma) }\end{array}$ & Erro & Ri & Erro & MSWD & Observaçăo \\
\hline TP 24.1 & 312 & 42.9 & 21.55 & 1.189 & 1542 & 62 & & & & \\
\hline TP 24.2 & & & 6.14 & 0.8472 & 1615 & 39 & 0.7054 & 0.00151 & 0.13 & \\
\hline TP 25 & 157.8 & 82.1 & 5.64 & 0.8545 & 1756 & 72 & & & & \\
\hline TP 26 & 199.1 & 113.3 & 5.15 & 0.8373 & 1756 & 72 & & & & \\
\hline TP 27 & 184.2 & 18 & 31.5 & 1.352 & 1428 & 41 & & & & idade convencional \\
\hline TP 28 & 204.4 & 177.9 & 3.35 & 0.7844 & 1616 & 39 & 0.7054 & 0.0015 & 1.13 & \\
\hline TP 29 & & & 2.82 & 0.7709 & 1615 & 39 & 0.7054 & 0.0015 & & \\
\hline TP 3 & 274.8 & 126.1 & 6.404 & 0.8584 & 1760 & 41 & 0.7072 & & & \\
\hline TP 30 & & & 7.01 & 0.8008 & 1615 & 39 & 0.7054 & 0.0015 & & \\
\hline TP 31 & & & 6.14 & 0.8472 & 1615 & 39 & 0.7054 & 0.0015 & 1.13 & \\
\hline TP 32 & & & 1.16 & 0.7347 & 1756 & 72 & 0.7058 & 0.0031 & & \\
\hline TP 33 & & & 5.86 & 0.8364 & 1756 & 72 & 0.7058 & 0.0031 & & \\
\hline TP 34 & 148.7 & 30.1 & 14 & 1.061 & 1707 & 41 & 0.7056 & 0.0012 & 1.104 & \\
\hline TP 4 & 202 & 451.4 & 12.8 & 1.044 & 1900 & 41 & 0.7052 & & & \\
\hline TP 45 & & & 35.1 & 1.5058 & 1528 & & & & & Idade convencional \\
\hline TP 46 & & & 34.9 & 1.5045 & 1535 & & & & & Idade convencional \\
\hline TP 5 & 310.1 & 65.6 & 14.2 & 1.06 & 1900 & 41 & 0.7052 & & & \\
\hline TP 50 & & & 5.706 & 0.8597 & 1810 & & & & & Idade convencional \\
\hline TP 51 & & & 1.002 & 0.7282 & 1502 & & & & & Idade convencional \\
\hline TP 52 & & & 2.34 & 0.7624 & 1563 & & & & & Idade convencional \\
\hline TP 53 & & & 4.57 & 0.81 & 1501 & & & & & Idade convencional \\
\hline TP 55 & & & 25.7 & 1.3627 & 1711 & & & & & Idade convencional \\
\hline TP 6 & 288.5 & 65.8 & 13.1 & 1.041 & 1900 & 41 & 0.7052 & & & \\
\hline TP 63 & 202.3 & 178.1 & 3.31 & 0.7884 & 1680 & 13 & 0.705 & & & \\
\hline TP 64 & 157.6 & 335.3 & 1.36 & 0.7407 & 1680 & 13 & 0.705 & & & \\
\hline TP 65 & 80 & 209.4 & 1.11 & 0.7319 & 1650 & 20 & 0.706 & & & \\
\hline TP 66 & 74.2 & 232.9 & 0.92 & 0.7274 & 1650 & 20 & 0.706 & & & \\
\hline TP 67 & 164.2 & 274.4 & 1.74 & 0.7492 & 1650 & 20 & 0.706 & & & \\
\hline TP 68 & 190 & 124.7 & 4.45 & 0.8114 & 1650 & 20 & 0.706 & & & \\
\hline TP 69 & 192.9 & 126 & 4.48 & 0.8101 & 1650 & 20 & 0.706 & & & \\
\hline TP7 & 248.3 & 48.6 & 15.2 & 1.09 & 1900 & 41 & 0.7052 & & & \\
\hline $\operatorname{TP} 70$ & 493.4 & 11.7 & 168.84 & 4.5959 & 1650 & 20 & 0.706 & & & \\
\hline TP71 & 174.2 & 407.1 & 1.24 & 0.739 & 1650 & 20 & 0.706 & & & \\
\hline TP 76.1 & 232.3 & 17.8 & 41.03 & 1.5827 & 1490 & & 0.706 & & & \\
\hline TP 77 & 283.7 & 17.2 & 52.9 & 1.8057 & 1450 & & 0.705 & & & \\
\hline IP 78 & 171.8 & 99.1 & 5.08 & 0.8433 & 1400 & & 0.74 & & & \\
\hline TP79 & 170.1 & 63 & 7.95 & 0.8848 & 1400 & & 0.74 & & & \\
\hline TP 8 & 184.4 & 111.3 & 4.85 & 0.8335 & 1853 & & 0.705 & & & idade convencional \\
\hline TP 80 & 159.5 & 83 & 5.64 & 0.8461 & 1400 & & 0.74 & & & \\
\hline TP 81 & 146.9 & 83.9 & 5.13 & 0.8403 & 1400 & & 0.74 & & & \\
\hline TP 84 & 245 & 89.3 & 8.07 & \begin{tabular}{|l|l|}
0.8733 \\
\end{tabular} & 1150 & & 0.74 & & & \\
\hline TP 9 & 165 & \begin{tabular}{l|}
179.4 \\
\end{tabular} & 2.68 & 0.7798 & 1853 & & 0.705 & & & idade convencional \\
\hline TP 96 & 152 & 101.9 & 4.36 & 0.8192 & 1765 & 116 & 0.705 & & & \\
\hline TU1 & 214.4 & 144.4 & 4.307 & 0.8221 & 1854 & 10 & 0.7077 & 0.0002 & & \\
\hline TU 10 & 118 & 575 & 0.596 & 0.7199 & 1854 & 10 & 0.7077 & 0.0002 & & \\
\hline TU 11 & 166.9 & 195.6 & 2.487 & 0.7739 & 1854 & 10 & 0.7077 & 0.0002 & & \\
\hline TU 16.2 & 191.1 & 103.1 & 5.443 & 0.8523 & 1901 & 36 & 0.705 & & & \\
\hline TU 18.1 & 102.5 & 161.4 & 1.848 & 0.7566 & 1901 & 36 & 0.7055 & 0.0008 & & \\
\hline TU 18.2 & 255.1 & 213.6 & 3.49 & 0.8011 & 1901 & 36 & 0.7055 & 0.0008 & & \\
\hline TU 19 & 93.7 & 564.2 & 0.481 & 0.7186 & 1901 & 36 & 0.7055 & 0.0008 & & \\
\hline TU2 & 192.9 & 195 & 2.886 & 0.7857 & 1854 & 10 & 0.7077 & 0.0002 & & \\
\hline TU21 & 54.7 & 606.1 & 0.261 & 0.7123 & 1901 & 36 & 0.7055 & 0.0008 & & \\
\hline
\end{tabular}




\begin{tabular}{|c|c|c|c|c|c|c|c|c|c|c|}
\hline Ordem & $\begin{array}{c}\mathrm{Rb} \\
(\mathrm{ppm})\end{array}$ & $\begin{array}{c}\mathrm{Sr} \\
(\mathrm{ppm})\end{array}$ & ${ }^{87} \mathrm{Rb} /{ }^{86} \mathrm{Sr}$ & ${ }^{87} \mathrm{Sr} /^{86} \mathrm{Sr}$ & $\begin{array}{c}\text { Idade } \\
\text { (Ma) }\end{array}$ & Erro & $\mathbf{R i}$ & Erro & MSWD & Observação \\
\hline TU 22 & 138.1 & 73.9 & 5.501 & 0.8769 & 2201 & & 0.705 & & & idade convencional \\
\hline TU 23 & 104.5 & 738.2 & 0.41 & 0.714 & 1901 & 36 & 0.7055 & 0.0008 & & \\
\hline TU 24 & & & 6 & 0.872 & 1901 & 36 & 0.7055 & 0.0008 & & \\
\hline TU 25 & 147.1 & 168.9 & 2.536 & 0.7666 & 1755 & 41 & 0.7055 & 0.0008 & & \\
\hline TU 26 & 265.3 & 60.6 & 13.105 & 1.0511 & 1755 & 41 & 0.705 & & & \\
\hline TU 27 & 202 & 49.8 & 12 & 0.9809 & 1579 & 57 & 0.705 & & & idade convencional \\
\hline TU 28 & 164 & 57.4 & 8.464 & 0.9418 & 1901 & 36 & 0.705 & & & \\
\hline TU 3 & 87.4 & 470.8 & 0.538 & 0.7221 & 1854 & 10 & 0.7077 & 0.0002 & & \\
\hline TU 30 & 185 & 8.3 & 73.62 & 2.412 & 1615 & 57 & 0.705 & & & idade convencional \\
\hline TU 31 & 72.6 & 42.9 & 4.95 & 0.8382 & 1901 & 36 & 0.705 & & & \\
\hline TU 32 & 211.4 & 481.6 & 1.275 & 0.7431 & 1901 & 36 & 0.705 & & & \\
\hline TU 33 & 124 & 454.6 & 0.791 & 0.7268 & 1901 & 36 & 0.705 & & & \\
\hline TU 34 & 118.5 & 13.9 & 25.61 & 1.2268 & 1531 & 35 & 0.705 & & & idade convencional \\
\hline TU 35 & 269.6 & 229.7 & 3.423 & 0.7817 & 1560 & 86 & 0.705 & & & idade convencional \\
\hline TU 36 & 193.3 & 6.2 & 107.526 & 2.983 & 1476 & 38 & 0.705 & & & idade convencional \\
\hline TU 37 & 229.2 & 174.5 & 3.837 & 0.7967 & 1665 & 79 & 0.705 & & & idade convencional \\
\hline TU 38 & 245.1 & 72.6 & 9.983 & 0.923 & 1521 & 51 & 0.705 & & & idade convencional \\
\hline TU 4 & 236.6 & 81 & 8.651 & 0.9401 & 1854 & 10 & 0.7077 & 0.0002 & & \\
\hline TU5 & 171.3 & 156 & 3.195 & 0.7915 & 1854 & 10 & 0.7077 & 0.0002 & & \\
\hline TU 50 & 145.5 & 357.7 & 1.18 & 0.7354 & 1890 & 25 & 0.704 & & & idade convencional \\
\hline TU51 & 296 & 219 & 3.95 & 0.8179 & 1890 & 25 & 0.704 & & & idade convencional \\
\hline TU 52.1 & 201 & 186 & 3.15 & 0.7871 & 1860 & 28 & 0.707 & & & idade convencional \\
\hline TU 53 & 170.5 & 136.5 & 3.65 & 0.8065 & 1860 & 28 & 0.707 & & & idade convencional \\
\hline TU54 & 142.3 & 307 & 1.35 & 0.7418 & 1860 & 28 & 0.707 & & & idade convencional \\
\hline TU 55 & 211.3 & 139.2 & 4.45 & 0.8282 & 1860 & 28 & 0.707 & & & idade convencional \\
\hline TU 59 & 376.1 & 10.5 & 133.8 & 3.656 & 1540 & & 0.705 & & & idade convencional \\
\hline TU6 & 142.1 & 271.8 & 1.52 & 0.7477 & 1854 & 10 & 0.7077 & 0.0002 & & \\
\hline TU7 & 284.5 & 146.1 & 5.724 & 0.8617 & 1854 & 10 & 0.7077 & 0.0002 & & \\
\hline TU 8 & 324 & 86.1 & 11.216 & 1.006 & 1854 & 10 & 0.7077 & 0.0002 & & \\
\hline TU9 & 193.7 & 231.3 & 2.44 & 0.7706 & 1854 & 10 & 0.7077 & 0.0002 & & \\
\hline
\end{tabular}




\begin{tabular}{|c|c|c|c|c|c|}
\hline Ordem & $\% \mathrm{~K}$ & $\% \operatorname{Ar}(\mathrm{atm})$ & $\begin{array}{c}{ }^{40} \mathrm{Ar}(\mathrm{rad}) \times 10^{-6} \\
\text { cCSTP/g }\end{array}$ & Idade (Ma) & Erro \\
\hline $\mathrm{BE} 1$ & 0.78 & 42 & 6.69 & 204 & 6 \\
\hline BE 10 & 0.25 & 17.2 & 5.85 & 510 & 15 \\
\hline BE 11 & 8.13 & 2.7 & 1.893 & 509 & 15 \\
\hline BE 12 & 0.51 & 9.2 & 0.207 & 811 & 24 \\
\hline BE 13 & 0.3871 & 47.99 & 2.13 & 130 & 6 \\
\hline BE 2 & 0.73 & 17.68 & 6.55 & 213 & 7 \\
\hline $\mathrm{BE} 3$ & 0.71 & 20.27 & 5.09 & 171 & 9 \\
\hline BE 4 & 0.31 & 42 & 1.69 & 30 & 6 \\
\hline BE 5 & 0.58 & 45.4 & 4.59 & 88 & 6 \\
\hline BE 6 & 3.15 & 1.78 & 174.7 & 1040 & 46 \\
\hline BE 7 & 1.84 & 3.12 & 42.1 & 01 & 18 \\
\hline BE 8 & 0.55 & 17.4 & 12.75 & 509 & 15 \\
\hline $\mathrm{BE} 9$ & 0.61 & 35.1 & 7.7 & 300 & 50 \\
\hline C 126.10.3 & 1.281 & 1.53 & 86 & 1358 & 31 \\
\hline C 126.12.2 & 0.758 & 1.67 & 101 & 1740 & 27 \\
\hline C 126.12 .3 & 4.928 & 1.53 & 646 & & \\
\hline C 126.13 & 1.679 & 2.1 & 227 & 1903 & 35 \\
\hline C 126.14 & 7.94 & 1.3 & 1113 & 1983 & 47 \\
\hline C 126.15 & 7.62 & 0.7 & 1101 & 2022 & 73 \\
\hline C 126.16 & 6.003 & & 917 & 1971 & 27 \\
\hline C 126.6 .2 & 6.704 & 1.88 & 891 & 1920 & 53 \\
\hline C 131.2 & 6.99 & 2.78 & 786 & 1727 & 72 \\
\hline C 133.1 & 0.54 & 4.11 & 92 & 2230 & 59 \\
\hline C 134.1 & 7.57 & 1.26 & 918 & 1813 & 40 \\
\hline C 137.2 & 1.0911 & 5.62 & 27.85 & 560 & 12 \\
\hline C 138.1 & 2.65 & 1.18 & 348.2 & 1905 & 58 \\
\hline C 138.2 & 5.37 & 2.25 & 485.2 & 1488 & 13 \\
\hline C 139.1 & 2.14 & 2.36 & 195 & 1496 & 55 \\
\hline C 140.1 & 0.44 & 7.58 & 40.15 & 1492 & 16 \\
\hline C 141.1 & 0.79 & 14.1 & 71.7 & 1491 & 31 \\
\hline C 142.1 & 1.99 & 5.82 & 171.7| & 1439 & 38 \\
\hline C 143.1 & 0.71 & 11.05 & 36.5 & 986 & 47 \\
\hline C 144.1 & 3.11 & 2.46 & 157.8 & 973 & 34 \\
\hline C 144.2 & 2.67 & 5.63 & 131.8 & 951 & 14 \\
\hline C 145.1 & 0.15 & 82.14 & 2.3 & 348 & 20 \\
\hline C 146.1 & 0.7 & 82.95 & 6.2 & 210 & 14 \\
\hline C 147.1 & 0.75 & 15.6 & 6.36 & 203 & 6 \\
\hline C 148.1 & 0.21 & 97.3 & 0.89 & 105 & 15 \\
\hline C 156.1 & 0.7681 & 1.68 & 177.91 & 2638 & 91 \\
\hline C 156.2 & 6.7668 & 0.2 & 929.36 & 1958 & 54 \\
\hline C 192.12 & 1.274 & 3.63 & 125.97 & 1587 & 30 \\
\hline C 192.13 & 0.682 & 32.73 & 120.73 & 2274 & 67 \\
\hline
\end{tabular}




\begin{tabular}{|l|r|r|r|r|r|}
\hline Ordem & \% K & \% Ar (atm) & $\begin{array}{c}{ }^{40} \text { Ar (rad) } 10^{-6} \\
\text { ccSTP/g }\end{array}$ & Idade (Ma) & Erro \\
\hline C 192.14 & 0.634 & 8.58 & 111.75 & 2268 & 41 \\
\hline C 203 & 0.2878 & 2.8 & 82.26 & 2930 & 89 \\
\hline C 204 & 2.4181 & 2.74 & 452.8 & 2350 & 90 \\
\hline C 205 & 0.3633 & 2.34 & 56.08 & 2100 & 71 \\
\hline C 206 & 0.6076 & 11.07 & 89.81 & 2045 & 58 \\
\hline C 207 & 0.9344 & 1.5 & 144.5 & 2040 & 61 \\
\hline C 208 & 6.062 & 0.73 & 876.5 & 2020 & 57 \\
\hline C 209 & 2.748 & 1.33 & 394.9 & 2010 & 45 \\
\hline C 215 & 0.5988 & 2.39 & 85.39 & 2000 & 49 \\
\hline C 216 & 7.4255 & 0.48 & 101.4 & 1960 & 39 \\
\hline C 217 & 4.2462 & 0.99 & 580.4 & 1953 & 62 \\
\hline C 220 & 0.6836 & 11.92 & 72.08 & 1656 & 21 \\
\hline C 221.1 & 2.65 & & 227 & 1632 & 44 \\
\hline C 221.2 & 4.38 & & 353 & 1567 & 38 \\
\hline C 221.3 & 1.99 & & 156.7 & 1543 & 43 \\
\hline C 222 & 0.7264 & 16.85 & 67.6 & 1523 & 22 \\
\hline C 223 & 2.142 & 2.4 & 193.6 & 1495 & 62 \\
\hline C 224 & 4.9959 & 2.28 & 417.2 & 1420 & 67 \\
\hline C 225 & 1.995 & 5.9 & 157.5 & 1350 & 44 \\
\hline C 226 & 4.3459 & 9.48 & 294.6 & 1220 & 40 \\
\hline C 228 & 4.7104 & 5.12 & 116.2 & 540 & 26 \\
\hline C 229 & 0.153 & 83.4 & 2.13 & 330 & 37 \\
\hline C 230 & 0.415 & 83.08 & 2.73 & 160 & 24 \\
\hline C 33.4 & 1.217 & 24 & 27.4 & 495 & 15 \\
\hline C 34.4 & 0.244 & 6.9 & 39.2 & 2160 & 140 \\
\hline C 37.1 & 0.152 & 26 & 33.8 & 3283 & 113 \\
\hline C 38.1 & 0.981 & 10.6 & 209.7 & 2540 & 75 \\
\hline C 39.1 & 6.29 & 0.5 & 1223 & 2409 & 70 \\
\hline C 40.1 & 0.73 & 2.4 & 123.3 & 2222 & 32 \\
\hline C 41.1 & 0.677 & 8.4 & 106.6 & 2130 & 78 \\
\hline C 42.1 & 7.62 & 0.7 & 1101 & 2022 & \\
\hline C 43.1 & 1.093 & 16.6 & 155.2 & 2000 & 60 \\
\hline C 44.1 & 0.33 & 11 & 56.5 & 1989 & 77 \\
\hline C 45.1 & 0.166 & 10.2 & 229 & 1961 & 31 \\
\hline C 46.1 & 7.22 & 8.5 & 963 & 1920 & 50 \\
\hline C 47.1 & 2.101 & 46 & 53.7 & 550 & 30 \\
\hline C 48.1 & 0.681 & 15.7 & 15.8 & 507 & 29 \\
\hline C 49.1 & 0.28 & 69 & 2.66 & 225 & 25 \\
\hline C 50.1 & 7.53 & 2.9 & 1156 & 2098 & 67 \\
\hline C 51.1 & 2.65 & 1.2 & 348 & 1909 & 59 \\
\hline C 51.2 & 5.37 & 2.2 & 485 & 1488 & 13 \\
\hline C 52.1 & 1.24 & 2.5 & 152.5 & 1828 & 52 \\
\hline
\end{tabular}




\begin{tabular}{|l|r|r|r|r|r|}
\hline Ordem & \multicolumn{1}{|c|}{$\%$} & \% Ar (atm) & $\begin{array}{r}{ }^{40} \text { Ar (rad) } 10^{-6} \\
\text { cCSTP/g }\end{array}$ & Idade (Ma) & Erro \\
\hline C 52.2 & 0.684 & 11.7 & 72.7 & 1663 & 15 \\
\hline C 53.1 & 3.11 & 2.5 & 157.8 & 973 & 35 \\
\hline C 53.2 & 2.67 & 5.6 & 131.8 & 951 & 14 \\
\hline C 54.1 & 1.744 & 12.2 & 63.5 & 744 & 39 \\
\hline C 55.1 & 1.386 & 5.5 & 154.9 & 1720 & 170 \\
\hline C 55.2 & 5.23 & 31 & 719 & 1960 & 60 \\
\hline C 67.1.2 & 3.331 & 2.09 & 191.4 & 1071 & \\
\hline C 68.1.2 & 5.115 & 1.44 & 283.1 & 1040 & \\
\hline C 69.1.2 & 4.859 & 3.95 & 150.7 & 651 & \\
\hline C 70.1 & 1.978 & 5.24 & 161.4 & 1403 & \\
\hline C 71.1 & 3.152 & 1.78 & 175.3 & 1045 & \\
\hline C 72.1 & 3.207 & 58.78 & 217.5 & 1213 & \\
\hline C 73.1 & 3.924 & 3.22 & 118 & 866 & \\
\hline C 75.1 & 8.31 & 4.6 & 181.7 & 481 & \\
\hline C 87.1 & 0.696 & 82.95 & 6.2 & 210 & \\
\hline CB 16.2 & 6.699 & 2.3 & 317.7 & 933 & 19 \\
\hline CB 17 & 0.508 & 3.6 & 31.73 & 1140 & 80 \\
\hline CB 18 & 0.973 & 4.8 & 48.8 & 966 & 68 \\
\hline CB 19 & 6.587 & 2.8 & 697.2 & 1104 & 20 \\
\hline CB 20 & 5.735 & 2.3 & 737.6 & 1881 & 26 \\
\hline CB 21 & 3.716 & 1.3 & 448.1 & 1805 & 26 \\
\hline CB 22 & 0.363 & 8 & 309.6 & 1430 & 22 \\
\hline CB 23 & 5.4592 & 1.17 & 373.1 & 1229 & 26 \\
\hline CB 26 & 0.125 & 10.58 & 127 & 1615 & 32 \\
\hline CB 27 & 0.548 & 17.3 & 384.9 & 1245 & 35 \\
\hline CB 28 & 0.572 & 4.7 & 605 & 1227 & 25 \\
\hline CB 32 & 1.355 & 4.1 & 133.5 & 1450 & 20 \\
\hline CB 33 & 1.716 & 4.9 & 909.1 & 1006 & 16 \\
\hline CB 35 & 1.028 & 1.74 & 44.91 & 875 & 21 \\
\hline CB 36 & 1.553 & 1.84 & 68.25 & 878 & 10 \\
\hline CB 37 & 1.069 & 5.32 & 50.55 & 930 & 14 \\
\hline CB 38 & 1.007 & 2.14 & 49.51 & 960 & 21 \\
\hline CB 41.2 & 7.59 & 2.6 & 355.7 & 698 & 21 \\
\hline CB 42 & 0.998 & 9.58 & 312.3 & 656 & 10 \\
\hline CB 43 & 8.34 & 1.5 & 370.4 & 875 & 43 \\
\hline CB 58 & 0.371 & 79 & 188.7 & 123 & 13 \\
\hline CB 59 & 0.412 & 41.6 & 214 & 126 & 4 \\
\hline CB 60 & 0.567 & 27.7 & 267 & 112 & 4 \\
\hline CB 71.1 & 5.2135 & 1.08 & 497 & 1549 & 29 \\
\hline CB 71.2 & 1.0282 & 6.09 & 98.43 & 1553 & 34 \\
\hline CB 71.3 & 1.3005 & 4.94 & 113.57 & 1460 & 47 \\
\hline CB 71.4 & 6.5181 & 1.07 & 603.19 & 1519 & 41 \\
\hline
\end{tabular}




\begin{tabular}{|c|c|c|c|c|c|}
\hline Ordem & $\% \mathrm{~K}$ & $\% \operatorname{Ar}(a t m)$ & $\begin{array}{c}{ }^{40} \mathrm{Ar}(\mathrm{rad}) \times 10^{-6} \\
\text { ccSTP/g }\end{array}$ & Idade (Ma) & Erro \\
\hline CB 71.5 & 1.0485 & 15.97 & 193.93 & 1581 & 44 \\
\hline CB 71.6 & 6.3714 & 4.05 & 581.71 & 1505 & 43 \\
\hline CB 72 & 0.7309 & 4.18 & 68.67 & 1535 & 47 \\
\hline CB 73 & 0.3311 & 15.79 & 30.2 & 1503 & 42 \\
\hline CB 74 & 0.7472 & 4.51 & 65.45 & 1463 & 41 \\
\hline CB 75.1 & 0.2192 & 21.53 & 18.98 & 1453 & 50 \\
\hline CB 75.2 & 0.307 & 11.47 & 27.9 & 1503 & 82 \\
\hline CB 76 & 1.0646 & 3.28 & 99.39 & 1527 & 35 \\
\hline CB 77 & 0.6604 & 2.8 & 60.97 & 1516 & 40 \\
\hline CB 78 & 0.2692 & 7.33 & 22.23 & 1404 & 42 \\
\hline CB 79 & 1.218 & 1.97 & 111.48 & 1507 & 37 \\
\hline CB 94 & 7.9297 & 1.62 & 368.84 & 918 & 10 \\
\hline CB 95 & 8.4183 & 0.61 & 395.05 & 924 & 14 \\
\hline CB 96 & 6.3022 & 0.34 & 311.54 & 964 & 42 \\
\hline GP 10.1 & 0.0117 & 48.86 & 1.04 & 1477 & 26 \\
\hline GP 19 & 0.711 & 79.7 & 4.126 & 140 & 6 \\
\hline GP 20 & 1.5862 & 1 & 114.4 & 1268 & 15 \\
\hline GP 21.1 & 0.4167 & 17.1 & 2.62 & 151 & 2 \\
\hline GP 22 & 0.5164 & 12.1 & 3.85 & 178 & 3 \\
\hline GP 23 & 0.1411 & 90.1 & 3.31 & 515 & 37 \\
\hline GP 24 & 0.2288 & 12.2 & 16.16 & 1250 & 22 \\
\hline GP 25 & 0.4766 & 33.8 & 2.96 & 150 & 2 \\
\hline GP 26 & 1.9736 & 1.6 & $\begin{array}{l}95.25 \\
\end{array}$ & 936 & 20 \\
\hline GP 27 & 0.1225 & 44.5 & 4.37 & 732 & 13 \\
\hline GP 28 & 0.0313 & 45.7 & 1.739 & 1045 & 23 \\
\hline GP 3.1 & 0.6756 & 13.89 & \begin{tabular}{|l|}
37.79 \\
\end{tabular} & 1049 & 13 \\
\hline GP 4 & 0.2139 & 42.2 & 17.17 & 1370 & 18 \\
\hline GP 5.1 & 0.2131 & 17.1 & 12.65 & 1097 & 13 \\
\hline GP 6 & 1.5009 & 4.2 & 119.1 & 1359 & 18 \\
\hline GP 7 & 0.7804 & 11.9 & 44.23 & 1060 & 14 \\
\hline GP 8 & 6.3087 & 0.22 & 401.8 & 1161 & 71 \\
\hline GP 9.1 & 0.1763 & 7.26 & 14.49 & 1394 & 22 \\
\hline 120.6 & 7.74 & & & 1311 & 39 \\
\hline 122.2 & 4.66 & 1.25 & 438.4 & 1530 & 18 \\
\hline 13.2 & 1.07 & 1.12 & 80.86 & 1311 & 15 \\
\hline 132.2 & 1.11 & 3.51 & $91.87 \mid$ & 1406 & 19 \\
\hline 137 & 7.87 & 1.24 & 582.8 & 1293 & 18 \\
\hline 138 & 8.37 & 1.84 & 465.5 & 1045 & 19 \\
\hline | 44.2 & 7.44 & 1.02 & 594.8 & 1372 & 16 \\
\hline 148 & 5.92 & 1.12 & 471.6 & 1292 & 20 \\
\hline 49 & 4.72 & 3.22 & 293.8 & 1140 & 39 \\
\hline 150 & 0.26 & 3.61 & 31.05 & 1815 & 60 \\
\hline
\end{tabular}




\begin{tabular}{|c|c|c|c|c|c|}
\hline Ordem & $\% \mathrm{~K}$ & $\% \operatorname{Ar}(\operatorname{atm})$ & $\begin{array}{c}{ }^{40} \mathrm{Ar}(\mathrm{rad}) \times 10^{-6} \\
\text { ccSTP/g }\end{array}$ & Idade (Ma) & Erro \\
\hline 151 & 0.78 & 3.28 & 72.51 & 1512 & 22 \\
\hline 152 & 4.47 & 1.08 & 306.8 & 1223 & 12 \\
\hline 153 & 6.312 & 3.88 & 49.8 & 1353 & 34 \\
\hline 154 & 8.653 & 1.05 & 65.49 & 1314 & 34 \\
\hline 155 & 1.201 & 2.04 & 9.47 & 1352 & 50 \\
\hline 158 & 0.74 & 4.02 & 38.15 & 984 & 12 \\
\hline 159 & 1.11 & 3.56 & 53.9 & 941 & 14 \\
\hline 16.3 & 5.81 & 2.17 & 528.4 & 1495 & 21 \\
\hline 162 & 5.92 & 0.86 & 471.6 & 1369 & 14 \\
\hline 18.3 & 6.62 & 1.12 & 489.7 & 1299 & 20 \\
\hline 19.4 & 0.5 & 0.55 & 43.29 & 1444 & 46 \\
\hline JA 1.2 & 4.68 & 5.65 & 47.43 & 238 & 3 \\
\hline JA 1.4 & 4.6811 & 5.66 & 47.38 & 245 & 5 \\
\hline JA 2.2 & 4.4704 & 14.18 & 165.5 & 765 & 16 \\
\hline JA 3.1 & 0.15 & 11.84 & 6.99 & 920 & 20 \\
\hline JA 3.2 & 0.6213 & 7.15 & 26.15 & 850 & 33 \\
\hline JR 107 & 1.4693 & 3.44 & 83.3 & 1070 & 19 \\
\hline JR 108 & 0.9458 & 3.05 & 42.24 & 890 & 23 \\
\hline JR 109 & 2.4167 & 0.54 & 156.6 & 1180 & 35 \\
\hline JR 110 & 7.7228 & 0.76 & 616.4 & 1370 & 44 \\
\hline JR 111 & 2.4421 & 0.62 & 220.3 & 1490 & 29 \\
\hline JR 112 & 7.2974 & 0.81 & 678.6 & 1520 & 20 \\
\hline JR 113 & 0.86 & 4.22 & 79.49 & 1520 & 46 \\
\hline JR 114 & 7.431 & 0.84 & 798.8 & 1640 & 28 \\
\hline JR 115 & 1.0434 & 1.45 & 109.1 & 1650 & 37 \\
\hline JR 116 & 0.7313 & 5.91 & 79.88 & 1690 & 39 \\
\hline JR 121 & 0.6995 & 2.76 & 48.65 & 1244 & 24 \\
\hline JR 18.2 & 1.5224 & 4.33 & 124.5 & 1389 & 16 \\
\hline JR 2.2 & 7.6667 & 1.07 & 607.5 & 1357 & 16 \\
\hline JR 3.2 & 7.431 & 0.84 & 79.71 & 1672 & 27 \\
\hline JR 66.7 & 4.052 & 2.09 & 260.8 & 1169 & 57 \\
\hline JR 70 & 1.158 & 2.8 & 92.89 & 1369 & 17 \\
\hline JR 71 & 7.2974 & 0.82 & 677.2 & 1516 & 18 \\
\hline JR 72 & 0.7313 & 5.94 & 79.7 & 1690 & 37 \\
\hline JR 73 & 0.3219 & 19.76 & 22.12 & 1225 & 20 \\
\hline JR 74 & 0.5537 & 27.41 & 14.55 & 565 & 6 \\
\hline JR 75 & 0.9411 & 6.16 & 69.33 & 1289 & 27 \\
\hline JR 76 & 0.4461 & 4.94 & 37.5 & 1416 & 14 \\
\hline JR 77 & 1.0836 & 3.34 & 40.89 & 767 & 9 \\
\hline JR 78 & 2.7606 & 0.41 & 210.1 & 1321 & 58 \\
\hline JR 79 & 0.8804 & 1.15 & 67.89 & 1333 & 43 \\
\hline JR 80 & 0.7913 & 9.19 & 57.24 & 1271 & 20 \\
\hline
\end{tabular}




\begin{tabular}{|l|r|r|r|r|r|}
\hline \multicolumn{1}{|c|}{ Ordem } & \multicolumn{1}{|c|}{$\%$ K } & \% Ar (atm) & $\begin{array}{r}{ }^{40} \text { Ar (rad) } 10^{-6} \\
\text { ccSTP/g }\end{array}$ & Idade (Ma) & Erro \\
\hline JR 92.2 & 2.7434 & 1.15 & 175.4 & 1170 & 37 \\
\hline JR 93.2 & 2.417 & 0.54 & 156.8 & 1182 & 37 \\
\hline JU 1.1 & 0.962 & 6.69 & 12.79 & 307 & 12 \\
\hline JU 1.2 & 1.0339 & 69 & 13.09 & 294 & 22 \\
\hline JU 2.1 & 10.786 & 0.75 & 700.8 & 1175 & 45 \\
\hline JU 3 & 0.3913 & 71.12 & 3.48 & 216 & 19 \\
\hline JU 4 & 0.273 & 57.86 & 13 & 920 & 60 \\
\hline JU 5 & 1.4506 & 1.24 & 95.06 & 1190 & 27 \\
\hline JU 7 & 1.964 & 5.39 & 149.7 & 1321 & 50 \\
\hline JU 8 & 0.49 & 12.26 & 45.4 & 1519 & 57 \\
\hline M 10 & 0.177 & 42.4 & 1.539 & 207 & 18 \\
\hline M 11 & 0.5152 & 29.1 & 4.87 & 224 & 17 \\
\hline M 12 & 0.4506 & 41.3 & 4.328 & 227 & 10 \\
\hline M 13 & 0.8992 & 47.1 & 9.68 & 254 & 27 \\
\hline M 14 & 0.6492 & 10.7 & 4.761 & 176 & 9 \\
\hline M 15 & 6.851 & 2.6 & 9474 & 1968 & 60 \\
\hline M 17 & 8.444 & 1.93 & 1033 & 1822 & 40 \\
\hline M 18 & 5.636 & 4.85 & 817 & 2026 & 32 \\
\hline M 19 & 7.563 & 0.85 & 1149 & 2084 & 24 \\
\hline M 20 & 6.722 & 0.41 & 999 & 2058 & 30 \\
\hline M 21 & 7.579 & 10.73 & 181.4 & 521 & 25 \\
\hline M 22 & 7.724 & 0.31 & 941.2 & 1817 & 17 \\
\hline M 23 & 7.721 & 1.42 & 843.8 & 1769 & 58 \\
\hline M 24 & 3.565 & 74.54 & 504.6 & 1997 & 291 \\
\hline M 25 & 0.6087 & 28.5 & 12.73 & 463 & 18 \\
\hline M 30 & 0.3651 & 56.4 & 0.8693 & 589 & 6 \\
\hline M 31 & 6.527 & 4.58 & 757 & 1761 & 41 \\
\hline MN 1 & 3.72 & 0.54 & 227.7 & 1123 & 14 \\
\hline MN 11.2 & 7.2 & 0.78 & 530 & 1287 & 19 \\
\hline MN 13.2 & 7.48 & 0.73 & 532.6 & 1257 & 15 \\
\hline MN 18 & 6.06 & 0.69 & 442.3 & 1279 & 20 \\
\hline MN 19 & 7.06 & 0.51 & 492.8 & 1240 & 35 \\
\hline MN 2 & 0.64 & 3.18 & 37.87 & 1090 & 13 \\
\hline MN 23.2 & 6.18 & 0.42 & 454.4 & 1289 & 60 \\
\hline MN 27.2 & 7 & 0.81 & 470.4 & 1024 & 18 \\
\hline MN 29.2 & 6.82 & 4.16 & 590.9 & 1447 & 38 \\
\hline MN 3 & 0.74 & 16.8 & 7.83 & 248 & 4 \\
\hline MN 30.2 & 7.55 & 0.27 & 858.1 & 1737 & 37 \\
\hline MN 34.2 & 6.7 & 1.92 & 612.2 & 1515 & 16 \\
\hline MN 35 & 6.79 & 0.46 & 732.4 & 1679 & 34 \\
\hline MN 4 & 0.42 & 21.2 & 3.68 & 209 & 8 \\
\hline MN 49 & 0.13 & 14.09 & 24.1 & 2382 & 33 \\
\hline
\end{tabular}




\begin{tabular}{|c|c|c|c|c|c|}
\hline Ordem & $\% \mathrm{~K}$ & $\% \operatorname{Ar}($ atm) & $\begin{array}{c}{ }^{40} \mathrm{Ar}(\mathrm{rad}) \times 10^{-6} \\
\mathrm{ccSTP} / \mathrm{g}\end{array}$ & Idade (Ma) & Erro \\
\hline MN 5 & 0.61 & 50.9 & 4.29 & 165 & 7 \\
\hline MN 50 & 0.03 & 15.33 & 4.8 & 2151 & 143 \\
\hline MN 51 & 0.1 & 7.5 & 23.7 & 2700 & 162 \\
\hline MN 53 & 0.54 & 81.01 & 31.2 & 1079 & 18 \\
\hline MN 57 & 6.14 & & & 1324 & 40 \\
\hline MN 58 & 1.5778 & 0.77 & 403.5 & 2773 & 61 \\
\hline MN 59 & 1.44 & 2.39 & 210.1 & 2032 & 63 \\
\hline $\mathrm{MN} 60$ & 1.03 & 1.31 & 88.91 & 1452 & 71 \\
\hline MN 62 & 5.326 & 1.45 & 384.9 & 1300 & 29 \\
\hline PU 1.1 & 7.5 & 0.86 & 678.2 & 1490 & 32 \\
\hline PU 2.1 & 4.82 & 1.42 & 405.8 & 1418 & 44 \\
\hline PU 25.2 & 1.49 & 1.63 & 126.1 & 1420 & 22 \\
\hline PU 29 & 1.78 & 0.48 & 151.8 & 1429 & 16 \\
\hline PU 3.1 & 7.18 & 0.94 & 597 & 1405 & 22 \\
\hline PU 30 & 0.66 & 1.59 & 52.9 & 1366 & 15 \\
\hline PU 31 & 2.51 & 0.85 & 161.6 & 1167 & 25 \\
\hline PU 32 & 1.65 & 1.57 & 115.8 & 1241 & 15 \\
\hline PU 33 & 0.4 & 61.4 & 3.69 & 218 & 8 \\
\hline PU 34 & 0.87 & 20.5 & 8.21 & 222 & 3 \\
\hline PU 35 & 0.716 & 39.47 & 5.36 & 179 & 3 \\
\hline PU 40 & 1.781 & 0.48 & 151.6 & 1430 & 21 \\
\hline PU 42 & 1.16 & 2.8 & 92.89 & 1374 & 17 \\
\hline PU 43 & 10.08 & 1.6 & 547.5 & 1035 & 28 \\
\hline PV 10.2 & 4.19 & 0.39 & 186.5 & 877 & 25 \\
\hline PV 104.2 & 3.377 & 3.91 & 159.3 & 918 & 14 \\
\hline PV 105.2 & 4.604 & 0.62 & 211.8 & 900 & 24 \\
\hline PV 109.2 & 7.965 & 9 & 585.2 & 1257 & \\
\hline PV 11.2 & 4.77 & 3.88 & 473.3 & 1505 & 25 \\
\hline PV 110 & 0.276 & 10 & 13.6 & 955 & \\
\hline PV 112 & 0.16 & 75 & 11.2 & 1244 & \\
\hline PV 113 & 1.657 & 3.17 & 112.4 & 1214 & 55 \\
\hline PV 114 & 2.14 & 2.2 & \begin{tabular}{l|l|}
171.3 \\
\end{tabular} & 1366 & 18 \\
\hline PV 115 & 1.37 & 6.38 & 96.3 & 1243 & 15 \\
\hline PV 116 & 2.07 & 0.7 & 136.9 & 1188 & 13 \\
\hline PV 117 & 0.84 & 2.57 & 54.11 & 1164 & 23 \\
\hline PV 118 & 1.28 & 1.4 & 76.7 & 1108 & 25 \\
\hline PV 119.1 & 1.3 & 3.2 & 82.9 & 1132 & 12 \\
\hline PV 119.2 & 0.9 & 1.1 & 55 & 1095 & 32 \\
\hline PV 120.1 & 1.48 & 0.98 & 81.55 & 1038 & 14 \\
\hline PV 121.1 & 1.85 & 0.68 & 96.41 & 991 & 10 \\
\hline PV 121.2 & 1.85 & 0.53 & 95.14 & 982 & 10 \\
\hline PV 124.1 & 4.21 & 0.88 & 185.9 & 872 & 10 \\
\hline
\end{tabular}




\begin{tabular}{|c|c|c|c|c|c|}
\hline Ordem & $\% \mathrm{~K}$ & $\%$ Ar (atm) & $\begin{array}{c}{ }^{40} \mathrm{Ar}(\mathrm{rad}) \times 10^{-6} \\
\text { ccSTP/g }\end{array}$ & Idade (Ma) & Erro \\
\hline PV 125.1 & 1.98 & 2.67 & 117.4 & 1098 & 17 \\
\hline PV 125.2 & 0.88 & 6.13 & 45.72 & 988 & 22 \\
\hline PV 125.3 & 0.26 & 7.19 & 13.19 & 982 & 18 \\
\hline PV 125.4 & 1.07 & 1.91 & 53.73 & 967 & 17 \\
\hline PV 130.2 & 6.96 & 1.29 & 548.5 & 1353 & 46 \\
\hline PV 131.2 & 6.48 & 0.93 & 399.2 & 1130 & 28 \\
\hline PV 134.3 & 4.1707 & 0.28 & 263.9 & 1160 & 44 \\
\hline PV 141 & 6.31 & 1.11 & 361.5 & 1069 & 21 \\
\hline PV 144.1 & 6.94 & 0.58 & 550 & 1360 & 54 \\
\hline PV 151.2 & 6.421 & 7.8 & 478.5 & 1310 & 59 \\
\hline PV 158 & 1.4175 & 0.91 & 107.3 & 1320 & 16 \\
\hline PV 161 & 0.23 & 11.71 & 16.83 & 1289 & 25 \\
\hline PV 162.1 & 0.379 & 4.48 & 26.07 & 1240 & 76 \\
\hline PV 162.2 & 0.7116 & 4.38 & 44.7 & 1160 & 80 \\
\hline PV 162.3 & 1.8144 & 1.22 & 111.4 & 1135 & 25 \\
\hline PV 162.4 & 1.0101 & 3.83 & 56.49 & 1060 & 28 \\
\hline PV 163 & 2.0755 & 0.68 & 136.8 & 1195 & 17 \\
\hline PV 164 & 7.64 & 1.08 & 500.7 & 1190 & 25 \\
\hline PV 168 & 1.02 & 2.47 & 54.39 & 1020 & 13 \\
\hline PV 169 & 0.19 & 9.51 & 10.11 & 1019 & 22 \\
\hline PV 171 & 7.19 & 10.28 & 366 & 985 & 41 \\
\hline PV 172 & 4.6044 & 0.63 & 210.4 & 905 & 29 \\
\hline PV 2.2 & 6.62 & 0.96 & 497.8 & 1308 & 59 \\
\hline PV 27.2 & 2.14 & 2.2 & 171.3 & 1366 & 18 \\
\hline PV 28.2 & 1.06 & & & 1450 & 15 \\
\hline PV 41 & 2.13 & 1.17 & 184.2 & 1448 & 52 \\
\hline PV 43 & 0.05 & 17.4 & 3.88 & 1372 & 21 \\
\hline PV 54.2 & 0.7 & 4.4 & 44.7 & 1153 & 91 \\
\hline PV 54.3 & 1.8 & 1.2 & 111.5 & 1127 & 19 \\
\hline PV 54.4 & 1 & 3.8 & 56.5 & 1050 & 23 \\
\hline PV 68.2 & 2.76 & & & 1120 & 34 \\
\hline PV 82.3 & 7.48 & 6.4 & 367.36 & 958 & 29 \\
\hline PV 83.10 & 6.37 & 1.6 & 327.6 & 992 & 30 \\
\hline PV 83.8 & 8.16 & 1.3 & 422.24 & 997 & 30 \\
\hline PV 83.9 & 7.12 & 1.2 & 387.52 & 1036 & 31 \\
\hline PV 92 & 6.48 & 5.83 & 940 & 2023 & 61 \\
\hline PV 93 & 7.08 & 7.25 & 520 & 1293 & 39 \\
\hline PV 94 & 5.7 & 13.63 & 386.1 & 1219 & 37 \\
\hline PV 95 & 1.47 & 3.56 & 73.9 & 975 & 29 \\
\hline PV 96 & 6.98 & 6.1 & 336.2 & 943 & 28 \\
\hline PV 97.1 & 7.19 & 0.89 & 406.8 & 1066 & 32 \\
\hline RB 1 & 3.458 & 1.21 & 166.8 & 935 & 39 \\
\hline
\end{tabular}




\begin{tabular}{|c|c|c|c|c|c|}
\hline Ordem & $\% k$ & $\% \operatorname{Ar}(\mathrm{atm})$ & $\begin{array}{c}{ }^{40} \mathrm{Ar}(\mathrm{rad}) \times 10^{-6} \\
\text { cCSTP/g }\end{array}$ & Idade (Ma) & Erro \\
\hline RB 16 & 7.06 & 0.75 & 495.9 & 1244 & 15 \\
\hline RB 17 & 7.62 & 0.55 & 542.2 & 1257 & 34 \\
\hline RB 18 & 6.26 & 0.59 & 486.1 & 1337 & 18 \\
\hline RB 19 & 7.97 & 0.6 & 597.7 & 1305 & 17 \\
\hline RB 20 & 7.02 & 0.76 & 499 & 1255 & 14 \\
\hline RR 1 & 6.163 & 0.99 & 739.7 & 1800 & 30 \\
\hline RR 13 & 0.5572 & 11 & 395.4 & 1250 & 40 \\
\hline RR 15 & 0.3455 & 2.7 & 361.4 & 1650 & 50 \\
\hline RR 20 & 0.3796 & 3 & 464.2 & 1820 & 40 \\
\hline RR 3.1 & 6.25 & 2.1 & 787 & 1860 & 30 \\
\hline RR 3.2 & 5.82 & 0.7 & 718.9 & 1840 & 70 \\
\hline RR 37.2 & 6.5239 & 0.68 & 678.66 & 1640 & 50 \\
\hline RR 38.2 & 5.1746 & 0.74 & 586.67 & 1740 & 70 \\
\hline RR 41 & 4.3426 & 0.38 & 774.2 & 2280 & 70 \\
\hline RR 50.2 & 8.87 & 0.48 & 831.9 & 1530 & 30 \\
\hline \begin{tabular}{|l|} 
RR 56 \\
\end{tabular} & 3.574 & 3.97 & 1.252 & 721 & 36 \\
\hline RR 57 & 3.654 & 2.15 & 2.127 & 1102 & 57 \\
\hline RR 58 & 0.72 & 4.09 & 94.15 & 1891 & 69 \\
\hline RR 59 & 0.5 & 26.93 & 57.84 & 1757 & 81 \\
\hline RR 60 & 0.91 & 8.03 & 94.42 & 1635 & 60 \\
\hline RR 61 & 0.71 & 5.49 & 69.96 & 1574 & 60 \\
\hline RR 67 & 1.28 & 4.95 & 108 & 1420 & 58 \\
\hline RR 68 & 0.7 & 33.66 & 54.11 & 1336 & 15 \\
\hline RR 69 & 0.49 & 24.12 & 8.18 & 372 & 22 \\
\hline RR 70 & 0.35 & 5.49 & 0.35 & 356 & 32 \\
\hline RR 72.1 & 1.79 & 26.28 & 11.26 & 152 & 13 \\
\hline RR 72.2 & 1.79 & 36.9 & 15.64 & 208 & 14 \\
\hline RR 74 & 0.83 & 75.51 & 6.22 & 179 & 33 \\
\hline RR 76 & 0.42 & 82.04 & 2.78 & 161 & 17 \\
\hline RR 77 & 1.37 & 30.8 & 10.1 & 151 & 38 \\
\hline RR 78 & 0.368 & 80.18 & 2.3 & 151 & 14 \\
\hline RR 79 & 1.18 & 34.44 & 7.24 & 148 & 9 \\
\hline RR 8 & 1.187 & 0.61 & 147.3 & 1840 & 20 \\
\hline RR 81 & 1.02 & 76.5 & 5.33 & 127 & 12 \\
\hline RR 83 & 4 & 2.35 & 190.4 & 924 & 10 \\
\hline RR 85 & 5.005 & 0.87 & 358.7 & 1263 & 47 \\
\hline RR 86 & 0.682 & 3.64 & 66.89 & 1575 & 64 \\
\hline RR 87 & 0.266 & 33.31 & 25.78 & 1563 & 58 \\
\hline RR 88 & 0.284 & 37.32 & 11.57 & 816 & 48 \\
\hline RR 89 & 0.171 & 6.15 & 21.18 & 1837 & 73 \\
\hline RR 90 & 0.357 & 34.38 & 37.87 & 1659 & 62 \\
\hline RR 91 & 3.531 & 1.31 & 379.7 & 1675 & 68 \\
\hline
\end{tabular}




\begin{tabular}{|l|r|r|r|r|r|}
\hline Ordem & \multicolumn{1}{|c|}{$\%$} & \% Ar (atm) & $\begin{array}{c}{ }^{40} \text { Ar (rad) } \times 10^{-6} \\
\text { ccSTP/g }\end{array}$ & Idade (Ma) & Erro \\
\hline RR 92 & 0.163 & 4.12 & 114.5 & 4402 & 89 \\
\hline RR 93 & 3.94 & 4.72 & 153.4 & 797 & 101 \\
\hline RR 95 & 4.37 & 1.31 & 453.6 & 1636 & 75 \\
\hline RR 98 & 0.3317 & 8.3 & 440.8 & 1920 & 40 \\
\hline RR 99 & 0.4629 & 3 & 543.4 & 1780 & 50 \\
\hline SA 1.2 & 6.31 & 6.3 & 38.99 & 1155 & 40 \\
\hline SA 10 & 4.25 & 7.6 & 311.1 & 1288 & 38 \\
\hline SA 11.1 & 3.92 & 27.7 & 388 & 1584 & 75 \\
\hline SA 12 & 0.15 & 21.7 & 17.96 & 1832 & 82 \\
\hline SA 13 & 2.08 & 3.6 & 121.1 & 1083 & 49 \\
\hline SA 14 & 3.54 & 6.8 & 234.9 & 1193 & 12 \\
\hline SA 15 & 0.54 & 16 & 37 & 1220 & 58 \\
\hline SA 16 & 3.82 & 4.9 & 236.5 & 1132 & 46 \\
\hline SA 17 & 4.53 & 2.2 & 331.7 & 1283 & 56 \\
\hline SA 18 & 4.92 & 2.6 & 385.2 & 1346 & 15 \\
\hline SA 38 & 3.06 & 8 & 12.19 & 803 & 60 \\
\hline SA 39 & 0.39 & 47.5 & 2.16 & 135 & 53 \\
\hline SA 40 & 0.31 & 35.3 & 2.27 & 175 & 15 \\
\hline SA 41 & 0.38 & 32.3 & 2.95 & 183 & 14 \\
\hline SA 42 & 0.48 & 10.6 & 2.84 & 143 & 6 \\
\hline SA 43 & 0.45 & 16 & 3.72 & 196 & 7 \\
\hline SA 44 & 1.8 & 27.2 & 33.43 & 416 & 7 \\
\hline SA 45 & 2.66 & 0.8 & 170.3 & 1164 & 62 \\
\hline SA 46 & 0.76 & 2 & 6.78 & 1375 & 37 \\
\hline SA 47 & 2.93 & 0.8 & 238.8 & 1385 & 39 \\
\hline SA 48 & 1.09 & 3.7 & 92.44 & 1420 & 32 \\
\hline SA 49 & 0.78 & 1.3 & 6.28 & 1376 & 19 \\
\hline SA 50 & 1.85 & 2.2 & 154 & 1408 & 50 \\
\hline SA 51 & 0.91 & 2.79 & 39.44 & 854 & 12 \\
\hline SA 52 & 2.45 & 1.06 & 103.1 & 839 & 22 \\
\hline SA 54 & 0.452 & 9.38 & 30.08 & 1195 & 55 \\
\hline SA 55 & 4.838 & 2.38 & 249.9 & 986 & 41 \\
\hline SA 57 & 0.22 & 69 & 24.3 & 259 & 6 \\
\hline SA 58 & 0.35 & 64.5 & 33.5 & 232 & 19 \\
\hline SA 59 & 0.36 & 40.7 & 20.9 & 140 & 6 \\
\hline SA 60 & 0.33 & 57.7 & 17.1 & 126 & 6 \\
\hline SA 61 & 3.281 & 1.66 & 193.2 & 1091 & 42 \\
\hline SA 71 & 2.2107 & 1.71 & 249.7 & 1730 & 57 \\
\hline SA 73 & 1.3745 & 0.66 & 103.2 & 1310 & 32 \\
\hline SA 74 & 2.4751 & 1.02 & 162.2 & 1190 & 31 \\
\hline SA 75 & 2.6368 & 0.73 & 159 & 1120 & 29 \\
\hline SA 76 & 1.7003 & 4.32 & 89.11 & 1007 & 25 \\
\hline
\end{tabular}




\begin{tabular}{|c|c|c|c|c|c|}
\hline Ordem & $\% \mathrm{~K}$ & $\% \operatorname{Ar}(a t m)$ & $\begin{array}{c}{ }^{40} \mathrm{Ar}(\mathrm{rad}) \times 10^{-6} \\
\mathrm{ccSTP} / \mathrm{g}\end{array}$ & Idade (Ma) & Erro \\
\hline SA 77.1 & 0.0232 & 97.43 & 0.63 & 609 & 187 \\
\hline SA 77.2 & 0.048 & 85.09 & 0.87 & 409 & 78 \\
\hline SA 77.3 & 0.2768 & & 2.87 & 249 & 13 \\
\hline SA 78 & 0.734 & 63.13 & 5.44 & 181 & 5 \\
\hline SA 79 & 0.3512 & 56.54 & 2.5 & 175 & 10 \\
\hline SA 8 & 6.57 & 15.6 & 96.29 & 2040 & 23 \\
\hline SA 80 & 0.329 & 55.78 & 1.67 & 130 & 9 \\
\hline SA 9 & 3.32 & 1.2 & 192.9 & 1081 & 49 \\
\hline $\mathrm{T} 1$ & 7.4 & 13.6 & 174.9 & 516 & 10 \\
\hline T10 & 6.815 & 2.4 & 170.5 & 551 & 6 \\
\hline T2 & 7.85 & 1.3 & 175.4 & 491 & 24 \\
\hline T25.2 & 6.3 & 0.97 & 701.9 & 1714 & 46 \\
\hline T26.2 & 6.61 & 0.34 & 1076 & 2174 & 33 \\
\hline T 26.3 & 2.46 & 0.01 & 374.8 & 2082 & 51 \\
\hline T 27.2 & 7.26 & 0.31 & 840.6 & 1760 & 21 \\
\hline T29.1 & 8.2 & 0.6 & 123.2 & 2070 & 63 \\
\hline T29.2 & 7.66 & 1 & 711.3 & 1517 & 46 \\
\hline T3 & 7.14 & 3.3 & 157.1 & 485 & 26 \\
\hline T30 & 8.36 & 0.81 & 1010 & 1808 & 58 \\
\hline T 31 & 0.49 & 6.5 & 531 & 1679 & 15 \\
\hline T 32 & 6.12 & 0.7 & 780.3 & 1872 & 62 \\
\hline T33 & 2.48 & 0.78 & 308.3 & 1844 & 55 \\
\hline T34 & 5.83 & 0.78 & 664.9 & 1741 & 21 \\
\hline$T 4$ & 7.66 & 3.6 & 164.1 & 474 & 25 \\
\hline T5 & 8.54 & 2.8 & 183.2 & 473 & 25 \\
\hline T6 & 7.89 & 2.3 & 168.6 & 473 & 25 \\
\hline T7.1 & 7.92 & 11.2 & 156.9 & 440 & 24 \\
\hline T7.2 & 78 & 3.3 & 151.8 & 434 & 23 \\
\hline T 75 & 0.76 & 2.58 & 98 & 1886 & 40 \\
\hline T 76 & 2.14 & 2.36 & 195 & 1496 & 55 \\
\hline T 77 & 0.5 & 23.2 & 3.5 & 168 & 5 \\
\hline T 78 & 0.56 & 30.01 & 4.53 & 197 & 4 \\
\hline T79 & 0.8 & 20.45 & 20.56 & 565 & 6 \\
\hline T 8 & 7.65 & 1.9 & 145.7 & 426 & 22 \\
\hline$T 80.1$ & 0.24 & 12.44 & 9.21 & 780 & 12 \\
\hline$T 80.2$ & 0.04 & 81.85 & 0.83 & 480 & 22 \\
\hline T 81 & 0.39 & 4.79 & 19.37 & 963 & 10 \\
\hline T 82 & 0.83 & 10.09 & 32.74 & 795 & 18 \\
\hline T 83 & 0.5 & 26 & 12.56 & \begin{tabular}{|l|}
547 \\
\end{tabular} & 40 \\
\hline T 84 & \begin{tabular}{l|l}
0.54 \\
\end{tabular} & 4.11 & 92.68 & 2230 & 59 \\
\hline$T 89.1$ & 6.983 & 2.74 & 792.6 & 1735 & 63 \\
\hline T9 & 0.221 & 18.5 & 5.11 & 514 & 7 \\
\hline
\end{tabular}




\begin{tabular}{|c|c|c|c|c|c|}
\hline Ordem & $\% \mathrm{~K}$ & $\% \operatorname{Ar}($ atm) & $\begin{array}{c}{ }^{40} \mathrm{Ar}(\mathrm{rad}) \times 10^{-6} \\
\text { ccSTP/g }\end{array}$ & ldade (Ma) & Erro \\
\hline T 90 & 8.2 & 0.62 & 1223 & 2058 & 17 \\
\hline T93 & 8.71 & 4.8 & 255.6 & 631 & 26 \\
\hline T94 & 6.8149 & 2.42 & 170.3 & 550 & 42 \\
\hline T95 & 7.885 & 2.43 & 167.4 & 480 & 26 \\
\hline T96 & 7.924 & 11.59 & 154.6 & 440 & 25 \\
\hline T 97 & 7.8 & 0.33 & 150.7 & 440 & 24 \\
\hline T98 & 7.65 & 1.93 & 144.7 & 430 & 23 \\
\hline T99 & 0.5013 & 22.93 & 3.59 & 175 & 10 \\
\hline T92.2 & 7.567 & 1.25 & 925.3 & 1820 & 33 \\
\hline TP 17 & 0.492 & & & 1715 & 51 \\
\hline TP 18 & 3.37 & & & 1801 & 54 \\
\hline TP 19 & 0.338 & & & 1696 & 51 \\
\hline TP 20 & 5.58 & & & 1241 & 37 \\
\hline TP 23 & 2.267 & 0.4 & 202.2 & 1475 & 65 \\
\hline TP 35 & 4.262 & 2.31 & 299.7 & 1245 & 52 \\
\hline TP 36 & 2.873 & 7.4 & 196.1 & 1218 & 46 \\
\hline TP 37 & 3.022 & 2.89 & 186.8 & 1132 & 51 \\
\hline TP 38 & 1.063 & 3.24 & 62.1 & 1085 & 45 \\
\hline TP 39 & 4.277 & 1.13 & 325.5 & 1313 & 20 \\
\hline TP 40 & 3.744 & 12.74 & 118.0 & 660 & 39 \\
\hline TP 41 & 1.11 & 11.56 & 158.5 & 2000 & 95 \\
\hline TP 42 & 1.57 & 0.9 & 150.5 & 1553 & 26 \\
\hline TP 43 & 0.41 & 14.93 & 23.41 & 1072 & 18 \\
\hline TP 44 & 0.54 & 6.93 & 31.75 & 1043 & 27 \\
\hline TP 48 & 3.765 & 1.62 & 24.86 & 1189 & 46 \\
\hline TP 49 & 6.885 & 0.85 & 78.66 & 1743 & 67 \\
\hline TP 54 & 6.885 & 0.85 & 78.66 & 1743 & 67 \\
\hline TP 56 & 7.647 & 0.4 & 101.7 & 1921 & 39 \\
\hline TP 57 & 1.961 & 5.87 & 26.09 & 1922 & 65 \\
\hline TP 58 & 0.716 & 39.47 & 0.536 & 179 & 3 \\
\hline TP 59 & 3.744 & 12.74 & 11.8 & 660 & 39 \\
\hline TP 61 & 1.7022 & 3.92 & 189.1 & 1715 & 22 \\
\hline TP 62 & 0.4917 & 21.72 & 54.75 & 1715 & 60 \\
\hline TP 72 & 1.566 & 0.9 & 150.4 & 1560 & 25 \\
\hline IP 73 & 1.4706 & 2.12 & 138.9 & 1540 & 50 \\
\hline TP 74 & 2.4731 & 0.58 & 232.7 & 1536 & 31 \\
\hline TP 75 & 0.3178 & 91.81 & 29.64 & 1530 & 313 \\
\hline IP 76.2 & 5.9623 & 4.68 & 346.1 & 1490 & 29 \\
\hline TP 82 & 1.6435 & 1.62 & 134.4 & 1400 & 52 \\
\hline TP 83 & 5.579 & 1.25 & 186.9 & 1240 & 40 \\
\hline TP 85 & 3.0216 & 2.89 & 186.8 & 1140 & 40 \\
\hline TP 86 & 0.8618 & 4.13 & 39.55 & 910 & 30 \\
\hline
\end{tabular}




\begin{tabular}{|l|r|r|r|r|r|}
\hline Ordem & \multicolumn{1}{|c|}{$\%$ K } & \% Ar (atm) & $\begin{array}{c}{ }^{40} \text { Ar (rad) } \mathbf{1 0} 0^{-6} \\
\text { ccSTP/g }\end{array}$ & Idade (Ma) & Erro \\
\hline TP 87 & 4.6408 & 2.17 & 181.5 & 800 & 20 \\
\hline TP 88 & 3.3925 & 0.99 & 110.3 & 690 & 19 \\
\hline TP 89 & 3.7441 & 12.95 & 117 & 665 & 44 \\
\hline TP 90 & 0.537 & 27.86 & 3.21 & 148 & 6 \\
\hline TP 91 & 0.9808 & 27.36 & 7.26 & 180 & 9 \\
\hline TP 94 & 0.548 & 17.4 & 12.75 & 509 & 15 \\
\hline TP 95 & 0.25 & 17.2 & 5.85 & 510 & 15 \\
\hline TU 12 & 0.2 & 8.2 & 30.22 & 2057 & 90 \\
\hline TU 13 & 0.6 & 4.8 & 50.03 & 1467 & 30 \\
\hline TU 14 & 7.47 & 0.8 & 752.6 & 1604 & 32 \\
\hline TU 15 & 1.19 & 1.2 & 135.7 & 1741 & 46 \\
\hline TU 16.1 & 1.62 & 0.8 & 76.2 & 1687 & 66 \\
\hline TU 17 & 2.47 & 0.2 & 524.5 & 2531 & 12 \\
\hline TU 20 & 3.564 & 2.15 & 212.7 & 1102 & 57 \\
\hline TU 29 & 3.574 & 3.97 & 125.2 & 721 & 36 \\
\hline TU 39 & 10.08 & 1.6 & 547.5 & 1026 & 28 \\
\hline TU 40 & 0.79 & 25.2 & 6.69 & 201 & 23 \\
\hline TU 41 & 0.1 & 9.1 & 12.99 & 1946 & 57 \\
\hline TU 43 & 1.21 & 1.06 & 93 & 1333 & 67 \\
\hline TU 44 & 0.602 & 56.68 & 5.1 & 201 & 18 \\
\hline TU 45 & 2.194 & 7.99 & 132.6 & 1113 & 91 \\
\hline TU 46 & 1.367 & 31.31 & 10.11 & 177 & 16 \\
\hline TU 47 & 0.933 & 31.52 & 5.66 & 146 & 4 \\
\hline TU 48 & 4.249 & 7.64 & 311.1 & 1288 & 38 \\
\hline TU 49 & 0.8096 & 0.76 & 108.7 & 1930 & 72 \\
\hline TU 52.2 & 1.423 & 2.8 & 137.4 & 1560 & 74 \\
\hline TU 56 & 6.2595 & 0.33 & 787.4 & 1850 & 57 \\
\hline TU 57 & 0.9982 & 0.62 & 104.7 & 1650 & 49 \\
\hline TU 58 & 5.2999 & 10.23 & 534.5 & 1600 & 56 \\
\hline TU 60 & 4.3581 & 0.74 & 376 & 1448 & 32 \\
\hline TU 61 & 4.9188 & 2.68 & 332.3 & 1350 & 23 \\
\hline & & & & & \\
\hline
\end{tabular}




\begin{tabular}{|c|c|c|c|c|c|c|c|c|}
\hline Ordem & $\begin{array}{c}\mathrm{Sm} \\
(\mathrm{ppm})\end{array}$ & $\begin{array}{c}\mathrm{Nd} \\
\text { (ppm) }\end{array}$ & ${ }^{147} \mathrm{Sm} /{ }^{144} \mathrm{Nd}$ & ${ }^{143} \mathrm{Nd} /{ }^{144} \mathrm{Nd}$ & $T_{D M}$ & \begin{tabular}{|c|} 
Idade \\
Isocrónica \\
\end{tabular} & Erro & $\varepsilon_{\text {Nd }}(0)$ \\
\hline C 163.5 & 3.61 & 22.63 & 0.09646 & 0.510862 & 2860 & 2690 & & 34.6 \\
\hline C 163.6 & 3.177 & 17.85 & 0.10763 & 0.510956 & 3040 & 2860 & & 32.8 \\
\hline C 168.2 & 3.086 & 23.81 & 0.07838 & 0.510393 & 3030 & 2870 & & 43.8 \\
\hline C 171.2 & 1.994 & 13.696 & 0.08804 & 0.51081 & 2730 & 2550 & & 35.7 \\
\hline C 18.2 & 2.7 & 11.97 & 0.13642 & 0.511781 & & 2876 & 163 & 3.6 \\
\hline C 19.1.2 & 3.55 & 12.23 & 0.17551 & 0.51254 & & 2876 & 163 & 4.6 \\
\hline C 19.2.2 & 3.55 & 11.82 & 0.18134 & 0.51206 & & 2876 & 163 & - \\
\hline C 19.3.2 & 13.61 & 75.73 & 0.10866 & 0.511286 & & 2876 & 163 & + \\
\hline C 19.4.2 & 2.76 & 12.34 & 0.13524 & 0.511711 & & 2876 & 163 & 2.6 \\
\hline C 19.5 .2 & 2.94 & 12.84 & 0.13869 & 0.511544 & & 2876 & 163 & 1.9 \\
\hline C 193.5 & 5.553 & 50.242 & 0.06684 & 0.510149 & 3030 & 2900 & & 48.6 \\
\hline C 193.6 & 1.175 & 7.919 & 0.08972 & 0.510641 & 2980 & 2830 & & 39 \\
\hline C 199.5 & 6.705 & 39.935 & 0.10152 & 0.511121 & 2630 & 1810 & & 29.6 \\
\hline C 199.6 & 8.651 & 50.908 & 0.10276 & 0.511115 & 2670 & 2420 & & 29.7 \\
\hline C 20.1.2 & 3.03 & 13.58 & 0.13507 & 0.511634 & & 2876 & 163 & 1.2 \\
\hline$C 21.1 .2$ & 3.25 & 15.82 & 0.12437 & 0.511352 & & 2876 & 163 & 0.6 \\
\hline C 23.1.2 & 2.7 & 11.86 & 0.13776 & 0.511789 & & 2876 & 163 & 3.2 \\
\hline C 24.1.2 & 2.9 & 12.99 & 0.137 & 0.511483 & & 2876 & 163 & 1.8 \\
\hline CB 109 & 5.853 & 36.314 & 0.09746 & 0.511593 & & 1600 & & 20.4 \\
\hline CB 110 & 4.074 & 28.58 & 0.0862 & 0.511547 & & 1500 & & 21.3 \\
\hline CB 111 & 5.11 & 25.858 & 0.1195 & 0.511841 & & 1570 & & 15.5 \\
\hline CB 80 & 4.3 & 15.1 & 0.174566 & 0.512711 & 1.3 & 1921 & 387 & +0.5127 \\
\hline CB 81 & 3.9 & 13.5 & 0.177144 & 0.51274 & 1.27 & 1921 & 387 & +0.5127 \\
\hline$C B 82$ & 4.5 & 14.5 & 0.188218 & 0.512881 & 1.05 & 1921 & 387 & +0.5128 \\
\hline GP 10.2 & 0.498 & 1.298 & 0.232 & 0.513187 & 1060 & & & 10.7 \\
\hline GP 21.2 & 3.936 & 14.665 & 0.1623 & 0.512639 & 1180 & & & 0.02 \\
\hline GP 3.2 & 6.295 & 21.314 & 0.1786 & 0.512832 & 1140 & & & 3.8 \\
\hline GP 5.2 & 3.847 & 11.479 & 0.20266 & 0.513004 & 1140 & & & 7.1 \\
\hline GP 9.2 & 1.786 & 4.65 & 0.23226 & 0.513209 & 1480 & & & 11.1 \\
\hline 142 & 14.688 & 81.796 & 0.10859 & 0.511651 & 2020 & 1700 & & 19.3 \\
\hline 143.3 & 14.973 & 86.604 & 0.10455 & 0.511624 & 1980 & 1670 & & 19.8 \\
\hline 443.4 & 17.167 & 93.06 & 0.11155 & 0.511671 & 2050 & 1730 & & 18.9 \\
\hline 17.3 & 2.087 & 9.526 & 0.13248 & 0.511771 & 2400 & 2050 & & 16.9 \\
\hline JR 122 & 5.745 & 30.717 & 0.1131 & 0.511602 & 2190 & 1880 & & \\
\hline JR 123 & 4.767 & 24.521 & 0.11756 & 0.511757 & & 1690 & & 17.2 \\
\hline JR 34.2 & 6.305 & 39.099 & 0.09751 & 0.511192 & 2440 & 2210 & & 28.2 \\
\hline JR 39.2 & 9.189 & 48.415 & 0.11477 & 0.511688 & 2090 & 1760 & & 18.5 \\
\hline M 16.5 & 7.143 & 52.174 & 0.08278 & 0.510443 & 3060 & 2920 & & 42.8 \\
\hline M 16.6 & 7.18 & 49.68 & 0.08739 & 0.510508 & 3100 & 2950 & & 41.6 \\
\hline M 28.7 & 0.464 & 2.054 & 0.1366 & 0.511921 & 2220 & 2020 & & 14 \\
\hline MN 12.2 & 2.675 & 21.485 & 0.07529 & 0.511123 & & 1900 & & 29.6 \\
\hline MN 16.2 & 2.953 & 27.898 & 0.064 & 0.511026 & 2060 & 1850 & & 31.5 \\
\hline MN 21.2 & 6.289 & 31.873 & 0.11932 & 0.511758 & 2080 & 1730 & & 17.2 \\
\hline $\mathrm{MN} 30.3$ & 4.441 & 38.277 & 0.07016 & 0.511081 & 2090 & 1870 & & 30.4 \\
\hline PU 25.3 & 2.837 & 14.454 & 0.118 & 0.512527 & 1470 & & & 2.2 \\
\hline PV 120.2 & 7.53 & 33.982 & 0.13399 & 0.512274 & & 890 & & 7.1 \\
\hline PV 127.2 & 7.243 & 32.537 & 0.13461 & 0.511964 & & 1650 & & 13.2 \\
\hline PV 16.2 & 8.893 & 41.327 & 0.13012 & 0.511857 & & 1780 & & 15.2 \\
\hline PV 20.2 & 21.478 & 116.52 & 0.11146 & 0.511902 & 1700 & 1310 & & 14.4 \\
\hline PV 25.2 & 12.523 & 62.941 & 0.12031 & 0.511898 & 1870 & 1470 & & 14.4 \\
\hline PV 35.2 & 11.845 & 69.098 & 0.10366 & 0.511772 & 1760 & 1420 & & 16.9 \\
\hline
\end{tabular}




\begin{tabular}{|c|c|c|c|c|c|c|c|c|c|}
\hline Ordem & $\underset{(\mathrm{ppm})}{\mathrm{Sm}}$ & $\begin{array}{c}\mathrm{Nd} \\
(\mathrm{ppm})\end{array}$ & ${ }^{147} \mathrm{Sm} /{ }^{144} \mathrm{Nd}$ & ${ }^{143} \mathrm{Nd} /{ }^{444} \mathrm{Nd}$ & $T_{D M}$ & $\begin{array}{c}\text { Idade } \\
\text { isocrónica }\end{array}$ & Erro & & d (0) \\
\hline RB 2.4 & 28.377 & 185.28 & 0.09261 & 0.511715 & 2280 & 1350 & & - & 18 \\
\hline RB 2.5 & 27.665 & 135.31 & 0.12364 & 0.511815 & & 1710 & & 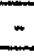 & 16.1 \\
\hline RB 21 & & & 0.17 & 0.512342 & 1920 & 1690 & & $=$ & 5.8 \\
\hline $\mathrm{RB} 4.2$ & & & 0.1 & 0.511763 & & 1380 & & - & 17.1 \\
\hline $\mathrm{RB} 4.2$ & & & & 0.511763 & 1680 & & & + & 2.62 \\
\hline RR 100.3 & & & 0.15 & 0.512053 & 2380 & 1900 & & - & 11.4 \\
\hline RR 100.4 & & & 0.1 & 0.511541 & 2020 & 1720 & & - & 21.4 \\
\hline RR 12,2 & 6.954 & 37.569 & 0.11166 & 0.511636 & 2110 & 1790 & & - & 19.6 \\
\hline RR 26.2 & 1.86 & 7.36 & 0.1525 & 0.5115 & 1471 & & & & 4.5 \\
\hline RR 27.2 & 7.63 & 38.16 & 0.1209 & 0.51114 & 1543 & & & & 5.7 \\
\hline RR 28.2 & 6.15 & 30.6 & 0.1216 & 0.51112 & 1545 & & & & 5.1 \\
\hline RR 29.2 & 7.59 & 38.79 & 0.1183 & 0.51143 & 1107 & & & & 12.2 \\
\hline RR 30.2 & 10.57 & 55.03 & 0.1161 & 0.51077 & 1963 & & & & -0.3 \\
\hline T 22.2 & 9.27 & 62.03 & 0.09037 & 0.510938 & 2620 & 2430 & & - & 33.2 \\
\hline T59.2 & 5.834 & 34.05 & 0.10361 & 0.511118 & 2690 & 2480 & & 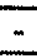 & 29.7 \\
\hline T 66.2 & 14.77 & 88.94 & 0.10043 & 0.511386 & 2240 & 1980 & & $n$ & 24.4 \\
\hline T71.2 & 1.155 & 7.616 & 0.09171 & 0.51113 & 2400 & 2180 & & $\approx$ & 29.4 \\
\hline
\end{tabular}




\begin{tabular}{|c|c|c|c|c|c|c|c|c|}
\hline Ordem & $\begin{array}{c}U \\
(\mathrm{ppm})\end{array}$ & $\begin{array}{c}\mathrm{Pb} \\
(\mathrm{ppm})\end{array}$ & ${ }^{207} \mathrm{~Pb} /{ }^{235} \mathrm{U}$ & ${ }^{206} \mathrm{~Pb} / /^{238} \mathrm{U}$ & $\begin{array}{c}\text { Concórdia } \\
\text { Idade (Ma) }\end{array}$ & Erro & $\begin{array}{l}\text { MSWD } \\
(\mathrm{U}-\mathrm{Pb})\end{array}$ & Intersecção \\
\hline C 1.1 & 185 & 122 & 15.545 & 0.5534 & 2859 & 2 & & Superior \\
\hline C 1.2 & 176 & 91 & 10.856 & 0.4739 & 2573 & 2 & & Superior \\
\hline C 1.3 & 181 & 123 & 15.628 & 0.5556 & 2859 & 2 & & Superior \\
\hline C 1.4 & 160 & 109 & 15.63 & 0.5552 & 2859 & 2 & & Superior \\
\hline C 1.5 & 356 & 229 & 15.248 & 0.5464 & 2851 & 4 & & Superior \\
\hline C 1.6 & 213 & 120 & 14.931 & 0.5371 & 2251 & 4 & & Superior \\
\hline C 1.7 & 188 & 116 & 14.125 & 0.5127 & 2851 & 4 & & Superior \\
\hline C 1.8 & 178 & 109 & 14.555 & 0.5254 & 2851 & 4 & & Superior \\
\hline C 10 & 923 & 859 & 11.331 & 0.4854 & 2555 & $+4 /-3$ & & Superior \\
\hline C 11.1 & 74 & 27 & 5.339 & 0.3368 & 1880 & 2 & & Superior \\
\hline C 11.2 & 93 & 34 & 5.321 & 0.3356 & 1880 & 2 & & Superior \\
\hline C 12.1 & 47 & 19 & 5.357 & 0.3373 & 1883 & 2 & & Superior \\
\hline C 12.2 & 67 & 27 & 5.087 & 0.3229 & 1883 & 2 & & Superior \\
\hline C 13.1 & 2371 & 797 & 5.257 & 0.3331 & 1874 & 2 & & Superior \\
\hline C 13.2 & 1077 & 369 & 5.18 & 0.3285 & 1874 & 2 & & Superior \\
\hline C 13.3 & 721 & 218 & 4.377 & 0.2816 & 1874 & 2 & & Superior \\
\hline C 14.1 & 49 & 21 & 5.965 & 0.3493 & 1883 & $+5 /-2$ & & Superior \\
\hline C 14.2 & 72 & 28 & 5.327 & 0.3358 & 1883 & $+5-2$ & & Superior \\
\hline C 14.3 & 74 & 29 & 5.316 & 0.3353 & 1883 & $+5 /-2$ & & Superior \\
\hline C 14.4 & 99 & 37 & 5.43 & 0.3416 & 1883 & $+5 /-2$ & & Superior \\
\hline C 15.1 & 140 & 57 & 8.669 & 0.3268 & 2758 & 39 & & Superior \\
\hline C 15.2 & 139 & 57 & 8.495 & 0.3291 & 2758 & 39 & & Superior \\
\hline C 15.3 & 155 & 59 & 7.824 & 0.3003 & 2758 & 39 & & Superior \\
\hline C 15.4 & 150 & 50 & 6.981 & 0.2669 & 2758 & 39 & & Superior \\
\hline C15.5 & 121 & 59 & 10.294 & 0.3898 & 2758 & 39 & & Superior \\
\hline C 16.1 & 146 & 57 & 8.227 & 0.3122 & 2758 & 39 & & Superior \\
\hline C 16.2 & 203 & 63 & 6.707 & 0.2506 & 2758 & 39 & & Superior \\
\hline C 17.1 & 1496 & 191 & 1.647 & 0.1217 & 1820 & 49 & & Superior \\
\hline$C 17.2$ & 816 & 118 & 1.942 & 0.1351 & 1820 & 49 & & Superior \\
\hline C 17.3 & 724 & 93 & 1.703 & 0.1198 & 1820 & 49 & & Superior \\
\hline C 17.4 & 670 & 128 & 2.648 & 0.179 & 1820 & 49 & & Superior \\
\hline$C 2.1$ & 69 & 45 & 14.031 & 0.5302 & 2759 & 2 & & Superior \\
\hline C 2.2 & 71 & 46 & 13.882 & 0.5245 & 2759 & 2 & & Superior \\
\hline C 2.3 & 70 & 46 & 13.938 & 0.5267 & 2759 & 2 & & Superior \\
\hline C 2.4 & 67 & 44 & 14.143 & 0.5343 & 2759 & 2 & & Superior \\
\hline C 26.1 & 776 & 202 & 5.7048 & 0.231756 & 2971 & $+30 /-28$ & & Superior \\
\hline$C 26.10$ & 446 & 246 & 13.955 & 0.478817 & 2971 & $+30 /-28$ & & Superior \\
\hline C26.11 & 400 & 137 & 8.2012 & 0.312738 & 2971 & $+30 /-28$ & & Superior \\
\hline C 26.12 & 488 & 182 & 9.1865 & 0.342467 & 2971 & $+30 /-28$ & & Superior \\
\hline C26.2 & 710 & 179 & 5.5367 & 0.225041 & 2971 & $+30 /-28$ & & Superior \\
\hline C 26.3 & 1114 & 216 & 4.2452 & 0.173152 & 2971 & $+30 /-28$ & & Superior \\
\hline C 26.4 & 607 & 158 & 5.8609 & 0.23357 & 2971 & $+30 /-28$ & & Superior \\
\hline C 26.5 & 407 & 123 & 6.6766 & 0.267715 & 2971 & $+30 /-28$ & & Superior \\
\hline C 26.6 & 460 & 140 & 7.0859 & 0.272392 & 2971 & $+30 /-28$ & & Superior \\
\hline C 26.7 & 1035 & 201 & 4.009 & 0.170519 & 2971 & $+30 \%-28$ & & Superior \\
\hline C 26.8 & 829 & 150 & 3.766 & 0.159562 & 2971 & $+30 /-28$ & & Superior \\
\hline C 26.9 & 434 & 170 & 9.7684 & 0.341522 & 2971 & $+30 /-28$ & & Superior \\
\hline C 27.1 & 531 & 124 & 4.7867 & 0.199068 & 2874 & $+9 /-10$ & & Superior \\
\hline C 27.10 & 456 & 249 & 12.8066 & 0.466338 & 2874 & $+9 /-10$ & & Superior \\
\hline C 27.11 & 211 & 131 & 14.839 & 0.523028 & 2874 & $+9 / \cdot 10$ & & Superior \\
\hline C 27.2 & 904 & 217 & 5.108 & 0.207111 & 2874 & $+9 / .10$ & & Superior \\
\hline$C 27.3$ & 765 & 113 & 2.8809 & 0.126029 & 2874 & $+9 / 10$ & & Superior \\
\hline C 27.4 & 448 & 171 & 8.5856 & 0.326805 & 2874 & $+9 /-10$ & & Superior \\
\hline C 27.5 & 1274 & 152 & 2.4392 & 0.101904 & 2874 & $+9 /-10$ & & Superior \\
\hline C 27.6 & 584 & 102 & 3.6782 & 0.1490949 & 2874 & $+9 /-10$ & & Superior \\
\hline
\end{tabular}




\begin{tabular}{|c|c|c|c|c|c|c|c|c|}
\hline Ordem & $\begin{array}{c}U \\
(\mathrm{ppm})\end{array}$ & $\begin{array}{c}\mathrm{Pb} \\
(\mathrm{ppm})\end{array}$ & ${ }^{207} \mathrm{~Pb} / /^{235} \mathrm{U}$ & ${ }^{208} \mathrm{~Pb} / /^{238} \mathrm{U}$ & $\begin{array}{l}\text { Concórdia } \\
\text { Idade (Ma) }\end{array}$ & Erro & $\begin{array}{l}\text { MSWD } \\
(\mathrm{U}-\mathrm{Pb})\end{array}$ & Intersecçăo \\
\hline C 27.7 & 552 & 110 & 3.7363 & 0.15915 & 2874 & $+9 /-10$ & & Superior \\
\hline C 27.8 & 791 & 195 & 5.0792 & 0.212935 & 2874 & $+9 /-10$ & & Superior \\
\hline C 27.9 & 204 & 114 & 13.1026 & 0.471949 & 2874 & $+9 /-10$ & & Superior \\
\hline C 28.1 & 539 & 181 & 7.24539 & 0.286522 & 2971 & 18 & & Superior \\
\hline$C 28.2$ & 494 & 172 & 7.68793 & 0.296113 & 2971 & 18 & & Superior \\
\hline$C 28.3$ & 509 & 179 & 7.82382 & 0.29943 & 2971 & 18 & & Superior \\
\hline C28.4 & 214 & 125 & 14.2952 & 0.28953 & 2971 & 18 & & Superior \\
\hline C 28.5 & 293 & 173 & 13.923 & 0.480358 & 2971 & 18 & & Superior \\
\hline C 28.6 & 1538 & 342 & 3.50347 & 0.187762 & 2971 & 18 & & Superior \\
\hline C 28.7 & 973 & 206 & 3.68687 & 0.180049 & 2971 & 18 & & Superior \\
\hline$C 29.1$ & 736 & 178 & 5.20839 & 0.21895 & 2971 & 18 & & Superior \\
\hline C 29.2 & 1448 & 117 & 1.63963 & 0.073892 & 2971 & 18 & & Superior \\
\hline C 29.3 & 549 & 121 & 4.88353 & 0.199215 & 2971 & 18 & & Superior \\
\hline C 29.4 & 491 & 137 & 6.54067 & 0.260679 & 2971 & 18 & & Superior \\
\hline C 29.5 & 483 & 49 & 1.60004 & 0.098465 & 2971 & 18 & & Superior \\
\hline C29.6 & 222 & 63 & 7.05471 & 0.241455 & 3189 & $+22 /-18$ & & Superior \\
\hline C 29.7 & 121 & 40 & 8.34124 & 0.280946 & 3189 & $+22 /-18$ & & Superior \\
\hline C 29.8 & 119 & 44 & 9.50458 & 0.316376 & 3189 & $+22 /-18$ & & Superior \\
\hline C 29.9 & 54 & 40 & 17.7021 & 0.52292 & 3189 & $+22 /-18$ & & Superior \\
\hline C 3.1 & 178 & 145 & 13.377 & 0.5066 & 2763 & 6 & & Superior \\
\hline C 3.2 & 384 & 269 & 13.361 & 0.5058 & 2763 & 6 & & Superior \\
\hline C 3.3 & 208 & 138 & 12.936 & 0.4912 & 2763 & 6 & & Superior \\
\hline C 4.1 & 1000 & 611 & 13.678 & 0.5254 & 2732 & 3 & & Superior \\
\hline C 5.1 & 347 & 225 & 15.048 & 0.5409 & 2732 & 3 & & Superior \\
\hline C 5.2 & 486 & 318 & 13.609 & 0.5205 & 2851 & 4 & & Superior \\
\hline C 5.3 & 1281 & 824 & 13.38 & 0.5109 & 2732 & 3 & & Superior \\
\hline C6.1 & 840 & 480 & 14.092 & 0.5317 & 2732 & 3 & & Superior \\
\hline $\mathrm{C} 6.2$ & 55 & 31 & 10.653 & 0.4713 & 2573 & 2 & & Superior \\
\hline C 7.1 & 159 & 96 & 13.96 & 0.5278 & 2732 & 3 & & Superior \\
\hline$C 7.2$ & 333 & 194 & 13.28 & 0.51 & 2732 & 3 & & Superior \\
\hline C 7.3 & 84 & 67 & 11.585 & 0.4866 & 2573 & 2 & & Superior \\
\hline C 7.4 & 79 & 66 & 11.621 & 0.4888 & 2573 & 2 & & Superior \\
\hline C 8.1 & 446 & 232 & 11.598 & 0.4904 & 2573 & 2 & & Superior \\
\hline C 8.2 & 703 & 351 & 11.29 & 0.4787 & 2573 & 2 & & Superior \\
\hline C9.1 & 4033 & 2006 & 10.945 & 0.4687 & 2555 & $+4 /-3$ & & Superior \\
\hline C 9.2 & 513 & 258 & 10.762 & 0.4625 & 2555 & $+4 /-3$ & & Superior \\
\hline C 9.3 & 642 & 329 & 10.385 & 0.4462 & 2555 & $+4 /-3$ & & Superior \\
\hline 16.4 & 325 & 93 & 3.433 & 0.2635 & 1521 & 13 & & Superior \\
\hline 16.5 & 122 & 33 & 3.303 & 0.2529 & 1521 & 13 & & Superior \\
\hline 16.6 & 410 & 104 & 2.994 & 0.3202 & 1521 & 13 & & Superior \\
\hline 16.7 & 325 & 93 & 3.433 & 0.2635 & 1521 & 13 & & \\
\hline 16.8 & 122 & 33 & 3.303 & 0.2529 & 1521 & 13 & & \\
\hline 16.9 & 410 & 104 & 2.994 & 0.2302 & 1521 & 13 & & \\
\hline 163.1 & 561 & 211 & 3.52022 & 0.2607 & 1570 & 17 & & \\
\hline 163.2 & 601 & 268 & 3.52456 & 0.26552 & 1570 & 17 & & \\
\hline 163.3 & 599 & 214 & 3.56141 & 0.26464 & 1570 & 17 & & \\
\hline 163.4 & 302 & 165 & 3.71173 & 0.24474 & 1570 & 17 & & \\
\hline 164.1 & 276 & 159 & 4.51838 & 0.30747 & 1750 & 24 & & \\
\hline 164.2 & 175 & 82 & 4.67534 & 0.31128 & 1750 & 24 & & \\
\hline 164.3 & 217 & 105 & 4.56985 & 0.30851 & 1750 & 24 & & \\
\hline 164.4 & 263 & 164 & 4.69357 & 0.32058 & 1750 & 24 & & \\
\hline 19.3 & 482 & 159 & 3.905 & 0.2744 & 1703 & 7 & & Superior \\
\hline 9.4 & 612 & 185 & 3.778 & 0.2668 & 1703 & 7 & & Superior \\
\hline 19.5 & 432 & 126 & 3.637 & 0.2575 & 1703 & 7 & & Superior \\
\hline 19.6 & 482 & 159 & 3.905 & 0.2744 & 1703 & 7 & & Superior \\
\hline
\end{tabular}




\begin{tabular}{|c|c|c|c|c|c|c|c|c|}
\hline Ordem & $\begin{array}{c}U \\
(\mathrm{ppm}) \\
\end{array}$ & $\begin{array}{c}\mathrm{Pb} \\
(\mathrm{ppm})\end{array}$ & ${ }^{207} \mathrm{~Pb} /{ }^{235} \mathrm{U}$ & ${ }^{206} \mathrm{~Pb} /{ }^{238} \mathrm{U}$ & $\begin{array}{c}\text { Concórdia } \\
\text { Idade (Ma) }\end{array}$ & Erro & $\begin{array}{l}\text { MSWD } \\
\text { (U-Pb) }\end{array}$ & Intersecção \\
\hline 19.7 & 612 & 185 & 3.788 & 0.2668 & 1703 & 7 & & Superior \\
\hline 9.8 & 432 & 126 & 3.637 & 0.2575 & 1703 & 7 & & Superior \\
\hline PV 5.1 & 561 & 5 & 3.52022 & 0.26027 & 1570 & 17 & & Superior \\
\hline PV 5.2 & 601 & 40 & 3.52456 & 0.26552 & 1570 & 17 & & Superior \\
\hline PV 5.3 & 599 & 9 & 3.56141 & 0.26464 & 1570 & 17 & & Superior \\
\hline PV 5.4 & 302 & 18 & 3.71173 & 0.24474 & 1570 & 17 & & Superior \\
\hline PV 6.1 & 276 & 15 & 4.51838 & 0.30747 & 1750 & 24 & & Superior \\
\hline PV 6.2 & 175 & 11 & 4.67534 & 0.31128 & 1750 & 24 & & Superior \\
\hline PV 6.3 & 217 & 14 & 4.56985 & 0.30851 & 1750 & 24 & & Superior \\
\hline PV 6.4 & 263 & 11 & 4.69357 & 0.32058 & 1750 & 24 & & Superior \\
\hline PV 7.1 & 240 & 9 & 3.60413 & 0.26411 & 1588 & 16 & & Superior \\
\hline PV 7.2 & 174 & 6 & 3.66439 & 0.27246 & 1588 & 16 & & Superior \\
\hline$P \vee 7.3$ & 147 & 5 & 3.7488 & 0.26796 & 1588 & 16 & & Superior \\
\hline PV 7.4 & 1184 & & 3.6036 & 0.26849 & 1588 & 16 & & Superior \\
\hline PV 7.5 & 116 & 12 & 3.51243 & 0.26479 & 1588 & 16 & & Superior \\
\hline PV 7.6 & 260 & 6 & 3.68584 & 0.2706 & 1588 & 16 & & Superior \\
\hline RR 21.1 & 1093 & 279 & 3.96 & 0.23 & 2171 & 16 & 5 & \\
\hline RR 21.2 & 598 & 203 & 5.706 & 0.3114 & 2171 & 16 & 5 & \\
\hline RR 21.3 & 417 & 151 & 6.122 & 0.3331 & 2171 & 16 & 5. & \\
\hline RR 21.4 & 260 & 103 & 6.636 & 0.3628 & 2171 & 16 & 5 & \\
\hline RR 22.1 & 1344 & 407.5 & 5.707 & 0.2957 & 2235 & 19 & 5.5 & \\
\hline RR 22.2 & 812.1 & 281.9 & 6.555 & 0.3343 & 2235 & 19 & 5.5 & \\
\hline RR 22.3 & 715.9 & 271.4 & 7.098 & 0.3652 & 2235 & 19 & 5.5 & \\
\hline RR 22.4 & 517.8 & 202.1 & 7.249 & 0.3769 & 2235 & 19 & 5.5 & \\
\hline RR 23.1 & 2185.6 & 370.5 & 1.965 & 0.156 & 1548 & 40 & 35.9 & \\
\hline RR 23.2 & 1443.2 & 275.7 & 2.404 & 0.1795 & 1548 & 40 & 35.9 & \\
\hline RR 23.3 & 309.5 & 26.7 & 0.9668 & 0.0797 & 1548 & 40 & 35.9 & \\
\hline$R R 23.4$ & 260.4 & 13.8 & 0.5127 & 0.0457 & 1548 & 40 & 35.9 & \\
\hline RR 24.1 & 577 & 148.7 & 3.64 & 0.247 & 1883 & 46 & & Superior \\
\hline RR 24.2 & 436.1 & 108.8 & 3.507 & 0.2384 & 1883 & 46 & & Superior \\
\hline RR 24.3 & 384.9 & 100.6 & 3.67 & 0.2496 & 1883 & 46 & & Superior \\
\hline RR 24.4 & 209.4 & 59.6 & 4.112 & 0.2712 & 1883 & 46 & & Superior \\
\hline RR 25.1 & 273.3 & 92.1 & 5.185 & 0.3156 & 1943 & 7 & 0.05 & \\
\hline RR 25.2 & 259.5 & 88.9 & 5.26 & 0.3206 & 1943 & 7 & 0.05 & \\
\hline RR 25.3 & 275 & 80.8 & 4.481 & 0.2735 & 1943 & 7 & 0.05 & \\
\hline $\mathrm{RR} 25.4$ & 237.3 & 84.6 & 5.457 & 0.3326 & 1943 & 7 & 0.05 & \\
\hline RR 31.1 & 2057.4 & 387.3 & 2.65 & 0.1805 & 1827 & 19 & 0.02 & \\
\hline RR 31.2 & 2034.4 & 392.3 & 2.742 & 0.1863 & 1827 & 19 & 0.02 & \\
\hline RR 31.3 & 8736.9 & 369.2 & 0.6059 & 0.0412 & 1827 & 19 & 0.02 & \\
\hline RR 31.4 & 1537.1 & 371.8 & 3.528 & 0.2344 & 1827 & 19 & 0.02 & \\
\hline RR 32.1 & 1251.1 & 413.8 & 4.962 & 0.3087 & 1911 & 13 & 0.6 & \\
\hline RR 32.2 & 1520.6 & 493.5 & 4.857 & 0.3045 & 1911 & 13 & 0.6 & \\
\hline RR 32.3 & 899 & 309.9 & 5.146 & 0.3211 & 1911 & 13 & 0.6 & \\
\hline RR 32.4 & 802.5 & 286.7 & 5.344 & 0.332 & 1911 & 13 & 0.6 & \\
\hline RR 33.1 & 708.6 & 274 & 5.306 & 0.3313 & 1921 & 15 & 0.94 & \\
\hline RR 33.2 & 774.4 & 310.4 & 5.471 & 0.3398 & 1921 & 15 & 0.94 & \\
\hline RR 33.3 & 696.8 & 283 & 5.619 & 0.3464 & 1921 & 15 & 0.94 & \\
\hline RR 33.4 & 543.9 & 210.1 & 5.373 & 0.3323 & 1921 & 15 & 0.94 & \\
\hline
\end{tabular}




\begin{tabular}{|c|c|c|c|c|c|c|}
\hline Ordem & ${ }^{206} \mathrm{~Pb} /{ }^{204} \mathrm{~Pb}$ & ${ }^{207} \mathrm{~Pb} /{ }^{204} \mathrm{~Pb}$ & ${ }^{208} \mathrm{~Pb} /{ }^{204} \mathrm{~Pb}$ & $\begin{array}{l}\text { Idade } \\
\text { (Ma) }\end{array}$ & Erro & $\mu 1$ \\
\hline 14.2 & 24.146 & 16.266 & 44.492 & 1632 & 250 & 8.163 \\
\hline 16.2 & 19.37 & 15.722 & 48.688 & 1632 & 250 & 8.163 \\
\hline 17.2 & 17.302 & 15.54 & 36.033 & 1632 & 250 & 8.163 \\
\hline 18.2 & 23.448 & 16.095 & 39.524 & 1632 & 250 & 8.163 \\
\hline 19.2 & 22.009 & 15.99 & 39.205 & 1632 & 250 & 8.163 \\
\hline CB 97 & 17.7681 & 15.6445 & 36.7674 & 724 & & 10.08 \\
\hline CB 98 & 17.6655 & 15.5739 & 36.5211 & 669 & & 9.78 \\
\hline CB 24 & 17.7934 & 15.6813 & 36.8968 & 772 & & 10.25 \\
\hline CB 99 & 16.813 & 15.423 & 36.343 & 1717 & 115 & 8.099 \\
\hline CB 100 & 18.75 & 15.955 & 40.463 & 1717 & 115 & 8.099 \\
\hline CB 101 & 21.046 & 15.858 & 39.278 & 1717 & 115 & 8.099 \\
\hline CB 102 & 17.531 & 15.524 & 40.693 & 1717 & 115 & 8.099 \\
\hline CB 103 & 18.893 & 15.654 & 38.512 & 1717 & 115 & 8.099 \\
\hline CB 104 & 19.932 & 15.748 & 39.95 & 1717 & 115 & 8.099 \\
\hline JR 12.2 & 24.103 & 16.259 & 43.421 & 1672 & 85 & 8.241 \\
\hline JR 21.2 & 18.284 & 15.673 & 38.123 & 1672 & 85 & 8.241 \\
\hline JR 2.3 & 21.26 & 15.973 & 40.916 & 1672 & 85 & 8.241 \\
\hline JR 3.3 & 24.736 & 16.332 & 46.492 & 1672 & 85 & 8.241 \\
\hline JR 4.6 & 19.007 & 15.718 & 38.979 & 1672 & 85 & 8.241 \\
\hline JR 4.7 & 19.764 & 15.83 & 39.806 & 1672 & 85 & 8.241 \\
\hline JR 9.2 & 19.922 & 15.846 & 41.145 & 1672 & 85 & 8.241 \\
\hline
\end{tabular}


NOTA

DEVIDO A GRANDE DENSIDADE DE PONTOS DATADOS NA REGIÃO DA SERRA DOS CARAJÁS, A ESCALA DO MAPA DO CRÁTON AMAZÔNICO TORNOU-SE INCOMPATÍVEL, E PARA UMA MELHOR DEFINIÇÃO DESTES PONTOS, O MAPA REFERENTE A ESTA REGIÃO FOI FEITO SEPARADO EM ESCALA ADEQUADA. 
MAPA GEOCRONOLÓGICO DA REGIÃO DA SERRA DOS CARAJÁS

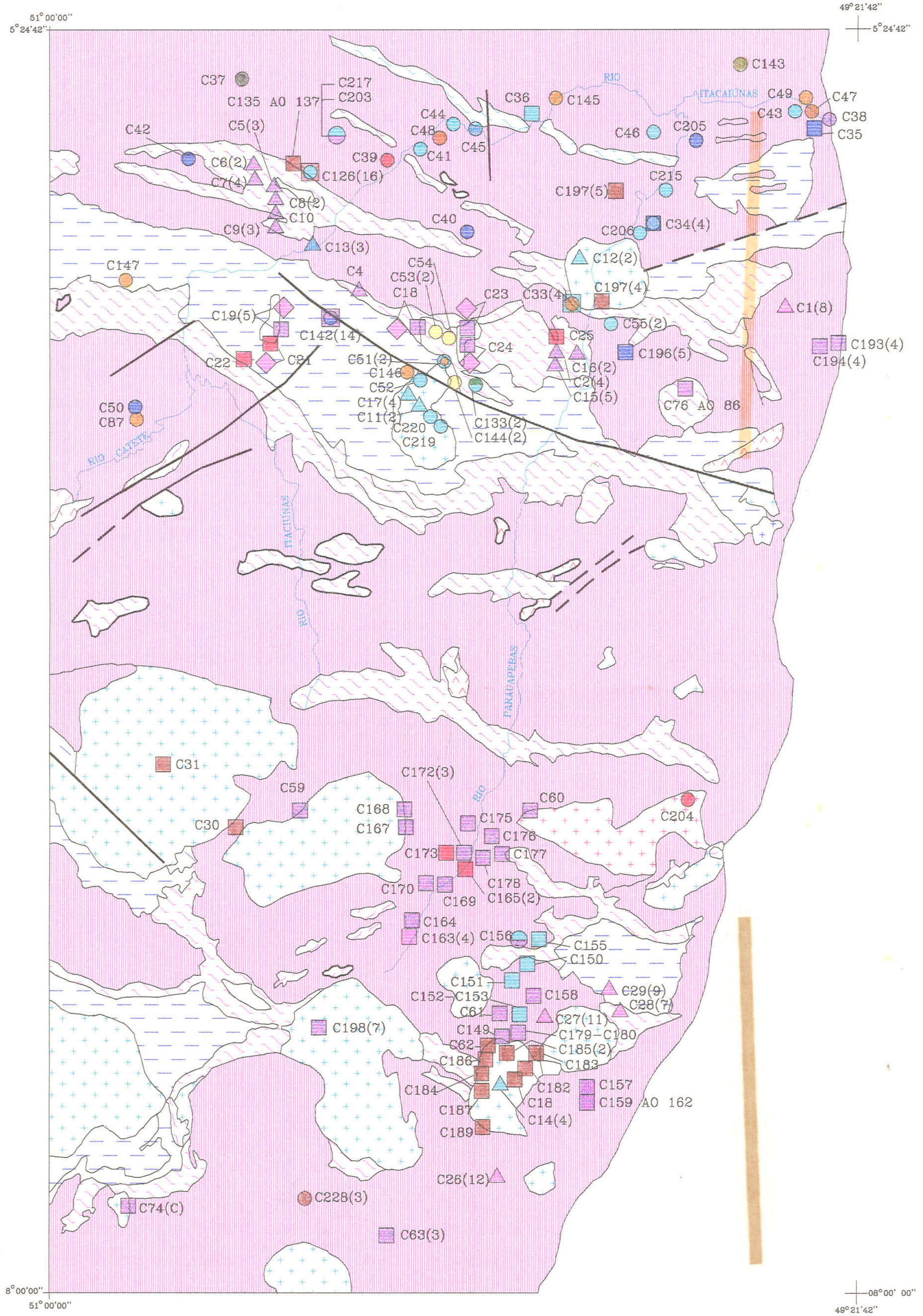

$\begin{array}{llllll}0 & 10 & 20 & 30 & 40 & 50 \mathrm{Km}\end{array}$ 
MAPA GEOCRONOLÓGICO DO CRÁTON AMAZÔNICO NO BRASIL

AUTOR: COLOMBO CELSO GAETA TASSINARI

(1996)

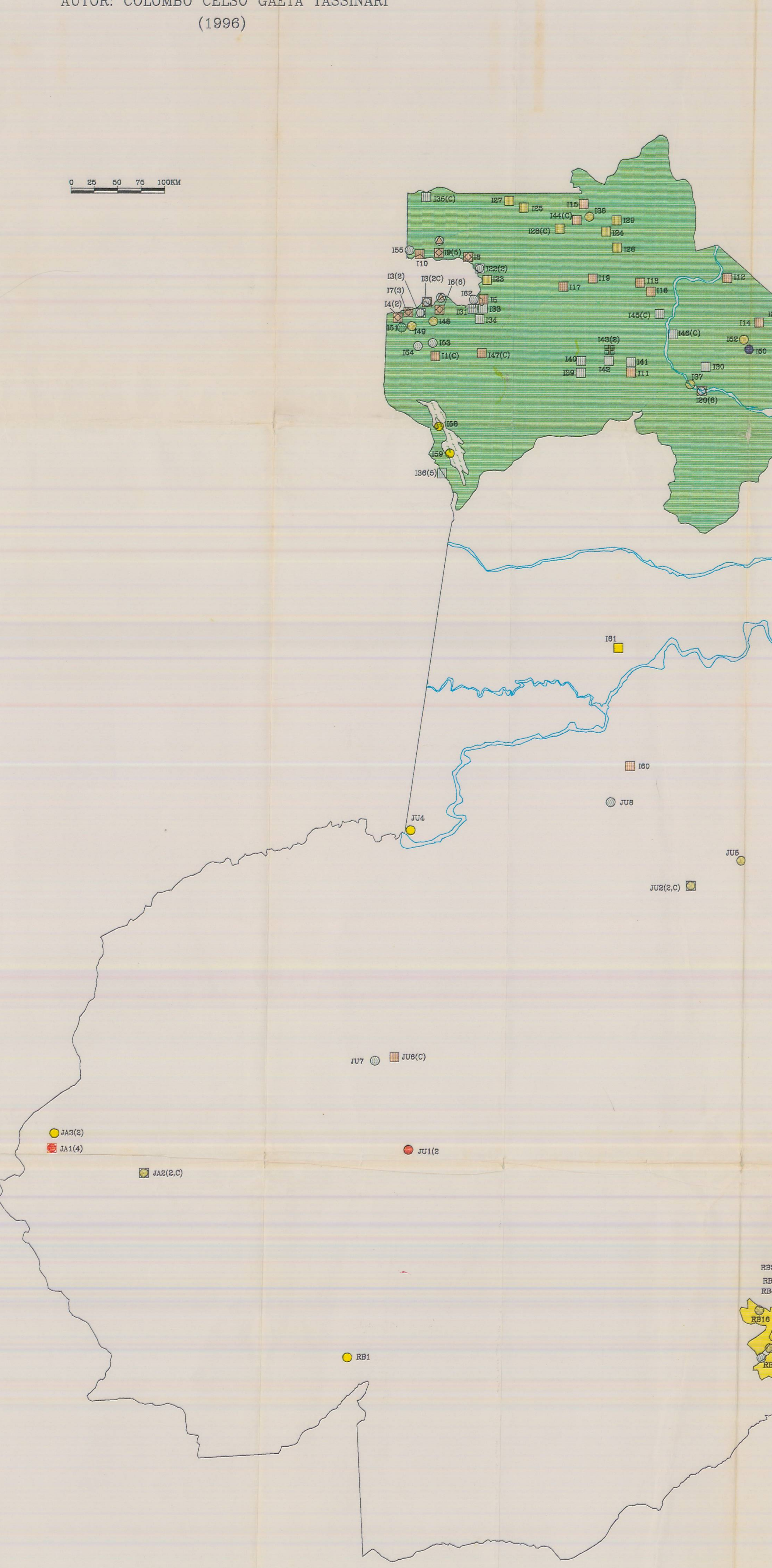

rs

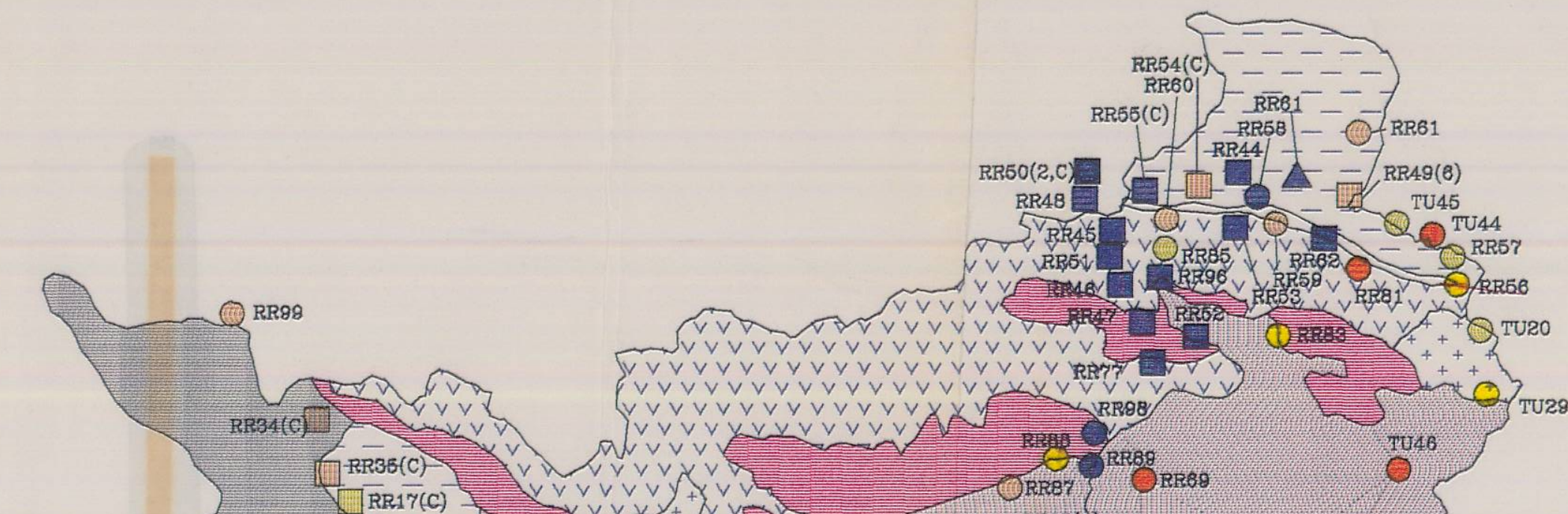

(1)

LEGENDAS

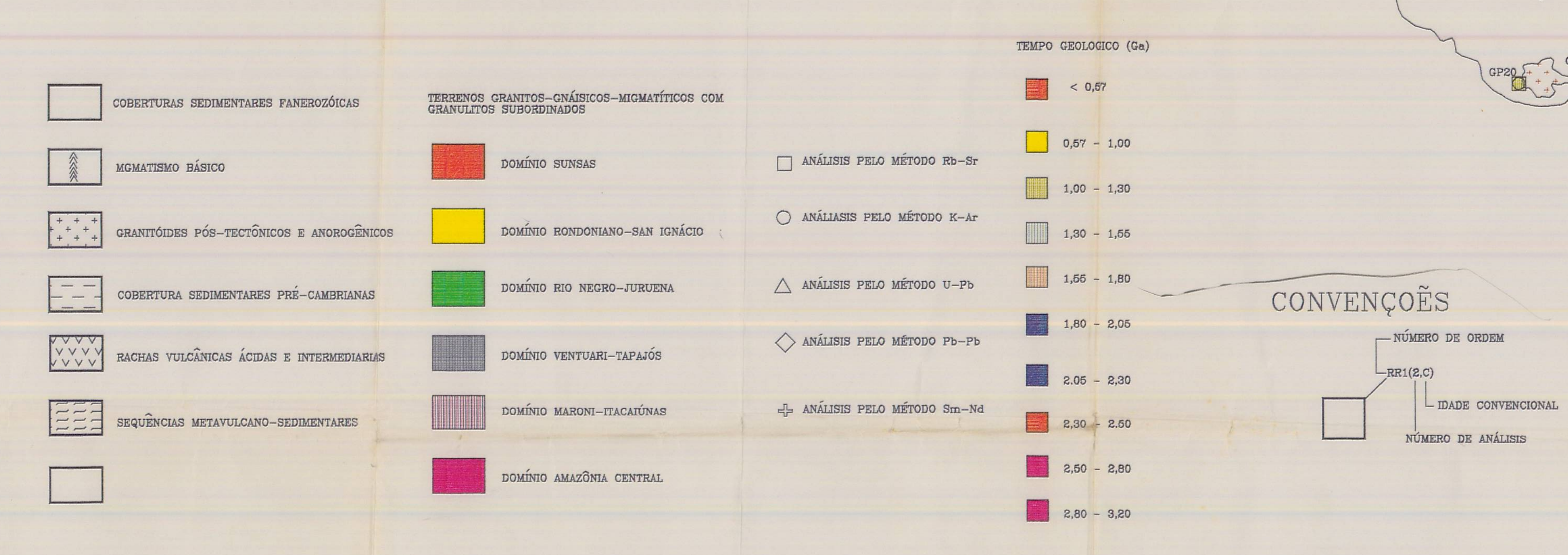

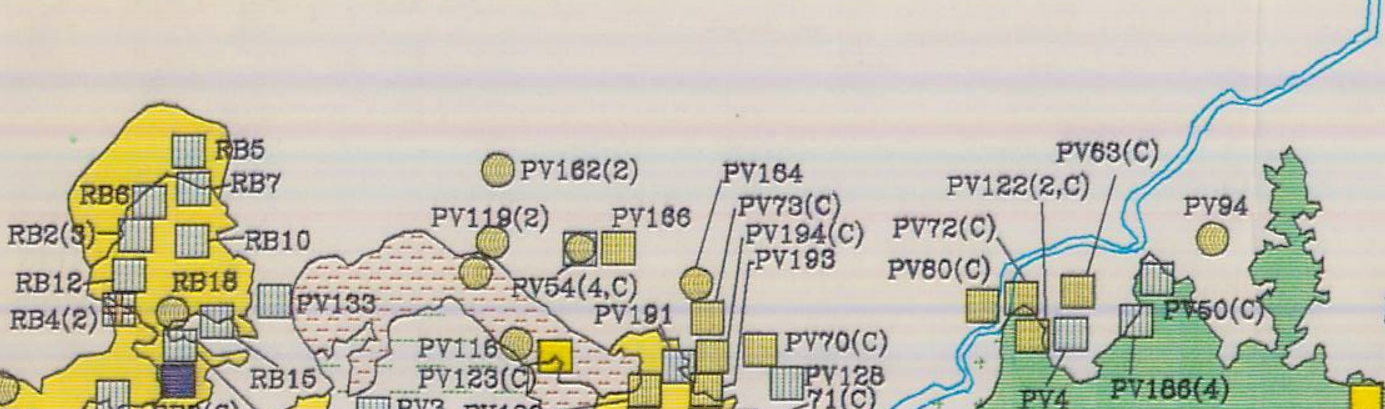

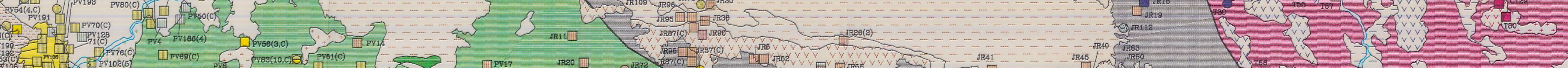

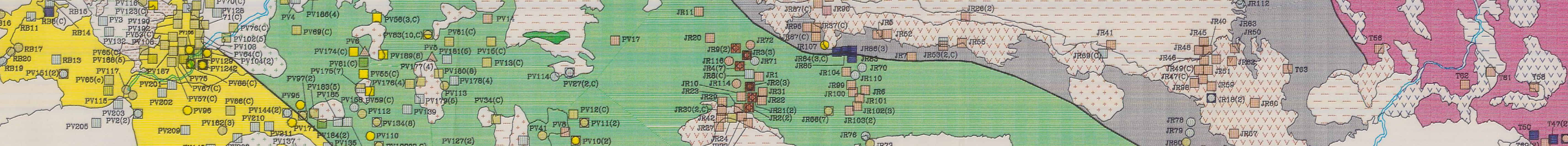

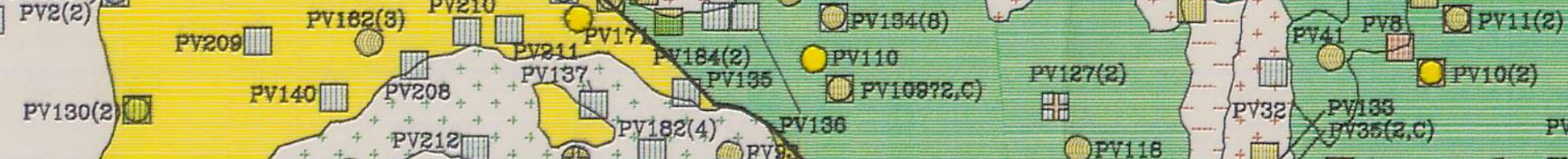

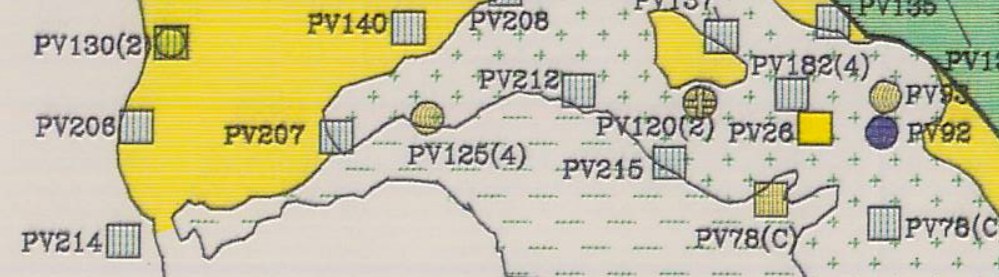
द्युद

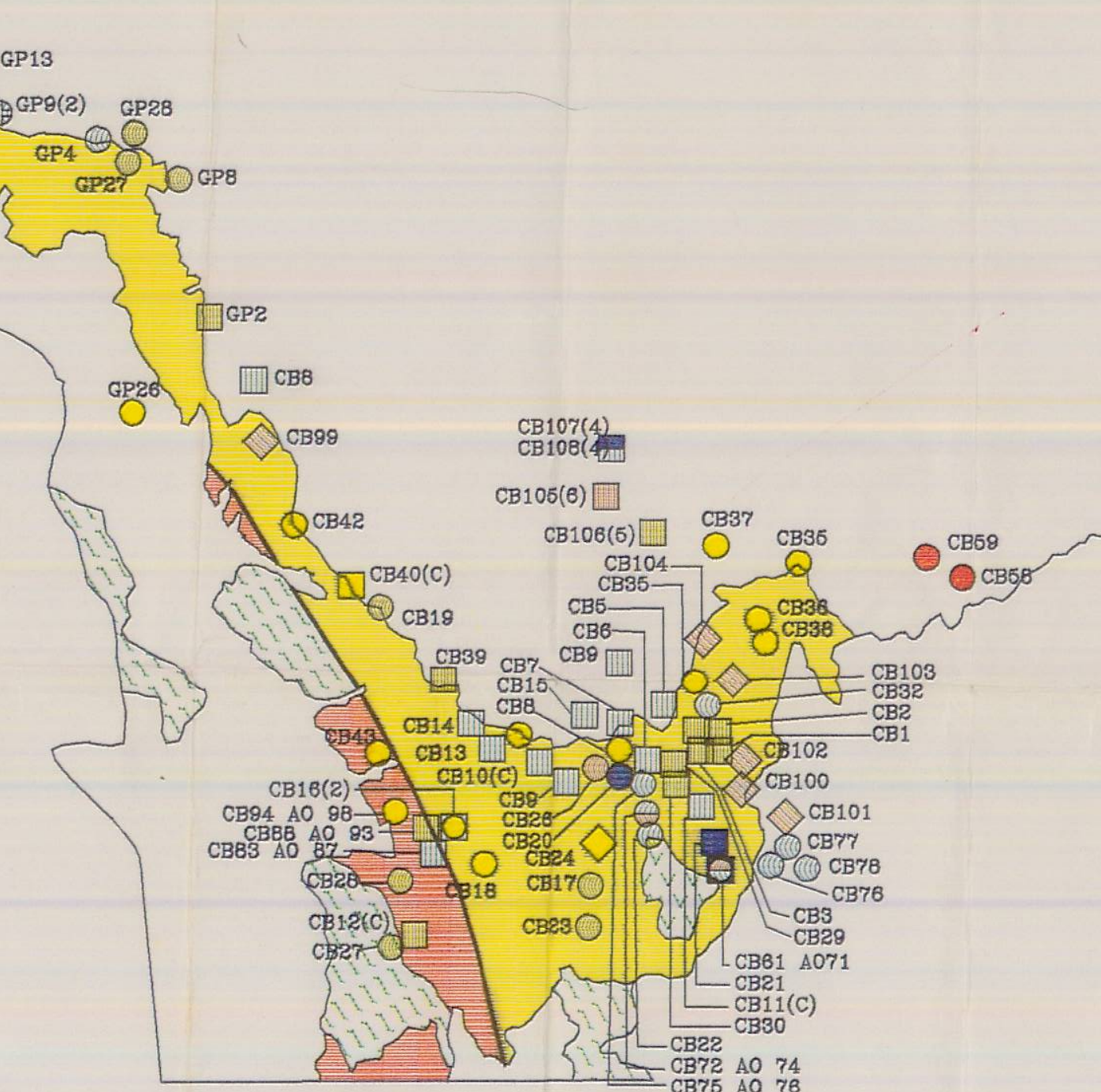

